Historic, Archive Document

Do not assume content reflects current scientific knowledge, policies, or practices. 



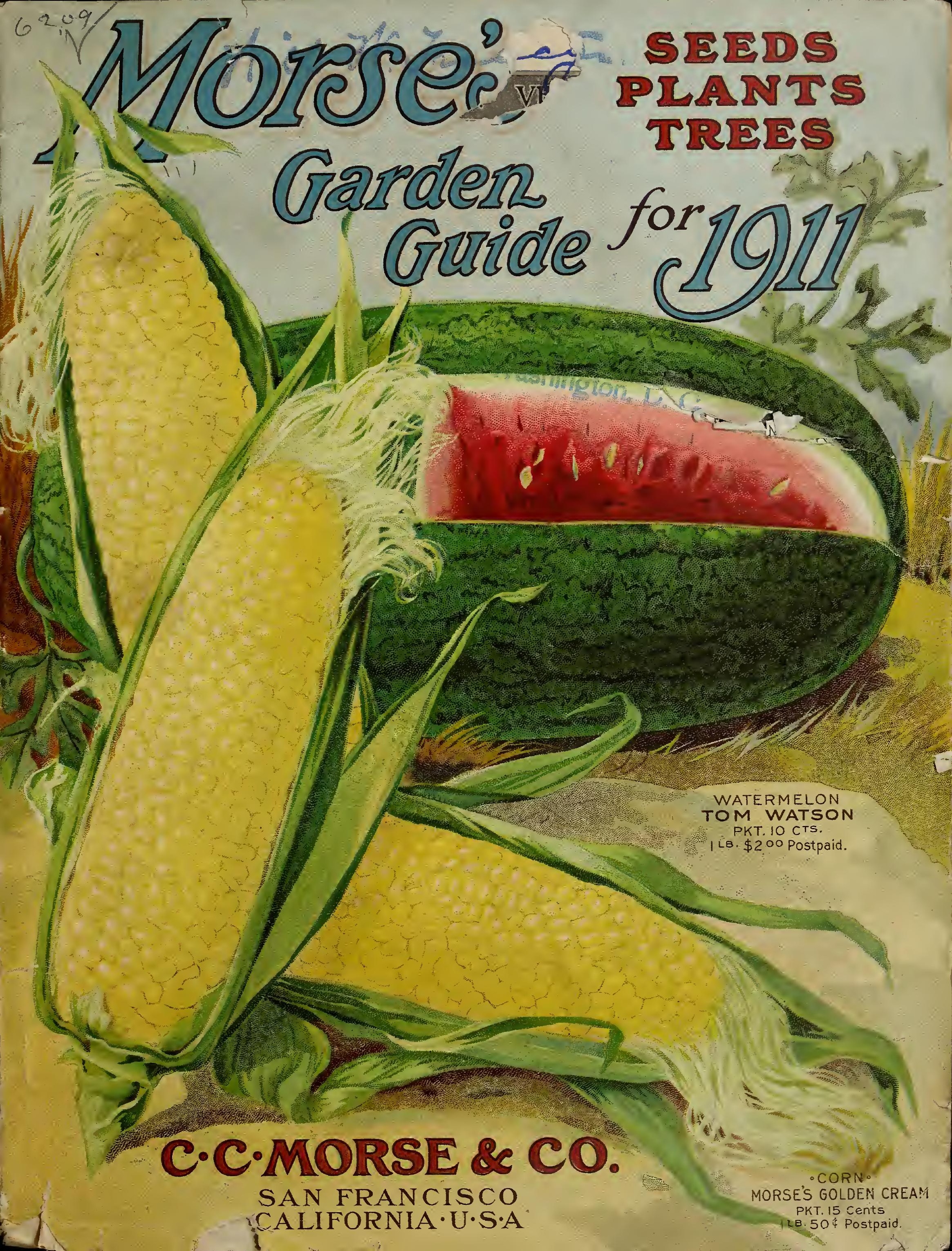




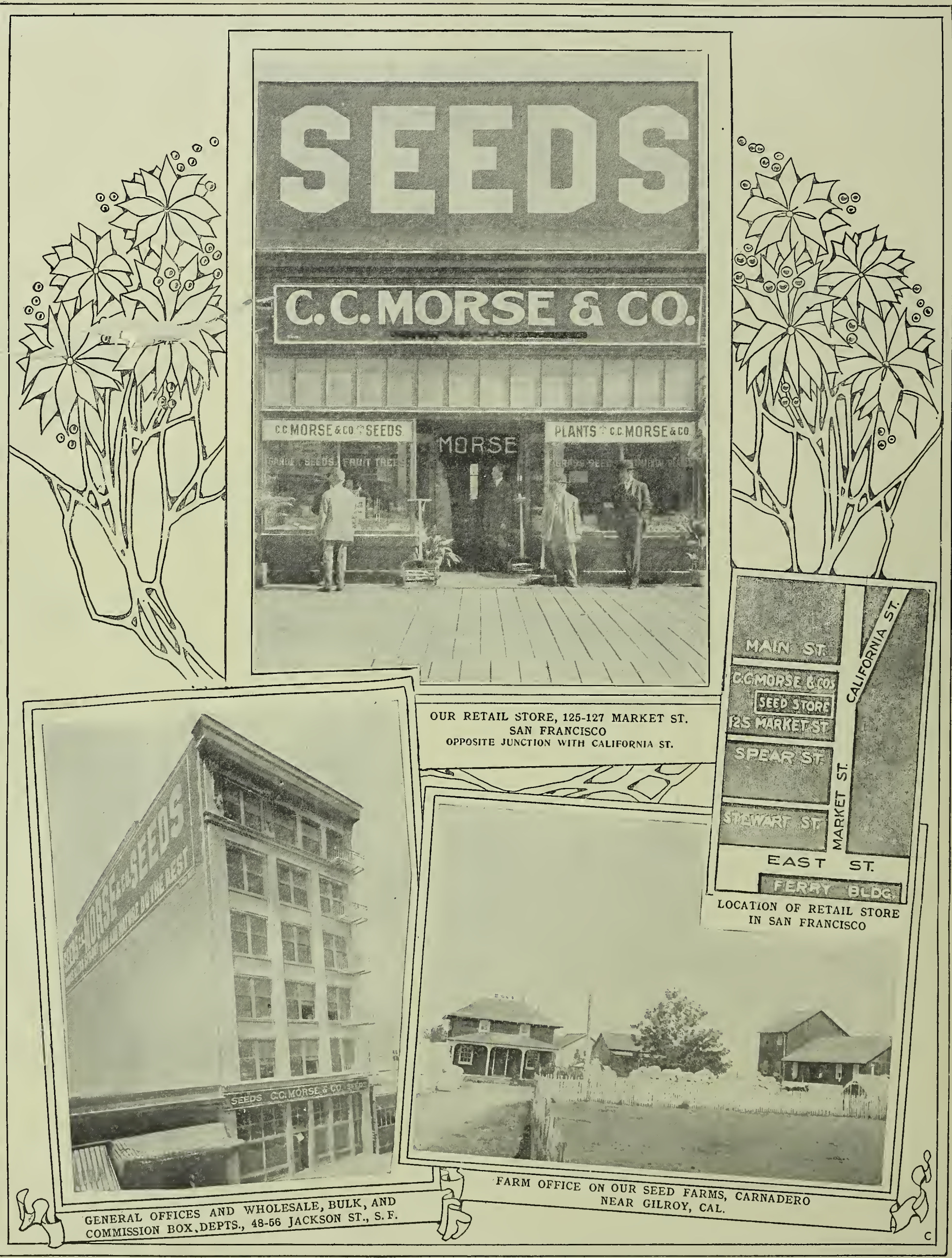




\section{Atiel of Yracy of.}

(D) C.C MORSE \& CO VEGETABLE SEEDS OP

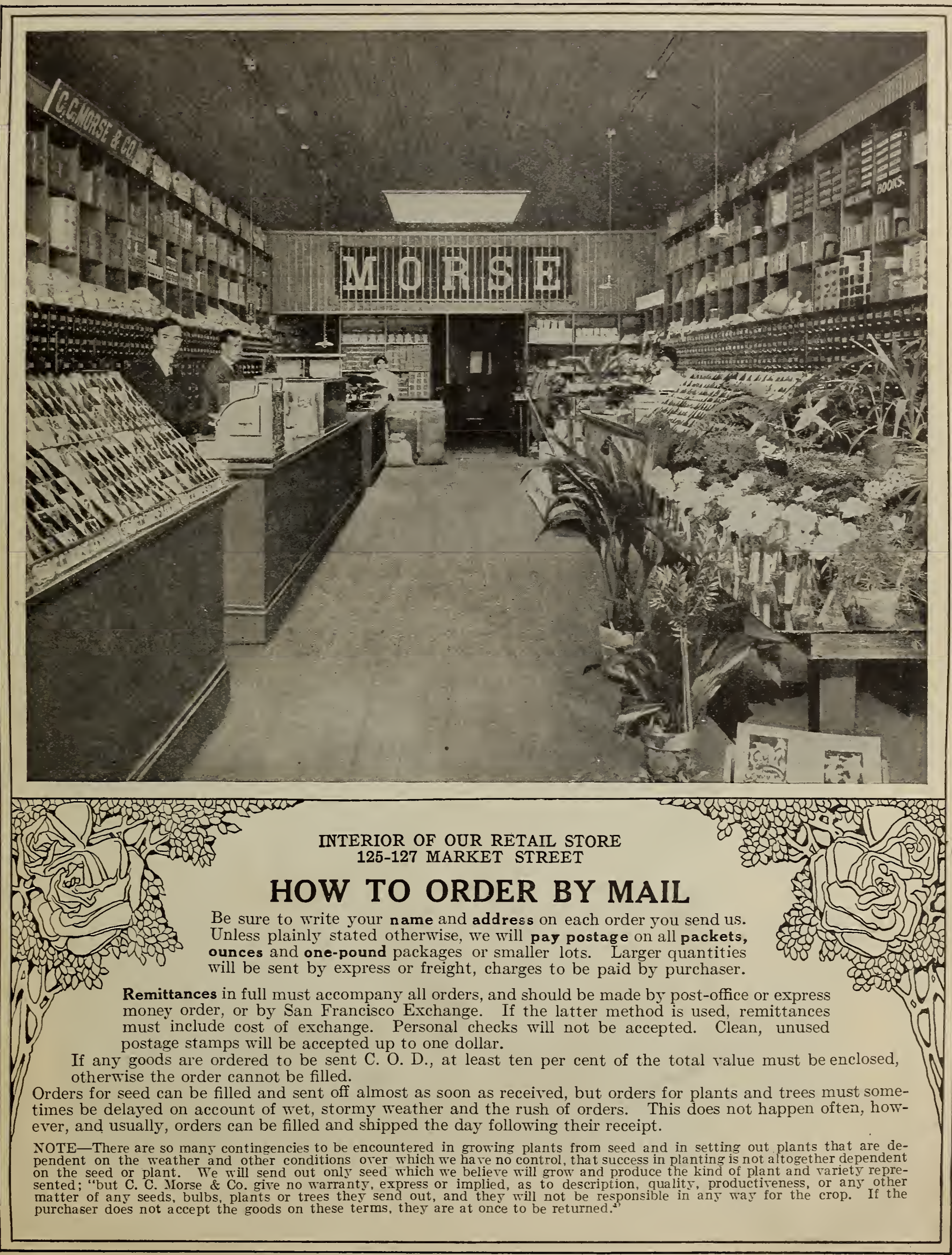




\section{C.C.MORSE \& CO. VEGETABLE SEEDS C?}

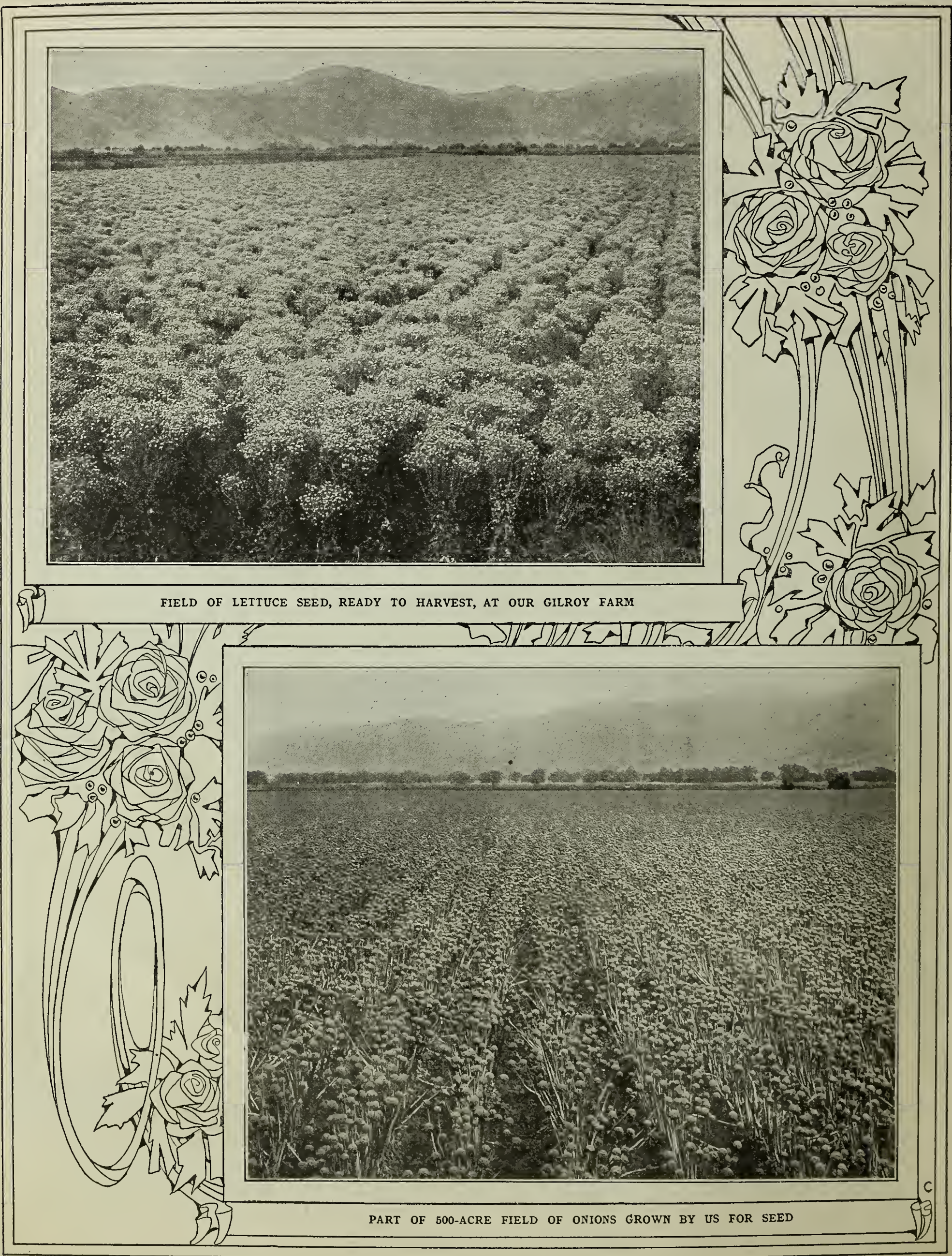


H. SAN FRANCISCO, CALIFORNIA. U.S.A KGgY

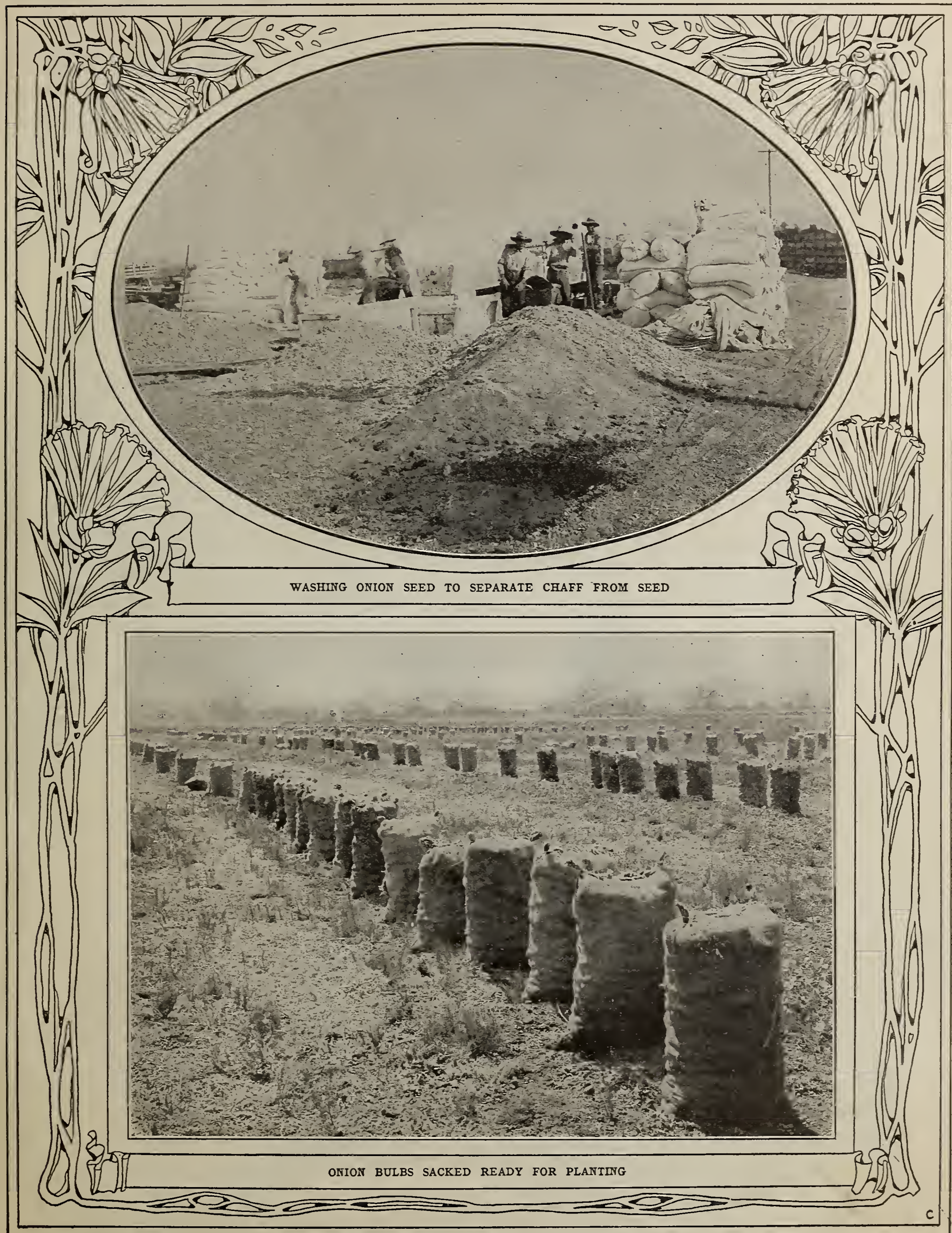




\section{C.C.MORSE of CO VEGETABLE SEEDS S C}

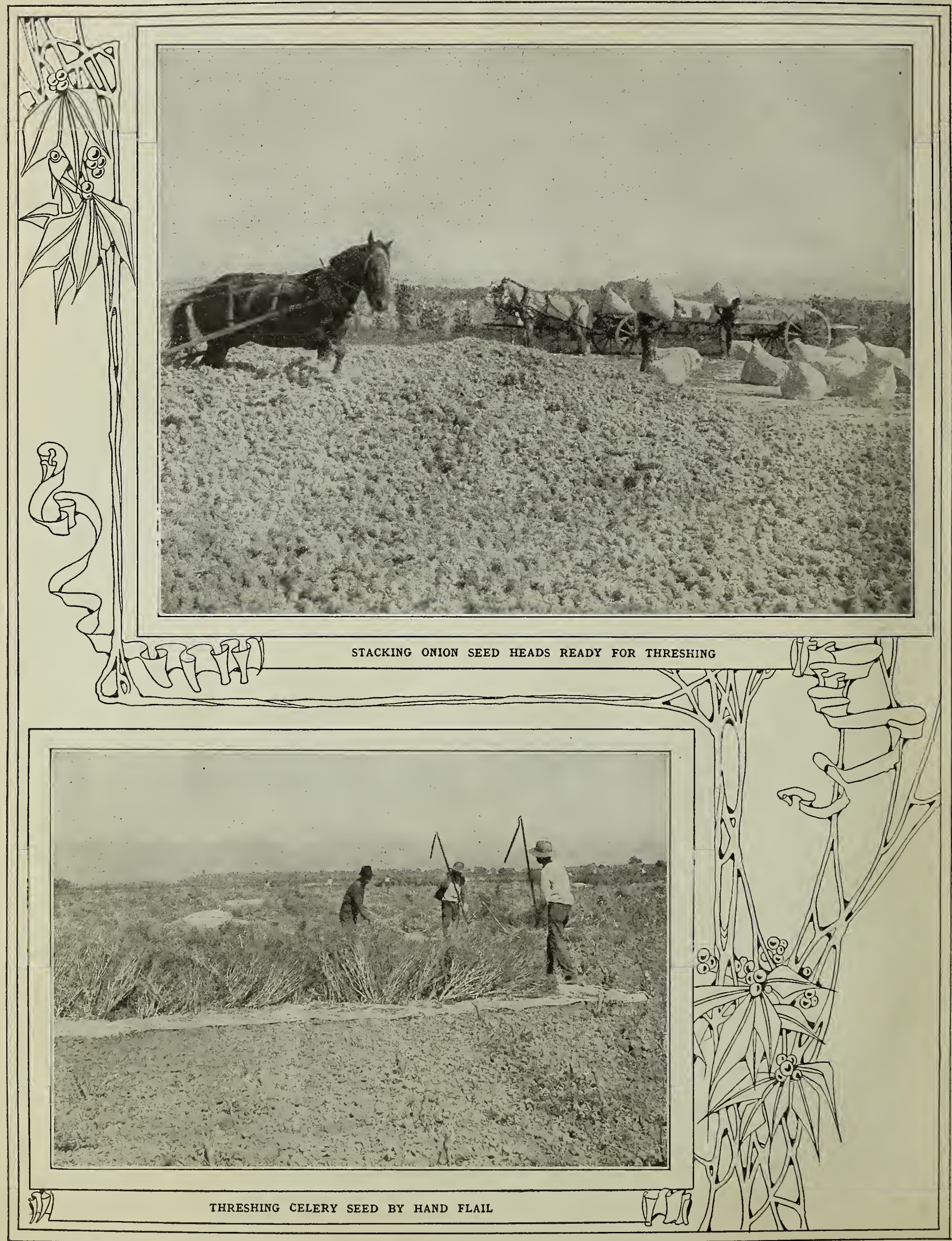




\section{WATERMELON TOM WATSON \\ (Our front cover illustration in natural colors.)}

TOM WATSON was illustrated and listed in our last year's catalogue and met with such great success that we did not have near enough seed for our orders and were obliged to return money sent us for some seed time and again.

TOM WATSON is noted for its immense size.

TOM WATSON is noted for its delicious flavor. TOM WATSON is noted for its beautiful deep red flesh
TOM WATSON is noted for its very thin rind, which is shipping quality.

.It is a grand, good melon and everybody should try it. Per Pkt. 10c; 0z. 20c; $1 / 4$ lb. 60c; lb. $\$ 2.00$.

\section{LETTUCE \\ THE CELEBRATED "LOS ANGELES"}

This is the popular variety known to American seedsmen as NEW YORK and to European seedsmen as NEAPOLITAN CABBAGE.

The outside leaves are deep green and slightly curled, while the inside head is pure white. It is very crisp and brittle and is unsurpassed in our southern California climate for fall and winter markets, from Los Angeles and north to Portland.

The flavor is remarkably good and we recommend it for house garden or market.

Pkt. 5 c ; oz. 20c; $1 / 4$ lb. 50c; lb. $\$ 1.50$.

\section{ONION AILSA CRAIG}

This is the great long-keeping giant English variety so widely advertised by seedsmen in England and so highly recommended by Prof. R. E. Mansell of the Agricultural Department of the State University.

AIISA CRAIG is similar in appearance to the famous PrizeSA CRAG taker but has better keeping qualities.

AILSA CRAIG frequently grows to an $_{\text {immense size and the }}$ illustration herewith was but one of six bulbs sent us as samples. This one measured eighteen inches in circumference and weighed two pounds.

AILSA CRAIG is a light clear yellow is yellowish crystal, fine in color and the inside

AILSA CRAIG is a heavy cropper, a fable variet $y$, of fine flavor, and easily grown from seed.

Pkt. 10 c ; 0z. 30c; $1 / 4$ lb. $\$ 1.00 ; 1 b . \$ 3.00$.

A testimonial from Prof. R. E. Mansell of Berkeley:

"I consider that the Ailsa Craig onion is one of the very best of all onion varieties.

"I happened to know how highly it is esteemed in England, where it is hopeless to place other kinds in competition with it on the exhibition table, and this led me to give it a place in the variety trials I have been conducting at the University experiment grounds.

"With a four years' test as a guide I have no hesitancy in saying that it is the heaviest yielder of all onions, and besides its heavy yielding characters, heavy yielding characters, it is extremely handsome in appearance, having a clear skin and a tendency to be uniform in size.

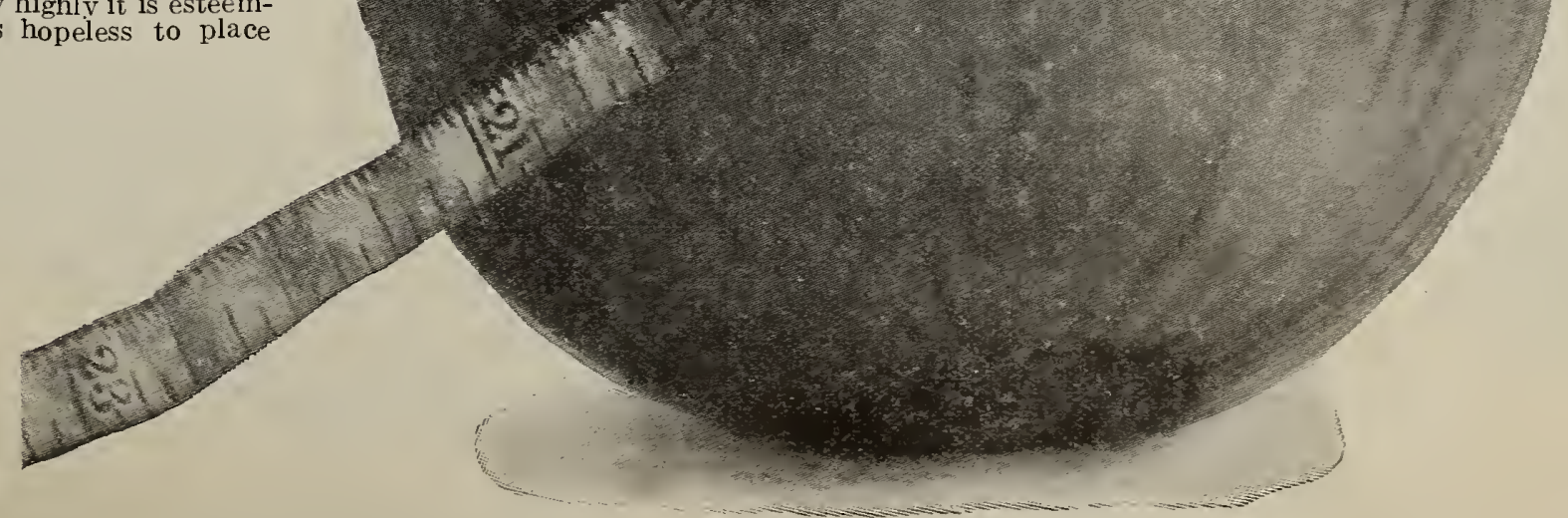




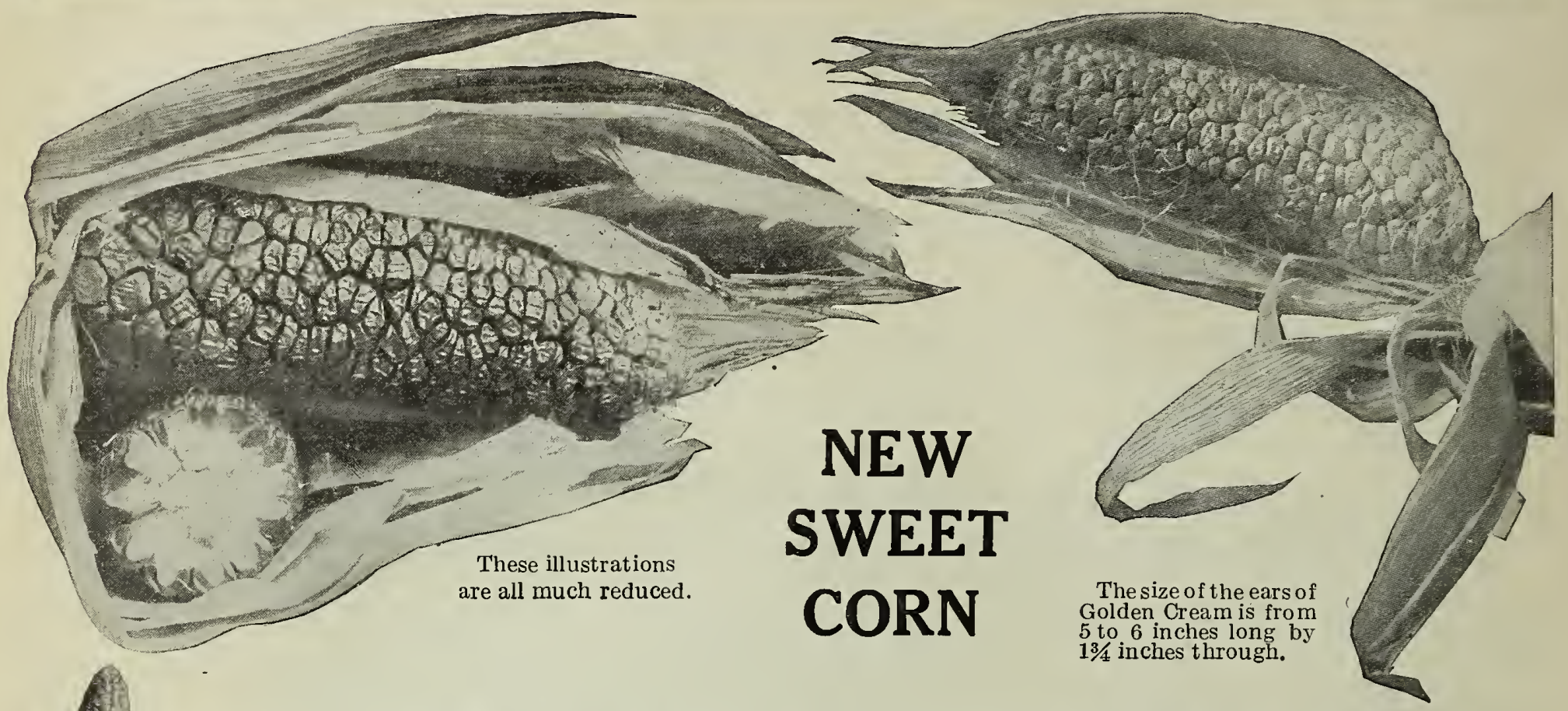

\section{MORSE'S GOLDEN CREAM}

\section{AN ABSOLUTELY NEW THING CREATED BY A CALIFORNIA MAN: ADAPTED TO THE CALIFORNIA CLIMATE BY NATURE. A CROSS BETWEEN GOLDEN BANTAM AND COUNTRY GENTLEMAN}

One hesitates about introducing a new Sweet Corn, since some one in the Seed Trade seems to have something new in this line every year. Some are of sterling merit and become standard varieties and some are soon forgotten.

In MORSE'S GOLDEN CREAM, however, we positively have a new creation. It was created by Mr. Thos. Gould, of Ventura, Cal., who crossed Country Gentleman on Golden Bantam and secured a Golden Gentleman, with the irregular shoepeg kernels of the former and the early habit and golden color of the latter. It combines the delicious juicy, sweet flavor of both.

We had Golden Cream ready for introduction a year ago but kept it back another season in order to get it true and pure, and the stock we are now offering was grown for us by two of the best sweet corn growers in the East.

Golden Cream has the advantage of being a California creation and has the elements in it that are adapted for our Coast. Now by growing the stock East we have an Eastern grown but acclimated sweet corn.

Golden Cream is light yellow in color, but is not a field corn, nor anything like one; it is the finest table corn.

Golden Cream is of unsurpassed flavor, sweet, tender and delicious.

Golden Cream will bec. - in California because it is a California production, a "Native Son"-to borrow an expression.

Plant Morse's Golden Cream in your garden if you love corn, for it is worthy of a trial and a place.

Golden Cream derives its name not only from the fact that it is the cream of the best, and golden in color, but because it took so much gold to buy it. C. C. Morse \& Co. paid the discoverer of this corn $\$ 100.00$ a pound for the exclusive control of it.

Price per packet 10c; $1 / 4$ lb. $15 \mathrm{c} ; 1 \mathrm{lb}$. 50c, postpaid. By express or freight, $1 \mathrm{lb} .40 \mathrm{c} ; 10 \mathrm{lbs} . \$ 3.00$.

An opinion from J. C. Robinson, the largest grower of Sweet Corn for seed in America:

We had the pleasure yesterday of making a good fair trial of your Golden Cream corn on our table, and I want to say to you that we are very much pleased with it. It was tender and very sweet, equal in quality and all respects to the varieties that I take to be its parents, Country Gentleman and Golden Bantam, in size of stalk it seems to be midway between the two, though probably somewhat earlier than the Country Gentleman. 


\section{VEGETABLE SEEDS}

Our list is as long as it should be and in the following pages are catalogued all the best and standard varieties, as well as some of the newer kinds which liave recently been introduced in rarious sections of this country and Europe.

OUR SEED FARMS- We are the largest Seed Growers on the Pacific Coast, but since all seed cannot be grown to the best adrantage

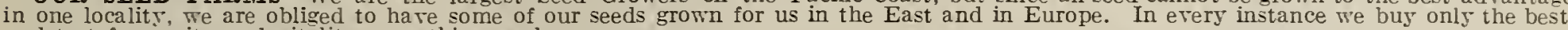
and test for purity and vitality everything we buy.

On our own seed farms we grow all of our Carrot, Celery, Cucumber, Endive, Leek, Lettuce, Mustard, Onion, Parsley, Parsnip, Radish and Salsify.

Our total acreage of our orn seed farms is about 2000 acres.

FARMER GROWERS-All of our Peas and Beans as well as many of our Melon seeds are grown by various Pacific Coast farmers

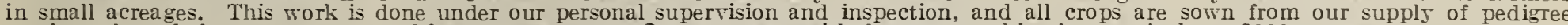
stock seeds and the crops are rogued by our own men. Our contracts with farmers on this plan total about 3000 acres.

TRIAL GROUNDS- We conduct rery extensive Trial Grounds where samples of ererything we grow and of ererything we purchase

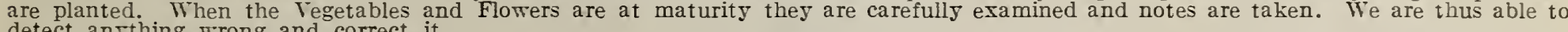
detect anjthing wrong and correct it.

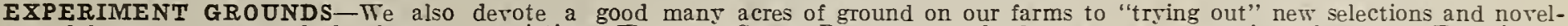

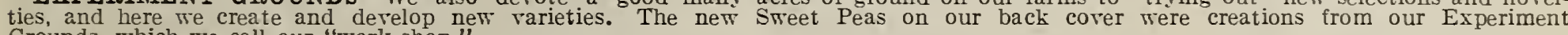
Grounds, which we call our "work shop."

\section{ARTICHOKES}

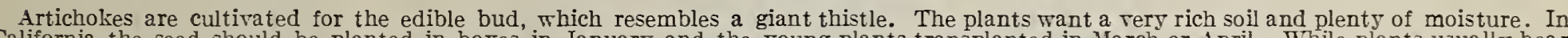

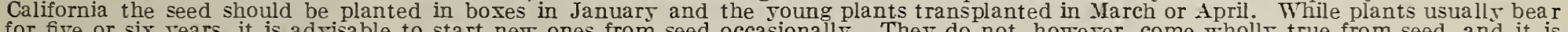

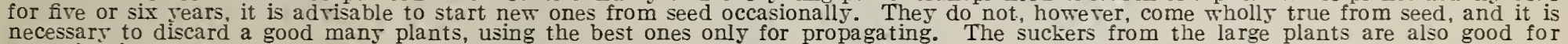
transplanting.

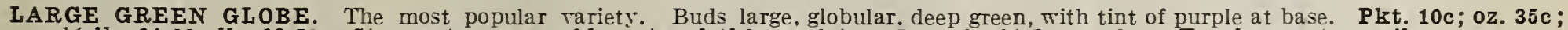
$1 / 1$ 1b. $\$ 1.00 ; 1 b$. $\$ 3.50$. Strong two-year-old roots of this variety, $15 \mathrm{c}$ each; $\$ 1.50$ per doz. Too hea $\mathbf{1}$. to mail.

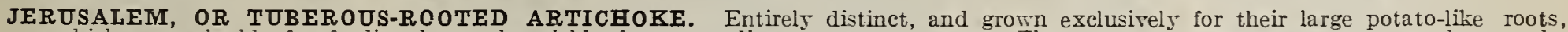
which are raluable for feeding hogs, the field often exceeding two tons per acre. They
dug. but the hogs can be turned into the field to root them up; one acre will heep twenty dug. but the hogs can be turned into the field to root them up; one acre will heep twenty
condition until Spring. The tubers are also edible, and are delicious when well cooked.

\section{ASPARAGUS SEED AND ROOTS}

It requires three or four rears from the time of planting asparagus seed to the time that the plant produces shoots suitable for eating. To raise plants from seed about one pound peracre is required, or one ounce for about 800 plants. Sow earls in the Spring in drills 12 to 14 inches apart and thin to about 3 inches in the row. Allow the plants to grow two full seasons and then transplant to permanent beds. It requires plants to set an acre. When set out for crop, in in beds, thes require plenty of room, since In the field the rows should be from six to ten A loose, porous soil is necessary for good asparathe flaror of the roung shoots depends greatl character of the soil. The light, fibrous soils of mento River Islands seem especialls adapted for asparagus.

In the house garden, the soil, if naturalls heavy must be made porous and light by spading in the amount of manure and sand. D u ring the

\section{PAL-}

\section{METTO}

This is the most popular rariety gromn purposes, especially for ship ping. Shoots a re light green and tinted slightls with pink (see illustration). Plat. 5c Oz. $10 \mathrm{c} ; 1 / 1 \mathrm{Ib}$. $25 \mathrm{c} ; 1 \mathrm{~b} .85 \mathrm{c}$

ASPARGAUS ROOTS Large rigorous roots of Paldoz., postpaid; $\$ 1.00$ per 100 , by express; $\$ 7.00$ per 1000 . Per 1b. 15c: postpaid, $25 \mathrm{c}$ per 1b. 100 lbs. at mar. ket rates.

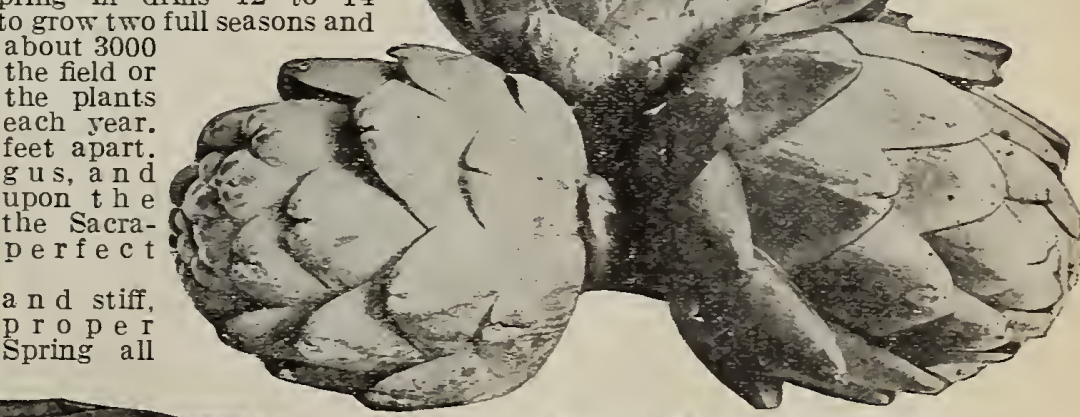

Artichoke-Large Green Globe
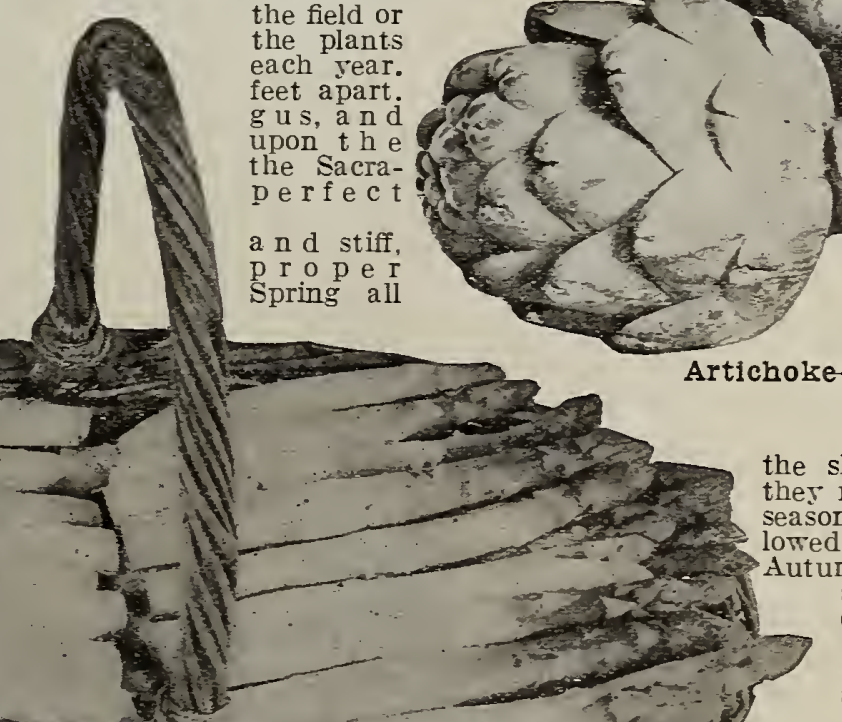

the shoots must be cut as fast as ther reach the surface. Later in the shoots should be alumn all the tops should be cut off and burned and the land thoroughly cleaned up, and a good ashes and sand should be ashes and sand

Barr's Mammoth. A farorite with market gardeners. Shoots rery large, tender, quick grow$5 \mathrm{c} ;$ oz. $10 \mathrm{c} ; 1 / 1 \mathrm{Ib}$. $25 \mathrm{c}$; $1 \mathrm{~b} \cdot 85 \mathrm{c}$. Columbia Mammoth White. A large, thich Pkt. 5c;0z. 10c; 1/1 1b. 25c;1b. 85c.

CONOVER'S COLOSSAL OR BOULDIN ISLAND $\begin{gathered}\text { A standard rariety } \\ \text { for all purposes, es- }\end{gathered}$ pecially for canning. It is the popular rariet $x$ formerly used on Bouldin Island and other river points in California, where it is canned in immense quantities. It makes large thick, white shoots of delicious flaror, and we recommend it as the best rariety for all purposes. Pkt. 5c; oz. 10c; $1 / 1$ Ib. 25c; 1b. $85 \mathrm{c}$. 


\section{BEANS}

BEANS are naturally divided into several distinct classes, and each class is represented by a great number of varieties. You will find each class listed here, and we have chosen the best assortment of all varieties.

Beans require a light friable soil, with plenty of moisture, and they are very sensitive to frost. In California they should not be sown earlier than April 15th. In the garden the soil should be made mellow and rich, and kept so, and all pole varieties should be provided with poles or a trellis on which to climb. For a garden crop plant string beans in a succession every four weeks throughout the season. Sow in rows 18 inches to 24 inches apart and cover from one to two inches deep but not more. Keep the pods picked and the vines well watered and the beans will continue bearing much longer than if vines are allowed to become dry. Hoe the rows occasionally.

For farm crop plant about 25 pounds pole beans per acre in rows 36 inches apart; plant bush beans about 35 pounds per acre in rows 24 inches apart. Heavy clay or adobe soils are not best for beans. For the home garden there should be a succession of five or six varieties to provide the table with early, medium and late beans. Use one pound of seed for 100 feet of row.

Express and freight charges are not prepaid. Write us for special quotations if large quantities are wanted.

DWARF OR BUSH BEANS GREEN PODDED

In this class are the dwarf beans having green pods. The newest and best varieties are now absolutely stringless.

Canadian Wonder. A hardy and thrifty variety bearing long green pods of fair quality. The seed is a rich mahogany red and very attractive. Pkt. 10c;1b. 25c; postpaid; or $1 \mathrm{~b} .15 \mathrm{c}$; $10 \mathrm{lbs}$. $\$ 1.25 ; 100$ lbs. $\$ 10.00$, by express or freight, charges to be paid by purchaser.

Early Long Yellow Six Weeks. A long podded green variety. Plants strong and vigorous and leaves large; of fair quality. Seed long. kidney-shaped, light-yellow with darker marks about the eyes. Pkt. 10c;1b.25c, postpaid; or by express or freight, 1b. 15c; $10 \mathrm{lbs}$. $\$ 1.25$

Extra Early Refuǧee. A very early, greenpodded variety, with medium-sized, green, fleshy pods; seed drab, freely spotted with dark purple. The vines are smaller and of more upright growth, and leaves a little larger than the Late Refugee. Pkt. 10c; 1b. 25c, postpaid; or by express or freight, 1b. 15c; 10 lbs. $\$ 1.25$.

\section{EXTRA EARLY RED VAL-}

ENTINE A popular variety; erect vine with length fleshy round leaves. Pods of mediuin length; fleshy, round, and saddle-backed, with red. Pkt. 10c; ib. 25c, postpaid; or by red. Pkt. 10c; 1b. 25c, postpald; or b
express or freight, 1b. $15 \mathrm{c} ; 10 \mathrm{lbs}$. $\$ 1.25$.

\section{REFUGEE, OR 1,000 TO 1}

A variety rather later than other green-podded varieties. Vines large, spreading, and very hardy; pods long and green, becoming white streaked with purple as they mature. Seed yellowish; heavily splashed with bluish black. Pkt. 10c; 1b. 25c; postpaid; or by express or freight, $1 \mathrm{~b} .15 \mathrm{c} ; 10$ lbs. $\$ 1.25$.

Early Mohawk. A liardy and early variety, with large, flat, darkgreen pods with tapering points; seed long, kidney-shaped; drab, purple, and brown. Pkt. 10c; purple, and brown: Pkt, 10c; press or freight, 1 b. $15 \mathrm{c} ; 10$ press or fr. $\$ 1.10$.

Dwarf Horticultural. A very vigorous variety with large leaves; used as a shell bean, green or dried. Pods are of medium length, slightly curved, and when nearly ripe are striped and splashed with crimson on yellowish-brown; seed pale pink, splashed with bright red. Pkt. $10 c ; 1 b .30 c$, postpaid; or by express or freight, lb. 20c;
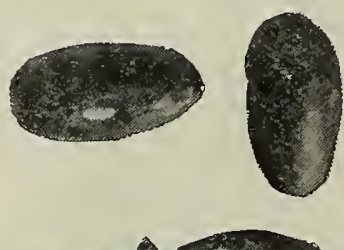

In this state the bean crop is so far limited only by the amount that can be profitably sold-the best bean districts are in San Louis Obispo, Santa Barbara and Ventura counties. The California bean crop in 1909 was 2, 500,000 sacks, and is being increased each year. Commercial plantings are made usually from May $10 \mathrm{th}$ to 25 th.

Black Valentine. A long-podded green variety, especially recommended for shipping. Seed black. Pkt. 10c; 1b. 30c: postpaid. By express or freight, 1 b. 20c; $10 \mathrm{lbs}$., $\$ 1.75$.

GIANT STRINGLESS GREEN POD. An exceedingly productive and very handsome sort. The pods mature a few days later than those of Stringless Green Pod, and are a little longer and more nearly straight. The quality is very good. Leaves small and light green. Seed long, slender, yellow. Pkt. 10c; 1b. 30c, postpaid; or by express or freight, lb. $20 \mathrm{c} ; 10$ lbs. $\$ 1.50$.

LONGFELLOW. This variety produces an abundance of large green pods which are very ten-
der and of fine flavor. The pods der and of fine flavor. The pods are long, slender and straight. by express or freight, $1 \mathrm{~b}$. $15 \mathrm{c}$ $10 \mathrm{lb}$. $\$ 1.25$.

ENGLISH OR BROAD WINDSOR This is not a string bean of any sort, but a very well-known popular variety with many farmers. Familiarly the Horse Pean Pkt $100^{\circ}$ the or freight, 1b. 15c; $10 \mathrm{lbs}$. 70c: $100 \mathrm{lbs}, \$ 6.00$.

MORSE SEEDS GIVE RESULTS

Singac, N. J.,
Sept. 21, 19io.
Dear Sirs: I purchased some of
I pur seed last spring when I
was out west and sent it home
here and the results have as-
tounded the natives. I desire
your catalogue now for refer-
ence next spring. If the seed
can be shipped here by express
or mail at a reasonable expense
I shall order all my seed from
you. Faithfully,
W. R.
Mme. Schumann-Heink.

The express rate is no more than 8 cents per pound anywhere East, and is much cheaper to near points. Remember we prepay all charges on seeds except on Beans, Peas, Corn, Onion Sets, and Field Grass and Clover Seeds. 


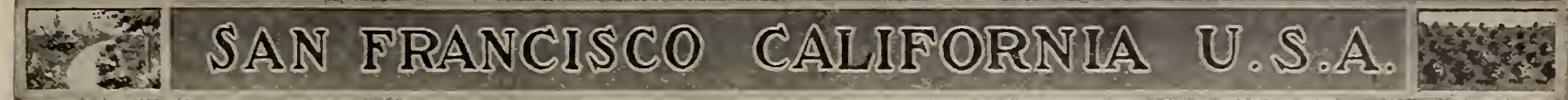

French String Bean. A hardy green-podded rariety, with black seed. Is much esteemed by the Italian market-gardeners for a rery productive string bean and a good shipper. Pkt. 10c; 1b. $25 \mathrm{c}$, postpaid; or by express or freight, 1b. $15 \mathrm{c} ; 101 \mathrm{bs}$. 90c; 100 lbs. $\$ 8.50$.

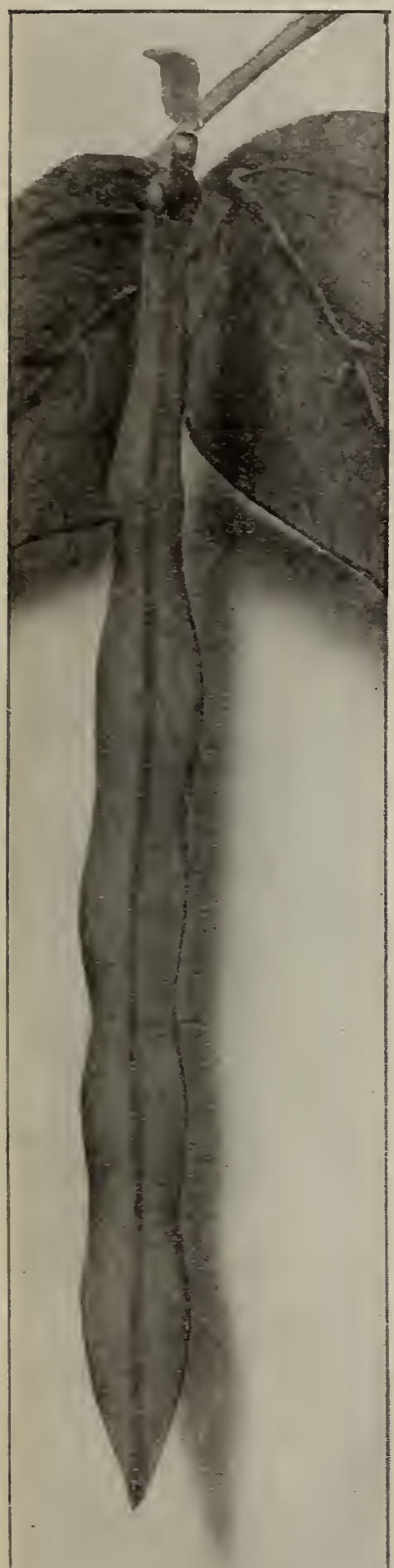

STRINGLESS GREEN POD A rery raluable iety absolutely free from strings. Is rery earlseen-podded varrather round re for real brow. Pkt $10 \mathrm{c}$ ib. $30 \mathrm{c}$ postpaid; or by express or freight, 1b. 20c; 10 lbs. $\$ 1.50$.

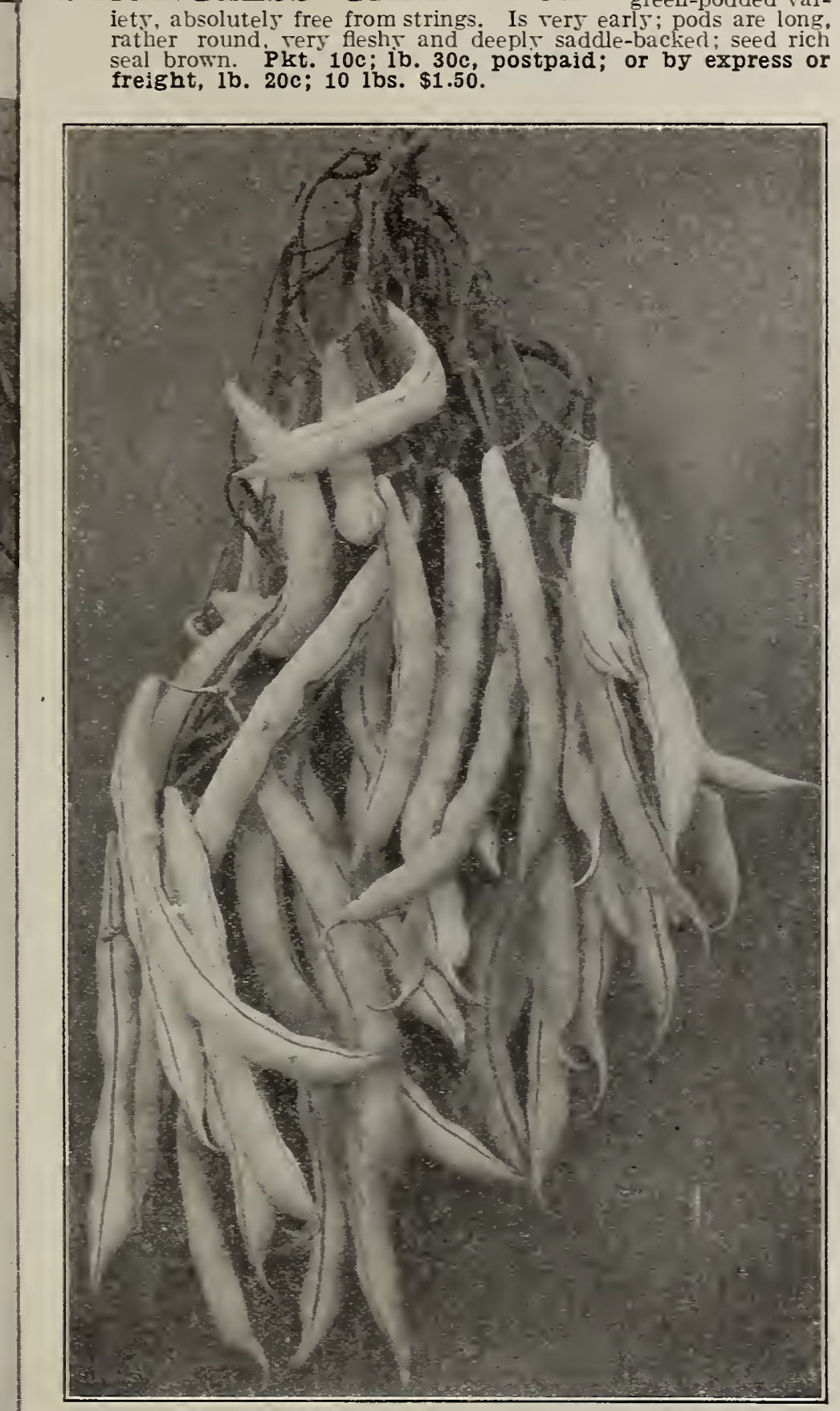

Refugee, or 1000-to-1

An extremely productive Bean. Note the number of pods.

with marks darker about the eses. Pkt. $10 \mathrm{c} ; 1 \mathrm{~b}$. $25 \mathrm{c}$, post-
paid; or by express or freight, $1 \mathrm{~b}$. $15 \mathrm{c} ; 10 \mathrm{lbs}$. $\$ 1.10$.
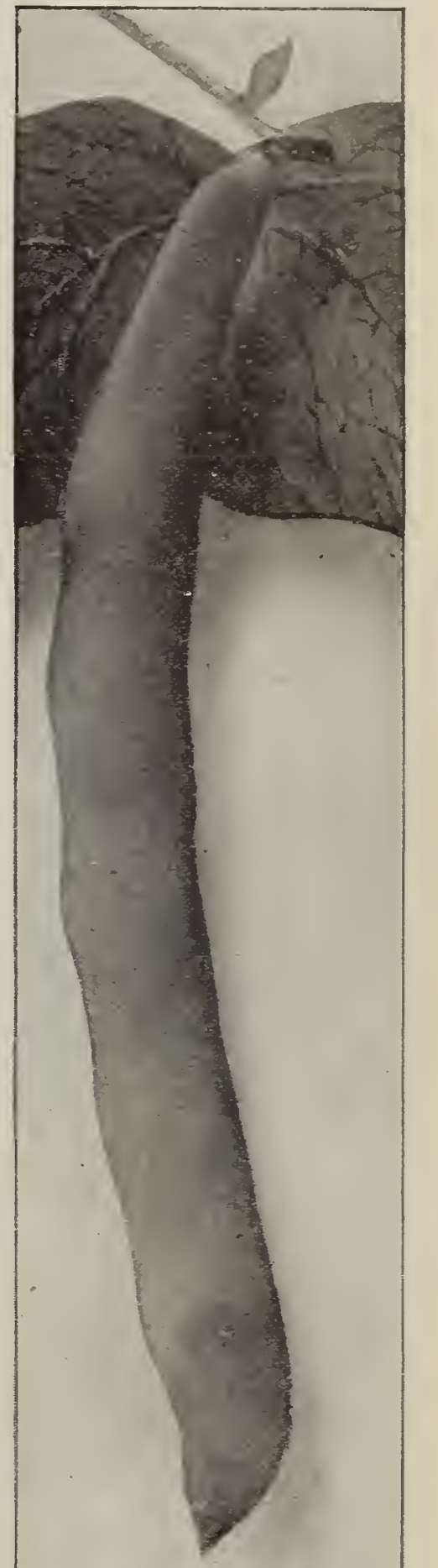

ound Yellow Six Weeks. A large, vigorous, productive bean, with long, straight, flat, light-green pods, seed lightt-5ellow:
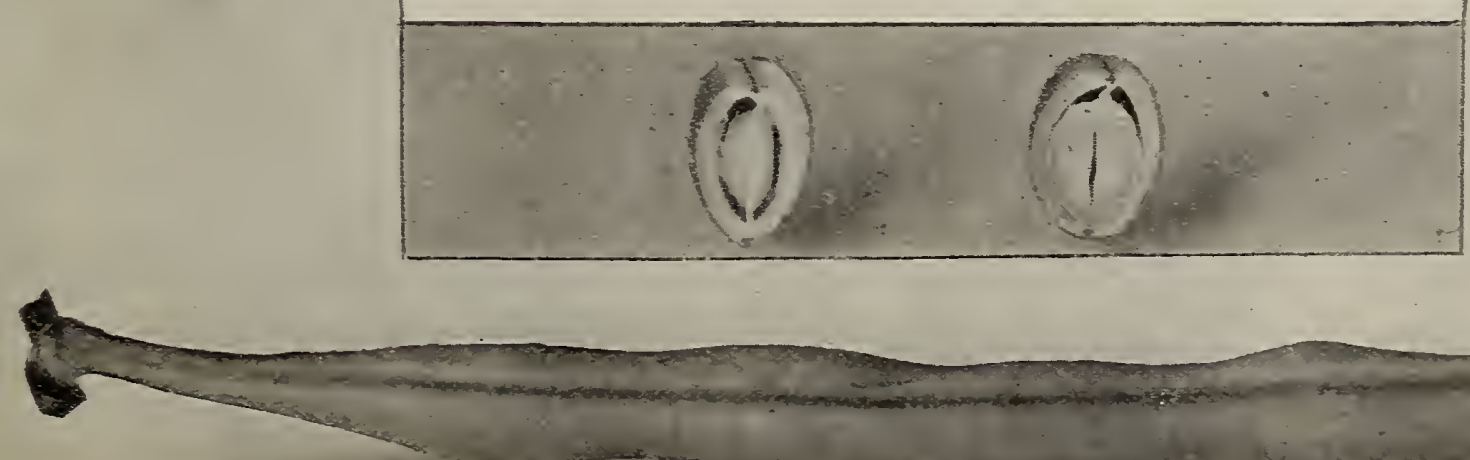


\section{DWARF OR BUSH BEANS-WAX PODDED}

In this class are the dwarf beans, having creamy white, yellow, and golden yellow pods. Most of the varieties we list are stringless. The choice of wax or green podded varieties is purely a matter of cholce. Both classes are quite hardy and

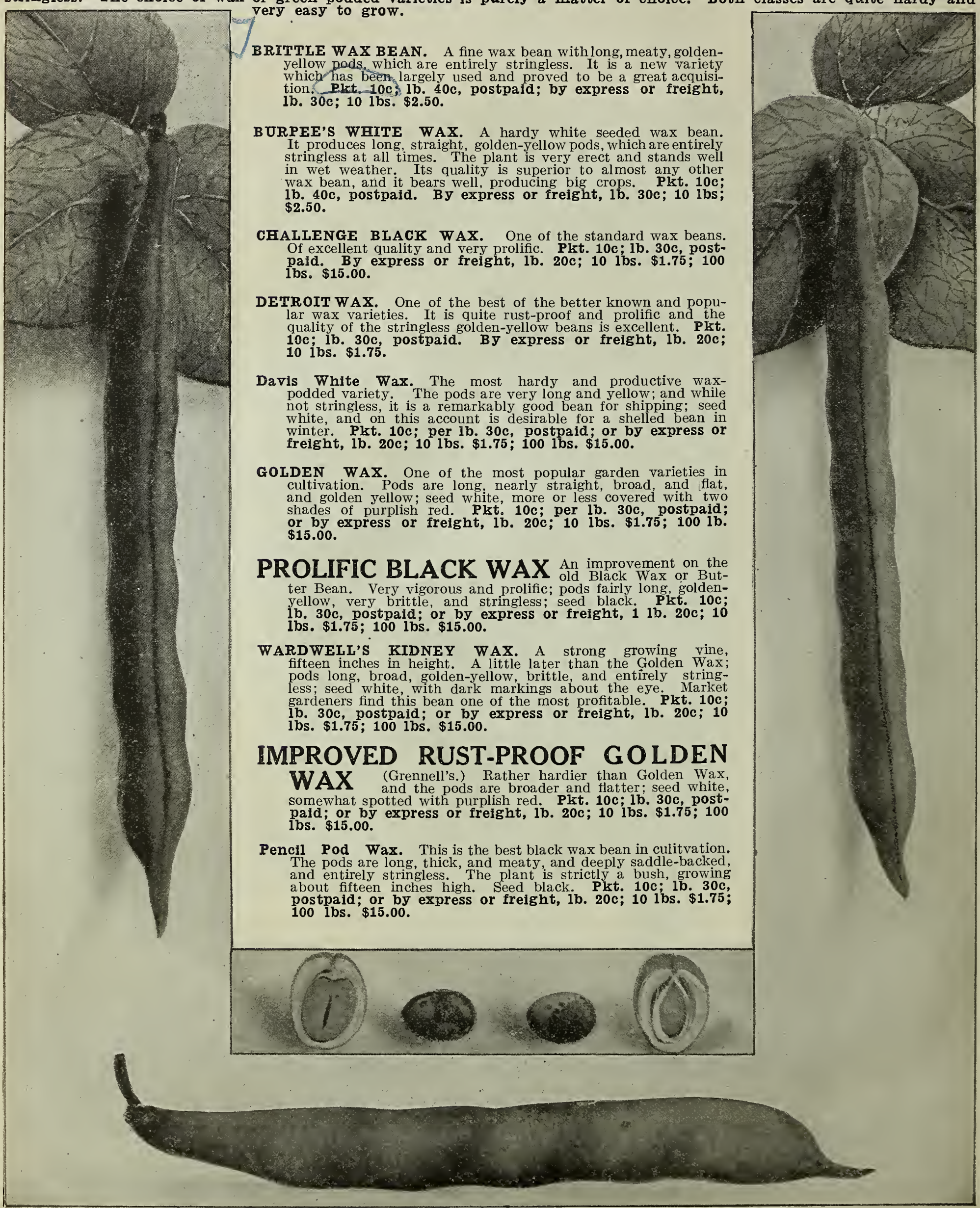

Improved Rust-Proof Golden Wax Bean. 


\section{SAN FRANCISCO, CALIFORNIA. U.S.A}

\section{POLE OR RUNNING BEANS}

\section{GREEN AND WAX PODDED}

These beans require a pole or trellis to climb on, if planted in the garden, although when raised as a seed crop in the open field they need no support whaterer. Pole beans are usually rerr prolific, and bear longer pods and a great mant more of them than the bush rarieties. For home garden use set the poles well in first scrape the soil amar to a depth of two inchs and irrigate $\pi^{2}$ ell. Then plant fire to nine beans to each hill corering to a depth of one inch. Sare only the best three or four plants. Pole Beans will continue bearing often planted $w$ it hout poles.

Burger's Pole. \& new pole rariety of great merit. Bears long, brittle, stringless pods of excellent flaror. It rirals all other pole beans and is destined to become the most popular of all. 20c; 10 Ibs. $\$ 1.50 ; 100$ lbs. $\$ 13.00$.

Cut Short, or Corn Bill. A popular rariety for planting among corn, since the rines climb the corn-stalks without the use of poles. Pods short and green: leares deep oreen: seed white spotted freel. with reddish brown. Pkt. 10c; 1b. 25c, postpaid; or by express or freight, 1b. $15 \mathrm{c} ; 10 \mathrm{lbs}, \$ 1.35 ; 100 \mathrm{lbs} . \$ 12.00$.

EARLY GOLDEN CLUSTER WAX. A rerT popular, earlT, and fine rariet5; pods six to eight inches long, wide and flat. borne in clusters, each containing from three to six pods, Thich are golden sellow. The pods are of fine qualits and remain in con1b. 40c; postpaid; or by express or freight, lb. $30 \mathrm{c} ; 10 \mathrm{Ibs}$. $\$ 2.00$.

Horticultural or Speckled Cranberry. An old farorite. Pods short, pale green, becoming splashed with brownish red. Seed blush, pink. spotted with red. Valuable either green or dry
shelled. Pkt. 10c; 1b. 25c, postpaid; by express or freight, 1b. $15 \mathrm{c} ; 10$ lbs. $\$ 1.35 ; 100$ ibs. $\$ 12.00$.

Indian Chief or Tall Black Wax. A black-seeded rax rariets with thick. golden-5ellow pods. Very hardy and prolific, and the most popular of the pole Tax beans. Pkt. 10c; 1b. 25c, postpaid; by express or freight, Ib. $15 \mathrm{c} ; 10 \mathrm{lbs}$. $\$ 1.25 ; 100 \mathrm{Ibs}$. $\$ 11.00$.

\section{KENTUCKY- WONDER, OR OLD} HOMESTEAD The most popular of the pole rariwhere beans are planted. It grows luxuriantly and bears for a long period. Pods are rers long. Ters flesh5: and deepls creased or saddle-backed, green in color, and stringless, seed freight,

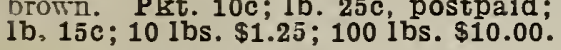

Kentucky Wonder $\mathbf{W}$ ax. An excellent rariets, and one of the Ters best pole beans. The pods are long, rers thick, meats, deeply saddle-backed, entirely stringless, and bright jellow in color. The vine is thritty and rery prolific. Seed deep brown. 10 Ibs. $\$ 1.50$.

Lazy Wife. A green-podded rarietr bearing good, long pods in clusters; stringless and of peculiarls fine flaror; seed rather large, thick and white. Pkt. 10c; lb. 30c, postpaid; by express or freig bt, $1 \mathrm{~b} .20 \mathrm{c} ; 10 \mathrm{Ibs} . \$ 1.50 ; 100 \mathrm{lbs}$. $\$ 14.00$.

Scarlet Runner. The rell-known and old-fashioned climber, having bright scarlet, pea-like flowers. It not onls holds its place as a flower, but the pods when roung are of fine qualit for cooking. Seed large, bright scarlet, heavils blotched with purple. Pkt. 10c; 1b. 35c, postpaid; by express or freight,
Ib. $25 \mathrm{c}$.

White Creasebaci. An earls, green-podded rariets. Pods fire to six inches in length, deeply creased or saddle-backed, and borne in clusters. Are rers fleshr and stringless: seed white and can be used as a shelled bean for winter use. Pkt. 10c;1b. 25c; postpaid; or by express or freight, Ib. $15 \mathrm{c} ; 10 \mathrm{lbs}$. $\$ 1.25$; 100 lbs. $\$ 11.00$.

White Dutch Case Knife. A climbing rariety with long, flat, irregular pods, which become creams white as thes mature; seed broad, flat and clear white Plat 10c; 1b. 25c postpaid; by express or freight, $1 \mathrm{~b} .15 \mathrm{c} ; 10 \mathrm{lbs} . \$ 1.20 ; 100 \mathrm{lbs} . \$ 10.00$.

Danish Consulate, Yokohama, Japan. Aug. 25, ' 10 .

I must again tell rou that the flower and regetable seeds rou sent to me earls this spring hare prored most satisfactory, and I hare had pleasure in recommending sou to sereral friends.

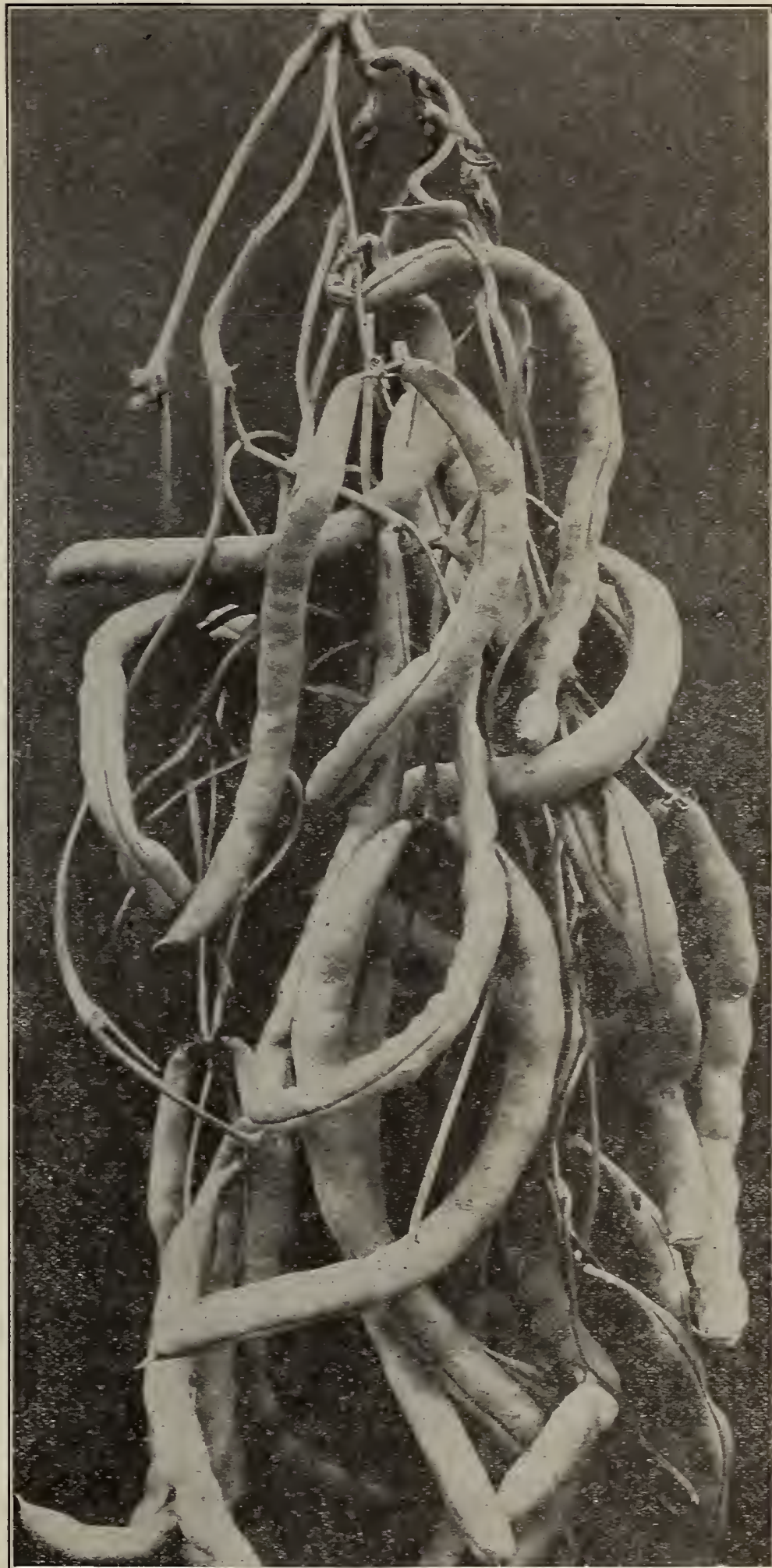

Kentucky Wonder Bean-(Much reduced pods) Brittle, tringless, meat 5 , delicious flaror

CALIFORNIA VEGETABLES

(Mailed postpaid for \$2.00) JUST PUBLISHED.

For two rears this work on gardening and regetable groming in California has been awaited by many planters. The book is standard and authentic for California conditions and is most valuable. By Prof. E. J. Wickson, Dean in the College of Agriculture of the Unirersity of California. 


\section{LIMA BEANS}

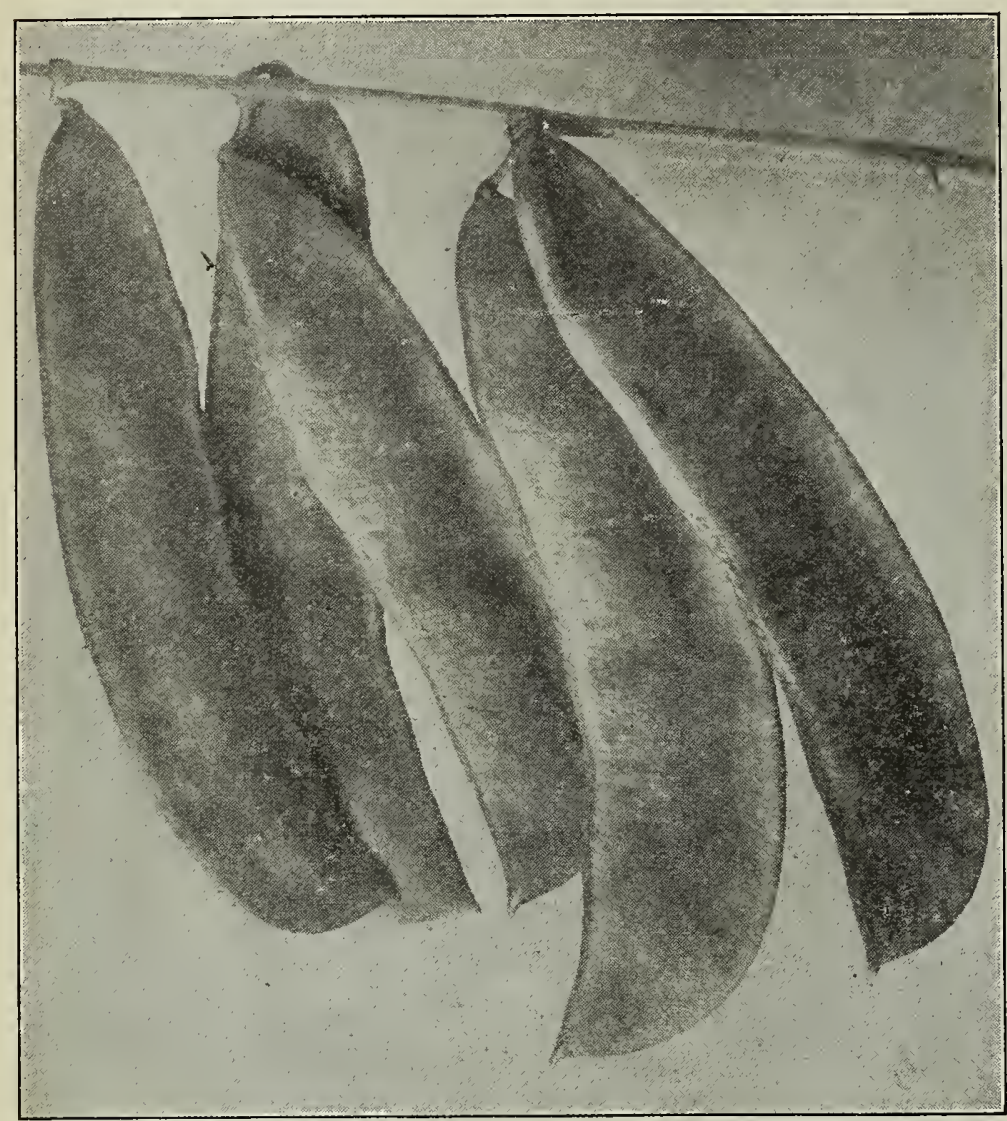

Henderson's Ideal Lima Beans

Lima beans are delicious when used green shelled, and can be grown for this purpose in any climate. The dry ripened bean is also a staple article of food for winter use, but in California these beans ripen only from San Luis Obispo County and south to Pasadena. San Buenaventura counties, where we grow our stock.

\section{BUSH VARIETIES}

BURPEE IMPROVED BUSH $\begin{gathered}\text { This is one of the } \\ \text { greatest of mod- }\end{gathered}$ ern vegetable introductions and we have secured for our customers some seed of it direct from the introducer.

This bean produces magnificent crops of pods, which measure from five to six inches long by one and one-quarter inches wide. As compared with the original Burpee Bush Lima, both pods and beans are very much larger, while the beans, either green or dry, are nearly twice as thick. The beans have the same luscious flavor as the best flavored Limas, and are ready to use six to eight days earlier. It will outyield the Burpee Bush lima by fully one-third, this greater yield being due to the increased size of both pod and beans. The dried beans are Pht. 10c; 1 b. 35c, postpaid; by express or freight, 1 lb. $25 \mathrm{c}$; 10 lbs. $\$ 2.00$.

BURPEE'S BUSH. The best late dwarf variety. Plant eighteen to twenty-four inches high; very prolific. Pods large, and the beans are also large and heavily ribbed. Will bear until stopped by frost. Pkt. $10 \mathrm{c} ; 1 \mathrm{~b}$. 35c, postpaid; by express or freight, $1 \mathrm{~b} .25 \mathrm{c} ; 10 \mathrm{lbs}$. $\$ 1.75 ; 100 \mathrm{lbs}$. $\$ 15.00$.

Dreer's Bush or Xumerle. A very prolific variety, a little later than Burpee's and having short, thick pods, closely filled with short, almost round, seed. The plant does not grow upright, but spreads or trails over the ground about three feet in diameter. 10 1b. $\$ 1.60 ; 100$ lbs. $\$ 15.00$.

FORDHOOK BUSH This bean is of the type of Dreer's

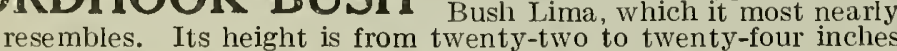
and it bears its beans in clusters of two to five, well out from the plant on long spikes. There are from three to five beans in

\section{BUSH VARIETIES-Continued.}

each pod, with an average of four. The beans are round and thick, like those of Dreer's Bush, and have the same mild, delicious flavor. This delicious bean is far ahead of anything which anybody has known in lima Beans up to the present time. $25 \mathrm{c} ; 10$ ibs. $\$ 2.00$.

Henderson's Bush. The earliest variety we have, being fully two weeks earlier than any other variety. Plant about sixteen inches high and very prolific. Beans are small. Especially recommended where the season is short. Pkt. 10c; lb. 30c,
postpaid; by express or freight, $1 \mathrm{lb}$. 20c; 10 1bs. $\$ 1.60$; 100 lbs. $\$ 15.00$.

\section{POLE VARIETIES}

Challenger, or Dreer's Pole. A splendid pole variety, quite early, very prolific, and of very fine quality. The pods are borne in clusters, and the beans are sliort and thick, almost round, and crowded so closely in the pod that the ends are flattened. A very popular variety with market gardeners. Pkt. 10; 1b. 30c, postpaid; by express or freight, 1b. 20c; 10 lbs. $\$ 1.60 ; 100$ lbs. $\$ 15.00$.

EARIY LEVIATEAN. One of the newer varieties and the very best pole variety in cultivation. Vine very tall and strong; pods long and borne in clusters; beans large and white. Is early, express or freight, $1 \mathrm{~b} .20 \mathrm{c} ; 10 \mathrm{lbs}$. $\$ 1.60 ; 100 \mathrm{lbs}$. $\$ 15.00$.

HENDERSON'S IDEAL A new variety with large and prolific and one of the best pole varieties. Pkt. 10c; $1 \mathrm{~b}$. $30 \mathrm{c}$, postpaid; by express or freight, $1 \mathrm{~b} .20 \mathrm{c} ; 10 \mathrm{lbs}$. $\$ 1.50$ 100 lbs. $\$ 12.50$.

KING OF THE GARDEN One of the best and crop varieties. It is medium early and has very popular main to $6 \frac{1}{2}$ inches long, which are well filled with 4 or 5 good-sized beans. The pods are very straight and handsome, and the fine, hardy vines bear abundantly. Pkt. 10c; 1b. 30c, postpaid; by express or freight, $1 \mathrm{~b}$. 20c; $10 \mathrm{lbs} . \$ 1.60 ; 100 \mathrm{lbs}$. $\$ 15.00$.

Large white. A very good variety of the pole or running type. Is very prolific and of good quality, but is now being superseded by Early Leviathan. Pkt. 10c; 1b. 25c, postpaid; by express or freight, $1 \mathrm{~b} .15 \mathrm{c} ; 10 \mathrm{lbs}, \$ 1.25 ; 100 \mathrm{lbs} . \$ 11.00$

Sieberts Early. A standard early variety, with good-sized pods and large beans. Pkt. 10c; lb. 30c, postpaid; by express or freight, 1b. 20c; 10 ibs. $\$ 1.60 ; 100$ lbs. $\$ 15,00$.

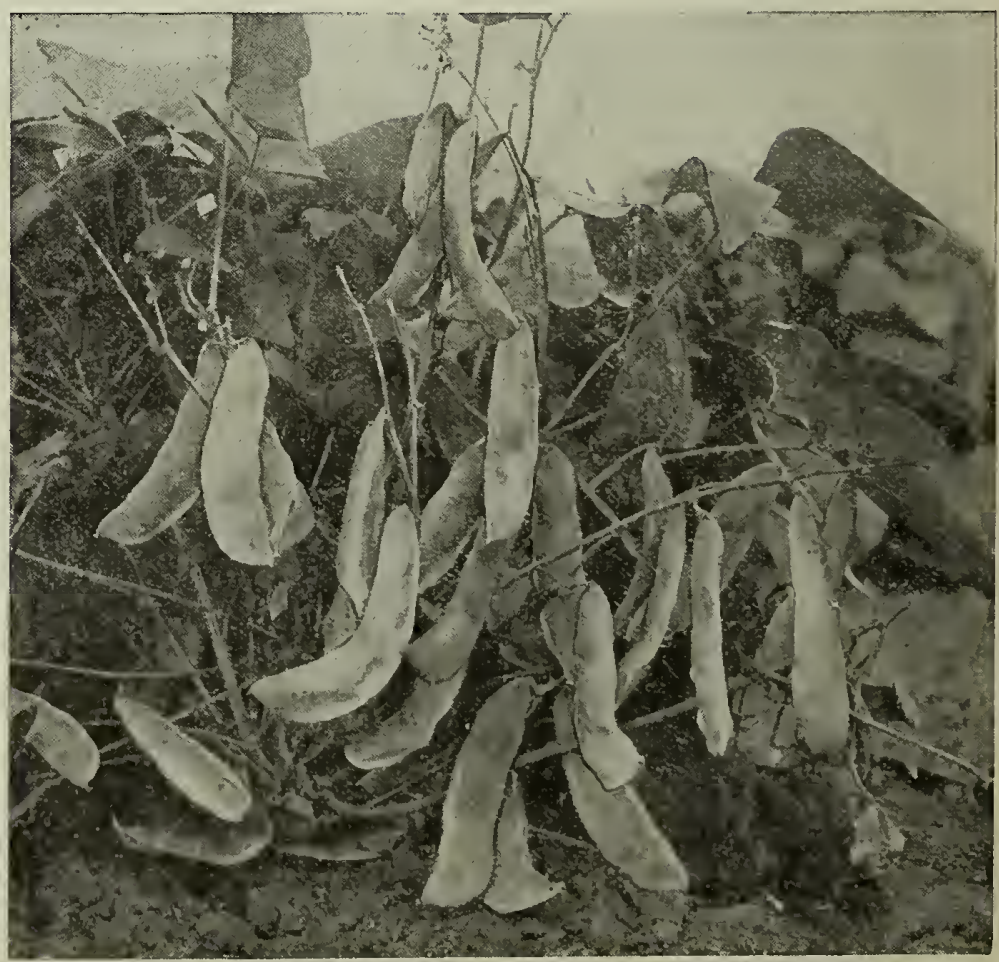

A Plant of Fordhook Bush Lima 


\section{BEETS - FOR TABLE AND FARM}

Beets are divided into three classes-TABLE, MANGEIS, or STOCK-FEEDING, and SUGAR.

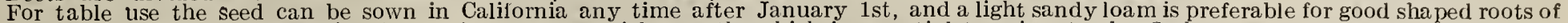
good color. The soil must be rich and moist to get a quick growth, which is essential to crisp, tender flesh.

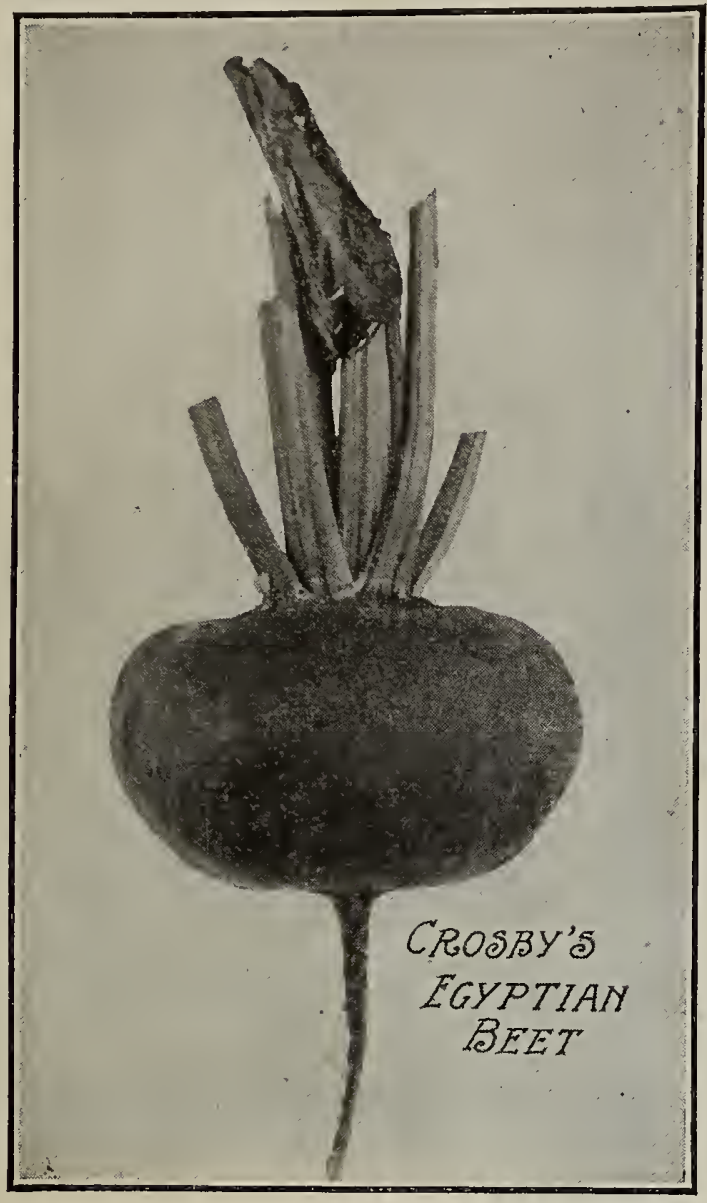

MANGEL WURZEL

OR STOCK FEEDING. For main crop, sow about March 1st in rows 22 inches apart, using about six pounds of seed per acre. To get good, large and uniform beets, the plants should be thinned when in the fourth leaf to six inches apart in the row.

If large lots of seed are wanted, write us for special prices.

Champion Yellow Globe. A large, round, orange-yellow variety. Good for shallow soils. Pkt. 10c; 1b. 35c; postpaid, or by freight or express, 1b. 25c; 10 lbs. $\$ 2.00$.

Giant Yellow Intermediate or Gate Post. A yellow-skinned variety with white flesh, zoned with yellow shape. Pkt. 10c; 1b. 35c, postpaid; or by freight or express, 1b. $25 \mathrm{c} ; 10$ 1bs. $\$ 2.25$.

GOLDEN TANKARD YELLOW- Very large. FLESHED fleshed variety. Giant oval shape: small yellow-stemmed top. Plt. 10c; 1b. 40c, MAMMOTH LONG RED The largest of all the iest cropper. Skin is red; flesh white, zoned with red heavint variety produces a larger amount of good feed than any other beet, 35c, postpaid; or by freight or express, 1b. 25c; 10 ibs. $\$ \mathbf{2 . 0 0}$.

Red Globe. A large globe-shaped variety with red skin. Flesh white, zoned with pink. Pkt. 10c; 1b. 35c, postpaid; or by freight or express, 1b. 25c: 10 lbs. $\$ 2.00$.

Yellow Leviathan. A large yellow olive-shaped variety, with clear, white, brittle flesh. The root grows partly out of the ground. rendering it easy to dig. Pkt. $10 \mathrm{c} ; 1 \mathrm{~b}$. 35c, postpaid; or by freight or express, $1 \mathrm{~b}$. 25c; $10 \mathrm{lbs}$. $\$ 2.00$.

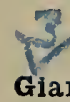

\section{SUGAR BEETS}

Giant Half Sugar for Stock-Feeding. (Green Top) A beet which is superior to mangels for stock-feeding purposes, as it is more nutritious, having a large amount of sugar. It is oval in shape and grows partly out of ground. Is of large size and yields enormous crops. Pkt. 10c; 1b. 35c, postpaid; or by freight or express, 1b. 25c; $10 \mathrm{lbs}$. $\$ 2.00$. 1b. $75 \mathrm{c}$.

\section{TABLE VARIETIES} More globe-shaped than Extra Early fine quality. Bright red with clear vermilion RED One of the best table varieties, and the one Globe-shaped; bright, but rich red flesh. Tops small and green. Pkt. 5c; oz.
10c; 1/4 1b. 30c; 1b. 90c.

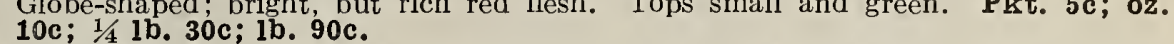
rly Eclipse. A fine, early table variety, top-shaped or tapering globe-shaped. Flesh
deep crimson, zoned with pink. Crisp and sweet. Pkt. 5c; oz. 10c; 1/4 1b. 25c;

Elood Turnip. A good variety for Summer and Autumn use. Is turnipLong Blood. A half-long variety, about eight inches long and tapering abruptly。 of a lighter shade. Dark leaves; a good table variety and very early. Pkt. 5c; of a lighter shade. Dark leave

IONG SMOOTH DARK BLOOD. A very desirable variety for light soils, where MORSE'S IMPROVED BLOOD TURNIP A turnip-shaped deep red flesh. Tops green. A fine selected strain, $w$ i $t h$ deep red flesh. Tops green. A fine selected strain and one
of the best varieties. Pkt. 5c; oz. 10c;1/4 1b. 30c;1b. $\$ 1.00$.

Klein Wanzeleben $\mathbf{s} \mathbf{u}$ a $\mathbf{r}$. Th $\mathrm{T}$ most popular variety for sugar factories $T$. $h$. suctories. $\mathrm{T}$ h pends on intellipent c a r e and development on the part of the seed grower. I is wedge-shaped, wide at the top and $t$ a p e rin $g$ gradually to a loc pound $40 \mathrm{c}$ 10c; pound 40c postpaid; or by freight or ex10 lbs. $\$ 2.50$.

ane's Improved Imperia] sugar. Large, thick. tapering variety. Yields lmost as much as mangels. Is sweet and rich and very desirable for stock. Pkt. 10c; 1b 35c, postpaid; or by freight or express, lb. $25 \mathrm{c} ; 10 \mathrm{Ibs}$. $\$ 2.00$.

Vilmorin's Improved sugar. A little smaller than Klein Wanzeleben, but even $\mathrm{r}$ i c h e $\mathrm{r}$ in sugar and a valuable variety for $s$ u a $r$ factories. Grows entirely under ground, and yields good crops under ordinary crops under ordinary conditions, Pkt. 10c; by freight or express 1b. $30 \mathrm{c} ; 10 \mathrm{lbs}$. $\$ 2.50$.

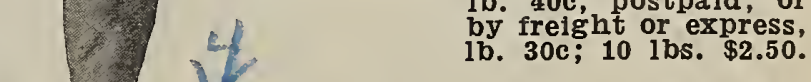

WHITE SUGAR (RED TOP.) A or feeding variety, producan little care. The root is large and very rich in sugar and while not suffciently so for sugar purposes, it makes a remarkably fine, rich food for stock. Pkt. $10 \mathrm{c}$; press, 1b. $25 \mathrm{c} ; 10$ lbs. $\$ 2.00$. 


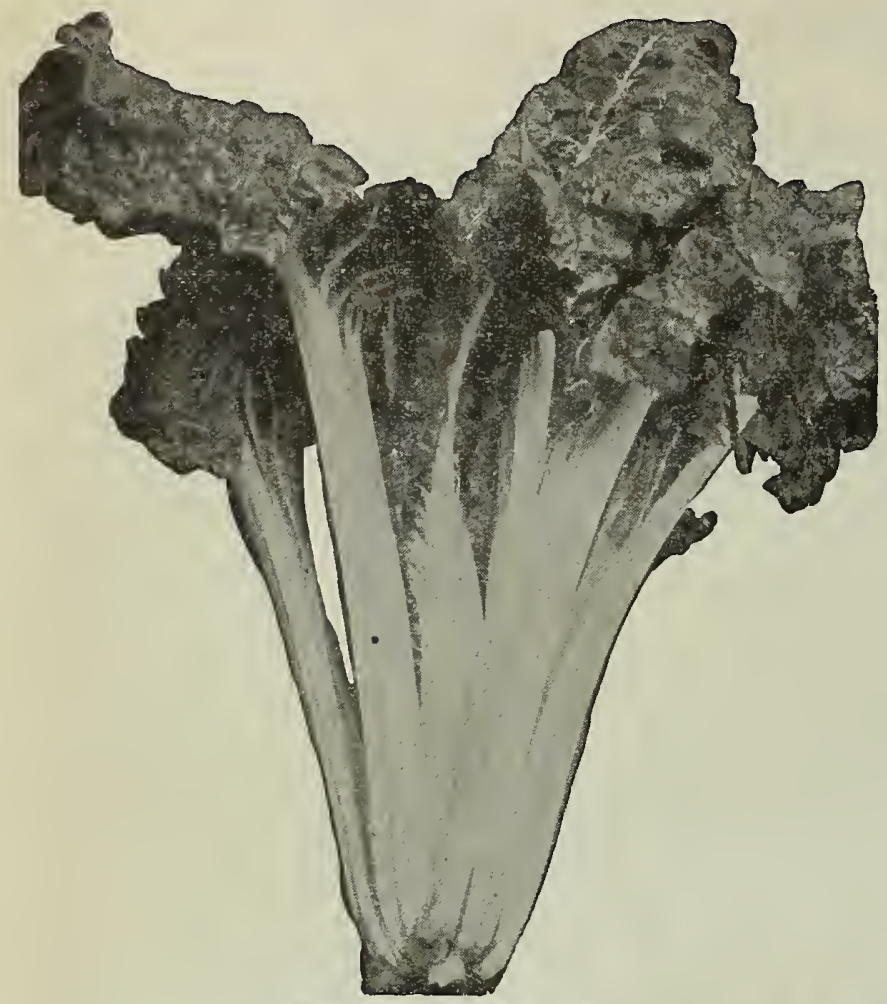

\section{SWISS CHARD OR SEA KALE BEET}

Sometimes called Spinach Beet. Used for greens by cutting the stem and leaf, which are also very ornamental. It resembles an ornamental beet top, but has no edible root. It is a plant which is becoming very popular and should be in every garden. Pkt. 5c; oz. 10c; 1/4 1b. 25c; 1b. 75c.

\section{BROCCOLI}

Should be treated the same as cauliflower, which it resembles. In fact, it is practically a coarse cauliflower, more divided in the head, grows larger and taller, and is hardier and easier to grow.

Plant and cultivate the same as Winter cabbage or kale.

EARLY LARGE WHITE. The best variety. Heads white and large. Pkt. 5c;0z. 40c; $1 / 4$ lb. $\$ 1.25 ; 1 \mathrm{~b} . \$ 4.00$.

Purple Cape. Good, large heads, which are tinged with purple. Pkt. $5 \mathrm{c}$; 0z. 35c; $1 / 4$ lb. $\$ 1.00 ; 1 \mathrm{~b}$. $\$ 3.50$.

\section{BRUSSELS SPROUTS}

The plants are very hardy and grow from two to three feet high, bearing a large mass of leaves at the top. The sides of the main stem are covered with three or four dozen small cabbage heads, which are broken off and cooked the same as cabbage.

IMPROVED HALF DWARF. The standard variety. Grows two or three feet high, and the stem is well covered with small, firm, round sprouts. Pkt. 5c; 0z. 15c; $1 / 4$ 1b. $45 \mathrm{c} ; 1 \mathrm{~b} . \$ 1.50$.

Swiss Chard (White)

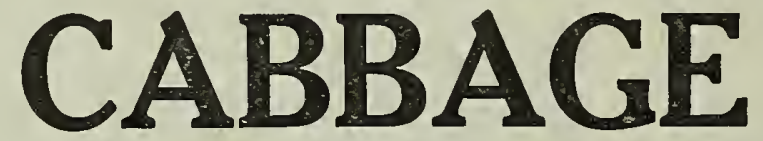

It is difficult to give definite cultural directions for cabbage, since it is possible to have good cabbage at all seasons of the year in some part of the country, and seed can be planted almost any time of the year. There are three good seasons for sowing the seed, however-in September for late Winter and early Spring cabbages, in March for Summer and Fall cabbages, and in June and July for Winter cabbages. The seed sprouts quickly, and is likely to come up very thick in the seed bed. It should be thinned early, or the plants become spindling, and then do not head well. Transplanted to the field, they should be put twelve inches apart, in rows eighteen inches apart. To prevent the heads splitting open in the field before they are ready to be harvested, the plants should be loosened a little at the root. Cabbages require considerable moisture, but too much water causes them to rot very readily.

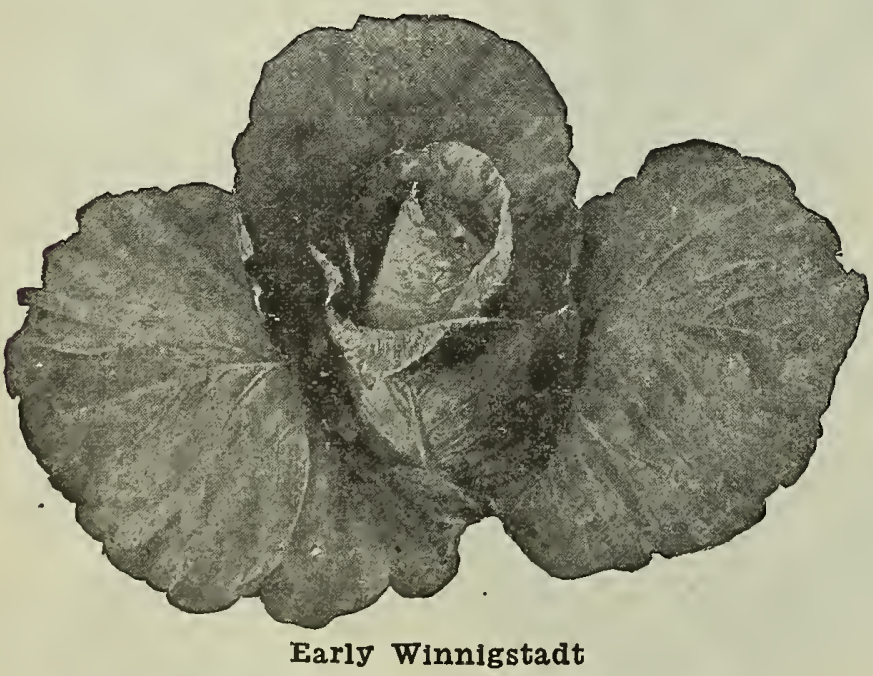

EARLIEST VARIETIES

Early Baseball. One of the earliest varieties. Forms tight, solid, perfectly globular heads of rather small size. Pkt. 5c; 0z. 30c;
$1 / 4$ 1b. 90c; 1b. $\$ 3.00$.

EARIY JERSEY WAKEFIELD One of the bee

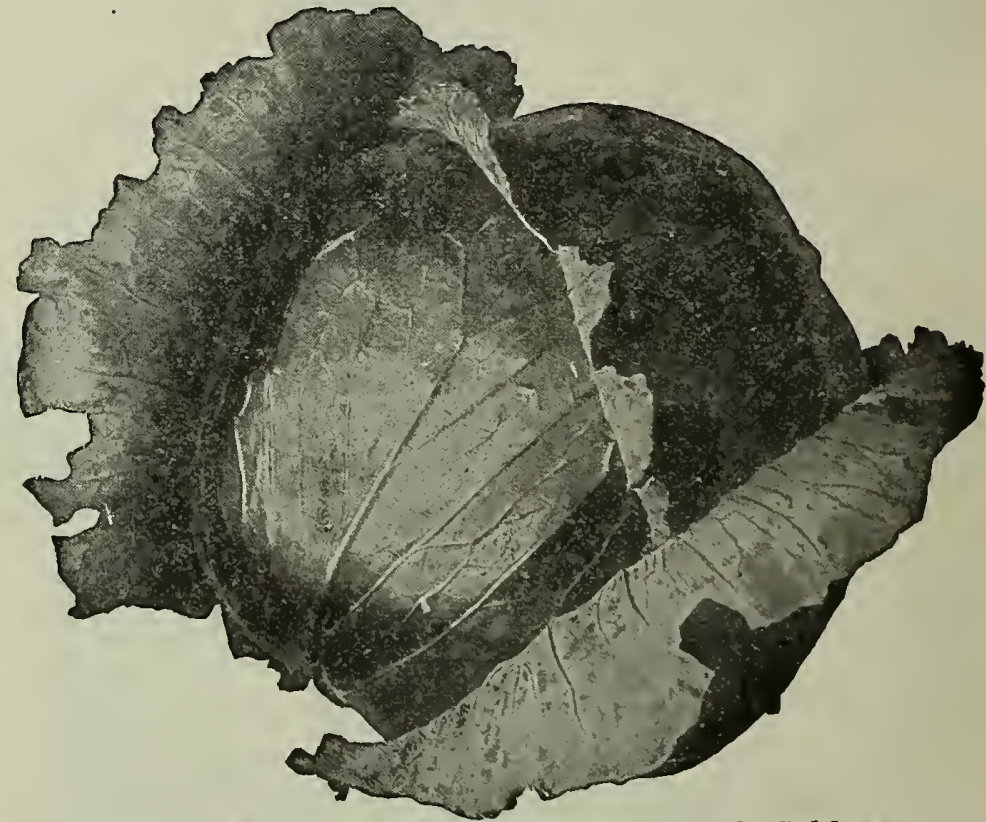

Morse's Selected Strain Early Flat Dutch Cabbage

JERSEY WAKEFIELD one of the best and most popular early varieties. Forms round, pointed heads resist cold and other unfavorable conditions to a great extent. Pkt. 5c; oz. 25c; 1/4 1b. 75c; 1b. $\$ 2.50$.

EARLY WINNIGSTADT A decidedly pointed head of good size and fine quality-the most sharply pointed of all cabA it very desirable; we recommebd it as one of the best early varieties. Pkt. 5c; oz, 20c; $1 / 41$ b. 60c; $1 \mathbf{b} . \$ 2.00$.

Early Spring. A very early flat-headed variety. Medium sized and good for summer use. Pkt. 5c; oz. 25c; 1/4 1b. 75c; 1b. \$2.50.

Large Early Wakefield (Charleston). Is very similar to Early Jersey Wakefield, but nearly a third larger and a little later. Pkt. $\mathbf{5 c}$ 0z. 20c; $1 / 4$ 1b. 60c; 1b. $\$ 2.00$.

\section{SECOND EARLY VARIETIES}

ALLHEAD EARLY. Probably the earliest of the large, flat-headed varieties. Is good for Summer, Autumn, and Winter crop. Desirable for all sorts of planting. Pkt. 5c;0z. 20c; 1/4 1b. 60c; 1b. $\$ 2.00$. 


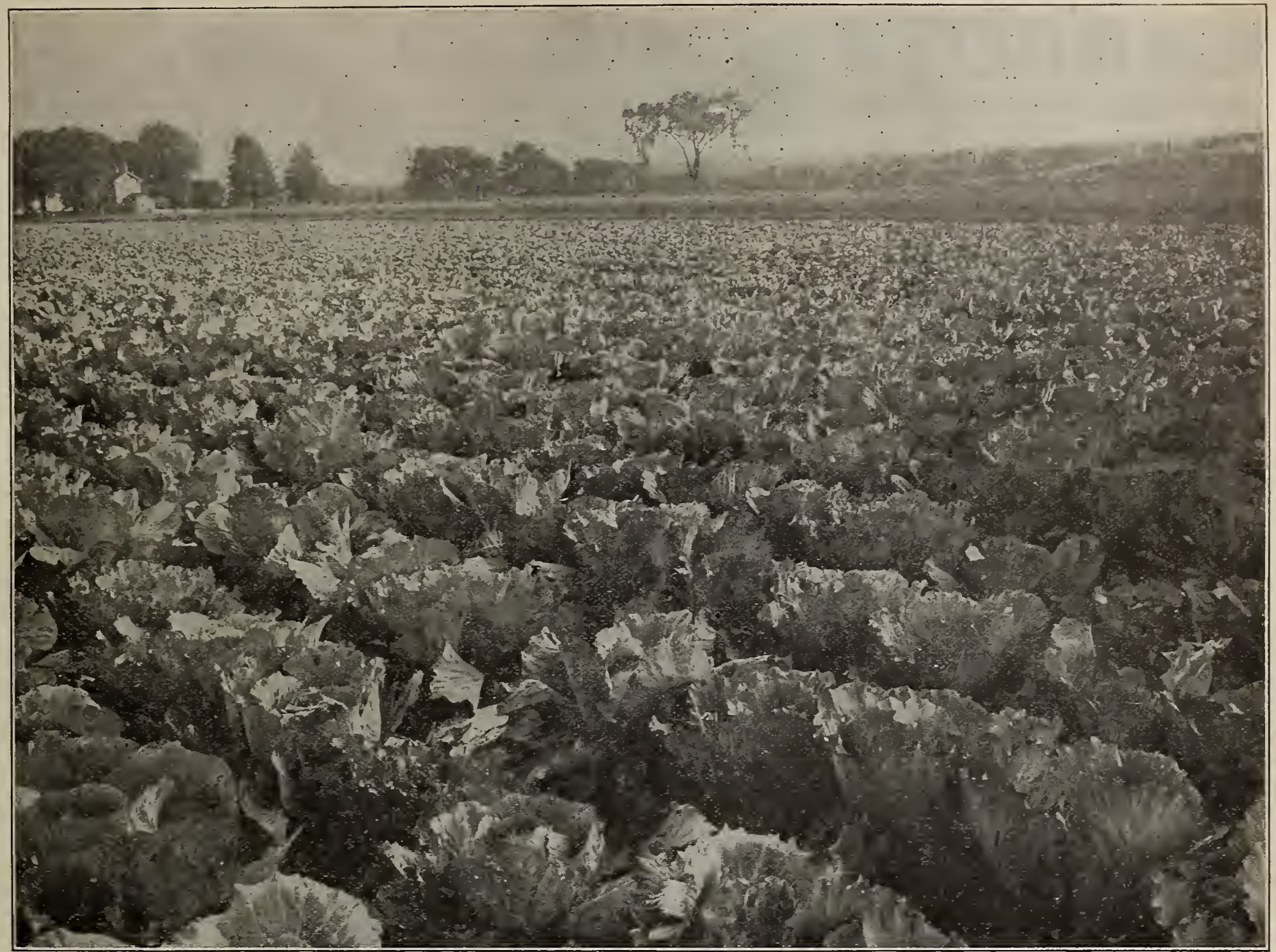

A Fine Field of Marketable EARLY JERSEY WAKEFIELD Cabbages

EARLY DRUMHEAD. Second early; round, flat heads. Pkt. $5 \mathrm{c} ; 0 \mathrm{z} .15 \mathrm{c} ; 1 / 4 \mathrm{lb} .60 \mathrm{c} ; 1 \mathrm{~b} . \$ 2.00$.

Early Dwarf Flat Dutch. A good flat-headed variety, with short stem and hard. firm head. Forms heads early and is valuable for Summer. Pkt. 5c; oz. 20c; $1 / 1$ 1b. 60c; 1b. $\$ 1.75$.

Fottier's Brunswick. One of the most popular of the flat-headed trpes, especially with the home gardener. Best for autumn and winter use. Pkt. 5c; oz. 20c; $1 / 4$ 1b. 60c; 1b. $\$ 2.00$.

Henderson's Early Summer. A desirable medium sized, early. flat-headed variety. A good keeper, and does well in summer
and autumn. Pkt. 5c; 0z. 20c; $1 / 4$ lb. 60c; 1b. $\$ 2.00$.

Henderson's Succession. Is about ten days later than Early Summer. Is a dwarf, flat head, light green, and very solid. Pkt. 5c;0z. 20c; $1 / 4$ lb. 60c; 1b. $\$ 2.00$.

MORSE'S SELECTED EARLY FLAT DUTCH A very superior strain of this variety. An early Pkt. $5 \mathrm{c} ; 02.35 \mathrm{c} ; 1 / 4 \mathrm{lb} . \$ 1.00 ; 1 \mathrm{~b}$. $\$ 3.50$.

\section{WINTER VARIETIES}

Autumn King, or Worldbeater. A fine winter variety of vigorous growth. Large, well-formed globular heads of bluish green. Pkt. $5 \mathrm{c} ; 0 \mathrm{z} .25 \mathrm{c} ; 1 / 41 \mathrm{~b} .75 \mathrm{c} ; 1 \mathrm{~b} . \$ 2.50$.

Burpee's Surehead. One of the most popular varieties. Large round, slightly flattened head; hard and firm. Pkt. 5c; oz. 20c round, slightly flatten

\section{DANISH BALL HEAD, OR THE HOL-} LANDER A very late variety, forming globular heads: shipper. The color is bluish-green. Pkt. 5c; oz. 30c; $1 / 41 \mathbf{b}$. $90 \mathrm{c} ; 1 \mathrm{~b} . \$ 3.00$

Premium Flat Dutch. A well-known, large, late variety. Flattish round heads, very solid and firm; has rather tall, stout stem. Pkt. 5c; 0z. 20c; $1 / 4$ 1b. 60c; $1 \mathrm{~b} . \$ 2.00$.
Sione-Mason Marblehead. Medium-sized, late, flat-headed variety, forming a good, solid head. The lea res a re bright green, We carry Cabbage Plants at various seasons. See list on page 39.

\section{RED CABBAGE}

Mammoth Rock Red. Best hard-headed, red variety. Large heads, globular, and very deep red on top. Outer leaves greenish. Especially used for pickling. Pkt. 5c; 0z. 20c; 1/4 1b.60c; 1b. $\$ 2.00$.

\section{CABBAGE-SAVOY}

Perfection Drumhead Savoy. A variety that is much prized in Europe and also by those who are familiar with it in this country. It is very sweet and crisp, and always tender. Heads medium

\section{COLLARDS}

A plant bearing a large mass of leaves on the top of a stout stalk It is a species of cabbage, and the flavor is the same. It bears leares all through the winter, and is used especially in the South for cabbage greens. Young plants may be started in boxes in early spring, and the roung plants transplanted, allowing plenty of room for each plant.

TRUE GEORGIA. The well known very large variety. Grows from four to five feet high, and forms a very large, loose head. Leaves are

\section{CORN SALAD OR FETTICUS}

A salad plant used as a substitute for lettuce in salads, or may be cooked like spinach for greens. It does well in winter and spring. On rich soil the leaves grow quickly and are exceedingly tender.

Large Leaved. Very tender leaves, which grow out rapidly after being cut. Pkt. $5 \mathrm{c} ; 0 \mathrm{z} .10 \mathrm{c} ; 1 / 41 \mathrm{~b} .20 \mathrm{c} ; 1 \mathrm{~b} .60 \mathrm{c}$. 

FOR TABLE AND STOCK

Good, sandy loam is best adapted for carrots of all varieties. The shorter varieties, however, can be sown on heavier lands, with good results. For garden, sow the early and short varieties at any time after January 1st. For general crop sow in the open field about April 1st, using two or three pounds per acre for rows sixteen to eighteen inches apart. While you get a good uniform root by thinning the young plants, it is not necessary to do so to get a crop of good, average carrots.

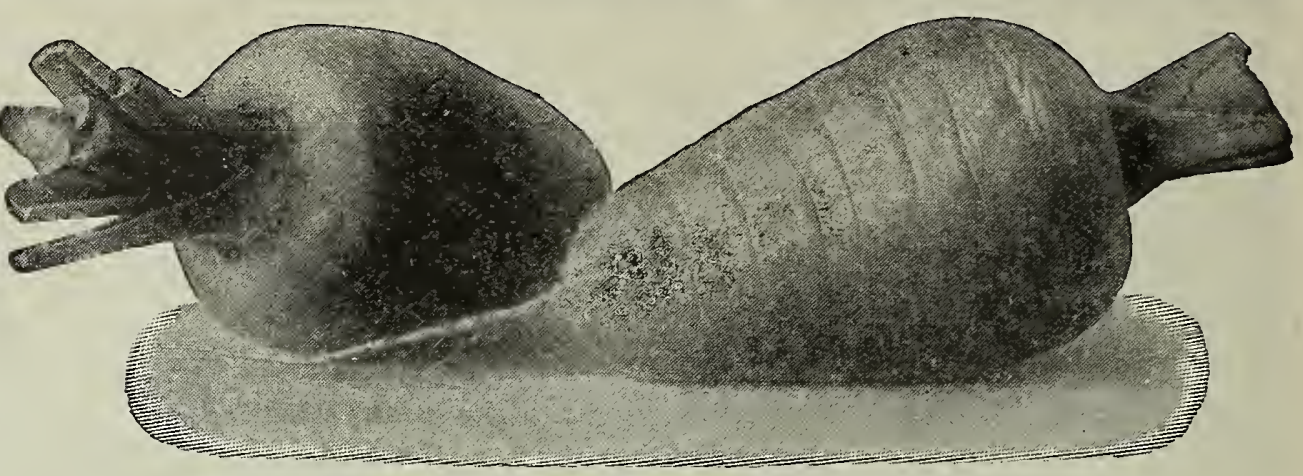

Oxheart, or Guerande Carrot (Much reduced)

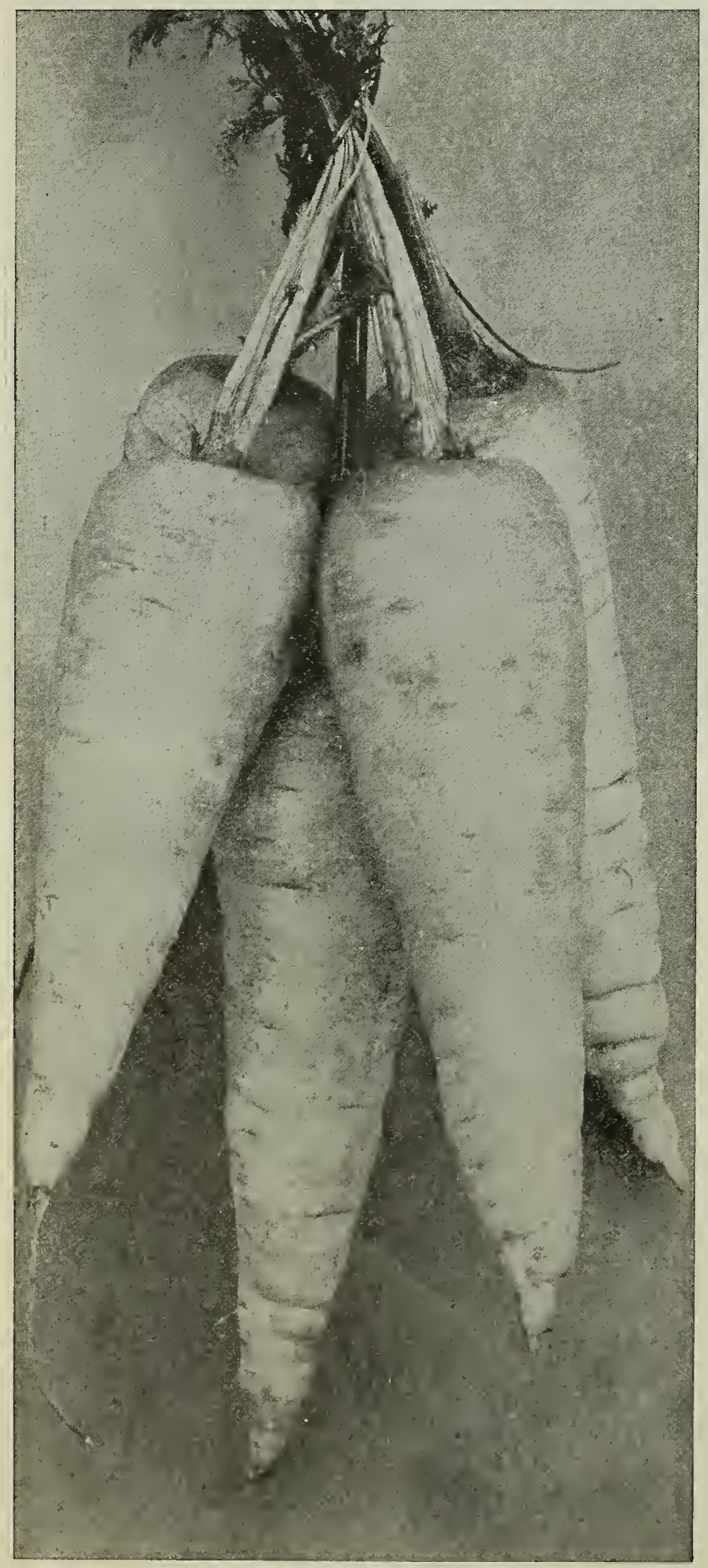

Improved Short White Carrot

Chantenay, or Model. A very popular variety for general purposes. five to six inches long; very stump-rooted, about three inches thick at shoulder; tapering slightly; bright orange-scarlet. Pkt. 5c;0z. 10c; $1 / 4$ 1b. 25c; $1 \mathrm{~b} .80 \mathrm{c}$

DANVER'S HALF-LONG The best variety for the most largely used not only for stock raising but for table use as well. The perfect type is about eight inches long and about two and a half inches wide at the shoulder, tapering to a sort of half-point at the bottom. Color is a bright orange-scarlet. It is a very heavy cropper. Pkt. 5c; 0z. 10c; $1 / 4$ 1b. 25c; 1b. 90c.

French Forcing. A very popular variety for forcing. The root is globe-shaped, with distinct tap root. Color bright orangescarlet. Pkt. 5c; oz. 10c; $1 / 4$ 1b. 30c; lb. $\$ 1.00$.

Half-Long Scarlet Stump-Rooted. A variety about as long as Danver's, but not so thick. It is of uniform thickness from shoulder to root, and very stump-rooted. Pkt. 5c; oz. 10c: shoulder to root, and
$1 / 41$. 25c; 1 b. $80 \mathrm{c}$.

IMPROVED SHORT WHITE. The most popular of all white varieties, being a heavy cropper and of a desirable shape to allow easy digging in heavy soils. The true type is very thick in the middle and should not taper abruptly from the shoulder. Pkt. 5c; 0z. 10c; $1 / 4$ 1b. 20c; $1 \mathrm{~b}$. 65c.

Large white Belgian. The best known and one of the oldest white varieties-is a long-pointed root, and should only be planted on light soils where roots are fairly easy to dig. The variety we offer does not grow above ground with a green shoulder as do some strains oz. $10 \mathrm{c}$ $1 /$ ib $20 \mathrm{c}$ Ib. 65 c.

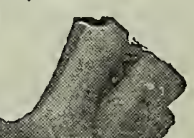
Scarlet Horn, or Early short Horn. A good, short variety, for table use. The full grown $t \mathrm{y} p$ i about three inches lo $n \mathrm{~g}$ a $\mathrm{d}$ 1 inches thick at the shoulder: $t$ at the ( only slightly and is very $\mathrm{st} \mathrm{u} \mathrm{m}$ poz. $10 c ; 1 / 41 b .25 c$; 1b. $90 \mathrm{c}$.

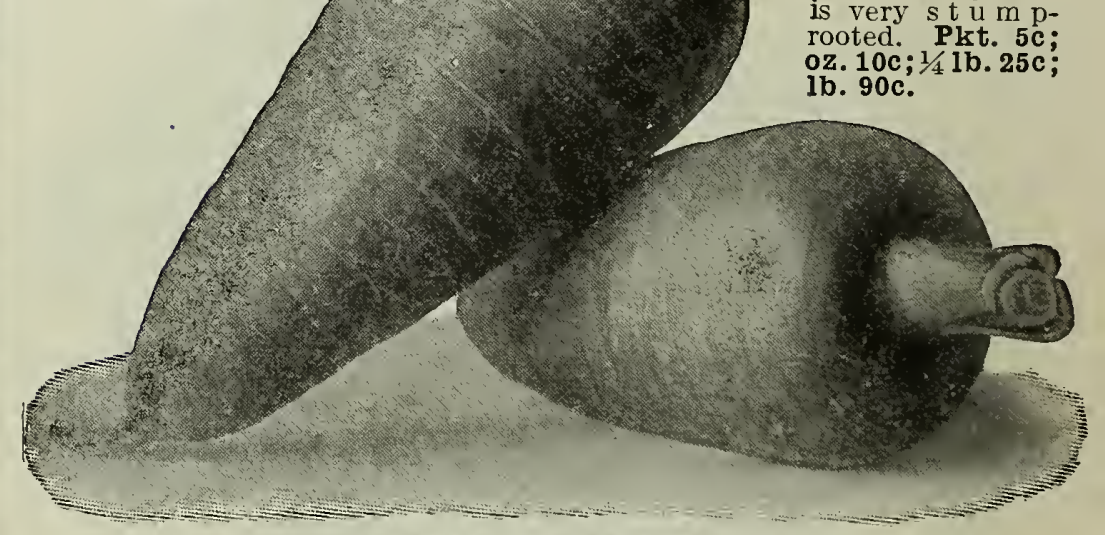

Chantenay, or The Model Carrot

LONG ORANGE The best long variety, and a good, roots scarlet, and fairly thick. The strain we offer is a bright orangeno green shouler Pkt. 5c;0z. 10c; 1/4 1b. 25c;1b. 75c.

OXHEART, OR GUERANDE One of $t \mathrm{~h} e$ and best croppers a mong the short carrots. The shape is particularly desirable for leavy soils. The true type is about 41 inches long and $31 / 2$ inches thick at the shoulder. It tapers slightly to the bottom, and is very stump-rooted. Pkt. 5c; oz. $10 \mathrm{c} ; 1 / 4 \mathrm{lb} .25 \mathrm{c} ; 1 \mathrm{~b} .85 \mathrm{c}$.

Red Saint Valery, or New Intermediate. A little longer than Danver's, ta pering abruptly, with pointed root. A very desirable, long variety, and rather preferable to Long Orange, being thicker at the shoulder and not so long. Color bright orange scarlet. Pkt. 5c;0z. 10c; $1 / 4$ lb. 25c; 1b. 80c. 


\section{CAULIFLOWER}

The culture of cauliflower is much the same as that of cabbage. It does not make a good summer crop, however, as it will not head up well in hot weather. It is especially popular as a fall and winter crop, and with market gardeners proves a profitable crop, owing to the scarcity of good market vegetables when cauliflower is at its best. It is easy to grow in the garden, providing the soil is made rich and porous. Plant the seed in beds in June for fall crop, and transplant to the garden or field in August. For spring crop, plant the seed in protected beds early in January, and the plants will be ready to transplant probably early in Narch. The young plants should be thinned, since they become very spindling if allowed to grow too thick.

Algiers. One of the best late varieties, forming good, large white heads, late in the fall. Pkt. 10c; $1 / 4$ oz. $25 \mathrm{c} ; 0 \mathrm{z} .75 \mathrm{c} ; 1 / 41 \mathrm{~b} . \$ 2.50$.

Dry Weather. A strain of the Early Snowball type, which is especially adapted to California. It is a Danish rariety (the best Cauliflower comes from Denmark) and is destined to become very popular in our climate. Pkt. 20c; $1 / 4$ oz. $75 \mathrm{c} ; 0 z . \$ 2.50 ; 1 / 41$ b. $\$ 8.00$.

CALIFORNIA WONDER A late rariety, forming good, large, solid heads during in California wherever tried. Pkt. 10c; $1 / 4 \mathbf{0 z}$. 25c; 0z. 75c; $1 / 41 \mathbf{1 b} \mathbf{\$ 2 . 5 0}$.

Early Favorite. An early, hard-heading variety. It is quite hardy and a good market variety. Pkt. 5c; $1 / 4$ oz. 35c; oz. $\$ 1.00 ; 1 / 41$ b. $\$ 2.50$.

EARLY SNOWBALL The best and most popular early variety grown. There is what we offer is the best imported stock. Those who have had trouble with cauliflower should try this Snowball. It will make uniformly fine heads eren under, adverse conditions. Pkt. $25 \mathrm{c} ; 1 / 4.0 \mathrm{z} .75 \mathrm{c} ;$ oz. $\$ 2.50 ; 1 / 4 \mathrm{lb}$. $\$ 9.00$.

Extra Early Dwarf Erfurt. An early variety, forming good, solid white heads. Is very early and almost as good as the best quality of Snowball. Pkt. 20c; $1 / 4$ oz. $65 \mathrm{c} ; 0 \mathrm{z} . \$ 2.25 ; 1 / 4 \mathrm{lb}$. $\$ 8.00$.

Extra Early Paris. A hardy variety quite easy to grow, and forming good heads. Pkt. 10c; $1 / 4$ Oz. 25c;0z. 75c; $1 / 4$ lb. $\$ 2.50$.

Veitch's Autumn Giant. A large, late variety, very hardy, but especially desirable for the South. The heads are well protected by the foliage, enabling it to resist unfarorable climatic conditions to a greater degree than other varieties. Pkt. $5 \mathrm{c} ; 1 / 40 z .15 \mathrm{c} ; 0 z .50 \mathrm{c} ; 1 / 4 \mathrm{~b} . \$ 1.50$.

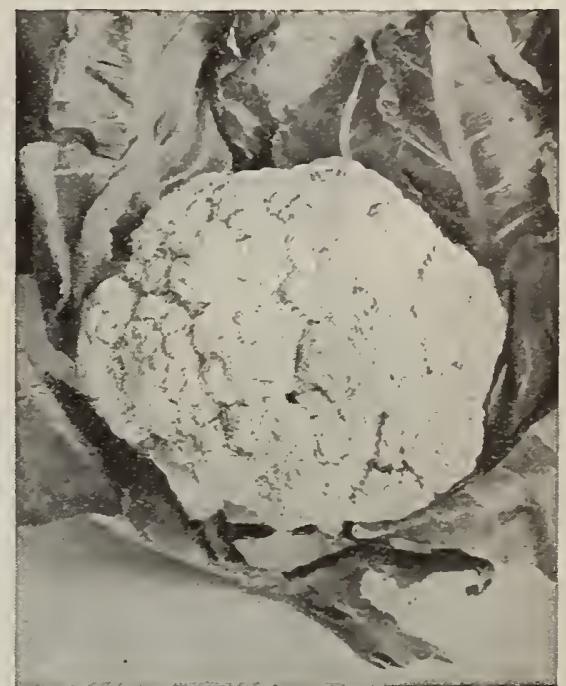

Cauliflower-California Wonder

\section{CELERY}

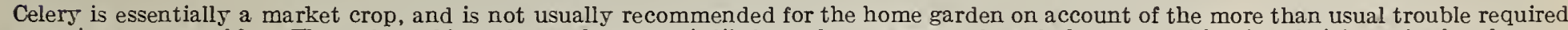

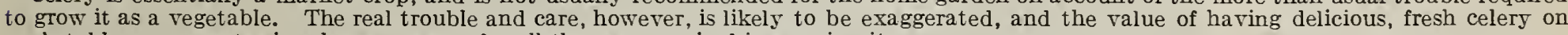
one's table compensates in a large measure for all the care required in growing it.

Celery requires water, and lots of it, from the time the seed is sown in boxes in March, until it is pulled in the autumn or winter. The seed

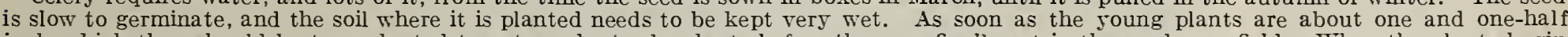

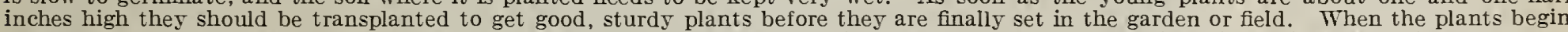

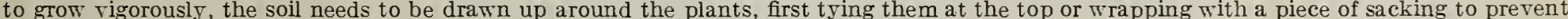

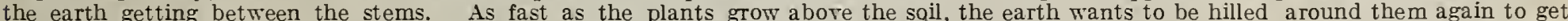

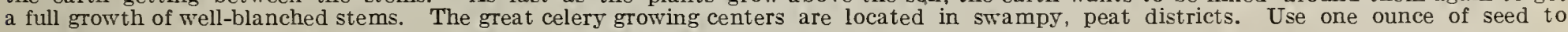
15,000 plants, or two ounces per acre.

Dwarf Golden Heart. The most popular of the old green winter varieties. Rather tall, forming a large bunch, and blanching white and crisp. Is hardy and a good shipper. Pkt. 5c; oz. $20 \mathrm{c} ; 1 / 4 \mathrm{lb}$. $75 \mathrm{c} ; 1 \mathrm{lb}$. $\$ 2.50$.

Evan's Triumph. A good, green, winter variety, very popular in the North. Forms a large bunch, blanches well, and is very hardy. Pit. 5c; oz. 20c; 1/4 1b. 75c;1b. \$2.50.

Giant Pascal. The most popular of the newer green winter varieties. Rather tall with stems nearly round, and when blanched is white, brittle, and especially good flavor. Pkt. 5c; oz. 20c; $1 / 41$ b. 75c; $1 \mathrm{~b}$. $\$ 2.50$.

Kalamazoo. A medium-short, dark green variety; very hardy: blanches easily, and ships well. Pkt. 5c; oz. 20c; $1 / 41 \mathrm{~b} .75 \mathrm{c}$; 1b. $\$ 2.50$.

\section{GOLDEN SELF-BLANCHING, OR PARIS} GOLDEN The most popular market variety in use, naturally golden-yellow (both stem and leaves), but needs to be blanched to make it brittle and fit for table use. Forms a rather small bunch.

Celery seed for flavoring. (Soup Celery). 1/2 1b. 30c; 1b. 50c.

Perfection Heartwell. A good, green winter rariety, rather tall, forming a large bunch. Pkt. 5c;0z. 20c; $1 / 41$ b. $75 \mathrm{c} ; 1 \mathrm{lb} . \$ 2.50$.

WHITE PLUME This is one of the most popular of the a varieties now in use. Used mostly for a very early crop. A comparatively easy variety to grow, as it is fairly hardy, and being naturally white is easy to blanch.
The"leaves are also white, tinted with green at tips. Forms a medium-sized bunch and is fairly tall. Pkt. 5c; 0z. 25c;1/4lb. $75 \mathrm{c} ; 1 \mathrm{~b} . \$ 3.00$.
WINTER QUEEN One of the best winter varieties, and ket gardeners. It is tall and forms a large bunch. The leaves are light green which blanche to a creamy white. Grows a thick, solid, heary stalk with a large heart. $1 / 41 \mathrm{~b} .75 \mathrm{c} ; 1 \mathrm{~b} . \$ 2.50$

\section{CELERIAC, OR TURNIP ROOTED CELERY}

This plant resembles celery in flaror, but the stems are very strong, and only the root is palatable. It should be treated much as celery so far as planting the seed is concerned. The plant requires only a little hilling, however, to get a well-formed, goodsized root.

Giant Smooth Prague. The best variety. Forms a good, thick root as much as four and nearly globular. and nearly globular: $1 / 41 \mathrm{~b}$. $60 \mathrm{c} ; 1 \mathrm{~b}$. $\$ 1.75$.

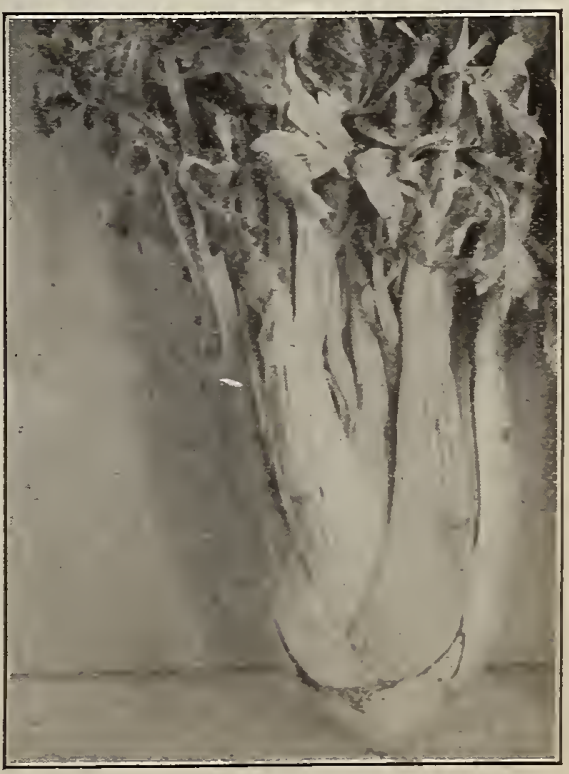

Golden Self-Blanching or Paris Golden Celery 


\section{CORN-SWEET OR TABLE VARIETIES EXTRA EASTERN GROWN STOCK-ESPECIALLY SWEET}

As corn is very sensitive to frost, it cannot be planted with any degree of safety until about the middle of April, except in sections that are notably free from late frost. Moist, rich soil is best for corn, and frequent hoeing or cultivating improves it. The small but rich mountain valleys seem especially favorable for good table corn.

In cutting corn for the table it is important that it be picked at just the right time, especially when not too old. Frequent small plantings of the several varieties in succession will keep a good supply available for the table all summer.

Express or freight charges are not prepaid. If large quantities are wanted, write us for special quotations.

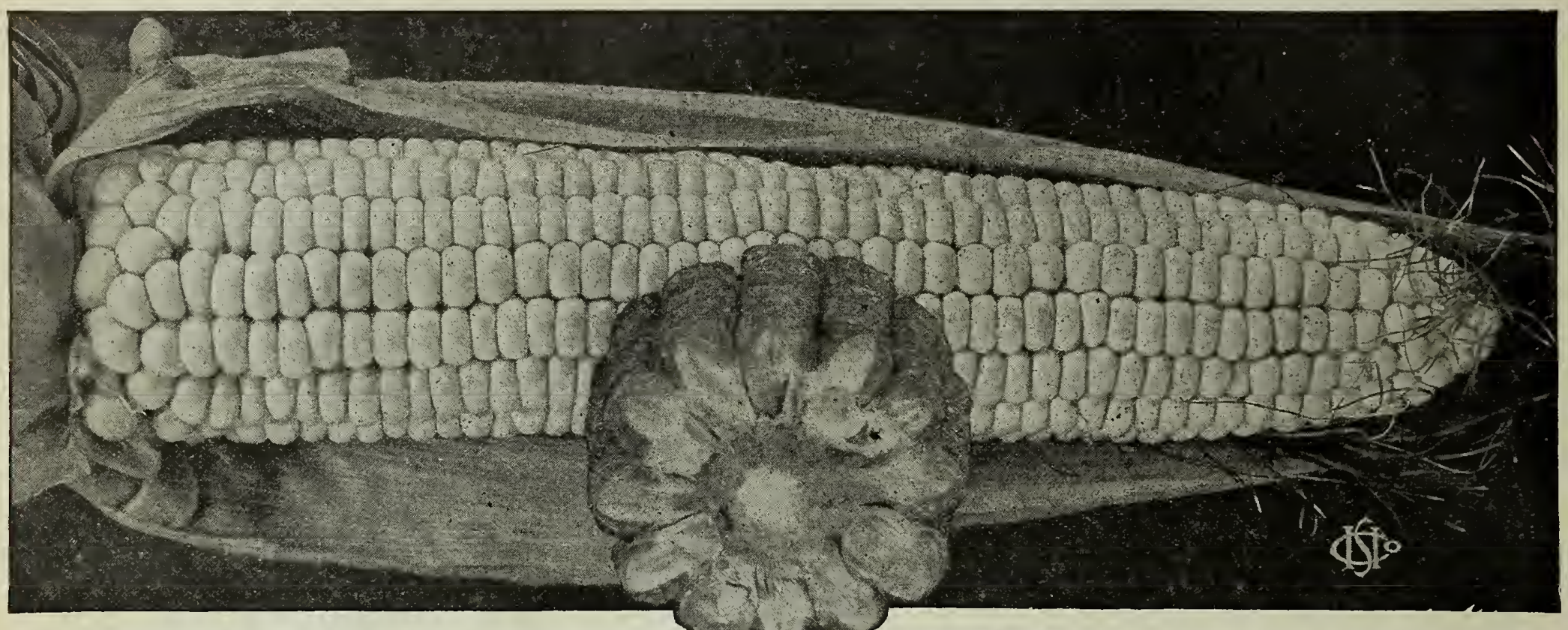

Black Mexican. One of the best medium early varieties. Although when ripe the seed is dark bluish or black when ready for table use it is white. It is of especially fine, sweet flavor and very tender. Pkt. $10 \mathrm{c}$; 1b. 25c; postpald by express or frelght lb. $15 \mathrm{c} ; 10$ lbs. $\$ 1.00$ 100 lbs. $\$ 9.00$.

Golden Bantam. A very early variety. The ears are but medium size, but are thickly set with delicious yellow kernels. licious yellow kernels. ety is superb, and it has ety is superb, and it has become a general favorite early sweet corn with all who have tried it. pald; by express or Ireight, lb. 15c; 10 lbs. $\$ 1.25 ; 100$ lbs. $\$ 10.00$.

Crosby's Early. A fine, early variety, growing about 4 feet in height. very popular. Pkt. 10c; lb. 25 c, postpaid; by express or freight, Ib. 15c; 10 lbs. $\$ 1.00 ; 100$ lbs. $\$ 9.00$.

Holmes' Delicious-Early-Superior flavor

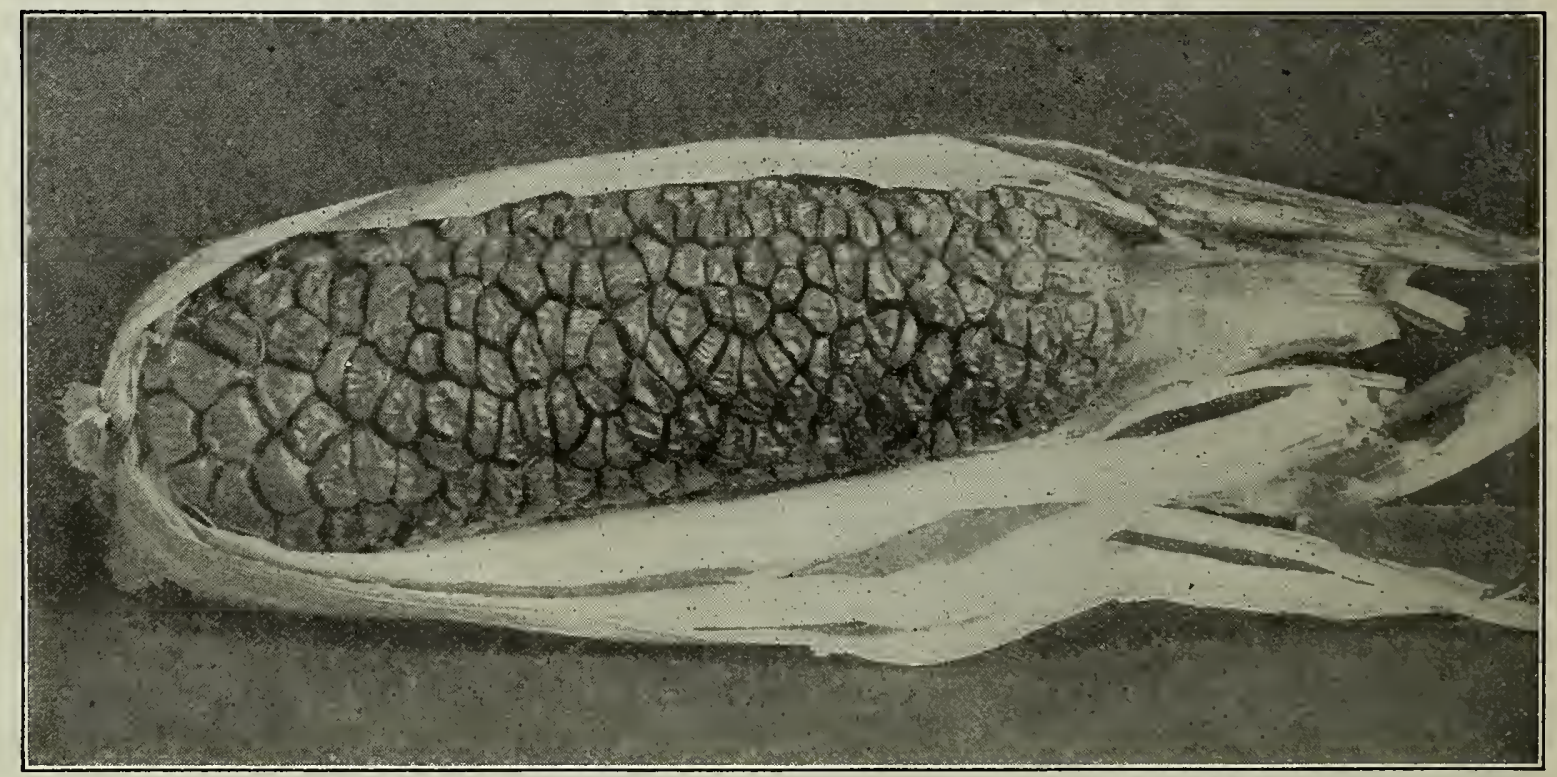

MORSE'S GOLDEN CREAM Our sensational 1911 sweet corn. A yellow Country Gentleman sweet corn by express or freight, lb. 40c; $10 \mathrm{lbs}$. $\$ 3.00$.

COUNTRY GENTLEMAN OR SHOE PEG One of the best of the late varieties. Has a long PEW white cob, closely filled with long " "shoe peg" kernels.

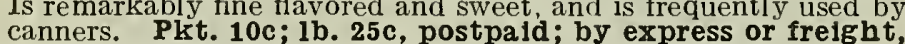

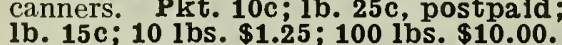

Early Red Cob Cory. One of the best extra early varieties Ears are about six inches long, and eight-rowed. Pkt. 10c; ib. 25c, postpaid; by express or freight, lb. $15 \mathrm{c} ; 10 \mathrm{lbs} . \$ 1.00 ; 100$ lbs. $\$ 9.00$.

EARLY MINNESOTA The best early variety for Between Crosby's and Cory's in market and private gardens. feet high; ears long and eight rowed. Pkt. 10c; 1b. 25c postfeet high; ears long and eight rowed. Pkt. 10c; 1 b. 25c, post-
paid; by express or freight, $1 \mathrm{~b}$. 15c; 10 lbs. $\$ 1.00 ; 100$ lbs. $\$ 9.00$.
Early White Cob Cory. An extra early variety with remarkably white grains, especially when cooked. Ears are six to seven by express or freight, $1 \mathrm{~b} .15 \mathrm{c} ; 10 \mathrm{lbs} . \$ 1.00 ; 100 \mathrm{lbs}$. $\$ 9.00$.

\section{EARLY MAMMOTH, OR ALAMEDA} The very best variety for practically all California, and the one most generally used here. Forms very large ears, which are quite sweet and of fair quality. It withstands our dry summers well, and is usually quite free from worms, and the ears fill well. Pkt. 10c; lb. 25c, postpaid; by express or freight, 1b. 15c; 10 lbs. $\$ 1.00$; 100 lbs. $\$ 8.00$.

Holmes' Delicious. A very early distinct new sweet corn. Especially attractive on account of its very fine sweet flavor. Grows five to six feet high and bears an average of three ears to the stalk.
Pkt. 10c; lb. 35c, postpaid; by express or freight, $1 \mathrm{~b}$. 25c, $10 \mathrm{lbs}$. \$2.00. 


\section{SWEET CORN-Continued}

Late Mammoth. A mammoth rariet 5 , with very long, thick ears, which are corered with rery wide thick kernels. Has the largest ears of any rariets. Is very late. Pkt. 10c; 1b. 25c postpaid; by express or freight, 1b. 15c; 10 lbs. $\$ 1.25 ; 1001 \mathrm{bs}$. $\$ 10.00$.

Moore's Early Concord. A medium early variety. Ears are rather short and well filled with 14 to 16 rows of kernels. A good variety for prirate garden or for canning. Pkt. 10c; lb. $15 \mathrm{c} ; 10 \mathrm{lbs}$. $\$ 1.00 ; 100 \mathrm{lbs}$. $\$ 9.00$.

old Colony. A good late rariety of rich, sreet fla vor. Ears bear 16 to 20 rows of kernels, and are rery heary and solid. Pkt. 10c; 1b. 25c, postpaid; by express or freight, $1 \mathrm{~b} .15 \mathrm{c}$; $10 \mathrm{lbs}$. $\$ 1.00 ; 100 \mathrm{lbs}$. $\$ 9.00$.

Perry's Hybrid. A good second earls variet5. Usually produces two good-sized ears, set low on the stalk. Of fine quality, sweet and express or freight, $1 \mathrm{~b}$. $15 \mathrm{c} ; 10 \mathrm{lbs}$. $\$ 1.00$; $100 \mathrm{lbs}$. $\$ 9.00$.

POTTER'S EXCELSIOR. A fine sweet rariets for second-early season. One of the standard sorts for home or market garden. Pkt. 10c: lb. $25 \mathrm{c}$, postpaid; by express or freight, $1 \mathrm{~b}$. $15 \mathrm{c} ; 10 \mathrm{lbs}$. $\$ 1.00 ; 100 \mathrm{lbs}$. $\$ 9.00$.

STABLER'S EARLY. A rery early variety with larger ears than most sorts. Fine white meaty kernels. Pkt. 10c; 1b. 25c, postpaid; by express or freight, lb. $15 \mathrm{c} ; 10$ lbs. $\$ 1.00$ press or freight
$100 \mathrm{lbs}$. $\$ 9.00$.

STOWELL'S EVERGREEN ${ }_{\text {most }}^{\text {The }}$ popular and best main crop rariety and the popular and best main crop rariety and the sest all-round table rarietr. Of good, in condition for boiling for a remarkably long time. The quality is excellent. Pkt. 10c; lb. $25 \mathrm{c}$, postpaid; by express or freight, lb. $15 \mathrm{c} ; 10$ lbs. $\$ 1.00 ; 100$ lbs. $\$ 9.00$.

White Evergreen. Like Stowell's Evergreen, it is a good main crop rariet $y$, but has the remarkable qualits of being snow-white. It is invaluable for canners, market gardeners, and 10c;1b. 25c, postpaid; by express or freight lb. $15 \mathrm{c} ; 10 \mathrm{lbs}$. $\$ 1.25 ; 100 \mathrm{lbs}$. $\$ 10.00$.

\section{FIELD VARIETIES}

Extra Early Adams. The earliest of all corn an the first to make ears. Plant dwarf and 1b. $20 \mathrm{c}$, postpaid; by express or fre. $10 \mathrm{c}$ $15 \mathrm{c} ; 10 \mathrm{lbs}$. 90c; $100 \mathrm{lbs}$. $\$ 8.00$..

Early Adams. Although not a sweet corn, can often be used as such on account of its fine white bernels, which are quite sweet and tender. Is rery hards and can be planted earlier than the early varieties of sweet corn. Pkt. $10 \mathrm{c} ; 1 \mathrm{~b} .20 \mathrm{c}$, postpaid; by express or
freight, $1 \mathrm{~b} .15 \mathrm{c} ; 10 \mathrm{bs}$. $90 \mathrm{c} ; 1001 \mathrm{bs} . \$ 8.00$

Early Eight-Rowed Canada, also known as the Yellow Flint. A rapid growing, early rariety, and for this reason largely used A rapid growing, early variety, and for this reason largely used Lb. 20c, postpaid; by express or freight, $1 \mathrm{~b}$. 10c;10 10s. 60c $100 \mathrm{lbs} . \$ 5.00$.

King Phillip. An old Ner England fa vorite. The ears are long, and the rariets is rery earls. Grains, coppery red. I b. 20c, costpaid; by express or freight, $1 \mathrm{~b}$. $10 \mathrm{c} ; 10 \mathrm{lbs} .60 \mathrm{c} ; 100 \mathrm{lbs} . \$ 5.00$.

Early Golden Dent, or Pride of the North. A very early dent variety, and especially raluable on account of its extreme earliness. Ears 8 to 10 inches long, with 10 to 16 rows of slender deep yellow grains. Lb. 20c, postpaid; by express or freight $1 \mathrm{~b} .10 \mathrm{c} ; 10 \mathrm{lbs} .60 \mathrm{c} ; 100 \mathrm{lbs}$. $\$ 5.00$.

LEAMING A rery popular, tall-growing rariety. Is early nels are long and deep golden sellow. It is the best yellow corn on the market. Lb. 20c, postpaid; by express or freight, 1b. $10 \mathrm{c} ; 10 \mathrm{lbs}$. 60c; $100 \mathrm{lbs}$. $\$ 5.00$.

White Cap Yellow Dent. An early and hardy variet5. growing 6 to 7 feet in height. Ears are 8 to 10 inches in length. Cob small and 16 to 18 romed. The outer end of the grain is white, express or freight, Ib. $10 \mathrm{c} ; 10 \mathrm{lbs}$. $60 \mathrm{c} ; 100 \mathrm{lbs}$. $\$ 5.00$.

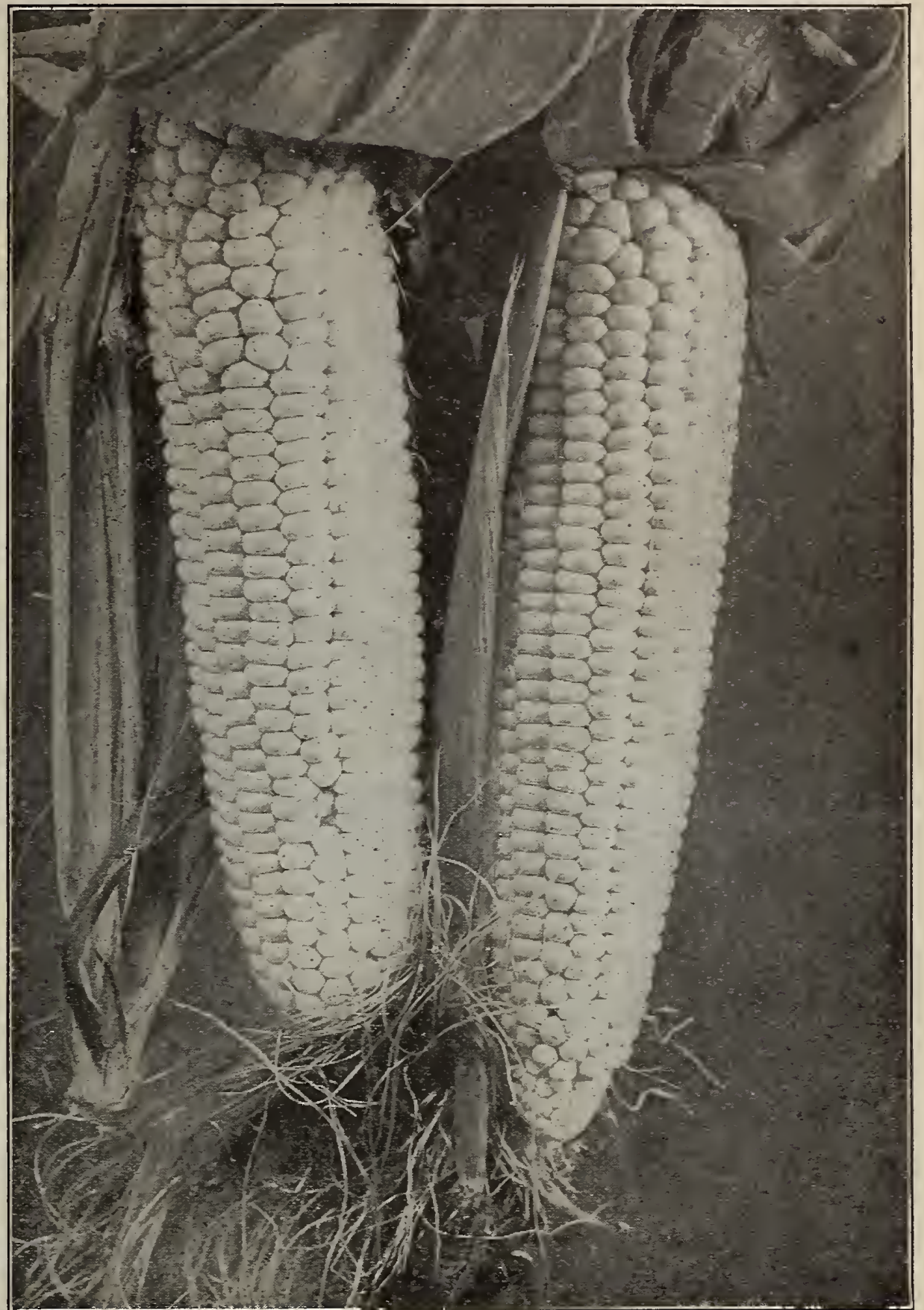

Early Mammoth, or Alameda Sweet The best all-round sweet corn for California.

SANFORD WHITE FLINT An earls, tall rariets, which are well filled with long, pure white kernels. The rery or freight, 1b. 10c; $10 \mathrm{lbs}$. $60 \mathrm{c} ; 100 \mathrm{ibs}$. $\$ 5.00$.

Wisconsin White Dent. A tall-growing variety; large eared; 16 to 18 rowed; grains large and white. Lb. $20 \mathrm{c}$, postpaid; by express or freight, 1b. $10 \mathrm{c} ; 10 \mathrm{Ibs} .60 \mathrm{c} ; 100 \mathrm{lbs} . \$ 5.00$.

sweet Corn for Fodder. As this corn is almass wanted in large quantities, write us for special quotations.

POP CORN, WHITE RICE The most popular

ears short: lernels long resembling rice in shape; color white: Lb. 20c, postpaid; by express or freight, $1 \mathrm{~b} .10 \mathrm{c} ; 101 \mathrm{bs} .80 \mathrm{c}$; $1001 \mathrm{bs} . \$ 7.00$. Kaffir Corn

EgJptian Cor

Broom Corn

See Field Seeds. Page 42

Jerusalem Corx

Campo Seco, California. Sept. 14, 1910.

I had rood success with rour seeds this year. The Holmes' Delicious Corn is the best that I erer ate. 


\section{CUCUMBERS}

Are sensitive to frost, and cannot be planted until the last of April. They require a great deal of water, and unless planted on very wet soil, will require frequent irrigation throughout the summer. Plant in hills four feet each way, dropping about twelve seeds in each hill. Later when plants are well started, thin out, leaving only four or five of the strongest plants to each hill. Sow one-half inch deep. The soil should be made very rich with well-rotted stable manure, well spaded in.

Cucumbers are very easy to grow, and a few hills will produce an abundance for an average family. The Cucumbers should be gathered when large enough for use, whether required or not; if left to ripen, it destroys their productiveness. For pickles, plant from June until the middle of July.

ARLINGTON WHITE SPINE A rich, dark-green white when ripened. The fruit is about 7 inches long white when ripened. The fruit is about 7 inches long
when in marketable condition and very straight and even in shape. Is early, and good for forcing and outof door culture. Pkt. 5c; oz. $15 \mathrm{c} ; 1 / 41 \mathrm{~b}$. $40 \mathrm{c}$; $1 \mathrm{~b}$. $\$ 1.25$.

Chicago Pickling. A mediumlong deep-green variety, turning yellow at maturity, turning yellow at maturity. The fruit is finely shaped, being slightly blunt at both ends. It is the popular pickle variety in $;$ : oz. 10c; $1 / 4$ 1b. 30c; 1b. $5 \mathrm{c} ; \mathrm{Oz}$.

Cool and Crisp. A fine garden variety, deep $\mathrm{g} r \mathrm{e} e \mathrm{n}$ and crisp, and is of the White Spine type, p u re white when $\mathrm{r}$ i p e. Pkt. 5c; oz. $15 \mathrm{c} ; 1 / 4 \mathrm{lb}$. $45 \mathrm{c} ; 1 \mathrm{~b} . \$ 1.25$
Cumberland Pickling. This variety is the result of a cross between Paris Pickling and White Spine, and retains the characteristics of the former in being thickly covered with small white covines, The sine white spines. The vine is sturdy and very prolific. The mature fruits are from 9 to 10 0z. $10 \mathrm{c} ; 1 / 41 \mathrm{lb} .30 \mathrm{c} ; 1 \mathrm{~b} . \$ 1.00$.

Early Cluster. A very productive variety, bearing its fruit in clusters of two or three. The fruit is short and very dark green. Pkt. 5c: 0 z. $10 \mathrm{c} ; 1 / 4 \mathrm{Ib} .30 \mathrm{c} ; 1 \mathrm{~b}$. $\$ 1.00$.

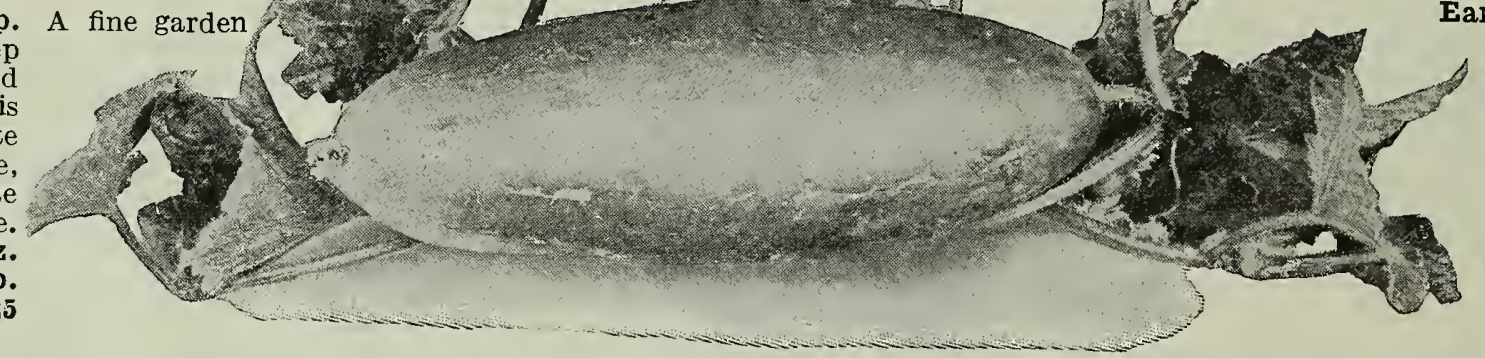

Early Short Green. or Early Frame. A very desirable variety for either pickling or table use. Fruit straight small at each end bright green. Pkt. 5c;0z. 10c; $1 / 41 \mathrm{~b}$. $30 \mathrm{c} ; 1 \mathrm{~b} . \$ 1.00$.

Arlington White Spine Cucumber

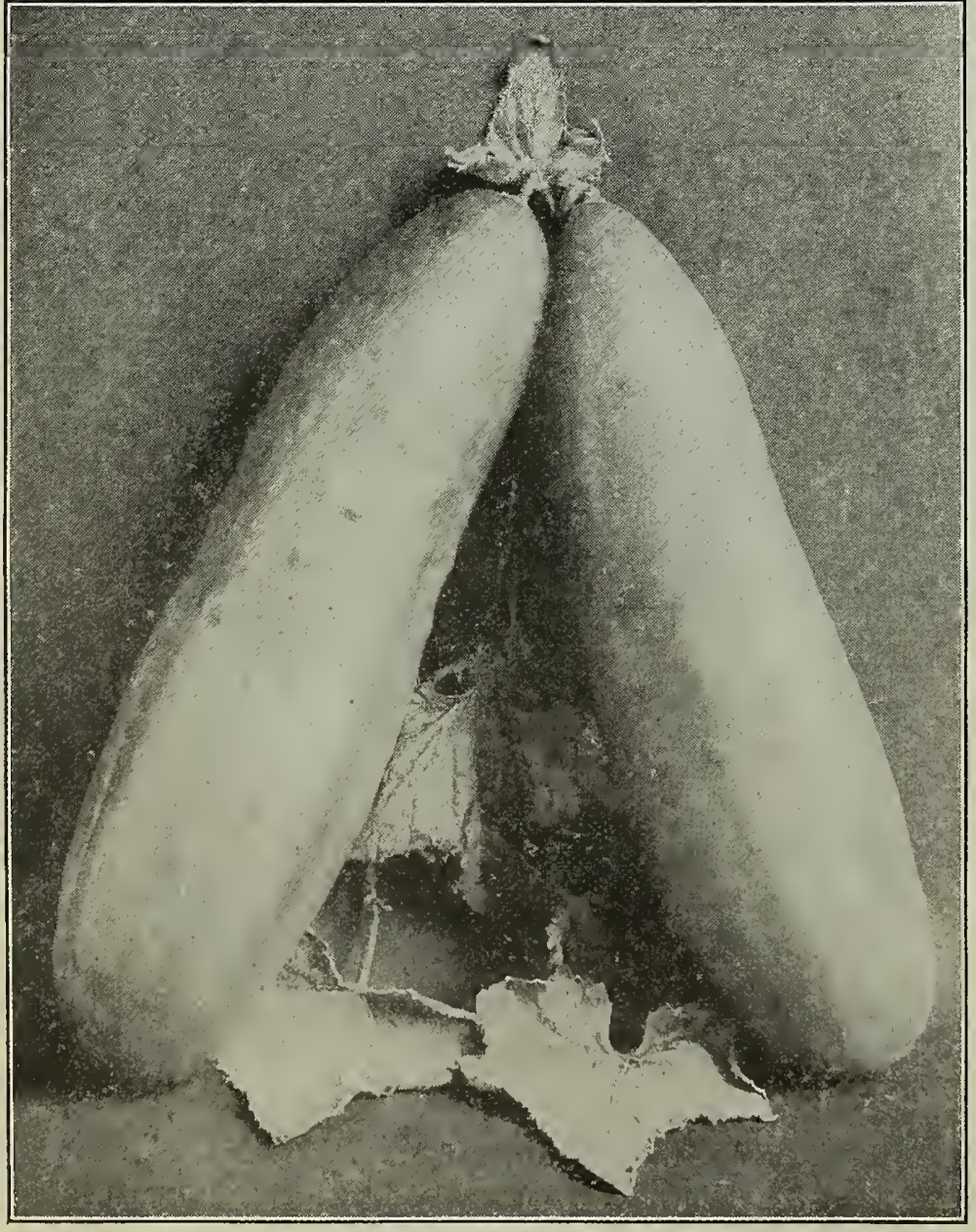

Long Green Cucumber
Everbearing. Very early and very prolific. Fruits 4 to 6 inches long; quite thick and blunt at the ends and of a rich, dark-green color. Pkt. 5c;0z. 10c; $1 / 4$ 1b. 30c;1b. $\$ 1.00$.

Extra Early Green Prolific, or Boston Pickling. A very prolific variety, used principally for pickles. Fruit medium sized, bright green, very even and symmetrical. Pkt. 5c;0z. 10c;1/4 lb. 30c; ib. $\$ 1.00$.

Extra Long White Spine, or Evergreen White Spine. A popular variety having long, rich dark-green fruits with very tender, white, and crisp flesh. Pkt. 5c;0z. 15c; 1/4 1b. 35c; 1b. \$1.25.

Fordhook Famous. A long White Spine variety, growing from 10 to 12 inches. Fully as long as Long Green and of equally good quality. Pkt. 5c; 0z. 15c; $1 / 4$ lb. $40 \mathrm{c} ; 1 \mathrm{~b}$. $\$ 1.50$.

Gherkin, or West India Gherkin. An extremely small fruited variety, grown exclusively for pickles. It has no value for slicing is very prickly, but tender and crisp if picked when young. Seed germinates slowly. Pkt. 5c;0z. 20c;1/4 1b. 60c;1b. \$2.00.

Japanese Climbing. A good variety for training to a trellis. Forms long fruit of rich, dark-green color. The flesh is white, crisp, and of good flavor. Pkt. $5 \mathrm{c} ; 0 z .15 \mathrm{c} ; 1 / 41 \mathrm{~b} .40 \mathrm{c} ; 1 \mathrm{~b} . \$ 1.50$.

LONG GREEN The best known and most popular variety tive, and forms fruit fit for use almost as early as the shorter varieties. The mature fruit is almost 12 inches long. The skin is of a deep green, and the flesh is solid, crisp, and of fine quality. We have the very best strains of this variety and recommend it as much the best cucumber of all, and the variety every one should plant. Pkt. 5c;0z. 15c; $1 / 41$ 1b. 35c; $1 \mathrm{~b} . \$ 1.25$.

\section{CHERVIL}

Can be planted any time in the early spring. The leaves should be kept cut, and if not allowed to run to seed, will keep green for a long time. Is more finely curled and handsome than parsley, and makes an excellent plant for garnishing.

Curled. Very finely curled, somewhat resembling parsley and used in same manner. Pkt. 5c;0z. 10c; $1 / 4$ lb. 30c; 1b. $\$ 1.00$.

\section{CHIVES}

A plant resembling a tuft of grass, but the leaves have the flavor of onions. The leaves are used in soups and salads, giving a mild onion flavor to same. Pkt. 10c; 0z. 50c. See plants of chives listed under vegetable plants, page 39 . 


\section{SAN FRANCISCO CALIFORNIA U.S.A.}

\section{CHICORY}

Used as a substitute for coffee when the roots are dried and ground. The roots are also used for cooking and are very palatable. Sow early in the spring, thin the young plants to six inches, and keep well hoed. The plant spreads from the root and is perennial.

Large Rooted, or Coffee. The largest rooted and best variety Pkt. 5c;0z. 10c; 1/4 1b. 25c; 1b. 75c.

\section{CRESS}

There are two species of cress, as noted below. The first named should be sown in drills about 16 inches apart in rich ground, early in the spring. Sereral sowings should be made at intervals to secure a succession. Watercress should be sowed along the banks of running water where there is good soil, and after the seed is up it needs no further cultiration, since the plants spread orer the water and make a mass of fine, edible leaves.

Fine Curled (Pepper Grass). Leares finely cut or curled like parsley. The leares are pungent. and are used to
lettuce. Pkt. 5c; oz. 10c; $1 / 1 / \mathbf{l b} .20 \mathrm{j} ; \mathbf{1 b}$. 50c.

True Water. Forms a plant, the leaves of which are used for salad or for garnishing. Thrires only when the roots and stems are submerged in water. Pkt. 10c; oz. 35c; $1 / 4 \mathbf{l b}$. $\$ 1.00 ; 1 \mathrm{~b} . \$ 3.50$.

\section{DANDELION}

An easily grown plant. now much esteemed for greens, which are cooked like mustard and spinach. Sow the seed in May or June on good rich soil, and thoroughly cultivate, when the leares will be ready to cut the following spring. An ounce will sow 200 feet of row.

Improved Large Leaved. The largest leaved and best cutting variety. Pkt. $10 \mathrm{c} ; 0 \mathrm{0z} .75 \mathrm{c} ; 1 / 4$ 1b. $\$ 2.00$. parsley. The leares are pungent and are used to mix with

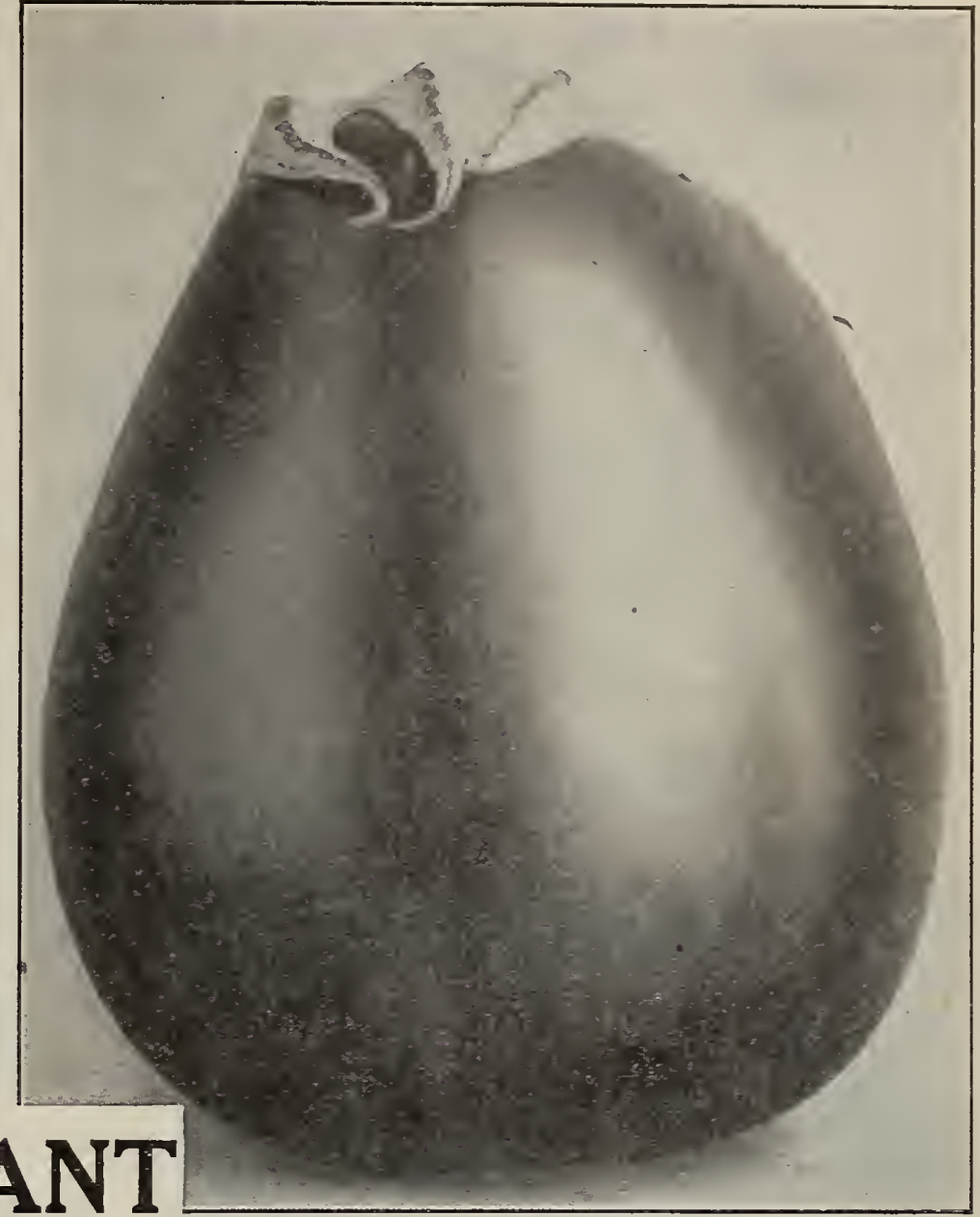

Black Beauty Eggplant

The seed germinates slowly and should be started under glass, with moderately high temperature, about March 1st. When about an inch high transplant carefully to the garden or field, but not until all danger of frost is orer. Eggplant does not do so well where cool nights prevail, as in places where the nights are warm. It needs a warm climate to insure quick and uninterrupted growth.

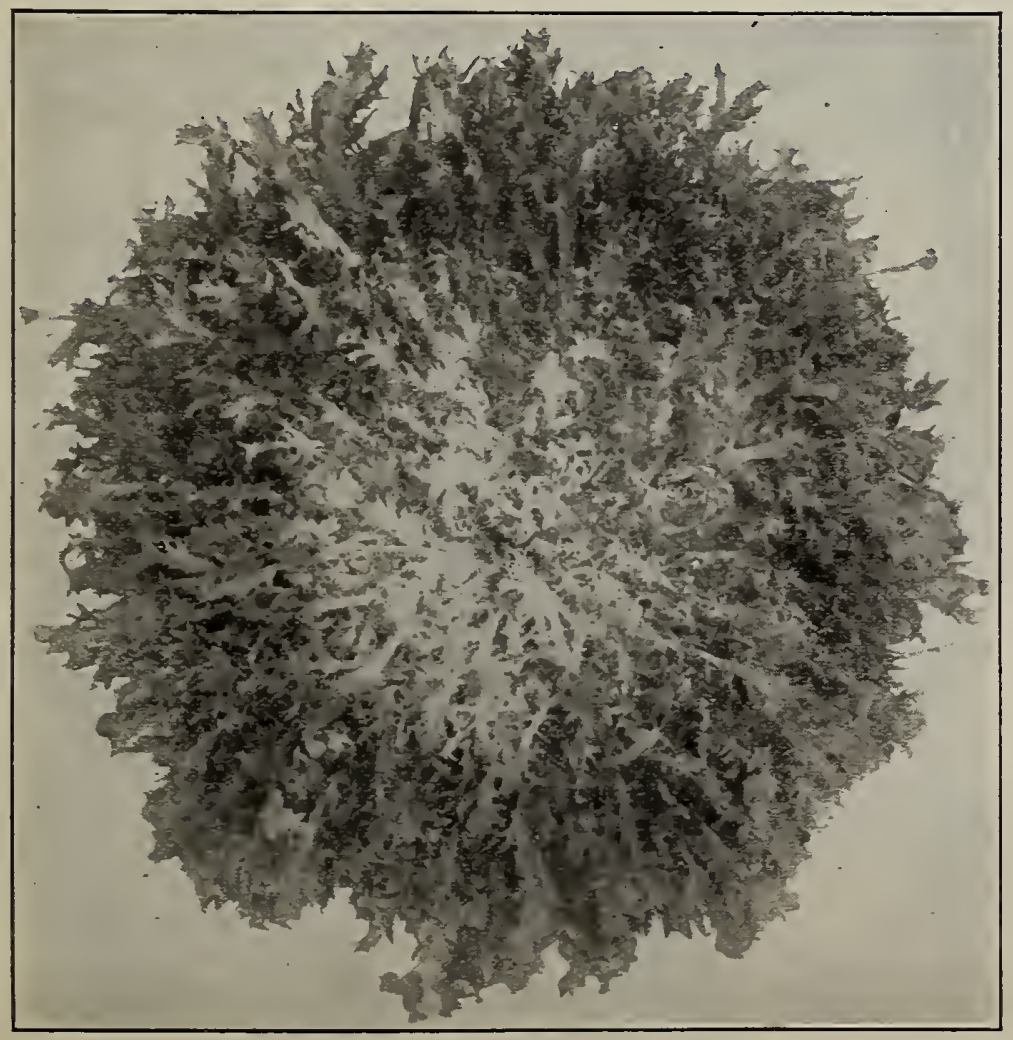

Green Curled Endive
BLACK BEAUTY A rery early rariety; rich purple market variety. Pkt. 10c; 0z. 50c; $1 / 41 \mathrm{~b} . \$ 1.50 ; 1 \mathrm{~b} . \$ 5.00$.

Early Long Purple. An early rariety and also a very profitable one. The fruit is long and of a rich dark purple. Pkt. 5c; oz. $25 \mathrm{c} ; 1 / 41 \mathrm{~b}$. 75c; 1b. $\$ 2.50$.

NEW YORK IMPROVED The principal marLAGE PURPIE are large and spints LARGE PURPLE fruit large and of deep rich

purple. Pkt. $10 \mathrm{c}$; 0z. 30c; $1 / 1 \mathrm{lb} . \$ 1.00 ; 1 \mathrm{~b} . \$ 3.50$.

Black Pekin. An early, prolific rariety, and valuable for market gardeners' use. Fruit is nearly round: skin smooth and black. Pkt. $10 \mathrm{c} ; 0 \mathrm{z} .35 \mathrm{c} ; 1 / 4 \mathrm{lb} . \$ 1.00 ; 1 \mathrm{~b} . \$ 3.50$.

White Pearl. A smooth-leared rariet with large, egg-shaped, pure white fruit. Pkt. 10c; oz. 35c; $1 / 41 \mathrm{lb} . \$ 1.00 ; 1 \mathrm{~b} . \$ 3.50$.

\section{ENDIVE}

A salad vegetable which is becoming very valuable for winter use. The seed should be sown in June or Jul in rows, and thinned to about six inches apart. When quite well grown, the outer leares should be tied, thus blanching the innerlea res and the heart. It is hardly palatable until after frost, being rather bitter if used in summer.

\section{BROAD-LEAVED BATAVIAN, OR ES-} CAROLE A variets having wide, thick leares, the center. Color dull green. Pkt. 5c; oz. 10c; $1 / 41 \mathrm{~b} .30 \mathrm{c}$; 1b. $\$ 1.00$.

GREEN CURLED A rery $\operatorname{curl} 5$ varietw, the midrib outer edges rery much indented and curled. A very attractire plant, and one of the rery best rarieties. Pkt. $5 \mathbf{c} ; \mathbf{~ o z}$ $15 \mathrm{c} ; 1 / 1 \mathrm{lb}$. 40c; $1 \mathrm{~b} . \$ 1.25$.

Staghorn. A curly type, the lobes and divisions of the leares being wider than in the curled rarieties. Is a popular garden sort in San Francisco. Pkt. 5c;0z. 15c; 1/41b. 30c; 1b. \$1.00.

White Curled. A light jellowish-green variety; very curly and quite ornamental. A good variety for general use. Pkt. $5 \mathrm{c} ; 0 \mathrm{z} .15 \mathrm{c} ; 1 / 41 \mathrm{~b} .50 \mathrm{c} ; 1 \mathrm{~b} . \$ 1.50$. 


\section{C.C.MORSE \& CO. VEGETABLE SEEDS S Pit}

\section{KALE, OR BORECOLE}

A species of cabbage, forming a mass of leaves, some varieties being very beautiful and curly. The leaves are cooked as greens. The seed should be planted in September, and the plants will be ready to use in the winter. It is hardy and will withstand frost and snow.

\section{DWARF CURLED SCOTCH The most popular}

The leaves are very curly and very tender. Color bright green. Pkt. 5c; oz. 10c; $1 / 41$ 1b. 25c; 1b. 75c.

Green Curled Scotch, Tall. A very hardy variety, growing about $21 / 4$ feet high. Is very curly and makes a beautiful plant. Stands the winter well Pkt. 5c;0z. 10c;1/41b. 25c;1b.75c.

Dwarf Purple German. Similar to Dwarf Curled Scotch, excepting the leaves are purple. Pkt. 5c; oz. 10c; $1 / 41$ b. 30c; 1b. $\$ 1.00$.

JERSEY KALE A tall variety with smooth leaves. Es5c;0z. 10c; 1/4 1b. 25c;1b. $75 \mathrm{c}$.

Siberian. A plain-leaved variety, having very little curl to the large green leaves, although the edges are cut and curled slightly. Pkt. 5c;0z. 10c; $1 / 41 \mathrm{~b} .25 \mathrm{c} ; 1 \mathrm{~b} .75 \mathrm{c}$.

\section{KOHL RABI}
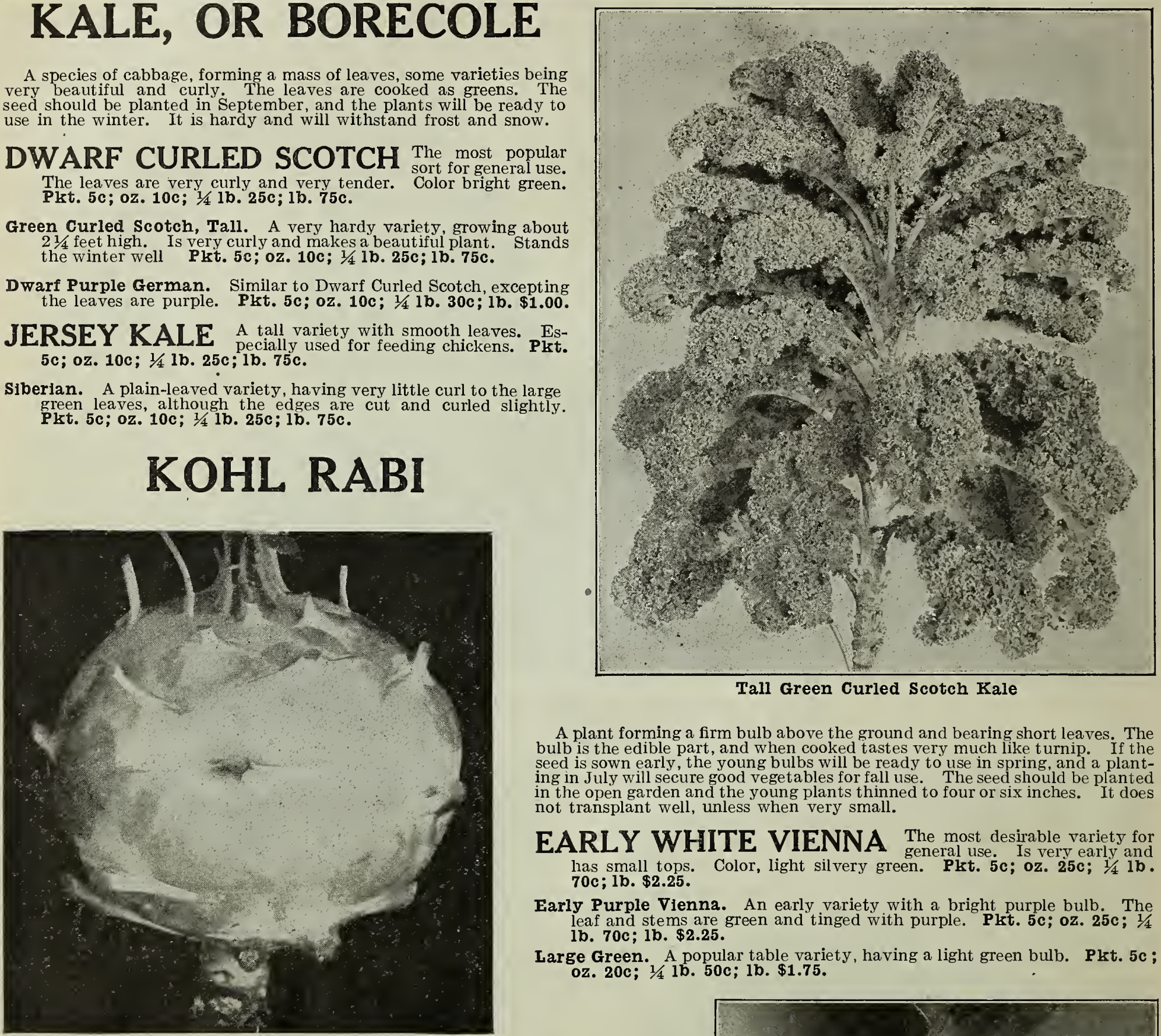

Tall Green Curled Scotch Kale

A plant forming a firm bulb above the ground and bearing short leaves. The bulb is the edible part, and when cooked tastes very much like turnip. If the seed is sown early, the young bulbs will be ready to use in spring, and a planting in July will secure good vegetables for fall use. The seed should be planted in the open garden and the young plants thinned to four or six inches. It does not transplant well, unless when very small.

EARLY WHITE VIENNA The most desirable variety for has small tops. Color, light silvery green. Pkt. 5c; oz. 25c; $1 / 4 \mathbf{1 b}$. $70 \mathrm{c} ; 1 \mathrm{~b}$. $\$ 2.25$.

Early Purple Vienna. An early variety with a bright purple bulb The leaf and stems are green and tinged with purple. Pkt. 5c; oz. 25c; $1 / 4$ 1b. $70 c ; 1 b . \$ 2.25$.

Large Green. A popular table variety, having a light green bulb. Pkt. 5c ; 0z. $20 \mathrm{c} ; 1 / 41 \mathrm{~b}$. 50c; $1 \mathrm{~b}$. $\$ 1.75$.

White Vienna, Kohl Rab.

\section{LEEK}

A species of onion which does not form a bulb, but is used for its mild and delicious root, stem, or neck. It can be planted in rows, and the young plants thinned to about four inches. When well grown, hill up with earth to get a long white stem. Seed should be planted in June for good plants in the Fall and Winter Leek is a vegetable of unusual merit, and is not half appreciated by the American people, while it is regarded as a great favorite by many of our foreign population.

American Flag. A very good, strong-growing variety, forming large stems of good flavor. Pkt. 5c; 0z. 15c; 1/ 1b. 40c; 1b: \$1.25.

Carentan. The largest variety, though the stems are not so long as some other varieties. Leaves are very broad. Plt. 5c; oz. 15c; $1 / 4 \mathbf{1 b} . \mathbf{4 0 c} ; \mathbf{1 b} . \$ 1.50$.

GIANT MUSSELBURGH The best variety, having good, thick vigorous and of sweet, mild flavor. Pkt. 5c;0z. 15c; $1 / 4 \mathbf{1 b} . \mathbf{4 0 c} ; \mathbf{1 b} . \mathbf{\$ 1 . 2 5}$.

\section{MARTYNIA, OR UNICORN PLANT}

The young pods are much esteemed for pickles, but must be pickled young, since they become very hard and flinty with age. Sow in hills after all danger of frost is over. The plant grows to about five or six feet in diameter, and is very ornamental. Proboscidea. The common variety. Flowers creamy white with dark purple throat. Pkt. 10c; oz. 30c; 1/4 ib. $85 \mathrm{c} ; 1 \mathrm{~b} . \$ 3.00$.

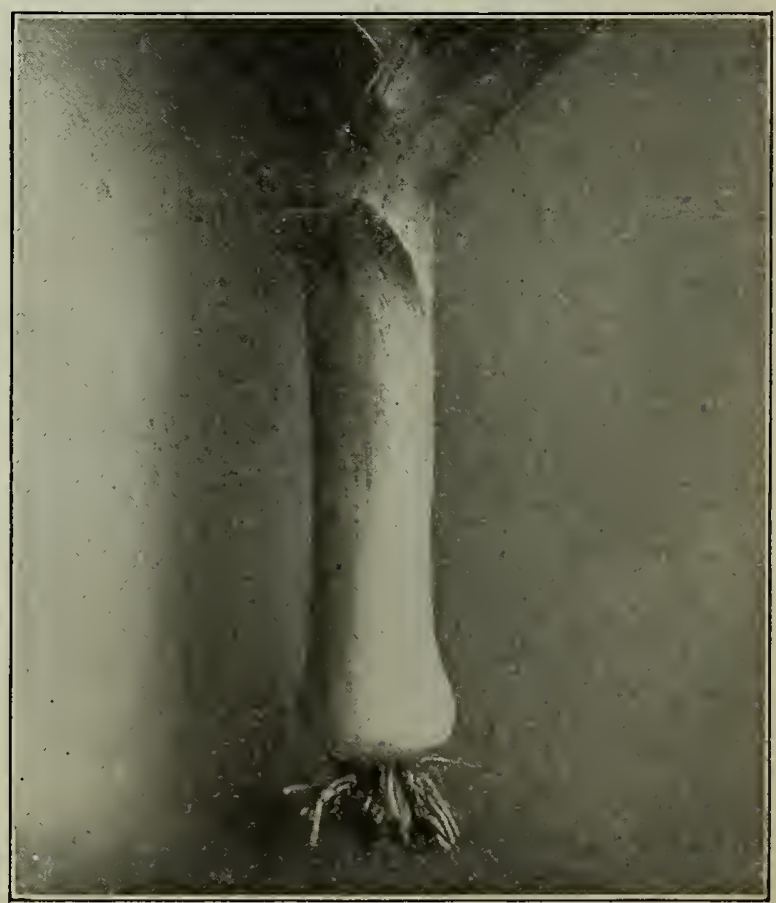

Leek-Giant Musselburgh 


\section{SAN FRANCISCO, CALIFORNIA. U.S.A}

\section{LETTUCE}

Lettuce is represented by four distinct classes or types-by the thick-leared, smooth-edged cabbage-heading tpye; the curl5 and

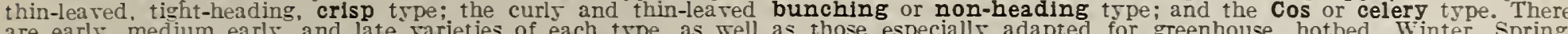

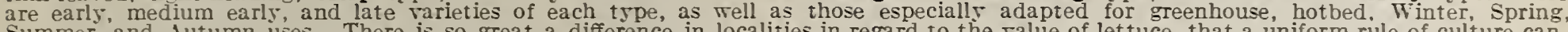

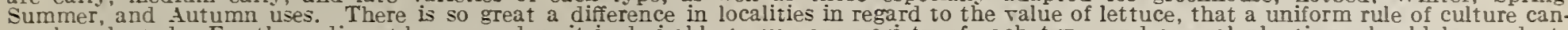

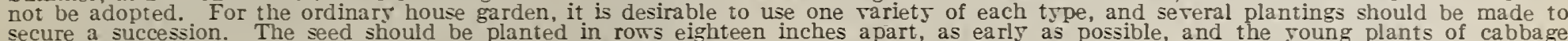

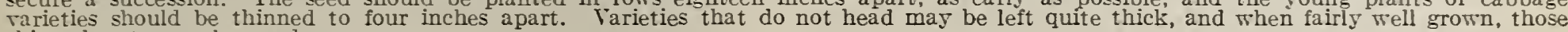
thinned out mar be used.

BIG BOSTON A popular market rariets, used largely Forthern markets. in the south to grom Winter lettuce for Northern markets. A light-green cabbage rariety, slightly
tinged with brown in the head. Has a particularl fine golden butters head. Plit. $5 \mathrm{c} ; 0 \mathrm{z} .15 \mathrm{c} ; 1 / 1 \mathrm{lb} .40 \mathrm{c} ; 1 \mathrm{~b} . \$ 1.25$.

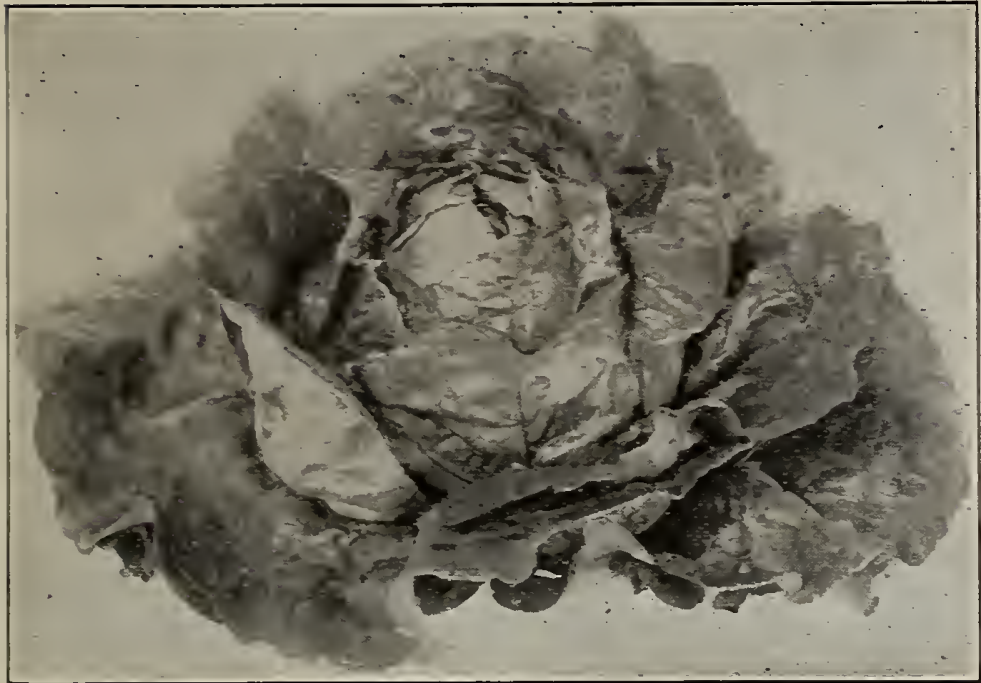

Big Boston Lettuce

Black Seeded Simpson. A bunching rarietr, forming no definite atractire color. Pkt. $5 \mathrm{c} ;$ oz. $15 \mathrm{c} ; 1 / 1 \mathrm{~b} .40 \mathrm{c} ; 1 \mathrm{~b}$. $\$ 1.25$.

Black Seeded Tennisball. An old, well-known rariets. Very desirable for hotbed culture in Winter and for withstanding heat Pkt. 5c; 0z. 15c; 1/1 1b. 40c; 1b. \$1.25.

Boston Market. The rell-known and popular hothouse rariety of New England. Needs to be quickls gromn to be of good flaror. Light-green cabbage rariets slightls tinged with brown on the head Forms a compact, butters head, Pkt. 5c; oz. 15c; $1 / \pm 1 \mathrm{~b}$. $40 \mathrm{c} ; 1 \mathrm{~b}$. $\$ 1.25$.

CALIFORNIA CREAM BUTTER or $\underset{s \text { moral }}{\text { mor }}$ Cabbage. A rert popular rariet for Autumn and Tinter Forms a rert large head, which is rerr butters, and of a rich golden-rellow inside. The leares are thick and of bright green, slightlr tinged with brown on top of head, and the outer leares are slightls spotted with inconspicuous brown spots. Easy to grow and a good shipping variet5. Pkt. $5 \mathrm{c} ; \mathrm{oz}$. 15c; $1 / 4 \mathrm{~b}$. $40 \mathrm{c}$; $1 \mathrm{~b}$. $\$ 1.25$.

Deacon. A large cabbage rariety haring thick, bright green leares; forms a large, butterr head; herr bright golden-Jellow inside. Pkt. 5c; 0z. 15c; $1 / 1 \mathrm{~b}$. $40 \mathrm{c}$; $1 \mathrm{~b}$. $\$ 1.25$.

Denver Market. A handsome rariety, forming tight, conical heads. The leares are rerr deeplr sarored, and even the outside leares are tender and crisp. Color is light-green. Pkt. 5c; 0z. 15c; $1 / 11 \mathrm{~b} .45 \mathrm{c} ; 1 \mathrm{~b} . \$ 1.50$.

Drumbead, or Malta. Sometimes called "Chinese" lettuce. A rery large, tight-heading varietr. Leares are rather coarse, but very brittle and tender. Is dark-green and slightl 5 curled. Pkt. $5 \mathrm{c}$; $0 \mathrm{z}$. $15 \mathrm{c} ; 1 / 1 \mathrm{tb} .40 \mathrm{c} ; 1 \mathrm{~b}$. $\$ 1.25$.

Early Curled Simpson. A loose-bunching sort, forming no definite head. Is crisp and tender: light oreen in color. Is rerv hards and east to grow. Pkt. $5 \mathrm{c} ; 0 \mathrm{z} .15 \mathrm{c} ; 1 / 1 \mathrm{tb} .40 \mathrm{c} ; 1 \mathrm{~b}$. $\$ 1.25$.

Grand Rapids. The well-known forcing variets for the middle Test. Where butter-headed or cabbage rarieties do not grow well under glass. Is a loose-bunching rarietr, forming no definite head. Is extremels curly, and its light yellowish-green color makes it very attractire. Pkt. $5 \mathrm{c} ; 0 \mathrm{z} .15 \mathrm{c} ; 1 / 1 \mathrm{tb}, 40 \mathrm{c} ; 1 \mathrm{~b} . \$ 1.25$

HANSON A fine, large-heading rariet5. Leares curled The head is crisp and brittle; and fla rollowish-green in color. best house garden rariety in, existence, and much the finest

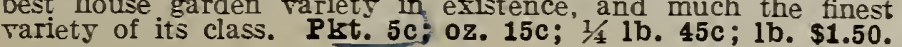

Hubbard's Market. A large cabbage rariety forming a solid head, buttery and rellow inside, and of Terv fine flaror. Color light-green. Is a farorite in some markets. Pkt. $5 \mathrm{c} ; 0 \mathrm{0z} .15 \mathrm{c}$; $1 / 1$ 1b. $40 \mathrm{c} ; 1 \mathrm{~b}$. $\$ 1.25$.

Iceberg. A large-heading rariets; crisp and brittle, and color bright on the edges. Pkt. $5 \mathrm{c} ; 0 \mathrm{z}$. $15 \mathrm{c} ; 1 / 1 \mathrm{~b}$. $40 \mathrm{c} ; 1 \mathrm{~b}$. $\$ 1.25$.

Mammoth Black Seeded Butter. A rery large, green cabbageheading rarlet. $5 \mathrm{c}$; 0z. $15 ; 1 / 41 \mathrm{~b} .45 \mathrm{c} ; 1 \mathrm{~b}$. $\$ 1.50$.

MAXIMUM, OR IMMENSITY A rers 1 a r r ge one of the largest of the cabbage sorts. It is especially adapted for planting in the Fall and Winter, and makes a fine tender buttery head. A number of our best local market gardeners hare been growing it and find it unsurpassed for a fine heary Prof. R. E. Mansell of the Experiment Station at the Unirersity of California, who plants a Terr large number of sa mples annually, pronounces Maximum as entitled to lead the list of all lettuces. Pkt. 5c; 0z. 15c; $1 / 1$ 1b. 40c; $1 \mathrm{~b}$. \$1.25.

MAY KING A rery early new variety, forming fine hard 7 is medium sized, light green, with butters but crisp heads. There is just a faint tint of brown on the head.
We hare had no end of praise from our friends and customers Who hare had no end of praise from our friends and customer does $\pi$ ell all Summer. Being of rapid growth and quick hea ding it is especialls recommended for home garden and is universally esteemed. It came to us from one of the leading growers of

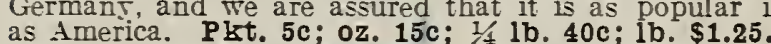

NEW YORK, OR LOS ANGELES $\underset{\text { crisp, }}{1 \text { a r tight- }}$ (ark green, curly leares; hea

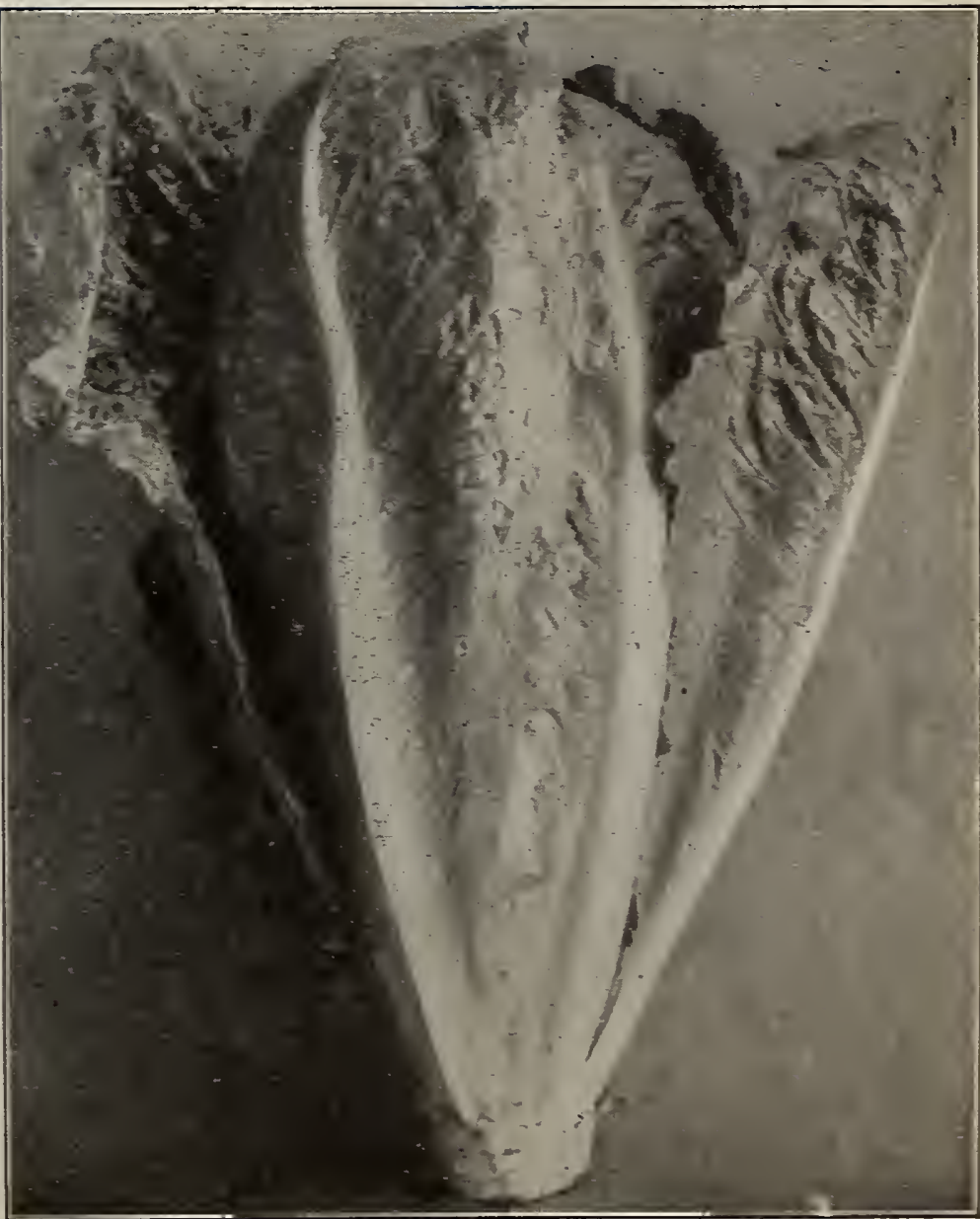




\section{C.C.MORSE \& CO VEGETABLE SEEDS C C}

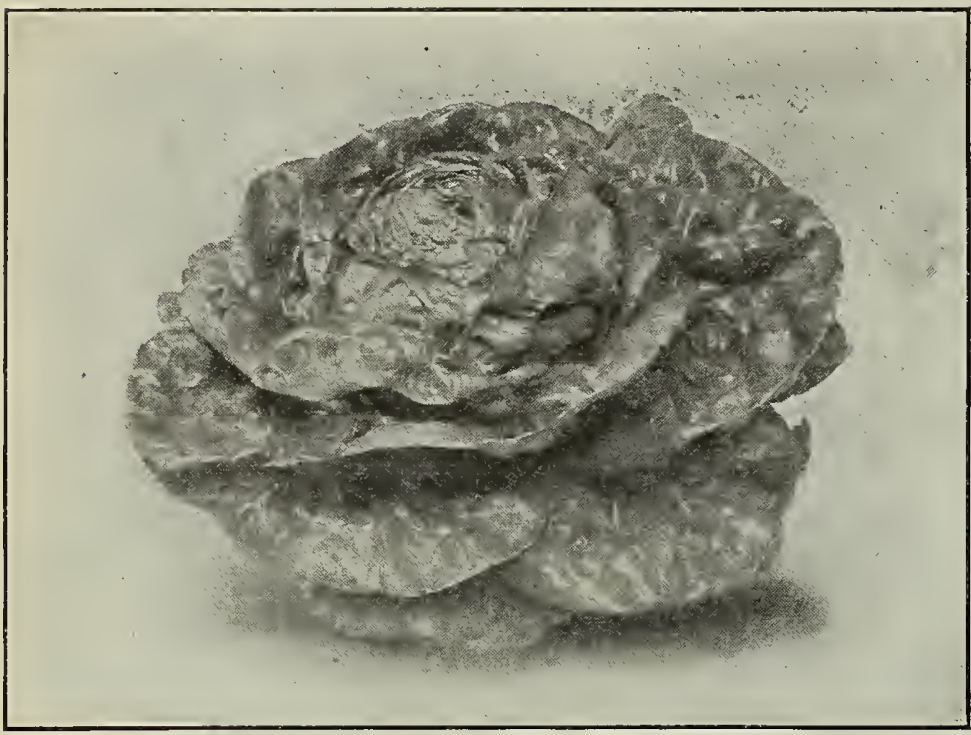

May King Lettuce-Very early and tender

PRIZE HEAD. One of the very best loose-bunching or non-heading varieties. Leaves brown, very curly, and of remarkably fine flavor. Grows quickly and all except the outer row of leaves are cultivation. Pkt. 5c;0z. 15c; 1/4 1b. 40c; 1b. \$1.25.

Salamander. One of the most popular varieties for withstanding heat. Medium size, light green, and forms a hard buttery head of fine quality. Pkt.5c; 0z. 15c; $1 / 4 \mathrm{lb}$. 40c; 1b. \$1.25.

PASSION The most popular variety among California and - cabbage, butter-heading sort. We have the best and truest cabbage, butter-heading sort. We have the best and truest recommended as a garden lettuce for our climate. It heads well, and bears shipping remarkably well, since it re-
vives nicely after wilting. Pkt. 5c; oz. 15c; $1 / 4$ 1b. $45 \mathrm{c} ; 1 \mathrm{~b} . \$ 1.50$.

THE MORSE A large, loose-

non-heading va r i et $y$,

A forming a large bunch of leaves, which are very crisp and of fine flavor. In color it is a light green and very attractive Pkt. 5c; 0z. 15c; $\$ 1.25$.
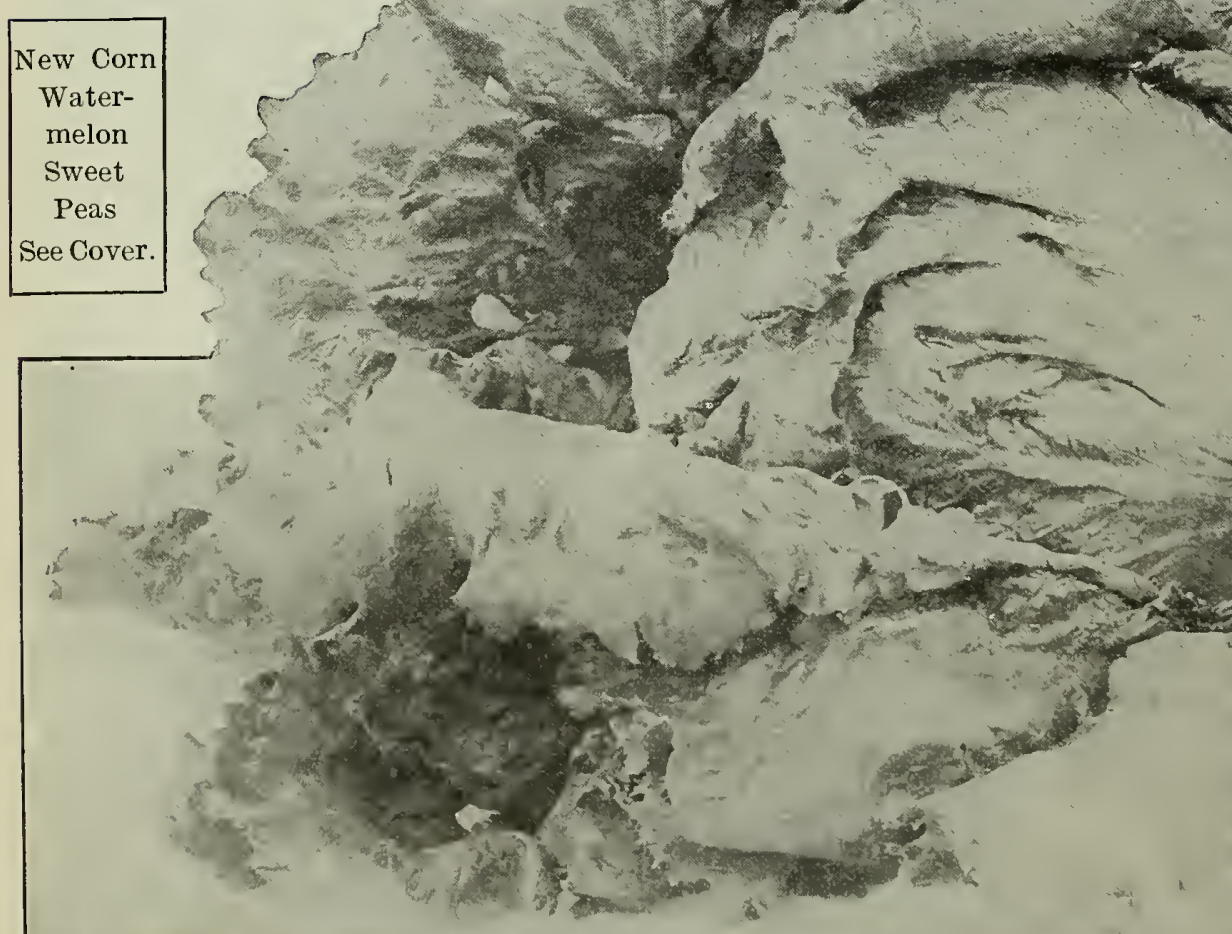

Hanson Lettuce-One of the very best garden varieties 1b. $\$ 1.25$.

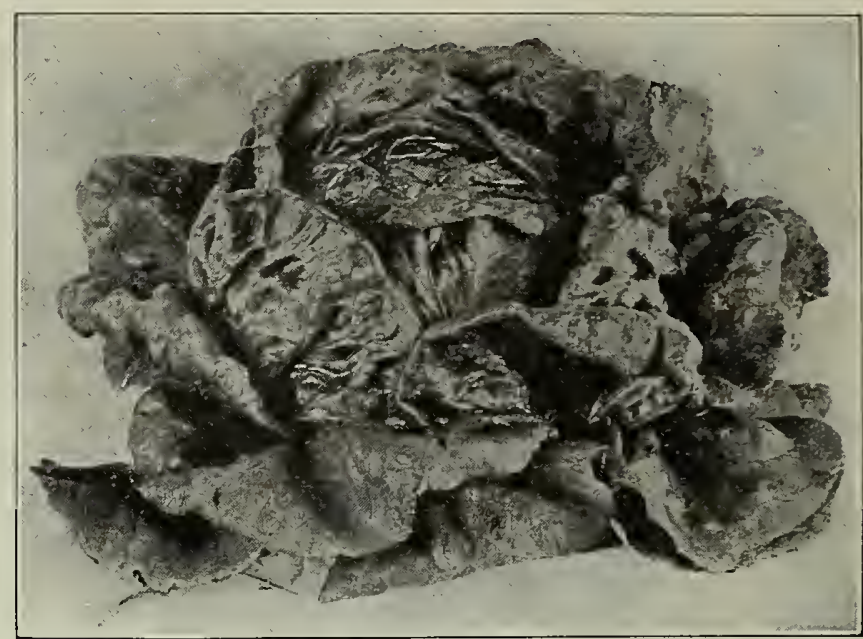

Maximum Lettuce-Very large buttery head

7 Strawberry. Our last season's novelty A medium-sized variety t with hard, compact heads. Brownish-red on the surface and having pink colored heart. Pkt. 5c oz. 20c.

White Seeded Tennis Ball. This variety is the same as Boston Market, which see for description. Pkt. 5c; oz. 15c; $1 / 4 \mathrm{lb} .40 \mathrm{c}$;

White summer Cabbage. The oldest and best known cabbageheading variety, Forms a medium-sized, hard

WHITE PARIS COS. The best of the Cos or a large, light-green plant, with the head well folded and quite solid. Cos lettuce is also called Romaine, and is very popular with our foreign population, for it is highly prized in England and France, while lit tle known to our own people. Pkt. 5c; oz. 15c: $1 / 4 \mathrm{Ib}$. 40c; $1 \mathrm{~b}$. $\$ 1.25$ famous. We exhibited some very large views of these fields at the World's Fair at St. Louis and they attracted more than usual attenIn miniature form these fields are now illustrated on the first pages of this catalogue. Imagine these pareat stretches of beautiful Let tuce in brown and gold and brilliant green, for all these shades are peculiar to Lettuce. We are the largest single gro wers in
the world of Lettuce Seed. It is our precialty and we ship it to all parts of the world. 


\section{MUSKMELON OR CANTALOUPE}

Plant hills in rich, moist land, using one ounce to 100 hills, or two to three pounds per acre. Som the seed after all danger of frost is orer

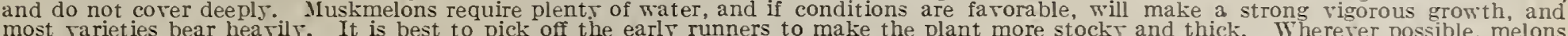
should be grown in the home garden, for the charm of a good melon is in getting it fresh from the garden and direct to the table.

Acme, or Early Baltimore. One of the best all-round melons in cultivation, and recommended for its uniform shape and size and fine qualit 5 . Is slightly pointed at stem end; somewhat ribbed and coarselr netted. The flesh is thick, green, and rery sweet. Pkt. $5 \mathrm{c} ; 0 \mathrm{z}$. $15 \mathrm{c} ; 1 / 1 \mathrm{lb} .40 \mathrm{c} ; 1 \mathrm{~b} . \$ 1.25$.

Bay View. A standard rariets. Fruit large, oblong, hearils $5 \mathrm{c} ; 0 \mathrm{z} .15 \mathrm{c} ; 1 / 4 \mathrm{lb} .40 \mathrm{c} ; 1 \mathrm{~b} . \$ 1.25$.

BURRELL'S GEM A medium-sized oral rariets deeply flesh. It is larger than Rock5 Ford and of an entirels distinct flaror. There is a growing demand for the fine grained, smooth faron-red flo one of the best in cultiration. Pkt. 5c; oz. 20c; $1 / 41$ b. 60c: 1b. $\$ 2.00$.

Extra Early Citron. A rery earls, medium-sized rariety. Fruit ball-shaped, shin green, and flesh light green. Yers productire fragrant and of

Emerald Gem. A salmon-fleshed rariety of remarkabls fine flaror and fine qualits. Fruit medium sized, globular, slightiy flattened at the ends; shin onlr slightls netted; rers thick, and well ripened close to the rind. Pkt. 5c; oz. 15c;1/4 lb. $40 \mathrm{c}, 1 \mathrm{~b} . \$ 1.50$. xtra Early Hackensack. An early rariets with almost globular fruit, which is hearily ribbed and hearils netted. Fl
and light green. Pkt. $5 \mathrm{c} ; \mathbf{0 z} .15 \mathrm{c} ; 1 / 1 \mathbf{1 b} .40 \mathrm{c} ; 1 \mathbf{b} . \$ 1.25$

FORDHOOK One of the best home garden melons; of ends. Roughly netted while the shin showing through the ends. Roughly netted while the shin showing through the
netting is emerald green. The flesh is rich salmon in color, rery solid and of delicious flaror. The rind is extremel 5 thin and the seed carity unusually small. Pkt. $10 \mathrm{c} ; 0 \mathrm{z} .25 \mathrm{c} ; 1 / 1 \mathrm{~b} .75 \mathrm{c}$; 1b. $\$ 2.50$.

Hackensack, or Turk's Cap. An excellent green-flesh rariet5, with flattened ends, thich, irregular ribs, and coarse netting. The flaror is st
$1 \mathrm{~b}$. $\$ 1.25$. Jenny Lind. Terr earls and rery prolific. Fruit is small, some-
what flat tened, deepls ribbed and netted. Flesh green and rers sweet. Pkt. 5c; oz. 15c; 1/1 1b.40c;1b. \$1.25.

Large Yellow Cantaloupe. Although there are sereral rarieties frequentl substituted for this sort, we hare a distinct trpe, and find it rery popular $\pi$ ith all who hare tried it. The fruit is large, oblong, slightly ribbed and coarsely netted. The flesh is light rellowish-green, rery 15c; $1 / 1 \mathrm{lb}, 35 \mathrm{c} ; 1 \mathrm{~b}$. $\$ 1.10$.

Melrose. A fine shipping rariety owing to the rather tough shin. Fruit is slightly oral. rery much netted but not ribbed. Flesh light green, shading to salmon at seed oz. $15 \mathrm{c} ; 1 / 41 \mathrm{~b} .40 \mathrm{c} ; 1 \mathrm{~b} . \$ 1.25$.

Montreal Market. A large-fruited rariet nearls globular with flattened ends. Shin dark green; hearils netted. Flesh light green.

Osage, or Miller's Cream. A salmon-flesh rariet $\bar{y}$ 1 a $r \mathrm{~g}$ e $\mathrm{r}$ than" Eme r a 1 d $\mathrm{G}$ e $\mathrm{m}$. Skin dark $\mathrm{g} r$ e e $\mathrm{n}$. slightly n e. $t$ t e d and $r$ i bb e d.

fa.rorite rariet 5 f or the later markets. Pkt. $5 \mathrm{c} ; 0 \mathrm{z}$.

$15 \mathrm{c} ; 1 / 4$

1b. $40 \mathrm{c}$; 1b. $\$ 1.25$.

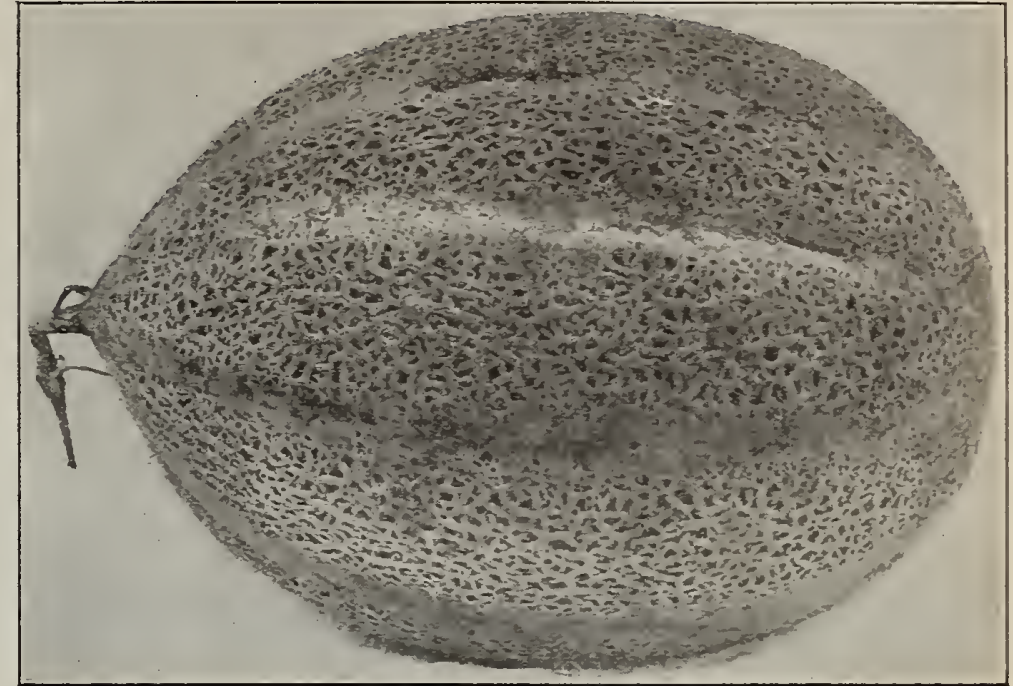

Acme or Baltimore

THE HOODOO The fruit is of medium size; the seed carit 5 rery mall; the rind rery thin indeed; and the edible fleshy par rers thick and meat 5 . It is of orange or salmon color, the trpe much preferred now. Pkt. 10c;0z. 35c;1b. $\$ 3.50$.

KRIS KRINGLE The best of the rinter casabas. Do not pick until the light streaks become quite Jellow. Stow awas in a the rind becomes slightls softened and moist ther are readr to eat. Some of the melons will actually keep till Februars. Pkt. $10 \mathrm{c} ; 0 \mathrm{z} .25 \mathrm{c} ; 1 / 1 \mathrm{1b} .75 \mathrm{c} ; 1 \mathrm{~b}$. $\$ 2.50$.

Petoskey, or Paul Rose. Excellent market rariety with thick, firm, orange-colored flesh. Rather larger than Netted Gem; is slightls oral, ribbed, and heavils netted. Shin light green, $15 \mathrm{c} ; 1 / 1 \mathrm{lb} .45 \mathrm{c} ; 1 \mathrm{~b} . \$ 1.50$.

ROCKY FORD OREM E TTED ROCKY FORD Grown in great quantities in Colorado. Fruit is slightls oral, finely netted, and slightly ribbed. Flesh thick, green, rery that from the immense areas of land deroted deroted to the Rocks Ford or Netted Gem Melon, that there is but one rariety in cultiration. In fact, there is but one for most of the large planters and it is this rariety. It gires equally splendid results in the home It gires equally splendid results in the home garden and is the best all-round rariety to
plant. Some of the best melons in the plant. Some of the best melons in the
market the past season came from the Imperial Valles, pidls growing melon section of California them were the Rocky Ford rariety Pkt. $5 \mathrm{c} ; 0 \mathrm{z}, 10 \mathrm{c} ; 1 / 4$
$1 \mathrm{~b} .30 \mathrm{c} ; 1 \mathrm{~b}$. $\$ 1.00$.

Iarge Green Nutmeg. A medium sized globular fruit. green, hearily green, hearily slightls ribbed. Flesh $t \mathrm{hick}$,
green and ragreen and raA desirable rariety for hotels and $\mathrm{I}$ e s t a u-
rants. P kt. $5 \mathrm{c}$; oz. $15 \mathrm{c} ; 1 / 1 \mathrm{~b}$. $40 \mathrm{c}$; 1b. $\$ 1.25$. 


\section{WATERMELON}

Light, sandy, or gravelly soil is necessary for the best watermelons. They seldom do well on heavy adobe or clay soils, and these lands should be avoided for watermelons as a farm crop. In the garden the soil can be made suitable by spading in each hill some well-rotted manure and sand or loam.

Plant the seed about the first of May, in hills about five feet apart. Use five or six seeds to a hill, and thin out to two plants as soon as the second or third leaf shows. Use about four ounces of seed to 100 hills, or as a farm crop, two to four pounds per acre. The five best

EASTERN GROWN SEED-For some reason, not wholly understood, watermelon deteriorates if the seed is constantly West. The very best strains come from the extreme East and we get our supply from one of the best growers in Florida. The most critical melon growers claim that well-grown Eastern seed produces more uniform market melons and that they are more solid and uniformly ripened at the heart.

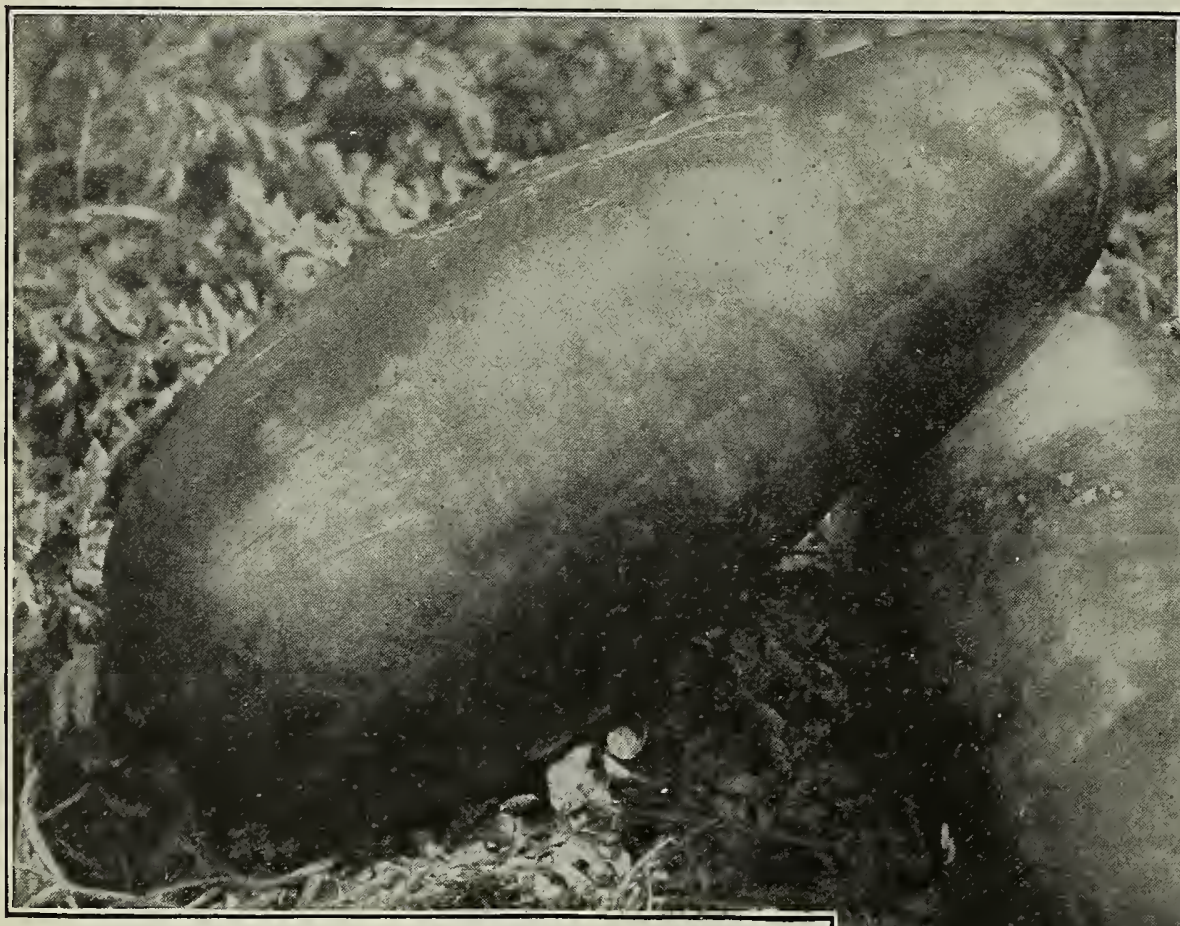

ANGELINO. A new melon of great promise. Fruit round, deep green. Rind very thin, flesh bright red and heart unusually large and heavy. Ships well and sells readily in all $\mathrm{m}$
$0 \mathrm{z} .20 \% ; 1 / 41 \mathrm{~b} .50 \mathrm{c} ; 1 \mathrm{~b}$. $\$ 1.50$

Black Boulder, or Black Diamond. A round, very dark green melon, with bright red flesh and black seeds. It is similar to old Black Spanish, but supersedes it in every way. Pkt. $5 \mathrm{c} ; 0 \mathrm{oz} .10 \mathrm{c} ; 1 / 4$ 1b. 20c; 1b. 60c.

CHILIAN. A very brittle, thin-skinned variety, of highest quality, and especially valuable for home garden. It is slightly oblong; the skin is deep rich green, mottled and striped with a still deeper green; the flesh is bright red and the flavor is remarkably fine and sweet. Pkt. 5c;0z. 10c; 1/4 lb. 30c;1b. $\$ 1.00$.

Citron, Red Seeded. A small, globular variety, striped and marbled with light green. Flesh white and solid; seeds red. Used exclusively for
$25 \mathrm{c} ; 1 \mathrm{~b} .75 \mathrm{c}$

Citron, Green Seeded or Colorado Preserving. An oblong dull green variety about eighteen inches long. The flesh is green with green seeds and is used largely for stock feeding. A common plan is to split them open with an axe and feed them to cattle in the field. Pkt. 5c;0z. 10c; $1 / 41 \mathrm{~b} .25 \mathrm{c} ; 1 \mathrm{~b} .75 \mathrm{c}$.

Cole's Early. A great favorite for a large area of different climates. Fruit medium sized, oblong, striped and mottled. Flesh, bright red, solid, and of fine sweet flavor. Pkt. 5c; oz. 10c; 1/4 1b. 25c; 1b. $75 \mathrm{c}$.

Cuban Queen. An excellent shipping variety of medium to large size and globular to oval shape. Rind quite thin, flesh bright red and firm. Skin striped with light and dark green. Pkt. 5c; 0z. $10 \mathrm{c} ; 1 / 4$ ib. $30 \mathrm{c}$; 1b. $90 \mathrm{c}$.

Dixie. A good market variety with large oblong fruit. Skin striped light and dark green. Rind thin but tough. Flesh bright red. Pkt. $5 \mathrm{c} ; 0 \mathrm{z} .10 \mathrm{c} ; 1 / 41 \mathrm{~b} .25 \mathrm{c} ; 1 \mathrm{~b} .75 \mathrm{c}$.

Fordhook Early. The earliest of all melons and of the finest quality . Fruit almost globular; color deep mottled green with occasional faint stripes of lighter green; flesh bright red and crisp; rind tough, which makes it a good shipping variety. Pkt. 5c; oz. $10 \mathrm{c} ; 1 / 41 \mathrm{~b} .25 \mathrm{c} ; 1 \mathrm{~b} .75 \mathrm{c}$.
FLORIDA FAVORITE A very large large, oblong fruit and dark-green skin, mottled with a deeper shade. Rind thin, flesh deep red and of fine quality. The flavor is excellent and the melon is well suited for either table or market. Pkt. 5c;0z. 10c; $1 / 4$ 1b. 25c;1b. 75c.

HALBERT HONEY

A large oblong variety of the best quality. Is especially sweet in flavor, crisp and brittle, and well ripened to a very thin rind. Pkt. $5 \mathrm{c} ; \mathbf{o z}$. $10 \mathrm{c} ; 1 / 41 \mathrm{~b}$. 30c; $1 \mathrm{~b}$. $\$ 1.00$.

Ice Cream. A popular homemarket variety. The fruit is oblong, with dark green motoblong, with dark green motPkt. 5c; oz. 10c; $1 / 41$ 1b. 25c; 1b. $75 \mathrm{c}$.

Iceberg. In general appearance this variety resembles Kolb's Gem, but the skin, which is dark green with markings of a lighter shade, is darker in Iceberg, and shows a spot of bright yellow where the fruit bright yellow where the fruit rests on the ground. The red. It is the best darkcolored shipping variety in colored shipping variety in $25 \mathrm{c} ; 1 \mathrm{~b}$. $75 \mathrm{c}$.

\section{KLECKLEY SWEETS}

OR MONTE CRISTO. A very desirable variety for the home garden or near-by markets. The most extensively grown shipping variety in California. Fruit medium sized, oval, and skin dark green; flesh bright red and very sweet. It is the

Kleckley Sweets very sweet honey-like flavor that makes it especially distinct from all other varieties. Pkt. $5 \mathrm{c} ; 0 \mathrm{z} .10 \mathrm{c} ; 1 / 4 \mathrm{lb} .25 \mathrm{c} ; 1 \mathrm{~b} .75 \mathrm{c}$.

Kolb's Gem. The well-known shipping variety. The fruit is large, thick, and oval, with flattened ends. Skin striped with light and dark green. Flesh bright red. Pkt. 5c; oz. 10c; $1 / 41 \mathrm{lb} .25 \mathrm{c}$; 1b. $75 \mathrm{c}$.

Mountain Sweet. A good lome-garden variety and an old favorite. Fruit large and oval : skin green, and flesh bright red. Pkt. 5c; 0z. $10 \mathrm{c} ; 1 / 4$ 1b. $25 \mathrm{c} ; 1 \mathrm{~b} .75 \mathrm{c}$.

Sweet Heart. A very productive and fine shipping variety. Fruit large, oval, with thin but firm rind. Flesh bright red, solid, and sweet. Skin light mottled green. Plrt. 5c;0z. 10c; $1 / 41 \mathrm{~b}$. $25 \mathrm{c} ; 1 \mathrm{~b}$. $75 \mathrm{c}$.

The Lodi, or San Joaquin. Well-known and popular California variety, grown on an immense scale in San Joaquin Valley and shipped to all parts of the Pacific Coast. Fruit larce and oblong. shin ed and red and sweet; seeds white. Pkt. 5c;0z. 10c; 1/41b.25c;1b. 75c.

TOM WATSON A novelty in watermelons, and of sterseason ling merit. It was introduced last season and has been quite extensively tried so that it has passed its period of experiment. The fruit is very large, many melons weighing 50 to 60 pounds and measuring 18 to 24 inches in length. Its rind is very thin but exceedingly tough, and on this account it is one of the very best shipping varieties. The skin is a dark mottled green, while the flesh is a brilliant scarlet, and the heart is very large with a small seed area. The flavor is most delicious and refreshing. See cover. Pkt. 10c;0z. 20c; 1/4 lb. 60c;1b. $\$ 2.00$. 


\section{SAN FRANCISCO CALIFORNIA U.S.A.}

WATERMELONS-Continued.

\section{GEORGIA}

\section{RATTLESNAKE}

One of the oldest and most popular sorts and frequently known as GYPSY. A large oblong variety with decided stripes, of light and deep green. Rind is tough, but flesh is of good quality and bright red; a good shipping and market melon. Is quite as generally used by the large melon growers as Kleckley Sweets and is perhaps hardier and more profitable, being very easily

\section{NASTURTIUM}

The green seed of nasturtium has a sharp, pungent flavor, and when pickled makes an excellent condiment. It is also valuable as flower and serves a double purpose in the garden. Pkt. 5c; oz. 10c; $1 / 41 \mathrm{~b}$.
$\mathbf{2 5 c}$; 1b. 75c.

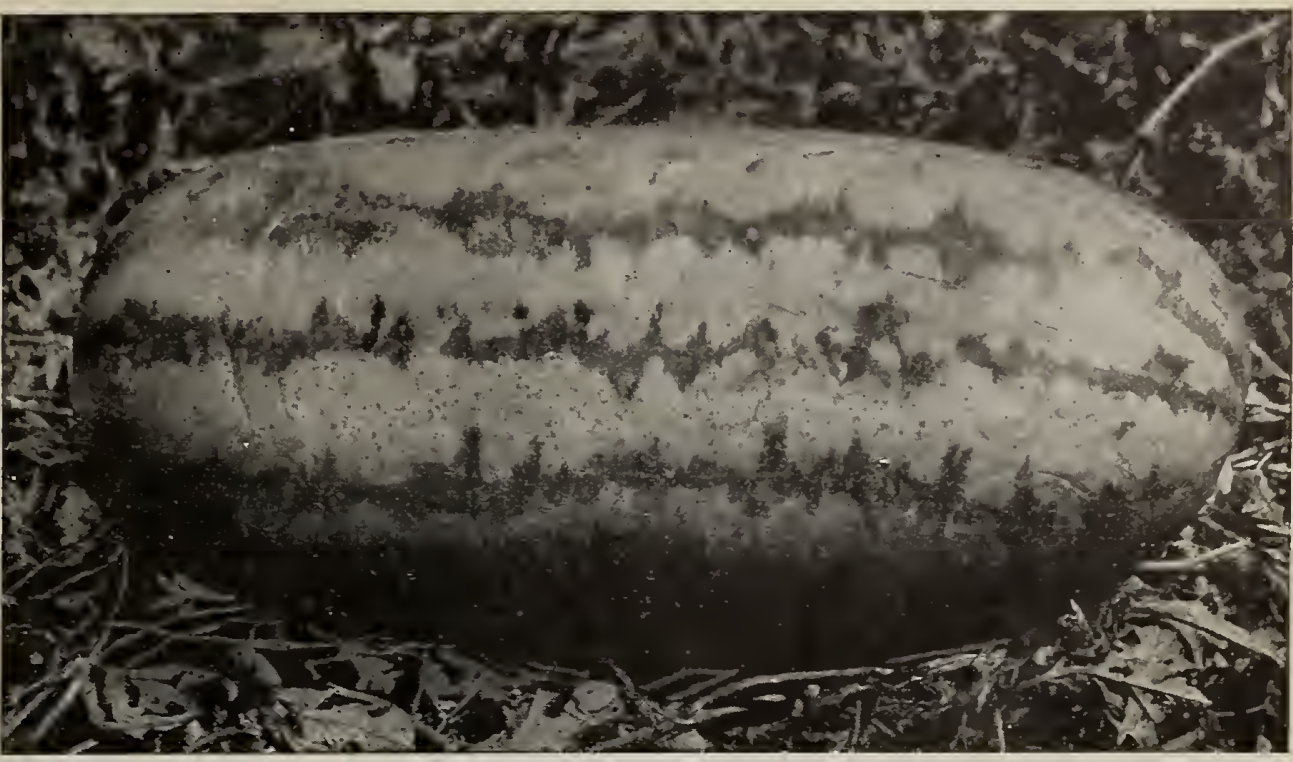

Georgia Rattlesnake Watermelon

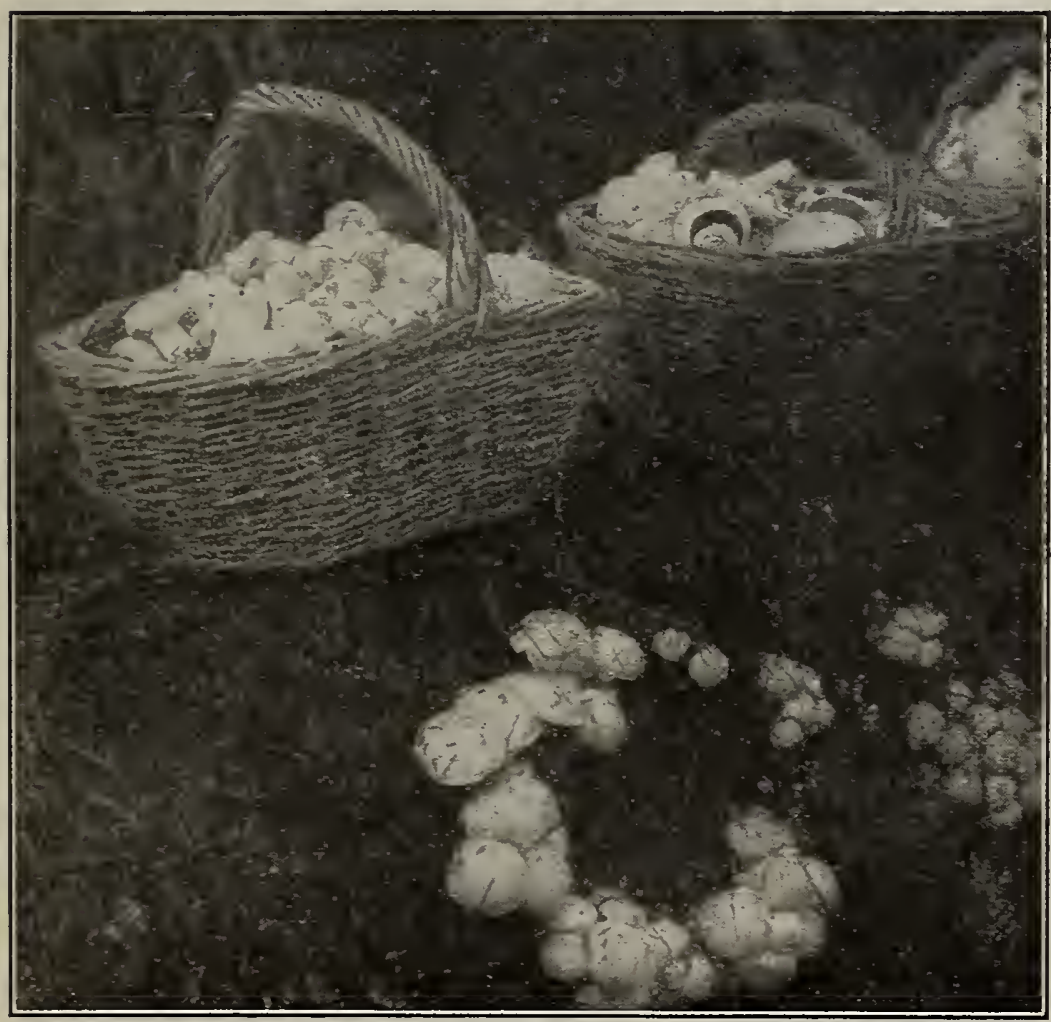

English Mushrooms

\section{MUSHROOM SPAWN}

\section{CULTURAL DIRECTIONS}

Ten pounds will spawn about ten feet square. Mushrooms can be grown in any dark room or cellar where the temperature can be kept at from 50 to 70 degrees. From some old pasture procure good rich soil, and to every bushel of this soil add two bushels of fresh horse manure. Of this well-mixed compound prepare a bed, say four feet wide. Put down a thin layer and prepare a bed, say four feet wide. Put down a thin layer and pound it down hard, and go on until you have a bed twelve or eighteen inches thick. As soon as the tem me inserted in pieces falls from 75 to 50 degrees, the spawn may be inserted in pieces about the size of a walnut about two inches deep and six
inches apart. Cover with loamy soil about two inches deep and beat it down erenly and firmly. Finish off with a covering of clean hay, about a foot thick, and the work is done. If the temperature is right, in six or eight weeks you may except mushrooms. The beds will continue bearing from twenty to thirty dass. After the first crop is gathered spread over the bed an inch of fresh soil moisten with warm water, and cover bith growing are proper and uniform temperature and very rich soil.

English Mushroom Spawn. It comes in pressed bricks weighing about twe ounces, Brick, 35c, postpaid; by express, brick $25 \mathrm{c} ; 10$ bricks, $\$ 2.00$.

\section{MUSTARD}

The leares of these varieties of mustard, as here listed, make excellent greens of sharp pungent flavor. and are cooked the same as spinach or beet leaves. Sow the seed in drills early in the spring and at frequen

secure a constant supply of fresh greens. Mustard is hardy and is easily grown. One ounce will sow fifty feet of row.

Chinese. A very hardy, broad-lea.ved variety Leares are thick and deeply saroyed, with broad white midrib. Pkt. $5 \mathrm{c} ; 0 z .10 \mathrm{c} ; 1 / 41 \mathrm{~b} .15 \mathrm{c} ; 1 \mathrm{~b}$.

dhook Fancy. A rery handsome parietr with dark green foliage. Leaves very finely curled on the edges. Plant medium sized. Pkt. $5 \mathrm{c} ; 0 \mathrm{oz}$.
10c; $1 / 1 \mathrm{lb}$. 30c;1b. 90c.

\section{OKRA, OR GUMBO}

The long, tender pods of okra are rery delicious when sliced and cooked in soups. While this is its chief use it is also boiled and served like other classes of vegetables. The tall sorts should be planted in hills about a foot apart, using about one ounce to 100 hills. The dwarf sorts may be planted in hills or in rows about three feet apart. Plant in any good soil about April 1st. The pods should be gathered when rery young, as they are

\section{PERKINS MAMMOTH LONG}

POD A dwarf-growing. very early and prolific variof fine quality. Pkt. 5c; oz. 10c; $1 / 4$ 1b. 20c; of fine $60 \mathrm{c}$.
White Velvet. A medium-sized variety, bearing long, smooth, white pods, which are very tender. long, smooth, white pods, which are very

DWARF GREEN. An early, dwarf, and prolific variety with thick, green pods. Pkt. 5c; oz. 10c; $1 / 41 \mathrm{~b}$. 20c;1b.60c.

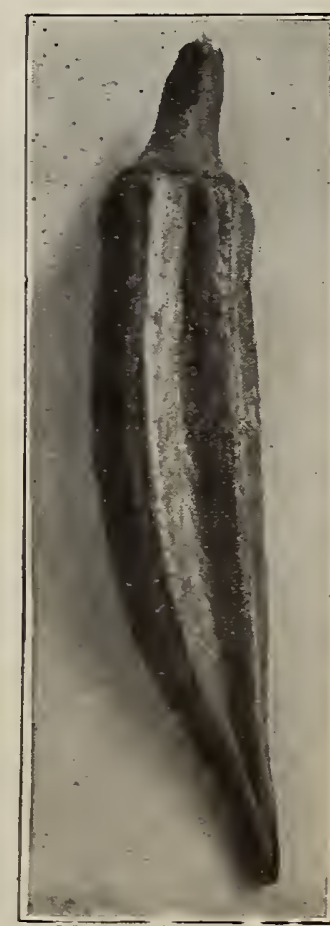

Okra-LOng Pod 


\section{HOW TO GROW ONIONS FOR MARKET}

The most essential item in growing Onions for market is good seed-seed that will come up and seed that will produce the variety you want-cheap seed is very poor economy.

For general crop the seed must be sown during the month of January or before February 1st, and, if the location is a fairly dry one, it is best to sow about the middle of December. The seed should be sown with a seed drill in rows 14 inches apart, using 4 to 4,2 pounds of seed per acre. In very weedy land the rows may be 18 or 20 inches apart when less seed is required.

For planting a single row of onions among strawberry plants about 2 pounds of seed per acre is sufficient.

The land must be thoroughly worked before planting, and usually two good plowings, a good disking, and a harrowing are necessary.

The crop must always be kept free from weeds, and it is usually necessary to weed out in the row by hand once or twice. Hoeing between the rows may be done oftener. It is not necessary to thin the plants in the row, since some thinning is naturally done during the hand weeding. The land chosen for onions should be wet land, preferably loose, sandy loam or peat, and should always be kept well drained. Heavy adobe or clay soil is good, but needs to be irrigated in May, June, and July, and the onions are not so well colored or even in shape in heavy, stiff soils. Steady, even growth is necessary to good onions, and a check in the growth, whether from disease or drought, causes them to run to seed badly. Onions are ready to harvest usually the latter part of August, when, with a good crop, the tops are pretty well ripened down If the tops are still standing and green it is well to run a light roller or plank over them to press the tops down, and the onions should be pulled in about ten days after this is done, whether the tops have dried off or not. It requires not less than two full weeks to properly cure onions in about ten days after this is done, whether the tops have dried off or not. It requires not less than two full weeks to properly cure onions
after they are pulled. In localities where fog is prevalent it is best to spread the onions out on the ground, not more than one bulb deep. It is usual in other climates to throw into windrows a foot or more It is usual in other climates to throw into windrows a foot or more top and sack until ready to ship to market, and if onions are to be

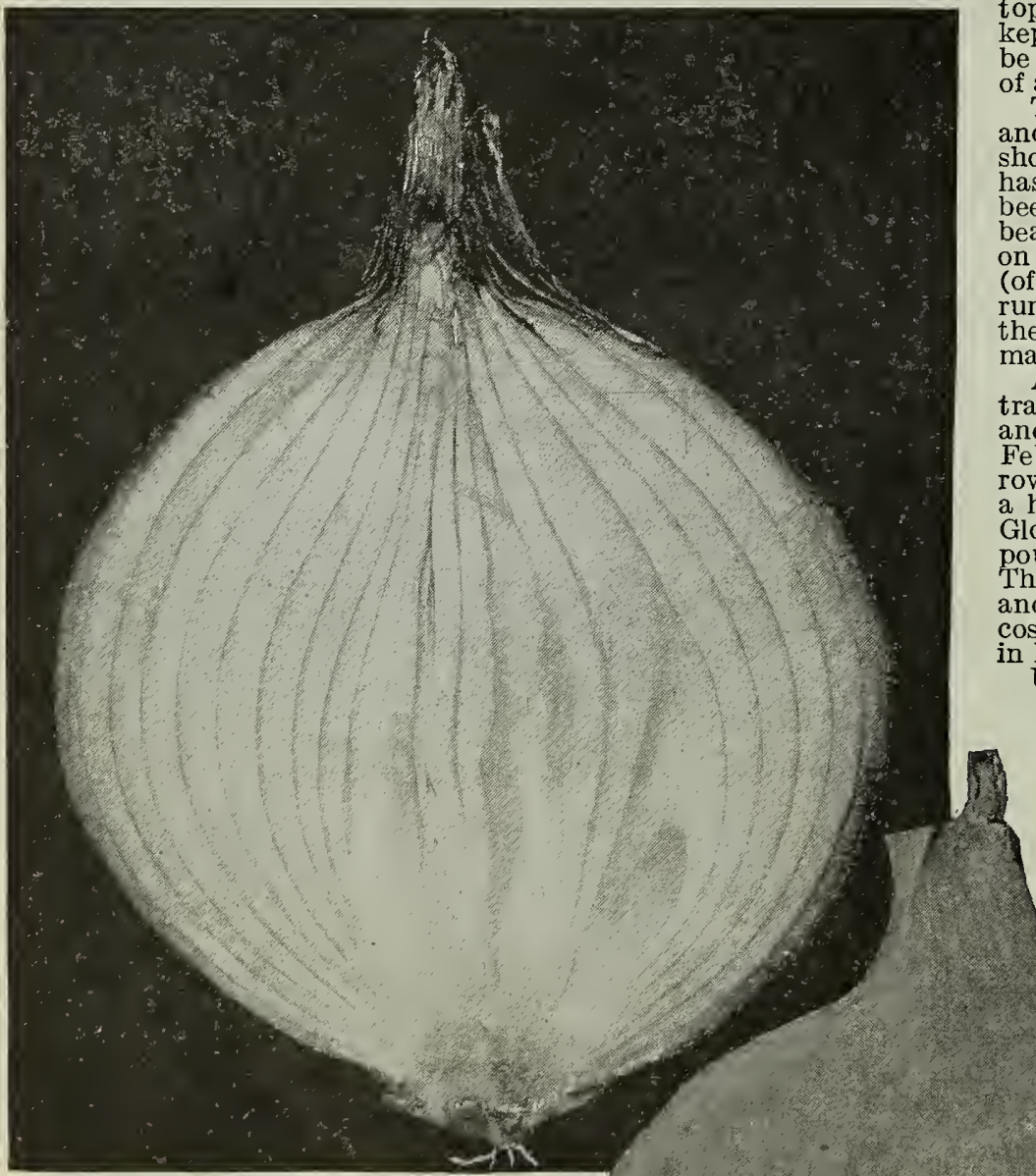

Prize Taker

Alsa Craig. The great English heavy cropper. Of giant size and immense weight. See page 5. Prt. 10c; oz. 30c: $1 / 1 \mathrm{lb}$ ustralian Brown. An early and very hardy variety which does especially well in the South. Should be planted early, on low, wet grounds to get large bulbs. is a rich brown. Is especially noted as a long keeper, as it keeps noted as a long keeper, as it keeps well into spring, and much long0z. $10 \mathrm{c}$; $1 / 41 \mathrm{~b}$. $35 \mathrm{c}$; 1b. $\$ 1.00$.

California Early Red. A variety much used for very early onions. If the set in the field in November or December, good market onions can be had in May. It is not a good keeping variety, but is of very mild flavor and of fine quality. Is very much esteemed as a green onion before the bulb
is formed. Pkt. 5c;0z. $15 \mathrm{c} ; 1 / 4 \mathrm{~b} .40 \mathrm{c} ; \mathbf{1 b}$. $\$ 1.25$. be put under cover on a floor or in a bin with abundant circulation of air, and be kept absolutely dry.

The value of an onion crop is naturally dependent on the market and on the character of the land planted. Land that is very foul should usually be avoided as too expensive. Also avoid land which has just had a hay or grain crop, and if possible use land that has been planted to vegetables or some hoed crop, especially peas and beans. An onion crop should not be repeated more than three times on the same land, and usually twice is best, since onion diseases of which there are many) appear very plentifully. An average crop runs from 150 to 200 centals $(15,000$ to 20,000 ibs.) per acre, and the cost represented by labor, rent, sacks and transportation is estimated roughly at $\$ 75$ per acre.

Another very good system of growing fancy market onions is by transplanting. By this method the seed is sown in beds in August and September, and the plants are pulled and transplanted about February 15th to March 1st. Put the plants 6 inches apart in lateral rows, 14 inches apart when they make a uniform sized bulb and also a hard and firm one. This plan is especially recommended for the Globe varieties, since they do best under this treatment. About 2 pounds of seed will furnish plants enough for an acre by this method. The expense is considerably greater than .by the ordinary plan cost is simply in labor in transplanting, for there is some saving in hoeing and hand weeding.

Unless the land is porous and friable and also very moist all through the summer this method is usually unsuccessful and is not recommended. The seed should never be sown later than september 15th, and the transplanting should never be done later than March 15th.

Crystal White Wax. A pure white variety, very flat and extremely early. Is of the Bermuda type and the best strains come from Teneriffe, Canary Islands, where we receive our supply. The beautiful clear white onion seen in our markets in crates, early in the spring, is this variety. Pkt. 5c; oz. 40c; $1 / 4$ lb. $\$ 1.20$ : $1 b$. $\$ 4.00$.

Extra Early Pearl. A very early variety with white skin, rather coarse grain and mild flavor. In shape it is flat and is unsurpassed for early sets or home-made pickles. Pkt. 5c; oz. 25c; $1 / 41$ b. $65 \mathrm{c} ; 1 \mathrm{~b}$. $\$ 2.25$.

Extra Early Barletta. Extremely early variety. Seed planted in February will form ripe onions the last of July. Is a white onion, forming small bulbs for home-made pickles. Pkt. $5 \mathrm{c} ; \mathbf{0 z}$. $25 \mathrm{c} ; 1 / 4$ 1b. $65 \mathrm{c} ; 1 \mathrm{~b}$. $\$ 2.25$.

Extra Earley Golden Globe, or Australian Extra Early Yellow Globe. A handsome and valuable yellow globe-shaped variety. It is very early and extremely hard and firm, and almost as good in long-keeping qualities as Australian Brown. It runs very uniform in shape, is of good average size, and perfectly globular. The skin is rich orange yellow and the flesh is quite strong and fine grained. Pkt. 5c; 0z. 25c; $1 / 41 \mathrm{lb}$. $75 \mathrm{c} ; 1 \mathrm{~b}$. $\$ 2.50$.

Extra Early Red Flat. A very early, flat variety with dark purplish-red skin. Forms a hard bulb with good keeping qualities. 


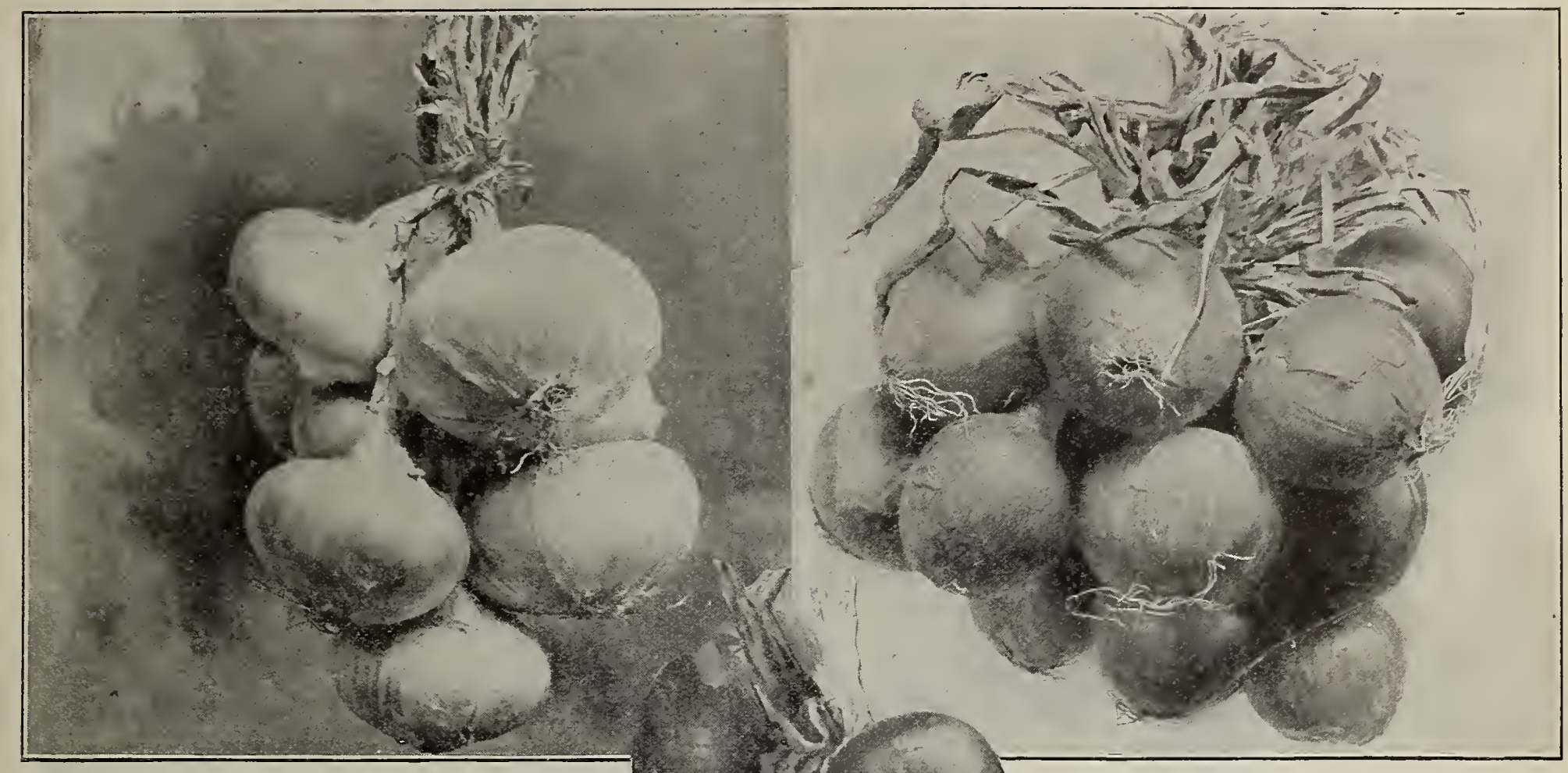

Mammoth Silver King. An early, large, white, flat variety. Is not a keeping is valuable for home use and nearby is valuable for home use and nearby flavor. Pkt. 5c; oz. 25c; $1 / 4$ Ib. 65c; 1b. $\$ 2.25$.

\section{MORSE BROWN GLOBE}

A fine, large, globe-shaped sort, of a rich, seal-brown color. It ripens uniformly and nearly every plant makes a solid, hard bulb. It has all the long-keeping characteristics of Australian Brown, and is one of the very boomed this onion a great deal the past three seasons and do not think we have said anything in its favor that has not been completely corroborated by actual results. It is one of the handsomest of the Globe onions, is hard as a brick and a great keeper. We have not as yet had sufficient seed of it to allow us to put it on the market except in small quantities. to offer it now in larger quantities and recommend it to all large growers who want a fancy and profitable market onion. Pkt. 5c; 0z. 15c; $1 / 4$ 1b. 45c; 1b. \$1.50.

OHIO YELLOW GLOBE The best of the yellow skin is bright, glossy, orange-yellow, and the flesh is white and fine grained. The bulbs are remarkably uniform in size and shape, and being firm and hard possess fine keeping and shipping qualities. Pkt. 5c;0z. 15c; 1/4 1b. 45c; 1b. $\$ 1.50$. (See cut.)

PRIZE TAKER A very large globe-shaped variety with flavor. It is a heavy cropper and a fairly good keeping onion, and is very popluar as a market variety. Individual bulbs sometimes weigh four pounds and very often two or three pounds. Pkt. 5c;0z. 20c; $1 / 4$ 1b. 60c; 1 b. $\$ 2.00$.

RED WETHERSFIELD The best-known and most In shape it is flattish, but thick, with very firm flesh. Is hard. and an excellent keeper, as well as a heavy cropper. The color is a bright purplish-red. Pkt. 5c;0z. 20c; $1 / 41 \mathrm{~b} .60 \mathrm{c} ; 1 \mathrm{~b} . \$ 1.75$. (See cut.)

Red Bermuda. A very early, flat variety, used largely in the South for planting in the fall and marketing in the spring. Is of mild flavor and a good shipper, but not a winter-keeping variety. The color is a pale red. The best stock is imported from Teneriffe, Canary Islands, and we offer only this stock. Pkt. $5 \mathbf{c} ; \mathbf{0 z}$. 30c; $1 / 4$ 1b. 90c; 1 b. $\$ 2.75$. 


\section{WHITE PORTUGAL, OR SILVERSKIN}

The best-known and most largely used white onion. Is flat on the bottom and thick toward the top. Very hard and firm and an excellent keeper. Is largely used for white onion sets as well as for market onions and pickles. 1b. $\$ 2.50$. (See Cut, page 29).

White Queen. A very early white onion. Rather small and does not keep well. Is of fine, mild flavor, and largely used for homemade pickles. Pkt. 5c;0z. 25c; $1 / 41 \mathrm{~b}$. 65c; $1 \mathrm{~b}$. $\$ 2.25$.

NOTE.-The Yellow Danvers is frequently called Silverskin on the market, but this is an error, for the true Silverskin is a white, flat onion. We recommend as heavy croppers and adapted practically to all localities the Australian Brown, Yellow Danvers, and Ohio Yellow Globe.

C. C. Morse \& Co. grow more acres and sell more seed of onions than any other seed establishment in the world, and we hold the highest reputation for supplying the best onion seed on the market.

\section{PARSNIPS}

A well-known vegetable for table use. It is also a very good stock food and quite as nutritious as carrots. It prefers very wet soil, and will thrive where carrots will not grow. A sandy soil ís preferred since the roots are very long, and are difficult to dig in stiff soil. Sow the seed in the Spring in drills, using onefourth ounce to 100 feet. In the field sow in rows twelve inches apart, using three pounds per acre.

Early Short Round French. A flat turnip-shaped variety. Of rather coarse grain, and not as good quality as the long varieties, but early and easy to dig in stiff, hard soil. Pkt. $5 \mathrm{c} ; 0 \mathrm{z} .10 \mathrm{c} ; 1 / 4$ lb. $20 \mathrm{c} ; 1 \mathrm{~b} .50 \mathrm{c}$.

HOLLOW CROWN A variety with a hollow or cup-shaped top, where the leaf stem begins. The most popular and best variety for all purposes. Skin smooth and white, and flesh tender, while the root grows eightteen to twenty inches long. The best part of it is con tained in the first eight tained in the first eight inches from the top. our the thick-shouldered type called "student" by some dealers. It is particularly fine, smooth, and regular Pkt. 5c; oz. 10c; $1 / 4$ lb. $20 \mathrm{c} ; 1 \mathrm{~b}$. $50 \mathrm{c}$.

Long Smooth. A very long variety with Pkt. 5c; 0z. 10c; 1/4 1b. 20c; 1b. 50c.
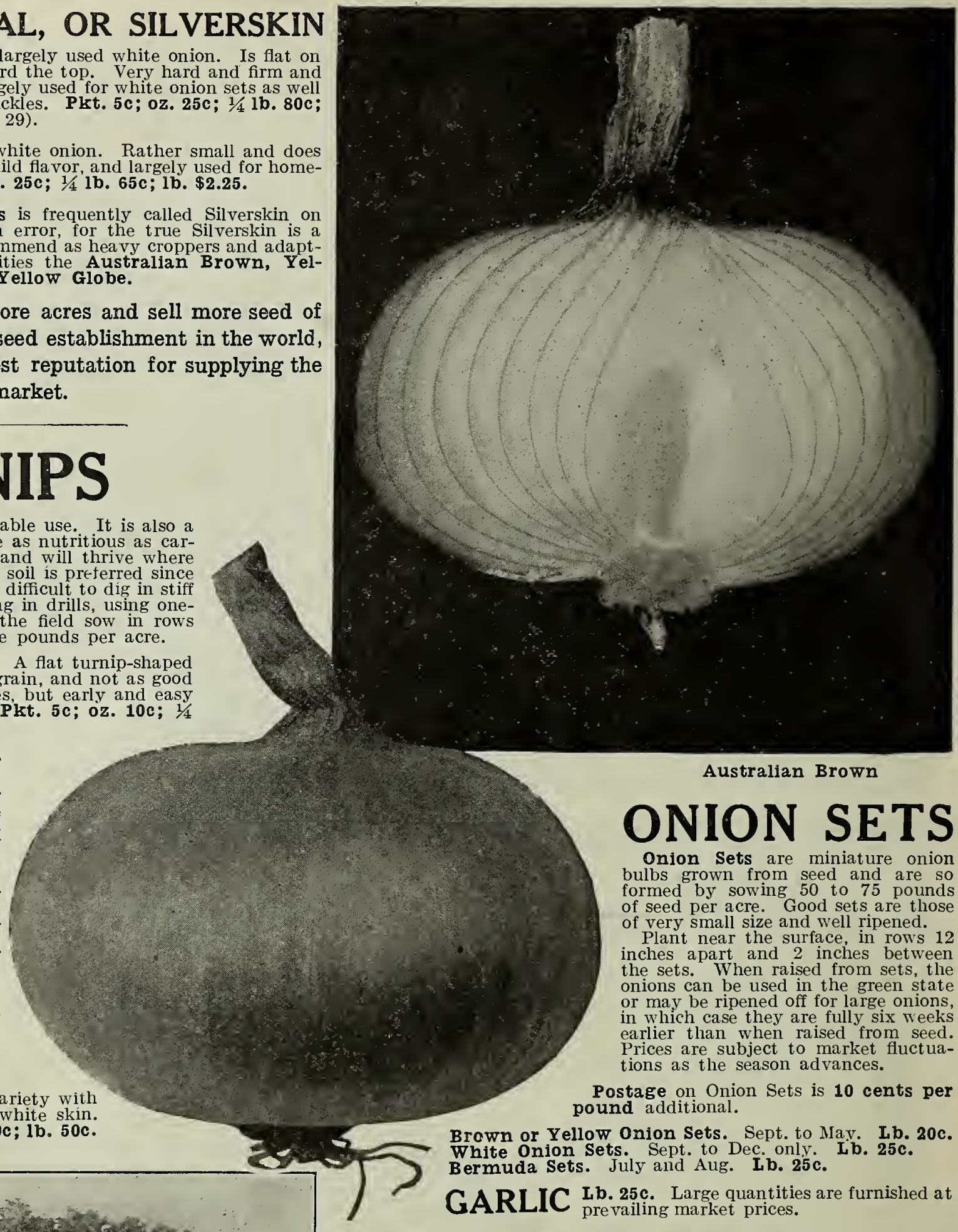

\section{ONION SETS}

Onion Sets are miniature onion bulbs grown from seed and are so formed by sowing 50 to 75 pounds of seed per acre. Good sets are those of very small size and well ripened.

Plant near the surface, in rows 12 inches apart and 2 inches between the sets. When raised from sets, the onions can be used in the green state or may be ripened off for large onions, or may be ripened off for large onions, in which case they are fully six weeks Prices are subject to market fluctuations as the season advances.

Postage on Onion Sets is 10 cents per pound additional.

Brown or Yellow Onion Sets. Sept. to Mav. I b. 20c. White Onion Sets. Sept, to Dec. only. Ib. 25c. Bermuda Sets. July and Aug. Lb. $25 \mathrm{c}$.

GARIIC Ib. 25c. Large quantities are furnished at

\section{PARSLEY}

Used for garnishing dishes of meat, or cooked in soups. A few plants in the garden will yield sufficient for a family, providing the in drills early in Spring, using one-fourth of an ounce to 100 feet.

Champion Moss Curled. A very finely curled, bright-green and very ornamental variety. Pkt. 5c; oz. 10c; $1 / 4$ 1b. 20c; 1b. 60c.

Hamburg, or Turnip Rooted. A plain-leaved variety, forming a

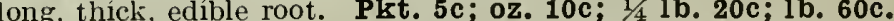

Plain or Single. A very hardy variety. The leaves are flat and not curled. Pkt. 5c; oz. $10 \mathrm{c} ; 1 / 41 \mathrm{lb} .20 \mathrm{c} ; 1 \mathrm{~b} .50 \mathrm{c}$

DOUBLE CURLED A curled variety very hardy and and by many preferred to the extremely curly varieties. Preen, 5c;0z. 10c; $1 / 4$ lb. 20c; 1b. 60c,

EXTRA TRIPLE CURLED Very finely curled green color. One of the best varieties for all purposes. Pkt. 5c; oz. 10c; 1/4 1b. 20c; 1b. 60c. 


\section{SAN FRANCISCO CALIFORNIA U.S.A.}

\section{PEAS}

Peas are quite hardy, and for very early market can be planted in the fall in protected places, and ripe peas can be had in February. They

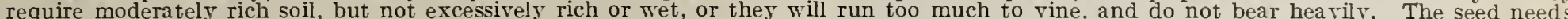
to be planted thick, using from 150 to 200 pounds per acre for seed or regetable crop, or one pound for sixty feet of row.

The dwarf varieties can be planted in rows twelve to eighteen inches apart, and the tall ones three feet. By using the various classes of peas

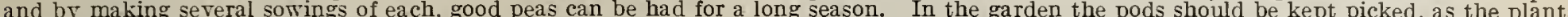
will then continue to bear longer.

Express or freight charges are not prepald. Write us for special quotations on large quantities. Peas are a short crop all over the morld this sear.

\section{EXTRA EARLY VARIETIES}

ALASKA, OR EARLIEST OF ALL. A very early tall variety, vines two to two and one-half feet with smooth, small peas green seeded, of good quality and short wellfilled pods. The crop matures practically all at one time, and is very popular $w$ it $h$ canners and market gardeners. Thi market gardeners. in the ground if planted in the ground if planted in vers cold, wet soil and so is recommended for the rerr earliest plantpostpaid. В y express or freight, 1b. 20c; 10 1bs. $\$ 1.75$.

FIRST AND BEST, OR EXTRA EARL Y. One of the earliest tall varieties, w i t h smooth, round peas, which ripen almost at we time Grows two to two and one-half feet high; seed vellowish white; pods vellowish white; pods straight, short, and well-
filled. Quality best of fmooth seeded early varieties. Pkt. 10c;1b. $35 \mathrm{c}$, postpaid. By express or freight, $1 \mathrm{~b}$. 25c; 10 lbs. $\$ 2.00$.

\section{AMERICAN WONDER. A} dwarf or short-vine variety, growing about 12 inches tall, bearing short thick, well-filled pods, which are a rich darkgreen. It bears well, is easily grown, and very easily grown, and very early. The peas are on especialls fine flavor and it is the best dwarf varidried peas are wrinkled. Pkt. 10c; $1 \mathrm{~b} .35 \mathrm{c}$, postpaid. By express or freight, $1 \mathrm{~b} .25 \mathrm{c} ; 10$ lbs. $\$ 2.00$.

NOTT'S EXCELSIOR. The popular dwarf, wrinkled variety for the home garden or market garden. The vines are larger and more productive than American Wonder and the peas are of especially fine flavor and good quality Some planters reand good qualty as the best for the home garden, claiming it to be of peculiarly delicious flavor of long continuous bearing quality and easy to grow. Pkt. 10c; 1b. 35c, postpaid. By express or freight, 1b. 25c; 10 1bs. $\$ 2.00$.

PREMIUI GEM, sometimes called IITTLE GEM, The best and most popular dwarf, wrinkled variety, especially with market gardeners. It grows about fifteen inches high and bears good-sized pods, which are filled with six to eight peas of especially fine, sweet flavor. Pkt. 10c; 1b. 35c, postpaid. By express or freight, 1b. 25c ; $101 \mathrm{bs}$. \$2.00.
Gradus

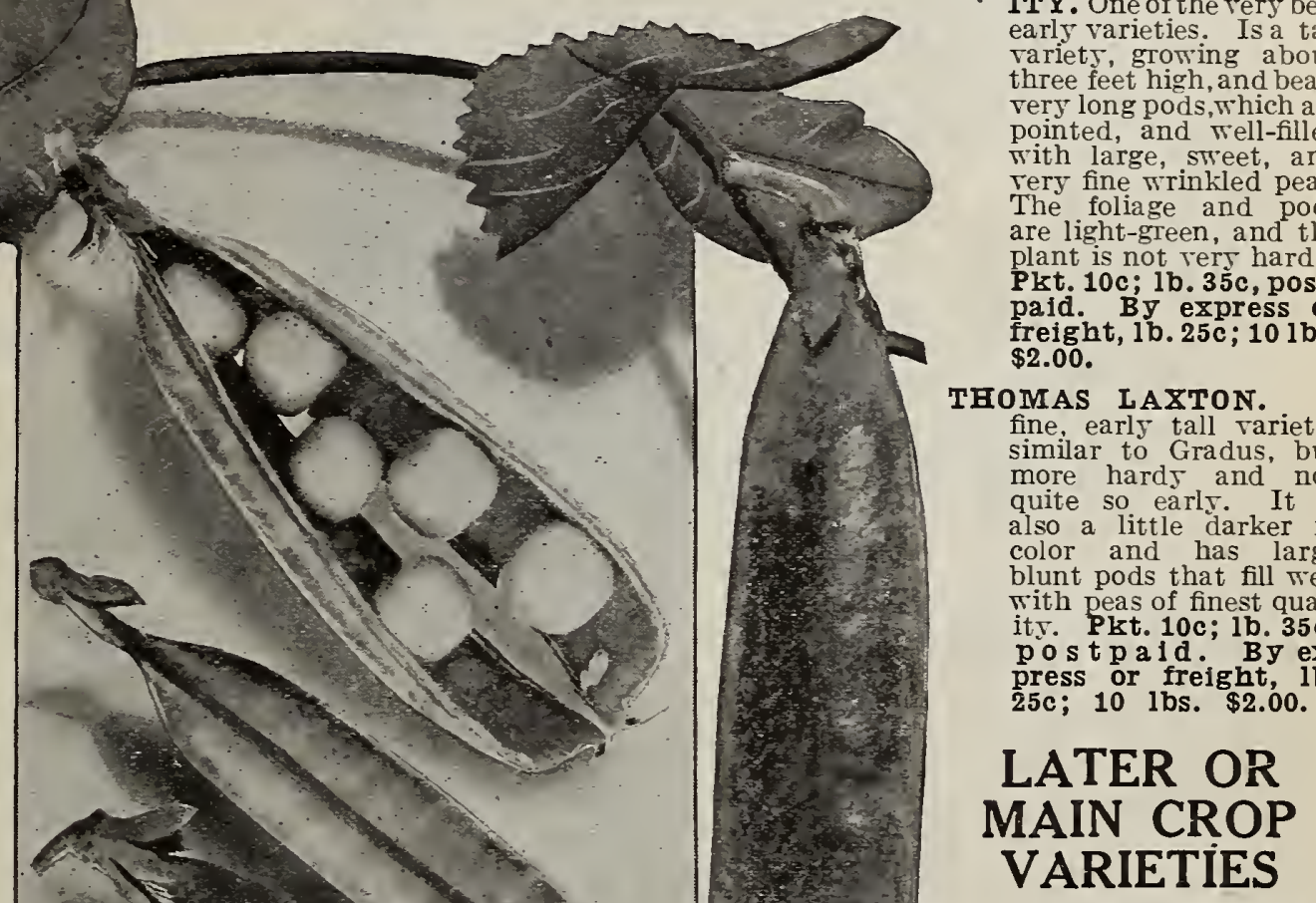

MCLEAN'S ADVANCER. A good, tall variety with wrinkled peas of very fine quality. Is and rery popular with market gardeners. Pkt. 10c; 1b. 30c, postpaid. By express or freight. 1b. 20c; $10 \mathrm{lbs}$. $\$ 1.75$. A B U NDA N C E. A tall branching variety bearing medium-sized pods with large peas of good quality. It matures evenis, and is used argely by canners. Pkt. By ibpress or freight. By express or freight,
lb. 20c; 10 lbs. $\$ 1.75$. BLISS'S EVERBEARING. A stout branching vari-
ety, bearing broad pods grown in pairs, well
filled with large peas of good quality as indicated by its name. Will keep on bearing a long time and is a farorite for home gardens. Peas large, tender and of marrow flavor. Pkt. 10c; 1b. 30c postpaid. By expres 20c; 10 lbs. $\$ 1.75$.

HORSFORD'S MARKET GARDEN. A tall Tariety of medium height; very prolific; peas small and mrinkled, but pods well filled. Dark green and hardy and very popular as a canning rariety. press or freight, 1b. 20c; 10 lbs. $\$ 1.75$.

CHAMPION OF ENGLAND. One of the most popular, tall, wrinkled varieties. Is very prolific and hard $y$, and the peas are of especially fine, rich quality. Pkt. or freight, 1b. 20c; $10 \mathrm{lbs}$. $\$ 1.75$. 


\section{SC.C.MORSE \& CO. VEGETABLE SEEDS CP}

\section{PEAS Continued}

TELEPHONE. The best mid-season variety. Is tall, and large, wrinkled peas of remarkably fine quality, A popular home garden and market variety. We have an especially fine 10 lbs. $\$ 2.00$.

STRATAGEM. A semi-dwarf variety with large leaves and large pods. Of all the Peas wo list and all of those we have tried, we do not know of another variety so well adapt 1 list and all of those we have tried, we do not know of another variety so well adapt 1 to most sections of our coast as stratagem. The vines bear well, and the pods are lol : thick and well filled. This variety has a tendency to run out or revert to a small-poddid type and many stocks of Stratagem offered contain many small-podded plants. We and offer an especiallyo fine strain free from small pods. Prices- Reselected strain: Pkt. 10c;1b. 35c, postpaid. By express or freight, 1 b. $25 \mathrm{c} ; 10 \mathrm{lbs}$. $\$ 2.00$.

YORKSHIRE HERO, OR ALAMEDA SWEETS. A very hardy and prolific, semi-dwarf, wrinkled variety. The peas are large and of fine quality and the pods, which are broad and medium-sized, remain in condition for a long time. It bears immense crops, both of pods and dried peas, and is the variety most largely planted by gardeners. Pkt. 10c; lb. 30c, postpaid. By express or freight, 1b. $20 \mathrm{c} ; 10 \mathrm{lbs}$. $\$ 1.75$.

LARGE WHITE MARROWFAT. A very tall, hardy variety. Very productive, but of inferior quality. Pkt. 10c; 1b. 25c, postpaid. By express or freight, 1b. 15c; 10 lbs. $\$ 1.15$.

MELTING SUGAR. A tall variety, bearing long, flat, brittle pods which are cut or broken and cooked like string beans. Is a delicious vegetable, and should be better known and
more generally used. Pkt. 10c; 1b. 35c, postpaid. By express or freight, 1b. 25c; more generally
10 1bs. $\$ 1.50$.

\section{PEPPER}

There are varied uses for Peppers, and while they are more popular in the South among the Spanish and Mexican people, they are used very largely by all who like strong, hot condiments. The several varieties are used for stuffing when green, for pickles, for pulverizing when dry, and for soups, etc. Our selection of varieties includes all of the very best.

Peppers do best in hot climates, but can be grown quite successfully in most places. They require very rich soil. The seed germinates slowly and should be started in boxes, and the young plants transplanted after all danger of frost is over.

CHINESE GIANT A very large, deep-red variety, very thick and blunt. It four or five inches thick at the top and about six inches long. Pkt. 10c; oz. 50c; 1/4 1b. $\$ 1.60 ; 1 \mathrm{~b}$. $\$ 5.50$.

Golden Dawn. A short, thick variety, similar to Large Bell, or Bull Nose, in shape, but a rich golden yellow, with a mild, sweet flavor. Pkt. 5c; 0z. 25c; 1/4 1b. 75c;1b. \$2.50.

Large Squash. An early variety, bearing large, flat, tomato-shaped fruit, which is bright red when fully ripe. Pkt. 5c; oz. $25 \mathrm{c} ; 1 / 4$ 1b. $75 \mathrm{c} ; \mathbf{1 b}$. $\$ 2.50$.

LARGE BELL, OR BULL NOSE The most popular variety for stuffing. about three inches long and two inches thick. The color is deep green when fruit is young, but when fully ripened it is a rich, glossy blood-red. Plant grows about two feet high. Pkt. 5c; oz. 25c; $1 / 4$ 1b. 75 c; 1 b. $\$ 2.50$.

LONG RED CAYENNE A strong, pungent, variety, having long, pointed known and popular variety. Pkt. $5 \mathrm{c} ; \mathbf{0 z} .25 \mathrm{c} ; 1 / 41 \mathrm{~b} .75 \mathrm{c} ; 1 \mathrm{~b} . \mathbf{\$ 2 . 5 0}$.

Red Cherry. An ornamental as well as useful variety, the plant being tall and bearing profusely, small, bright, red fruit. The fruit ís small, round, very hot, and is largely used for pickles. Pkt. 5c; oz. 25c; 1/4 1b. 75c; 1b. \$2.50.

Red Chili. A rather small, bright-red variety about two inches long, and pointed. The pods are used in making Chili sauce, and are very pungent and hot. Pkt. 5c; oz. 25c; $1 / 4$ 1b. 75c; 1b. $\$ 2.50$.

Ruby King. A popular variety of the Bell, or Bull Nose type. The fruit is large, bright, glossy-red, and the flavor is mild and sweet. A desirable variety for slicing in salads
and for stuffing. Pkt. 5c; oz. 25c; $1 / 41 \mathrm{~b} .85 \mathrm{c} ; 1 \mathrm{~b} . \$ 3.00$.

\section{SWEET MOUNTAIN, OR SPANISH MAMMOTH}

A very popular variety with some market gardeners. It is a late variety, bearing large, thick fruit, which is frequently eight inches long and two or three inches in diameter. When mature, it is a deep, glossy-red, and the flavor is mild and sweet. Pkt. 5c; oz. 25c; $1 / 4$ 1b. 75c; 1 b. $\$ 2.50$.
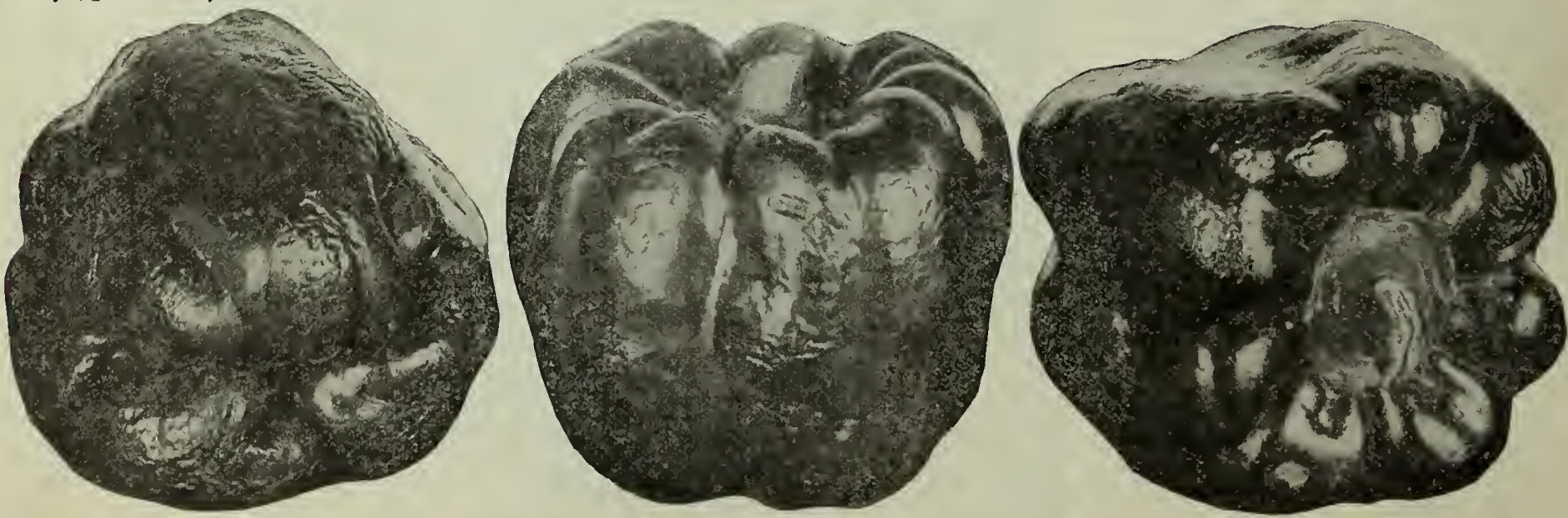

Large Bell or Bull Nose Peppers-best for stuffing 


\section{SAN FRANCISCO CALIFORNIA U.S.A.}

\section{PEPPER - Continued}

\section{SWEET UPRIGHT}

Sweet Upright produces fine large fruits of nearly square or blocky form, with exceptionally thick flesh of the very mildest and sweetest flaror.

The plants are of sturdy erect growth. The fruits are borne stiffly erect, and form at each fork of the branches; they are very broad, divided into four lobes, and when fully ripened are deeply indented at the blossom end. An average pepper measures three inches in length, two and threequarter inches at the stem end and two inches across the blossom end, with a weight of seven ounces.

The color when ripe is rich glowing scarlet both in the thin tender skin and in the unusually thick sweet flesh. The thick flesh is as crisp, mild, and sweet as a fine apple. It is as early as the Sweet Bell or Bull Nose, with heavier fruit, much thicker flesh and greatly superior in flavor. Pkt. $10 \mathrm{c} ; 0 \mathrm{z} .45 \mathrm{c} ; 1 / 1$ lb. $\$ 1.25 ; \mathrm{lb} . \$ 4.50$.

\section{PUMPKIN}

While pumpkins are of strong growth, they will not stand frost, and cannot be planted until about April 15th. A moderately rich soil is sufficient for good pumpkins. Plant in hills about six to eight feet apart. Three to four pounds of seed will plant an acre and one ounce will plant 100 hills. Do not plant near squashes on melons, they are likely to mix. If large quantities are wanted, write for special price.

\section{CONNECTICUT FIELD, OR NEW ENG-}

LAND PIE A fine, large, orange-colored variety used is smooth and ribbed and the flesh is brittle and sweet. Pkt. 5c; oz. 10c; $1 / 41 \mathrm{~b} .20 \mathrm{c} ; 1 \mathrm{~b}$. 50c, postpaid.

Large Cheese, or Kentucky Field. A very large, flattened rariety, a reraging about two feet through. When ripened the skin is a rich cream color. Flesh rellow and of fine quality. Pkt. 5c; oz. $10 \mathrm{c} ; 1 / 41 \mathrm{~b}$. 20c; 1b. 60c, postpaid.

\section{MAMMOTH KING, OR POTIRON}

The best large pumphin in use. Forms immense globular melons, flattened a little at the end. Skin reddish vellow in color and flesh rich orange. This is unquestionably the very best mammoth pumpkin is unquestionably the very best mammoth pumpkin and all are of immense size. Pkt. 5c; oz. 15c; 1/4 1b. $45 \mathrm{c} ; 1 \mathrm{~b}$. $\$ 1.50$.

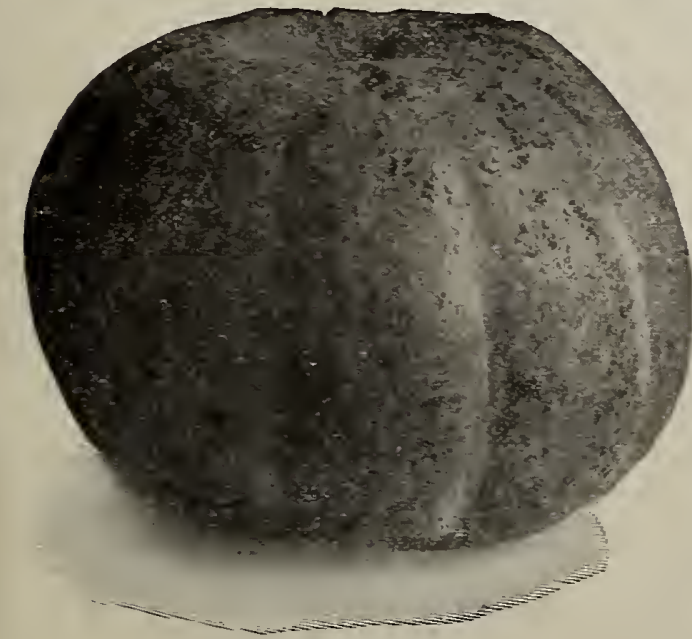

Mammoth King

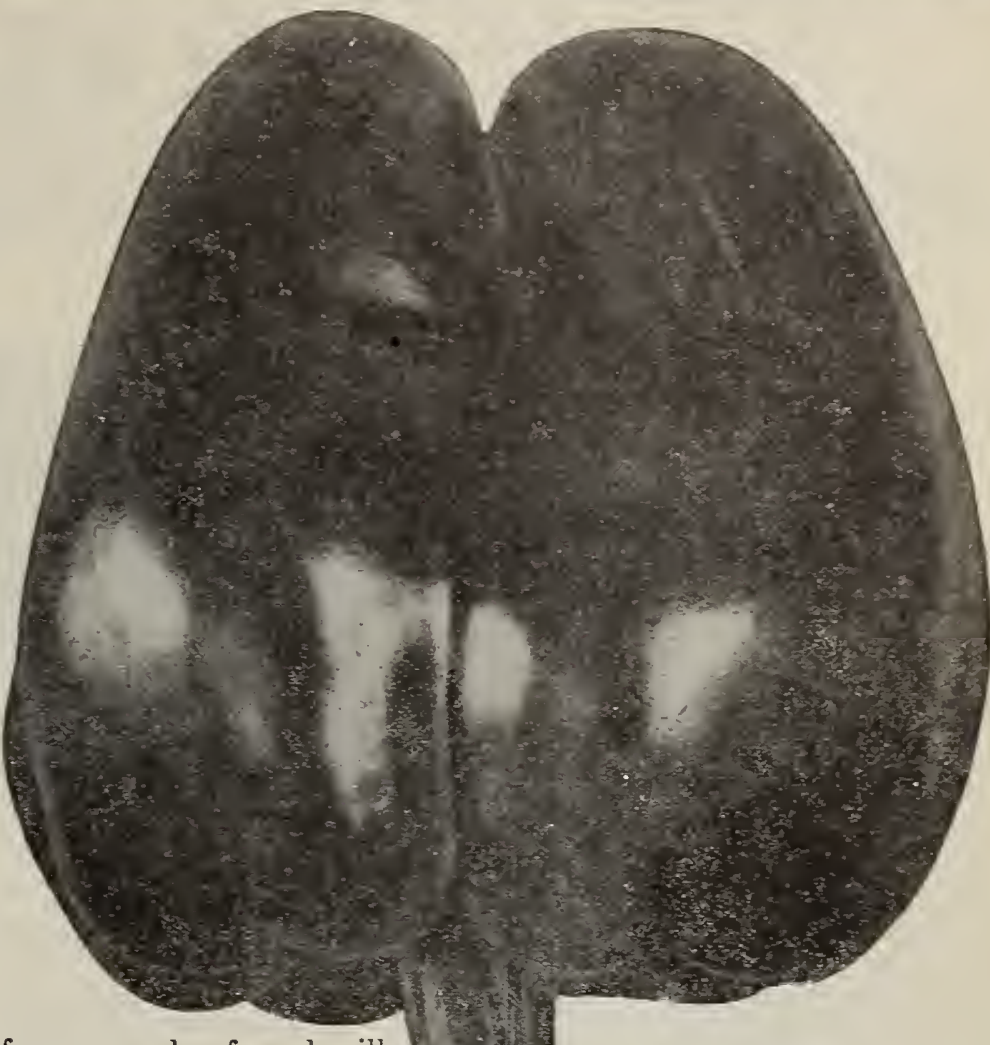

Natural size of the new Pepper, Sweet Upright
COMMON FIETD The well-known, ordinary pumpkins fruit is various largels used for stock-feeding. The fruit is variousiy colored in 5ellow, drab, red and orange, and raries also in size, but is usually rers large. Is a heavy cropper and ver5 easily gromn. Plt. 5c; 1b. 35c, postpaid. By express or freight, $1 \mathrm{~b} .25 \mathrm{c} ; 10 \mathrm{lbs}$. \$2.25.

Mammoth Golden Cushaw. One of the best stockfeeding varieties. Is a solid, Tellow crooknecked sort, and is nearly all flesh, having a very small 1b. $\$ 1.00$, postpaid.

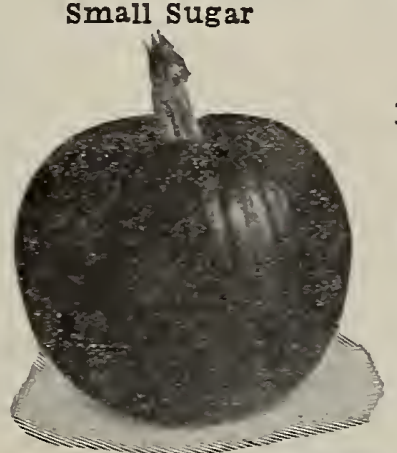

Pie Pumpkin. A small, round, zellow sort, with fine, pinkish netting. Flesh is thick, sweet, and of excellent quality. Pkt. 5c; oz. 10c; $1 / 41 \mathrm{~b}$. 30c; $1 \mathrm{~b} . \$ 1.00$, postpaid.

SMIALL SUGAR. A small, round variety of excellent quality. The flesh is rich Jellow, very thick and sweet, and the skin is deep orange. We recommend this variets as the Fer 5 best for pies. Pkt.5c;0z, 10c; $1 / 11$ b. 30c; 1b. $\$ 1.00$, postpaid.

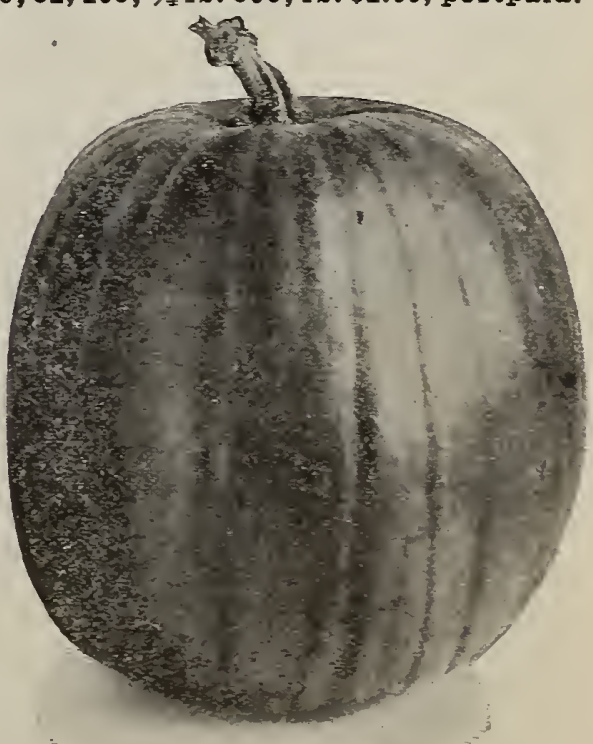




\section{C.C. MORSE \& CO. VEGETABLE SEEDS}

\section{RADISH}

Being a root crop, good brittle radishes require light, well-worked soil, made very rich and mellow to insure quick growth. If permitted to grow slowly, they become tough and pithy. They are easy to grow and frequent plantings will insure a constant supply for the table Use two-thirds ounce for 100 feet of row, and thin the very young plants somewhat to prevent crowding. Summer varieties can be sown all spring and well into summer. Winter varieties, however, require some time to mature, and the seed should be planted in August and September for good radishes in November and December.

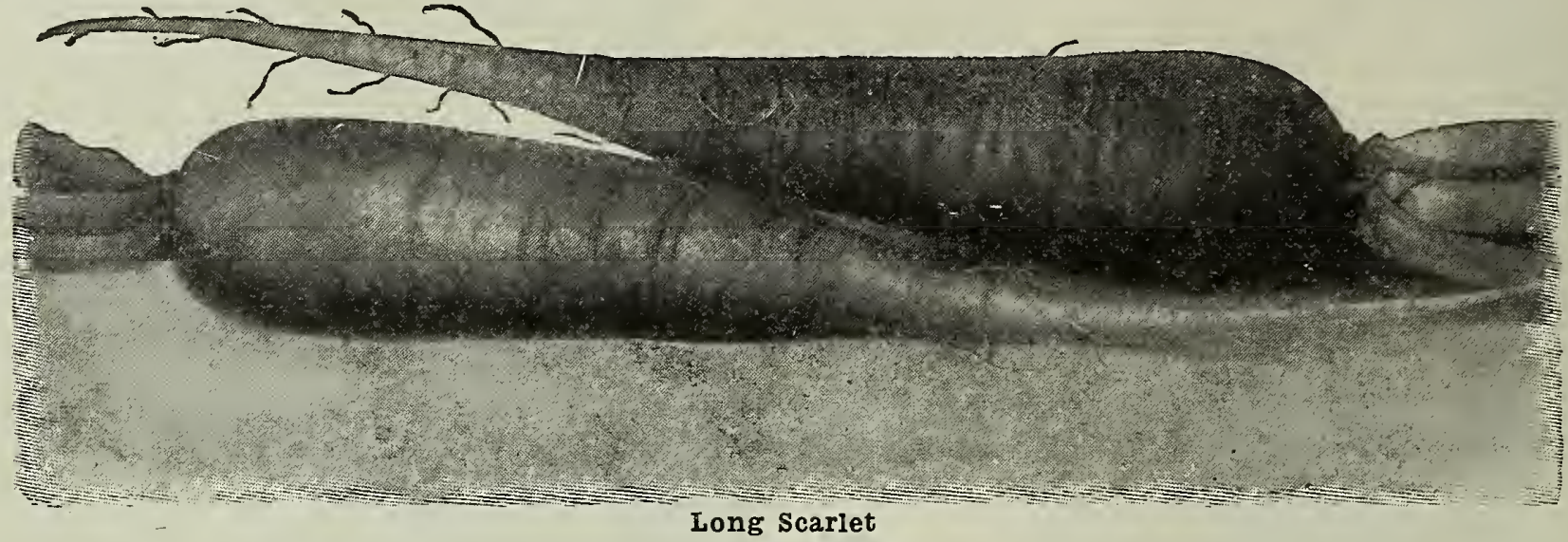

Brightest Long Scarlet. A very showy, long variety. Is thick at the shoulder and tapering Bright rose scarlet with distinct white tip. Plst. 5c;0z. 10c; $1 / 41 \mathrm{~b} .25 \mathrm{c} ; 1 \mathrm{~b} .75 \mathrm{c}$.

Chartier. A very long variety and larger in diameter and general size than Long Scarlet. Keeps hard and crisp longer than most varieties, and is an excellent garden sort. Color bright rose with lighter colored tip. Pkt. 5c;-0z. 10c; $1 / 41$ lb. 25c; 1 b. 75c.

Cincinnati Market. An early and quick-growing long variety. which keeps hard and crisp for a long time. A favorite market garden $75 \mathrm{c}$.

Chinese Rose Winter. A bright scarlet winter variety. About 4 inches long and stump-rooted. Matures two or three weeks earlier than the Chinese White Winter and like it is firm and crisp and does not grow pithy until it runs to seed. Pkt. 5c; oz. $10 \mathrm{c} ; 1 / 41 \mathrm{~b} .25 \mathrm{c} ; 1 \mathrm{~b} .90 \mathrm{c}$.

\section{CHINESE WHITE WINTER, OR CELES-}

TIAL (or Cal. Mammoth White Winter). The well-known AL and popular winter variety. Clear white, about 4 inches long and half stump-rooted. Keeps firm and crisp until it runs to seed. Is a good cooking variety, and when cooked the flavor resembles turnip. Plt. 5c; oz. 10c; $1 / 41$ 1b. 25c;1b. 90c.

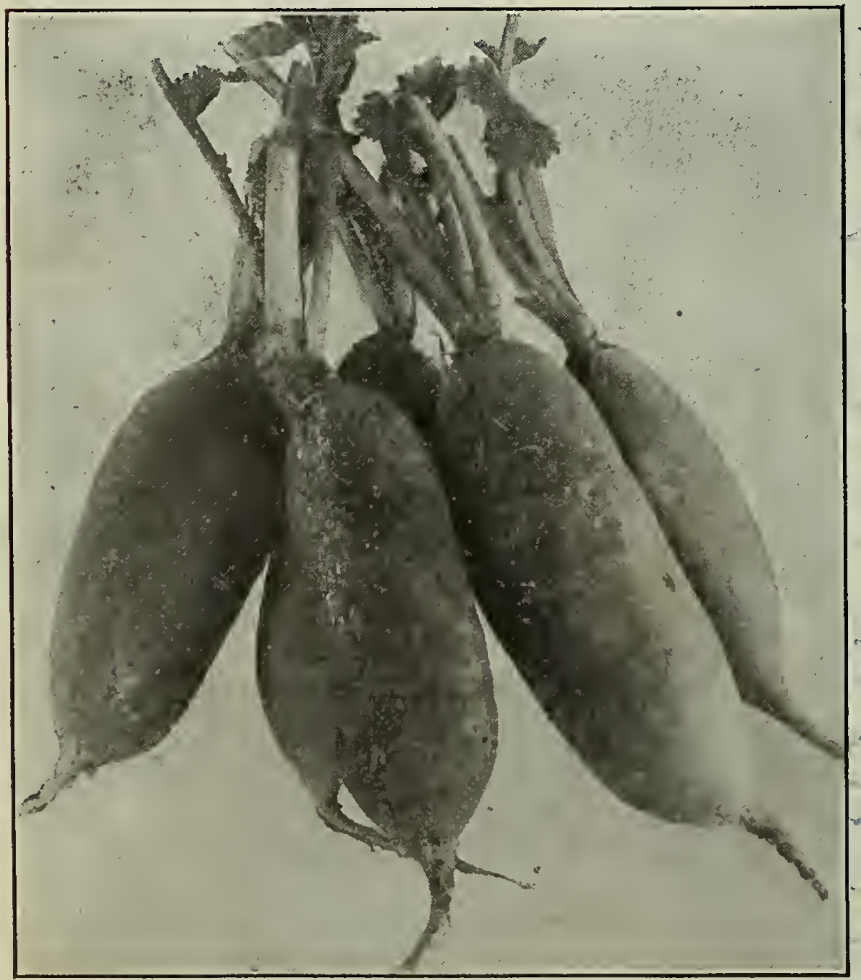

Half Long or Olive Sha ped
Crimson Giant Forcing. A new variety which will be a popular market and home garden variety, since it matures very early and remains firm and crisp much longer than other short varieties. Color rose carmine with white tip. It is top-shaped. Pkt. 5c: 0z. 10c; $1 / 4$ 1b. 25c; 1b. 75c.

Early Round Dark Red, or Prussian Globe. A bright scarlet turnip-shaped variety. Early, quick-growing, and a handsome radish. Pkt. 5c;0z. 10c; $1 / 4$ ib. 25c;1b. 75c.

Early Scarlet Turnip. A valuable variety for forcing or outdoor culture. Is a small, turnip-shaped variety, and in color entirely culture. Is a small, turnip-shaped variety, and
crimson. Pkt. 5c;oz. 10c; $1 / 41$ 1b. 25c; 1b. 75c.

EARLY SCARLET GLOBE A popular forcing its very quick growth and fine, bright scarlet color. Shape, a trifle oblong. Plst. 5c;0z. 10c; 1/4 Ib. 25c;1b. 75c.

Early White Turnip. A very quick-growing, small, turnip shaped variety. Color, clear white; very mild flavor, and valuable for forcing. Plt. 5c; oz. 10c; $1 / 4$ lb. 25c; lb. 85c.

French Breakfast. A popular variety for market or forcing. it is rose with bottom of root and the tail pure white. Pkt. 5c; oz. $10 \mathrm{c} ; 1 / 41 \mathrm{lb} .25 \mathrm{c} ; 1 \mathrm{~b} .75 \mathrm{c}$.

Golden Globe. Quite a large top-shaped variety with yellow skin, and solid white flesh. Is not a quick-growing variety, but retains its solidity a long time after maturity. Pkt. 5c;0z. 10c;1/4 Ib. 25c;1b. 75c.

Half Long, or Olive-Shaped. The variety most largely used by gardeners in California. It is about 3 inches long with half stump-root and sloping top. Color, carmine. Quick growing and hardy. Remains solid longe than any other variety. Pkt. 5c;0z. 10c; 1/4 ib. 20c; Ib. 60c.

Half Long Deep Scarlet. A shorter, olive-shaped variety, with half stumproot and sloping top Color, bright scarlet. Valuable for forcing. Pkt. $5 \mathrm{c} ; 0 \mathrm{z} .10 \mathrm{c} ; 1 / 4 \mathrm{lb} .25 \mathrm{c} ; 1 \mathrm{~b}$. $75 \mathrm{c}$.

ICIC A handsome white variety, about 5 inches long, with sloping CLep and pointed root. Quick growing, brittle, and mild in flavor. Pkt. 5c; oz. 10c; $1 / 41 \mathrm{~b} .25 \mathrm{c} ; 1 \mathrm{~b} .75 \mathrm{c}$

Long Black Spanish. A winter variety with almost black skin and white 1b. 75 c.

IONG SCARIET (short top). The best known and most mine, and flesh brittle and firm. About 6 inches long, the top growing out of the ground about one inch. Pkt. $5 \mathrm{c} ; 0 \mathrm{oz} .10 \mathrm{c} ; \mathrm{1} / \mathrm{Ib} .20 \mathrm{c} ; \mathrm{Ib} .60 \mathrm{c}$.

Long White Japanese. A winter variety, growing frequently 2 feet long and about 3 inches in diameter. Skin, white; flesh, solid and tender. and very pungent. A staple article of diet with the Japanese, who use it both green ani dried. Our seed is imported from Japan. Pkt. 5c: 0z. 10e: $1 / 4$ 1b. 25c; Ib. $\$ 1.00$.

Round Black Spanish. A winter variety, with black skin and white flesh. It is top-shaped or almost globular. PKt. 5c;0z. 10c; $1 / 41 \mathrm{~b} .25 \mathrm{c}: 1 \mathrm{~b} .75 \mathrm{c}$.

SCARLET TURNIP, WHITE TIPPED page 35). Pkt. 5c; 0z. 10c; 1/4 Ib. 25c; Ib. 90c.

White strasburg. A large, white variety for late summer use. Rather thick at the shoulder and tapering to about 5 inches in length. Keeps firm and solid a long time. Pkt. 5c;0z. 10c;1/1 1b. 25c;1b.75c.

White Vienna (or Lady Finger). A very fine, long, white variety, quick growing, and ready for use when very young. 


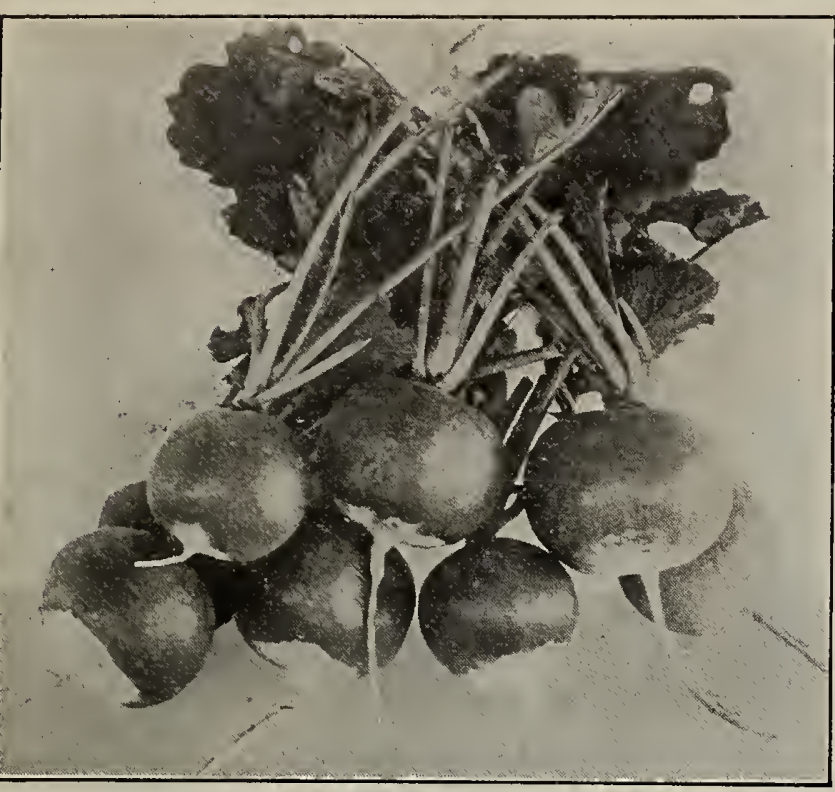

Scarlet Turnip White Tipped Radish

\section{CRIMSON WINTER The new}

which has become very popular and iet $y$, able to the growers, is of delicious flavor extremely hardy, very prolific, and very

\section{RADISH}

\section{Continued}

SCARLET TURNIP WHITE TIIPPED, or Rosy Gem. One of the most popular and attractive short varieties. It is globe-shaped, bright roseCarmine with bottom and tip clear white. Stems and leaves small. Very valuable for forcing as well as for the house garden and market. Pkt. 5c;0z. 10c; 1/4 1b. 25c;1b. 90c.

\section{RHUBARB}

A rich, sandy soil, wet but well drained, is best for rhubarb. While it is frequently propagated from seed, only a percentage comes true, but it is cheaper to grow from seed and discard untrue plants. The popular method, however, is to use young plants propagated from the crown. Set plants three feet by six. The best stems are produced the second year. but it continues to produce for several years. When the blossom stalk appears, it should be cut back well into the ground. Set the crowns of the plants so that they are $1 / 2$ inch under the surface of the soil. Choose a place where the soil will be moist at all times.

Myatt's Victoria. The variety most generally in use. It comes fairly true from seed. 1b. $45 \mathrm{c} ; 1 \mathrm{~b}$. $\$ 1.50$. Roots-15c each, $\$ 1.50$ per dozen.

quick growing. Produces good stems all Weed-Pkt. 10c; oz. 65c; $1 / 4$ 1b. $\$ 2.00$; Ib. $\$ 6.50$.

Roots- 25 c each 5 for $\$ 1.00$.

Add $15 \mathrm{c}$ each for postage.

\section{SALSIFY, OR VEGETABLE OYSTER}

The salsify root, which grows about twelve inches long and one inch in diameter, is becoming a very popular vegetable. When cooked it has a distinct flavor of the oyster, and may be served in a great variety of ways. A loose, light soil, especially sandy loam, is desirable for a long smooth root. In stiff soils the roots are usually uneven and hard to dig. Use three-fourths ounce for 100 feet of row, and thin to one or two inches to prevent crowding.

MAMMOTH SANDWICH ISLAND. The improved, large-rooted variety, growing about 12 inches long and being from 1 to 2 inches thick. Pkt. 5c;0z. 20c; $1 / 41$ b. 50c; Ib. $\$ 1.75$.

\section{SORREL}

The large leaves, when cooked like spinach, make a very palatable vegetable. In California it grows luxuriantly, spreads rapidly from the root, and becomes an obnoxious weed unless given attention. A confined location in the garden is therefore recommended.

Large Lea ved French. The variety having the largest leaves, and therefore the most desirable. Pkt. 5c;0z. 15c; i/4 1b. 40c; 1b. \$1.25.

\section{SPINACH}

An easily grown plant, the seed of which may be planted in the fall to secure good spinach early in the spring or even throughout the winter. The better and richer the soil, the larger and more tender the leaves will be. As a field crop for the market garden, use 8 pounds of seed per acre. For the home garden use one-half ounce for 100 feet of row.

\section{BLOOMSDALE SAVOY}

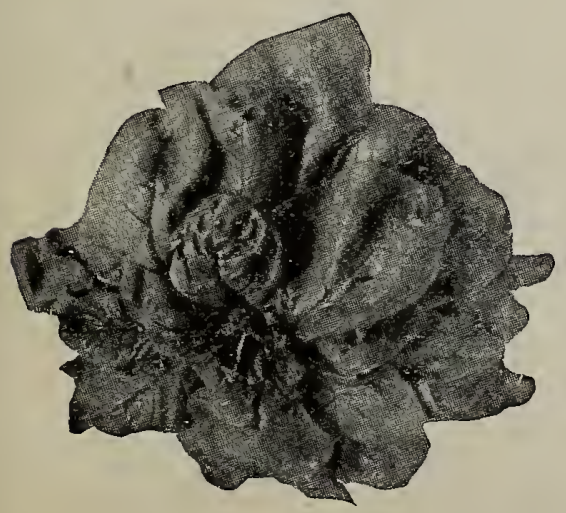

Prickly Spinach
The variety most generally used in the East, and especially throughout the South for shipping. Leaves large, round, and thick, very much savoyed and rich deep green. One of the earliest varieties. Seed, round. Pkt. 5c; 0z. 10c; $1 / 4$ lb. 15c;1b. $\mathbf{3 5 c}$.

Long Standing. A deep green variety with rather elongated smooth leaves. Seed, round. Stands a long time without running to seed. Pkt. 5c;0z. 10c; $1 / 41 b .15 c$; 1b. $40 \mathrm{c}$.

Victoria. A long-standing variety with round slightly savoyed leaves. Deep green and hardy. Forms good, edible leaves early hardy. Forms good, edible leaves early period. Pkt.5c;0z.10c;1/41b.15c;1b. 40c.

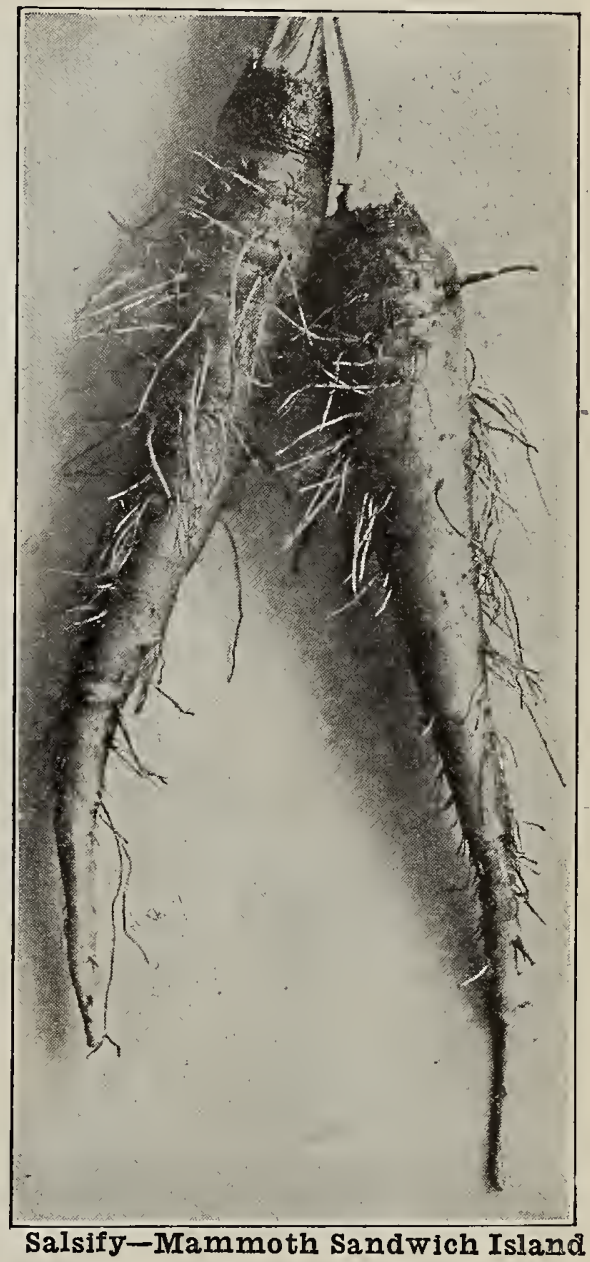

New Zealand, A plant with thick, fleshy texture and soft crystalline leaves. Is not like the ordinary spinach in a ppearance, but it is used in the same way. Pkt. 5c; oz. $10 c ; 1 / 41 b .30 c ; 1 b . \$ 1.00$.

PRICKLY The variety commonly used very hardy and easily grown; bears large. smooth leaves, which are shaped like an arrow point. Color, bright green. Seed, irregular, with 3 or 4 sharp points. Pkt. 5c;0z. 10c; 1/4 1b. $15 \mathrm{c} ; 1 \mathrm{~b}$. 30c.

Round, Thick Leaved. A large-leaved, bright green variety. Leaves rather smooth and rounded at the top. A good variety for la te spring and summer. Seed. round. Pkt. 5c;0z.10c;1/41b.15c;1b.40c. 


\section{SQUASH}

The summer varieties come into use early in the summer, but being sensitive to frost the seed cannot be sown until late in April. The seed should be planted in hills four feet apart, using four ounces to 100 hills. The winter varieties are also unable to resist frost, and should be planted at the same time. The fruit does not mature until late in the fall, and, having a very firm, hard shell, keeps well, and with a little care squashes can be had all winter and until late in the spring. In gathering winter squashes, it is important to protect the stems, since, if broken off, the fruit will not keep so well. Plant in hills six to eight feet a part, using two or three seeds to the hill. Use eight ounces to 100 hills, or two pounds to an acre. Moderately rich soil will grow good squashes.

\section{SUMMER VARIETIES}

\section{EARLY WHITE BUSH SCALLOP}

A very early variety, with flat, creamy white, scalloped squashes, 4 to 6 inches in diameter. The vine is bush in habit and rather $\mathrm{dwa} r \mathrm{r}$. This variety

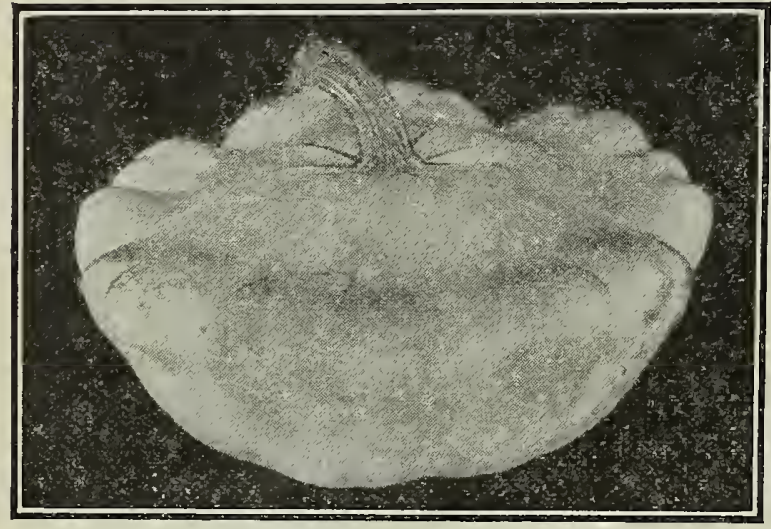

Early “White Bush Scallop" is the common "patty pan" squash. Pkt. 5c; Mammoth Summer Crookneck. A large goldenyellow variet $\mathrm{y}$, thickly warted; is eighteen inches long, brittle, and tender. Plants are bush and very prolific. This is an improved strain of the old proved strain of the ond considerably larger. Pkt. 5c: oz. 10c: $1 / 4$ b. $25 \mathrm{c} ; \mathrm{ib} .80 \mathrm{c}$.

Mammoth White Bush Scallop. A fine, large variety with round, scalloped fruit twelve to fourteen inches in diameter. Color, white, clear and wax-like. Pkt. 5c; oz. 10c; 1/4 lb. $25 \mathrm{c} ; 1 \mathrm{~b}$. 85c.

\section{VEGETABLE OR ITALIAN MARROW}

A large, oblong variety, producing fruit which is dark green at first, becoming marbled and striped with yellow and lighter green as they mature. Pkt. 5c; oz. 10c; $1 / 41 \mathrm{~b}$. 30c; 1b. $\$ 100$

White Summer crookneck. Long, crooknecked variety, similar to Summer Crookneck in size and shape, but it is pure white. Is of especially fine quality. Pkt. 5c;

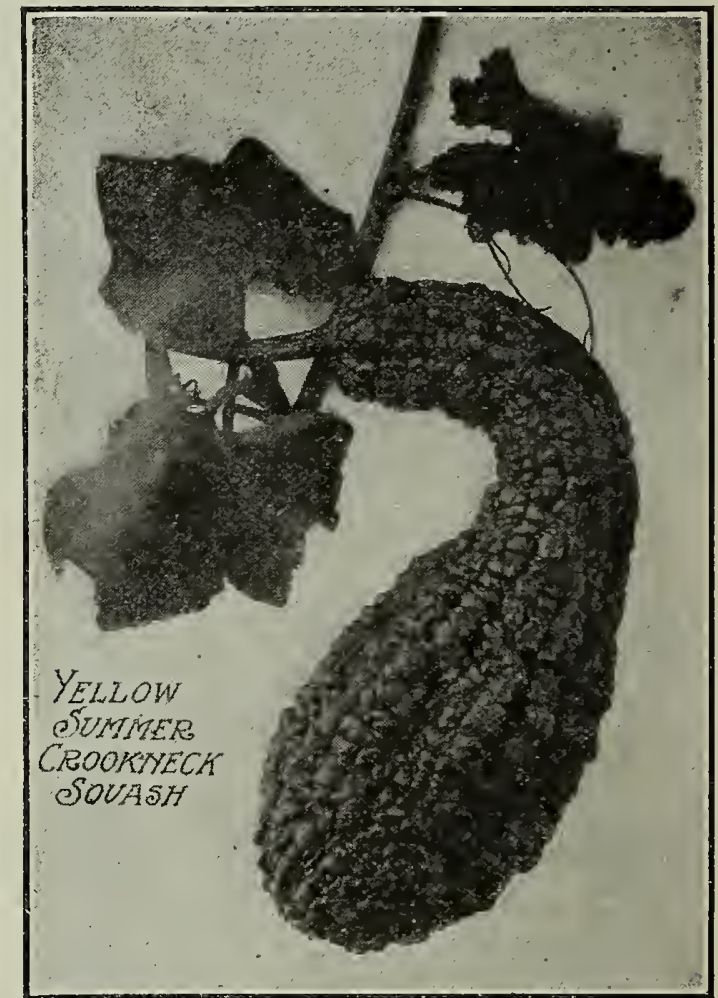
oz. $10 \mathrm{c} ; 1 / 4$ 1b. 25c; ib. $75 \mathrm{c}$.

Yellow Bush Scallop, or Custard. An early variety with flat, round, scalloped fruit. Skin, deep yellow; flesh, pale yellow.

Pkt. 5c; oz. 10c; $1 / 4$ 1b. 25c; 1b. 75c.

YELLOW SUMMER CROOKNECK The known Summer variety. Fruit long, skin very much warted, bright golden yellow. Pkt. 5c;0ze 10c; $1 / 4$ 1b. 25c; 1b. 75c.

\section{WINTER VARIETIES}

BOSTON MARROW $\begin{gathered}\text { A popular variety, with large, } \\ \text { oval fruit skin bright, red- }\end{gathered}$ dish orange, with light cream netting. Flesh, orange. Fine grained, and of excellent quality. This is the most popular variety for canning. The California canners plant several hundred acres annually and the fruit makes a rich orange-red, and delicious flavored dish. Plat. 5c; oz. $10 \mathrm{c} ; 1 / 41 \mathrm{~b} .25 \mathrm{c} ; 1 \mathrm{~b} .75 \mathrm{c}$. Deliclous. A dark green variety, with thick, orange-colored flesh:
of very best quality. Pkt.5c; oz. 15c; $1 / 4$ 1b. $45 c ; 1 b . \$ 1.50$.

Essex Fybrid, or Hard Shell Turban. An early, quick-growing variety, with very hard shell. Is broad, with large neck or 1b. $75 \mathrm{c}$.

Fordhook. A good variety for early Winter or even Summer use. The fruit is oblong, slightly ridged; is creamy yellow outside and Is solid and hard and is a splendid keeper. Pkt. 5c;oz. 10c; $1 / 4$ 1b. $25 \mathrm{c}$; $1 \mathrm{~b}$. 90c.

Golden Hubbard. An exceptionally attractive variety of the true Hubbard type. At maturity the color is red, and the flesh bright orange. The vine is productive and the fruit is fit for use earlier than the Hubbard. Pkt. 5c; oz. 10c; $1 / 4$ 1b. 25c 1b. $75 \mathrm{c}$.

HURBARD The most popular and widely used of the Winter squashes. Fruit is oblong and pointed, heavily markable for its keeping qualities. Pkt. 5c; oz. 10c; 1/4 1b. 30c; $1 \mathrm{~b} . \$ 1.00$

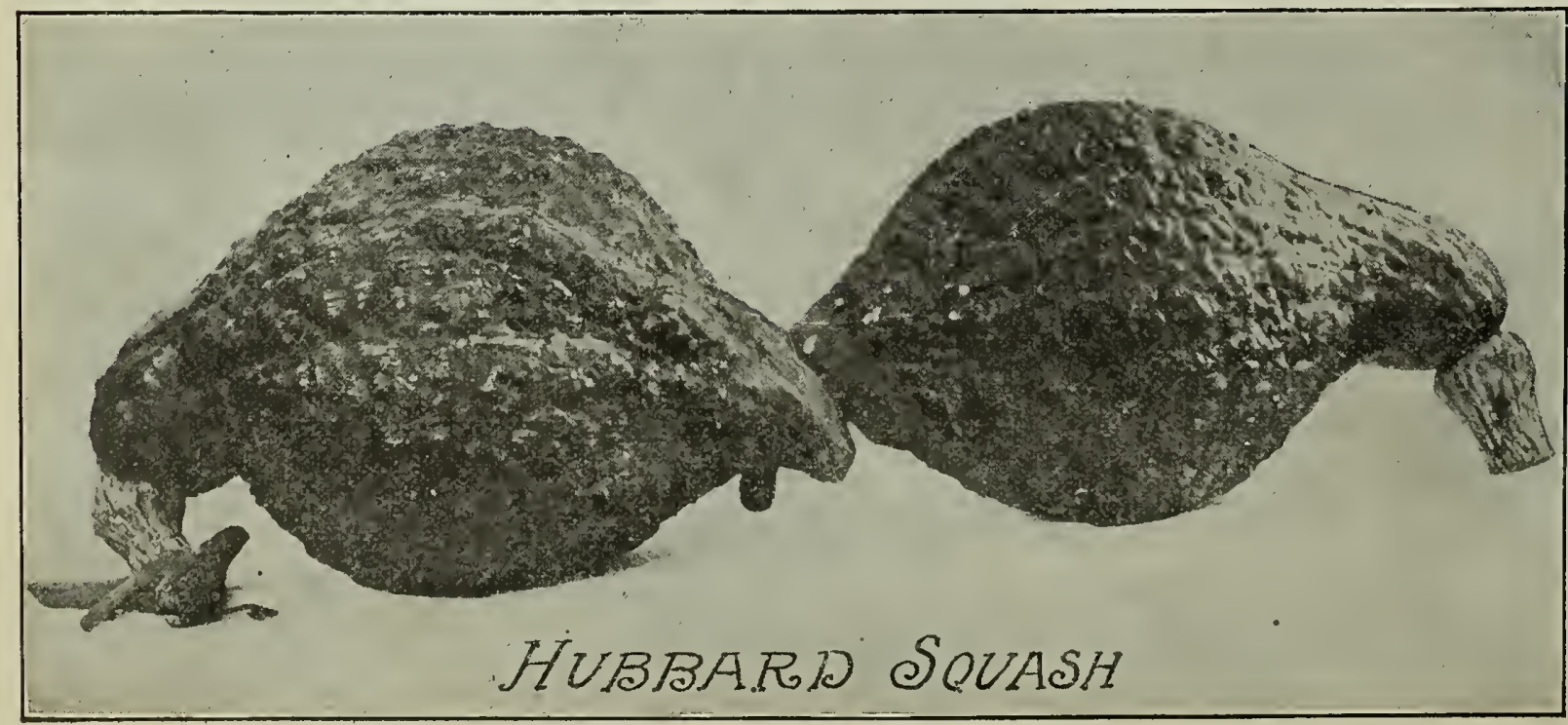

Perfect Gem or Cream. Long-keeping Winter squash, 4 to 6 inches in diameter; appleshaped, distinctly ribbed with smooth cream colored skin. Is solid and rather hard, but bakes to a delicious soft consistency on the inside Although a small variety, it is a great keeper and is used mostly in the Winter Pkt $5 \mathrm{c}$ 02. 10c; 1/4 Ho $-26 c$ ? 1b. $85 \mathrm{c}$.

Mammoth Chili. A very large variety with smooth, oblong fruit flattened at both ends. Skin, $\mathrm{rich}$ orange-yellow; flesh, orange, fine grained, and sweet. Plzt. 5c; oz. $15 \mathrm{c} ; 1 / 4$ lb. $45 \mathrm{c}$; Ib. $\$ 1.50$. 


\section{SAN FRANCISCO, CALIFORNIA. U.S.A}

\section{TOMATO}

As tomatoes are rery sensitire to frost, they cannot be set in the open field until about Mar 1st. The seed must be sown in well-protected

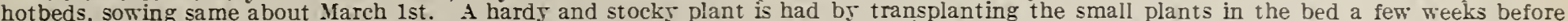
transplanting to the field. Or when about four inches high, the top may be pinched off and the plant grows stockier.

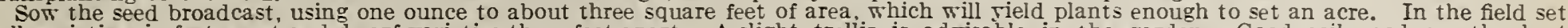

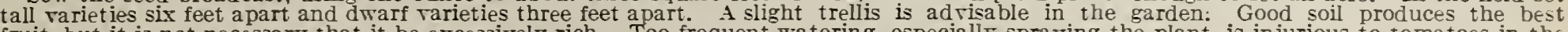

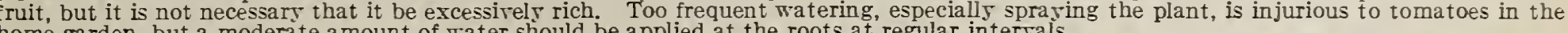
home garden, but a moderate amount of water should be applied at the roots at regular intervals.

Acme. A tall rariets, medium early, bearing flattish globe fruit of a purplish-carmine color, and medium size: The fruit is smooth and unifor $\$ 2.25$.

Beauty. A rather early, tall variets; rery prolific, with good-sized, smooth fruit of a purplish-
carmine color. Pkt. 5c; oz. 25c; $1 / 41 \mathrm{~b}$. $75 \mathrm{c}$; carmine col

BONNY BFST An earls, scarlet-fruited success all orer the country. It is from ten days to two weeks earlier than Chalk's Early Jewel, which it otherwise resembles. It is smooth, rers eren in size, rery solid, and also very prolific. It is one of the best housegarden, canning and shipping Tomatoes in ib. $\$ 5.00$.

\section{CHALK'S EARLY JEWEL}

A wonderful new variety, in that it is earl and bears continuously throughout the season. The fruit is large, smooth, uniform, and wellripened clear to the stem, and the flavor and quality are especially fine. Color, bright $\$ 2.75$.

Dwarf Champion. A dwarf variety, sometimes called the tree tomato on account of its upcalled the tree tomato on account of its upright growth and its ability to stand alone without trellising. F r u i medium-sized, color. Pkt. 5c; oz. 25c; $1 / 41 \mathrm{~b}$. $75 \mathrm{c} ; 1 \mathrm{~b}$. $\$ 2.50$.

DWARF GIANT Dwarf plant and giant of a cross between Ponderosa and Dwarf Co Champion, and it partakes of the nature of both parents. The fruit has the mild sweet flaror of Ponderosa, is also large and meaty, with very little core. It is deep purplish-
crimson in color and belongs to the latercrimson in color and belongs to the later$\$ 3.00 ; 1 \mathrm{~b}$. $\$ 10.00$.

Earliana. (Sparks). The earliest tall rariets forming ripe fruit much earlier than ans other rariety. The fruit is large, smooth, of a bright scarlet color, and of fine qualits. Fers raluable for early market use. Pkt. 10c; oz. 35c: 1/1 1b. $\$ 1.00 ; 1 b . \$ 3.25$.

Favorite. A tall rariety, bearing globe-shaped, scarlet fruit. The fruit is smooth and uniform, and $\pi$ rll ripened to the stem. PKt. 5c;oz. $25 \mathrm{c} ; 1 / 4$ 1b. $75 \mathrm{c}$; 1b. $\$ 2.25$.

Golden Queen. A large-fruited, tall rariety, bearing smooth, bright rellow fruit of fine qualits. Pkt. $5 \mathrm{c} ; 0 \mathrm{z} .25 \mathrm{c} ; 1 / 41 \mathrm{~b} .75 \mathrm{c} ; 1 \mathrm{~b}$. $\$ 2.50$.

Eusk Tomato, or Ground cherry. A rariety that is corered by a loose covering or husk for preserves. Pkt. $5 \mathrm{c} ; 0 \mathbf{0 z} .25 \mathrm{c} ; 1 / 41 \mathrm{~b}$. 90c; 1 b. $\$ 3.00$.

MATCHIESS A tall-growing, prolific rariety with large uniform. Color, bright scarlet. For canning and general main crop market, there is no better tomato grown. Extra select crop market, there is no better tomato grown. Extra se
ed strain. Pkt. 10c; oz. $40 \mathrm{c} ; 1 / 41 \mathrm{~b}$. $\$ 1.10 ; 1 \mathrm{~b} . \$ 4.00$.

Perfection. A tall variet 5 , with medium-sized, globular, uniform fruit, which is smooth and well ripened to the stem. Color bright scarlet. Pkt. 5c; oz. 25c; $1 / 4$ lb. 75c; 1b. \$2.25.

Ponderosa. An extremely large, irregular-fruited rariety. Tine tall, and fruit rery solid and purplish-carmine in color. Rather coarse and of fair quality only. Pkt. $10 \mathrm{c} ; 0 \mathrm{z} .40 \mathrm{c} ; 1 / 4 \mathrm{ib} . \$ 1.00$; 1b. $\$ 3.50$.

Red Cherry. The fruit is small and globe-shaped, about one to two inches in diameter. It is rerr raluable for preserving. Pkt. 5c; oz. 25c; $1 / 4$ ib. $75 \mathrm{c} ; 1 \mathrm{~b}$. $\$ 2.50$.

Red Pear Shaped. As the name implies, the fruit is shaped like a pear-small at the stem and enlarged at the top. It is small, being about two or three inches long. It is bright scarlet. Pkt. 5c; 0z. 25c; $1 / 4$ lb. 75c; 1b. \$2.50.

STONE The best main crop variety for all purposes, and Fruit smooth, large, and uniform. Color bright scarlet. Pkt. Fruit smooth, large, and uniform.
5c; oz. 25c; $1 / 4$ 1b. 75c; 1 b. $\$ 2.25$.

TROPHY An old favorite and much esteemed for its proirregular, but of fine quality, and is raluable for canning. The true stock is scarlet is color, and the fruit shows a distinct narel at the blossom end. Pkt. 5c; oz. 20c; $1 / 41 \mathrm{~b} .60 \mathrm{c} ; 1 \mathrm{~b}$. \$2.00. 
While turnips are a favorite fall and winter vegetable, they may also be had in spring by proper sowings. They are of easy culture, but need well-worked, rich soil to insure a quick, uninterrupted growth, when they will be tender and free from woodiness.

For fall and winter use sow the seed in August, using one ounce to 250 feet of row, thinning the plants when very young to three or four all art. For spring

For field culture sow in rows about two feet apart, using one to three pounds of seed per acre.

Amber, or Yellow Globe. One of the best yellow-fleshed varieties.

Skin also clear yellow. Is of large size and flne flavor. Pkt.

$5 \mathrm{c} ; 0 \mathrm{z} .10 \mathrm{c} ; 1 / 4$ 1b. 20c; 1b. 60c.

Cow Horn. A long, pure white variety, resembling a white carrot more than a turnip. The flesh is tender and sweet, and it is 0z. 10c; $1 / 4$ 1b. 25c; 1b. 75c.

Early Snowball. A medium globe-shaped variety of pure white. Very solid and of the best quality. Pkt. 5c;0z. 10c; $1 / 41$ ib. 25c; 1b. $80 \mathrm{c}$.

\section{EARLY WHITE FLAT DUTCH (Strap} Leaf) A medium-sized, flat variety; clear white, early, oz. 10c; 14 1b. 20c; 1b. 60c.

Extra Early White Milan. A very early variety, medium sized, flat and clear white A fine home-garden variety. Pkt. 5c: 0z. $10 \mathrm{c} ; 1 / 4$ 1b. $25 \mathrm{c}$; ib. $80 \mathrm{c}$.

Extra Early Purple Top Milan. A very early variety, medium sized, very flat, and white with purple top. Pkt. 5c; 0z. 10c;
$1 / 4$ 1b. 25c; 1b. 80c.

Orange Jelly, or Golden Globe. A globe-shaped, yellow variety with firm and crisp yellow flesh. A very fine table variety. Pkt.

\section{PURPLE TOP FLAT DUTCH (Strap}

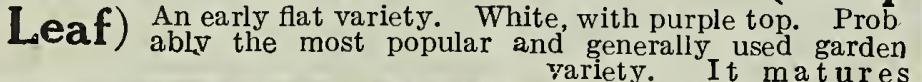

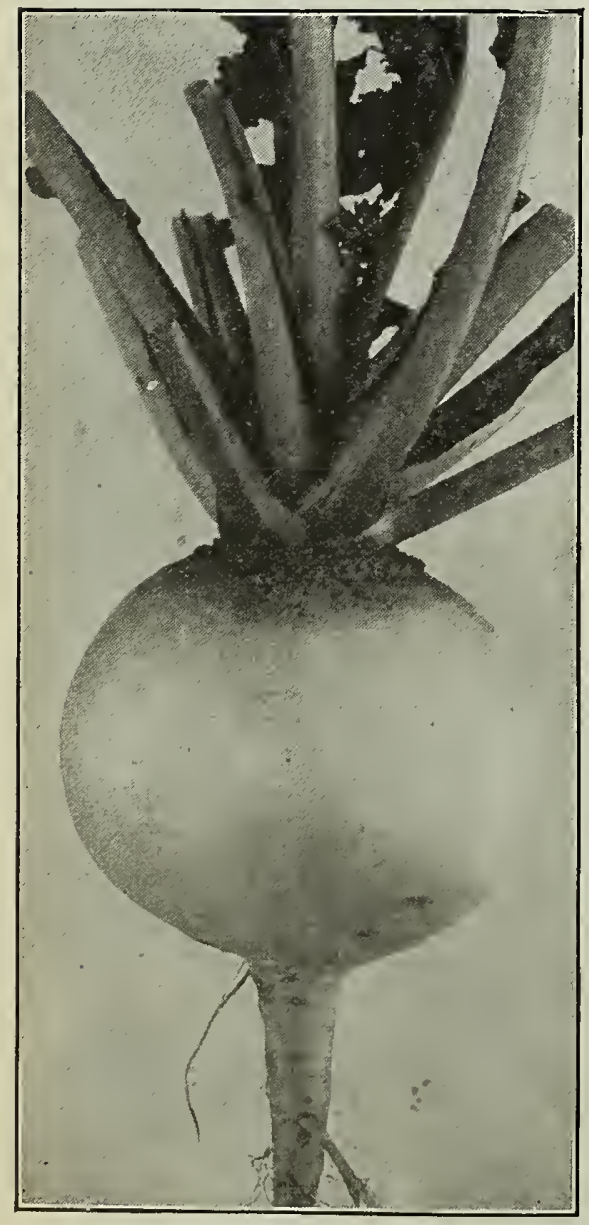

Purple Top White Globe Turnip

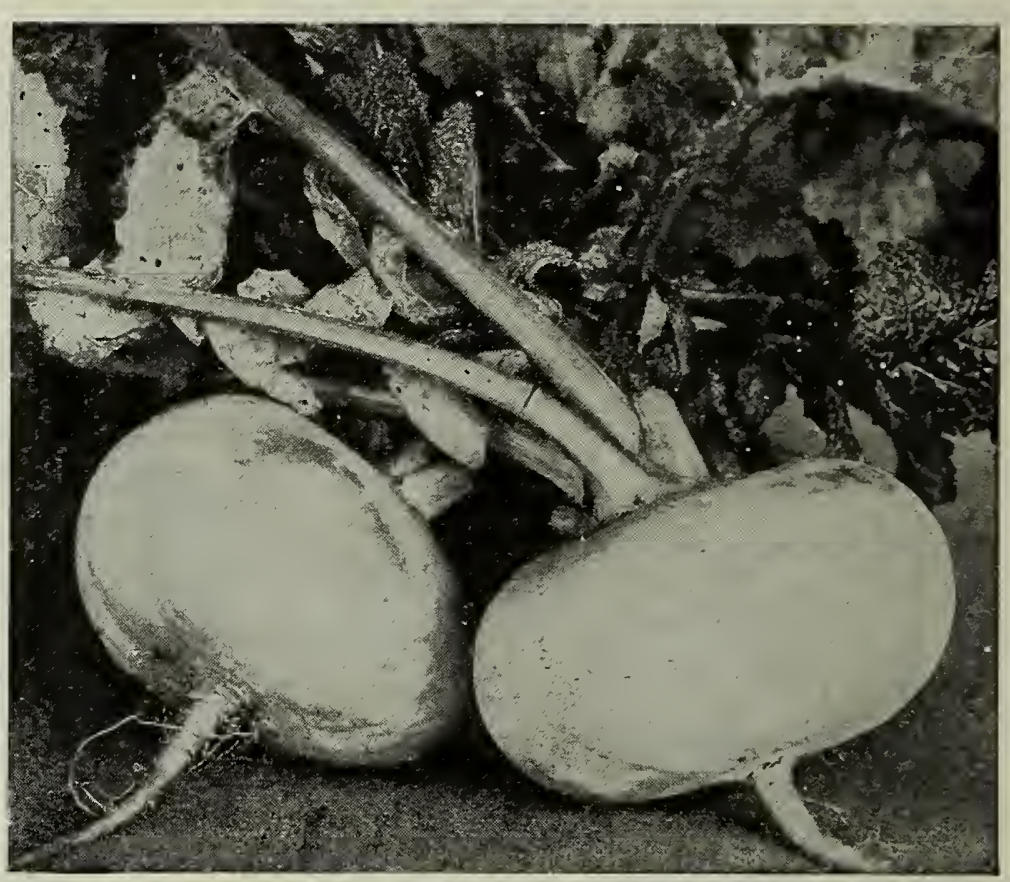

White Flat Dutch Turnips grained flesh of mild $1 / 4 \mathrm{Ib} .20 \mathrm{c} ; 1 \mathrm{~b} .60 \mathrm{c}$.

PURPLE TOP WHITE GLOBE A valuable sort for either table use or with purple top. Flesh, white, firm and tender. Pkt. 5c; oz. 10c; 1/4 1b. 20c; 1b. 60c.

Purple Top Yellow Aberdeen. A medium sized variety, generally used for stock feeding. Is yellow, with purple top. Flesh, light yellow. A winter variety, seed of which can be sown in summer. Pkt. 5c; 0z. 10c; $1 / 4$ Ib. 20c; 1b. 60c.

Pomeranean White Globe. Iarge white variety, used largely for stock feeding. Is globe-shaped. large leaves. Hardy. Pkt. 5c; 0z. 10c; 1/4 1b. 20c; 1b. 60c.

Seven Top (for greens). Cultivated for its leaves; cooked same as spinach and mustard. The root is small and not used. Pkt. 5c; oz. 10c; $1 / 4$ lb. 20c; 1b. 60c.

White Egg. A small, oval-shaped variety with pure, white skin and white, fine-grained flesh. A handsome variety and very early. Pkt. 5c;0z. 10c; $1 / 41 \mathrm{lb} .25 \mathrm{c} ; 1 \mathrm{~b}$. 65c.

\section{RUTA BAGAS, OR SWEDES}

These are grown very extensively for stock feeding, and make an excellent and valuable crop. Treatment same as for winter turnips, but require a longer season to grow, and the seed should be planted early in July. The rows should be at least two and one-half feet apart, and the plants thinned to eight or twelve inches. The roots frequently grow to enormous size.

AMERICAN PURPLE TOP, or LONG ISLAND One of the popular varieties, with yellow flesh. It is yellow below ground, with purple top above, and the popular varieties, with yellow flesh. It is yellow below ground, with purple top above, and the
leaves are small. A good stock feeding or table variety. Pkt.5c; 0z. 10c; 1/4 1b. 20c; Ib. 60c.

Laing's Purple Top. A globe-shaped variety of good quality. Flesh, yellow; skin, yellow below ground and purple above. Pkt. 5c; oz. 10c; $1 / 41$ b. 20c; 1b. s0c.

LARGE WHITE, or SWEET GERMAN. A very large variety with white skin and white flesh. which is tender and sweet. Pkt. 5c; oz. 10c; 1/4 1b. 20c; lb. 60c.

Monarch, or Tankard. Roots ovoid in shape and very large. Flesh, yellow; skin, yellow below ground and purple above. Pkt. 5c;0z. 10c; $1 / 4$ 1b. 20c; ib. 60c。

Yellow Purple Top Swede. The well-known and most commonly used variety. Roots, globular; skin, yellow under ground and purple above. Flesh of fine fla vor. Valuable for either table use or stock feeding. Pkt. 5c;0z. 10c; $1 / 4$ 1b. 20c; 1b. 60c.

\section{TOBACCO}

CONNECTICUT SEED LEAF. The best known and most widely used variety throughout the middle and northern States and Canada. It is the hardiest variety in cultivation. Pkt. 5c; os. $25 \mathrm{c} ; 1 / 4 \mathrm{Ib}$. $75 \mathrm{c} ; \mathrm{Ib}$. $\$ 2.50$.

Havana (Domestic). Plzt. 10c; 0z. 25c; 1/4 1b. 75c; 1b. $\$ 2.50$.
Vuelta de Abajo (Imported Havana). Pkt. 15c; 0z. \$1.50. White Burley. Pkt. 5c; 0z. 30c; $1 / 4 \mathrm{Ib} . \$ 1.00 ; 1 \mathrm{~b} . \$ 3.00$.

Yellow Pryor. Pkt. 10c; 0z. 25c; 1/4 Ib. 75c; Ib. \$2.50.

Kentucky Yellow, Pkt. 10c; 08. 25c; 1/4 1b. 75c; 1b. 52.60. 


\section{AROMATIC, MEDICINAL AND POT HERBS}

Anise. A hardy annual. The seed especially being used for seasoning food, also for flavoring liquors and for medicinal purposes. to stand. Pkt. 5c; oz. $10 \mathrm{c} ; 1 / 41 \mathrm{~b} .25 \mathrm{c} ; 1 \mathrm{~b} .85 \mathrm{c}$.

Balm. A perennial herb used for seasoning, especially in liquors. Has a lemon-like flavor. Thrives in any warm location, and is easy to grow. Plant grows one to two feet high. Pkt. 5c; oz. $25 \mathrm{c} ; 1 / 4$ ib. $75 \mathrm{c}$.

Basil, sweet. A hardy annual, the leaves of which have a clover like flayor. Used for seasoning soups, meats, and salads. Of the easiest culture. Seed can be sown as early as the weather permits. Pkt. 5c; oz. 15c; $1 / 41 \mathrm{~b}$. 40c; 1b. $\$ 1.50$.

Borage. The leaves are used for flavoring and the flowers furnish bee pasture. Pkt. 5c; 0z. 10c; $1 / 41 \mathrm{~b}$. 30c; 1b. $\$ 1.00$.

Caraway. A biennial herb, grown for its seeds, which are used for flavoring breads, cakes and cheese; also occasionally for the young shoots and leaves, which are eaten. Grows two feet high. following year. Pkt. 5c; oz. 10c; $1 / 41 \mathrm{~b} .25 \mathrm{c} ; 1 \mathrm{~b} .75 \mathrm{c}$.

Catnip. Practically a wild plant. Is a hardy perennial, the leaves of which are used for medicinal purposes. Pkt. 5c; oz;. 40c $1 / 4$ lb. $\$ 1.25 ; 1 \mathrm{~b}$. $\$ 4.00$.

Coriander. An easily grown herb, the seeds. of which are used for flavoring pastry, confectionery and liquors. Grows two to three feet high. Pkt. 5c; $1 / 4$ 1b. 15c; ib. 45c.

Dill. An annual herb, the seeds of which are used for seasoning. The foliage is also used for flavoring as well as for medicinal purposes. Grows two to three feet high. Its largest use is pickling cucumbers in what is known as "Dill Pickles." Pkt. $5 \mathrm{c} ; 0 \mathrm{z} .10 \mathrm{c} ; 1 / 4 \mathrm{lb} .20 \mathrm{c} ; 1 \mathrm{~b} .60 \mathrm{c}$.

Fennel, Sweet. A hardy perennial. the leaves of which are used in soups, garnishes, and salads. The seed should be sown early 5c; 0z. 10c; $1 / 4$ 1b. 30c; 1b. $\$ 1.00$.

Horehound. A hardy perennial shrub, one to three feet high, with whitish, hairy leaves, which are used in confectionery, and in medicines for coughs and colds. Pkt. 5c; oz. 20c; $1 / 41 \mathrm{~b} .60 \mathrm{c}$.

Hyssop. A hardy perennial shrub, growing eighteen inches high. Used for medicinal purposes, both green and dried. Pkt. 5c; oz. 20c; $1 / 4$ lb. 60c.

Lavender. A hardy perennial, growing two feet high and forming a bush about four feet in diameter. Used as a garden plant on account of its fragrant blossoms and foliage. Its long, fragrant oz. $15 \mathrm{c} ; 1 / 4 \mathrm{lb}$. $40 \mathrm{c} ; 1 \mathrm{~b}$. $\$ 1.25$.

Sweet Marjoram. A half-hardy perennial, the leaves of which are used both green and dried for fla

Rosemary. A hardy perennial shrub, the leaves of which are used for seasoning and medicinal purposes. Oil of Rosemary is distilled from the leaves. Pkt. 5c; oz. 35c; $1 / 4$ 1b. $\$ 1.00$.

Rue. A hardy perennial, thriving on poor soil. Has a peculiar smell; leaves are bitter. Is used as a stimulant, but should be used with caution, since its
Pkt. 5c;oz. 15c;1/4 1b. $40 \mathrm{c}$.

sage. A hardy perennial shrub, with whitish-green, oval, and very much wrinkled leaves, which have a pleasant smell and which are used for seasoning. It is easily grown and the seed can be sown almost any time. Its fragrant, purplish flowers are especially sage blossoms. Pkt. 5c; 0z. 25c; $1 / 41 \mathrm{~b}$. $60 \mathrm{c} ; 1 \mathrm{~b} . \$ 1.75$.

summer Savory. A hardy annual, the stems and leaves of which are used for flavoring dressings and soups. Pkt. $5 \mathrm{c} ; 0 \mathbf{0 z} .10 \mathrm{c}$; $1 / 4$ lb. $30 \mathrm{c}$.

Winter Savory. A hardy perennial, the leaves of which are used for seasoning. Pkt. $5 \mathrm{c} ;$ oz. $20 \mathrm{c} ; 1 / 41 \mathrm{~b} .60 \mathrm{c}$.

Tansy. A very easily grown perennial plant, growing about three feet high. Its leaves are used for medicinal purposes, especially

Tarragon. The leaves are used for seasoning. The plants continue to bear leaves for a long period. Pkt. 10c.

Thyme. A low-growing, half-shrubby perennial, with fragrant leaves, having a mint-like odor, which are used for seasoning. Pkt. 5c;0z. 25c; $1 / 4$ lb. 75c; ib. $\$ 2.50$.

Wormwood. A hardy perennial, growing about four feet high. The leaves, which are greatly divided, have a strong, bitter flavor. They are gathered in the Summer and dried, and are in liquors, especially absinthe. Pkt. 5c;0z. 20c; $1 / 41 \mathrm{~b}$. 60c.

\section{VEGETABLE PLANTS AND ROOTS}

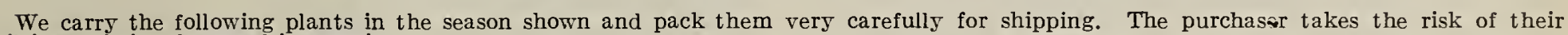
wilting or being damaged in transit. Artichoke Plants. January to May. Doz. $\$ 1.00$. Too heavy to
mail.

Asparagus Roots. 2 years old. January to April. Doz. 20c (postpaid 25c doz.); $100 \$ 1.00 ;$ special price per 1000 .

Cabbage Plants. November to June. Doz. 15c; $10085 \mathrm{c}$; doz. $20 \mathrm{c}$, postpaid.

Cauliflower Plants. November to June. Doz. 20c; $100 \$ 1.00$; doz. $25 \mathrm{c}$, postpaid.

Celery Plants. March to May. Doz. 20c; $100 \$ 1.20 ;$ doz. 25c, postpaid.

Egg Plant. March 15 th to May 15th. Doz. 25c; doz. 30c, postpaid.

Garlic. November to May. 25c per 1b.

Horse Radish Roots. January to May. Doz. 50c; doz. 55c, postpaid. Extra large roots, $15 \mathrm{c}$ each, or $\$ 1.00$ per 10 .
Pepper, Iarge Bell. March 15 th to May. Doz. 25c; $100 \$ 1.50$; doz. $30 \mathrm{c}$, postpaid.

Pepper, Cayenne. March 15th to May. Doz. 25c; $100 \$ 1.50$; doz. 30c, postpaid.

Rhubarb Roots. December to May. Each 15c; doz. \$1.50; doz. $\$ 1.75$, postpaid.

Rhubarb Roots, Crimson Winter. Each 25c; 5 for $\$ 1.00$, postage additional $15 \mathrm{c}$ each root.

Sweet Potatoes. April to June. Doz. 20c; $100 \$ 1.00$; doz. 25c, postpaid.

Tomato, Extra Early Plants. March. Doz. 25c.

Tomato, Stone, Etc. April to June. Doz. 20c; $100 \$ 1.25 ; \mathrm{doz}$.

25c, postpaid.
Herbs, Chives, Sweet Marjoram, Sage, Savory, Thyme, Tarragon. Two plants of any kind or assort ed for $25 \mathrm{c}$; postpaid; $30 \mathrm{c}$.

\section{SEASONS TO PLANT IN}

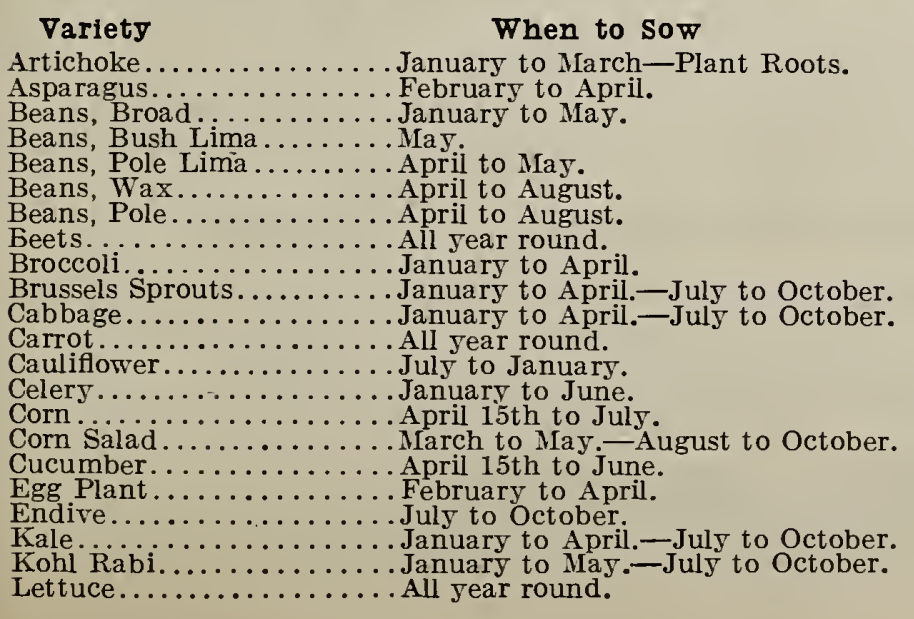

CENTRAL CALIFORNIA

Variety

Muskmelon

Watermelon

Mustard

Onion.

Parsley.

Parsn

Pepper

Radish.

Radish...

Rhubarb Roots

Salsify

Spinach

Squash

Tomato

Veget able Marrow................... and Tomatoes. which should be started early in frames or in the house and transplanted out of doors about the first of May. 


\section{WE ARE HEADQUARTERS IN CALIFORNIA FOR ALFALFA, CLOVER AND GRASS SEEDS}

\section{ALFALFA}

ALFALFA (MEDICAGo SATIVA), also known as Lucerne $A$ and Chili Clover. One of the most valuable forage or pasture grasses, being very nutritious, both as a green feed and as hay. It requires moist land or frequent irrigation and often bears from five to six crops of hay a year. It does well in almost any climate and improves any soil that is sown with it. A good stand of it will choke out and practically kill wild morning-glory. Prepare the land by deep plowing and thorough harrowing, and sow 17 to 25 pounds per acre broadcast and harrow in. It is best to sow in the fall after the first rains, but it can also be sown in the spring.

Alfalfa seed is graded by the amount of dead matter and the percentage of weed seeds it contains. The very worst weed is dodder, which infests seed grown on low lands. Dodder (called also Golden Thread and Love Vine), is a yellow parasitic plant with abundant stems but no leaves; the roots live on the alfalfa plant and quickly kill it spreading to other plants. Isolated plant and quickly kill it, spreading to other plants. Isolated spots may be checked by hauling straw to the place and burning it. Dodder infests much of the seed from the San Joaquin will show that alfalfa which contains no dodder is worth several cents a pound more than alfalfa which contains this weed. Our alfalfa is grown out of the state on high land, and we believe is dodder free. We use the greatest care in selecting the fields which are to be cut for our seed, and while we do not guarantee its purity, we have such confidence that we urge our customers to procure samples and have the sacks set aside. These samples may be sent to Washington, D. C., and there tested by the Government, who will report to the sender whether the seed contains dodder or not.

We handled twenty-two carloads of alfalfa last year, and are always prepared to quote the lowest market prices for seed of the grade we carry, which is the best. Lb. 40c, postpaid; by freight or express, $1 \mathrm{~b}$. 30c; 10 lbs. $\$ 2.50$; larger quantities at market price.

Arabian Alfalfa. This is a new species of alfalfa especially recommended by the U. S. Government. It is a taller growing variety, of hardier growth, and is supposed to yield one more crop per season. It is worthy a trial but as there is but little seed of it to be had we advise trials only for the first season. We offer it at $50 \mathrm{c}$ per lb, postpald; by freight $40 \mathrm{c}$ per $1 \mathrm{~b}$; $\$ 35.00$ per $100 \mathrm{lbs}$.

Turkestan Alfalfa. This variety comes from Asia Minor and is claimed to be superior to our domestic variety for high lands, as it requires less water. For dry lands this alfalfa is coming into great favor. Lb. 30c; larger quantities at market price.

\section{CLOVER SEEDS}

The prices of some varieties of Clover, Grass and Field seeds may change as the season advances. Prices now given are those prevailing when this catalog was published. It will be to advantage of intending purchasers to write for samples and special prices before ordering in large quantities.

\section{ALSIKE, OR SWEDISH CLOVER}

(Trifolium Hybridum). A perennial variety, sometimes preferred to Red Clover, as it is generally finer and makes better hay for horses. The blossoms are also valuable for bees. Alsike 10 lbs per acre. Lb. 35c, postpaid; by freight or express, lb. 25c; larger quantities on application.

Bokhara, or Sweet Clover (Melilotus Alba). Grows 3 to 5 feet high, covered with small, white flowers of great fragrance. Very
valuable for bee pasture. Sow 10 pounds to the acre. Lb. 40c, postpaid; by express or freight, 1b. 30c.

Burr Clover (Medicago Denticulata). The native forage plant of California. Of the easiest culture, growing all, winter and well into summer. We offer only "Hulled seed," which is much easier to sow than in the burr. Sow from August to October,
using 15 to 20 pounds of hulled seed per acre. Ib. 35c, postpaid; by express or freight, 1b. 25c.

Crimson, or Italian (Trifolium Incarnatum). An annual variety, growing 20 to 30 inches high, and having long, crimson blossoms. Excellent for both pasture and hay. Sow from 12 to 15 pounds per acre, and cut for hay when in full bloom. Lb. 35c, postpald; by freight, lb. 25c.

Japan Clover (Lespedeza Striata). Thrives in any soil and in the driest seasons; it makes fair hay and stock eat it readily when green. Sow in the spring, 15 lbs. per acre. Ib. 45c, postpaid; by freight, Ib. 35c.

Mammoth Red or Sapling (Trifollum pratense). Similar to Red Clover, but coarser, taller and more hardy. Sow from 12 to 15 pounds per acre. Ib. 35c, postpaid; by freight, 1b. 25c.

RED CLOVER (TRIFOLIUM PRATENSE). Standard heaviest crop of any variety except alfalfa, makes superior heaviest crop of any variety except alfalfa, makes superior pounds per acre. Lb. 35c, postpaid; by freight, Ib. 25c.

WHITE DUTCH (TRIFOLIUM REPENS). Dwarf blossoms; used largely for bee pasture. It is also an excellent pasture plant for either sheep or cat tle; also makes a beautiful lawn. Sow 10 pounds per acre. Lb. 45c, postpaid; by freight, Ib. $35 \mathrm{c}$

\section{LAWN GRASSES}

On the inside of the back cover you will find listed the various lawn grasses and lawn mixtures, together with directions for lawn making. Our lawn mixtures have made many fine lawns under conditions which were unfavorable and seemingly impossible. They are well worth trying. See inside of back cover for prices and descriptions.

Fertllizer. To insure a rapid growth of grass some kind of fertiizer is necessary, especially in lawns where the nourishment of the soil has been used up by continuously growing on the same place. We have a fertilizer especially prepared to invigorate the growth of grass and to keep it that dark green color. Use one and one-hal pounds to one hundred square feet and make two applications each year. Special prices on lawn and field fertilizers upon application. By express or freight only. Lawn Dressing, $10 \mathrm{lbs}$. 65c;25 lbs. $\$ 1.25 ; 50$ lbs. $\$ 2.00$.

"Lawns and How to Make Them," is an excellent, well illustrated book, dealing with lawns and lawn grasses and should be consulted where more information is required. Mailed for $\$ \mathbf{1 . 4 0}$.

MORSE'S CALIFORNIA LAWN MIXTURE. Our best general mixture for fine lawns. Per. 1b. 35c; if by mail 45c.

PACIFIC RYE GRASS (MORSE'S). Makes a fine bright green lawn on sandy soils. Per lb. 25c; if by mail 35c.
MORSE'S “GOLDEN GATE PARK" IAWN MIXTURE. A very hardy mixture, containing a little white clover. Per Ib. 35c; if by mail $45 \mathrm{c}$.

AUSTRALIAN RYE GRASS. Per 1b. 15c; if by mall 25c.

KENTUCKY BLUE GRASS. Makes a fine dark green lawn. Per Ib. 35c; if by mail $45 \mathrm{c}$.

MORSE'S SPECIAL SHADE MIXTURE. A lawn grass for sunless spots. Per lb. 55c; if by mall 65c.

MORSE'S VELVET IAWN MIXTURE. A lawn grass for wet places. Per 1b. 35c; if by mail 45c.

WHITE CLOVER. The dwarf clover for lawns. Per 1b. 35c; if by mall 45c. 
Add 10c per pound for all grass seeds ordered by mail; prices below do not include postage.

AWNLESS BROME GRASS (Bromus Inermis). Will stand droughts and produce heavy crops in dry sections and on poor soils where other grasses perish. It is one of the hardiest grasses
and succeeds on our dry hillsides. Sow 35 lbs. per acre. $\mathbf{L} \mathbf{b}$. and succeeds on our
$20 \mathrm{c} ; 100 \mathrm{lbs}$. $\$ 16.00$.

Beach Grass (Ammophila Arundinacea). Valuable on the sandy seashore, canal and railway banks, etc. Its strong, creeping, matting roots bind the drifting sand into natural embankments against the action of wind and waves. Also propagat
transplanting in the fall. Height 2 to 3 feet. Lb. 75c.

Bermuda Grass (Cynodon Dactylon). Dwarf with creeping stems which root at the joints, making it a difficult grass to eradistems which root at the joints, making it a difficult grass to eradicate. Makes a mat which will stand any amount of tramping or
heat. Valuable for pasturage for dry stock, and for binding heat. Valuable for pasturage for dry stock, and for binding steep embankments, and for lawns around Sacramento. The lbs. per acre. Ib. $75 \mathrm{c}$.

Creeping Bent Grass (Agrostis stolonifera). Being of fine texture this grass is most valuable for lawns and ideal for putting greens. It is of rapid growth and spreading habit and makes a
strong, enduring turf. Sow 40 lbs. per acre. Lb. 50c; 100 Ibs. $\$ 40.00$.

Crested Dog's Tall (Cynosurus Cristatus). Should enter in moderate quantity in permanent pasture and lawn mixtures. It does well in the shade, roots deeply, is stoloniferous and perennial. Valuable in mixture for lawns, putting greens, and for pasture.
If sown alone 30 lbs. should be used per acre. Lb. 60c; 100 Ibs. $\$ 50.00$.

Hard Fescue (Festuca Duriuscula). A dwarf-growing grass, forming a dense, tufted mat, succeeding well in dry situations. mended for lawns. Sow 30 lbs. per acre. Lb. 35c; 100 lbs. mended

Hungarian Millet (Panicum Germanicum). Is a vauable quick growing annual forage plant. Seed is good for poultry. Cut for fodder just before blooming. Sow 30 lbs. per acre. Lb. 10c; $100 \mathrm{lbs}$. $\$ \mathbf{5 . 5 0}$.

Italian Rye Grass (Lolium Italicum). Thrives in almost any soil and yields early and abundant crops. Sown in the fall, will produce an excellent hay crop the following season, but lasts only one year. Much sown in Humboldt County for pasture and 15c; 100 Ibs. $\$ 10.00$.

KENTUCKY BLUE GRASS (Poa Pratensis). Fancy or double extra clean. Though offered at the standard weight of $14 \mathrm{lbs}$. per bushel, the natural weight of this fancy seed is 20 lbs. per measured bushel. As this grass takes some time to become established, it is preferably sown in mixtures for pasturage. Is truly perennial and prefers lime soils. As a lawn grass it is the finest there is - spreading habit, even texture, permanent, fine leaf and dark color. For pasture sow 50 lbs per acre; for

Meadow Fescue, or English Blue Grass (Festuca Pratensis). A valuable grass for permanent pastures, and for meadows for cutting which are rather damp. Makes a quick second growth, but does not do well on dry soils. Often sown in mixtures. Sow 30 lbs. per acre. Lb. $50 \mathrm{c} ; 100$ ibs. $\$ 40.00$.

Meadow Foxtail (Alopecurus Pratensis). One of the best grasses for permanent pasture, early and of rapid growth. Is never sown alone, but always in mixtures, using about 4 lbs. per acre. L b. 50c; 100 ibs. $\$ 45.00$.

Mesquite (Holcus lanatus). Valuable on the cleared redwood and pine lands of California and Oregon, giving large crops of hay and good pasture. Sow $35 \mathrm{lbs}$. per acre. Lb. 25c; $100 \mathrm{lbs} . \$ 18.00$.

Millet German (Panicum Germanicum; Var.). Will grow on any good land and yields heavily when artificially watered; yields from 40 to 60 bushels of seed per acre, which is excellent food for stock or poultry. A good green fodder plant. Sow 30 lbs. per acre. Lb. $10 \mathrm{c} ; 100$ lbs. $\$ 6.00$.

ORCHARD GRASS, or COCKSFOOT (Dactylis Glomerata). One of the most valuable of all pasture grasses; produces an immense quantity of forage, and hay of best quality. After being mown comes up quicklv and yields very heavily. Suitable for pasture under trees. Sown in the ashes on cleared redwood land in Humboldt County. Not suitable for lawns as it grows in tussocks. Sow $35 \mathrm{lbs}$. per acre. Lb. 35c;100 Ibs. \$25.00.

Pearl Millet (Pencillaria). A perennial plant for fodder. Grows tall and yields an enormous a mount of corn-like leaves. Sown in drills or broadcast, using 3 to 5 lbs. per acre if in drills, or 25 lbs. broadcast. Lb. 20c; 100 1bs. $\$ 15.00$.
Perennial Rye Grass (Lolium Perenne). It grows rapidly and makes a good showing within month from time of sowing; grows very rapidly. The great pasture and meadow grass of Great
Britain. Valuable for planting early on dry hillsides, as it grows so very quickly. A good lawn grass, but a little coarse. Sow 60 lbs. per acre. L b. $15 \mathrm{c} ; 100$ lbs. $\$ 10.00$.

AUSTRALIAN RYE GRASS. Specially selected and recleaned for lawns; does especially well on sandy soils. Sow $5 \mathrm{lbs}$. per for lawns; does especially well on sandy soil
1,000 square feet. Lb. $15 \mathrm{c} ; 100 \mathrm{lbs}$. $\$ 10.00$.

Red, or Creeping Fescue (Festuca Rubra). Forms a close, rich sod and is valuable in lawns and should be in shade mixtures.
Makes a close, lasting turf on dry, sandy soils, and can be used to bind dry banks. Also an excellent bottom grass for moist mixbind dry banks. Also an excellent bottom grass for m
ture. Sow $30 \mathrm{lbs}$. per acre. Lb. 35c; $100 \mathrm{lbs}$. $\$ 30.00$.

RED TOP (Agrostis Vulgaris). Herd's grass. Second only to Timothy as hay grass and better if the ground is to be pastured afterward for Red Top makes one of the best permanent pastures. Succeeds on all soils, though doing best on moist and even swampy land. A permanent grass and valuable as a lawn 20c; 100 lbs. $\$ 15.00$. Fancy, Free from Chaff. Sow 15 lbs. per acre. Lb. 30c; 100 lbs. \$25.00.

Rhode Island Bent Grass (Agrostis Canina). Like Red Top this grass accommodates itself to all soils. Especially valuable for lawns on sand at the sea coast; from it the lawns at Newport are largely made. Is perennial, dwarf, and makes a beautiful,
fine, close turf. For lawn sow $50 \mathrm{lbs}$. per acre. Lb. $\mathbf{3 5 c ; 1 0 0}$ lbs. $\$ 30.00$.

Rough-Stalk Meadow Grass (Poa Trivialis). Excellent for pastures and meadows, particularly on damp soils. As a lawn grass it forms a fine turf and does well in shaded locations. Sow 20 lbs. per acre. Lb. $45 \mathrm{c} ; 100$ lbs. $\$ 40.00$.

Sheep's Fescue (Festuca Orina). Short and dense in growth, excellent for sheep pastures, because it will thrive on poor,
gravelly, shallow or hilly soils where other grasses fail. Not gravelly, shallow or hilly soils where other grasses fail. Not bunches. Sow 35 lbs. per acre. Lb. 30c; 100 Ibs. $\$ 25.00$.

Sweet Vernal, True Perennial (Anthoxanthum Odoratum). Emits an agreeable odor, which it imparts to hay or to the lawn when being cut. Sow only in mixtures, using 2 or 3 lbs. per acre. Per 1b. 75c.

Tall Fescue (Festuca Elatior). Early, nutritive and productive in permanent pastures on wet or clay soils. On moist lands yields a large amount of good hay. Height 3 to 4 feet. Not suitable for lawns. Sow 40 lbs. per acre. Lb. $45 \mathrm{c} ; 100$ Ibs. $\$ 40.00$.

Tall Meadow Oat Grass (Avena Elatior). Of rapid, luxuriant growth, recommended for soiling and in permanent hay mixtures, also for winter grazing. This variety is not a lawn grass. $\mathbf{L b}$. $30 \mathrm{c} ; 100$ Ibs. $\$ 25.00$.

TIMOTHY (Phleum Pratense). The grade we offer is particularly "choice," free from weed seeds and of high germinating power. Timothy is the great standard hay grass of the eastern part of the country. It makes hay of the best quality and produces larger crop on good soil than any other grass. Not adapted larger crop on good soil than any other grass. Not adapted of stock soon destroys it. Not a lawn grass and not adapted for dry soils; height 2 to 3 feet. Often sown with red top and red
clover. Sow 15 to 20 lbs. per acre. Price fluctuates. Lb. $20 \mathrm{c} ; 100-1 \mathrm{bs} . \$ 15.00$.

Various Leaved Fescue (Festuca Heterophylla). A perennial grass suitable for cold, moist soils in which it will yield heavily. Valuable in permanent meadows, either for mowing or grazing. Height 2 to 3 feet. As a lawn grass it is valuable, especially for shaded places. Sow $40 \mathrm{lbs}$. per acre. Lb. $40 \mathrm{c} ; 100 \mathrm{lbs}$. $\$ 35.00$.

Wood Meadow Grass (Poa Nemoralis). Of early growth and thriving well under trees where other grasses will not grow.
Valuable for pasture, but expensive. As a lawn grass its creeping roots soon form a good turf. Should be included in putting green mixtures and shaded lawn mixtures. Sow 30 lbs, per acre. Lb. $85 \mathrm{c} ; 100$ lbs. $\$ 80.00$.

We recommend as less expensive and as giving better crops $\mathbf{M i x}$ tures of Grasses for Pastures, varying according to the soil and moisture. Write us in regard to these, and also see our Mixtures of Lawn Grasses on inside of back cover.

For grasses and clovers which have prices that fluctuate, write for samples and market quotations.

If ordered by mall, 10 cents per pound must be added to above prices for postage. 


\section{MISCELLANEOUS FIELD SEEDS}

Alfilaria (Erodium cicutarium). One of the most nutritious of fodder plants and well liked by cattle and horses. Alfilaria will
thrive and make a good pasture on dry hillsides. May be found on Mit. Tamalpais as a pasture. Sow $20 \mathrm{lbs}$. per acre. Per $1 / \mathbf{4} \mathbf{1 b}$.

Australian SaIt B ush (Atriplex semi-bacata). A valuable forage plant for poor soils, especially those containing alkali. Sow seed in the fall to get the benefit of early rains, using 1 to 2 pounds per acre. After the plant gets a good start; it will grow with very crown of the plants. Oz. 10c; $1 / 41$ b. 35c; 1b. \$1.25, all postpaid.

Broom Corn (Improved Evergreen). Used for making brooms, and extensively used on account of its green color and fine long
straight brush. It grows about 7 feet high. Sow 10 lbs. per straight brush. It grows ab
acre. I b. 20c, postpaid.

Buckwheat (Japanese). The best and most profitable variety. It is earlier than Silver Hulled and usually more productive. Is
also excellent for bee pasture. Sow 25 lbs. per acre. Lb. 20c, postpaid.

Buckwheat (Silver Hulled). A very good and popular variety. Grain is of a light color, rounder than the common variety; has a much thinid.

Canary. The seed is used for bird food. Is valuable also as an ornamental grass and has considerable merit as hay for feeding cattle. Ib. 20c, postpaid.

Canada Field Peas. A strong, vigorous pea often planted for green manure to plow under in the spring. Makes an excellent winter growth when sown in fall; very useful for fodder. Sow quantities on application.

Cow Pcas (Black Eye). Used largely for green manure. It is also valuable if allowed to mature the seed, when the dry vines ean
be plowed under and the seed used to grind as feed for stock. If for green manure, sow broadcast, using 80 pounds per acre. If for seed or fodder, sow in rows 3 feet apart, using 40 pounds per acre. Sow late in spring. $L$ b. 20c, postpaid.

Egyptian or Jerusalem Corn, or Dhoura. Belongs to nonsaccharine sorghums. It is considered a good grain for dry sections and seasons. It produces several small heads on side
shoots, of ten as many as 8 heads on a stalk. The seed is small and makes excellent chicken food. Plant 8 lbs. per acre. Lb. and makes postpaid.

Fenugreek. Used in the South for green manure to gather nitrogen to be plowed under. Canada Field Peas and Vetches are superior in our opinion for this purpose. The seed is fed to hogs to aid in fattening them, and to horses to give temporary fire and vigor. Lb. 35c, postpaid.

Flax seed. Should be sown in the spring on moist land, using 30 pounds of seed per acre if grown for a seed crop, or twice that quantity if intended for a crop of fiber. L b. 20c, postpaid.

Hairy Vetch (Vicia Villosa). A pea-like plant growing about 4 feet high and doing well on dry, sandy soils for forage. Also a valuable green manure plant for sowing in the fall. Sow broadcast 30 to 50 pounds per acre. Sown in the fall this plant may $30 \mathrm{c}$, postpaid.

Hemp (Kentucky Hemp). A staple crop for manufacturing, sown broadcast, using 25 pounds of seed per acre. For a seed crop, with deep cut, dark-green leaves, which are rather fragrant. Makes a stately row along a walk, and is an interesting garden postpaid.

Jersey or Cow Kale. A tall-growing variety having a large bunch of cabbage-like leaves on top of a stout stem. Is much grown
for chicken and cow feed. The green feed from these plants is very great, and is borne continuously. Pkt. $5 \mathrm{c} ; 0 \mathrm{oz} .10 \mathrm{c} ; 1 / 4 \mathbf{1 b}$. $20 \mathrm{c}$; 1b. 60c.

Kaffir Corn. Grows from 6 to 10 feet high and thrives in hot, dry climates. Makes good fodder for cattle, and the seed is used for stock and chicken food. Sown in rows 3 feet apart, using 6 to 8 pounds per acre. Lb. 20c, postpaid.

Milo Maize. A non-saccharine sorghum, useful for the large amount of foliage, green feed or cured fodder that it furnishes and for its grain. Sow in spring, using 6 to 8 lbs. per acre. L b.

Niles Peas. Used principally for green manure. Is a strong, vigorous grower, making long vines and good roots. Sow broadcast,
using 100 to 150 pounds of seed per acre. L b. 20c, postpaid; Larger quantities on application

Paspalum Dilitatum, or Dallis Grass. A new grass for hot, dry climates. A hardy perennial from Australia, growing 5 feet high without getting tough, and seems to be particularly adapted for grazing dairy cattle. It stands drought remarkably well, and shoots rapidly again with the first shower of rain, and is a splendid winter grass. Although it will stand a considerable degree of frost and even snow without harm; still it requires hot summer weather to grow it to perfection. The seed requires about 3 weeks of moist, genial weather to germinate it, but once establish10c; ib. $75 \mathrm{c}$, postpaid.

Rape (Dwarf Essex). A biennial crop, used principally for sheep pasture, of which it yields an abundance of the best quality. pasture, of which it yields an abundance of the best quality. Is usually sown broad

Soja Bean. Valuable as a forage crop or green manure. Also as a green fodder and silo plant. Sow 30 pounds per acre after danger from frost is passed. $\mathbf{I} b .25 c$, postpaid.

Spring Vetches, or Tares (Vicia Sativa). A plant resembling pea vines and valuable for forage or green manure. It is usually sown with oats or wheat to hold them up. Sow 60 pounds per acre with grain, or 80 to 100 pounds if sown alone. Is hardy and makes a fine winter growth. Largely planted in the orange groves of the South for green manure and plowed under in spring. Lb. 20c, postpaid. Larger quantities on application.

Sugar Cane (Sorghum), Early Amber. A good fodder if cut when two feet high. Is nutritious and yields a heavy crop. Sow late in April, using ten pounds seed per acre in drills, or twenty-five pounds broadcast. Lb. 20c; postpaid, larger quantities on application.

"Early Orange. A strong, productive variety, either for fodder or for syrup. Ib. 25c, postpaid; larger quantities on a pplication.

Sunflower (Large Russian). A variety bearing large heads, frequently 12 to 20 inches in diameter and sometimes yielding 1000 pounds of seed per acre. The seed is used for feeding chinckens and parrots. Sow in the open field as soon as danger from frost is over, using 3 pounds of seed per acre, sowing in rows 5 feet
apart and thinning to 1 foot. Lb. 20c, postpaid; 10 lbs. 70c.

Speltz, or Emmer. A valuable grain from Russia. Grown in the United States for several years. It is adapted to a wide range of soil and climate, and is of superior feeding value, yielding much more heavily than oats and barley. This grain grows tall, like rye, and matures as early as barley, and yields from 40 to 80 bushels to the acre, and from 4 to 6 tons of straw hay. Tough and hardy, it stands the drought better than any other grain, making it a sure crop. Prepare your land as you would for wheat or oats, and sow at the rate of 75 or 100 pounds per acre. Sow very early in the Spring or Fall, and do not let it stand until it gets too ripe before cutting as any grain that yields well shell. easily. In the green state it makes an excellent pasture. $\mathbf{L} \mathbf{b}$. 20c, postpaid.

Teosinte (Reana Luxurians). This plant grows quickly and produces a large quantity of forage in warm locations. It makes splendid dry fodder, yielding enormously, and being more nutritious and better relished by all stock than corn fodder. The seed should not be sown until all danger of frost is past. If cut for green forage, which can be done at any stage during growth, two or more joints should be left at the base of the stalk. These will sprout out quickly into fresh growth, making an even larger crop than at first cutting. Sow in drills 4 feet apart, using 4 pounds of seed to an acre. Oz. 10c; 1b. 75c.

Velvet Bean. Used largely as a green-manure plant and also for forage. Grows taller and larger than any other soil plant, being sometimes 30 feet in length. Sow same as Cow Peas, in rows 5 feet apart and in hills 4 feet apart in the row. Lb. 25c, postpaid.

Whippoorwill Peas. This variety is a great favorite in the West and South as a green manure and fodder pea. Is early and grows
upright. Makes a good growth of vine, which can be easily upright. Makes a good growth of vine, which can
cut. Sow same as Cow Peas. Lb. 20c, postpaid.

Wild Rice (Zizania Aquatica). A native plant, growing in shallow water with mud bottom. The seed is difficult to germinate, and should be kept moist several days before sowing. The plant makes an excellent shelter for wild fowl, and is much esteemed on game preserves. Lb. 35c, postpaid. Larger quantities on application.

Owing to frequent market fluctuations on Clover and Field Seeds, we will not list the hundred-pound price, but request that all who are interested in quantities will write us for samples and quotations. We carry all Field Seeds in immense quantities and are able to quote low prices. For snipment by express or freight deduct 10c per pound from the above post-paid prices.

\section{BIRD SEEDS}

Prices do not include postage.

Blue Maw (Blue Poppy). 25c $1 \mathrm{~b}$.

Canary Seed. $10 \mathrm{c}$ lb.; 3 lbs. 25c; $71 \mathrm{bs} .50 \mathrm{c} ; 15$ lbs. $\$ 1.00$.

Corn, Parrot Soft Mexican. Lb. 10c; 4 Ibs. 25c.

Cuttle Fish Bone. 35c Ib.

Hemp. 10c 1b.; 3 lbs. 25c; 6 lbs. 50c.
Millet, Recleaned, 10c 1b. 3 lbs. 25c; 8 Ibs. 50c; 16 lbs. $\$ 1.00$. Mixed Bird Seed. A large per cent of Canary. $10 \mathrm{c} 1 \mathrm{~b} . ; 3$ ibs. Iixed Bird seed. A large per cent

Rape. $10 \mathrm{c}$ lb.; 3 lbs. $25 \mathrm{c} ; 8$ ibs. 50c; 16 lbs. $\$ 1.00$

Sunflower. $10 \mathrm{c}$ 1b.; 3 lbs. $25 \mathrm{c} ; 6$ lbs. $50 \mathrm{c} ; 14 \mathrm{lbs}$. $\$ 1.00$. Mixed Bird seed. Packed in 1-lb. cartons, including Gravel and Cuttlebone, 10c each. 


\section{CALIFORNIA TREE AND SHRUB SEEDS}

The ritalit 5 of tree and shrub seeds cannot be tested before the sale, but only such seeds are sent out as we beliere mill give complete

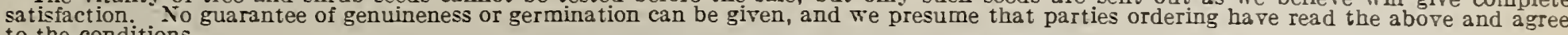
to the conditions.

Price per Packet, 10 cents, except where noted

Abies Douglasil (Douglas Spruce). A very large and important timber tree 200 to 300 feet high; of prramid shape. Found throughout the Rocky Mountains, from Oregon to Mexico. Very hardy. Oz. 30c; (Crop failed).

California Fan Palm (Washingtonia Filifera). Our well-known hardy fan palm with threads on the leaves. The leares hang on after they have died. Oz. 15c; 1b. $\$ 1.50$.

Christmas Berry (Photinia Arbutifolia). A California Evergreen shrub, 10 feet high, bearing clusters of bright red berries. These are gathered for decorations at Christmas time and are familiar to nearly everyone. 0z. 20c; $1 \mathrm{~b}$. $\$ 1.50$.

Cupressus Arizonica (Blue Cypress). A handsome tree with horizontal branches and open head. Forty feet high and very blue in color. Oz. $40 \mathrm{c} ; 1 \mathrm{~b}$. $\$ 4.00$.

“ Goveniana (Goven's Cypress). 30 to 40 feet high; very ornamental; found in the Coast Ranges of Monterey. Oz. 40c; 1b. $\$ 4.00$

Lawsoniana (Lawson's Cypress). A handsome tree. with white fragrant wood. free from knots; easily worked and ervy durable. $0 z .40 \mathrm{c} ; 1 \mathrm{~b}$. $\$ 4.00$.

Macrocarpa (Monterey Cypress). A tree 40 to 60 feet high rough bark; spreading, horizontal branches, rich green foliage; vert ornamental for lawns or parks; also used extensively for hedges. Oz. $15 \mathrm{c} ; 1 \mathrm{~b}$. $\$ 1.50$.

“. Pyramidalls (Itallan Cypress). This variety is of upright prramidal growth, and is much used in cemeteries. $\mathbf{0 z}$. $40 \mathrm{c}$; Ib. $\$ 4.00$.

Grefllea Robusta (Slik Oak of East Australla). Beautiful fernlike foliage; of rapid growth, flowering when about 20 feet in height; covered with bright orange-scarlet flowers. Pkt. 10c; Oz. $50 \mathrm{c} ; 1 \mathrm{~b}, \$ 5.00$.

Libocedrus Decurrens (Thuya Craigiana). A fine, hardy timber tree; known as White Cedar of California. 0z. 40c; Ib. $\$ 4.00$.

Madrone. A beautiful native tree of California. The foliage is a deep green and leathery; it attains a considerable size; flowers white. Plt. 25c.
Manzanita. A low-growing tree or shrub, bearing attractive white blossoms and beautiful red berries. Pkt. 25c.

Picea Grandis (Western Balsam Fir). Grows 200 to 300 feet high, 4 to 6 feet in diameter: grows rapidly in rich, moist soil raluable timber tree. Oz. $40 \mathrm{c} ; 1 \mathrm{~b}$. $\$ 4.00$.

Picea Magnifica. The Red Fir of the Sierras, found at an altitude of 7000 feet; very hardy. Oz. 50c; 1b. $\$ 5.00$.

Date Palm (Phoenix Canariensis). A beautiful, long-leared variety growing to an immense height. 100 seeds for $25 \mathrm{c} ; 1000$ seeds for $\$ 1.50$.

Dracaena Indivisa (Dragon Palm). A handsome palm-like tree used for planting along arenues. The leaves are borne in a head at the top of a branchless stem, eight to fifteen feet high. $\mathbf{O z}$. $35 \mathrm{c} ; 1 \mathrm{~b}$. $\$ 3.50$.

Pepper Tree (Schinus Molle). Well known handsome shade trees, $\pi$ ith feathery leaves and red berries. Oz. 15c; $1 \mathrm{~b} . \$ 1.50$.

Pinus Insignis (Monterey Pine). A very ornamental tree for parks and lawns; grows from 60 to 70 feet high; of rapid growth has beautiful green foliage. $0 z .25 \mathrm{c} ; 1 \mathrm{~b}$. $\$ 2.50$.

Jeffrey1. A magnificent tree, usually found at an elevation of 5000 feet; very hardy. 0z. 35c; Ib. $\$ 3.50$.

Lambertiana (Sugar Pine). A hardy tree of gigantic dimensions; found on both slopes of the Sierras. The finest pine timber tree. Oz. $30 \mathrm{c} ; 1 \mathrm{~b}$. $\$ 3.00$.

Ponderosa (Yellow Pine). One of the largest pines known. Found in Coast Range on the highest points. Very hardy. The most valuable timber variet5. Oz. $303 ; 1$ ib. $\$ 3.00$.

“ Sabiniana (Nut Pine). Abundant over the dry and hot hills of the Coast Range. Very hardy. Oz. 20c; 1b. \$2.00.

Sequoia Gigantea (Wellingtonia Gigantea). The mammoth tree of California. This is the largest tree known to exist on the American continent. (Crop failed).

Sempervirens. Uusally known as California Redwood. The most valuable timber of the California forests. Oz. $40 \mathrm{c} ; 1 \mathrm{~b} . \$ 4.00$.

Wild Cherry. A native California hedge plant resembling holly Oz. $20 \mathrm{c} ; 1 \mathrm{~b}$. $\$ 1.50$.

\section{ACACIA AND EUCALYPTUS TREE SEEDS}

EUCALYPTUS IS THE GREAT COMTNG SOURCE OF TIMBER FOR TEE PACIFIC COAST. OUR BOOKIET ON VARIETIES AND THEIR CULTIVATION WILL BE MAILED FREE ON REQUEST. Price per Packet, 15 cents, except where noted

ACACIA Balleyana. A handsome tree, with glaucous foliage: in great demand for street planting. One of the most beautifu of the Acacias. Oz. $40 \mathrm{c} ; \mathrm{Ib} . \$ 4.00$

Decurrens (The Black Wattle of Australia). In California it has grown over 50 feet in eight years. Oz. $40 \mathrm{c} ; 1 \mathrm{~b}, \$ 4.00$.

Iopantha. One of the rankest growing sorts, makes a bush 15 to 20 feet high with spreading leares. Largely used in Golden Gate Park. Oz. 20c; ib. \$2.00.

" Melanoxylon. In irrigated glens of deep soil this tree will attain the height of 80 feet with a stem sereral feet in diameter. $\mathbf{0 z .}$ $35 \mathrm{c} ; 1 \mathrm{~b} . \$ 3.50$.

Mollissima. A fine, erect, rapid-growing tree, with glaucous green. feathers foliage; flowers Jellow, and borne in racemes Oz. $40 \mathrm{c} ; 1 \mathrm{~b} . \$ 4.00$

EUCALYPTUS Amygdalina (Glant Gum Tree). Is one of the best for subduing malarial effluria in ferer regions, although it does not grow with quite the same ease as the Eucalyptus globulus. Plt. 25c;0z. 75c; 1b. $\$ 7.50$.

Citriodora. The well-known lemon-scented gum; a popular farorite. Pzt. 50c; 0z. \$2.00.

Corynocalyx (Sugar Gum). This rariety will stand more frost $\left(22^{\circ}\right)$ than any other Eucalyptus and will also stand more drought. Quick growing timber variety. Oz. 75c; 1b. \$7.50.

Ficifolia. Vert ornamental for lawn or avenue planting; has beautiful crimson flowers. 50c per packet of 50 seeds.

Globulus (Blue Gum). A very rapid-growing tree, making Faluable timber. The common variet5-the one most generally planted. Oz. $40 \mathrm{c} ; 1 \mathrm{~b} . \$ 4.00$.
EUCAIYPTUS Ieucoxylon (Ironbark Tree). The culture of this variety is desirable on poor, stony land, where other Eucalypt Would be unsatisfactory; flowers are a beautiful cerise pink. Pkt. 15c; 0z. $\$ 1.00$.

Marginata (Jarrah of Western Australla). A very excellent timber. Resists teredo, on which account it is largely used for piles. $0 \mathbf{z} .75 \mathrm{c}$.

* Robusta (Swamp Mahogany). Thrives best on low grounds especially near the sea coast. Oz. 50c; 1b. $\$ 5.00$.

" Rostrata (Red Gum). A rapid-growing tree; stands heat and considerable cold without injury. Imported, oz. $75 \mathrm{c} ; 1 \mathrm{~b} . \$ 7.50$. Domestic, oz. 50c; $1 \mathrm{~b}$. $\$ 4.00$.

“ Stuartiana (Apple-Scented Gum Tree). Seems to do equally Fell on rather dry and sand $y$ as on humid soils. The mood is of a handsome dark color and takes a good polish. Pkt. 15c; oz. $\$ 1.00$.

- Tereticornis (Gray Gum). A very hardy, quick-growing Eucalyptus; largely used for railroad ties. etc. One of the sorts most often planted for timber. $0 z .75 \mathrm{c} ; \mathrm{Ib}$. $\$ 7.50$.

- Viminalis. In poor soil it grows to a moderate height; in rich soil it attains gigantic dimensions. Oz. 50c; 1b. $\$ 5.00$

We import seed of the following desirable rarieties of Eucalspti, and offer at the uniform price of $15 \mathrm{c}$ per packet, $75 \mathrm{c}$ per ounce:
E. Cambagel
E. Hemiphlola.
Polyanthem
E. Coriacea.
E. Melliodora.
E. Resinifera.
E. Crebra.
E. Obllqua.
Gonicalyx.
E. Platyphilla.
E. Rudis.
E. Piperita.
E. Gunnil.
E. Saligna.
E. siderophloia.

See under the head of Eucalypti-in our nursery departmentfor rarieties we can furnish in plants. 


\section{OUR COMMISSION BOX SEEDS}
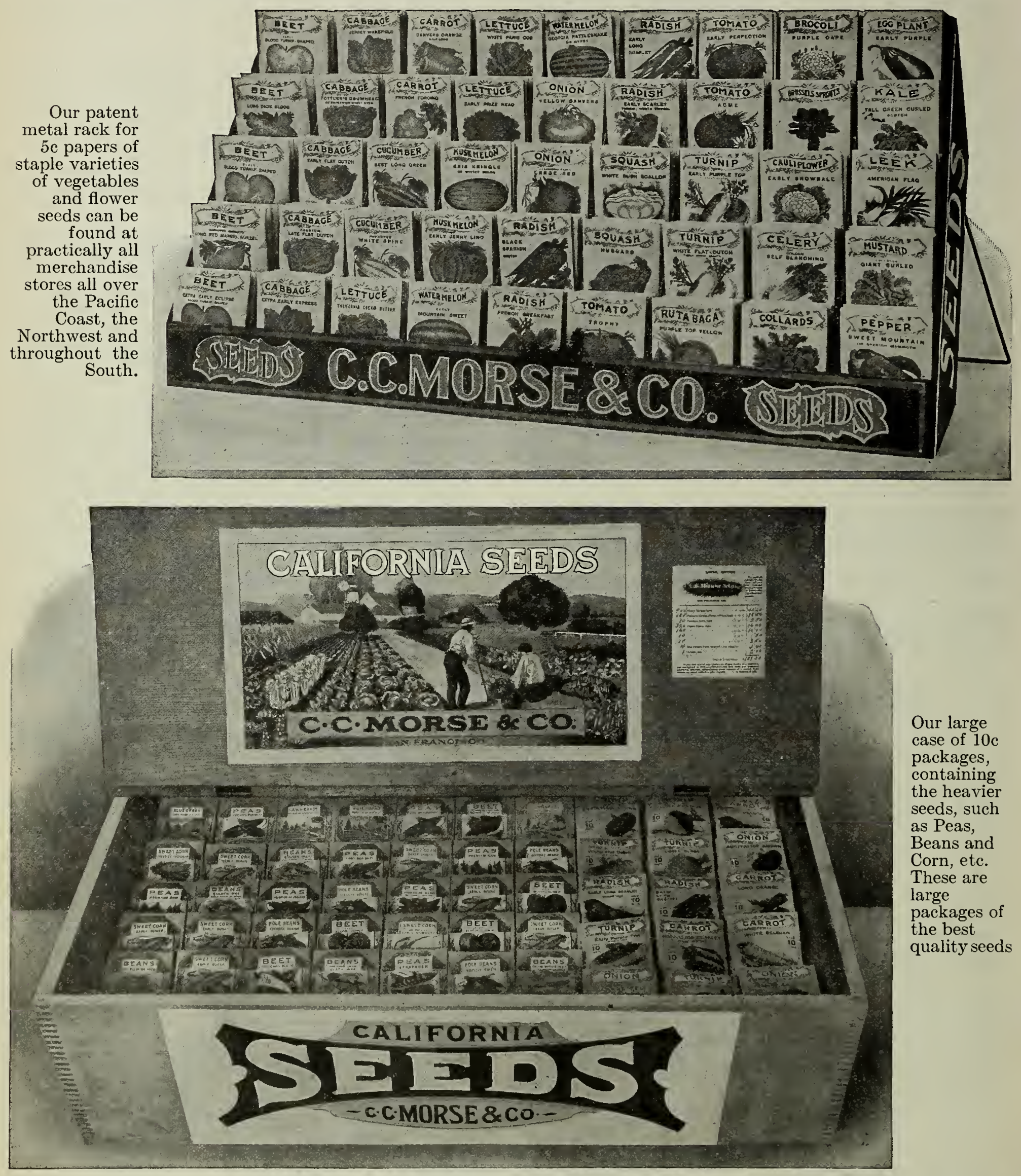

Our large

case of $10 \mathrm{c}$ packages, containing the heavier seeds, such as Peas, Beans and Corn, etc. These are large packages of the best quality seeds

The above pictures are modest photographs of our Commission Box outfit, sent each season togeneral dealers. "Nothing is too good for the Commission Box" is a motto in our establishment.

Only Seed that will grow is put up and there is more seed in our papers and packages than seedsmen usually put up for the money.

Whenever the name C. C. MORSE \& Co., is on the paper or package, the seed inside is sure to be good. 


\title{
CLASSIFICATION OF FLOWERS
}

To enable one to tell at a glance what flowers are suitable for any position, we have classified all the different flowers of which we sell seed, into the following classes.

Perennials are separated from Annuals and Biennials are classed with the Perennials. Plants which will do well in a shady location we have indicated by (s) after the name, and those that will do well in a partially shaded location are indicated by (p s).

We think these lists will be of great service to every careful planter.

\section{SEED OF GREENHOUSE PIANTS}

Asparagus Fern (s)

Auricula

Begonia, Rex

Tuberous (ps)

Calceolaria (ps)

Cineraria (s)

Coleus

\section{BEDDING PLANTS, PERENNIAL}

From 1 to 2 Feet High

Achillea

Agrostema

Asperula Odorata

Begonia, Vernon

Begonia, Ternon

Calceolaria Rugosa (ps)

Candytuft, Perennial

Carnation

Cineraria (s)

Columbine

Daisy, Shasta

Gaillardia

Glaucum Luteum

Linum, Blue Flax

Lychnis

Matricaria

Mimulus

Pentstemon

Salvia

Stevia Perpetual

Stocks, Perpetual

Sweet Will

Vinca, or Madagascar Periwinkle

Viola (s)

Violet (s)

Wallflower (ps)

\section{ANNUAL BEDDING PLANTS}

or Tall Border Plants

1 to 2 Feet

Adonis

Ageratum, Tall

Amaranthus

Aster

Balsam

Bartonia Aurea

Browallia (s)

Cacalia

Calendula

Candytuft

Celosia

Centaurea

Centranthus

Chrysanthemum

Clarkia

Clarkia

Daffodils (see Fall Bulb Cata-

logue) (ps)

Dianthus

Forget-Me-Not (s)

Four O'clock

Gaillardia

Gilia

Godetia (ps)

Gypsophila (for bouquets)

Grasses, Ornamental

Hunnemannia, or Bush Eschscholtzia

Whitlavia
Zinnia

See page 109 for miscellaneous bedding plants, etc.

\section{TALI GROWING SHRUB PLANTS, PERENNIAL} For Grouping ; from $2 \frac{1}{2}$ Feet Up

\section{Abutilon}

Aster, Michaelmas

Canna (s)

Canterbury Bell (s)

Chrysanthemum, White and

Yellow Marguerite (ps)

Columbine

Coreopsis

Dahlia (s)

Delphinium

Digitalis

Fuchsia (s)

Geranium

Gladiolus

Golden Rod

Grasses, Pampas, etc.

Helenium

Hollyhock

Hibiscus

Linum, Scarlet Flax
Sweet Rocket or Hesperis

Wallflower (ps)

TALL GROWING PLANTS FOR GROUPING, ANNUAL From $21 / 2$ Feet $0 p$

Amaranthus
Arctotis Grandis
Calliopsis
Castor Oil Bean
Cleome Pungens
Cosmos
Euphorbia
Honesty

Calliopsis

Castor Oil Bean

Cosmos

Honesty

\author{
Kochia Tricophylla \\ Larkspur \\ Lilies (ps) \\ Nicotiana \\ Rudbeckia \\ Salpiglosis \\ Scabiosa Grandiflora \\ Sunflower
}

LOW EDGING PLANTS, ANNUAL

6 to 12 inches $\mathrm{High}$

Ageratum, Dwarf

Bulbs of All Sorts (see Special Fall Catalogue)

Brachycome

Candytuf

Celosia, Dwar

Centaurea, Dusty Miller

Dianthus

\section{LOW EDGING PLANTS, PERENNIA}

6 to 12 Inches High

Feverfew, or Pyrethrum Gypsophila

Lobelia Compacta (very good)

Mignonette (s)

Nemophila

Pansy (ps)

Sweet Peas, Cupids
Alyssum Saxatile

Armeria Maritima (ps)

Border Pinks

Calandrinia

Daisy, English

Carnation, Vienna

Edelweiss

Forget-Me-Not (s) logue)

Leptosyne Maritima

Lupins

Mignonettes

Morning Glory, Dwarf

Nasturtiums, Dwarf

Nigella, or Love-in-a-Mist

Pansy (ps)

Perilla Nankinensis

Petunia

Poppy

Pyrethrum Grandiflorum

Scabiosa, Dwarf

Silene, or Catchfly

Snapdragon, Dwarf

Statice

Stock, Ten Weeks

Tulips (see Fall Bulb Catalogue)

Virginia Stock (s)

Viscaria

ROCKERIES, EANGING BASKETS, OR WINDOW BOXES

Abronia (Rockery)

Asparagus Fern (s)

Forget-Me-Not

Ice Plant (Rockery)

Kenilworth Ivy (s)

Lippia Repens

Lobelia, Trailing

Maurandia (s)

Mimulus

\author{
Lippia Repens \\ Oxalis \\ Poppy, Iceland \\ Primula, Vulgaris and P. Poly- \\ anthus (s) \\ Pyrethrum \\ Pyrethrum \\ Viola (ps)
}

Nasturtium

Oxalis (s)

Portulaca (Rockery)

Sanvitalia (Rockery)

Sedum (Rockery)

Thumbergia

Torenia

Verbena (ps)

EVERLASTING FLOWERS

Acroclinium

Gomphrena

Helichrysum

Rhodanthe

Statice

Xeranthemum

CLIMBING VINES, ANNUAI

7 to 25 Feet

Balloon Vine

Scarlet Runner Bean

Calampelis

Canary Bird Vine

Cobea Scandens

Cypress Vine

Convolvulus

Dolichos, or Hyacinth Bean

Echinocystis (Wild Cucumber

Vine)

\section{CLIMBING VINES, PERENNIAL}

\section{7 to 25 Feet}

Adlumia Cirrhosa, or Mountain Fringe

Aristolochia Sipho, Dutchman's Pipe

Australian Pea Vine

Bignonia

Boston Ivy

Centrosem

Clematis

Clianthus Diampieri

Gourds, Ornamental

Ipomea, all kinds

Mina Lobata

Homordica, or Balsam Apple

Moonflower

Morning Glory

Nasturtium, Tall

Sweet Peas

Heliotrope
Humulus, or Japanese Hop Kennedya

Lathyrus Latifolius

Lantana

Lophospermum

Mandevilla Suaveolens

Passion Vine

Solanum Seaforthianum

Smilax

Snail Vine

Virginia Creeper 

or special new varieties which they think will improve the garden and add either to the quality or productiveness of the crop, or to the pleasure of the flower-lover.

This year we have done mole than usual for the flower garden, but in a somewhat different way: First, we have procured and offered more than twenty of the very finest new Gladioli IVe urge you most strongly to try some of these new named sorts, as we know they are wonderfully handsome, and very easily grown. Secondly, we have added to our flower seed and included among our general list more than seventy new varieties of flowers and climbing vines. For these we refer you to the following pages where the varieties are described, and mention here only a few in passing-Boston Ivy, Wistaria, Anemones, Carnations and Columbines.

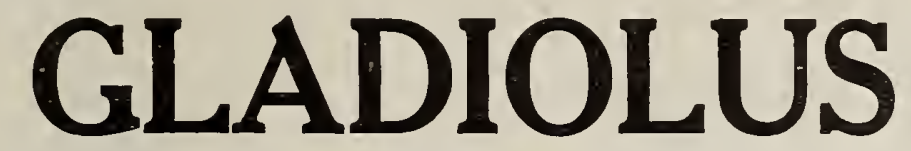

There are a number of very fine sorts of Gladioli which are the result of crossing and selecting done by horticulturists, both in America and Europe. These newer sorts have never been adequately presented to western flower lovers, and are therefore comparatively unknown.

The newer sorts which we offer below, however, are very handsome, and are away ahead. of any of the older types. The Childsii and the "hybrids" of Childsii in particular, have very fine flower spikes crowded with bloom; often the spikes are four feet and over tall, and the blossoms are always large.

The culture of the Gladiolus is of the easiest. Set the bulbs about 3 inches deep and 7 or 8 inches apart each way. Any good garden soil will make strong plants and good bloom, but for the finest results use manure and plenty of water. After the flowers are past, dig the bulbs up and dry them under cover in the open air for a month and then store in dry soil till next winter, when they may be reset. From January to April are the months in which to plant Gladioli, but for a succession of flowers they may be started to the middle of June.

It may be that the comparative high prices of these fine new sorts have kept them from being offered here before, but we believe that when the planter realizes that they are worth the price, and comes to know what grand flowers they are, our stock will soon go, with the result that many gardens will be made beautiful.

Gladioli do well in San Francisco, standing against the cold Summer winds, and blossoming most freely for weeks.

(If wanted by mail, add 8c per dozen for postage.)

\section{GIANT CHILDSII GLADIOLI}

This class is very tall and erect, often four or five feet high, with spikes of bloom over two feet long. The flowers are of great substance and of gigantic size, frequently seven to nine inches across, and with a great variety of colors.

America. A very popular sort and most deservedly so. The flowers are a soft lavender pink, or a light flesh pink, with a lavender tint; the blossoms all face one way and are very large. Each 10c; doz. \$1.00.

Attraction. A deep, rich, dark crimson, with conspicuous pure white center and throat. Each 10c; doz. \$1.00.

Blanche. Pure white, with faint markings. A large flower. Each 20c; doz. $\$ 2.00$.

Brilliant. Beautiful orange red with carmine and white throat. A very fine scarlet. Each 10c; doz. $\$ 1.00$.

Columbia. Light orange-scarlet, freely blotched and penciled with bluishpurple, especially at throat. Each $10 \mathrm{c}$; doz. $\$ 1.00$.

Deborah. Dark red, tinged with amaranth. Each 10c; doz. $\$ 1.00$.

Dr. Sellew. Large spike of rich rosy crimson, slightly penciled darker; center of petals and throat rayed white. Each 10c; doz. $\$ 1.00$.

Henry Gillman. Deep salmon scarlet, with pure white bands through each petal. Each 10c; doz. $\$ 1.00$

Nezinscott. Blood-scarlet with deep velvety crimson black blotched and white mottlings in throat. Each 20 c; doz. $\$ 1.75$.

Oddity. Deep amaranth red, throat mottled white and red. Each 10c; doz. $\$ 1.00$.

Rose Spray. A large and extra fine white beautifully sprayed with rose tint. Each 20c; doz. \$2.00.

Sunlight. Light crimson with canaryyellow throat. Each 10c; doz. $\$ 1.00$.

Wm. Falconer. Spike of great length and spike of enormous flowers. Beautiful clear light pink. Each 15c; doz. $\$ 1.50$.

Collection of 1 of each of 13 above sorts for $\$ 1.30$.

\section{GANDAVENSIS AND HYBRID GLADIOLI}

The following are the newer varieties and are the best sorts.

Augusta. Lovely pure white, with blue Canary Bird. Fine light yellow, with a anthers. Strong straight spike. Each 7c; doz. 75c.

Blue Jay (Baron Hulot). The finest blue gladiolus yet produced. Blue Jay is a rich deep indigo color. Each $20 \mathrm{c}$; doz. $\$ 2.00$. strong spike. Fach $15 \mathrm{c}$; doz. $\$ 1.50$

Ceres. Pure white, spotted with purplish rose. Each 7c; doz. $75 \mathrm{c}$.

Klondyke. Clear primrose yellow, with a blotch of vivid crimson maroon on the lower petals. Strong plants. Each 10c; doz. $\$ 1.00$.

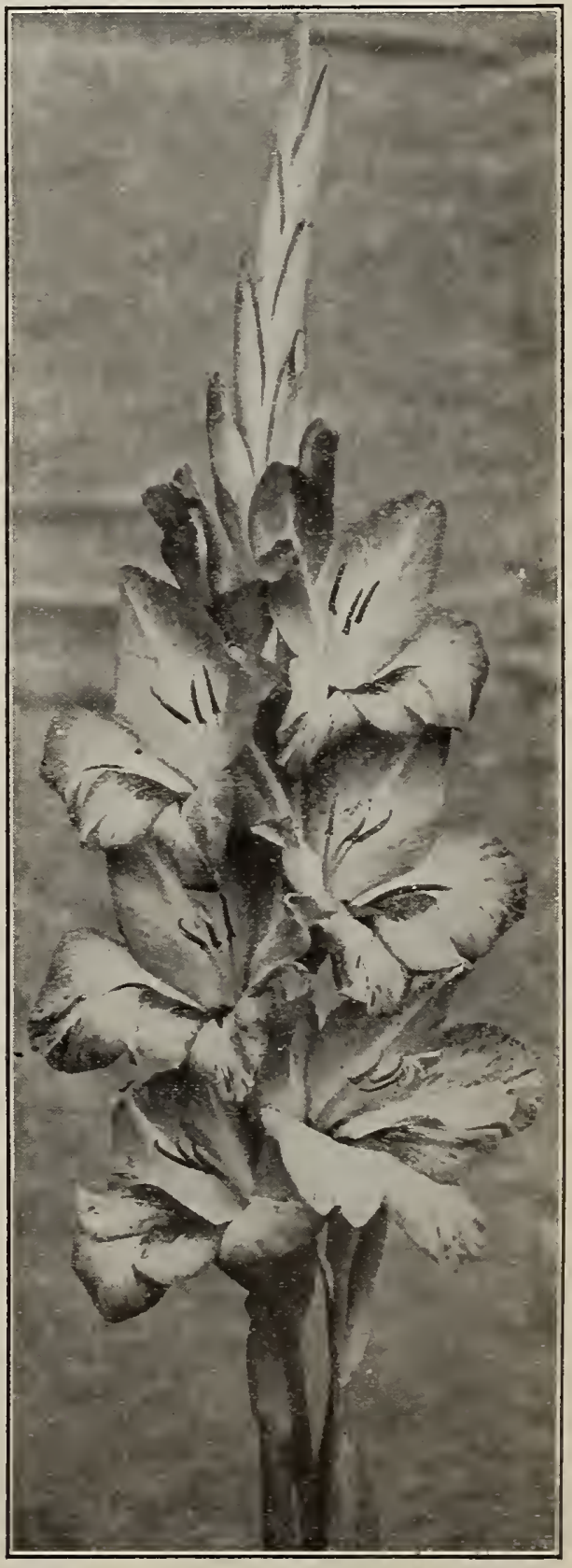

Gladiolus-"Brilliant" 


\section{NAMED GLADIOLI-Continued}

May. A lovely pure white flower, finely flaked with bright rosy crimson. Superb spike and often forced. Each 7c; doz. $75 \mathrm{c}$.

Mrs. Francis King. A lovely light scarlet; the flowers are unusually well arranged. Each 15c; doz. $\$ 1.50$.

Octoroon. A beautiful salmon pink; distinct shade. Each 10c; doz. $\$ 1.00$.

Princeps. A large wide-open, very handsome flower like an amaryllis. A rich crimson with broad white blotches across the lower petal. Each 20c; doz. \$2.00.

Sulphur King. Beautiful clear sulphur-yellow, the finest yellow ever introduced. Each 30c; doz. $\$ 3.00$.

Collection 1 of each of above 10 varieties for $\$ 1.15$.

\section{MIXED GLADIOLI}

These have the various types and colors separated and while not so fine as our named sorts offered above, still they have a great variety

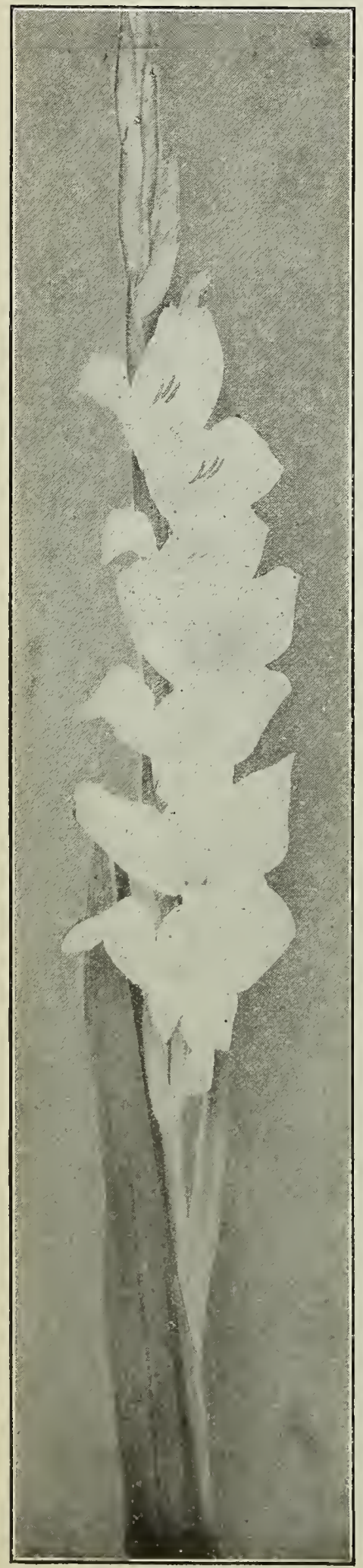

Sulphur King Gladiolus from seedlings.

Bxtra White and Very Light Shades Mixed. Doz. 50c; per 100, $\$ 3.50$.

Pink and Rose Shades Mixed. Doz. 50c; per 100, $\$ 3.50$.

Brilliant Scarlet and Red Shades Mixed. Doz. 50c; per $100, \$ 3.50$.

Orange and Yellow Shades Mixed. Doz. $\$ 1.00$; per $100, \$ 6.50$.

Striped and Variegated. Doz. 50c; per 100 $\$ 3.50$.

Lemoines Extra Fine Mixed. One of the best strains, with bright colorings and odd markings. Doz. 50c; per 100, $\$ 3.00$.

Groff's Hybrid Seedlings. Apt to contain some great novelty. Doz. 50c; per 100, $\$ 3.00$.

Childsii Type Mixed. Large flowers, soft and wavy on the edges. Doz. 60c; per $100, \$ 4.00$.

Childsii Lighter Shades. A lighter and better mixture. Doz. 75 c; per $100, \$ 5.00$.

\section{LILIES}

Plant six inches deep in a well-drained varieties consult our Fall Catalogue of Bulbs, issued in October.

The bulbs are ready for delivery in December, January, and February, but not later. If wanted by mail, add $3 \mathrm{c}$ each, 25c per dozen, for postage.

AURATUM. The grandest of all hardy Lilies, with large, graceful flowers of a delicate ivory-white color, thickly studded with chocolate crimson spots, and a bright golden band through the center of each petal. The largest Lily there is, ten inches across, and very fragrant. Each $15 \mathrm{c}$ and $20 \mathrm{c}$; doz. $\$ 1.25$ $\$ 2.00$, according to size of bulb.

Easter Lily, or Longiflorum. While if planted as late as January these will not be in bloom for Easter day, still they will bloom in the middle of Summer out of doors, and are most attractive in a garden. Watch for plant-lice on the unexpanded buds and treat with tobacco solution or tobacco dust (consult our list of insecticides at end of book). $15 \mathrm{c}$ and $20 \mathrm{c}$ each; $\$ 1.50$ and $\$ 2.00$ per dozen, according to size.

Speciosum Album. Beautiful pure white flowers of large size; petals recurve. Very easily grown and very handsome. The price is less than last year's. 15c each; $\$ 1.50$ per dozen. soil, preferably in a cool spot. For other

\section{LIIIES-Continued}

Speciosum Rubrum. This is the tall, light red Lily often seen in florists' windows. It is perfectly hardy in the open garden and is a strong and vigorous grower. Plant in well-drained soil in a partially shaded place. The Lily blooms in July and August, having a spike three to four feet tall with bright lilies of a light crimson and white color; the petals recurve. $15 \mathrm{c}$ each; $\$ 1.25$ per dozen.

Speciosum Rubrum Magnificum. This variety is much more crimson in color than the ordinary Rubrum and is heavily spotted. $15 \mathrm{c}$ each; $\$ 1.25$ per dozen.

Tigrinum (Tiger Lily). Fine showy blossoms, brilliant orange-red, spotted with black; three to five feet high, and blooms in August. The Tiger Lily is one of the best for out of doors, for it is perfectly hardy and will last for years in the garden, each year sending up its black and orange flower spike. 15c each; $\$ 1.25$ per dozen.

\section{BEGONIAS (Tuberous-Rooted)}

For January and February delivery. Splendid pot plants, and equally useful for bedding purposes; very free flowering, doing best with partial shade. (Prices include postage)

We offer Begonias in the following separate colors. Dark Rose, light pink, salmon, scarlet, white and yellow.

Double: all colors separate or mixed. 15c each; $\$ 1.50$ per doz.

Single: all colors separate or mixed. 10c each; $\$ 1.00$ per doz.

Begonia Crispa: a new sort with very large single flowers beautifully frilled on edge and crested. per doz.

\section{TUBEROSES}

For early flowers they can be started in February or March in the greenhouse or hot-bed; and for a succession they can be planted at intervals as late as August. For flowering in the open border plant about the middle of May.

Excelsior Double Pearl. Extra large bulbs. 3 for $15 \mathrm{c}$; doz. $40 \mathrm{c} ; 100, \$ 300$. If wanted by mail, add $12 \mathrm{c}$ per dozen extra.

\section{THE YELLOW CALLA LILY (CALLA ELLIOTtIANA)}

Is the only true yellow flowered calla in existence and on account of its marvelous beauty has created and on account of its marvelous beauty has created a sensation wherever exhibited. It is a summer flowering variety, with the same Cabit of growth as the we same size and shape, but of a clear, rich, of the same size and shape, but of a clear, rich,
golden yeilow. The foliage is dark green, with a golden yeilow. The foliage is dark green, with a number of white spots, which greatly add to the beauty of the plant-so much so that when not in flower the plant at once arrests the attention and is ever an object of enthusiastic admiration. $25 \mathrm{c}$ and $35 \mathrm{c} \mathrm{each}$. Crop falled.

\section{BULBS}

Besides the above we have usually in stock during December and January bulbs of Caladiums ( $\$ 1.00$ doz.): Cyclamen (\$2.00 doz.); Scarlet Freesias doz.); Cyclamen (\$2.00 doz.); Scarlet Freesias Valley (70c per 25): Montbretia (25c per doz.): and Spireas $(25 \mathrm{c}, 35 \mathrm{c}$ and $50 \mathrm{c}$ each).

OUR FALI CATALOGUE OF BULBS, issued ach October fully describes and lists these and many other bulbs. Ask to have this catalogue sent to you in the Fall. 


\section{FLOWER SEEDS}

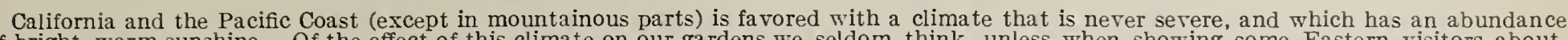

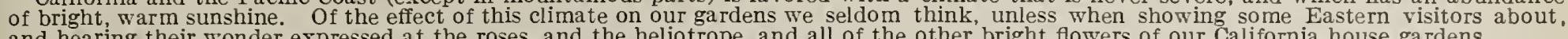
and hearing their wonder expressed at the roses, and the heliotrope, and all of the other bright flowers of our California house gardens.

With a little care one may easily make a selection of plants, seeds and bulbs that will make it possible to always have plants in bloom,

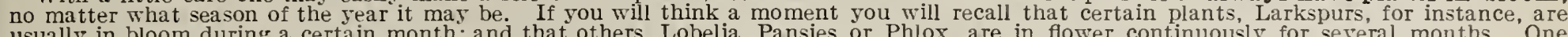

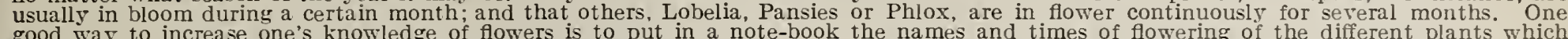

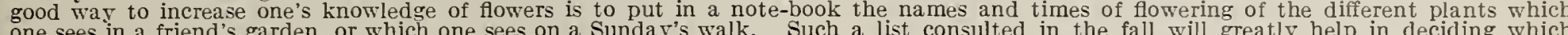
one sees in a friend's garden, or which one sees on a sunday's walk.

seed to sow. Any flowers we will gladly identify if we are able.

SELECTION. A perfect garden could not be made from seed alone; the grounds must hare some shrubbery for its permanent character.

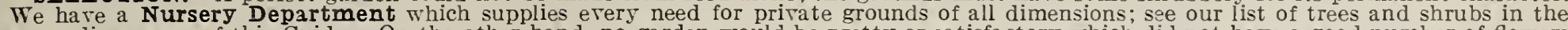

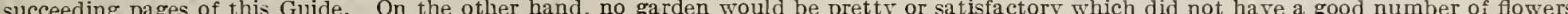
from our flower seed list most carefully chosen and placed in the garden.

There are no more satisfactory flowers than those grown from seed, especially the easily grown and brilliant flowered annuals. The beau-

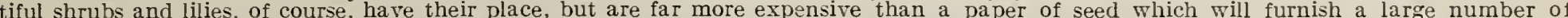
plants with usually enough for one's garden and some to spare.

Aim to hare rour garden one artistic unit, with some flowers in bloom at all seasons, with colors which harmonize, and with plants in

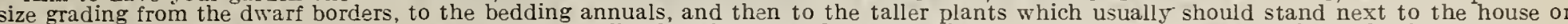
other confines of the garden or lawn. A garden carefully thought out and planned gives very much more pleasure than a haphazard one.

To help in finding the most suitable plants we hare classified all of the flowers of which we offer seed into different lists. We hope these ists will be helpful to you and full of suggestions. These tables on the page preceding are well worth consulting.

WHEN TO PLANT FIOWER SEED. There is doubt with many as to the best time to plant the different flower seed. It is to be

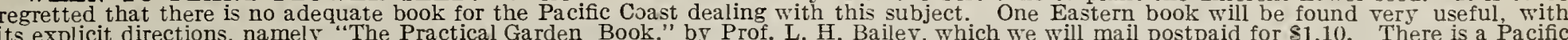

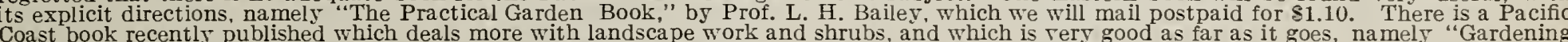

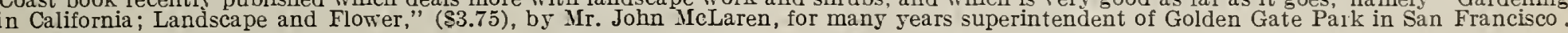

Perhaps you have noticed that many of the descriptions of flowers contain the words "annual," "hardy annual," "tender annual," "perennial," "tender perennial," etc. These may have seemed to you tiresome descriptions, but properly understood they tell much about planting. The dates in the following brackets will vary with the time that heavy frosts come in different places. While they show the best months for San Francisco, planting may be extended much later in all cases.

TENDER, or Greenhouse, means the plant will not stand the least frost. All such must be planted late in Spring (May) or in a greenhouse.

HALF HARDY means the plant will stand any light frost, but needs protection against very cold weather. These should be planted in the spring (March and April), not in the Fall.

HARDY means the plant will stand considerable frost, or practically all we have on the Pacific Coast. These may be planted in the fall or in the spring (October to May). If sown in the fall they will come into bloom earlier than if sown in spring, even if the plants do not make much progress during the cold weather.

ANNUALS are plants that bloom the first year from seed, and the plant dies after one season. Tender annuals must be sown in spring (April to June) and hardy annuals may be sown in either spring or fall (October to May).

BIENNIALS are plants that bloom the second year from seed, and the plant dies after the second year. In California many of these will bloom the first year if sown early. Sow under same conditions as perennials.

PERENNIALS are plants that bloom the second year from seed, and the plant lives and blooms during successive years. If sown in early spring (February to April 15) many perennials will bloom the first year from seed. Tender and half-hardy perennials are best sown in spring after frost is over (April 15 to June). Hardy perennials are best sown in the late summer and early fall (July to October) for next year's flowers.

HOW TO SOW FLOWER SEED. It is best in practically all instances except hardy annuals to start the seed in boxes, preferably a

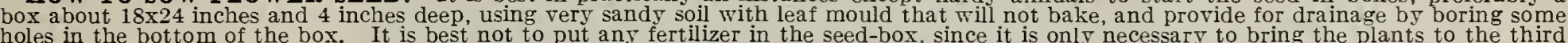

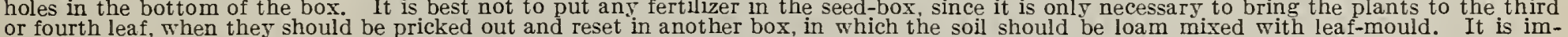
portant that the plant be of good size, strong and sturdy, when finally transplanted in the garden.

If the seed be sown directly in the garden, it should be sown in the spring after the soil is well worked and fertilized. A slight depression

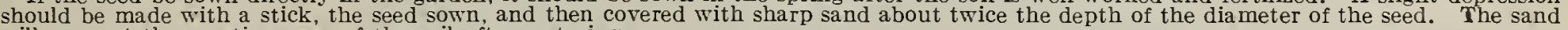
will prevent the crusting over of the soil after watering.

When up, the plants must be thinned from two to twelre inches, depending on the rariety, otherwise they will be weak and spindling. It is a common mistake in the garden to leare plants altogether too thick. Always keep the weeds out.

A common mistake in sowing flower, as well as other seeds, is covering too deep. As a general rule, cover only to the depth of the thickness of the seeds; or, with medium-sized seeds, like Balsams, Zinnias, etc., half an inch or less is the proper depth. Such fine seeds as Portulacas, Nicotiana, etc., need only to be pressed into the soil with a piece of board or the palm of the hand. Always press the earth down firmly after sowing all flower seeds, else there is danger of their drying up before the roots can get firm hold of the soil. Seeds of the hardier annuals may be sown where they are to grow; but, as a rule, it is preferable to transplant, as the plants are generally stronger and stand the drought better. During very dry weather, and when the seedlings are first set out, they should be watered frequently. Provide some support for all such annuals as require it.

The weeds should be kept down and the ground loosened often, so that the plants will receive the full benefit of the rains and dews, which they will not if the ground is allowed to become hard and baked.

On account of the long dry summers in California, it is necessary to apply water very often. Most of our gardens suffer for want of sufficient water. Where possible, it should be applied to the roots only, and after four o'clock in the afternoon.

With a little study of the garden and the colors and habits of the flowers, a beautiful garden can be had fram the use of Morse's Flower Seeds at very little cost. 


\section{C.C.MORSE \& CO. FLOWER SEEDS}

\section{HOT-BEDS}

Good hot-beds may be made by digging down about three feet and filling the excavation with rather fresh horse manure in which there is a good deal of bedding straw. About 18 inches of this manure is sufficient and then fill in on top of it with about one foot of good soil mixed with sand. This manure pile will be compressed, and will soon begin to ferment, and will then keep the top soil warm and cause the seed to sprout quickly, and the young plant will grow very fast. It is best to enclose the hot-bed with boards, making what is called a cold-frame this is done by running the length of the bed east and west and by making the north side about two feet high and the south side not more than six inches. The ends also should be enclosed and a sash of glass should be hung on hinges at the highest end This sash should be raised for ventilation during most of the day, since the bed gets very warm and the atmosphere very close if kept too tightly closed for too long a time. As the plants grow, the sash should be left up longer each day to harden them and prepare them for final transplanting.

The hot-bed should have a very sunny location near a hedge or some building, well protected from the prevailing wind.

The object of the cold-frame is to make an artificial heat, and to protect the plants from frost during winter. Seed may be started any time during the winter, and plants can be ready to set out just as soon as danger of frost is over

As the sun gets too hot it is necessary to shade the bed, and the glass should be white-washed or covered with sacking if necessary. Too much heat is fatal to the tender, young plants.

\section{FLOWER SEED LIST}

ABRONIA (Sand Verbena). A hardy annual, trailing in habit, about nine inches high bearing verbena-like clusters of flowers, about nine inches high, bearing verbena-like clusters of fowers, situations, and is valuable for rock-work or hanging baskets. Umbellata. Rosy lilac. Pkt. 5c; oz. 50c.

AB UTILON (Flowering Maple, or Chinese Bell-Flower). A half-hardy perennial shrub, used generally in greenhouses, but growing into small trees in California. The flowers are beautifully bell-shaped and appear in white, yellow, rose and orange. Mixed colors, pkt. $10 \mathrm{c}$.
ACHILleA Ptarmica, Double, "The Pearl." (Sneezewort). One of the best hardy perennials; bears a profusion of small. double, white flowers during the entire season. Fine for cutting and cemetery decoration. Height $2 \frac{1}{2}$ feet. Pkt. 15c.

ACROCLINIUM. Very pretty annual, producing white and rosecolored daisy-like flowers in August and September. These are the "Immortelles," so desirable for wreaths and Winter bouquets. One foot. Double mixed, pkt. 5c. Single mixed, pkt. 5c.

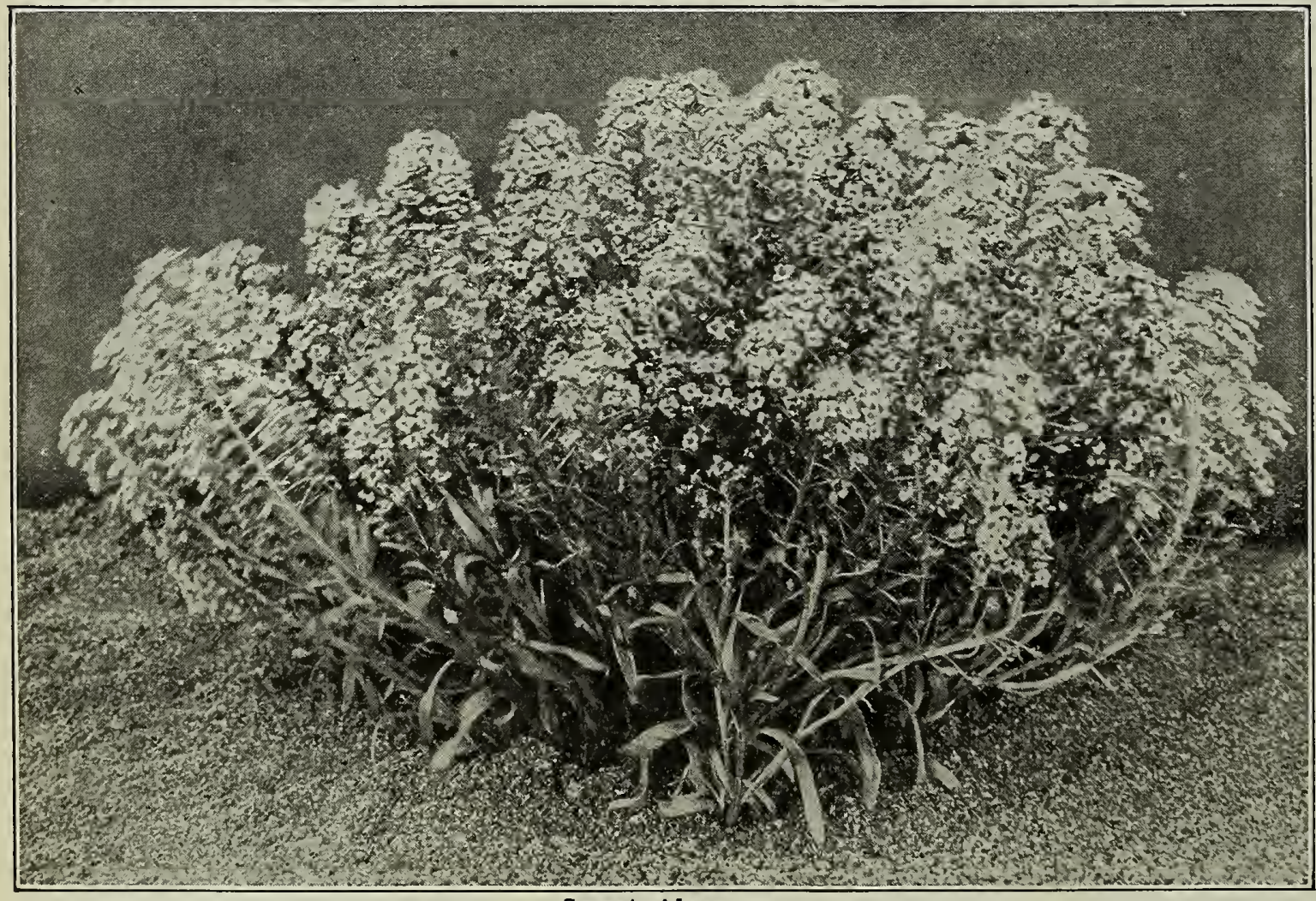

Sweet Alyssum
ADLUMIA CIR R HOS A (IMountain Fringe, or Allegheny vine), An attractive and beautiful hardy climber, biennial flowering the first season clusters of small rosy-lilac flowers and pale green feathery and pale green fifteen feet tall. Pkt. 10c.

ADONIS (Flos Adonis, or Pheasant's Eye). A hardy annual of easy culture, growing about one foot high. Leaves fine-cut and feathery; flowers crimand feathery; howers crimin the Autumn. Pkt. 5c.

\section{A G E R A T M (Floss} Flower). A hardy annual of easy culture, especially valuable for bedding, as it is literally covered with blossoms all summer. Sow the seed early in the spring, either in boxes to transplant, or out of doors, and thin to four or six inches.

Blue Perfection. Deep blue, one foot high. Pkt. 5c.
ALYSSUM (Maritimum). A fragrant, hardy annual, having the odor of honey, and bearing spikes of small, white flowers in great profusion throughout the summer and autumn. Useful for borders or early bedding flowers. Sow the seed early in spring.

Common Sweet Alyssum. One foot high, very sweet honey fragrance. Pkt. 5c; oz. 25c.

"Carpet of Snow." Pure white, very dwarf, and sweet scented. Pkt. 5c.

Little Gem. Three to four inches high; fine for borders. Pkt. 5c; 0z. 50c.

Saxatile. A yellowish perennial variety. Pkt. 5c; oz. 50c.
Mexicanum, Imperial Dwarf Blue. Eight inches high, flowers blue. Pkt. 5c; 0z. 40c.

Mexicanum, Imperial Dwarf White. Eight inches high, flowers white. Pkt. $5 \mathrm{c} ; \frac{1}{2}$ oz. 30c.

Little Dorrit. A perfect mass of blue flowers; plant is six inches high and a foot through. Pkt. 10c.

"Little Blue Star." A very dwarf variety, densely covered with small, light-blue flowers, which are purplish-red at center. Pkt. 15c. 
AGROSTEMA (Rose of Heaven). A hardy perennial, blooming the first season if the seed is sown in the Autumn. Plant grows the to and are borne on long, slender stems. Mixed colors, pkt. 5c.

AMARANTHUS. Hardy annuals, grown especially for their brilliant foliage.

Caudatus (Love Lies Bleeding). Light yellowish-green foliage; long, drooping, crimson flower spikes. Plant three to four feet high. Pkt. 5c.

Cruentus. Tall spikes of red flowers. Three feet. Pkt. 5c. Tricolor (Joseph's Coat). Plant three feet high with brilliant leaves in variegated red, yellow, green etc. Pkt. 5c.

Ampelopsis Quinquefolia. See Virginia Creeper.

Ampelopsis Veitchi. See Boston Iry.

Angel's Trumpet. See Datura.

Antirrhinum. See Snapdragon.

Aquilegia. See Columbine.
ANEMONE, Single Giant de Caen. The giant French Anemone. Half-hardy perennial. Excellent for cutting. Cup-shaped flowers in blue, red, and white. May and June. Nine inches. Pkt. 5c; $1 / 4$ oz. 50c.

St. Brigid (Irish Anemone). Enormous blooms the size of tulips, with great variety of striking colors. Pkt. $15 \mathrm{c} ; 1 / 80 \mathrm{z} . \$ 1$.

ARCTOTIS GRANDIS (The African Lilac Daisy). A remarkably handsome annual from Africa, forming branched bushes two to two and a half feet in height and breadth; are pure white on the upper surface, reverse of petals pale lilac. Pkt. 10c.

ARISTOLOCHIA SIPHO.(Dutchman's Pipe). Strong-growing hardy climber, with large, thick, shining foliage, and curious, yellowish-brown, pipe-shaped flowers. Pkt. 10c.

\section{ASTERS}

A popular half-hardy annual produced in a great variety of classes and an almost endless number of colors. The tallest varieties grow about two feet high, and some varieties of dwarfs are not over three inches high. The best method of culture is to sow the seed in boxes about January 1st, and transplant about April 1st to 15th. The seed can be sown, however, in the row where the plants are to remain thinning them from six to twelve inches apart, according to variety.

BOLTZE'S DWARF BOUQUET. An exceedingly dwarf variety, growing only three or four inches high, and containing a great variety of colors. Pkt. $15 \mathrm{c}$.

COCARDEAU, OR CROWN. A tall variety, growing 14 to 16 inches high. Of upright habit, with medium-sized blossoms. The center of the blossom is usually white with a bright-colored outer rim. Mixed, pkt. 10c.

COMET, A good bedding variety, with large blossoms, the petals of which are long, narrow, and curled backward. These colors are the best: Pink, Light Blue, Pure Lllac, Carmine, white. Pkt. 10c. Mixture of all colors, pkt. 10c. Collection five varieties, $40 c$.

GIANT COMET. A taller growing variety of the Comet type, with branching stems, which make it valuable for cutting. west colors: Crimson, Dark Violet, Light Blue, Rose, White, The Bride (white changing to light rose). Pkt. 10c. Collection six varieties, 50c. Mixture of all colors, pkt. $10 \mathrm{c}$.

HOHENZOLLERN. A new variety of the Comet type, with blossoms fully twice as large as the old variety. The petals are very long and curved like a flat chrysanthemum. Plant of branching habit, about sixteen inches high. Mixture, pkt. 15c.

TRUFFAUT'S PAEONY FLOWERED PERFECTION. This variety has the most brilliant and showy assortment of colors. Flowers, medium sized and almost globular. Plant about sixteen inches high, of upright growth, and flowers all borne on top.
Best colors: Dark Purple, Fiery scarlet, white. Pkt. 10c. Mixture of all colors, pkt. 10c.

VICTORIA. One of the best bedding varieties, with medium-sized blossoms, which are borne in great profusion from the bottom to the top of the plant. Grows 12 to 14 inches high. Best colors: ROSE, pkt. 10c; SNOW WHITE, pkt. 10c. Mixture of all colors, pkt. 10c; oz. $\$ 2.50$.

SEMPLES, OR GIANT BRANCHING. The tallest and best florist's variety, and we heartily recommend it as the very best type of Aster we have. The plant grows 18 inches high and about 18 inches in width, and the blossoms, which are large and full-petaled, are borne on long stems or branches. The most satisfactory type of all Asters, since it is not only a showy bedding flower, but owing to its long stems and large blossoms, is valuable for bouquets. Comes into flower late in the Autumn. Best colors:

$\begin{array}{ll}\text { Carmine } & \text { Crimson } \\ \text { Lavender } & \text { Light Blue } \\ \text { Pink or Rose } & \text { Purple } \\ \text { White } & \text { Viary Semple (very light pink) } \\ \text { Violet King. } & \end{array}$

Pkt. 10c; 0z. \$1.50. Collection nine varieties, 70c. Mixture of above colors, pkt. $10 \mathrm{c} ; 0 z$. $\$ 1.25$.

OSTRICH PLUME. A medium tall variety of the Comet type. The petals are long, narrow and curly, and the effect of both individual blossoms and bunches is beautiful. Mixture of all colors, pkt. 10c.

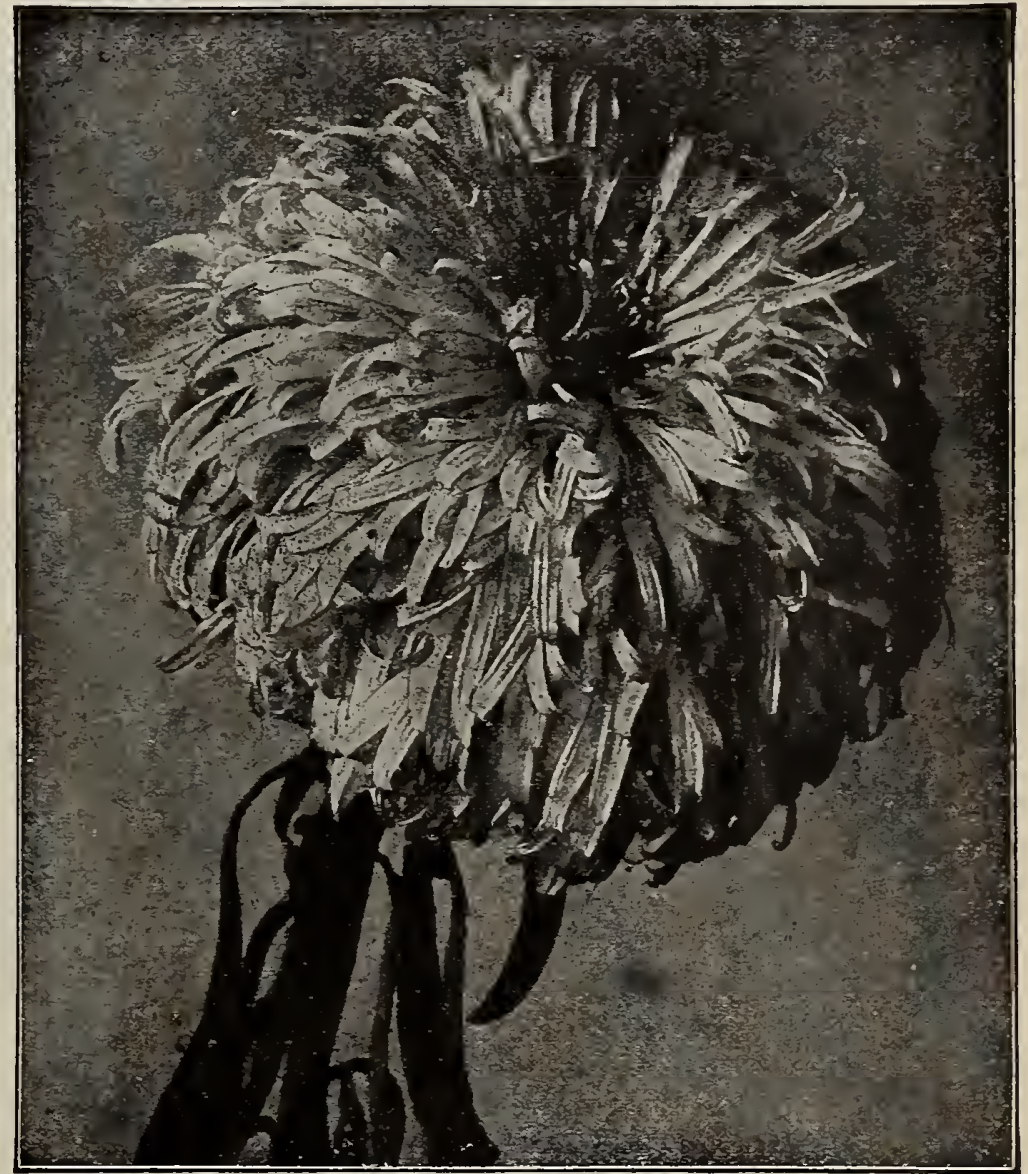

Hercules Aster. (Hohenzollern Type.)

HERCULES ASTER, Rosy Lilac. One of Benary's most beautif ful modern introductions. The Hercules type of Aster is one o the most beautiful, having long, curly petals, which droop and twist gracefully from the center, and are so dense and full as to resemble one of the finest chrysanthemums; five to six inches across. It needs, however, fine, rich soil to bring out its greatest beauty. 'Pkt. 25c.

QUEEN OF THE MARKET. One of the earliest blooming varieties, blossoming frequently in Julp. Of spreading habit, 8 curve inches high. Blossoms medium sized, and the petals

ASTER, New England Perennial (Michaelmas Daisies). In splendid assortment; four to five feet. Very handsome, hardy wild flowers of New England; Fall blooming. Colors: Blue, lilac and pinkish. Mixed, pkt. 15c. 
ARMERIA MARITIMA (Thrift, Sea Pink). Pretty edging plant, bearing tufts of rosy-pink flowers; hardy perennial. One foot. Pkt. 10c.

ASPARAGUS PLUMOSUS. A tender perennial for greenhouse or potted plant use, with long, fine feathery foliage. The sprays, when cut, retain their freshness in water from three to four weeks. Seeds start slowly and should be soaked in water before sowing. Pkt. 10c; 100 seeds $75 \mathrm{c}$.

"Plumosus Nanus. A dwarf variety and sometimes preferred on account of its beautiful, dense sprays of feathery green. Pkt. 10c; 100 seeds $75 c$.

"Sprengeri (Emerald Feather). An early, easily grown, feathery-leaved variety, with drooping branches. The best variety for hanging baskets. Pkt. 10c; 100 seeds $50 \mathrm{c}$.

ASPERULA ODORATA (Sweet Woodruff). An old-fashioned favorite, grown for its fragrant leaves and stems, which, when dried, have an odor not unlike new-mown hay, and are used for putting among clothes, etc. Used in Germany to flavor the "Maitrank," or May wine. Best grown in semi-shaded positions. Flowers white; perennial, Pkt. 5c; $1 / 4$ oz. 25 .

AURICULA (Primula auricula). A dwarf-growing plant, bearing umbels of fragrant flowers of many rich and beautiful colors. A great favorite in England, where flower shows are held of this plant alone. Extra choice mixed from a prize collection. Pkt. 15c.

AUSTRALIAN PEA VINE (Dolichos Lignosus). A rapidgrowing evergreen climbing perennial, flowering freely in large clusters of rose flowers. For covering arbors, trellises, etc., they have no superior. Pkt. 10c.

Bachelor's Button. See Centaurea Cyanus.

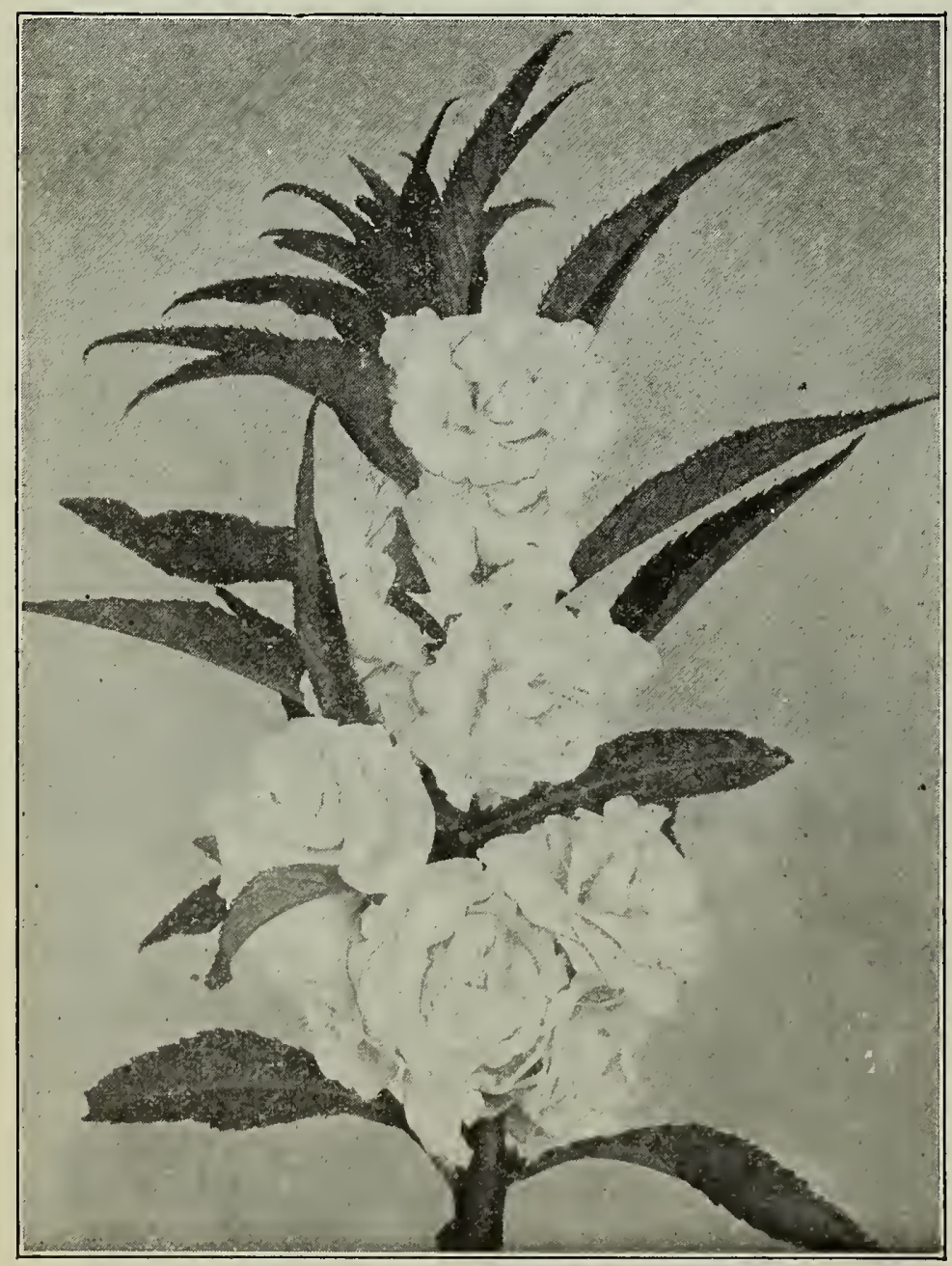

Balsam-Camellia Flowered, Double
BALLOON VINE, OR LOVE-IN-A-PUFF. Climbing annual, with small inferior flowers. The seed pods are curiously swelled or puffed, and are quite attractive. Pkt. 5c. oz. 25c.

BALSAM OR IADY'S SLIPPER. A tender annual, with brittle stems and foliage. Grows about 12 inches high. Flowers both single and double, in bright colors and variations; are wax-like and very attractive. The individual blossoms floating in a dish of water exhibit their beauty to the best advantage.

Camellia Flowered. Mixed; the largest double variety. Pkt. $5 \mathrm{c} ; \frac{1}{2}$ oz. $50 \mathrm{c}$.

Camellia Flowered. White. Pkt. 10c. ark Blood Red. Double. Pkt. 10c.

Lavender. Double. Pkt. 10c.

Peach Blossom. Double; shell pink. Pkt. 10c.

Red and White Spotted. Double. Pkt. 10c.

Snowball. Double; clear pearl white. Pkt. 10c.

Collection of 6 varieties, 40c.

Mixed Tall Doubles. Twelve inches high. Pkt. 5c; 0z. 60c.

Dwarf Double. Pkt. 5c.

BARTONIA AUREA (Golden Bartonia). A hardy annual, growing about two feet high and bearing golden-yellow flowers, which have a metallic luster when the sun shines on them. Is a native of California. Sow the seed where the plants are to remain. since it does not transplant easily. Pkt. 5c.

BEAN, Scarlet Runner. A popular climber; the seed is edible and much esteemed. Flowers scarlet; beans black and lake splashed. Pkt. 10c.

BEGONIA. Tender perennial, usually grown in the greenhouse. Some varieties are especially attractive on account of their foliage, but most varieties have exquisitely beautiful wax-like flowers, both single and double. The seed is very small and rather difficult to germinate. It is also very expensive, some strains being worth far more than their weight in gold.

Fibrous-Rooted Varieties. For outdoor culture, having beautiful leaves and bearing clusters of small, waxy flowers.

Rex. A beautifully marked, large-leaved variety, for indoors. Pkt. 25c.

Vernon. Deep-red flowers and dark-purple foliage often used for borders and for bedding; half hardy. Pkt. 10c.

Tuberous-Rooted Varieties. For greenhouse and pot culture, having large, waxy flowers in brilliant colors. Many prefer to start bulbs in December and January.

Double Varieties. Mixed. Pkt. 25c.

International Prize. The finest large flowered single mixture. Pkt. 35c.

Single Varieties. Mixed. Pkt. 25c.

BELLIS PERENNIS (Double Daisy). A hardy perennial, blossoming freely all spring and summer. Plant is about four inches high and is valuable for borders. Is much sown in lawns.

Extra Double White, or Snowball. A clear white variety. Pkt. 10c; $1 / 8$ oz. 75c.

Longfellow. Double dark rose. Pkt. 10c; 1/8 oz. 75c. Extra Double. Mixed. Pkt. 10c; $1 / 8$ 0z. 65c.

BIGNONIA (Trumpet Vine). Magnificent, hardy perennial climber, with brilliant scarlet or yellow flowers; a most ornamental and effective covering for walls, houses, eto. 30 feet. Pkt. 10c. Border Pinks. See Dianthus Plumarius.

BOSTON IVY OR JAPANESE IVY (Ampelopsis Veitch1). The popular Ivy which covers so many buildings. It clings to brick and wood without support. The leaves are heart-shaped and are off the vine for only two months in the Winter. Pkt. 10c; oz. 50c. 
BRACHYCOME (Swan River Daisy). A hardy annual. growing from 6 to 10 inches high and producing an abundance of pretty blue and white flowers. Pkt. 5c.

BROWALLIA. A half hardy annual, making a fine bedding plant. Blooms profusely. The flowers are bright ultramarine blue, and also sky blue with white center. Will bloom freely all Winter if seed is sown in August. Mixed, pkt. 5c.

CACALIA (Tassel Flower). A beautiful and profuse flowering plant, with tassel-shaped orange and scarlet flowers; flne for mixed borders; hardy annual. Pkt. 5c.

CALAMPELIS (Bugle Vine). A well known beautiful annual climber; trained to a trellis or south wall, it is an ornamental object throughout the Summer, its bright orange tubular flowers contrasting effectively with the delicate green of the foliage. Pkt. 10c.

CALANDRINIA Umbellata. Portulaca-like plants, fond of sunshine, well suited for rock-work. Vivid crimson violet. Height one-quarter foot; perennial. Pkt. 10c.

CALCEOLARIA. A tender perennial, used largely in greenhouses and conservatories. Is not of easy culture, but a very desirable flower. Bears a large profusion of small, pocket shaped flowers, many of which are beautifully tigered or spotted. There is a great variety of shades and colors in various markings.

Grandiflora. Large-flowered, self-colored, profuse flowers. Pkt. 25c.

Tigered and Spotted. Mixed. Pkt. 25c.

Rugosa Hybrid. A shrubby, profuse bloomer, and best for out door culture. Pkt. 25c.

CALENDULA (Pot Marigold). Very hardy annual, one foot high, blooming freely practically the whole year round. Is of the easiest culture and is desirable for rather inferior soils, where less sturdy flowers do not thrive. A medicinal extract resembling arnica is made from the flowers.

Double Mixed. A good mixture of 8 or 10 different shades of yellow, some clear colors and some shaded and striped. Pkt. 5c; oz. 15c.

Lemon King. Pkt. 5c.

Meteor. Large double yellow flowers, striped with orange. Pkt. 5c.

Prince of Orange. A fine deep orange. Pkt. 5c. California Poppy-see Eschscholtzia.

CALLIOPSIS. A half hardy annual, growing about three feet high, and valuable for bright bedding effects or for cutting. Leaves are narrow and stems slender. Blossoms single and about 2 to 4 inches in diameter.

Atrosanguinea. Velvety dark maroon. Pkt. 5c.

Golden Wave. The largest-flowering variety. Clear yellow. Pkt. 5c; 0z. 60c.

Drummondi. Mixed. A gorgeous mixture of golden yellow, brown, maroon, and other shades. Pkt. 5c;0z. 60c.

Bicolor Hybrida Semiplena. Semi-double flowers of garnet and yellow. The old-fashioned small Coreopsis. Pkt. 5 c.

Lanceolata. See Coreopsis.

CANARY BIRD FL OWER (Tropaeolum Canariense). A tender, climbing annual of the Nasturtium family. Blossoms have curiously winged petals and are light sellow. Pkt. 5c;0z. 40c.

CANNA. Mixture of the popular varieties. Red and jellow flowers. Plants have large ornamental leares. Pkt. 5c.

Crozy's Varieties. Mixed. New large-flowered and freeblooming sorts. Pkt. 10.
CANDYTUFT (Iberis). A hardy annual, growing about 6 to 18 inches high, according to the variety. The blossoms are borne on variously long spikes, and the newer varieties are quite large flowering and very fragrant. Of easy culture and valuable for bedding or massing.

Common Sweet Scented. Small white flowers. Pkt. 5c; 0z. 15c. Carmine, pkt. 5c. Purple, pkt. 5c.

Dwarf or Tom Thumb. White. Plant very dwarf. Pkt. 10c; oz. 30c.

Dwarf, or Tom Thumb. Hybrids. Mixed colors. Pkt $10 \mathrm{c} ; 1 / 4$ oz. $25 \mathrm{c}$.

White Rocket. Long Spikes and large flowers. Pkt. $5 c ; 0 z .25 c$.

Giant Hyacinth Flowered, or Improved Empress. Very large heads and long spikes of white flowers. An improved strain of Giant Empress and the best sort for cut flowers. Pkt. 10c; $1 / 4$ oz. 25c; oz. $75 \mathrm{c}$.

Mixture of all colors. Pkt. $5 \mathrm{c}$.

Gibraltarica, Perennial Lilac. Shading to white. Pkt. 10c. Sempervirens, Perennial White. Pkt. 10c.

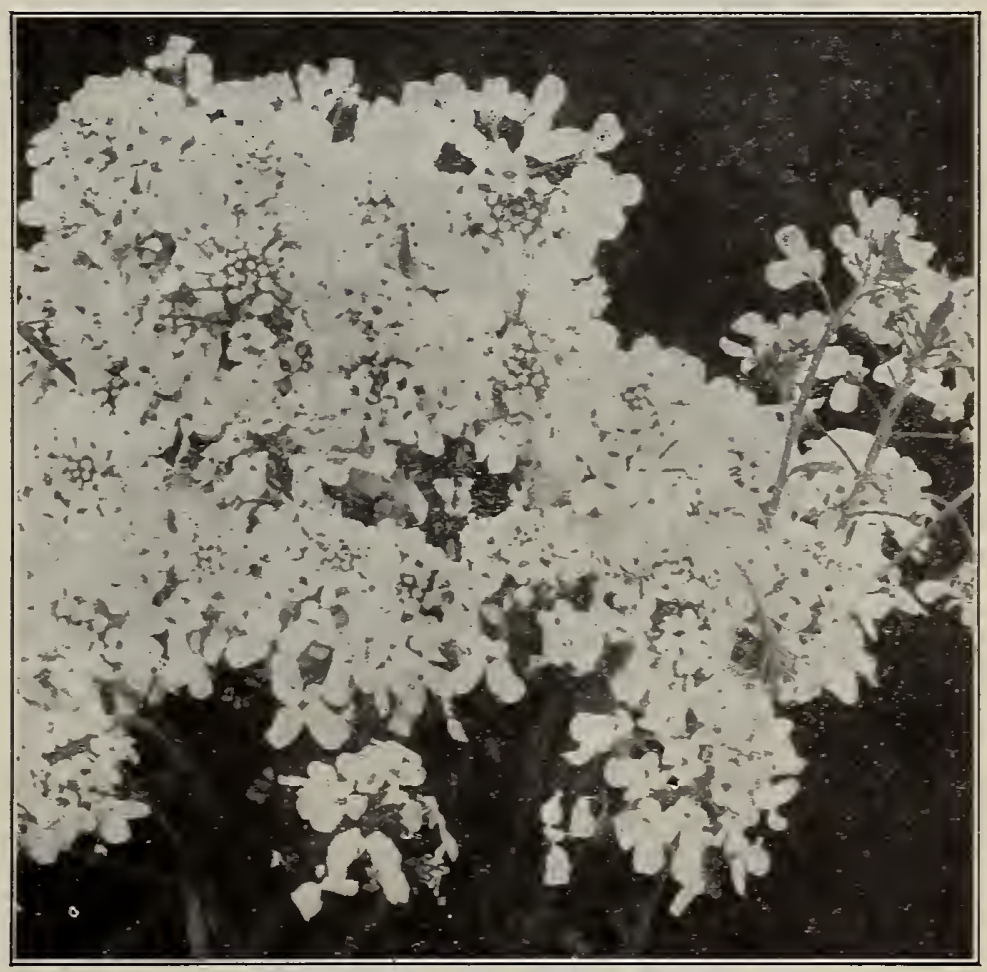

Candytuft-Giant Hyacinth Flowered.

CANTERBURY BELLS (Campanula Medium). A hardy biennial, blooming the second year from seed, or the first year, if sown early. Of easy culture, but preferring rich, moist soil. Grows about three feet high, and bears double and single varieties of blue, white, purple, and red flowers. Single Mixed, pkt. 5c; oz. 30c; Single White, pkt. 5c; oz. 40c; Single Pink, 5c; oz. 40c; Single Blue, pkt. 5c; oz. 40c; Double Mixed, pkt. 5c.

Carpatica (Carpathian Harebell). A d warf perennial; 9 inches; for rockeries, edges and beds. Blue and white. Mixed. Pkt. 5c. 


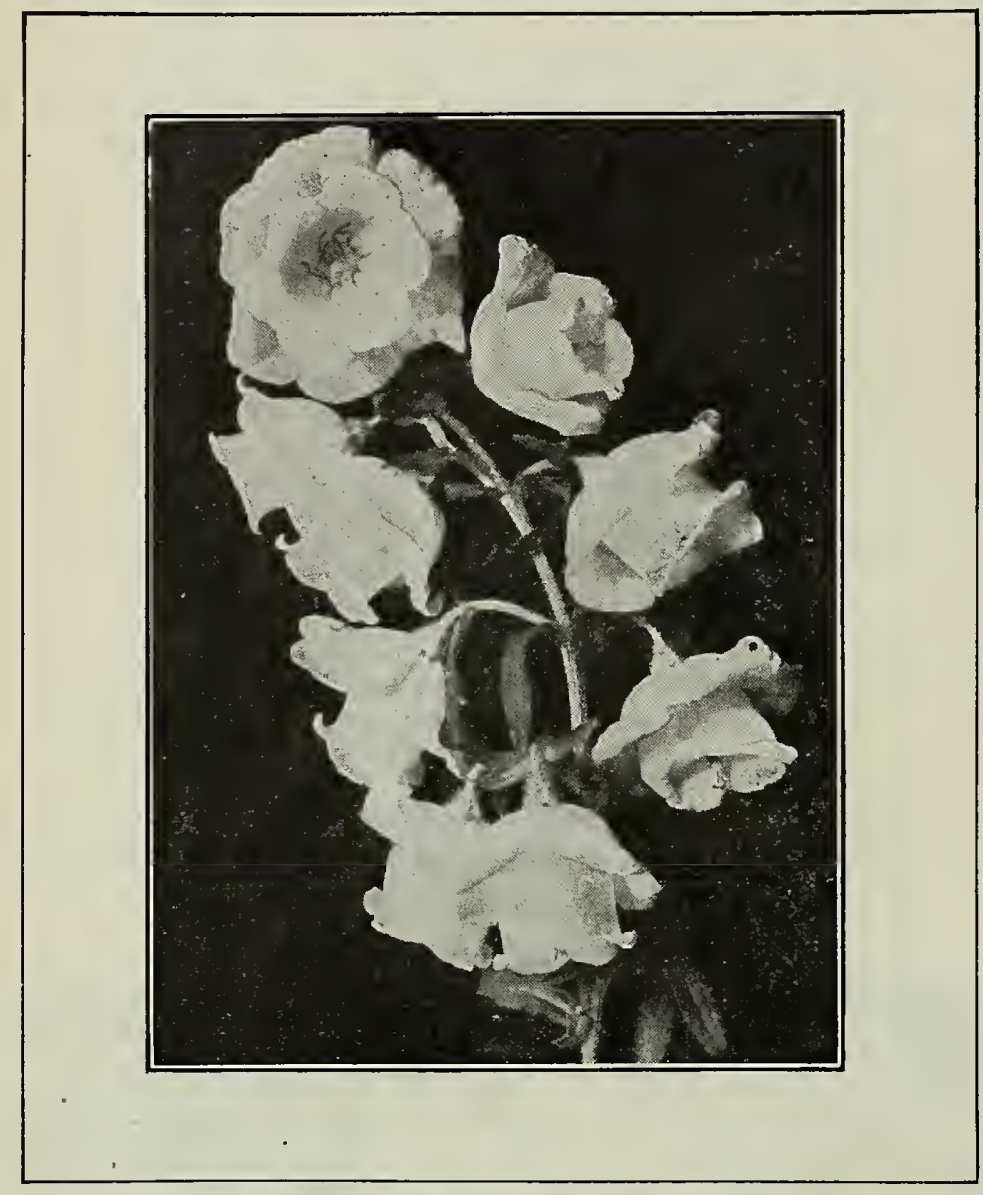

Canterbury Bells-Cup and Saucer Type

\section{CANTERBURY BELLS.-Continued}

CUP AND SAUCER TYPE. In this variety the outer petal forms a brim like a saucer.

Light Blue. Pkt. 10c.

Pink. Pkt. 10c.

Pure White. Pkt. 10c.

Mixed. Pkt. 10c; $1 / 4$ oz. 50c.

Persicifolia. Peach-bell. Perennial; 4 feet; large flowered. Mixed, pkt. 10c; Blue, pkt. 10c; White, pkt. 10c.

Pyramidalis. Chimney Bellflower. Large flowers on tall (6 foot) spikes; blooms late; perennial. Blue, pkt. 10c; White, pkt. 10c.

\section{CARNATION}

A half hardy perennial, used generally for greenhouse florists', trade in winter and for a garden favorite in summer. There are a large number of varieties and colors, but the early flowering mixtures are recommended for out-of-door culture. Sow the seed early in the year and transplant in March or April.

Chabaud's Everblooming. Earliest dwarf French type of perpetual, flowering in 5 to 6 months after seed is sown. The flowers are double and very freely borne. In mixed colors. Pkt. 15c.

German Extra Fine Double Mixed. A splendid strain, containing all the various types and colors mixed of the Perpetual or Tree Carnations. Pkt. 15c.
MARGUERITE. An extra vigorous race, especially adapted for out-of-door culture. The plants are trim in habit, perpetual, and flower abundantly in 5 months from sowing the seed. Margaret Carnations are highly fragrant, and have beautiful double flowers.

"White. Pkt. 10c.

"Yellow and Yellow Ground. Pkt. 20c.

" Light Red and Pink. Pkt. 10c.

" Dark Red. Pkt. 10c

" Striped Varieties. Pkt. 10c

"Collection. One Pkt. of each of above 5 for $45 \mathrm{c}$.

" Mixed. Pkt. 10c; 0z. $\$ 1.00$.

MARGUERITE GIANT, MORSE'S. An improved strain, with flowers frequently $21 / 2$ inches to 3 inches across; strong growers, free blooming.

White Perfection. Pkt. 25c.

Yellow, pure. Pkt. 25c.

Scarlet. Pkt. 25c.

Mixed. Pkt. 15c.

Picotee. Extra fine double mixed. White, edged with colors, or striped and splashed. Contains many rare sorts never seen at a florists'. Pkt. 25c.

Vienna. Double dwarf mixed, double border carnations; early flowering, all colors. Pkt. 10c.

Choice Double Border. Mixed colors. Pkt. 15c.

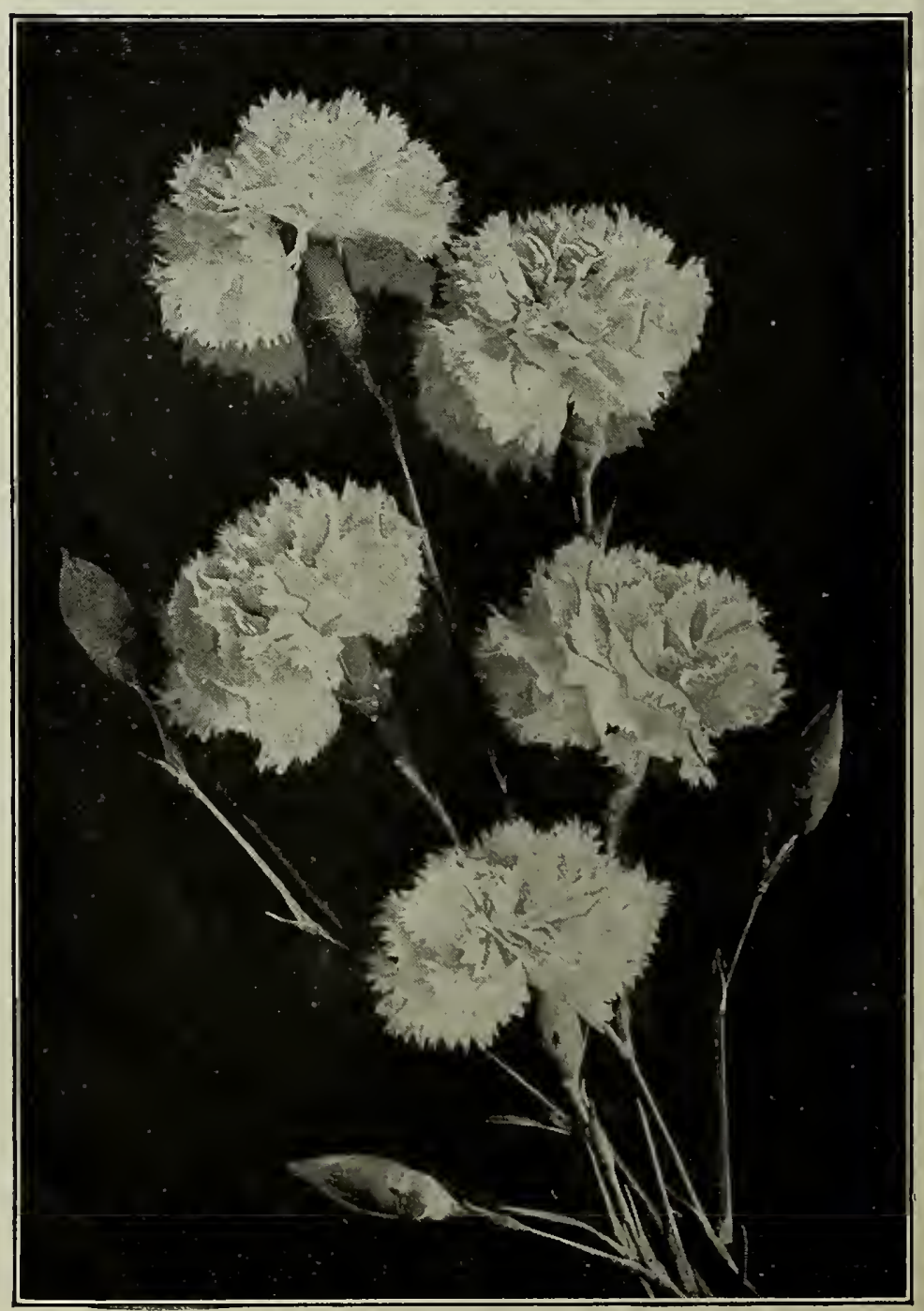

Carnation-Marguerite 


\section{SAN FRANCISCO, CALIFORNLA. U.S.A}

CASTOR OIL BEAN (Ricinus) A half-hardy annual, growing from 6 to 15 feet high and bearing large, green, deep purple and brown leaves and bright orange and scarlet flowers. The seed pods resemble a prickly fruit. Of the easiest culture. Individual plants, with plenty of room look best.

Gibson's dark red. Pkt. 5c, oz. 15c.

Sanguineus. Tricolor. Has blood-red stocks and green leaves, with red veins. Pkt. 5c; oz. 15c.

Zanzibarensis. Mixed. A large-leaved variety, deep green and bronze, growing 10 to 15 feet high. Pkt. 5c; oz. 15c.

Mixture of all varities. Pkt. 5c; oz. 10c.

CELOSIA CRISTATA, OR COCKSCOMB. A half hardy annual, growing 6 to 8 inches high, bearing a wide, wavy blossom that resembles a cock's comb. In brilliant colors and fine for massing or border work.

Dwarf Mixed. Several shades of red and yellow, mixed. Pkt. 15c.

Dwarf New Giant Empress. A rich, crimson variety, with dark foliage and very wide combs. Pkt. 10c.

Glasgow Prize. One of the best strains. Pkt. 10c.

CELOSIA PLUMOSIS, or Feathered Cockscomb. This species grows two or three feet high, and bears long, feathery plumes in brilliant colors. Mixed. Pkt. 5c oz. $60 \mathrm{c}$.

Magnificent (Thompson's). A new variety, superior to the older sorts, bearing grand spikes; flowers in mid-summer. Mixed. Colors have a wide range. Pkt. 10c.

Magnificent Crimson. A bright shade. Pkt. 10c.

Magnificent Golden Yellow. A fine contrast to the crimson. Pkt. 10c.

Spicata. Ostrich plumes of pink shading to silver at tips. Pkt. 5c.

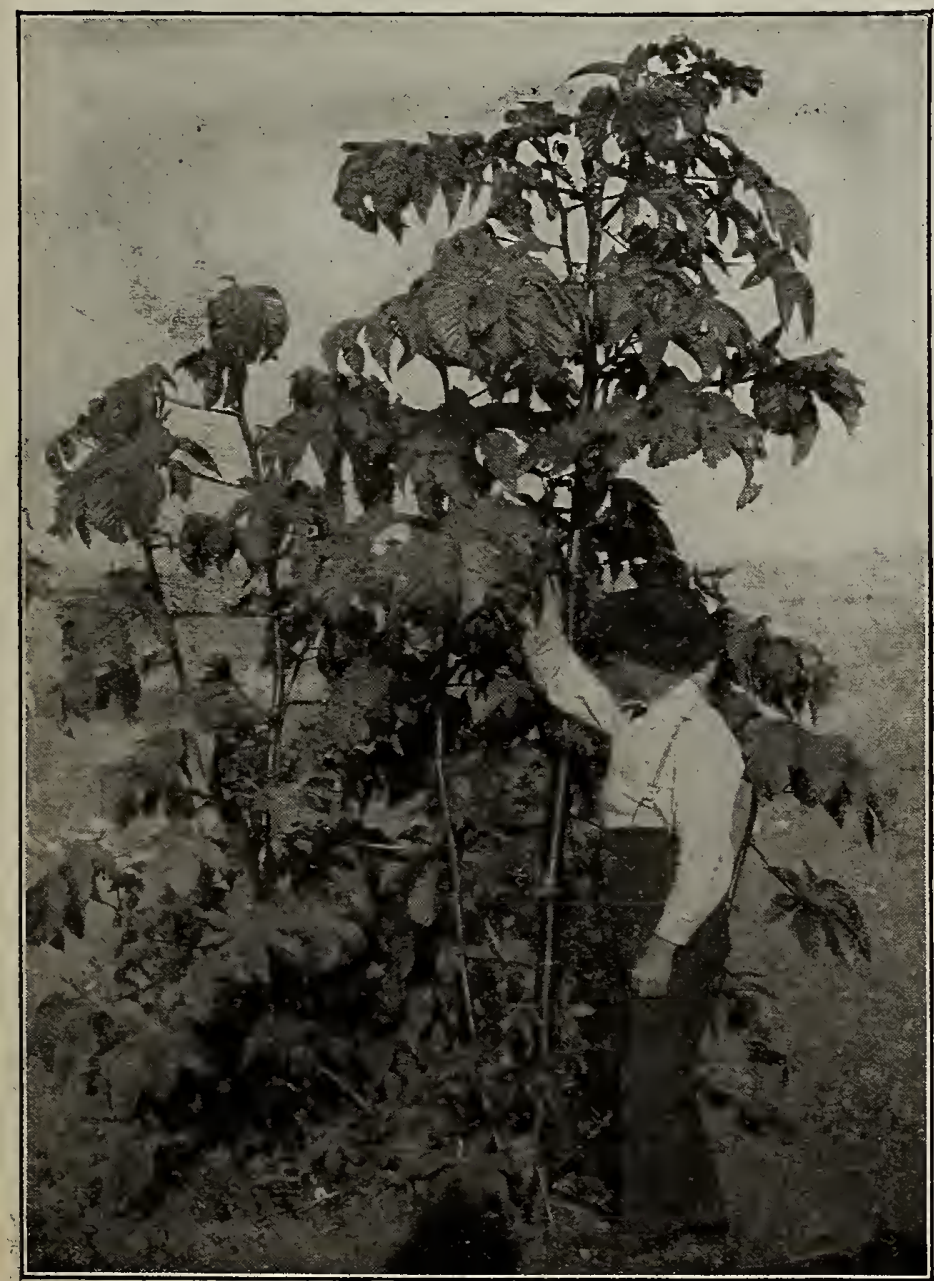

Castor Oil Bean-Zanzibarensis

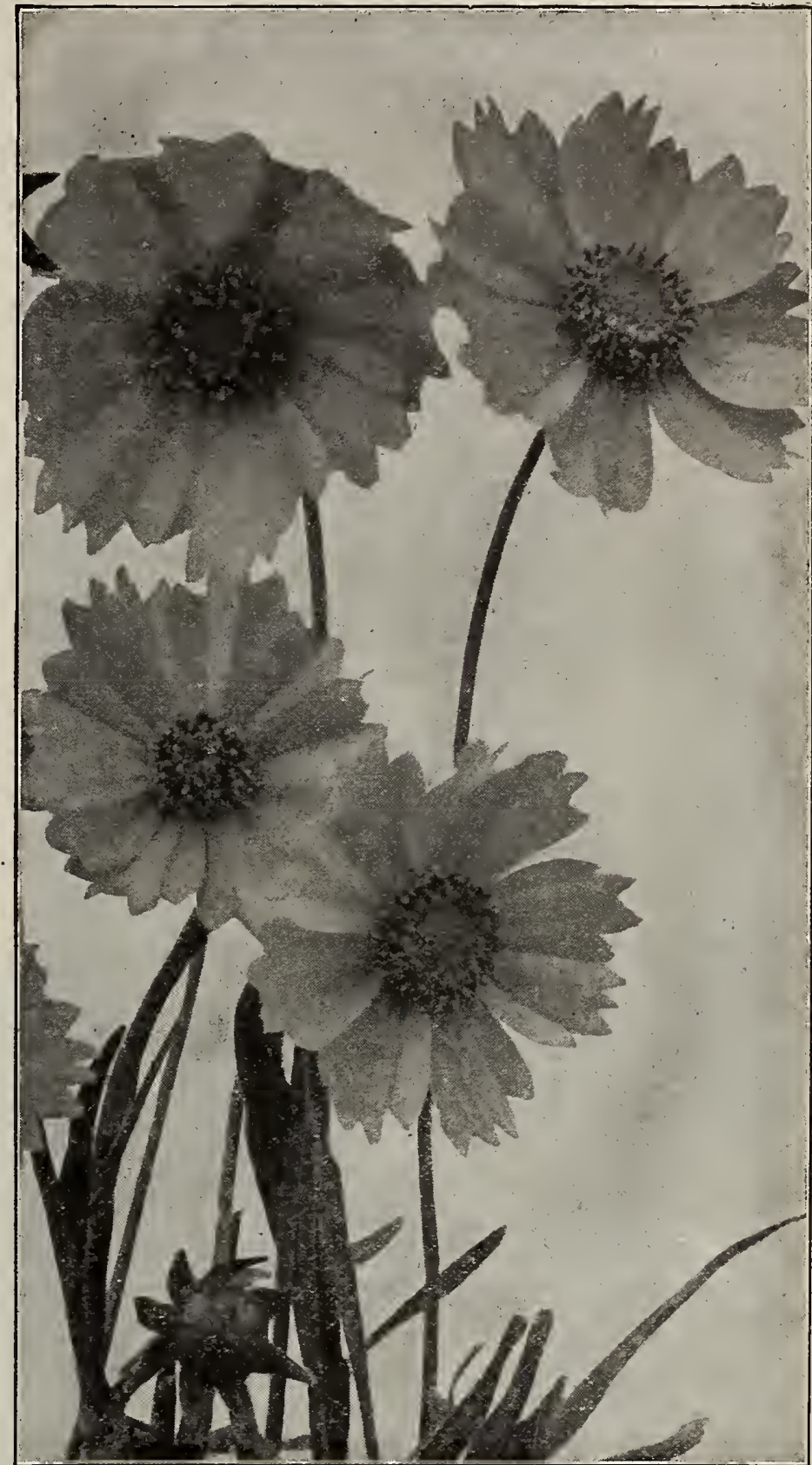

Coreopsis-Grandiflora

COREOPSIS. A perennial with light, graceful foliage and beautiful golden flowers. Blossoms in midsummer and is one of the best yellow cut flowers.

Lanceolata Grandiflora. Pkt. 10c.

CENTRANTHUS. The flowers are small pink, salmon color or white, borne in clusters on light-green, almost, transparent stems. Easy to raise from seed in open ground. Mixed, pkt. 5c.

CENTROSEMA, or Butterfly Pea. A hardy perennial vine of rare beauty, which blossoms in July from seed sown in March, and bears in great profusion pea-shaped flowers ranging in color from a rosy violet to a reddish-purple, with a feathery white marking through the center. Pkt. 10c.

CLARRIA. A hardy annual of easy culture, growing about 18 inches high and bearing bright rose, white, or purple flowers in great profusion. Native of California. Seed sown in the Fall will give early blossoms in the Spring. Seed can be sown almost any time. Double Mixed, pkt. 5c. Single Mixed, pkt. 5c.

CLEOME PUNGENS, OR GIANT SPIDER PLANT. A hardy annual growing 4 to 5 feet high and bearing in profusion rosepurple blossoms that are shaped something like a spider. Pkt.5c. 


\section{CENTAUREA}

A hardy annual, embracing a number of species, some being grown only for their foliage. All varieties grow from $11 / 2$ to 2 feet high. Sow the seed early and transplant in March. Except the white leaved sorts all make excellent cut flowers.

Cyanus (Batchelor's Button, or Bluebottle, or Corn Flower). Of easy culture. Sow the seed where it is to remain and thin to three or four inches. Mixed. Pkt. 5c; oz. 25c.

Emperor William (Large Blue). Pkt. 10c; oz. 35c.

Pink. Pkt. 5c.

White. Pkt. 5c.

Imperialis (Royal Sweet Sultan). The finest of all Sweet Sultans; the plants are very strong and bear giant flowers on stiff, long stems; excellent for cutting and lasting, when cut, unusually well. Mixed, pkt. 10c; $1 / 2$ oz. 50c. Pure White, pkt. 10c. Purple Shades, pkt. $10 \mathrm{c}$.

Marguerite. A large, white variety of the Imperialis class. Fragrant and pretty. Pkt. 10c.

Moschata, or Sweet Sultan. A well-known type. In white, yellow, lavender, and purple. Blossoms very fragrant. Mixed. Pkt. 5c.

Suavaelens. Yellow Sweet Sultan. Pkt. 10c.

Gymnocarpa. Called Dusty Miller; leaves silvery gray and deeply cleft; $11 / 2$ feet; perennial. Pkt. 5c.

Candidissima, White Leaved, or Dusty Miller. Grown for its silvery white foliage; leaves broader and less cleft; 1 foot; perennial. Pkt. 10c.

Montana. Large blue perennial Cornflower; for hardy border. 2 feet. Pkt. 5c. Catchfly. See Silene

\section{CHRYSANTHEMUM}

There are many widely different classes of this flower represented in the hardy annual or garden varieties, both single and double, and the perennial varieties, chief of which is the double or florists' varieties, so highly prized in the autumn and winter.

ANNUAL VARIETIES. Growing 11/2 to 3 feet high. Seeds should be planted early and the plants set out in April. Single varieties sometimes called "Painted Daisies." Very attractive. Mixed, pkt. 15c.

Coronarium Double. Mixed. Pkt. 10c.

White. Beautiful for cut flowers. Pkt. 10c.

"Yellow. Flowers early and very freely. Pkt. 10c.

Tricolor. These are large, single-flowered sorts with color in rings.

" Burridgeanum. Yellow center, crimson maroon band, and white tips. Pkt. 5c.

" Eclipse. Golden yellow with purple ring; very striking Pkt. 5c.

"White. Pkt. 5c.

" Mixed. Pkt. 5c.

Segetum, Morning Star. Large light yellow; single flowers; shading deeper; fine for cutting. Pkt. 10c. Segetum, Evening Star (Helios). Pure golden yellow; giant single flower, 3 inches in diameter. Excellent for cutting. Pkt. 10c.

\section{CHR YSANTHEMUM-Continued}

PERENNIAL VARIETIES. Growing $2 \frac{1}{2}$ to 3 feet high. Hardy and of easy culture.

Frutescens, or "Marguerite"; also called "Paris White Daisy." White petals radiating from a goldenyellow center. Pkt. 10c.

Japanese Hybrids. A mixture of the large-flowering, florists' varieties. These varieties are the large, autumn flowers used in exhibitions and by florists. They are usually grown from cuttings, and do not come absolutely true from seed. Pkt. 25c.

CINERARIA. A tender perennial, grown principally in the greenhouse, but can be grown safely in the garden in summer. Seed should be sown in summer, and the greenhouse requires only moderate heat. Plants grow from 1 to 2 feet high and bear clusters of large, single flowers of bright colors. Will do well in a partly shaded location.

Hybrida Mixed. The best variety, having large flowers and brilliant colors. Pkt. 25c.

Grandiflora Dwarf. Mixed. Pkt. 25c.

Grandiflora Stella. With twisted petals. Pkt. 25c.

Maritima Candidissima. Dusty Miller. Silvery foliage. Hardy border plant. $21 / 2$ feet. Pkt. 5c; oz. 40c.

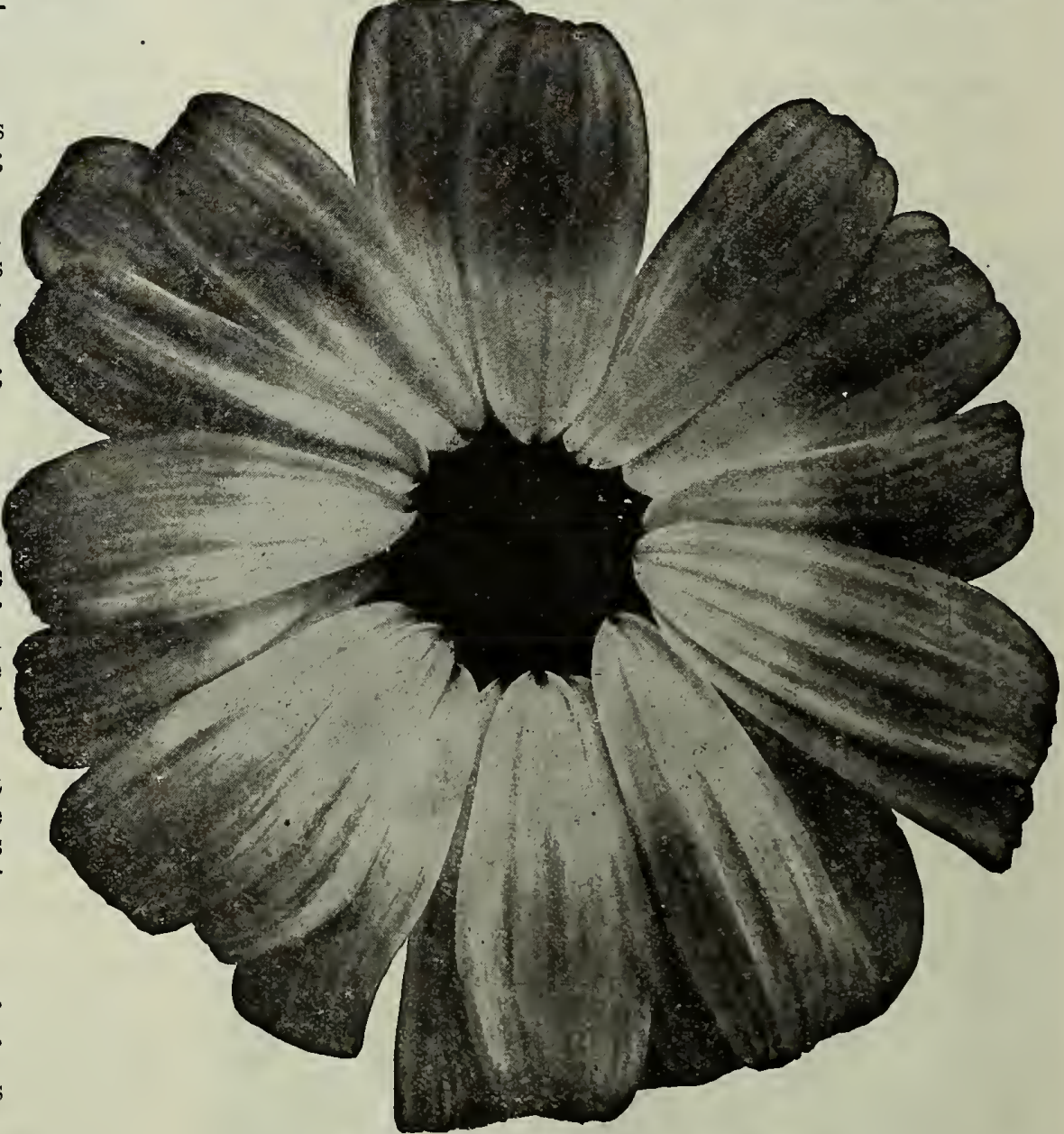

Cineraria, Hybrida Grandiflora

CLEMATIS. A popular hardy perennial climber. An old favorite and justly so, for there are few garden climbers that give more satisfaction.

Large Flowered Mixed. Pkt. 10c.

Virginiana (Virgin's Bower). Pkt. 10c.

Paniculata. A very fine hardy climber; leaves bright glossy green; flowers small and hawthorn scented, and just covering the plant when in bloom. Excellent for covering trellises, cemeteries, or fences. Pkt. 10c.

Flammula. Feathery white. Pkt. 10c.

Coccinea. Scarlet. Pkt. 10c.

Jackmanil. . Largest flowered hybrids in various colors. The blue does not come true from seed. Pkt. 15c. 
CLIANTHUS DIAMPIERI (Glory Pea of Australia). One of the most gorgeous flowers in existence; the flowers are pea-shaped, of a brilliant scarlet color with intense black center; requires a dry warm soil and little water. Soak seeds in hot water before sowing. Pkt. 15c.

COBAEA SCANDENS. A half hardy climbing annual, with large leaves and large bell-shaped flowers. Blossom is green until nearly grown, when it turns bright-purplish blue. Grows about 30 feet long, and is very desirable for covering a large lattice. A native of Mexico. Pkt. 10c.

COLEUS. A tender perennial, growing about 10 to 18 inches high, and grown for its beautiful, bright-colored velvety leaves. Valuable for window garden or pots, and can also be grown out of doors if taken up in winter.

Extra Large Leaved Mixed. Pkt. 15c.

Ornatus. The best large-leaved variety. Pkt. 15c.

Morse's Exhibition. A beautiful and gorgeous strain. Pkt. 25c.

COLLINSIA. A free-flowering and easily grown annual, growing from 1 to 2 feet; flowers white, crimson, purple, etc. A California wildfiower. Mixed, pkt. 5c.

\section{COLUMBINE}

(AQUILEGIA)

A hardy perennial, growing about 2 feet high and bearing an immense variety of colors on long, smooth stems.

California Hybrida. Large yellow flowers, orange spurs; an improvement on our native sort. Pkt. 15c.

Ohrysantha. Pure golden yellow, single long spurs; 3 feet. Pkt. 10c.

Ooerulea (Rocky Mountain Blue Columbine). Fine deep blue and white; long spurs. Pkt. 10c.

Rose Queen. A novelty, pink and white long spurs. Pkt. 15c.

Skinneri (Mexican Columbine). Very handsome and quite distinct; spurs and sepals long, crimson and light green; 3 feet. Pkt. 25c.

Truncata. Our native California wild flower found everywhere in the woods; flowers scarlet and yellow. Pkt. 10c; 0z. \$1.25.

White, Spurred. Pure white with long spurs. Pkt. 10c. Collection of the seven fine sorts above for 70c.

Long Spurred Hybrids Mixed. Showy. Pkt. 10c.

Single Mixed (A. Vulgaris). Pkt. 5c.

Double Mixed (A. Vulgaris). Pkt. 5c.

Convolvulus. See Morning Glory.

COSMOS. A tender annual, with fine-cut, feathery foliage and large, showy blossoms in rose, crimson, pink, and white. The late-flowering or giant type grows 5 to 6 feet high and its blossoms are larger than the early varieties, or about 4 to 5 inches in diameter. They bloom late in the Fall, or about November 1st, and rarely blossom very far North. The early varieties bloom in July. Sow about March 1st and transplant in May.

Early Flowering Dawn. White, slightly tinted with pink. Pkt. 10c; 0z. 80c.

Early Flowering Mixed. The usual Cosmos colors in mixtures. Pkt. 10c; oz. 60c.

Giants of California.

Pink. Pkt. 10c; 0z. 50c.

White. Pkt. 10c; oz. 50c.

Crimson. Pkt. 10c; oz. 50c.

Mixed. Pkt. 5c; oz. 35c.

Klondyke. A late blooming variety, with bright yellow blossoms. Pkt. 10c; oz. \$1.00.

\section{cosmos-Continued}

LADY LENNOX. A grand new variety which we have grown for a large New York seedman on our own farms. It is without question the finest Cosmos in existence. The plants are rather low growing (about $21 / 2$ feet high) and it bears profusely, the whole plant being a mass of bloom when in full flower. The blossoms are a bright rose pink, and the petals are very large and wide, completely overlapping each other. It comes into its full perfection of bloom about October 1 to 15 . Pkt. 10c. Cockscomb. See Celosia Cristata.

CYCLAMEN. A tender, bulbous perennial, used in greenhouses and window-gardens. It is easily grown from seed. Sow in the Fall or early Spring.

Persicum Giganteum. Mixed. Very large flowers and very free blooming. Pkt. 25c.

Album. Pure white. Pkt. 25c.

Rubrum. Red. Pkt. 25c.

Crimson King. A new variety. Pkt. 25c.

Papilio. Butterfly type, fringed and waved edges. Pkt. 25c.

CYPRESS VINE (Ipomoea Quamoclit). A tender, climbing annual, with soft fern-like foliage and small starlike flowers, in pkt.5c;0z. 30c. MIixture of several colors, pkt. 5c; oz. 30c.

DAHLIA. A well-known and popular late summer and autumn flowering plant. Is grown from seed or propagated from the bulbous roots. The seed may be planted early in the hotbed and the plants set out in May after all danger of frost is over. By sowing the seed early the plants may be made to bloom the first year.

Cactus. Mixed, double, with pointed petals. P\&t. 10c.

Double. Mixed, pkt. 10c.

Single. Mixed. The most easily grown and also the most satisfactory from seed. Pkt. 10c

Daisy, double. See Bellis Perennis.

DAISY, SHASTA DAISY. A fine perennial plant bearing large white single blossoms, with yellow centers; an excellent cut flower and admired everywhere. Soak seed in warm water over night before sowing. Pkt. 15c. Alaska. One of Burbank's new selections. Pkt. 25c.

DATURA (Trumpet Flower, or Horn of Plenty). A tender annual, growing three feet high. Flowers large and trumpetshaped.

"(Chlorantha) F. Pl. Double golden-yellow blossoms. Pkt.5c. "(Cornucopia). Blossoms single, white inside, shading to purple. Pkt. 5c.

Delphinium. See Larkspur.

Dianthus, Barbatus. See Sweet William.

Dianthus, Caryophyllus. See Carnation.

DIANTHUS, OR PINKS. Hardy annuals, about one foot high, and bearing beautifully colored, single and double blossoms in profusion all Summer. Sow seed early in boxes and transplant, or sow in rows where the plants are to remain, and thin.

Chinensis (China or India Pink). Double White. Pkt. 5c. Double Mixed. Pkt. 5c.

Heddewigi (Japanese Pink). Finest single, mixed. Pkt. 5c. Finest double, mixed. Pkt. 5c.

Diadematis Fl. Pl. (Double Diadem Pink). Large, double flowers in many colors. Pkt. 5c.

Mourning Pink. Very dark crimson margined pure white. Pkt. 5c.

Laciniatus. Single, fringed varieties. Pkt. 5c.

Mixture of all single varieties. Pkt. 5c; oz. 50c.

Imperialis (Double Imperial Pink). Very large. Pkt.5c.

Plumarius (Grass Pink, Pheasant Eye or Scotch Pink). A single hardy perennial pink with fringed edge light colored flowers, with a darker center, various colored. The old-fashioned garden favorite. Pkt, 5c. 


\section{C.C. MORSE \& CO. FLOWER SEEDS}

\section{ESCHSCHOLTZIA \\ OR CALIFORNIA POPPY.}

A hardy annual, with fine-cut, feathery foliage and beautiful velvety cup-shaped flowers. Grows from 1 to $11 / 2$ feet high, and blooms profusely. Seed may be sown in the Fall and any time thereafter till April, and blossoms may be had from early in January till late in Summer. Of the easiest culture. Any soil will do, but the better the soil, the larger the plants and blossoms. It is best to sow the seed in the garden, where the plants are to remain, as they do not transplant easily. The beautiful State flower of California.

Californicus. The bright, orange-yellow common variety. Pkt. 5c; oz. 20c; lb. \$2.25.

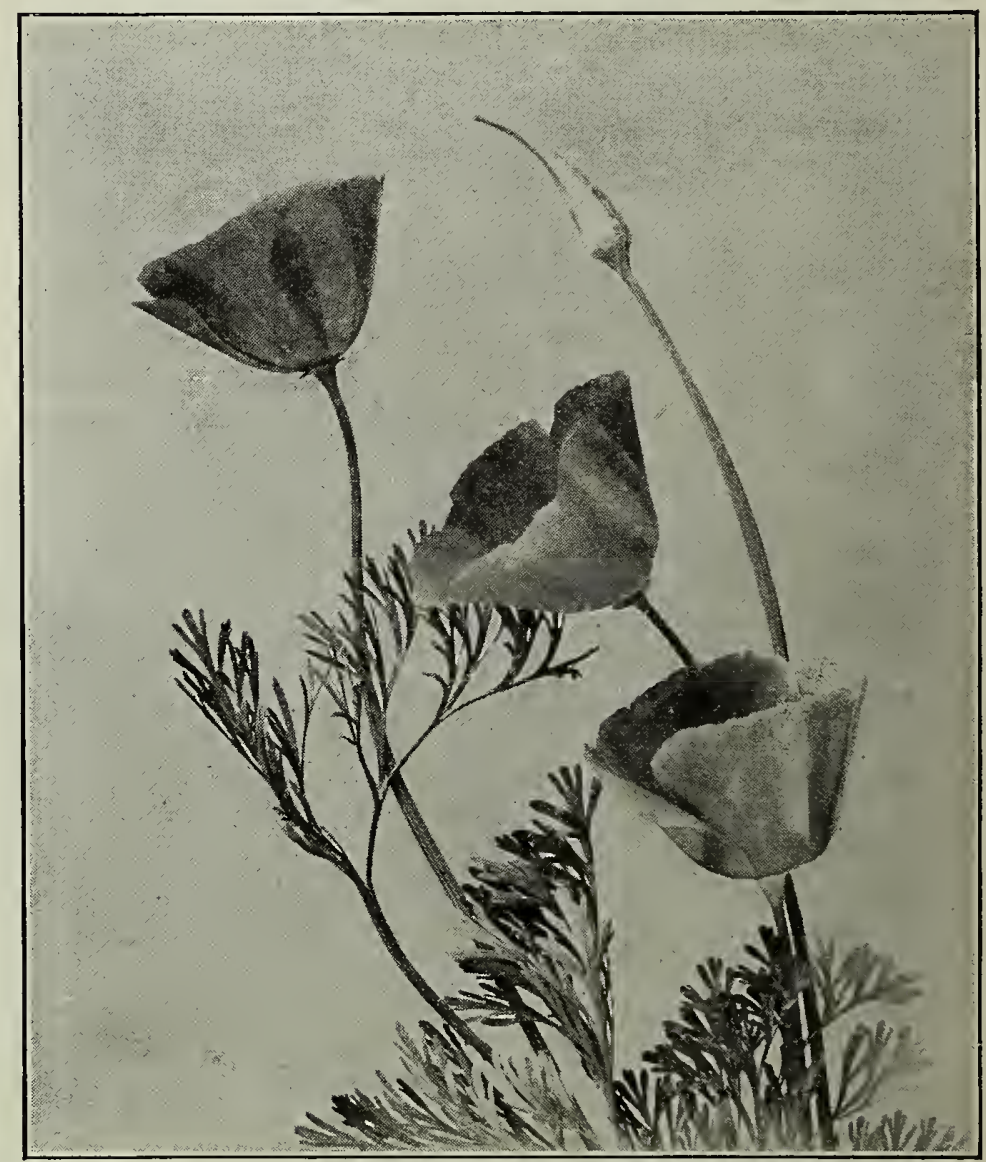

California Poppy-Eschscholtzia California

Burbank's Crimson Flowering. Pkt. 10c.

Crocea. Pure deep orange. Pkt. 5c; oz. 25c.

Double Rose. A semi-double blossom, rose colored outside and white inside the petal. Pkt. 10c; oz. $\$ 1.75$.

Erecta Mandarin. Brownish gold, erect growing plant. Pkt. 5c.

Golden West. Very large, orange-colored blossoms, shading to canary yellow at the edges. Pkt. 5c; oz. 25c.

ECHINOCYSTIS (Wild Cucumber Vine). One of the quickestgrowing vines we know of attaining a height of 30 feet in a season; growing vines we know of, attaining a height of 30 feet in a season; white, fragrant flowers, borne in great profusion, lollowed by an abundance of ornamental prickly seed pods; foliage very dense, on which account it is most
sired. Pkt. 5c; oz. 30c.

EDELWEISS (Leontopodium Alpinum). The true white-leaved famous Edelweiss of the Alps; perennial dwarf; 6 inches. Pkt. $15 \mathrm{c}$.

EUPHORBIA. A hardy annual, growing four to six feet high, and esteemed for its beautiful foliage. The blossoms are inconspicuous.

Heterophylla. Called Mexican Fire Plant or Annual Poinsettia. Smooth, glossy leaves, turning scarlet late in the summer. Pkt. 10c.

variegata. Called Snow on the Mountain. Leaves veined and margined with white. Pkt. 10c.

Mandarin. Blossoms are copper-colored outside and bright yellow inside the petals. Pkt. 5c; oz. 25c.

Rose Cardinal. White inside, light pink outside. Pkt. $5 c ; 0 z .40 c$.

Striata. Golden yellow, striped lightly with cream. Pkt. 5c; oz. 25c.

White. Large, ivory white. Pkt. 5c; oz. 25c.

Mixed Yellows. A mixture of the popular orange and yellow varieties. Pkt. 5c; 0z. 20c.

Collection one pkt. each of 10 kinds for $45 \mathrm{c}$.

Mixture of all varieties. Pkt. 5c; oz. 20c; lb. \$2.25.

Bush Eschscholtzia. See Hunnemannia. 


\section{SA SAN FRANCISCO CALIFORNLA U.S.A.JW}

EVERLASTING FLOWERS. See Acroclinlum, Gomphrena, Helichrysum, Honesty, Rhodanthe, Statice, Xeranthemum.

Evening Primrose. See Oenothera.

Everlasting Pea. See Lathyrus Latifolius.

Flax. See Linum.

FEVERFEW. Matricaria Capensis. Called Double Feverfew. A plant growing 18 inches high and bearing profusely pure white, very double flowers Prt. $5 \mathrm{c}$.

See also Pyrethrum for edging varieties.

Flowering Maple. See Abutilon.

Flowering Sage. See Salvia.

FORGET-ME-NOT (Myosotis). A hardy perennial, growing 6 to 12 inches high. Small star-like flowers are borne in clusters on long stems. The plant is of easy culture and blooms the first year if seed is sown early. Thrives best in a cool, moist location.

Alpestris. Blue. Pkt. 5c; oz. 75c.

Indigo Blue. A new dark indigo color. Pkt. 10c.

Rosea. Pink-flowering; a pretty contrast for the blue and white varieties. Pkt. 5c.

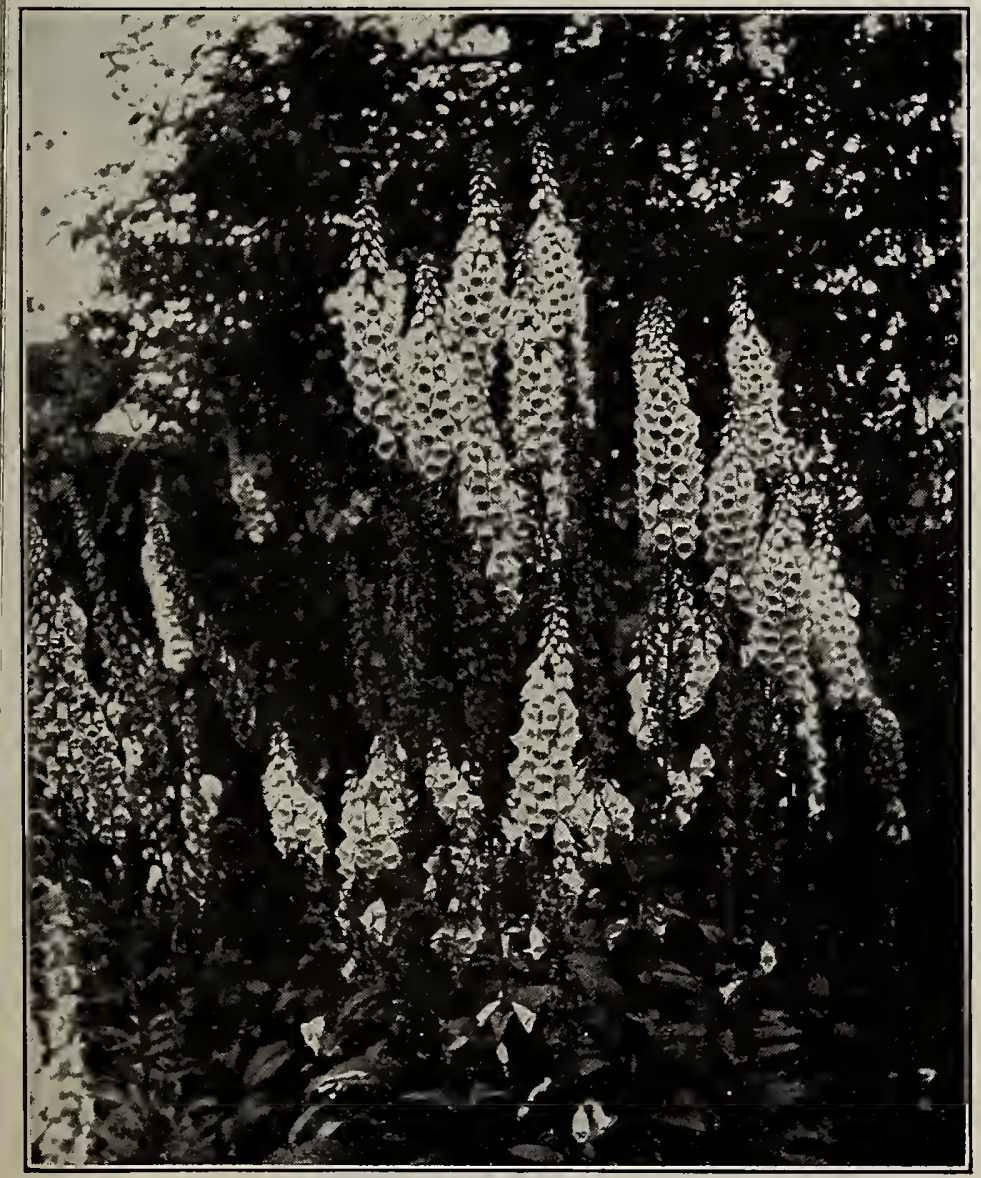

Foxglove, or Digitalis

White. Pkt. 5c.

Victoria. Large flowers; bright azure blue, with yellow center; plant symmetrical, dwarf and strong grower. Pkt. 10c.

Dissitiflora Perfection. Of dwarf compact habit, flowering profusely; looks like a sheet of blue. One of the best Forget-Me-Nots. Pkt. 15c.

Perennial Semperflorens. True marsh Forget-Me-Not Dwarf, and in flower from early spring till autumn. Pkt. 10c.

Collection of seven kinds, 1 pkt. of each, $45 \mathrm{c}$.
FOUR O'CLOCK. A A hardy annual, about two feet high. Of the easiest culture. Seed should be sown in the open and thinned to one foot. Is free-flowering, the blossoms in great variety of colors and stripes.

Mixture of all colors. Pkt. 5c; 0z. 20c.

Tom Thumb. Dwarf plant, mixed colors. Pkt. 5c. Variegated and striped leaved. Mixed. Pkt. 5c.

FOXGLOVE. See Digitalis.

FUCHSIA. (Lady's Eardrop). A well-known plant of easy culture in pots for the conservatory, parlor decoration, or the open ground. Start seed early under glass.

Double mixed, pkt. 35 c.

Single mixed, pkt. $35 \mathrm{c}$.

GAILLARDIA. A very showy garden plant, with brilliant flowers in scarlet and yellow, blended and shaded. Blooms freely from early summer till autumn. Grows one and one-half to two feet high, and the blossoms are borne on long, slender stems. Both single and double varieties are hardy.

Fine Single Mixed, Annual. Pkt. 5c.

Double Mixed, Annual. (Picta Lorenziana). Pkt. 5c. Grandiflora. Single perennial variety of varying shades of reddish brown and yellow. Pkt. 5c.

GLACUM LUTEUM (Horn Poppy). A showy plant, with long silvery leaves, gracefully curved and deeply cut and curled; flowers bell-shaped, orange yellow; perennial. Pkt. 5c.

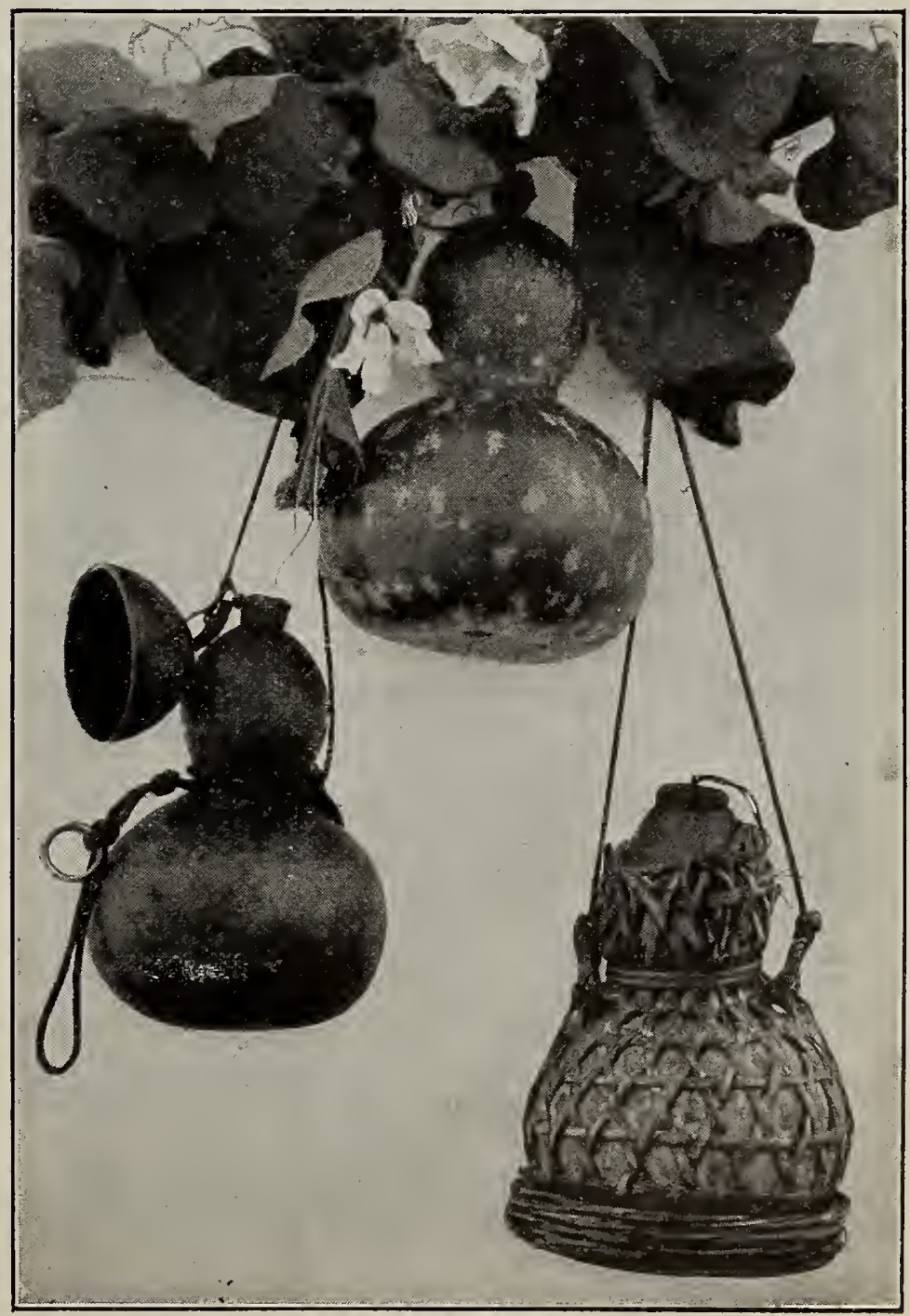

Gourds-Chinese Bottle 


\section{ORNAMENTAL GRASSES}

Ornamental grasses serve the double purpose of rendering the mixed flower-bed or border attractive during the summer, and for the use of the spikes or panicles in a dried state in winter bouquets. For large beds or groups on lawns nothing gives a finer effect. AGROSTIS NEBUL OSA. A very graceful and pretty grass-
charming for borders. Annual. One and one-half feet. Pkt. 5c.

AVENA STERILIS (Animated Oats). Drooping, very graceful. Annual. 'Two feet. Pkt. 5c.

BRIZA AUSTRALIS. Lately discovered in Western Australia, much larger than the other brizas. The black spotted shoulders make it unusually ornamental. Pkt. 15c.

BRIZA MAXIMA (Quaking Grass). Very pretty. Annual. One and one-half feet. Pkt. 5c.

BRIZA GRACILIS (Small Quaking Grass). Very delicate and graceful. Annual. One foot. Pkt. 5c.

BROMUS BRIZAEFormis. An elegant Briza-like grass. Pkt. 5c.
COIX IACRYMA (Job's Tears). Grows two feet high. Pkt. 5c. ERAGROSTIS ELEGANS (Love Grass). Very graceful and beautiful. Annual. One foot. Pkt. 5c.

EULALIA JAPONICA. One of the most beautiful of the tallgrowing grasses. Five feet. Pkt. 10c.

GYNERIUM ARGENTEUM (Pampas Grass). The finest ornamental grass in cultivation. Half-hardy perennial. Ten feet. Pkt. 10c.

STIPA PENNATA (Feather Grass). One of the prettiest and most interesting. Perennial. Two feet. Pkt. 10c.

ZEA JAPONICA (Striped Japanese Maize). Pkt. 5c.

Collection of 12 Varieties, 55c.

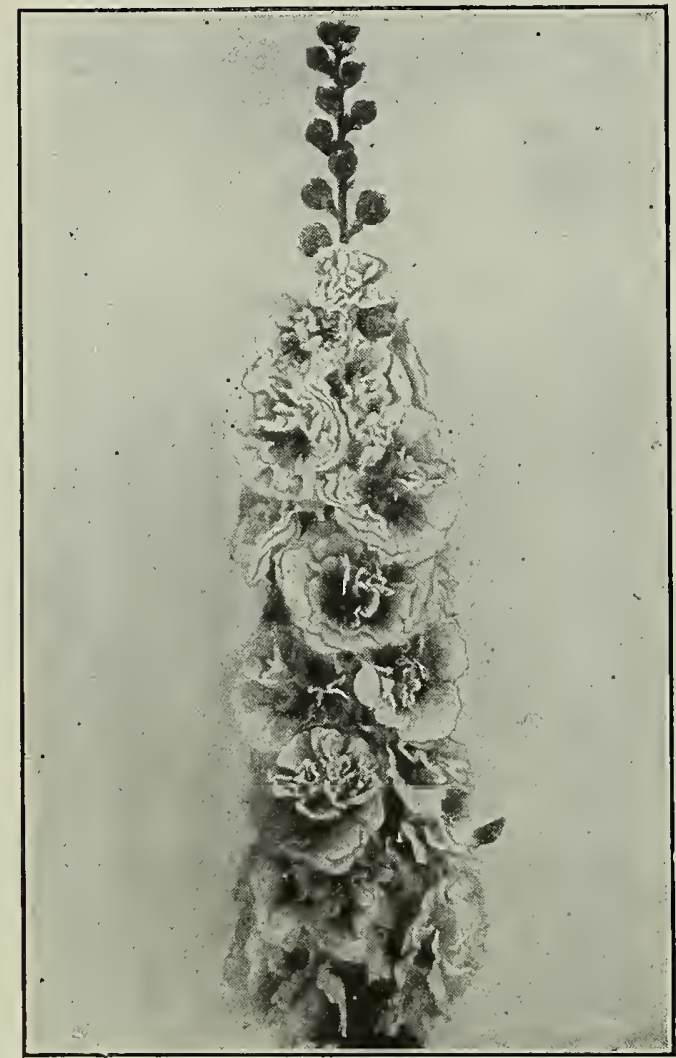

Hollyhock-Allegheny

GERANIUM. A half-hardy perennial, flowering the first year from seed if sown early. A popular flower in brilliant colors and variously fragrant and ornamental foliage. Grows easily from Apple scented. Very fragrant leaves. Pkt. 25 c.

Apple scented. Very fragrant leaves. Pkt. 25c. the most beautiful flowers we have; in rich, soft colors with beautiful markings. Fancy mixed. Pkt. 25c.

Zonale. Mixed. Beautiful scarlet shades. Pkt. 10c.

Gerbera. See Transvaal Daisy.

GILIA. A hardy annual growing one foot high, with white, lilac, or rose-colored flowers. A native of California. Valuable for rockwork or borders. Sow seed in the fall. Mixed. Pkt. 5c. Achillea efolia. This pretty gilia is common about San Francisco on the hills and sandy ground. Flowers come in clusters $11 / 2$ inches across and often give a blue look to the fields; 1 foot; hardy annual. Pkt. 5c; oz. 20c; 1b. \$1.25. Gilliflower. See Ten Weeks' Stocks.

GLADIOLUS. Well-known magnificent plants. with sword-like leaves and long spikes of flowers of every conceivable color and shade. Many new and rare varieties are produced from seed. Pkt. 10c.

GLOXINIA. Beautiful hot-house plants, with large, bell-shaped blossoms, which come in rich, velvety-deep, and bright colors, some of which are beautifully marked. Sow in the fall or early spring. Grandiflora, Mixed, pkt. 25c; tigered and spotted, Mixed, pkt. 25c. pkt. 5c.
GODETIA. A hardy annual, growing from six inches to ten inches high. Of compact growth, with a profusion of satiny cup-shaped flowers bedding or massing. Sow seed early in the year. Small flowered deep-red variety; grows wild in California. Tall Sorts. Fine mixed. Tom Thumb, or Dwarf Varieties. Mixed. Pkt. 5c.

Our pretty wild flower known as "Farewell to Spring." Pkt. c; 0z. $25 \mathrm{c} ; \mathrm{lb} . \$ 2.50$.

Duchess of Albany. White. Pkt. 10c.

Iady Albemarle. Dark Crimson. Pkt. 10c.

GOLDEN-ROD (Solldago Canadensis). Well-known golden-yellow hardy perder, and the flowers are very pretty, and are attractive, either while growing or dried. Mixed, pkt. 5c. White, pkt. 5c. Crimson,

Thin ornamental varieties. Pkt. 5c.

Dish Cloth, or Luffa. The inside lining resembles a sponge; very useful. Pkt. 5c. Dan readily be made into a dipper. Pkt. 5c. Plist. 5c. Trough.

. Pkt. 5c.

Useful for baskets or buckets, holding from two to ten gallons Red, green, striped, etc., orn
each of 7 kinds for $25 \mathrm{c}$.

GYPSOPHILA (Baby's Breath). A hardy annual of easy culture. Grows two to three feet high, and bears a profusion of small starshaped white and pink flowers.

Muralis. An excellent border plant; 6 inches; pink flowers. Pkt. 5c.

Paniculata. Fine for bouquets; white flowers; perennial. Pkt. 5c;0z. 40c.

Elegans. Annual white. Very largely grown by florists for use in bouquets. Pkt. $5 \mathrm{c}$; oz. $35 \mathrm{c}$.

HELENIUM, Autumnale Superbum. A showy perennial five to six feet tall, producing large deep-yellow single flowers durto six feet tall, producing large deep-yellow single
ing summer and fall; fine for cutting. Pkt. 10c.

Helianthus. See Sunflower.

HELICHRYSUM (Everlasting Flower). A free-flowering, hardy annual, growing four to five feet high and bearing beautiful straw-like flowers in a great variety of shades and colors. The stems are long and the blossoms large. It is the best and most satisfactory of the everlasting flowers, and makes a very handsome dried bouquet. Mixed. Pkt. 5c. 
HEIIOTROPE. A half-hardy perennial, growing four to eight feet high. Smail flowers, borne in graceful clusters and very fragrant. high. Small flowers, borne in graceful clusters and very fragrant. Blooms the first season from seed if sown early. Forms a large a wall and made to assume the character of a climber.

King of the Blacks. Dark purple, almost black. Pkt. 10c. Queen Marguerite. Purple Blue. Pkt. 10c.

White Iady. Pure white. Pkt. 10c.

Finest Mixed. A mixture of the ordinary true types. Pkt. 10c. Hesperis. See Sweet Rocket.

HIBISCDS. Giant Golden Bowl. Very large flowers, six to eight inches, of a deep cream color with velvety maroon center. Plants grow from three to five feet and are perennial and bear profusely. Pkt. 10c.

Crimson Eye. The flowers of this perennial are pure white with a crimson eye; six inches across; plants bloom the first year from seed and often bear fifty or more flowers at once; five feet; summer flowering. Pkt. 10c.

BONESTY (Satin Flower; Money Plant). The flat silvery seed pods are used for winter decoration. Very handsome, freeflowering. Two feet. Pkt. 5c.

HOLLYHOCK. A hardy perennial of upright, stately growth, five to eight feet high. The very double varieties are the most desirable, but the newer, semidouble, fringed types are also very popular. Hollyhocks make a fine row in a garden, or a fine background next to a building or high wall or fence.

DOUBLE VARIETIES. Mixed, pkt. 10c; oz. $\$ 1.50$. Black, Blood Red, Canary Yellow, Rose Pink, Salmon, Snow white, pkt. 10c; 6 pkts. assorted, 40c.

SINGLE VARIETIES. Mixed. The old-fashioned blossoms in all colors. Pkt. 5c.

Allegheny. Mixed. The semi-double, fringed variety. An artistic and pretty sort. Pkt. 10c.

Henderson's Everblooming. An early-flowering gorgeous mixture of single and semi-double blossoms. Pkt. 5c.

HUMUIUS, OR JAPANESE HOP. A rapid-growing, hardy climbing annual with dense leaves. Will grow twenty to thirty feet in a season, and is very valuable for covering a trellis.

Japonicus. Bright-green foliage. Pkt. 10c.

Japonicus Variegatus. Bright, variegated yellow, white and green leaves. Pkt. 10c.

HUNNEMANNIA, OR BUSH ESCHSCHOLTZIA. Known also as the Santa Barbara Poppy. An erect-growing, tender perennial, about two feet high. Foliage fine-cut and feathery. Blossoms, beautifully cupshaped, bright yellow, and about three to four inches across. Stems, iong and smooth. There are few more satisfactory flowers in the garden than the Hunnemannia. Fumariafolia. Pkt. 5c.

Hyacinth Bean. See Dolichos.

ICE PLANT (Mesembryanthemum Crystallinum). A lowgrowing and trailing tender perennial. The thick leaves seem to be covered with crystals. Used for edging embankments and box. work; thrives in bright sunlight and in dry situations. Pkt. 10c.

IMPATIENS SULTANI (Zanzibar Balsam). Much prized for window culture. The foliage is waxy green, and with the semi-transparent branches makes a plant in itself attractive. The bright rosy carmine flowers are very delicate and pretty. Pkt. 15c.

IPOMOEA. An extensive genus, including many wellknown garden flowers. Are tender climbing annuals, from five to ten feet long, and all classes are desirable. The seed of several varieties, especially the moon flower, should have the outer shell punctured and then soaked in water for twelve hours or more to germinate it.
IPOMOEA-Continued

Bona Nox (Evening Glory, or Good Night). Large fragrant violet blossoms, expanding in the night. Pkt. 5c; 0z. 25c.

Coccinea, or Star Ipomea. Small scarlet blossoms; vines about ten feet. Pkt. 5c.

Grandiflora Alba (Moon Flower). Large white blossoms, five to six inches across, which expand at night. The vine grows very rapidly, as much as fifty feet in a season, and is covered at night and in the early morning with a multitude of fragrant white flowers. Pkt. 10c.

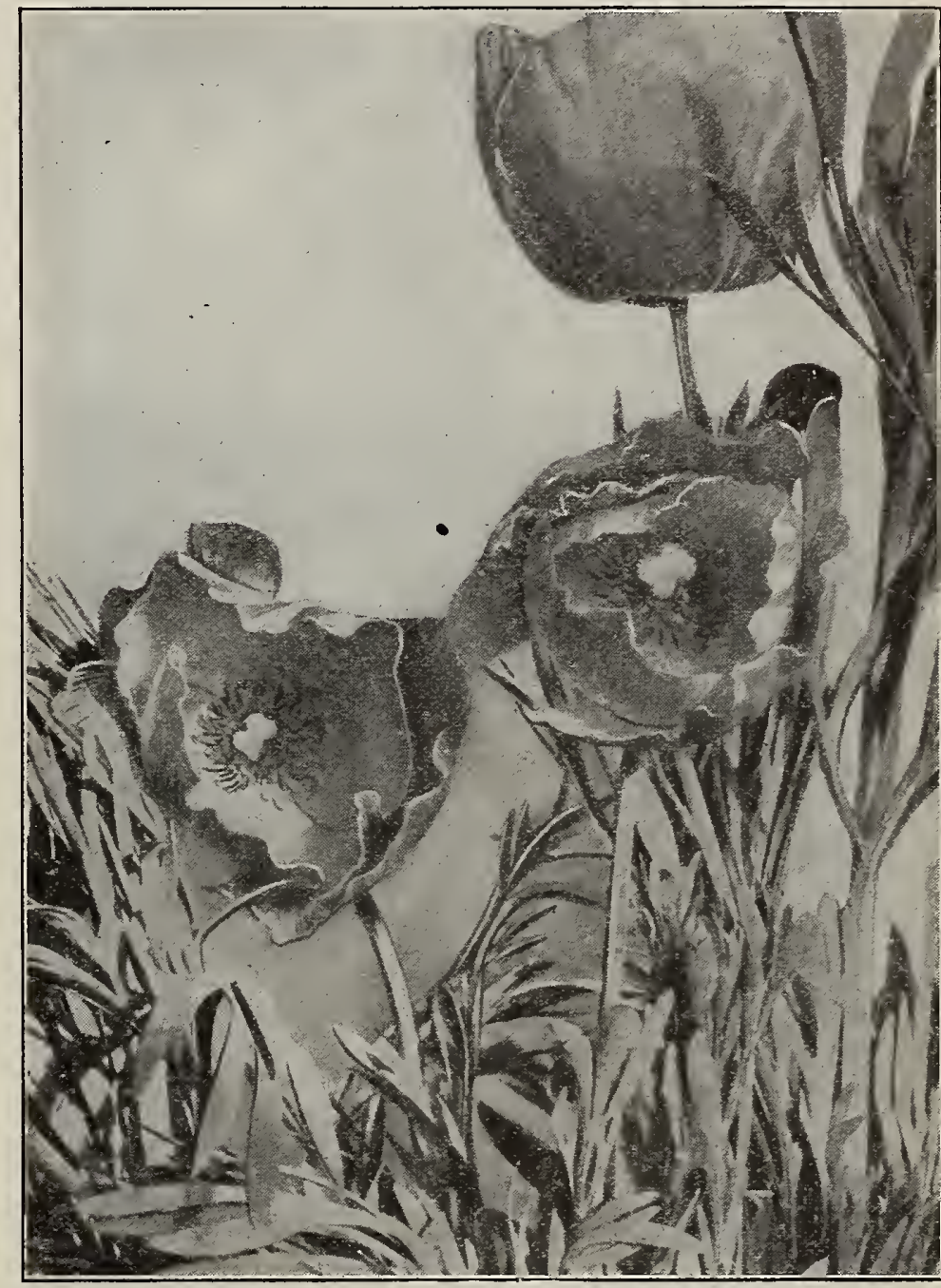

Hunnemannia, or Bush Eschschoitzia

NEW MOON FLOWER. Sky Blue. Of strong, vigorous growth, the plants quickly attain a height of twelve to fifteen feet. A dense mass of large heart-shaped leaves forms a most appropriate setting for the large sky-blue flowers, which come in September in great profusion. The flowers measure nearly four inches across, and are surpassingly beautiful-of the softest cerulean blue, shading to white at the throat. May be grown as a pot plant. Pkt. 10c.

Heavenly Blue. A tall climber with large light-blue flowers, yellow throated and measuring four to five inches across. Pkt. 10c.

Setosa, or Brazilian Morning Glory. The vine has large overlapping leaves eight to ten inches across, which make a dense shade; useful for covering porches or garden fences; annual. Beautiful rose-colored blossoms three inches in diameter. Pkt. 10c.

Learii. Large dark-blue flowers, on a quick-growing vine. Pkt. 25c.

Lutea. Yellow blossoms; vine of medium size. Pkt. 10c. Collection of the eight varieties for $60 \mathrm{c}$.

Imperial Japanese. See list under Morning Glory. Ipomea Quamoclit. See Cypress Vine. Japanese Hop. See Humulus Japonicus. 
KENIL WORTH IVY. A hardy perennial, trailing plant, especially adapted for hanging baskets or for trailing over walls. Pkt. 10c.

KENNEDYA (Bimaculata Grandiflora). A half-hardy perennial climber of much beauty. The flowers are borne in clusters of 20 or more; 10 feet; purplish blue. A pretty Australian vine. Plxt. 10c.

KOCHIA TRICOPHYLLA (Summer Cypress). A splendid ornamental annual plant, forming dense oval bushes 2 to $21 / 2$ feet high, of small, feathery, light green foliage. As summer advances this changes to a carmine hue and finally to a fiery red. $A$ very attractive plant at all times. Also called "Burning Bush." Pkt. 10c.

KUDZU VINE (Pueraria Thunbergiana). A new climber of great merit. This vine is one of the most rapid climbers there is, growing to 20 feet quickly. Call
Hardy perennial. Pkt. 15c.

IATHYRUS LATIFOLIUS. (Perennial or Everlasting Pea). A hardy perennial climber flowering the first year if seed is sown in the fall. Leaves and stems smooth. Flowers resemble sweet peas, but are borne on strong stems, with eight to ten blossoms to the stem. Is not fragrant, but is hardy and showy. and thrives in any good soil.

Pink Beauty. The ground of the petals is white, edged and shaded with pink. Pkt. 5c.

Crimson. Pkt. 5c.

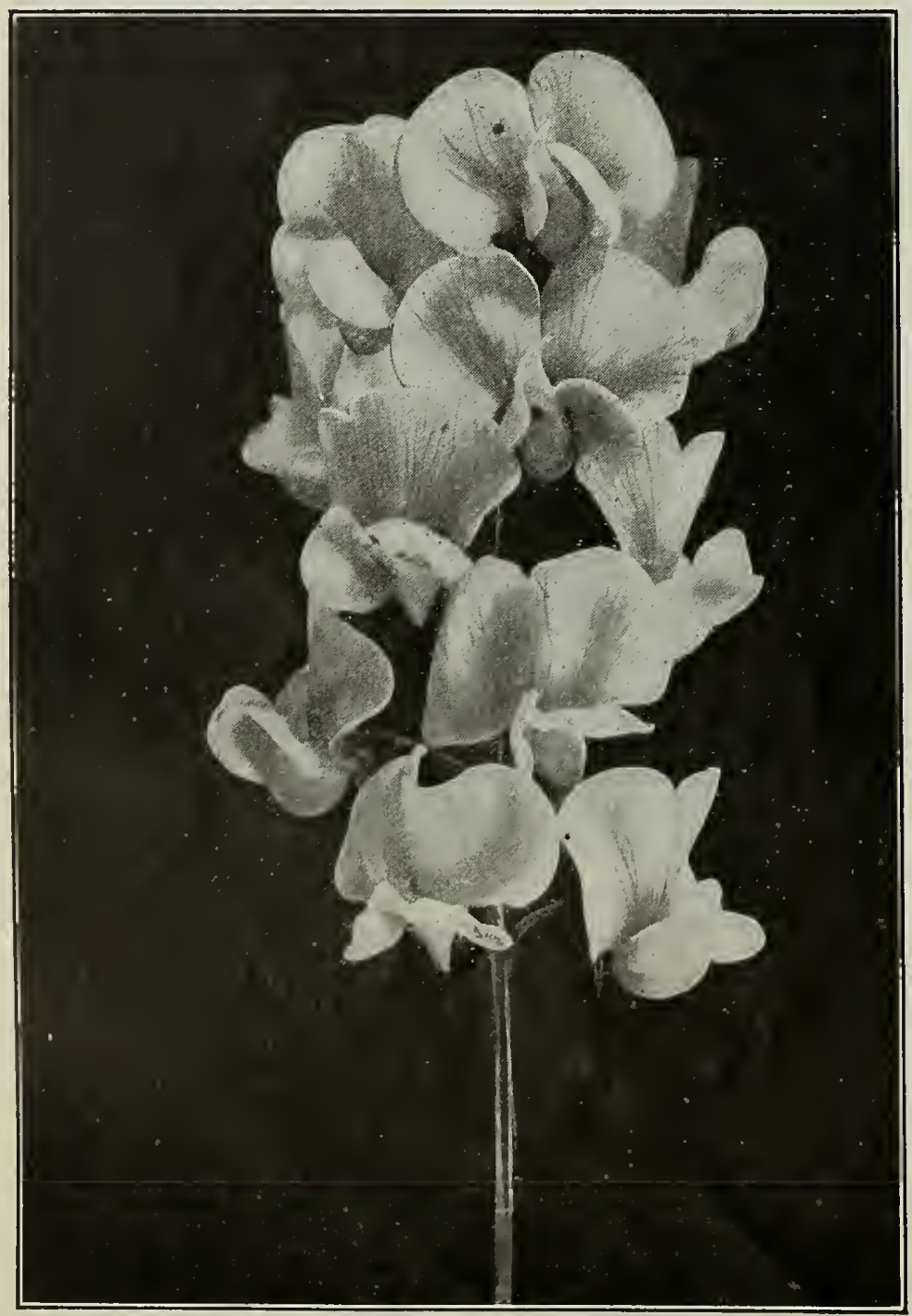

Lathyrus Latifolius-Pure White

White. The best variety for cutting, especially for florists' use. Pkt. 10c.

Mixed. Pkt. 5c.

Splendens. Called the "Pride of Callfornia." Not entirely hardy. Flowers are bright crimson-scarlet and are borne flower were highly bred, so beautiful is it, instead of being a wild flower from San Diego County. Pkt. 10c.

\section{LARKSPUR OR DELPHINIUM}

There are two classes of the Larkspur which are quite distinct-the annual and the perennial. Both are well known and are among the finest flowers.

HARDY ANNUAL VARIETIES. These Larkspurs grow about one and one-half to two feet high. A great variety of bright colors; of easiest culture, doing well in any soil.

Dwarf Rocket. Mixed. Dwarf plant, twelve inches for bedding; double flowers. Pkt. 5c; oz. 30c.

Emperor. Branching. The Emperor Larkspurs are very bright and showy and send up often forty or more erect spikes of double flowers; two feet. Rose, pink-flowered. Pkt. 5c.

White. Pkt. 5c.

Mixed, fine double flowers. Pkt. 5c.

HARDY PERENNIAL LARKSPURS (Delphiniums). These are taller than the annual sorts, and their brilliant flower spikes arrest your attention even at a distance. The foliage is attractive and the plants strong and neat in habit. By keeping the plants well watered and the flowers cut, a second crop of bloom may be had, and from some a third. The seed is a little difficult to start, so we advise sowing in a box in prepared soil and under a glass.

Cardinale. This is the grand "Southern Scarlet Larkspur," one of the brightest and finest of California wild flowers, and which makes the Southern mountainsides a blaze of glory in mid-June; three to five feet. Pkt. 20c.

Chinese Mixed. Large single flowers on spikes; two to three feet; the flowers have all the delicate shades of blue from white to deep indigo; flowers early from seed sown in the spring. Pkt. 10c.

Elatum Hybridum. Blue of various shades with black center; very handsome; three to five feet. Pkt. 10c.

Formosum. The variety most often seen. Bright blue flowers with white center. Tall spikes, three feet. Pkt. 10c.

Formosum Coelestinum. Like the above, but with azure or very light blue flowers. Pkt. 10c.

Collection of the five Perennial Larkspurs for $45 \mathrm{c}$.

IANTANA. A tender perennial often becoming shrub-like, two to three feet high, bearing verbena-like clusters of flowers, in orange, rose and other colors. Blooms constantly all summer. Fine mixed. Pkt. 10c.

IAVATERA. (Tree Mallow). A showy hedge plant, growing about six feet high and covered with shrimp-pink, cup-shaped flowers. Much used for windbreaks about San frants to twelve in May in the open ground and thin young plants to twelve

IAVENDER. Chiefly cultivated for the delicious and lasting fragrance of its flowers; succeeds in any common garden soil. Perennial. Pkt. 5c.

LEMON VERBENA. The leaves of this fine old favorite are delightfully fragrant and refreshing. Grown easily from seed. PKt. 10c.

LEPTOSYNE IMARITIMA (Sea Dahlia). Along the seashore of Southern California grows this very bright yellow wildflo: er. The plant is about two feet ligh and has succulent divided foliage. Flowers three to four inches across; annual. Pkt. 5c.

LINUM, OR SCARLET FLAX. A hardy annual, about one and one-half feet high. Of slender and graceful appearance, with smootl stems and bright-red flowers, which are borne in great profusion. Can be sown early out of doors, and thrives well in good soil.

Rubrum. Pkt. 5c.

Perennial Flax. Blue. Pkt. 5c.

LIPPIA REPENS. A dwarf branching plant which creeps over the ground, making a dense mat two inches deep. Thrives on very dry places, and after getting started needs water only once a month. Resembles white clover and is used as a substitute for grass on the lawn. Prt. 10c; 0z. \$2.50. 


\section{SAN FRANCISCO CALIFORNIA U.S.A.}

\section{LOBELIA}

A hardy annual and hardy perennial. The annual grows four to six inches high; is of compact growth, and literally covered with small bright flowers. By cutting back the plants during the summer and giving plenty of water, they may be kept in flower all summer. Used for ribbon work and borders or hanging baskets.

Crystal Palace Compacta. The variety most used for borders. Deep blue flowers and dark foliage; six inches; a constant bloomer. Pkt. 10c; 1/8 oz. 50c.

Emperor William. Sky-blue; compact. Pkt. 10c; 1/8 oz. 40c.

Golden Queen. Dwarf; blue flowers, yellow leaves. Pkt. 10c.

White Gem (Compacta). Snow-white flowers cover the plant. Pkt. 10c.

Gracilis. Light blue, trailing, light green foliage. Pkt. 5c.

Prima Donna. Maroon, with white eye. Pkt. 10c.

Speciosa. Deep blue flowers and dark foliage trailing. Pkt. 10c.

Mixed Compact Varieties. Pkt. 5c.

Perennial Lobelias are hardy and three feet high. The blossoms are produced in tall showy spikes.

Cardinalis, or Cardinal Flower. Brilliant scarlet flower spike. Worthy of more extensive cultivation. This plant loves a wet, boggy place, so water extra. Pkt. 10c.

Hybrids, Mixed. Large flowers, resembling Cardinalis. In all shades of rose, red, lilac, purple, etc. In flower all summer and fall. Pkt. 25c.

L OPHOSPERMUM SCANDENS. Tender climbing perennial, gTOTing ten to twelre feet long, with showy purplish-rose blossoms something like Foxglores. Pkt. 10c.

Lore-in-a-Mist. See Nigella.

Love Lies Bleeding. See Amaranthus Caudatus.

I UPINUS, OR LUPINS. Hardy native California annuals, in great variety, growing from one to three feet high, and bearing spikes of pea-shaped flotrers. Of the easiest culture. Sow in the open ground and thin to six inches apart.

Cruikshankil. Dark blue. Long racemes of beautiful blue flowers. Pkt. 5c.

Pink (Hybridus Roseus). Long spikes of bright pink flowers. Pkt. 10c.

Mixture of all colors. Pkt. 5c.

LYCHNIS. Hardy perennial growing about three feet high and bearing bright-colored flowers in clusters. Of easy culture. Chalcedonica. Scarlet flotrers. Pkt. 5c.

Haageana. Orange, crimson and scarlet flowers. Pkt. 5c.

MARIGOLD. A hardy annual, shrubby plant, in dwarf and tall varieties, growing from six inches to three feet high. Foliage, bright green, deeply cut, and graceful. The flowers are various shades of yellow and brown. The tall varieties are very valuable for large bedding or background work, and the dwarf varieties for borders.

Eldorado. Called "The African Marigold." The best tall variety, with large, very double blossoms.

Mized. Pkt. 5c;0z. 25c.

Dwarf French, Legion of Honor. Single brown and yellow. Pkt. 5c.

Striped. Pkt. 5c.

Mixed. Small flowers. Pkt. 5c; oz. $50 c$.

Tall French Mixture. A mixture of tall double, colors in yellow, brown, and stripes. Small flowered. Mixed, pkt. 5c.

Pot Marigold and Cape Marigold. See Calendula. Marguerite. See Chrrsanthemum frutescens.

Marvel of Peru. See Four O'clock.

Martynia. See Garden Seed List.

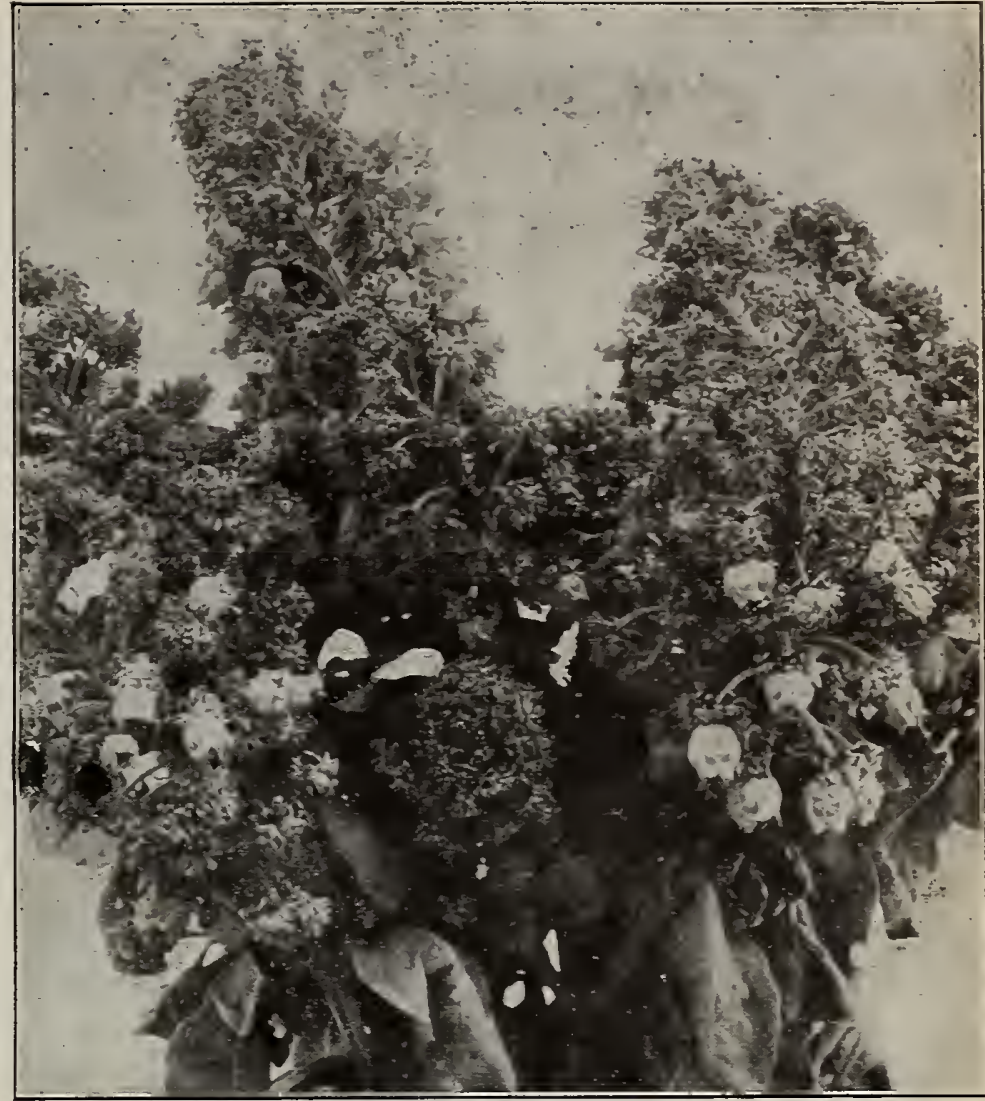

Mignonette

\section{MIGNONETTE}

A hardy annual, growing six to twelve inches high and bearing pyramidal-shaped flower spikes, made up of thickly-set flowerets, which are exceedingly fragrant. Grows easily from seed and can either be transplanted from boxes or sown out in the garden and thinned to four or six inches. Sow in the fall for early blossoms in the spring. Valuable for potting, or for bedding, or for border. The flowers are not attractive except for their fragrance.

Allen's Defiance. Long spikes of whitish flowers and compact growth. Pkt. 10c; 0z. 50c.

Golden Machet. A compact-growing variety, with medium long, thick spikes of yellow flowers. Pkt. 5c; oz. 50c.

Parson's White. A tall variety, with long spikes with silver-white flowers. Pkt. 5c; 0z. 50c.

Pure Machet. A compact-growing variety, with thick spikes and large flowèrets of copper color. Pkt. 5c; 0z. 50c.

Ruby Machet. A drarf compact variety, with large stubby spikes covered with copper-red flowers, etc. Pkt. 10c.

Sweet Scented (Reseda Odorata). Pkt. 5c; 0z. 25c. Collection of above six kinds for $25 \mathrm{c}$.

Mixture of the best compact varieties. Pkt. 5c;0z. 25c

MANDEVILIA SUAVEOLENS (Chili Jasmine). Fine summer climber with great clusters of large, waxy, star-shaped white
blossoms, exquisitely fragrant, resembling the single tuberose in shape. Pkt. 15c.

MATRICARIA (Double White Feverfew). Bushy perennial garden plant bearing quantities of white double button-like garden plant, bearing quantities of
flowers; useful for cutting. Pkt. 5c.

MAURANDIA (Giant-Flowering). Beautiful climber for either garden or greenhouse decoration and for hanging baskets; gemmed $\pi$ ith Gloxinia-shaped flowers of rich purple, white, and

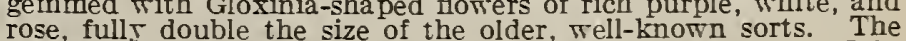
rose, fullr double the size of the older, mell-known sorts. The
plants from seed sown in spring will begin flowering by July plants from seed somn in spring will begin forrer. 
MINA LOBATA. A fine annual climber which grows very rapidly to a height of 20 or 30 feet in a season. Mina is one of our best climbers, the leaves are of good size and dense, and the flowers are freely borne in clusters; orange red. Useful for arbor, trellis, etc. Pkt. of 20 seeds, $10 \mathrm{c}$.

MIMULUS. A half-hardy perennial, growing from six inches to one foot high. Blooms freely and exists in a large variety of colors. Useful for window gardens and pot work or for garden in a moist, shady situation. Blooms first year from seed if sown early.

Moschatus, or Musk Plant. Fragrant plant, with small, yellow blossoms, spotted lightly with brown. Pkt. 5c.

Tigrinus, or Monkey Flower. Large flowers of several colors, and spotted. Pkt. 10c.

Cardinalis. Scarlet flowered perennial ; 18 inches high; useful for a border; free, flowering. Pkt. 10c.

MOMORDICA. Balsamina, or Balsam Apple. A climbing annual, growing about 10 feet long. Has graceful and ornamental foliage, yellow flowers, and warted golden-yellow fruit, with large carmine-red seeds. Balsam Apple and Balsam Pear are climbers which thrive in hot locations, and are much planted around Bakersfield. Pkt. 5c; oz. 30c.

Charantia, or Balsam Pear. Same as the Balsam Apple, but fruit is pear-shaped. Pkt. 5c; oz. 40c.

Moonflower. See Ipomea Grandiflora Alba.
MORNING GLORY (Convolvulus Major. See also Ipomea.) No climber is more popular than is the Morning Glory; for covering trellises or unsightly back fences they and climbing Nasturtiums are most often planted. Morning Glories grow quickly to a vine fifteen feet long and bear very abundantly brilliant flowers, funnel-shaped, of various colors, blue predominating. Soak the seed for two hours in warm water to hasten germination; of easy culture. See Ipomeas for Brazilian Morning Glory and for sorts not listed here.

Tall, or Climbing Varieties. Mixed. Pkt. 5c; 0z. 15c. Imperial Japanese. These are much the handsomest flowers in Morning Glories, of gigantic size and in colors ranging from snow white to carmine, through every shade of blue and purple to nearly black, also marbled, striped and slashed sorts. The vine is not quite so vigorous a climber as the above. Pkt. 5c; 0z. 20c.

Dwarf, or Bush Varieties (Convolvulus Minor). Plants grow ten to twelve inches high, and are hardy annuals. Useful for beds, edges, or hanging baskets. Mixed. Pkt. 5c.

Mourning Bride. See Scabiosa.

Musk Plant. See Mimulus Moschatus.

Myosot is. See Forget-me-not.

\section{NASTURTIUM}

Tender annual, in two distinct classes-Dwarf, and Tall or Climbing

The foliage of nasturtiums is pretty and the flowers very beautiful and contained in a great number of brightest colors and tints. Sow the seed where it is to remain late in the spring after danger of frost is over. It is seldom necessary to thin the young plants, as they will bear standing close together.

Nasturtiums prefer dry rather rocky soil, such as we usually call "poor" soil, and bear their flowers in such locations in greater profusion than in a rich garden, where they run too much to leaves. This adds to their value for planting over many unsightly places.

\section{TALL, OR CLIMBING VARIETIES}

Of quick growth, covering a wall, hedge, or trellis in a short time. The brilliant blossoms almost cover the plant from top to bottom.

Butterfly. Light yellow, with blotch of deep red on lower petal. Pkt. 5c; 0z. 20c; $1 / 4$ ib. 60c.

Caprice. A mixture of light colors, spotted and shaded, with dark foliage. Pkt. $5 \mathrm{c} ; 0 \mathrm{z} .15 \mathrm{c} ; 1 / 4 \mathrm{ib} .45 \mathrm{c}$.

Chameleon. A mixture of changing or inconstant shades. Pkt. $5 c ; 0 z .15 c ; 1 / 41 b .35 c ; 1 b . \$ 1.20$.

Dark Crimson. Pkt. 5c; 0z. 10c; $1 / 41$ b. 30c.

Jupiter. Large, bright, golden yellow. Pkt. 5c; oz. 20c; 1/4 1b. $60 \mathrm{c}$.

Midnight. Flowers deep brownish red; foliage deep green. Pkt. $5 c ; 0 z .20 c ; 1 / 41 b .60 c$.

Moonlight. Immense creamy-yellow flowers. Pkt. 5c; oz. 15c: $1 / 41 \mathrm{~b} .40 \mathrm{c}$

Orange. Pkt. 5c; oz. 15c; 1/4 1b. 40 c.

Pearl, or White. Light lemon or primrose. Pkt. 5c; oz. 15c; 1/4 1b. $40 \mathrm{c}$.

Rose. Pkt. 5c; 0z. 15c; $1 / 4$ 1b. 40c.

Scarlet. Pkt. 5c; 0z. 15c; 1/4 1b. 40c.

Sunlight. Bright yellow. Pkt. 5c; 0z. 15c; $1 / 4$ 1b. 40c.

Twilight. Large blossoms of light salmon, suffused with rosy salmon. Pkt. 5c; 0z. $15 \mathrm{c} ; 1 / 4$ 1b. 40c.

Yellow. Pkt. 5c; oz. 15c; 1/4 1b. 40c.

Tall Varieties Mixed. All the above varieties, besides many others, in a splendid mixture. Pkt. 5c; oz. 10c; $1 / 41 \mathrm{~b} .25 \mathrm{c}$; 1b. 70c.

Ivy-leaved. A mixture of several colors; have lobed or scalloped leaves. The blossoms have scalloped edges. Very pretty and leaves. The blossoms have scalloped edg
attractive. Pkt. 5c; oz. 25c; $1 / 41$ b. 75c.

VARIEGATED QUEEN, OR TALL VARIEGATED LEAVED IIIXED

Every leaf is variegated with yellow, white and green. Some of the leaves are one-half to two-thirds white and yellow wlile others are mostly oreen, but beautifully striped and blotclied. This gives a new and very handsome appearance to the plant.

The flowers are of all colors. It comes entirely true from seed. Pkt. 10c; 0z. 35c.

\section{LOBB'S CLIMBING NASTURTIUMS (TROPAEOLUM LOBBIANUM)}

A tall, or climbing class. The leaves are smaller and the flowers more numerous and prolific than the ordinary tall class.

These are very similar to the ordinary climbing nasturtiums, the chief difference being in the bright shades and darker leaves of some. The flowers are slightly smaller, but are borne more freely.

Lobb's Varleties Mixed. Pkt. 5c; 0z. 10c; 1/4 1b. 30c; 1b. \$1.00. Asa Gray. Light lemon or primrose. Pkt. 5c; oz. 15c; $1 / 41 b .45 c$. Crown Prince of Prussia. Blood red. Pkt. 5c; oz. 15c; $1 / 41 \mathrm{~b}$. $45 \mathrm{c}$.

Crystal Palace. Orange scarlet. Pkt. 5c; oz. 15c; 1/4 1b. 45c.

Giant of Battles. Sulphur yellow, blotched with red. Pkt. 5c; 0z. $15 \mathrm{c} ; 1 / 4 \mathrm{lb} .45 \mathrm{c}$.

King of the Blacks. Dark-red flowers and dark foliage. Pkt. 5c; oz. $15 \mathrm{c} ; 1 / 4 \mathrm{Ib} .45 \mathrm{c}$.

Lucifer. Blossoms, deep crimson; leaves, brownish green. Pkt. 5c; oz. $15 \mathrm{c} ; 1 / 4 \mathrm{lb}, 45 \mathrm{c}$

Regina. Salmon red, changing to almost cream color. Pkt. 5c; Oz. 15c; $1 / 41 \mathrm{~b} .45 \mathrm{c}$.

Spitfire. Brilliant scarlet. Plst. 5c;0z. 15c; 1/4 1b. 45c.

Hybrids of Madam Gunter. Mixed. A splendid mixture of blotched, shaded, and variously marked petals in bright, glowing tints. Pkt. 5c; oz. 10c; $1 / 41 \mathrm{~b} .30 \mathrm{c} ; 1 \mathrm{~b} . \$ 1.00$.

\section{DWARF NASTURTIUMS}

The plants form a small, round bush twelve to 16 inches high which is a mass of bloom all summer. Do not water too much nor sow on rich ground for abundance of bloom.

Aurora. Yellow, veined carmine. Pkt. 5c;0z. 10c; 1/4 1b. 30c.

Chameleon. Mixed. A dwarf mixture of blotched and inconstant shades on one plant; such as bronze and crimson or yellow. Pkt. shades on one plant; such
$5 \mathbf{5 c} ; 0 \mathbf{0 z} 20 \mathrm{c} ; 1 / 41 \mathrm{~b} .60 \mathrm{c}$.

Crimson. Pkt. 5c;0z. 15c; $1 / 41 \mathrm{~b} .45 \mathrm{c}$. 


\section{SAN FRANCISCO, CALIFORNIA. U.S.A GYMg}

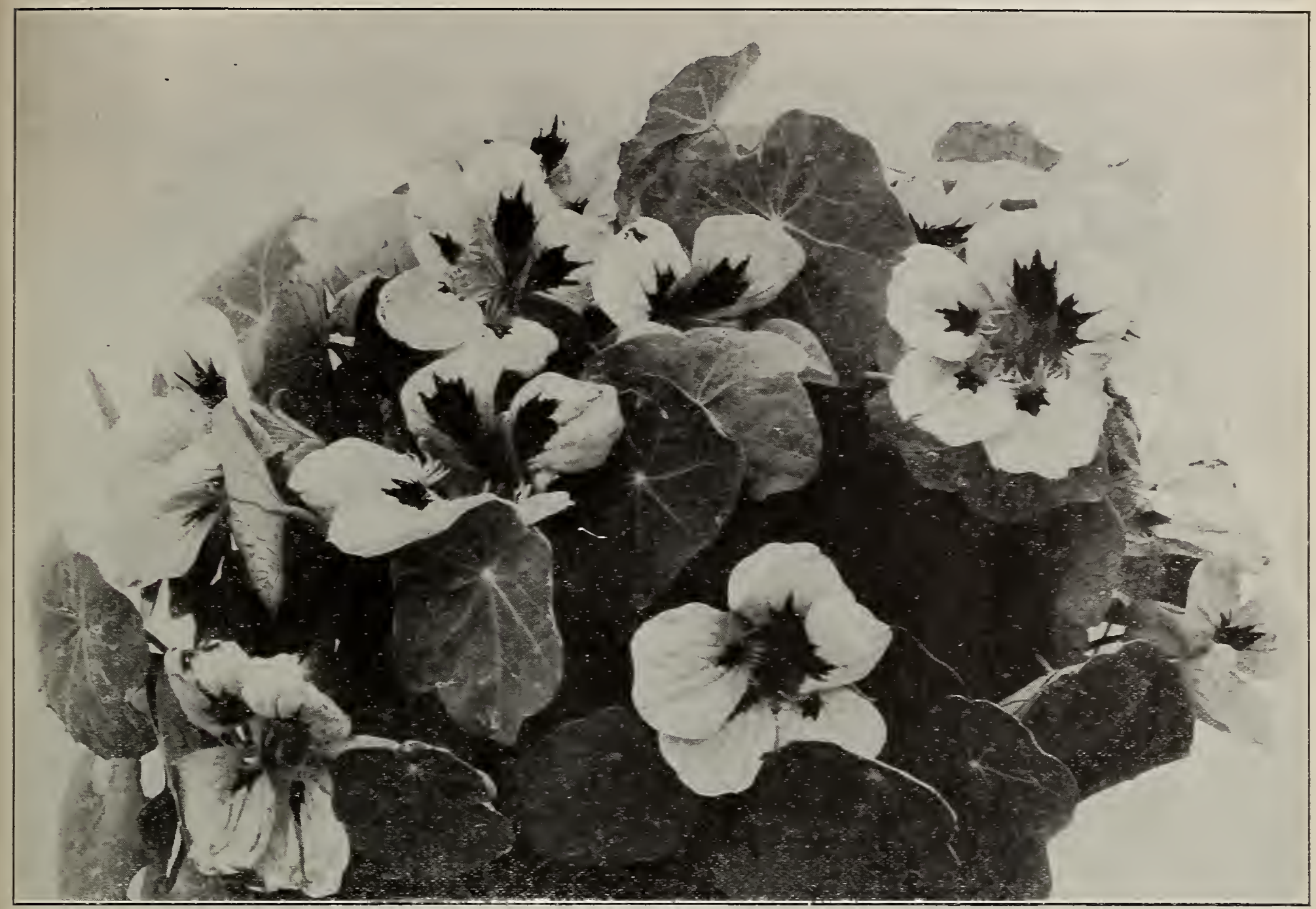

Crystal Palace Gem-Dwarf Nasturtiums

Crystal Palase Gem. Sulphur sellow, spotted with carmine. Pkt. $\mathrm{c}$ c; oz. $10 \mathrm{c} ; 1 / 1 \mathrm{~b} .30 \mathrm{c}$.

Empress of India Interse scarlet with foliage dark brown and green. A splendid rariet5. Pht.50;0z. $150 ; 1 / 11 \mathrm{~b} .45 \mathrm{c}$.

Golden King. Rich golden Je!lor. FLt. 5c;0z, 15c; 1/z lb. 45 c. "Golden Midnight." The foliage is a light reliowish-green, while the flowers are of such a dark maroon as to seem almost black. blossoms is unique and at the same time beautiul. Pkt. $15 \mathrm{c}$.

King of Tom Thumbs. Dark scarlet and dark-green leares. PLt. 5c;0z. 100; $1 / 11 \mathrm{~b} .30 \mathrm{c}$.

King Theodore. Ters deep crimson and dark foliage. The darkest of all, nearls blact. Pkt. $5 \mathrm{c} ; 0 \mathrm{z} .15 \mathrm{c} ; 1 / 1 \mathrm{~b} .45 \mathrm{c}$
Rose or Pink. Pkt. 5c; oz. $10 \mathrm{c} ; 1 / 41 \mathrm{~b} .30 \mathrm{c}$.

Ruby Ring. Bright red, tinted salmon. Pkt. 5c;0z. 10c; 1/ 1b. 300 .

Queen of Tom Thumbs. Silter rariegated foliage, crimson flotrScarlet. Ekt. 50;0Z 100;1/110. 30c.

White Fearl. Tert light lemon or primrose. Plzt. 5c; oz. 10c; $1 / 110.300$.

Yellow. Pzt. 5c;0z. 100;1/11 1b. 30c.

Dwarf Varleties Mized. A splendid mixture of all the abore, 1b. $85 \mathrm{c}$.
NEMOPAIIA, OR IOVE GRASS. A hards annual California mild-fiomer, growing about six inches high. Has small, cupshaped blossoms about vye inch in diameter, in white and shades ớ blue. Mised, plet. ŝc.

INSRGNIS (Baby BIue Eyes). ShJ blue, with white eres. Pl.t. Ec; $0 z .150 ; 1 \mathrm{~b}, \$ 1.00$

Maculata. Mhite, with each petal sposted riolet at tip. Pkt. $5 \mathrm{c} ; 0 \mathrm{z}, 200$.

NICOIIANA, OR FIOWERING TOBACCO. A half hard $\Gamma$ annual. growing 3 feet high with slender tubular floter. Belongs to the tobacco tamil: Prequires pienty of room in the garden. Affinis. Thite, and rers fragrant. Pkt. 5c.

Afinis Eybrids. Splencid net hrbrids of the popular $\mathrm{x}$. Affinis: theJ poss ss the delicious fragtance of the parent: colors blue, red, rose, white, etc. Pkt. $15 \mathrm{c}$.

Colossea. Giant foliage plant of a dark glossy green with reddish ribs. Pkt. $10 \mathrm{c}$.
Sanderaea, A new, large, flowering type, with rarious brightNIGEIIA, OR TOVE $=T N=A=$ TTST white, and curous seed pods. Oî̀ easy culture.

Damascena. Pikt. $5 \mathrm{c}$.

OENOTHEDA, OR ETENING FRIMROSE. A half hardJ 2mnual and petinniai, about sil inches figh, beating brigh, sitomy The blossom is fully expanded onle late in the aftemoon.

Annual Varieties. Mired. Pkt. 5c.

Yellow (Lamarckianz). A bzight jeltom erening primrose,

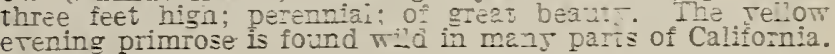
erening

0XALIS. A half hardr perennial bulbous p'ant growing about nine inches high and sultable for greenhouso, rocis-roriz. of edgings.

Flowers bright colored and showt. Mixed. Pkt. 10c. 


\section{C.C.MORSE \& CO. RLWER SEEDS}

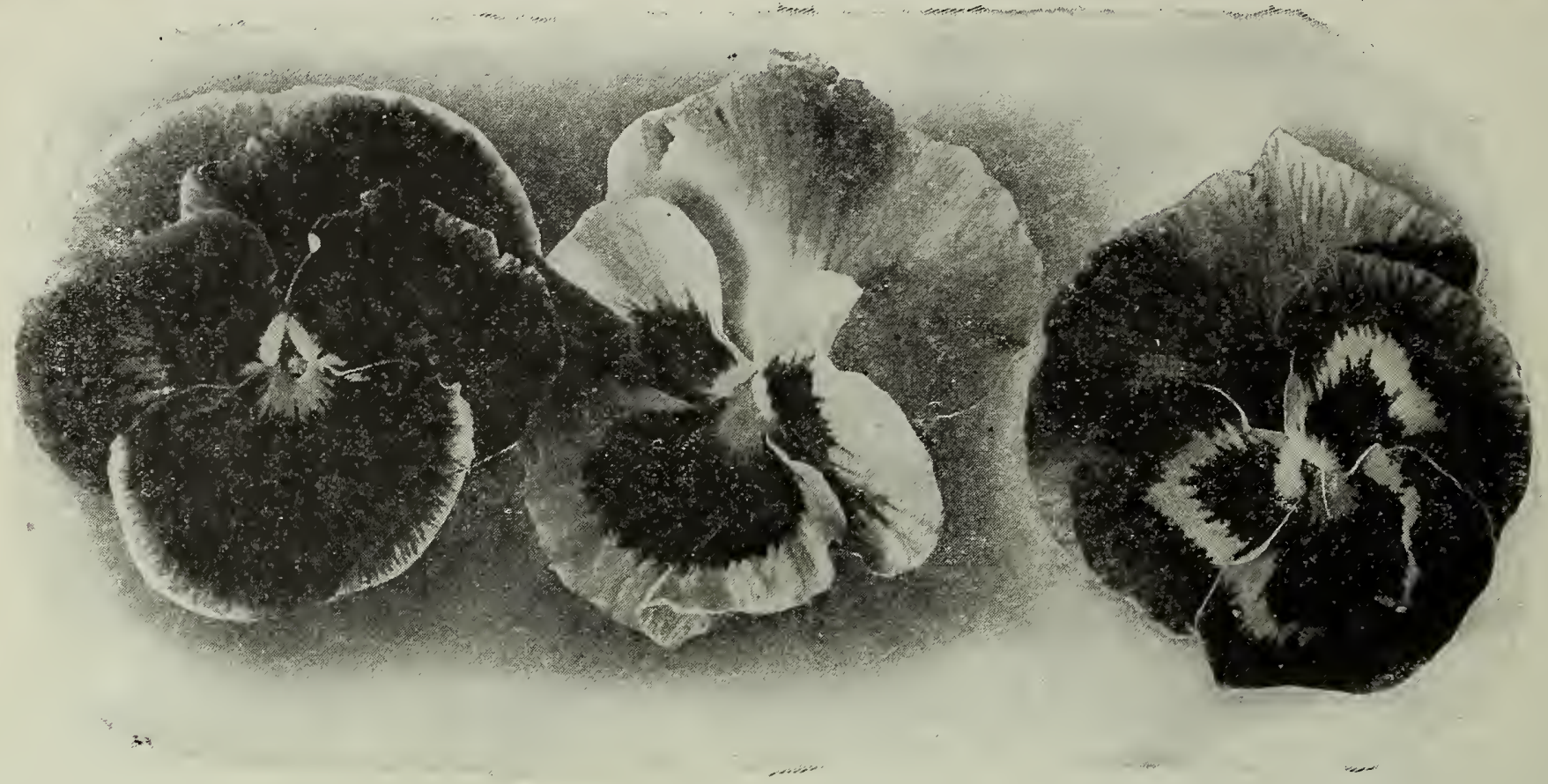

Morse's Prize Strain Pansies About $2 / 3$ natural size.

\section{MORSE'S SUPERB PANSIES}

All our Pansy seed is obtained from the most noted European specialists. Pansies thrive best in a moist, shady location and in rich, loamy soil. Seed should be sown in the autumn for early spring blossoms, or can be sown early in the year for good flowers later in the spring. The plants. must be transplanted twice in order to get the largest flowers; once from the seed box to a chosen bed, and again to the open garden. This is important for large size pansies; use manure liberally. The blossoms are usually larger in the spring and again in the fall, and whike they bloom freely all summer, the blossoms are small during the hot months. While the plants carry over well with a little covering during the winter, it is best to plant new seed each year.

\section{EXTRA FINE GIANT-FLOWERED PANSIES}

We offer in the following colors and varieties, these pansies, which are different from the named sorts listed. They are some of the separate sorts out of our famous "Prize Strain Mixture," and are truly giant in size.

Pure White,

White with Dark Center,

Hortense Red: old rose color,

Pure Yellow,

Yellow with Dark Center,

Madame Perret: wine color and white,

Emperor William: dark blue,

Lord Beaconsfield: purple and lavender,

Faust: pure black,

20c per packet; the collection of 9 finest sorts, $\$ 1.35$.

\section{SPLENDID MIXTURES}

MORSE'S PRIZE STRAIN. This is a mixture of all the giant-flowered varieties, all the plain colors, faced sorts, ruffled edged, and rare sorts; also the varieties exquisitely marbled, striped and blotched. The seed is saved from Germany's striped and blotched. The seed is saved from Germany's PRIZE STRAIN pansies are wonderfully beautiful in every way, and are the very best there are.

$$
\text { Pkt. of } \mathbf{5 0 0} \text { seeds, } \mathbf{5 0 c} \text {. }
$$

Morse's Imperial German Strains Mixed. A superfine mixture of the choicest German varieties in all colors. Pkt. 25c.

Bugnot Mixed. A circular, ruffled, and five-petaled type, with soft, blended colors and tints, veined on the margins and with a dark blotch at the base of each petal. One of the finest varieties. Pkt. 25c.

Cassier's Giant, Mixed. A splendid mixture of various shades and markings. The blossoms are perfectly round and are blotched at the base of 3 to 5 of the petals. Pkt. 25c.
Giant Trimardeau, Mixed. The largest flowering type of pansies, called the French strain. The top petals are larger than the
3 lower ones and are beautifully marked. Pkt. 15c; oz. $\$ 2.00$. Giant Odier or Prize Blotched, Mixed. A large flowered type, with round blossoms. The petals are all blotched at the base and distinctly margined on the edge. Pkt. 25c.

Giant Masterpiece. These new pansies have a most beautiful combination of rich velvety coloring and attractive wavy or ruffled petals. This wavy effect gives a graceful appearance rarely seen in pansies, and while they are really very large, they appear larger on this account. Pkt. 25c.

\section{THE BEST SEPARATE COLORS OR NAMED VARIETIES}

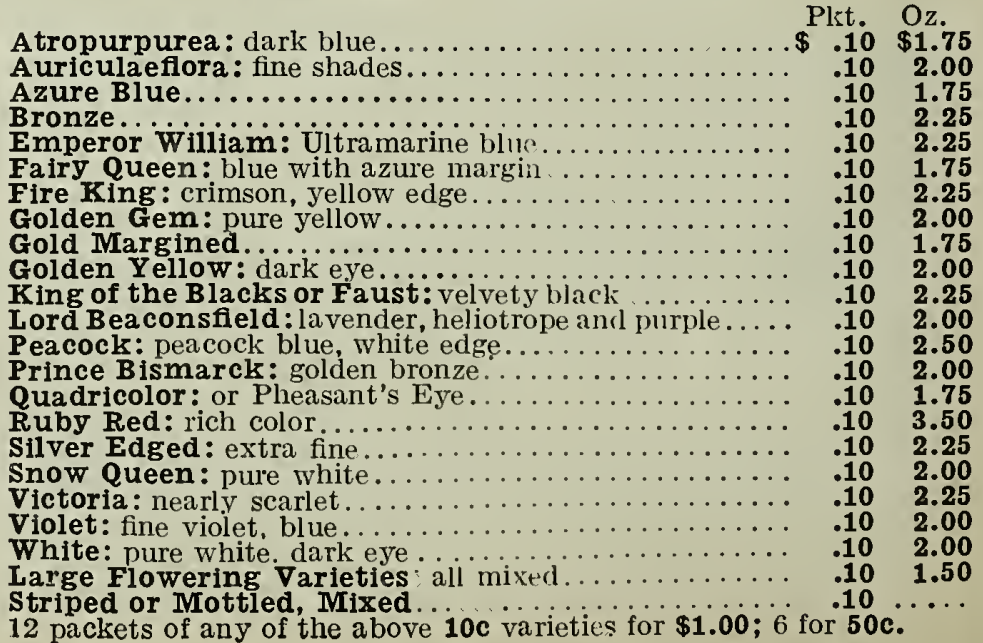


PASSION FLOWER (Passiflora). A half hardy perennial climber. shedding its leaves in winter. Grows luxuriantls either from sheding its leares in winter. growth, as it will corer a porch or small cottage in one summer.

Pink, evergreen foliage. Pkt. 10c.

Purple, pkt. 10c.

Scarlet, erergreen foliage, pkt. $10 \mathrm{c}$.

White, pkt. $10 \mathrm{c}$.

Pelargonium. See Geranium.
PENTSTEMON. One of our best flowers for the hardy perennia border; grows two feet high; flowers the first season from seed, and blossoms freely. Pentstemon sends up spikes of brightcolored and spotted flowers somewhat like the Foxglore, but in a great variet 5 of shades and colors. A decidediy beautiful and satisfactory flower. Mixed. Pkt. 10c. Perennial Pea. See Lat hrrus Latifolius.

PERIILA NANKINENSIS. Has very dark bronze, almost black foliage. Similar to Coleus. Is of easy culture. A half hardy annual. Pkt. 5c. Periwinkle. See Vinca

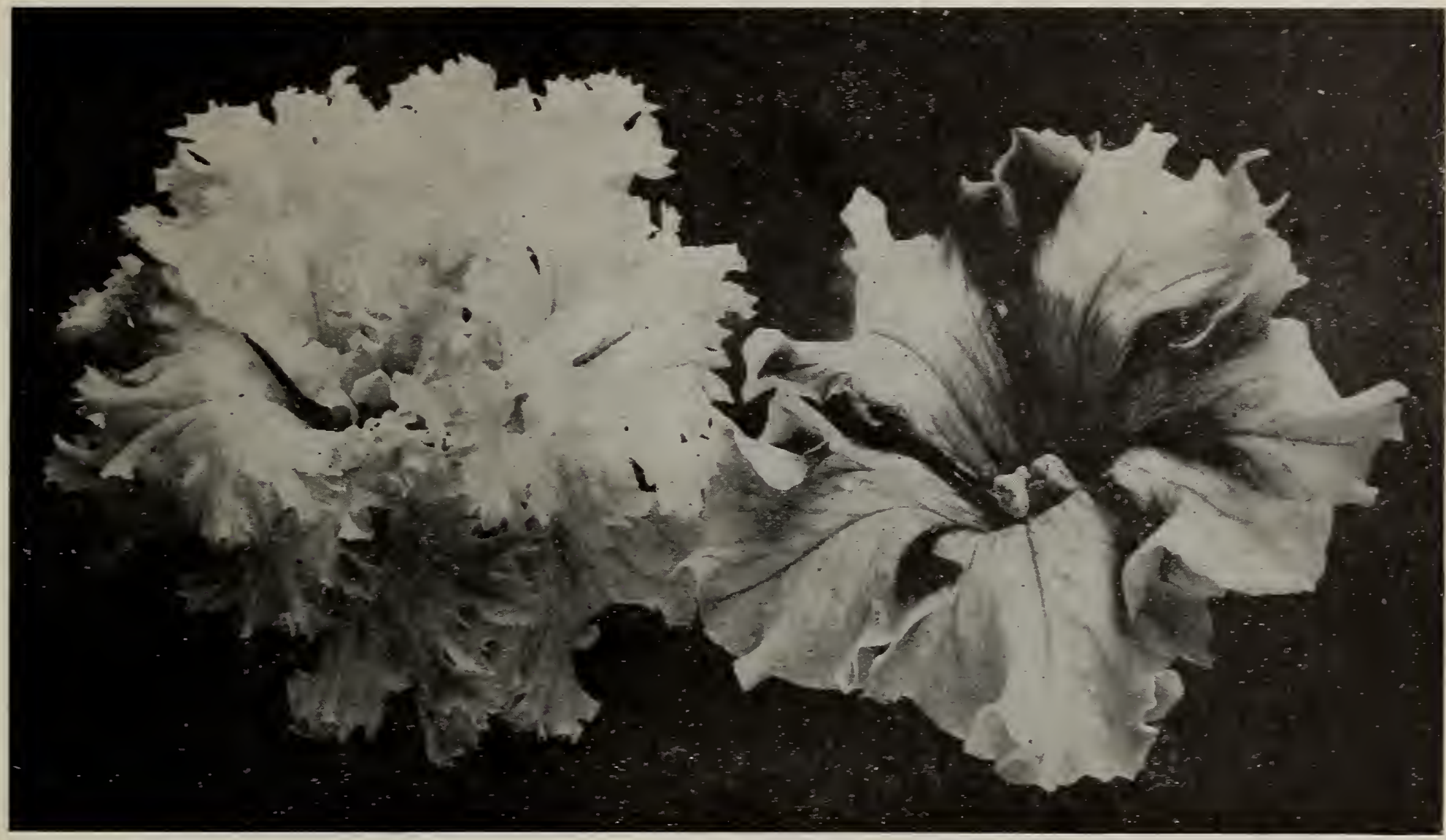

Strains of Giant Petunia-Single and Double Fringed

\section{PETUNIA}

A tender perennial, of several distinct types, and variously adapted for greenhouse and pot culture, and for open air. The latter grows with little attention or care, and in any soil, and blooms profusely all spring and summer. The large, double varieties do not produce seed, but the pollen from them is artificially crossed on the large, single, and fringed plants, and the seed so produced will make a percentage of double blossoms. The Giant Flowered types are in large, single, plain edged, or fringed edged blossoms, or in very thickly double flowers.

Giant Flowered Varieties, all fertilized by hand-

Single. Deep throated, brilliantly blotched, plain edge, mixed. Pkt. 25c.

Single. Deep throated, brilliantly blotched, fringed, mixed. Pkt. 25c.

Double. White, blotched, and brilliantly colored, mixed, plain edged. Pkt. $25 \mathrm{c}$.
Double. Striped, blotched, mixed, fringed. Pkt. 25c.

Small Flowered Varieties-

Dwarf Inimitable. Mixed. A rery free-blooming, dwarf plant; cherry red with white stripes. Pkt. 10c'

Fine Mixed. Good mixture of small free-blooming colors. Pkt. 5c.
PHYSALIS. FRANCHETTI, OR CHINESE LANTERN PLANT A show 5 annual, growing two feet high and esteemed for its seed pods which in fall change from brilliant rellow to scarlet seed pouch are round and pointed and resemble a small lantern. The fruit inside the pod is sometimes made into preserves. Pkt. 10c.

PLATYCODON GRANDIFLORA, OR JAPANESE BELL. A giant bell flower growing two feet tall and covered all summe with large steel-blue flowers. One of the rery best perennials and should be more widely planted. Pkt. 10c.
Phaseolus Caracalla, See Snail Vine.

Pinks. See Dianthus.

Polyanthus. See Primula.

PERENNIAL HARDY PHLOX. A beautiful and easily grown perennial about three feet high and bearing clusters of bright-colored, phlox-like blossoms. There is no more satisfactory flower for the garden, and should be in far more general use than it is now. Decussata Mixed. Pkt. 10c. 


\section{C.C.MORSE \&. CO. FLOWER SEEDS}

\section{PHLOX DRUMMONDII}

PHLOX DRUMMONDII. Grandiflora. A hardy annual, growing from six inches to one foot high and bearing beautiful, soft-petaled, and brilliantly colored flowers all spring and summer. Fine for bedding, and massing. Sow seed in the fall for early flowers. Atropurpurea. Deep purple. Pzt. 10c. Carnea. Pink, with chamois-rose center. Pkt. 10c. Coccinea. Brilliant scarlet. Plt. 10c. Eclipse. Bright, rosy purple and violet. Plat. 10c. Rermisina. Vivid crimson. Plst. 10c.
Large Blood Red. Pkt. 10c.

Pure White. Pkt. 10c.

Splendens. Dwarf, bright red, with white eye. Pkt.10e.

Yellow (Isabellina). Soft primrose. Plt. 10c.

Collection, one packet each of above nine sorts for $65 \mathrm{c}$.

Fine Mixture of all colors of the larger types. Pkt. 5c; 0z. 50c.

Dwarf Compact. Mixed. Low-growing plants, with good-sized fiowers. Pkt. 10c.

Starred and Fringed. Nixed. A mixture of starshaped and pointed blossoms. Pkt. 10c.

\section{POPPY}

A hardy annual, three to five feet high, and bearing single and large double blossoms in bright colors. Sow seed in open ground where plants are to remain, and thin to six or twelve inches. If left thick the. plants will be weak and spindling and the blossoms inferior. To avoid getting the seed too thick, it can be mixed with dry sand before sowing.

Double Varieties (Annual) -

Cardinal. A bright scarlet, fringed, double. Pkt. 5c; oz. $30 \mathrm{c}$.

Double White, Paeony Flowered. Straight edges. Plit. Sc; 0z. 30c.

Fairy Blush. A large, double fringed white, with pink edges. Plot. $5 \mathrm{c} ; 0 \mathrm{z} .30 \mathrm{c}$.

Shrimp Pink. Large double, straight edges. Pkt. 5c; oz. $30 \mathrm{c}$.

White Fringed, or Carnation Flowered. Large, double fringed. Ist. $5 \mathrm{c} ; 0 \mathrm{z} .30 \mathrm{c}$.

Large Double. Mixed. All colors. Pkt. 5c; oz. 25 c.

Single Varieties (Annual) -

Dannebrog. Brilliant scarlet, with white center; four arge petals. Pkt. 5c.

Tulip rlowered. Intense scarlet, single blossoms. Plant about two and one-half to three feet high. The brightest colored of all poppies. Pkt. 10c; oz. 50 c.

Shirley. The most beautiful type of poppies, having soft, hairy foliage, and an immense variety of single blossoms in white, pink, lavender, purple, shades of red, and scarlet. The petals are very dainty and look as if made from crepe paper. Free blooming and fine for bedding or tall border. Nixed. Pkt. 10c; oz. 50c.

Umbrosum. Vermilion petals, with black spots on each, similar to Shirley Poppy. Plt. 5c; oz. 30c.

Collection of one packet each of above ten kinds for $40 \mathrm{c}$.

\section{PERENNIAI POPPIES}

Hardy perennial, of easy culture; in bright, glowing colors. Blooms first year from seed.

Iceland. Mixed. A graceful, delicate variety, twelve inches tall, with white, orange, and yellow single blossoms, the petals rescmbling crumpled tissue paper. The plant is low and compact, but the flowers on their slender stalks are excellent for cutting. Sow in the fall, where plants are to remain, and thin. Pkt. 10c.

Orientale (The Iarge Oriental Poppy). A hardy plant, bearing large brilliant crimson flowers, with a black blotch on each petal. Very showy and attractive; two and one-half feet tall. Pkt. 10c.

Bracteatum. Immense orange-scarlet flowers very similar to the Oriental Poppy. Pit. 10c.

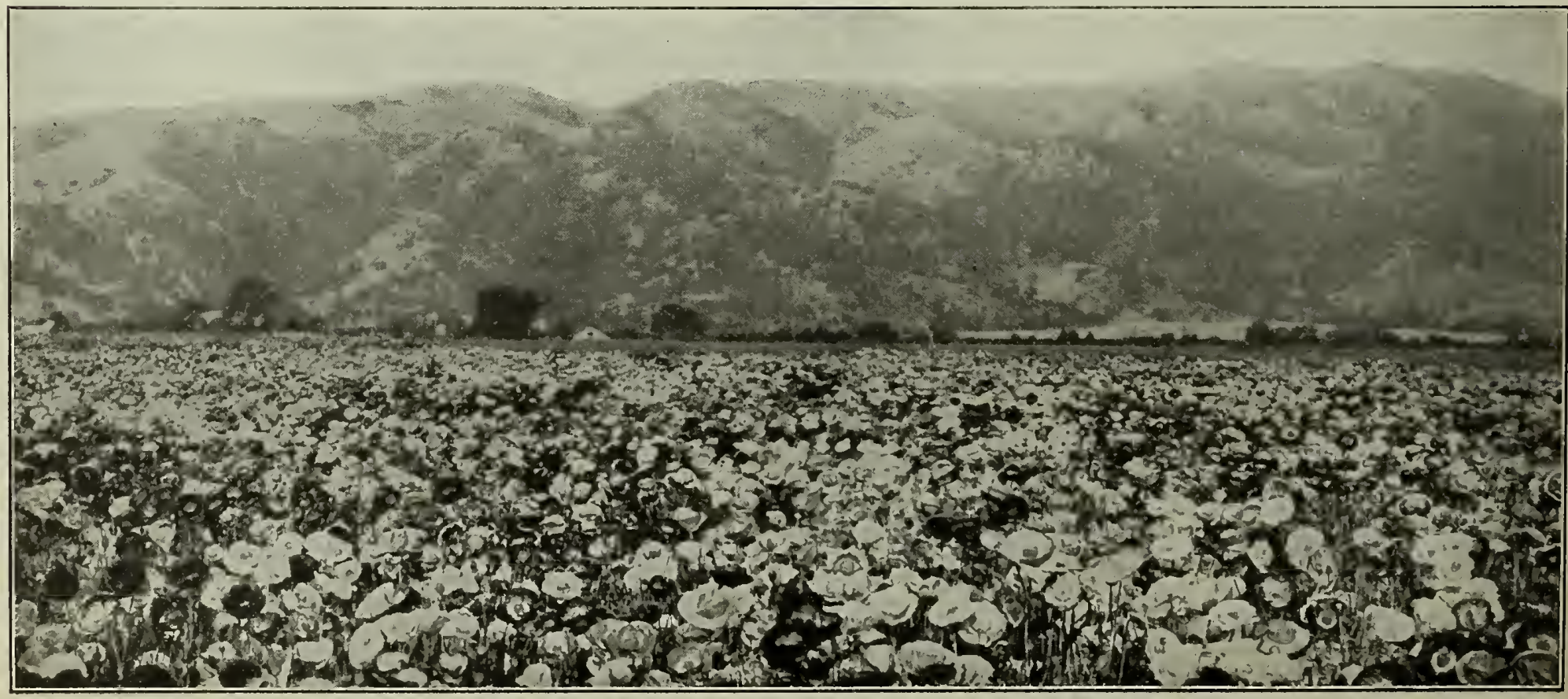


PORTUI.ACA. Low-growing or creeping, tender annual, six to eight inches high, and bearing glossy, cupshaped blossoms in very brilliant and gorgeous colors. The foliage and stems are thick. The seed germinates slowly and should be started under glass or when the weather is hot. These flowers love the sunshine and do best on rather dry ground; excellent for embankments.

Golden Yellow. Pkt. 5c.

Pink. Pkt. 5c.

Scarlet. Pkit. 5c.

White. Plst. 5c.

Single. Mixed. Large flowering. Pkt. 5c; oz. 50c.

Double. Mixed. Large flowering. Pkt. 10c.

Primrose, Evening. See Oenothera.

\section{PRIMROSES}

PRIMULA SINENSIS, OR CHINESE PRIMROSE. Greenhouse or pot plants, bearing trusses of large single or double blossoms in bright colors, as well as soft tints. Sow seed in April or May for winter blooming. Our seed is from the very finest strains.

Giant Single Fringed Varieties-

Alba Magnifica. Pure white. Pkt. 25c.

Bright Blue. Pkt. 25c.

Bright Rose. Pkt. $25 \mathrm{c}$.

Rosy Morn. Blush pink. Pkt. 25c.

Scarlet. Pkt. 25c.

Single Fringed Varieties. A splendid mixture. Pkt. 25c. Double Fringed Flowers. Saved from the finest blossoms. Pkt. 50c.

Single Mixed. Flotrers not fringed. Pkt. 25c.

Filicifolia, or Fern Leaved Varieties. Mixed. Pkt. 25c.

Half Hardy Primulas-

Auricula. The Primrose of the Alps. Flowers variously colored, mostly yellow; fragrant. Seed from selected strain. Pkt. 15c.

Forbesi (Baby Primrose). The flowers are small (onehalf inch across) and borne most profusely from the time the plants are a few weeks oid; pinch off the first blossoms if forced in conservatory. Culture same as P. Sinensis. Flowers lilac. Pkì. $25 \mathrm{c}$.

Obconica Grandiflora. A lovely free-flowering Primula, white tinged with lilac; stems nine inches high. Pirt. 25c.

Veris Poijyanthus. A hardy sort, blooming early in the open gardens. Colors mostly red and yeliow. Nixed colors. Pkt. 10c.

Vulgaris. The true yellow English Primrose. Pkt. 10c.

PYRETHRUM. Parthenifolium Aureum, or Golden Feather. Sinall-cut leaves of bright golden yellow. A hardy perennial.
with bright foliage, much used for edging and borders. Seed can we sown in the fall or spring and transplanted. Pizt $5 \mathrm{c}$.

Roseum, or Insect Powder Plant. A hardy perennial, with red-petaled fowers radiating from a golden-Jellow center. Buhach, or insect powder, is made from the dry leaves A mulching to keep the soil moist will greatly aid in producing the handsome llowers of this variety. pizt. 50.

Grandiflorum (Roseum Fybridum). A large-flowered type, with bright-colored and attractive blossoms for cutting, The flowers are often four inches across and vary from light pink to deep carmine, centers yellow, Mixed. Pkt. 10c.

Selesinoides. Fern-leaved edging plant-of great beauty. Plat. 100.

Red-Hot Poker Plant. See Tritoma

Ricinus. See Castor Oil Bean.

RHODANTHE (Everlasiting Flower). One of the finest and most beautiful of the many varieties of everlastings; for winter bouquets, the blossoms should be gathered before fully expanded. and if dried in the shade, will retain their brilliancy for years. Rose and white mixed. Pkt. 5c.

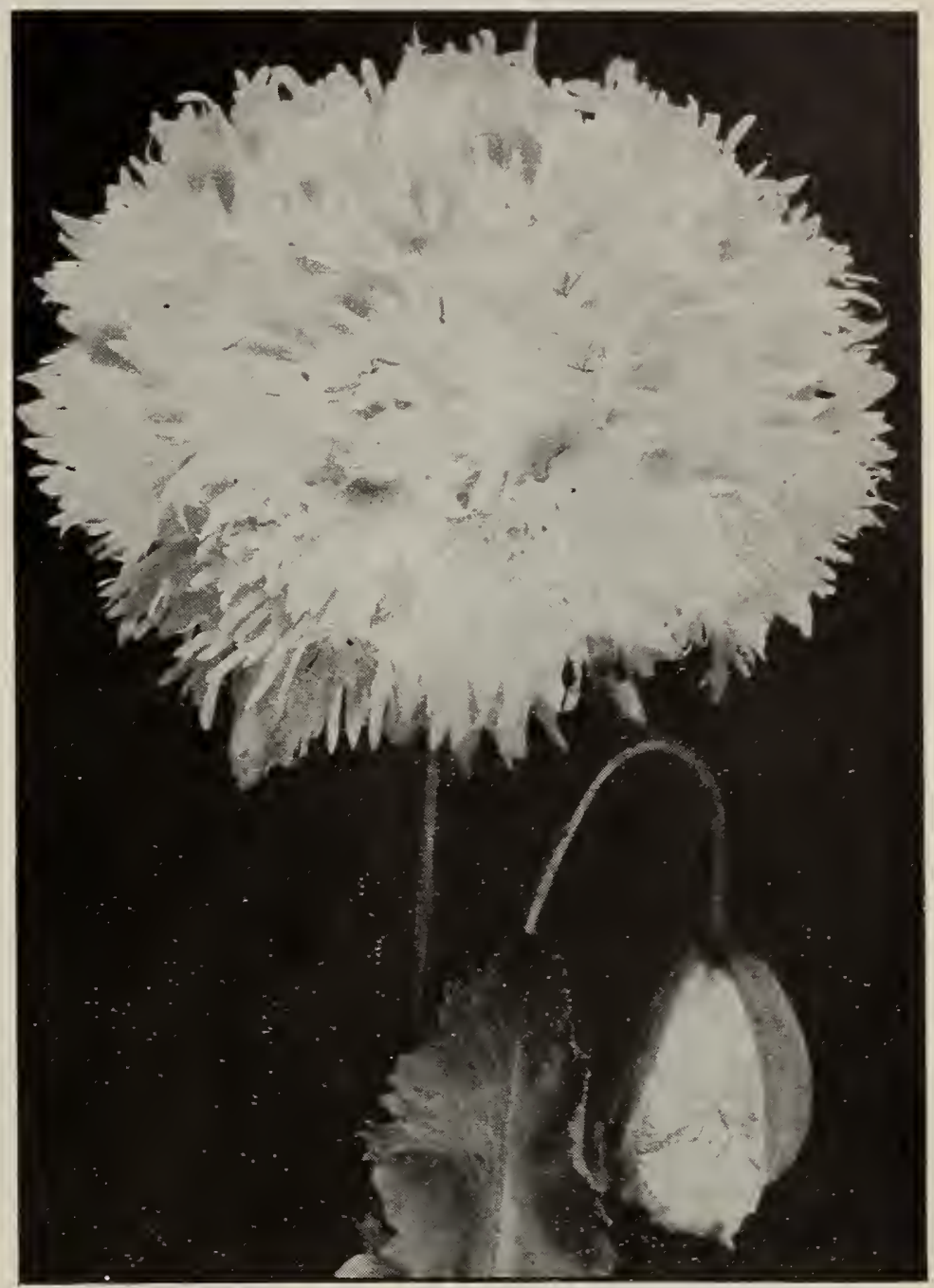

Double White Fringed Poppy

ROMNEYA COULTERI (California Tree Poppy). Also well known as the Matilija Poppy. This fine perennial is of a supreme and stately beauty. It is of value as a cut flower, lasting well in water, and its delicate primrose-like perfume is most acceptable. The texture of the petals is extremely delicate indeed, half transparent. They never lose the crumpled folds that in the case of most popples betoken newly opened state. that in the case of mosi popples betoken newry opened state.
with a fine bunch of yeliow stamens, resembling white, single with a fine bunch of yeliow stamens, resembling white, single
peonies. The seed takes from three to nine months to germinate. peonies.

RUDBECKIA (Cone Flower). Bicolor Superba. The center of this flower is brown, the petals golden yellow with velvety
brown spots at the base. A free-flowering annual; three feet high; very effective as a cut flower. Pkt. $5 \mathrm{c}$.

Laciniata. A single, bright yellow perennial plant, blossoming in the late summer. Four to six feet tall. The double the root crown. See under plants. Pkg. 100.

SALPIGLOSIS. A half-hardy annual, growing about three feet high and bearing trumpet shaped blossoms of rich shades and colors, all beautifully reined. It is valuable for bedding and massing, and its long stems make it excellent also for cut flowers. Sow seed early in the year and transplant, or sow the seed where it is to remain, in April, and thin to six or eight inches, enrich the soil. Mixed. Plit. 5c.

Emperor (Superbissima). A splendid large flowered strain; each stem is loaded with these most handsome flowers each one richly veined with gold. Pkt. 10c.

SALVIA OR FTOWERING SAGE. -A tender perennial blooming the first season from seed and growing two to three feet high. The blossoms are borne on long stems in racemes or spikes, and are fragrant. The plant forms a bunch and blooms profusely during the whole summer and fall. 


\section{C.C.MORSE \& CO. FLOWER SEEDS}

\section{SALVIA OR FLOWERING SAGE-Continued}

Patens. Bright blue flowers, 2 feet tall. Pkt. 25c.

Splendens. Bright scarlet flowers. Pkt. 10c; $1 / 4$ oz. 65c.

Bonfire. A new dwarf Scarlet Sage, of dense compact growth, from 20 to 24 inches high; useful for bedding or borders. Flowers dark scarlet on spikes which stand clear of the foliage and attract attention at once. Pkt. 10c; $1 / 8$ oz. 75c.

Dark Blood Red. A new tall variety with large flower spikes, much darker and richer than other scarlets. Dazzling and beautiful, $3 \frac{1}{2}$ feet. Pkt. 10c.

SANTOLINA. A low growing plant of a gray color very largely used for edging and ribbon work; it trims well and has a narrow leaf; a half-hardy perennial. Pkt. 10c.

SANVITALIA. A hardy trailing annual, six inches high and bearing bright yellow blossoms resembling a miniature double Zinnia. Of the easiest culture and valuable for rockwork or borders. Procumbens Fl. Pl. Pkt. 5c.

SCABIOSA OR MOURNING BRIDE. Also called Sweet Scabious, Old Maid's Pincushion, etc. Our mammoth flowered strain of this old-fashioned flower is very beautiful and worthy of a place in every garden; the tall flowers are especially adapted for cutting and massing in the garden. Annual (self sown in California) 21/2 to 4 feet high. These new flowers are double clear to the center, covering the thimble-shaped cone.

Mammoth Flowered, Double, or Maxima. Mixed. An improved strain, with large petals and beautiful colors. Pkt. 5c.

Dwarf Double Mixed. Pkt. 5c.

Tall Double Azure Fairy. Light Blue. Pkt. 10c.

Tall Double Black Purple. Pkt. 10c.

Tall Double Rose. Pkt. 10c.

Tall Purple Edged White. Pkt .10c.

Tall Double Snowball. Pkt. 10c.

Caucasica. A hardy perennial variety, with pale blue flowers 4 to 5 inches across and long stems. One of the handsomest perennial flowers; valuable for cutting. Pkt. 10c.

Scarlet Flax. See Linum.

SCHIZANTHUS. Hardy annuals, growing one and onehalf to two feet high and covered with kright, showy, butterfly-like blossoms. Large flowering. Mixed. Pkt. 10c.

WISETONENSIS. This variety is remarkably free-flowering, and presents a beautiful appearance with its myriads of blooms, the ground color of which is white, dotted with delicate rose. A very shy seeder. Make several plantings, as the plants come into bloom quickly, are a burst of color. and are out of bloom. Pkt. 25c.

SENECIO (Tall Double Jacobea). A showy, free-flowering hardy annual. It produces in great profusion, branching spikes of Cineraria-like double flowers, one and one-half inches in diameter, from spring until fall. Excellent for bouquets. Elegans. Double mixed. Pkt. 10c.

SILENE, OR CATCHFLY. Hardy annual, growing about one foot high and bearing small, attractive flowers in various colors. O easy culture and valuable for bedding. Mixed. Pkt. 5c.

SMILAX. A climbing perennial, with beautiful, bright-green glossy leaves, much esteemed for its long, delicate sprays of foliage. Largely used for decorating. Start seed under glass and transplant six inches apart. It requires strings or wires to climb on when very young. Pkt. 5c; 0z. 50c.

SNAIL VINE (Phaseolus Caracalla). The flowers of this perennial climber are coiled so as to resemble a snail shell, whence the name. The flowers are fragrant and of a buff yellow and light purple color. Grows to a height of twenty feet, and is a good climber. Pkt. 10c.

STATICE SINUATA (Sea Lavender). A blue everlasting flower much used by florists for winter bouquets. Annual, two to three feet. Each floweret is small but the plant is very effective. Pkt. 5c.

Spider Plant. See Cleome Pungens.

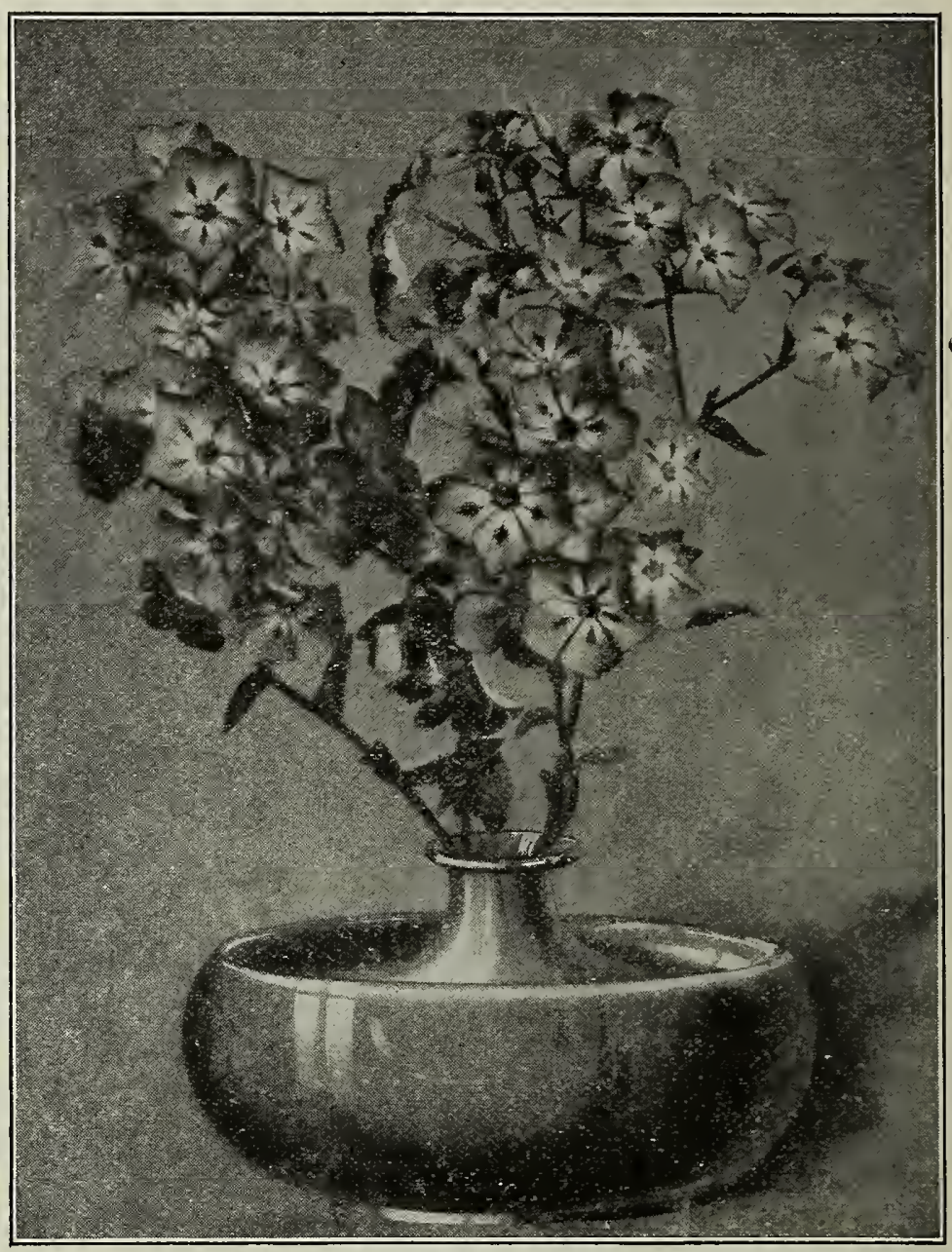

Phlox Drummondis

SNAPDRAGON (Antirrhinum). A half-hardy perennial, growing from $11 / 2$ to 3 feet tall. Flowers are oddly shaped and apparently closed, but by pressing the sides together can be made to open like a dog's mouth. The newer strains are large flowered and contained in a great number of shades and colors. Their rich spikes are beautiful for cutting and keep fresh a long time. Very easily raised.

\section{TALL LARGE FLOWERING TYPE}

Crescia. Scarlet. Pkt. 10c.

Firefly. Scarlet and white. Pkt. 10c.

Pink. Large. Pkt. 10c.

Queen Victoria. Pure white. Pkt. 10c.

Yellow. Large. Pkt. 10c.

Giant Flowered. Mixed. Plst. 10c.

\section{SEMI-DWARF TYPE}

8 to 12 inches high for bedding.

Niobe. Maroon with white throat. Pkt. 10c.

Picturatum. Blotched varieties mixed. Pkt. 10c.

Queen of the North. Pure white. Pkt. 10c.

Tom Thumb, or Dwarf. Mixed. Pkt. 5c.

Collecition of 8 named sorts for 60 c.

SOLANUM CAPSICASTRUM (Jerusalem Cherry). A very ornamental plant for house or garden culture, the flowers being followed by small brightly colored fruit or berries, which almost completely cover the plants. Flowering and fruiting the first completely cover the plants.

solanum Seaforthianum. Only in California in nearly frostless places can this handsome vine be found as a perennial climber. The flowers are a lovely light blue in immense drooping panicles like clusters of Wistaria. Scarlet seedberries follow the flowers. Six to twelve feet. May be treated as a tender annual. Pkt. 15c.

STEVIA. A tender perennial, one and one-half feet high and bearing clusters of small, white, fragrant blossoms. Suitable for summer clusters of small, white, fragrant blossoms. Suitable for summer Pkt. 10c. 


\section{WINTER STOCKS-Continued}

Beauty of Nice. A beautiful flesh pink with very large spikes. It is of the cut and come again type, bearing continuously throughout the season. Very large handsome spikes. Pkt. 15c; $1 / 4 \mathrm{oz} . \$ 1.00$.

Empress Elizabeth. A splendid Brompton or winter stock, rather dwarf, 18 inches high; covered with large double flowers of bright carmine rose. Pkt. $25 \mathrm{c}$.

Queen Alezandra. Similar to Beauty of Nice, except in color, which is rosy-lilac, a shade that shows beautifully under artificial light. Pkt. 15c.

Winter, or Perennial Brompton. Mixed. Pist. 10c.

STOKESIA, OR CORNFIOWER ASTER. A hardy perennial, two feet high, and bearing large blue flowers on long stems.
Blooms freely all Summer and Fall, and is of easy culture, but is hard to start from seed. Cyanea. Plkt. 10c.

Strawflowers: See Acroclinium: Gomphrena: Helichrysum; Honesty; Statice; Rhodanthe, Xeranthemum.

SUNFI.OWER (Helianthus). Hardy annuals, growing from three to six feet high. Of the easiest culture and suitable for a stately row or background, or even for bedding. Plant when the ground is well warmed in light or sandy soil.

Chrysanthemum Flowered. Large, densely double, bright golden flowers. The plant branches and affords fine, long stout stems for cutting. This is the best variety in existence; 6 to 8 feet. Plst. 5c; oz. 25c.

Russian. The common, large flowering single variety, with great brown centers and an edge of yellow petals. The seed is used for chicken feed. Pkt. 5e.

Cucumerifolius Perkeo (Miniature Sunflower). The Cucumerifolius sunflowers are small both in flower and plant and are often called Cut and Come Again Sunflowers. Perkeo is only 2 feet tall but is covered with small (three-inch) golden yellow flowers with a dark eye. Pkî. 10c.

Cucumexifolius Stella. Is considerably taller than Perkeo and has larger single flowers 6 inches across; yellow with black center. Pkt. 5c; oz. 50c.

Cucumerifolius, Double Hybrids. Fine double and semi-double miniature sunflowers. Pkt. $10 \mathrm{c}$.

Sweet Alyssum. See Alyssum.

SWEET ROCRET (Fesperis). A hardy perennial, growing two to three feet high. An old-fashioned, fragrant flower of the easiest culture, and
Mixed. Plrt. $5 \mathrm{c}$.

Sweet Sultan. See Centaurea Moschata.

SWEET WILITAM. (Diarthus Barbatus). A hardy perennial, blooming the second year from seed. Grows one to two feet high and bears its flowers in cluster's at the end of a stiff stem. The individual flowerets are handsomely colored and marked. It makes a beautiful bedding plant, and is of easy culture.

Single Varieties. Mixed. More attractive than the double. Pkt. $5 \mathrm{c}$; 0z. $25 \mathrm{c}$.

Double Varieties. Mixed. Pkt. $5 \mathrm{c}$.

THUNBERGIA, OR, BLACK-EYED SUSAN. A hardy annual climber, growing about four feet long, and raluable for low fences or hanging baskets. Prefers a sunny situation. Blossoms are buff, orange, or white, with dark centers. Mixed, pkt. 5c.

TORENIA. A hardy annual, with trumpet-shaped flowers, and growing four to six inches high; in bloom all summer. Good for hanging baskets or borders, or for bedding. In the hot parts of California where Pansies do not do so well Torenia will be found an excellent substitute, as it thrives under such conditions.

Fournierl. Velvety blue, with three dark spots of indigo and a bright yellow throat. Pikt. 5c.

White Wings. Dainty, white flowers, tinted with rose at throat. Plat. 10c.
TRITOMA, New Elybrids (Red-Hot Poker Plant). The plants make a dazzling spot in the garden in summer and fall; their tall spikes (4 feet) contain over one hundred flowers of bright orange or scarlet or yellow. South African perennials well adapted to California. Pkt. 15c.

TRANSVAAI DAISY (Gerbera Jamesoni Gigantea). This sensational new plant has recently been introduced from South Africa and should be in every garden.

It is a herbaceous perennial and grows in heavy clumps. The leaves are about one foot long and deeply cut. The stems are long and stout, growing erect about eighteen inches high and bearing a large daisy-like blossom, similar in shape to a Marguerite, but of an intense vermilion color. The blossoms measure from 3 to 4 inches in diameter and are beautiful and last well when cut.

The plant is easily grown from seed planted in the spring. Sow seed in boxes in clear sand mixed with leaf mold and cover about one-eighth inch deep. Plant with the fuzzy end of the seed just above the ground, being careful not to break it off. Do not overwater. They transplant easily to the garden and want a well-drained soil, as they do best in a rather dry situation.

Be sure to give the plants an airy, sunny place in the garden and a little protection on frosty nights.

Per packet of 25 seeds, 25 c.

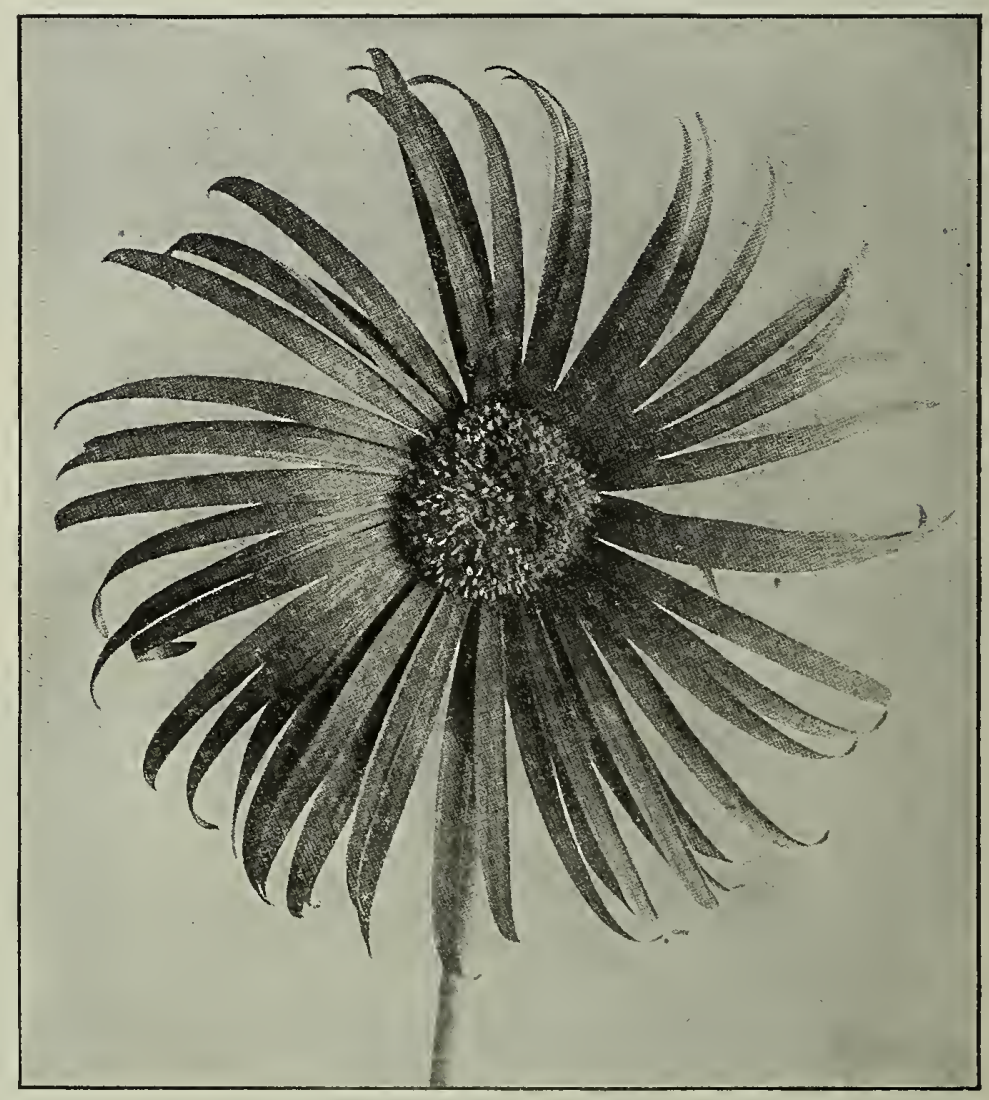

New Scarlet Transvaal Daisy

VALERIAN. Showy plants for mixed borders or shrubberies. bearing large corymbs of bright flowers; bears shade and moisture well Hardy perennial, two and one-half feet. Flowers bright red and white. Mixed, pkt. 5c.

VERBENA. A half hardy trailing perennial of easy culture. While it grows readily from division of the root or from cuttings, it does best from seed. It is well known as a bedding or border plant, and the improved large flowered and fragrant strains make it a handsome cut flower for low vases.

Mammoth Auricula Flowered. Various colors, with large white center. Pkt. 10c; 1/4 0z. 50c; 0z. $\$ 1.50$. 


\section{SAN FRANCISCO CALIFORNIA U.S.A.}

VERBENA-Continued

Mammoth Flowered. Mixed. Plat. 10c; $1 / 4$ oz. $35 \mathrm{c}$; oz. $\$ 1.25$.

Pink Shades. Mammoth strains of rose and pink shades. Pkt. 10c; $1 / 4$ oz. $35 \mathrm{c} ; 0 z$. $\$ 1.25$.

Pure White. Mammoth strain. Plt. $10 \mathrm{c} ; 1 / 4$ oz. $35 \mathrm{c} ;$ oz. $\$ 1.25$.

Purple and Blue Shades. Mammoth strains. Pkt. 10c; $1 / 4$ oz. $35 \mathrm{c}$; oz. $\$ 1.25$.

Scarlet Defance. Brilliant scarlet. Pkt. 10c; $1 / 4$ oz. $35 \mathrm{c}$; 0z. \$1.25.

Striped Varieties. Mixed. Plt $10 \mathrm{c}$.

Morse's Extra Selected Mammoth Strain. Pkt. $15 \mathrm{c}$.

Collection of 6 named varieties $45 \mathrm{c}$.

VINCA, OR IIADAGASCAR PERTWINLLE. A tender perennial. with ornamental foliage, useful for bedding in summer and for the

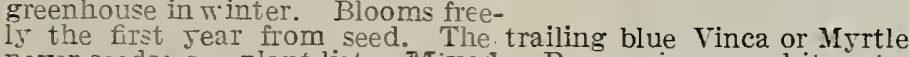
neter seeds; see plant list. IMixod. Rose, crimson, white, etc.
Plit. 100.

VIOLAS, or TUETRD PANSIES. These dainty violet-like flower's make one of the finest bedding plants; their colors are so clear and they bloom for such a long time during the whole summer; 6-inch perennial, blooming quickly from seed, excellent bedding "effect."

Purple Queen (Cornuta). Pkt. 10c.

White, Pkt. 10c.

Yellow. Pkt. 10c.

Mixed, all varieties. Pkt. 10c.

VIOLEI, OR VIOLA ODORATA. Although these flowers ${ }^{*}$ do best propagated from the cuttings, they grow readily from seed, and profarorite blue variety. Single, sweet-scented. Pkt. 10c.

VIRGINIA CEEEPER (Ampelopsis Quinquefolia). Perennial climber. Large leaves, which color in the tall: also bears clusters easily raised from seed. Height thisty feet. P2t. 5c;0z. 25c. VIRGINIA STOCKS. A hardy annual, growing about nine inches high and blooming profusely. Of easy culture, and can be had in continuous bloom by sowing the seed at frequent interrals
during spring and summer. Red and White mixed. Flt. 5c.

VISCARIA (Rose of Fieaven). Prett5, profuse flowering plants; adapted for beds, edgings or clumps, growing readiiy in any single pink; annual; twelte inches tall. Pkt. $5 \mathrm{c}$.

WAILFLOW IRR. Half hardy perennial blooming the first year from seed. Grows one to two feet. high and bears long stems of fragrant flowers. It is best to renew the plants every two or three years by resowing the seed. An old-fashioned flower, which is always popular. Sow early in the year in boxes and transplant.

Tall German Double. Mixed colors. Pkt. 10c.

Fine Single. Nixed. Fkt. 5c.

Tom Thumb Golden. Small, compact plant, single blossoms. Plt. 10c.

Dwarf German Double. Pkt. 10c.

WHITLAVIA. An easily grown. hardy annual, bearing small riolet-blue. cup-shaped blossoms. Plants one foot high. Sor

WISTARIA, Chinese Flowering, Tall Blue. One of our most popular hardy climbers. growing to a height of fifty feet. The flowers are abundantly borne in spring on long dronping
of light blue before the leaves appar. PLi. $15 \mathrm{c}$.

XERANTHEMUMI (Everlasting Flower). A hard" annual, a bout two feet high, and bearing $\pi$ hite, purple, or J tlow blossoms

prett5, stram-like everlasting fomer. Double irixed. Fizt. Ec.

ZINNIA. A half hardy annual, groming from one to two feet high. Blossoms are very double, and while the stems are stiff, they make an excellent bouquet flower. Probably no flotrer has such an assortment of kr-int
shades, tints, and colors; no bedding plant is m cre effective for a brilliant show. Sow in boxes early and transplant.

Mammoth Double-

Black Purple. Pkt. 10c.

Dark Crimson. Pkt. 10c.

Deep Red. Pkثt。10c.

Magenta. Pkt. 10c.

Orange. Fkt, 10c.

Scarlet. A bright shade. Pkt. 10c.

White. Pizt. 10c.

Yeilow. PIt. 10c.

Mixed, all colors. Pkt. 10c.

Collection of eight colors for 50c.

Double Iilliput. A dwarf plant, one foot high, bearing rather small, very double flowers. Mired. Pkt. 5i.

Grandifora Robusta. The largest variety in existence. The blossoms are globe-shaped, rery large, and in numerous colors. The plants

Pompon Miszed. A fine mixiure of globe-shaped flowers. Plt. $5 c$.

Elegans. Tall, double. Mixed. Pkt. 5c.

Striped, or Zebra. IIixed. Pkt. 5c.

\section{C. MORSE \& CO.}

Am enclosing an order for some ficmer seeds, principallr sweet peas. Can not tell you how delighted I was with mJ sweet peas purchased from you last jear. They $\pi \cdot e r e$ simply beautiful and greatly admired by all my friends. Sincerely Irs. P. T. R. 


\section{C.C.MORSE \& CO. FLOWER SEEDS 1.2}

\section{THREE GRAND NEW SWEET PEAS}

Of our own creation-created, developed and introduced from our own experiment grounds.

\section{SEE THEM IN NATURAL COLORS ON THE BACK COVER. \\ ETHEL ROOSEVELT-MARIE CORELLI, and W. T. HUTCHINS.}

ETHEL ROOSEVELT ABSOLUTELY NEW. No similar variety offered in this country or Europe.

In our Sweet Pea workshop, where we are developing scores of new varieties and practically all Spencers, or new forms of the waved type, we have a number of beautiful novelties, but as our policy is to thoroughly try out and test new varieties before introducing them, we could not consistently send out but one good one this season.

We have, therefore, chosen the most distinct and one of the most beautiful of its class and one which, for two successive seasons, has come perfectly true to name.

This beautiful, charming and dainty debutante we have christened "Ethel Roosevelt."

It is a true waved variety of the largest and most perfect Spencer form. There is naturally some variation even in Spencers, and Ethel Roosevelt claims the most exclusive Spencer perfection.

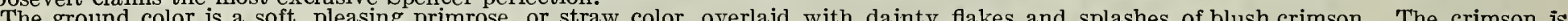

splashes of blush crimson. The crimson is not at all pronounced and simply gives vellowish warmth and golden tinting to the yellowish ground work.

It bunches splendidly and will easily lead in this type of coloring for a long time. Packet 20 seeds, 25c.

MARIE CORELII The color not quite do this variety justice, since it is a more pronounced crimson and extremely bright. Those, who are familiar with old "Splendor" or "Prince of Wales" can appreciate Marie Corelli as being of the same bright shade of red, but in Spencer form. It is of immense size with especially large wings.

MARIE COREIII was in our last season's list of novelties and has had the advantage of one year's experience with our customers.

It has been received enthusiastically everywhere and is easily the leading novelty of this color. Pkt.15c; oz. $\$ \mathbf{1 . 5 0}$.

W. T. HUTCHINS A most delbeautiful variety of soft tintsane beautiful variety of soft tints and dainty effect. Soft buff, primrose and blush, shading to pronounced apricot pink and rose at the margin. The blossoms are of immense size and of the true Spencer form, ruffled, fluffy and waved. W. T. Hutchins has the advantage of one year's proof, for we introduced it modestly last season and everyone who had it was delighted. In our own grounds it proved all we claimed for it last year and we are more than enthusiastic about it this year. We want everyone who loves Sweet Peas to try it. Pkt. 20 seeds, 15c; oz. $\$ 1.50$.

BURPEE'S NEW SWEET PEA

FLORENCE NIGHTIN-

GALE A beautiful lavender, and the introduced.

The flowers are truly magnificent and of immense size. The standard is unusually large and bold, pronouncedly waved, yet standing erect and broad,frequently measuring two inches across. The color is most charmingly soft and yet rich lavender, which is enlivened by yet rich lavender, which is enlivened by a very faint sheen of rose pink. The large, well spread wings are of the same
coloring, frilled and well waved. It is practically a self color and bunches beautifully, - attracting universal admiration. The plant is extremely robust in growth, flowering most profusely. The stout stems attain twelve to sixteen inches in length and a large proportion bear four well placed flowers. FLORENCE NIGHTINGALE comes entirely true from seed-both as to color and the highest ideal Spencer type seeds, 15c each. Pkt. of 20 seeds, 25c each.

Our book on Sweet Peas will be malled to any address on receipt of $25 \mathrm{c}$ in stamps or money. 


\section{SAN FRANCISCO CALIFORNIA U.S.A.}

\section{MORSE'S SWEET PEAS}

Sweet Peas hare now heen definitely classified into three distinct classes-Early Flowering or Christmas, Grandiflora, and Wared or Spencer. THE EARLY FLowERING TYPE usually blooms in about twelve weeks from the time the seed is planted. Florists usually sow their seed of these about September 1st for Thanksgiving and Christmas flowers. If planted early in the Jear theJ will still come into flower very early and should be planted by all who want a succession of bloom.

THE GRATDIFLORA TYPE is the better known or ordinary Sweet Pea, but not necessarily the old fashioned small flowered class. All of the hooded and shell-shaped types are in this class, as are also all of the best open form round standard types. There are many new shades and many new large flowered varieties among the grandifloras and they will always be popular, since they are the most easily grown and the seed of them will always be cheaper than that of the other classes.

THE WAVED, OR SPExCER CLASS represents a trpe of Sweet Pea which was discorered in 1902 in England. The original was Countess Spencer, still the best and most popular pink. The adrent of this rariet and the detelopment from it of numerous nem varieties, only Spencer, stil the best and most popular pink. The adrent of this rariety and the derelopment from it of numerous nem varieties, only corers a period of about fire jears, and the chief interest of all sweet Pea experts is centered on this class. Another trpe of waved Sweet Spencer type will be used whenerer the colors are the same. The Unwins seed more freel 5 and the seed is therefore usually cheaper.

All gardeners and florists prefer Wared Sweet Peas when the popular colors can be had. They are strong growers, bear long stems, and very large blossoms with usually four blossoms to a stem. The standard is alwars large, round, and fluted or wary on the edges. The wings, too, are always large and more or less wary, but not so much so as the standard. They set rery few seed pods and for this reason will continue blooming for a long period-Tery often from liay 1st till August 1st.

We have made Sweet Peas of all kinds our specialty for many years, have introduced scores of new rarieties, including some of the best Spencers, and we do not mean to boast at all when we claim that we offer the best and truest Spencer list to be had antwhere in the morld. There are now 435 rarieties of Sweet Peas, as recognized b5 the National Sweet Pea Societs of England and the National Sweet Pea Societ $y$ of America, and 611 as listed by Walter Wright, the eminent writer on Sweet Peas. No one wants them all and a few rarieties will include all the best colors and best types. Out of this multitude of named rarieties we have selected what we believe to be the cream of them all, and we offer them here.

If ansone is familiar with the name of a Sweet Pea which is not listed here and will write us about it, we can probabls either suppl it or can can probabls either upplo cally the cally the same thing. We grow a Trade which are not put in our abbreviated list here.

(Price is $5 \mathrm{c}$ per packet, except where noted otherwise). If interested in larger quantities than quoted here, write us.

\section{WHITE}

EARLY FLOWERING OR CHRISTMAS VARIETIES.

Burpee's Earliest White. Very early, hooded, black seeded. $0 \mathrm{z}$. 15c; $1 / 41 \mathrm{~b} .50 \mathrm{c}$.

Mont Blanc. Early, white seeded, open form. Oz. 10c; $1 / 41 \mathrm{~b} .25 \mathrm{c}$. GRANDIFLORA TIPES.

Dorothy Eckford. White seeded, large shell shaped. Oz. 10c; $1 / 4 \mathrm{ib} .25 \mathrm{c}$.

Shasta. Very large open form, white seeded. $0 z$. 10c; $1 / 4 \mathrm{lb}$.

White Wonder. A large double rarietr, fine for florists. $\mathbf{0 z}$. rariets, fine for

WAVED TYPES, OR SPENCERS.

MORSE'S PURE WHITE SPENCER. Re-selected, a superior strain of the vers finest Spencer. Can be used as the best raved white, no matter under what name. Per pkt. 10c; 0z. 25c; $1 / 11 \mathrm{lb} .75 \mathrm{c}$.

MRS. SANKEY SPENCER. Opens with a slight tint of pink, but with a slight tint of pink, but Is rerv large and black seeded. Per pkt. 10c; oz. 25c; $1 / 4 \mathrm{lb}$. $75 \mathrm{c}$.

\section{PRIMROSE or VERY LIGHT YELLOW}

EARLY FLOWERING OR CHRISTMIAS VARIETIES. Earliest Sunbeams. Very early,
white seeded, open form. Oz: 1cc; $1 / 1$ 1b. 30c

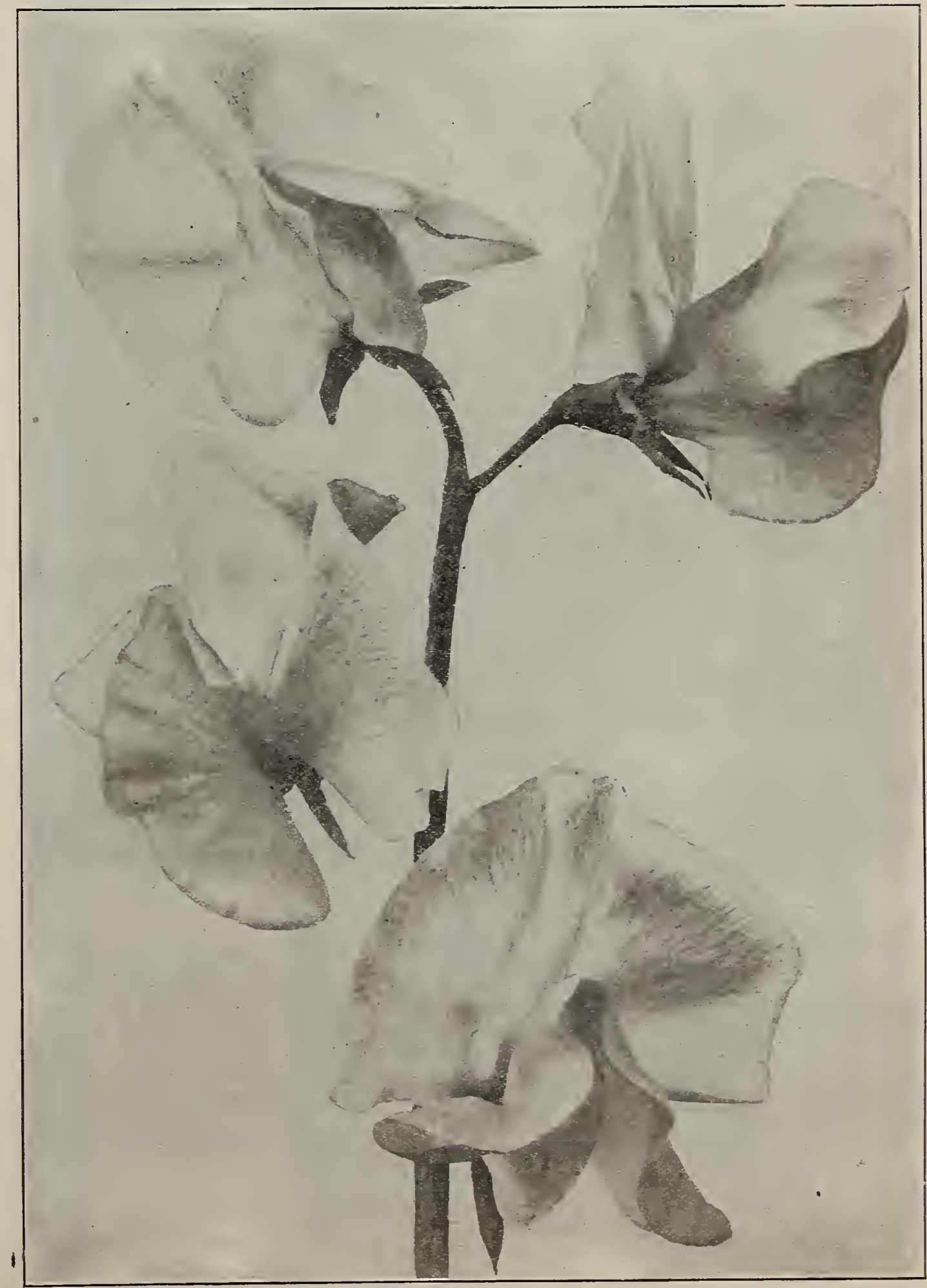




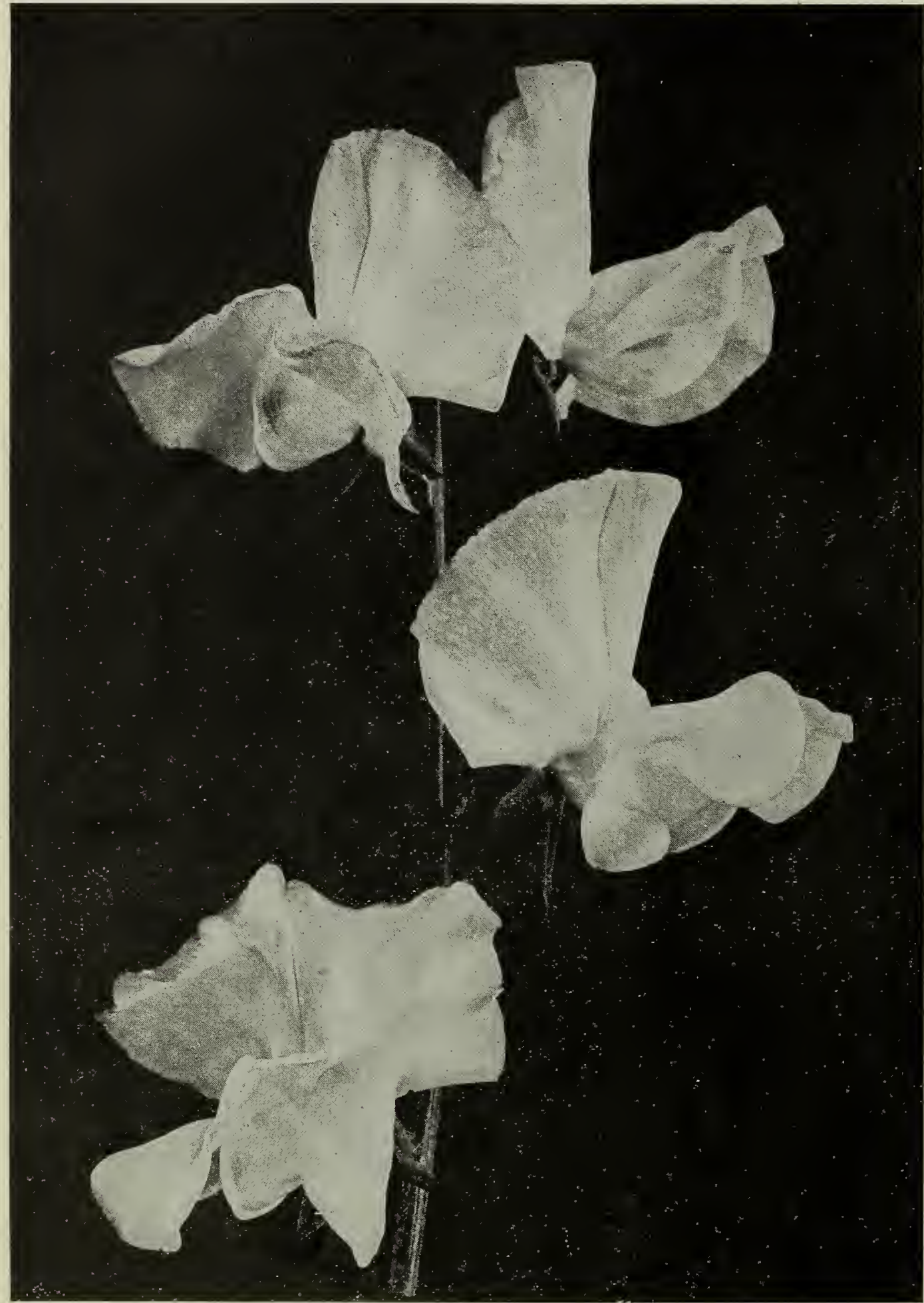

Countess Spencer (The Original Spencer color: deep pink)

WAVED OR SPENCER TYPES ETHEL ROOSEVELT. See cover and page 74.

MRS. ROUTZAFIN. A beautiful blending of straw color tinted with blush pink and shading to apricot and rose at edges. Per pkt. 10c; oz.

W. T. HUTCHINS. See cover and page 74 .

LIGHT PINK SHADES

EARLY FLOWERING OR CHRISTMAS VARIETIES.

Mrs. Wm. Sim。 Per pkt. 10c; oz. $25 \mathrm{c} ; 1 / 41 \mathrm{lb} .75 \mathrm{c}$.

GRANDIFLORA VARIETIES

Agnes Eckford, Very light pink, hooded or shell-shaped. Oz. 10c; $1 / 41 \mathrm{~b} .25 \mathrm{c}$.

Prima Donna. The most popular clear pink hooded. $0 \mathrm{z} .10 \mathrm{c} ; 1 / 4 \mathrm{lb} .20 \mathrm{c}$.

Queen of Spain. Buff pink or creamy rose. A very distinct shade. $\mathbf{0 z}$. $15 \mathrm{c} ; 1 / 4 \mathrm{lb} .50 \mathrm{c}$.

WAVED OR SPENCER TYPES.

FLORENCE MORSE SPENCER. Petals large and very wary. White and blush with distinct pink edge. Per pkt. $10 \mathrm{c} ; 0 \mathrm{z} .25 \mathrm{c} ; 1 / 1 \mathrm{tib} .75 \mathrm{c}$.

RAIIONA SPENCER. Ivory white, with soft blush carmine stripes and Ib. $75 \mathrm{c}$.

DEEPER PINKSHADES GRANDIFLORA VARIETIES.

Janet scott. Clear pink at base and shading to buff at edges. $\mathrm{Oz}, 10 \mathrm{c}$; $1 / 41 \mathrm{~b} .25 \mathrm{c}$.

WAVED OR SPENCER TYPES.

BEATRICE SPENCER. Buff, pink and rose, with deeper rose wings. COUNTESS SPENCER. The original giant flowered Spencer, with finest waved standard wings. Clear pink. The first choice of all Sweet Peas. 0z. $25 \mathrm{c} ; 1 / 41 \mathrm{~b} .75 \mathrm{c}$.

\section{ROSE AND VERY}

\section{LIGHT PINK Bi-color}

EARLY FLOWERING OR CHRISTMAS VARIETIES.

Earliest of All, or Extra Early Blanche Ferry. The earliest of all Sweet Peas. Bright rose standall Sweet Peas. Bright rose stand$1 / 4$ ib. 25 c.

GRANDIFLORA TYPES.

Apple Blossom. Crimson pink, shading lighter, wings white, tinted pink. Oz. 10c; $1 / 41$ b. 20c.

Jeannie Gordon. Standard bright rose, wings primrose tinted with
light rose. $\mathrm{Oz} .10 \mathrm{c} ; 1 / 4 \mathrm{~b}$. $20 \mathrm{c}$.

Royal Rose. Standard crimson pink, wings pink, large. $0 \mathrm{z} .10 \mathrm{c} ; 1 / 4 \mathrm{lb}$. 20c.

WAVED OR SPENCER TYPES.

PRIMROSE OR VERY LIGHT YELIOW-Continued. GRANDIFLORA TYPES.

Mirs. Collier. Large, shell-shaped, white seeded. Oz.10c;1/41b.30c. Hon. Mrs. E. Kenyon. Large, semi-hooded, white seeded. Oz. Queen Victoria. Black seeded, opens with blush tint then turns clear primrose. Oz. 10c; $1 / 41 \mathrm{~b} .20 \mathrm{c}$. WAVED OR SPENCER TYPES.

PRIMROSE SPENCER. Morse's Extra select strain. The finest of its class, clear primrose color, fine large wavy standard and wings; white seeded. Per pkt. 10c; 0z. 25c; 1/4 1b. 75c. QUEEN VICTORIA SPENCER. Black seeded and opens with tint of blush, but soon turns clear primrose. Of immense size and very wavy. Per pkt. $10 \mathrm{c} ; 0 \mathrm{z} .25 \mathrm{c} ; 1 / 4 \mathrm{ib}$. $75 \mathrm{c}$.

\section{VERY LIGHT PINK AND PRIMROSE}

\section{GRANDIFLORA VARIETIES.}

Golden Rose. Primrose lightly striped blush carmine. Oz. 10c; $1 / 4$ $1 \mathrm{~b} .20 \mathrm{c}$.

Stella Morse. Buff, suffused with tink of pink, $\mathrm{Oz}, 10 \mathrm{c} ; 1 / \mathrm{lb}, 20 \mathrm{c}$ Sybil Eckford. Light pink, buff and cream. Oz.10c; 1/4 1b. 20c.
APPLE BLOSSOM SPENCER. Very large, standard very bright rose, wings primrose with a flush of rose tint. Pkt. 10c; 0z. $25 \mathrm{c} ; 1 / 41 \mathrm{~b} .75 \mathrm{c}$.

\section{LIGHT PINK SHADED}

\section{GRANDIFLORA VARIETIES.}

Dainty. Clear white with rose pink edges. Oz. 10c; 1/4 1b. 20c.

Iovely. Standard and wings have white ground with distinct blotch of deep pink at base and shading to lighter pink and flesh at edges. Oz. 10c; $1 / 4$ 1b. 20c.

Hon. F. Bouverie. Deep pink shading light pink on buff and primrose ground. $0 \mathrm{z} .10 \mathrm{c} ; 1 / 4 \mathrm{lb}, 20 \mathrm{c}$.

WAVED OR SPENCER TYPES.

DAINTY SPENCER. Very large Spencer, white with rose-pink edges. Per pkt. $15 \mathrm{c}$.

IOVELY SPENCER. A Spencer type with the Lovely color combinations. Per pkt. 10c; 0z. 25c; $1 / 4$ 1b. 75c.

EVELYN HEMUS. Buff and primrose, with clear rose margin. Per pkt. $15 \mathrm{c} ; 0 \mathrm{z} . \$ 1.50$. 


\section{SAN FRANCISCO CALIFORNIA U.S.A.}

\section{ORANGE PINK SHADES}

\section{GRANDIFLORA VARIETIES.}

Aurora. White, with stripes and flakes of orange-pink. Oz. 10c; $1 / 4$ 1b. $20 \mathrm{c}$.

Bolton's Pink. Brilliant pink, with tint of salmon. Oz. 15c; $1 / 1$ 1b. $35 \mathrm{c}$.

Miss Willmott. Bright orange pink, showing veins of a deeper 0z, 10c; 11 1h, 25c

st. George. A brilliant orange pink, or more correctly, flame color The most brilliant of all sweet Peas. Per pkt. 10c; oz. 25c; $1 / 4$ 1b. $75 \mathrm{c}$.

\section{WATED OR SPENCER TTPES}

AURORA SPENCER. One of the finest Spencers, Bright orangepink striped. mottled and flalied on white. Per pirt. $10 \mathrm{c} ; \mathbf{0 z}$ $25 \mathrm{c} ; 1 / 41 \mathrm{~b}, 75 \mathrm{c}$.

HELEN LEWIS. TerF large orange-pink, with especially bright orange standard. Per pkt. $10 \mathrm{c} ; 0 \mathrm{z} .25 \mathrm{c} ; 1 / 1 \mathrm{lb} .75 \mathrm{c}$.

MIRIAII BEAVER. This is our last year's sensational novelty a clear apricot pink self color.
Unfortunately it broke badly last, season, and while we can offer stock that will come 50 per cent true, we will not recommend it until we put out our reselected strain next year. It is one of the most beautifui tarieties in existence. Per pkt. 15c.

\section{BRIGHT RED SHADES}

GRANDIFLORA VARIETIES. Coccinea. Pure cerise or cherry. Oz. 10c; 1/1 1b. $20 \mathrm{c}$.

King Edward VII, or Improved Firefly. One of the very best pure red

Queen Scarlet Gem. The nearest aproach to a true scarlet. $\mathbf{O z}$. $10 \mathrm{c}: 1 / 1 \mathrm{~b}, 25 \mathrm{c}$

Millie Maslin. A new shade of crimson red, very large and shell-shaped. 0 z. $15 \mathrm{c} ; 1 / 1 \mathrm{lb} .50 \mathrm{c}$ Salopian. A deep rich pure red semi-hooded. Oz. 10c; $1 / 41 \mathrm{~b}$. $20 \mathrm{c}$.

WATED OR SPENCER TYPES. AMERICA SPENCER. Bright red, striped and flaked on white KING EDWARD SPEN TR. The best pure red Spencer; Tery large with es $1 / 41 \mathrm{~b}, \$ 1.00$

\section{ROSE CRIMSON SHADES \\ GRANDIFLORA VARIETIES}

Lord Roseberry. Bright rose, suffused with magenta and showin veins of rose. $0 \mathrm{z} .10 \mathrm{c} ; 1 / 1 \mathrm{~s} \mathrm{~b} .20 \mathrm{c}$.

Prince of Wales. Clear rose-crimson, self color, large and shell shaped. Oz. 10c; 1/1 1b. $20 \mathrm{c}$

WAVED OR SPENCER TYPES

GEO. HERBERT A large Spencer rose-crimson, suffused with ma genta and showing veins in wings. Fer pkt. 10c; $02.25 \mathrm{c}$ MARIE CORELLI. See page 74 .

\section{LAVENDER SHADES}

EARLY FLOWERING OR CHRISTMAS VARIETIES.

Mrs. Alex. Wallace. Very early pinkish lavender. Oz. 20c $1 / 41 \mathrm{~b} .60 \mathrm{c}$.

GRANDIFLORA VARIETIES.

Lady Grisel Hamilton (Improved Countess of Radnor). Soft lavender, tinted with mauve in standard. $0 \mathrm{z} .15 \mathrm{c} ; 1 / 4 \mathrm{lb}$. $30 \mathrm{c}$ Flora Norton. Almost true sky-blue. Oz. 10c; $1 / 4 \mathrm{ib} .20 \mathrm{c}$. rs. Geo. Higginson, Jr. Clear azure blue self color. $\mathbf{O z}, 10 \mathrm{c}$ $1 / 4$ lb. 25c.

WAVED OR SPENCE TYPES.

ASTA OEN. The best lavender Spencer. Is more truly a soft pinkish lavender self. Very large and wavy. Per pkt. 10c FLORA NORTON SPENCER. This variety is more truly an Unwin in size, but is nicely waved. Bright blue with tint of purple. Per. pkt. 10c; 0z. 25c; $1 / 41 \mathrm{~b}$. $75 \mathrm{c}$.

FLORENCE NIGHTINGALE. See page 74 .

\section{MAUVE AND PURPLE SHADES}

\section{GRANDIFLORA VARIETIES.}

Mrs. Walter Wright (Improved Dorothy Tennant), Rosy purple self colored, large shell shaped. Oz. 10c;1/4 Ib. 20c.
Romolo Piazanni (Improved Emily Eckford). Rosy purple, turning clear blue with age. $0 \mathrm{z} .10 \mathrm{c} ; 1 / 1 \mathrm{~b} .20 \mathrm{c}$.

EMIIY ECKFORD SPENCER. A good Spencer of bluish purple similar in shade to grandiflora variets of this name. Per plst. 15c.

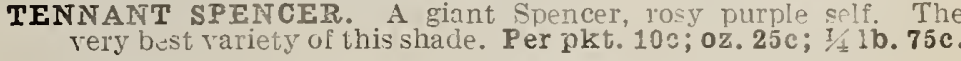

\section{LAVENDER AND MAUVE SHADED} Picotee Edged GRANDIFLORA YARIETLL.

Lottie Eckford White ground shaded with lilac, and haring a
deep border at the edges of both standard and wings. Oz. 10c; deep r bord
$1 / 4$ lb $20 \mathrm{c}$.

Maid of Honor. Clear white ground with blue edges. Oz. 10c; $1 / 4$ 1ib. $20 \mathrm{c}$.

Phenomenal. A large fluffy variety called orchid flowering; white ground shaded with blue and lavender, with edge of blue. Per
pkt. 10c; 0z. 20c; $1 / 4$ 1b. 60c. 


\section{LUE AND PURPLE SHADES}

\section{GRANDIFLORA VARIETIES}

Countess of Cadogan. Standard purple, wings clear blue. $\mathbf{0 z}$. $10 \mathrm{c} ; 1 / 41 \mathrm{~b}, 20 \mathrm{c}$

Dobbie's Mid Blue. A very clear bright blue. 0z. 15c; 1/4 1b. 50c. Helen Pierce. Clear blue marbled on ivory white, frequently called gloxinia flowered on account of its speckled effect. $\mathbf{0 z}$. 15c; $1 / 41$ b. $50 \mathrm{c}$.

WAVED OR SPENCER TYPES

CAPT. OF THE BLUES, or WAVERLY SPENCER. Clear purplish blue turning lighter at edges later in the season. Very large. Per pkt. 10c; 0z. 25c; $1 / 4$ 1b. 75c. ety and one of our best last season's set of novelties. Chocolate and seal brown striped, flaked and mottled on ivory white. Per pkt. 15c.

\section{DEEP MAROON SHADES}

\section{GRANDIFLORA VARIETIES}

Black Knight. Similar to Boreatton, the popular open form type, glossy deep maroon. The same shade as a Black Tartarian cherry. Oz. 10c; $1 / 41 \mathrm{~b}$. 20c.

othello. Same shade as Black Knight but of hooded or shell shape. 0z. 10c; $1 / 4$ 1b. 20c.

WAVED OR SPENCER TYPES

OTHELLO SPENCER. Of immense size with large drooping wings and large wavy standard. Deep rich maroon, very dark and adapted for many attractive combinations. Per pkt. 10c: oz. 25c; $1 / 41 \mathrm{~b}$. $75 \mathrm{c}$.

\section{DARK BLUE AND VIOLET SHADES}

\section{EARLY FLOWERING OR CHRISTMAS VARIETIES} Le IMarquis. A very early deep "Navy Blue." Per pkt. 10c;
oz. 15c; $1 / 4$ 1b. 50c.

GRANDIFLORA VARIETIES

Horace J. Wright. Large hooded or shell shape, violet and maroon. $\mathrm{Oz}$. 10c; $1 / 41 \mathrm{~b} .25 \mathrm{c}$

Lord Nelson, or Brilliant Blue. A darker strain of "Navy Blue," Very dark. Oz. 10c; $1 / 4$ 1b. 25c.

avy Blue. Standard indigo and violet, wings violet and bright Midnight, or Black Bird. Indigo blue and violet. The darkest shade in Sweet Peas. 0z. 15c; 1/4 1b. 50c.

\section{MIXTURES \\ EARLY FLOWERING OR CHRISTMAS VARIETIES MIXED}

Owing to short supply, we are able to offer but a few named varieties of these early flowering types but we have a number of colors including all the distinct shades which we are able to offer in a mixture. This is an especially attractive mixture and will give the planter a fine assortment of colors very early and several weeks before the other types are in bloom. Pkt. 10c; oz. 50c.

\section{BEST IJARGE FLOWERING MIXED}

ALL GRANDIFLORAS AND ECKFORD VARIETIES

This is the best possible mixture that can be made from existing grandiflora or Eckford varieties. The colors are well proportioned, and the amount of each variety is determined by a well-studied and carefully arranged formula which has been tested and improved upon from time to time for many years. All the newer and best grandiflora varieties are in this mixture. Pkt. 5c; oz. 10c; $1 / 4 \mathbf{l b}$. 20c; 1 1b. 45c

\section{MORSE'S SUPERB SPENCER MIXTURE}

ALL WAVED OR SPENCER VARIETIES

This mixture is made up from our carefully prepared formula and it contains practically all of the true Spencer varieties introduced to it contains practically all of the true Spencer varieties introduced to date, and it contains only the large

We do not think it possible for any one in the world to make up a better mixture of Sweet Peas than Morse's Superb Mixed.

Price per packet, 10c; 0z. 25c; $1 / 4$ 1b. 75c; 1 1b. $\$ 2.00$.

\section{CUPID SWEET PEAS}

These are low-growing or dwarf sweet peas, about one foot high and spreading to about two feet in diameter. The foliage is dark green and the stems are short, usually from three to six inches long. The blossoms, however, are larger than those of the tall varieties.

White. Pure White. Pkt. 5c; oz. 15c; $1 / 4$ lb. 40c; 1 lb. \$1.00. Pink. Color of Earliest of All. Pkt. 5c; oz. $15 \mathrm{c} ; 1 / 41 \mathrm{lb} .40 \mathrm{c} ; 1 \mathrm{lb}$. $\$ 1.00$.

Countess of Radnor. Lavender. Pkt. 5c; oz. 15c; 1/4 lb. 40c 1 lb. $\$ 1.00$.

Prima Donna. Pink. Pkt. 5c;0z. 15c; 1/4 1b. 40c; $1 \mathrm{lb} . \$ 1.00$. Mixture of all varieties, including those listed and many more besides. Pkt. $5 \mathrm{c} ; 0 \mathrm{z} .10 \mathrm{c} ; 1 / 4 \mathrm{~b}$. 25c; 1 1b. 75c

\section{SPECIAL COLLECTIONS OF BEST SH}

OUr "INCOMPARABLE" 25c COLLECTION of Sweet Peas. This package contains one packet each of the following 7 varieties:

King Edward VII: bright red.

Dorothy Eckford: large white.

Prima Donna: fine pink.

Lady Grisel Hamilton: lavender.

IIiss Willmott: orange-pink.

Hon. Mrs. E. Kenyon: soft primrose.

Countess Spencer: new giant pink.

Our "EXCELLENT" 50c COLLECTION of Sweet Peas. This package contains one packet of these 12 fine varieties: countess Spencer: mammoth pink.

Queen Alexandra: new brilliant scarlet.

Queen Alexandra: new briliant

Lady Grisel Hamilton: soft lavender.

Miss Willmott: large orange-pink

King Edward VII: giant bright red.

Helen Pierce: blue mottled white.

Hon. Mrs. E. Kenyon: soft primrose. Othello: deep maroon.

Navy Blue: violet and blue.

Earliest of All: the earliest pink and white.
OUr "SPIENDID" \$1.00 COLLECTION of the Best Sweet Peas. This package contains one packet each of the following 26 varieties-the newest and best-and 1 eties are described above.

King Edward VII: red.

Dorothy Eckford: white.

Countess Spencer: pink.

Lady Grisel Hamilon: lavender.

Lady Grisel Hamilton: lavend

Hon. Mrs. E. Kenyon.

Phenomenal.

Helen Pierce: blue mottled

\section{SWEET PEAS}

Aurora: orange-pink striped.

Queen Alexandra: scarlet.

Helen Lewis: orange-pink.

Shasta: fine large white.

Romolo Piazanni: lilac blue.

Janet Scott: buff and pink.

othello: deep maroon.

Navy Biue: violet and blue.

Earliest of All: the first to bloom, pink and

Stella Morse: buff and blush pink.

Mrs. George Higginson, Jr.: azure blue. Morse's Superb Mixture: Countess Spencer types mixed.

Lovely: pink with deep throat.

Golden Rose: primrose with soft pink stripes.

Apple Blossom: pink and white.

Iord Roseberry: bright magenta rose.

Florence Morse Spencer: blush white with

phink edge.

"STANDARD SPENCER" COLLECTION. A collection of 14 packets of the most distinct colors and varieties in the large flowered, wavy class of Sweet Peas. Price $\$ 1.00$.

Asta Ohn: pinkish lavender.

Aurora Spencer: orange-pink, striped.

Aurora Spencer: orange-pink, striped.

Captain of the Biues spencer: purple.

Florence Morse Spencer: light pink.
George Herbert: rose crimson.

Helen Lewis: orange-pink.

King Edward Spencer: pure red.

Miriam Beaver: apricot pink.

Mrs. Routzahn: apricot and straw.
Othello Spencer: dark maroon.

Primrose Spencer: pale yellow.

Countess spencer: bright pink.

White spencer: pure white.

Our "EXTRAORDINARY SPENCER COLLECTION" contains one packet each of all the best Spencer types of the Sweet Pea. Four of these are our latest novelties, just about to be introduced all over America and Europe, and offered here for the first time at retail. There are 27 packets in all. Price $\$ 2.50$.

\begin{tabular}{l|l} 
America Spencer: red and white striped. & Florence Morse Spencer: blush margined. \\
Apple Blossom Spencer: & Foseand primrose.
\end{tabular} Apple Blossom Spencer: rose and primrose. Asta Ohn: lavender and mauve.

Aurora Spencer: salmon striped.

Beatrice Spencer: rose, pink and buff.

Captain of the Blues Spencer: purple and blue.

Countess spencer: (original), bright pink. Dainty Spencer: white with pink edge.

Ethel Roosevelt: grand novelty-see p. 74.
Geo. Herbert: magenta rose.

Helen Iewis: orange pink

King Edward Spencer: bright red.

Lovely Spencer: deep rose shading to blush.

Marie Corelli: rose carmine.

Miriam B eaver: apricot pink.

Mrs. Sankey Spencer: black-seeded white.

Mrs. Sankey Spencer: black-seeded w
Mrs. Routzahn: primrose and blush.
Primrose spencer: clear, soft primrose. Othello Spencer: deep maroon. Queen Victoria Spencer: primrose. Ramona spencer: white with blush stripes. senator spencer: white with chocolate stripes.

Tennant spencer: purplish mauve. W. T. Hutchins: blush and cream. White spencer: pure white-seeded white. 


\section{SAN FRANCISCO CALIFORNIA U.S.A.}

\section{NURSERY DEPARTMENT}

The few following remarks should be read before making up order.

We have recently purchased a tract of land at Hayward, Alameda County, where we are growing our nursery stock. This is acknowledged to be one of the choicest sections in the State for such purposes. The climate is ideal and the soil of the richest.

OUR GREENHOUSES AND SALES YARD are situated on GLEN AVENUE, off Piedmont Avenue, OAKLAND, CAL. Visitors from San Francisco can reach there by taking the new Key Route Ferry (foot of Market Street) to PIEDMONT STATION; those from Oakland, by taking the Piedmont Avenue cars on Broadway to Glen Avenue. NURSERY TELEPHONE, PIEDMONT 30.

Customers will please remember that when our busy season commences we are rushed with orders, and it may be a few days before their orders receive attention; but they may rest assured that there will be no unnecessary delay in shipping. Prices quoted herein are f. o. b. cars, Nurseries, and cancel all previous quotations.

PACKING. Sufficient money should be added to remittance to cover cost of boxing, etc. Say ten per cent of purchase.

GUARANTEE. We do not guarantee stock to live, nor will we replace free of cost that which dies or fails to grow; nor can we, in view of the various incidents that the stock is subject to, as the success or failure depends largely on climatic conditions, manner of planting, after care, etc. We do guarantee, however, that our stock will be in a good, live and healthy condition upon departure from our nurseries.

SUBSTITUTION. Where particular varieties are ordered, and particular ages and sizes of trees, kinds of stock, etc., it should be stated whether and to what extent substitution will be allowed in case the order cannot be filled to the letter. Where no instructions in this respect accompany the order, we shall feel at liberty to substitute other varieties as nearly similar as possible. If the selection of varieties is left entirely to us, we shall endeavor to send only such sorts as are acknowledged to give general satisfaction.

AS USUAL, 5 will be furnished at 10 rates; 50 at 100 rates; 500 at 1,000 rates.

CLAIMS. Should any errors occur we desire to be informed upon receipt of goods, in order that we may rectify them without delay. All claims must be filed within ten days after the arrival of the shipments.

\section{THE ROSE}

\section{PLANTING}

December, January, February, and March are the best months, but should the season be favorable, and with a little extra care, jou can still plant during the early part of April. The plants sent during those months are what we call dormant two-year-old plants, and a verage from one and a half feet to two and a half feet in height, and are taken up without soil around the roots, and are packed in damp moss. Should the purchaser be unable to plant them immediately, they will take no harm to remain in the packing for a few days, or they can be opened up and "heeled" in the ground until ready to set out. The bushes sent out are already pruned. Our plants are budded on the Baltimore Belle and Manetti stocks; by so doing we get a strong root for the rose; our "stocks" are always disbudded but it sometimes happens that a sucker may grow from the root; planters should be careful to keep all suckers (if any), from below the bud, cut away, otherwise the stock outgrows the rosebud itself.

Roses give the best results when planted in good heavy sediment soil, to which may be added some good old stable manure, but remember that it ought to be well decayed. Under no circumstances use FRESH or new manure. After the hole is about three-quarters filled with that it ought to be well decayed. Under no circumstances use FRESH or new manure. After the hole is about three-quarters filled with during the winter, provided we have not a long, dry period; in that case the plants should get another watering at regular intervals. They during the winter, provided we have not a long, dry period; in that case the plants should get another watering at regular intervals.
will commence to bloom the first season after planting, in May and June, and if properly treated will give an abundance of flowers the first season. After the blooms are past, we advise you to cut the old flowers off; this treatment induces them to make new growth, from which you will obtain your next crop. To aid them at that time, keep them freely watered, and by so doing you can have flowers away into December.

\section{PRUNING}

A few remarks on this important point is now necessary. This should be done during the months of January and February; at that time the bushes are in a dormant condition. The "Teas," or Ever-blooming Varieties, require to be more severely pruned than any other sort, as they are the strongest growers. Cut back to about six or seven inches from the old wood, thinning out all weak wood and leaving about they are the strongest growers. Cut back to about six or seven inches from the old wood, thinning out all weak wood and leaving about
five or six shoots, according to size of plant; apply the same method that the orchardist does to his fruit trees, and you will be about right. five or six shoots, according to size of plant; apply the same method that the orchardist does to his fruit trees, and you will be about right.
The idea is not to leave too much wood on the plant. If you follow this method you will have large roses with long stems. If you fail in pruning and thinning out, you will have a plethora of small blooms.

THE HYBRID TEAS should have almost as much pruning done to them as to the Teas.

HYBRID PERPETUAL sorts, not being such strong growers nor making so much wood as the preceeding, do not require so much pruning done to them.

NOISETTE or CHAMPNEY varieties, being all climbers and strong, rampant growers, are not usually pruned as their duties are to cover certain objects. They should, however, be periodically thinned out.

BOURBON sorts should be pruned according to the growth they have made.

MOSS ROSES require very little pruning, as they usually make only a few shoots in a season. 

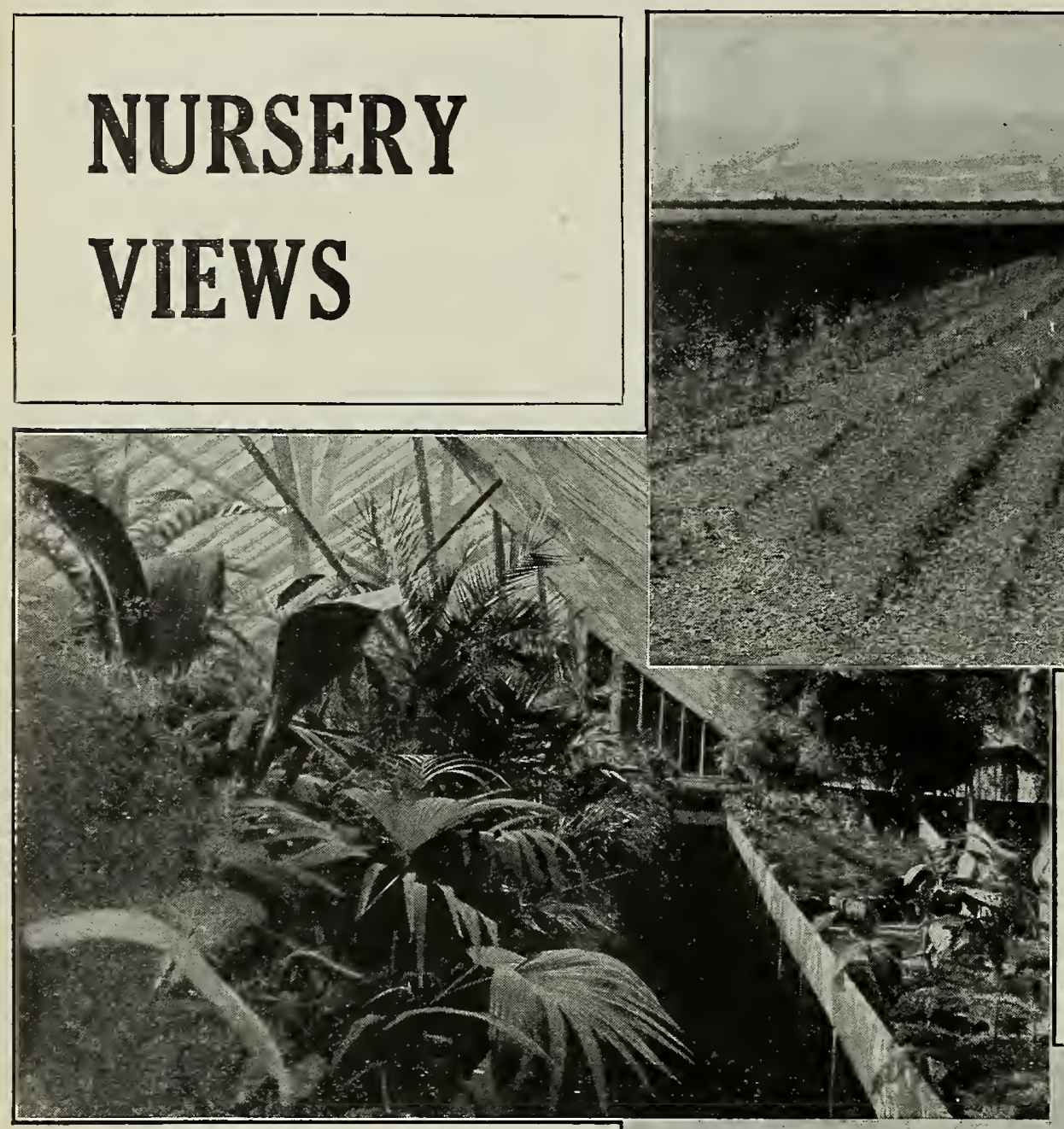

This photograph was taken at our Hayward Nursery May, 1910.

View in one of our greenhouses at our Glen Avenue, Oakland, Nursery.
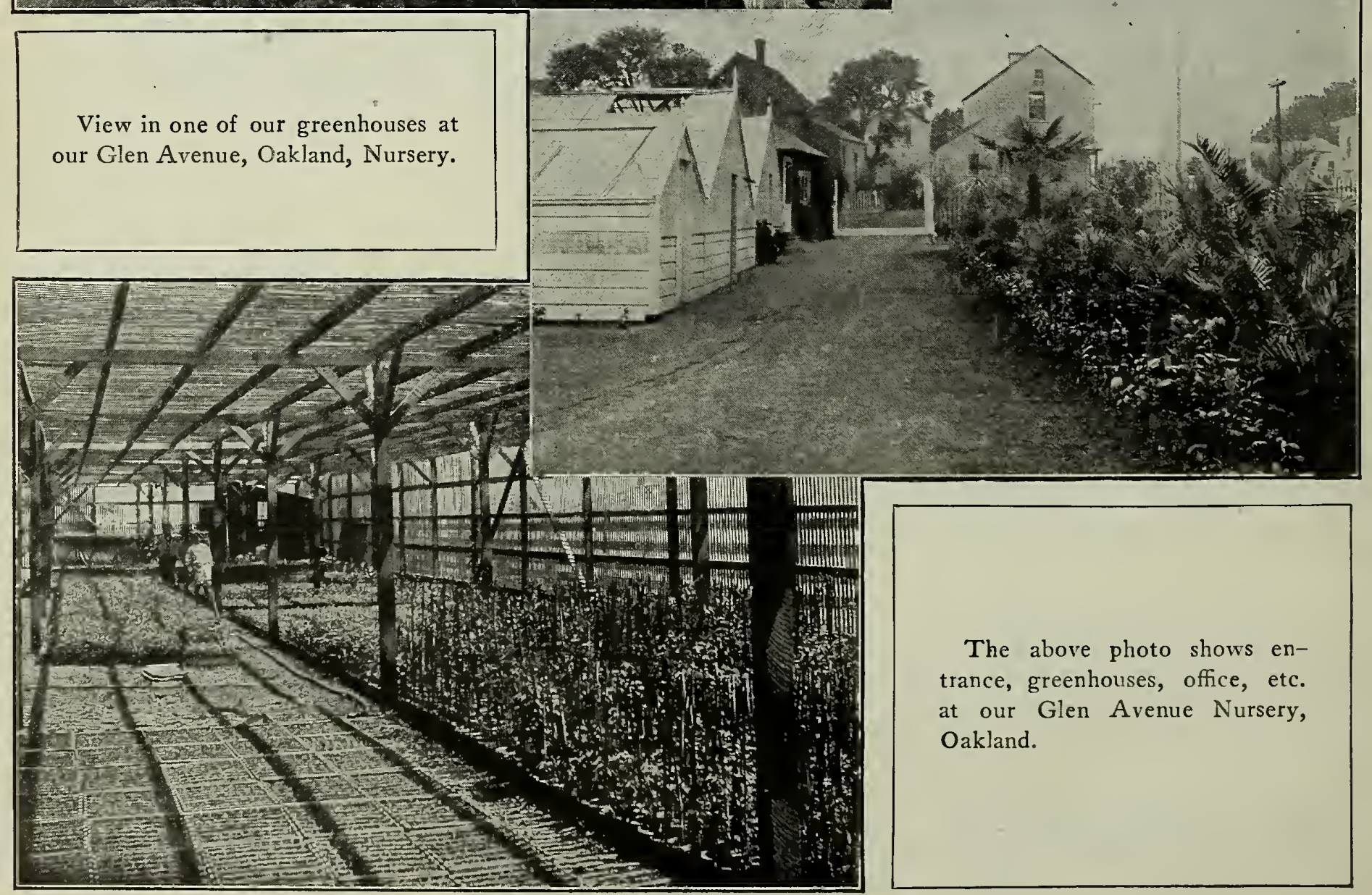

View in our large lath shed at our Hayward Nursery 


\section{SAN FRANCISCO CALIFORNIA U.S.A.}

\section{VARIETIES OF ROSES}

Te do not intend to enumerate all knomn sorts of the rosarian, but confine our remarks to such sorts as succeed best in California.

First of all come the TEAS, or ETER-BLOOMING. These are more generally planted in this State than any other Tariety for the reason that trey are the most profuse and longest blocmers. Jear. The first crop appears in April, May, and part of June.

The "Tea" is perfectly at home in this State, and this is tire only State in the Union. perhans, where ther can remain out all Tinter Trithout an protection. The TE AS have all rerr daintv, delicatel beautiful flowers, mostls with long pointed buds.

HYBRID TEAS are produced from crossing TEAS with Hrbrid PERPETUALS, and partake of the rich fragrance of the Hrbrids and the florification of the Teas. "La France." linomin to ereryone, is in this class. Thes are a most desirable class.

HIBRID PERPETEAL sorts produce much larger and mor? durable fowers than either of the tio preceding kinds, and hate a strong, rich fragrance, which to our thinking is the making of a rose. Take the American Beautr (knorn to all) for instance what other can compare with it in its rich penetrating odor?

THE NOISETTE or CHAIPNEY rarieties are all strong, rampant gromers, and are used as climbers, and include such sorts as the old farorite "Marechal Niol" so unirersalls esteemed, "Cloth of Gold," and "Milliam Allen Richardson."

POLTANTHA, or BABY ROSES. The blossoms of these are POI miniature blooms, appearing in clusters and are great farorites. Thes are free bloomers.

Beside the abore rarieties. we hare the BOURBON, BANKSIA IOSS, JAPAN, and SIIEETBRIARS.

\section{SOIL AND POSITION}

There are rers few places in the garden where the rose will not ucceed. Our California soil is pre-eminenels adapted for the health of the rose, and sunlight me hare to our heart's coritent; onlt, bear in mind, do not plant rour roses in a too shady place, and if rour soi the rose delights in good heary rich soil.

\section{WATERING}

The best mas to do this is to dig a ditch around rour bushes and The best me b th mo the water into it, afterward putting back the

in a great mant cases nerer

bake and harden the suriace Better orie GOOD spras them orerhead at night to keep the foliage free from Tou can aiso give them during the

\section{DISEASES}

You must not expect in the genial climate of Califormia to have sour roses entirely free from insects, but they are few and easily controlled.

APHIS, or GREEN FLI, is a small green louse, appearing on the roung, tender shoots and buds. Ther are Ters prolific in breeding. Through their tender beak ther suck the juices of the plants alvars working at the tender shoots, and rill in a short time, it inmolested destror the Tivor and ritalits oi ant plant thes infest. REUEDIES: Tobacco in anr form is fatal to trem; sprinkie porter作

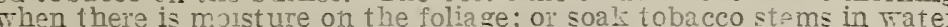
tili it is a bout the color of tooktea and appis with a siringe. Then possiole fumirate the plants with tobacco smcloe dinother cemedr: One pound Quassia (Quassia Armara) Chips. Thich can be obtained at any drug store, and put in four gallons of water and boil for ten the pound soit soap. This solution is to be applied with a syringe.

MILDE $\pi$. Then Jour plants become corered mith a $\pi$ hitishlooking mould or dust, the disaese is IIlder. Unless a Tert seter attack, it mill probably not kill them, but retard their gromth. It is caused bJ sudden atmospheric changes, and is generally morse in the Spring when the nights are cold and the dars are rarm. Some Tarieties are more susceptible to this than others. The best plan is NOI to Wait until the disease appears, but "taking time br the forelock, dust them in the morning with powdered sulphur, or sulphide of potassium.

ROSE SLTG. About the size of the common house fir, and comes from the ground in early Spring. The best remedies are pow dered Thite hellebore or a solution of whale oil soap.

ROSE BLG. Is of a grarish color, and about half an inch in length. It appears suddenly in earlJ Spring, and feeds upon the opening buds and flowers. Which it prefers to the foliage, and seems to be more fond of Thite and light colored flowel's than of the dariser colored ones. The best and really onls cure is handpicling.

From the abore, it Fill be noticed that the enemies of the rose are few, and really the only one which is at all troublesome is the Green Fly.
FORMS OF ROSES

In California there are only two forms of roses gromn-the BUSH and TREE (or STANDARD ROSE). The former is (as the name indicates) of bush form, branching from the sTound; the Tree Rose for this purpose three four and sometimes fre feet from the ground. The latter are usually preferred for planting on the lawn, as they tainly more showy for such places than the Bush Rose. To grow a Standard to salable size usually takes three jears; hence the difference in price.

\section{AEBEEVIATIONS IN FOLIOWING LIST}

$\mathbf{T}$ for Teas. $\mathbf{E} . \mathbf{T}$. for Hybrid Teas. $\mathbf{P}$ for Polyantha, or Bab Roses. 표. P. ior HJbrid Perpetuals. IN for Noiset te, or Champney.

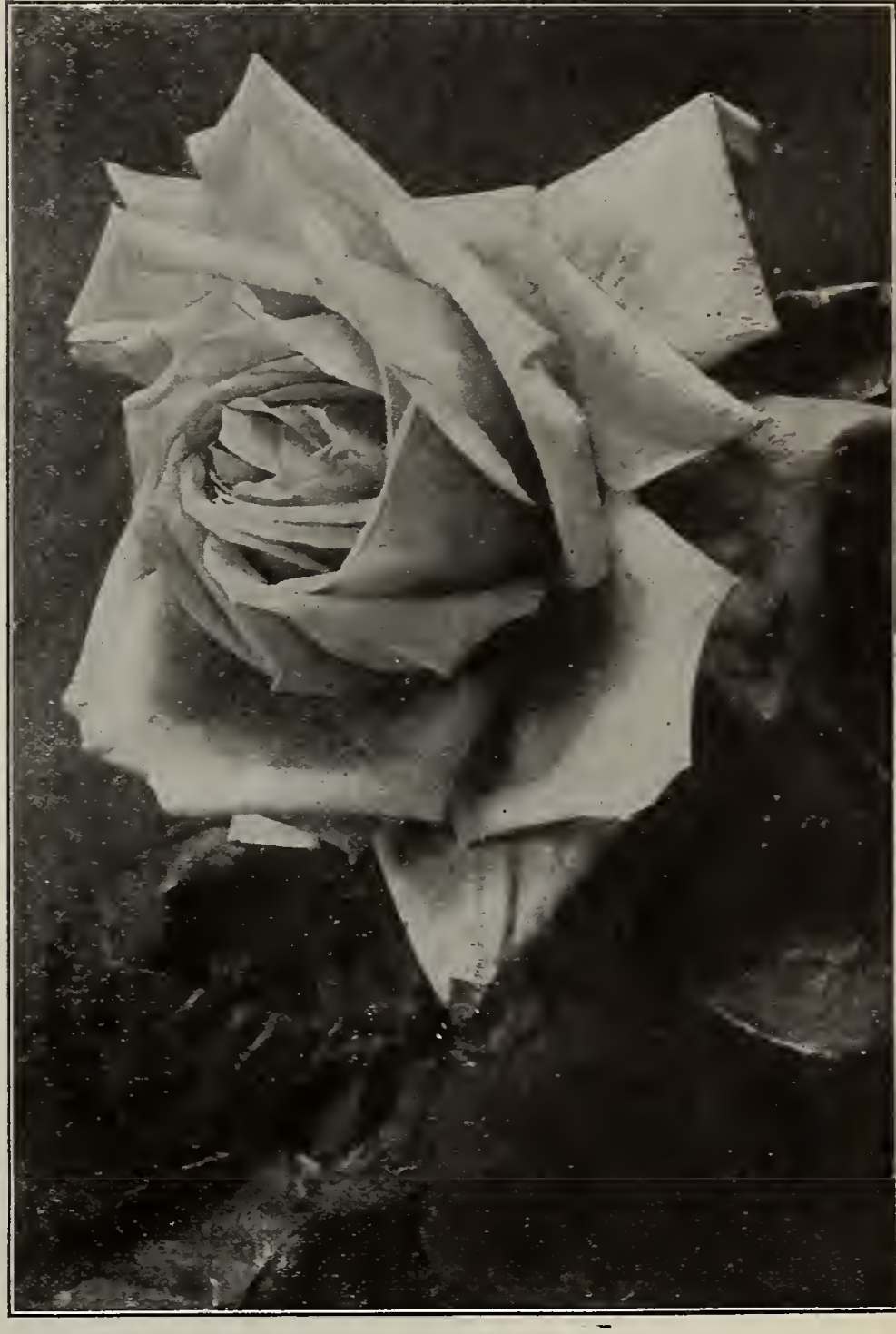

\section{THE LYON ROSE}

Two sears ago we introduced this mondrously beautiful rose; we predicted a truls come to pass. Ererjone $\pi$ ho has seen the Lron Rose is deighted with it.

The LJon is a Hrbrid Tea, thus insuring great blooming qualities. Te know of no other Tariets that will produce such a continuou crop of flowers. It mas raised by Pernet-Ducher company, an las a rarded a on marded the gold medal to this rose saTs: "I həTe no hesitaton in recom mendieg it as the most wonderiul color yet outalned anong roses. $12 i s$ mas de best compara seen in a giowing colve furrace.

A more detailed description is as follows: Shrimp pink at edges petals, center of flomer intense coral red, shaded chrome Jellow

Field grown, budded plants, $\$ 1.00$ each. 


\section{C.C.MORSE \& CO. PLANTS \& TREES}

\section{ALL THE LATEST AND BEST ROSES OF RECENT INTRODUCTION}

\section{HARRY KIRK}

Deep sulphur yellow, passing to a lighter shade at edge of petals. Large full perfect form, buds long and elegant. A splendid tea rose, flowering freely and continuously. This variety was awarded a Gold budded plants, $\$ 1.00$ each.

\section{WHITE KILLARNEY}

A pure white sport of the favorite pink Rose of Killarney. We have had this variety growing at our nurseries at Hayward for two seasons, and it has proved a very satisfactory sort. It is a pure white Hybrid Tea, very floriferous, of exceedingly strong growth plants, 750 each.

\section{MY MARYLAND}

Another American introduction that we have grown at our Hayward nurseries. for two seasons, a variety that we can highly recommend. The color is a most pleasing pink, somewhat of the same shade that can be seen in the "Lyon." The color is, however, not blended with any other shade, but solid. The flowers appear continuously, and are deliciously fragrant. The plant is of exceptionally strong habit: a Hybrid Tea. This rose will undoubtedly please strong habit; a Hybrid Tea. This rose will undoult

\section{OTTO VON BISMARCK}

A variety of German origin, of exceedingly strong, branching habit: flowering freely and continuously; color somewhat like that of "Caroline Testout." This variety we recommend for massing, as it is so extremely floriferous. A Hybrid Tea. Budded, fieldgrown plants, 50c each.

\section{LADY ROBERTS}

Rich apricot, base of petals coppery-red, edges of petals shaded orange; buds long and pointed. A most beautiful tea rose, that all
rose lovers should have in their collection, as it is of most undoubted excellence. Was awarded a Gold Medal, this fact alone branding it as something out of the ordinary. We have flowered it at our Hay-

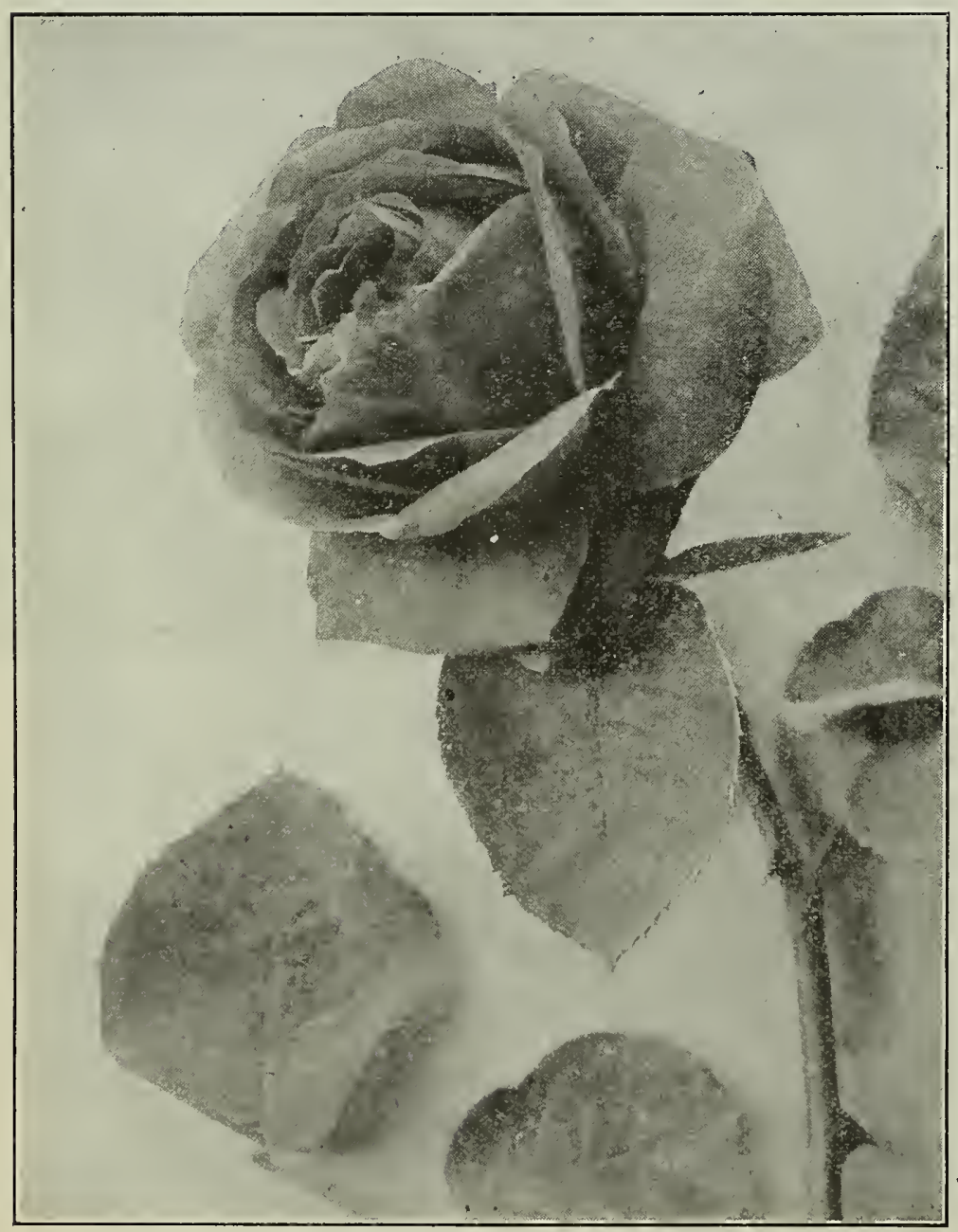

Hugh Dickson-Best red rose of recent introduction ward place this last season and considered it one of the best of the novelties. Strong field grown plants, 75c each.

\section{THE BLUE ROSE}

This rose has been extensively advertised as being such a grand novelty. We flowered it this past season and were much disappointed, as we expected, and we decided not to offer it, as we know our customers would not be pleased with it.

\section{HUGH DICKSON}

Introduced in 1904, and while not what we could call a novelty, it is of such excellent character that we list it prominently. The color is brilliant velvety crimson, shaded scarlet, most lovely; bud ong and pointed; flower when open very double; a most floriferous sort, continuing so for a long period; the fragrance is what we like in this rose, a fragrance that is entrancing. The habit of this sort is exceedingly strong, thrifty and healthy. It is most excellent for pillar or porch. Another Gold Medal rose, and one we have tried out for two seasons. Very strong field grown plants, $50 \mathrm{c}$ each; $\$ 4.00$ per 10 .

\section{COUNTESS OF GOSFORD}

Perhaps this is one of the loveliest pink roses that was ever in troduced. We cannot adequately describe this sort-words would fall far short. It is a Hybrid Tea, producing its flowers most freely. The buds are long, pointed, and sweetly fragrant. A Gold Medal rose. Strong field grown plants, 75c each; $\$ 6.00$ per 10.

\section{GENERAL McARTHUR}

Dazzling crimson scarlet; buds of ideal shape and exquisite perfume; foliage beautiful; plant a strong, thrifty grower. Hybrid Tea. Field grown plants, 50c each.

\section{FLORENCE PEMBERTON}

Creamy-white suffused pink; large, full, perfect in form, with very high pointed center. Awarded a Gold Medal by the National Field grown plants, 50c this

\section{MRS. MYLES KENNEDY}

Delicate silvery white shaded buff, while the center is pink, the reverse of the petals is a slightly deeper shade of pink. It is a wonderful bearer, producing great quantities of perfect blooms; the stems are strong, holding the flowers well up; the plant is of beautiful growth having very handsome foliage; a truly grand acquisition. A Gold Medal rose. Strong field grown plants, $75 \mathrm{c}$ each.

\section{MRS. EDWARD MAWLEY}

Bright carmine, shaded salmon; a superb variety; a chaste and perfectly formed flower of marvelous beauty. The blooms are very large, of great substance, beautifully formed, with highly-pointed center, from which the petals reflex; very sweetly scented and very floriferous. A Gold Medal rose. Strong field grown plants, $75 \mathrm{c}$ each.

\section{WM. SHAEN}

Purest pink; petals shell-shaped, four to five inches long; a glorious Hybrid Tea of immense size, perfect form and substance. Strong field grown plants, 75c each.

\section{J. B. CLARK}

An intense deep scarlet rose, shaded blackish-crimson; of ex quisite fragrance, and of very large size; a most prolific bearer; plant a strong, vigorous grower, with beautiful foliage. This rose whereever exhibited has attracted great admiration. It was awarded a Gold edal. strong two-year old fleld grown plants, $50 \mathrm{ceach}$ $\$ 4.7$.jer 10

\section{BETTY}

The coloring of this rose is wonderfully beautiful-ruddy gold overspread with golden yellow; flowers large, fairly double, fine form buds very long and pointed and very large petals; deliciously perfumed. Strong field grown plants, 50c each; $\$ 4.00$ per 10 .

\section{BEN CANT}

This rose was awarded a Gold Medal by the English National Rose Society, thus stamping it as a variety of remarkable beauty. The color is deep, clear crimson, with darker shading; of exquisite ragrance; very free in bloom and a strong, thrifty grower 


13. SAN FRANCISCO CAIIFORNIA U.S.A. DEY

\section{MRS. G. W. KERSHAW}

Glowing deep rose-pink; large, full, and of perfect form; a wonderful producer of most exquisite flowers. A superb and distinct rariety. strong two-gear-old plants, 50c each; $\$ 4.00$ per 10 .

\section{ALBERT DURAND}

A grand tea rose of recent introduction; color coppery-carmine shaded flesh, changing later in the season to canary yellow with flowers in great luxuriance; the plant itself is a strong, vigorous grower. Strong two-year old field grown plants, 50c each.

\section{CRIMSON CROWN}

Glowing dark crimson, with zones of lemon-white at base of petals wonderfully free flowering each shoot terminating with clusters of from six to nine blooms. Strong two-year-old plants, 50c each; from
$\$ 4.00$ per 10.

\section{ALICE GRAHAM}

Ivory-white, tinted salmon; a most beautiful delicate shade; buds long and pointed and very double. A rich variety. Field grown plants, 75c each.

\section{DR. CAMPBELL HALL}

Coral rose, suffused white, base of petals yellow; a charming rose of a color too difficult to describe. The flowers are large, full, and perfectly formed; very floriferous; a grand rose A Hybrid Tea. Fleld grown plants, $75 \mathrm{c}$ each.

\section{CHARLES J. GRAHAME}

A grand Hybrid Tea rose of great beauty; color, dazzling orangescarlet; of large, splendid form, and of floriferous habit: perfume exquisite. Strong two-year-old plants, 5Gc each; $\$ 4.00$ per 10

\section{COUNTESS OF DERBY}

Salmon at center outer petals rose, passing to flesh-veined peach as the flower expands; blooms very large and of perfect form. Hybrid Tea. Field grown plants, 50c each.

\section{LADY ROSSMORE}

Reddish-crimson, with claret shading; flowers medium, very ful and extremely floriferous; fragrance exquisite. Hybrid Tea. Strong two-year old field grown plants, 50c each.

\section{LADY BATTERSEA}

\section{(Red Niphetos)} Beautiful cherry-crimson; buds long and pointed, produced in
great luxuriance; habit of plant faultless. Hybrid Tea. Strong two-year old plants, 50c each; \$4.00 per 10.

\section{EARL OF WARWICK}

A lovely shade of soft salmon-pink, beautifully blended; the buds are long and pointed, and the open blooms come quite double: it is a most wonderfully free bloomer. A variety that we

\section{HONORABLE IDA BINGHAM}

A matchless pink of most charming tone, beautifully veined; the flowers are semi-double, thus adding greatly to its beauty; petals very large; a most distinct and unique sort. Strong two-year-old plants, 50c each; $\$ 4.00$ per 10 .

\section{NEWER ROSES}

Field Grown, 35c each; $\$ 3.50$ per dozen.

Customers selecting their own roses are respectfully requested to add to their orders a few supplementary sorts, lest by previous orders the stock of any particular variety should be exhausted.

CLIMBING CAROLINE TESTOUT. In this beautiful new introduction we have an exact counterpart in color and shape of that old favorite bush rose, Caroline Testout. To those who may be unfamiliar with that variety, we would say that the color is a beautiful, glistening pink; the blooms are large and produced most freely for a long period; the growth is rapid, and it very most freely for a long period; the growth is rapid, and it very quickly assumes large proportions, so that those wishing a in ordering the Climbing Caroline Testout.

CLIMBING BELLE SIEBRECHT. It is with real pleasure that we introduce this lovely new climbing rose. It is identical with the older bush form; color a most rare shade of pink; the buds are long and pointed; wonderfully profuse in bloom.

CLIMBING BRIDESMAID. We have a climbing sort of the wellknown favorite Bridesmaid to offer, which should be good news

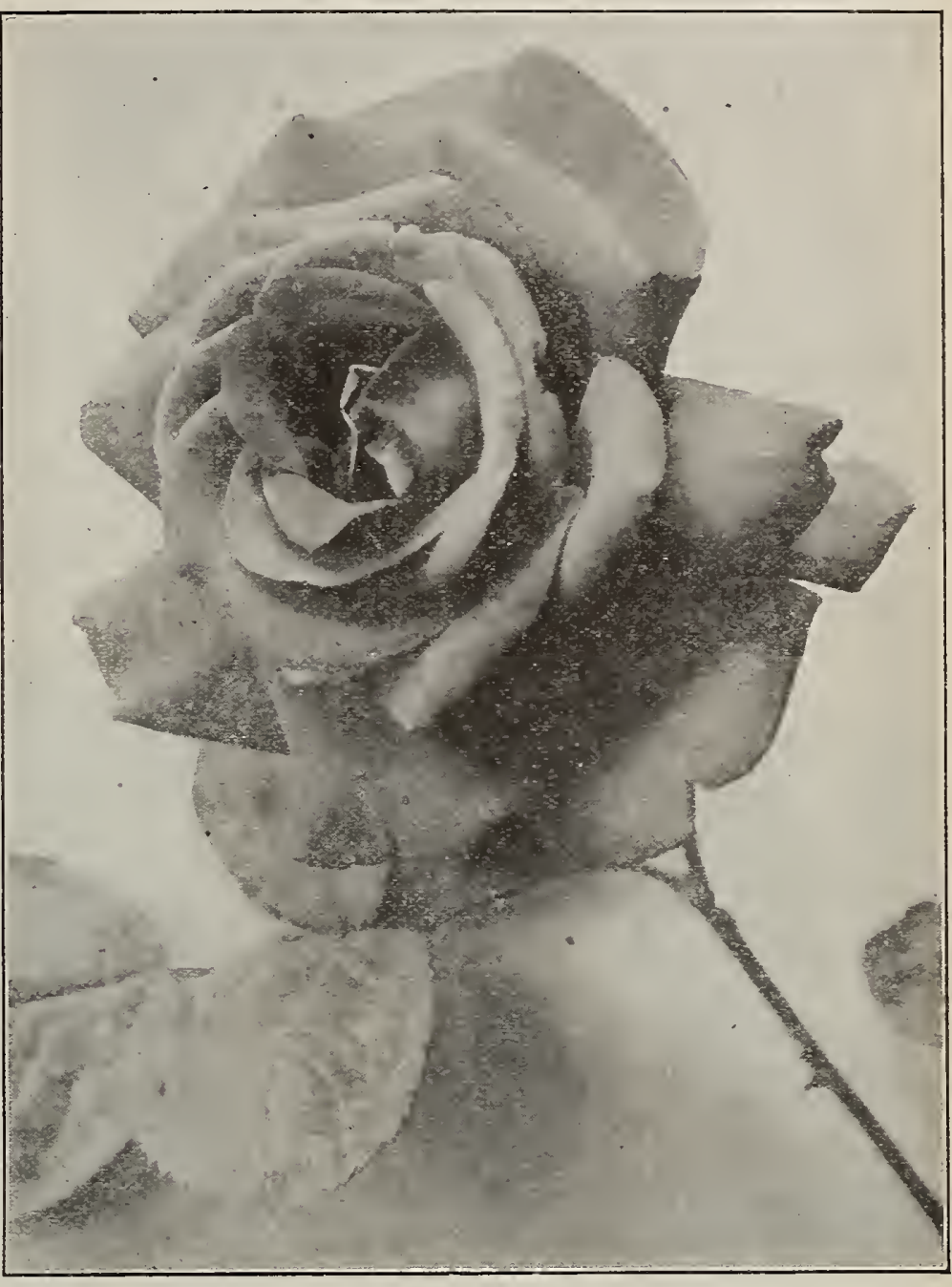

General McArthur

\section{DOROTHY PERKINS}

Flowers borne in large clusters, rery double, with pretty crinkled petals; clear shell-pink: a most profuse bloomer; a grand climbing variety and rery attractive. $35 \mathrm{c}$ each.

\section{SINGLE PINK · CHEROKEE}

A grand novelty, the single white Cherokee is a very well known variety, loved by all; in this new sort we have the same identical thing, excepting the color, which is a beautiful clear pink. A novelty
that we can very highly recommend. S Strong field grown, 75c each.

\section{LADY WENLOCK}

Coppery-yellow, apricot center, beautifully blended; buds long and pointed, open flowers rery double: a most prolific and continuous bloomer. The plant is a strong, rigorous grotrer. Strong two-year-old field grown plants, $75 \mathrm{c}$ each; $\$ 6.00$ ger 10 . 
ROSES-Continued

and pointed and of deep-red color. It is a free and continuous bloomer, like its parent. Habit of growth, strong and free.

duced very freely; an extremely strong grower; branches very thorny.

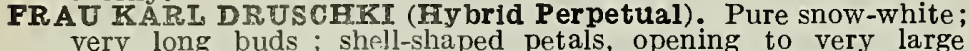
very long buds ; shell-shaped petals, opening to very large
flowers; has been well shown and is the finest white rose in cultivation; extra fine; superb.

This is the description of the introducer, Mr. Lambert of Germany, and we can fully corroborate all he has said about this magnificent rose. It has been well tested in this State during the last two years, and we send it out to the general public,

GRUSS AN TEPLITZ CLIMBING HERMOSA. There has always been a scarcity of good, dark, climbing, everblooming red roses, so the rose-loving public will be pleased to learn that we have one to offer in Gruss an Tepletz. The color is velvety
scarlet, and it is continually in bloom. It is of fast growth and scarlet, and it is continually in
very soom attains large size.

Irish Elegance of petals, flowers single. This interesting rose is a new type sent out by Dickson \& Co $\ddot{A}$
Newtonards, Ireland (distributors of so many fine roses). most unique variety. Should be in every collection. See "Maharajah" for another of this style.

Maharajah Deep velvety crimson, with prominent yellow ing single rose.

MAD. J. GROLEZ. (H. T.) Bright china pink; large, full, very fioriferous and of beautiful fragrance.

MILDRED GRANT. Ivory white, with a beautiful flush of pale peach bordering the petals; high pointed center, with unusually large and massive petals, opening to perfectly formed flowers of enormous size and substance.

PRINCESS VENUSA. An exceptionally pretty sort, ivory-white, tipped rose-pink; buds long and pointed.

ROSSL YN. Delicate rosy-flesh; a most unique and choice sort.

ROBERT SCOTT. Rosy-pink; very large well formed flowers, produced in great luxuriance.

ROSE OF KILIARNEY. This grand new rose was raised by Dickson \& Co. of Belfast, Ireland, who have sent out so many sterling novelties in the rose line. The color is a glistening, soft, silvery pink, the petals being waxy in appearance; the buds are long and pointed, slightly reflexed at the ends-; the rose when full blown being fairly double. In continuity of bloom the Rose of Killarney is unsurpassed.

\section{ROSES-CHOICE ASSORTMENT}

In this list will be found nothing but the very best older sorts.

These roses that we offer are thrifty, well-developed field grown plants, and are shipped in a dormant condition from about December 15th to about April 1st.

Price. 25c each; $\$ 2.50$ per dozen. Extra Selected large plants, 35c each; $\$ 3.50$ per dozen.

We will not supply less than six of a kind at dozen rates; if one of a sort is ordered single rates will be charged.

ADMIRAL DEWEY. (H. T.) Delicate light blush (a sport from Caroline Testout), with large, well formed flowers.

AMERICAN BEAUTY. "(H. P.) Large, globular, deep pink, shaded carmine, delicious odor; a fine variety for forcing.

ANNA DE DIESBACH. (H. P.) Brilliant pink. Long-pointed buds and large compact flowers.

ARD'S GEM. (H. P.) Crimson shaded maroon, flowers large foliage handsome; a great acquisition to climbing sorts.

AUGUSTINE GUINOISSEAU (White La France). (H. T.) This beautíful variety with flowers of pure white, shading to a center
of light rose, is a great favorite on account of its great freedom of bloom, fragrance, and large flowers. A vigorous grower, producing a great number of buds and flowers.

AVOCAT DUVIVIER. (H. P.) Crimson, large, full, well formed and fragrant; a fine rose.

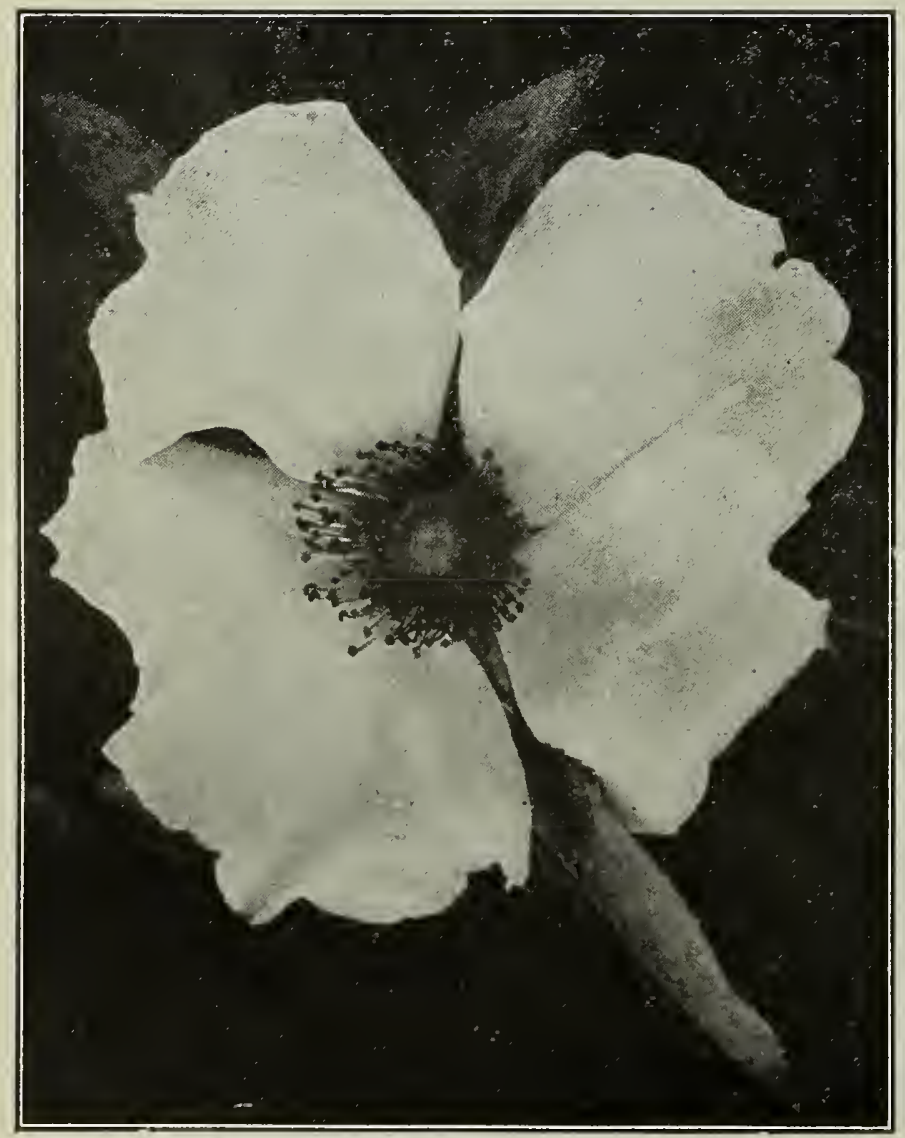

Single Pink Cherokee
BANKSIA, White and Yellow. These are the well-known thornless climbing roses. The flowers are small, but bloom in great profusion in Spring and early Summer.

BARDOU JOB. The color of this beautiful rose is rich velvety crimson, with yellow stamens. A grand climber.

BARONESS ROTHSCEILD. (H. P.) Very large flowers, shell pink, exquisite shape and fragrance.

BARON DE BONSTETTEN. (H. P.) Splendid large flowers; very double and full; color, a rich dark red, passing to a velvety maroon. Highly scented and very beautiful.

BEAUTY OF GLAZENWOOD. Variously known as San Rafael Rose, Hester Rose, Fortune Yellow, and erroneously named Gold of Ophir in Southern Califoinia. (Banksia.) A combination of copper, carmine, and salmon-yellow. A strong fast climber. This is the rose that blooms so bounteously in Springtime and which is admired wherever seen.

BELLE SIEBRECHT. (H. T.) A supcrb pink rose of recent introduction. The buds are long and pointed, and when halfblown the petals reflex in a graceful manner. The flowers have great substance and the petals are of heavy texture.

BEAUTE INCONSTANT. (T.) Flowers are pink, blotched white: a constant and profuse bloomer. Much admired.

BLACK PRINCE. (H. P.) Crimson, shaded with purple; medium size. A good dark rose.

BLANCBE MORREAU. (Moss) A pure white moss rose.

BON SILENE. (T.) Buds of beautiful form; an unusually free bloomer; color, deep rose-shaded carmine.

BRIDE. An everblooming pure white Tea Rose, of large size and most perfect form. The buds are pointed, and the ends of the petals are slightly recurved. It is a very free-blooming variety. and has a most delicious tea fragrance. One of the best white roses.

B RIDESMAID. In this exquisite Tea Rose we have an improved Catherine Mermet, from which it is a sport. Mermet, on account of its exquisite shape, large, solid, firm buds, with long stiff stems. has long been considered one of the best cut-flower varieties. Bridesmaid at all seasons is a clear, delicate pink, in all respects a counterpart of Mermet, with large, handsome, pointed buds on long stiff stems.

CATHERINE MERMET. (T.) Glistening pink, center shaded fawn and amber; buds and flowers very double, long and pointed. A most exquisite variety.

CAROLINE TEST OUT. A grand perpetual blooming Hybrid Tea of La France type, but much larger and of better color. being a bright, clear, delicate pink, retaining its color at all seasons.

CAPTAIN CHRISTY. (H. P.) Of delicate flesh color, rosy center; flowers extra large. double; full, and sweetly scented.

CECILE BRUNER. (P.) A charming "Baby" variety of sweet, delicate fragrance. Color, salmon-pink, with deep salmon center.

CHER OKEE, Single. One of the finest pillar roses in cultivation; large, clear white, single flowers, full of bright yellow stamens, which give it a most unique appearance; foliage dark, rich green. A most vigorous grower.

CHER OKEE, Double White. A rampant climber.

CHESHUNT HYBRID. (H. T.) Cherry carmine; large and full flowers of strong habit; constantly in bloom; good pillar rose.

CLAIRE CARNOT. (N.) Buff center, lighter toward edges. flowers in clusters; a lovely climbing sort, with beautiful glossy foliage. 
CLARA WATSON. (H. T.) Salmon, tinged pink; beautiful buds : a most lovely rose.

CLIMBING CAPTAIN CHRISTY. (H. P.) Those who know the old bush form of Captain Christy will be pleased to learn that we now have a climbing variety of this old favorite; delicate flesh color.

CLIMBING DEVONIENSIS. (T.) Large, creamy-white, shell-like petals of great substance; large, full and very fragrant.

CLIMBING KATSERIN AUGTSTA VICTORIA. (T.) Buds long strong and rapid glower.

CLIMBING IA FRANCE. A strong climbing sort of the old favorite La France.

CLIMBING NIPHETOS. (T.) A splendid companion to the Climbing Perle des Jardins. Color, pure white, with pale lemon center; beautiful long pointed buds; very fragrant.

CLIMBING PERLE DES JARDINS. (T.) Habit of growth is vigorous, young plants often sending up shoots six to eight feet in one season, with rich, glossy foliage, and bright red stems. The flowers are produced in profusion and are deep canary-

CLIMBING SAFRANo. See Reve d'Or. and pointed; pure white, of superb substance and texture;

ETOILE de IYON. (T.) Deep canary-yellow; flowers very large and durable; foliage beautiful.

EMPEROR OF IMOROCCO. (H. P.) An intensely dark rose, o velvety maroon.

ENGLAND'S GIORY. (H.T.) Flesh colored, with pink, satiny center; large, full and well formed blooms.

FLORA McIVOR (Sweet Briar). White, tinged l'ose.

GENERAL JACQUEMINOT. (H. P.) Rich velvety crimson, changing to scarlet crimson. A magnificent rose, beautiful in the bud or open. Is without a rival in fragrance and richness of color.

GLOTRE DE DIJON. (T.) A combination of rose, salmon and yellow; flowers very large and full. A good climber.

GLOIEE IYONNAISE. (H. P.) White, tinted yellow; large, very

GLOIRI DE MARGOTITN. (H. T.) The most beautiful of all red climbing roses. Specially adapted for planting against most brilliant shade of red; buds large, long and pointed.

GOIDEN GAIE. (T.) Canary-yellow flowers of delicate appearance; highly commendable in all respects.

GOLD OF OPFIR. (T.) Salmon-yellow, shaded with bright deep rose. Ciimber.

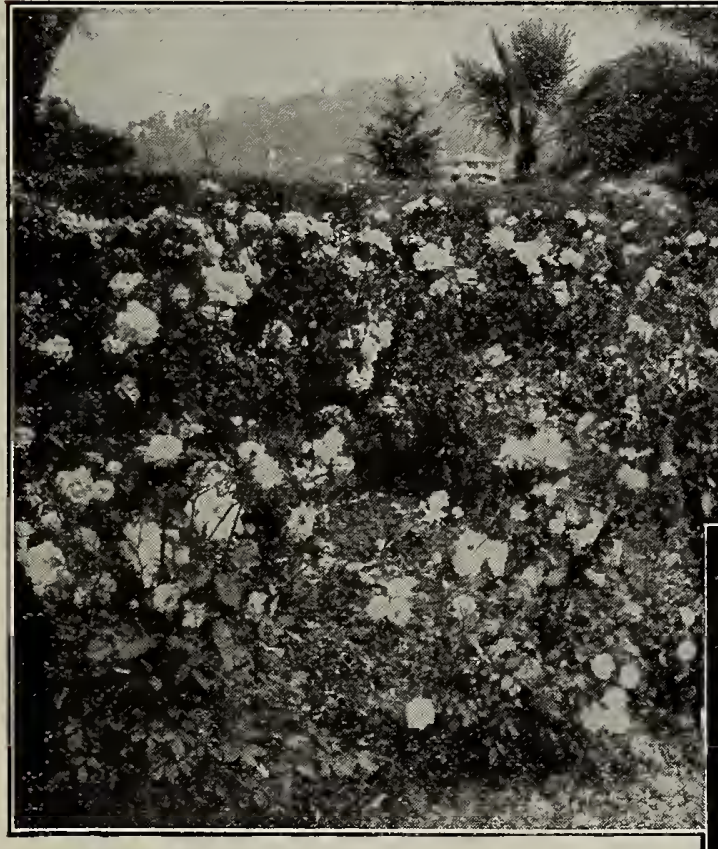

CLIMBING SOUVENIR DE WOOTTON. (H P.) Deep red, very large; flowers appea in great luxuriance; a very strong, rapis climber.

CLIO. (H. P.) A really grand rose; on the order of Baroness Rothschild; recommenoed by expert growers as the finest lose of this type; strong, vigorous grower; handscme foliage; flowers are flesh color, shaded in the center with rosy pink; large, of fine the center with rosy pink; large,
globular form; freely produced.

CLOTH OF GOLD. (N.) Deep yellow center, with sulphur-colored edges. A good climber.

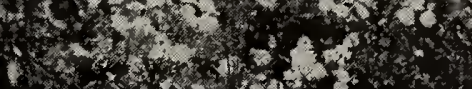

GRACE DARIING. (T.) Lovely pink tinted white, areat favorite.

EENRY MARTIN (MTOSS). Deep rosy carmine.

HERMOSA CJIMBING. See Grauss an Teplitz.

ISAEELIA SPRUNT. (T.) Beautiful canary-yellow; buds long and pointed.

JOEN HOPPER. (H. P.) Brilliant rose color changing to bright glowing pink; a very profuse bloomer very sweetly perfumed.

KAISERIN AUGUSTA VICTORIA. (T.) Full flowers; magnificent in bud; stems long, and bearing large, strong canes, with handsome foliage; flowers pure white. A grand sort.
CORNELIA COOK. (T.) Beautiful creamy white; petals of strong texture; free and continuous bloomer.

COUNTESS RIZA DU PARC. (T.) Bronzed rose; flowers medium size, moderately full; highly perfumed; very vigorous large and full.

CRIMSON RAMBLER. (P.) Of remarkably vigorous growth making shoots from eight to ten feet high in one season; flowers of brightest crimson, and produced in great pyramidal panicles, each having thirty to forty blooms.

DUCHESS d'AUERSTADT. (T.) Coppery-red, blended pink; a most lovely and unique variety.

DUCFESS DE BRABANT. (T.) Soft, rosy flesh, changing to deep rose color, edged with silver. Beautiful in bud, and highly
fragrant.

DR. GRILL. (T.) Clear buff pink, passing to a clear rose and fawn, elegantly suffused with pale canary yellow. A most profuse and regular bloomer.

ELIZE SAUVAGE. (T.) Pure snow white; buds and flowers elegant; one of the best whites.

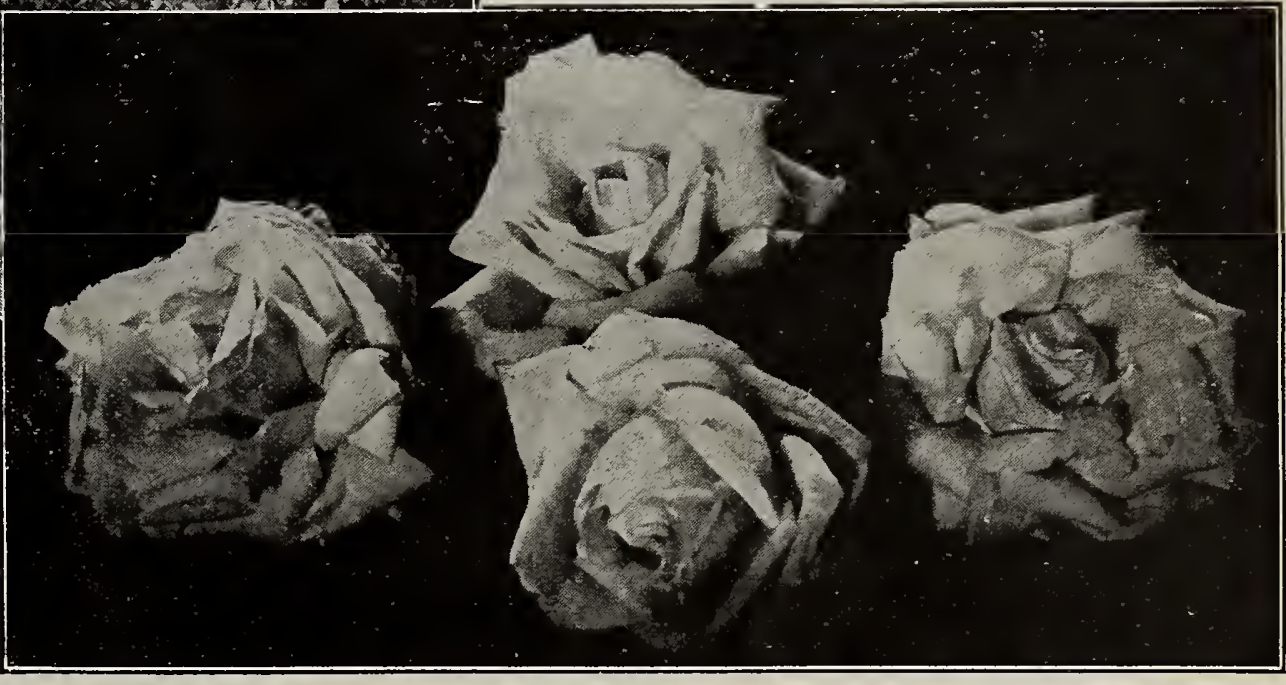

Frau Karl Druschk

KETTEN FRERES. (T.) Very deep yellow; bears double flowers foliage very beautiful; a grand sort.

IA FRANCE. (H. T.) Delicate silvery rose, shaded with cerise pink, often silvery pink, with peach shading; very large, very double; of superb form.

LA FRANCE OF '89. (H. T.) Long, elegant buds, approaching searlet; of sweet fragrance; a long and continuous bloomer; very desirable in every way.

IA MARQUE. (N.) Pure white buds, open flower tinged light canary-yellow; large and full. A grand climber.

LIBERTY (The New Century Meteor). (H. T.) Color, pure crimson-scarlet, of most intense hue; velvety in texture, cupshaped; of delicious fragrance; constant bloomer.

L'IDEAT. (T.) Coppery-yellow, blended pink; exquisite in every particular.

MADAME ALFRED CARRIERE. (N.) Creamy white, free bloomer, a strong and vigorous climber. One of the best for exposed cold situations. 


\section{2\% C.C.MORSE \& CO. PLANTS \& TREES ORIE}

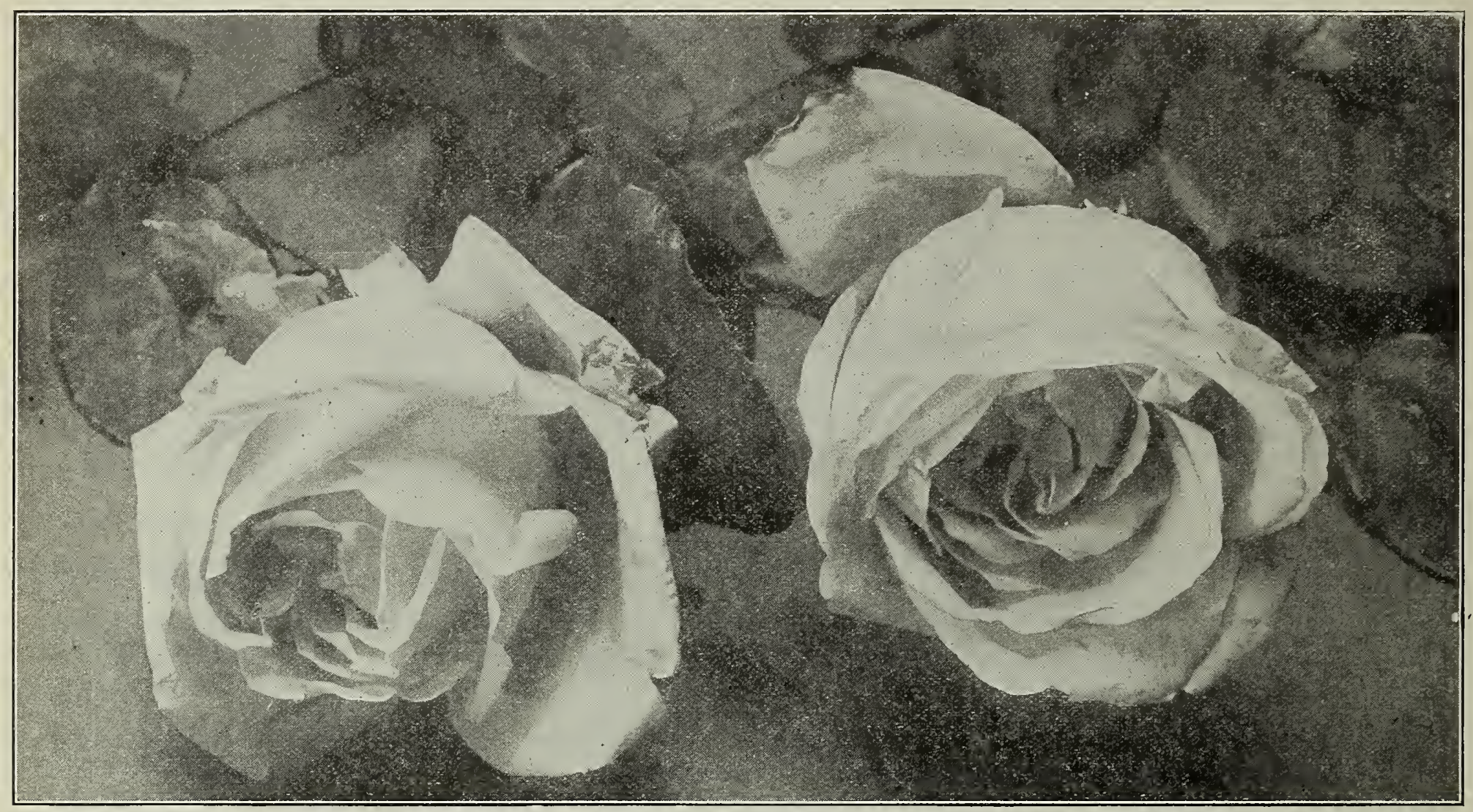

Mildred Grant

ROSES-Continued

MADAME C. TESTOUT. See Caroline Testout.

IMADAIME FALCOT. (T.) Deep apricot, shaded buff; beautiful in bud; very free in bloom; a most satisfactory sort.

M'LLE C. BRUNER. See Cecile Bruner.

MAGNA CHARTA. (H. P.) Bright, clear pink, flushed with violet crimson; flowers large, fine form, very double and full.

MAMAN COCHET PINK. (T.) Deep pink; buds long and pointed of great substance; a continuous bloomer.

MARECHAL NIEL. (N.) Beautiful deep yellow, large, full, and of globular form. A good pillar rose.

MARIE VAN HOUTTE. (T.) White, slightly tinged with yellow; free grower and fine bloomer. Exquisite.

MARSHALL P. WILDER. (H. P.) Cherry-carmine; very vigorous in growth, strongly perfumed, one of our best dark red "perpetuals."

MABEL MORRISON. (H. P.) Pure white, large flowers and very free in bloom.

MOSS ROSES. See Blanche Morreau, Henry Martin, Princess Adelaide.

MRS. JOHN IAING. Soft pink; large and of fine form, produced on strong stems; exceedingly fragrant.

MRS. R. G. SHARIAAN CRAWFORD. (H. P.) Color, deep rosy pink. Flowers large, of perfect imbricated form.

NIPEETOS. (T.) An elegant white rose. The buds are long and pointed.

PAPA GONTIER. (T.) A splendid variety, valuable both for open ground and greenhouse culture; it is a strong, vigorous grower and free bloomer; the buds are extra large, finely formed and very beautiful ; flowers double and full, and exceedingly sweet; color bright cherry red, passing to rich, glowing crimson, petals shaded with yellow; very striking and handsome.

PAUL NEYRON. (H. P.) Extra large and full; fine form; deep carmine color; very fragrant; free bloomer; an excellent rose.

PERLE DES JARDINS. (T.) Fine straw yellow; sometimes deep canary yellow; very large and full; and of the most perfect form; one of the finest roses grown; steps at once into fame as the finest yellow rose we liave.

PINK RAMBLER. Flowers pink; produced in great profusion, small, a most vigorous climber.

PRINCESS ADELAIDE. (Moss). Pale rose, good in bud and flower; very sweet.

PRINCE CAIMILE DE ROHAN. (H. P.) Rich, dark, velvety crimson, changing to scarlet maroon; full, double and sweet.

QUEEN OF EDGELEY. (H. P.) (Pink American Beauty。) Soft rich pink; buds long and pointed; sweetly perfumed.

RAINBOW. (T.) The color is a lovely shade of deep coral pink, beautifully striped and mottled in the most unique manner with intense glowing crimson, clegantly colored at centcr with rich golden amber; makes beautiful buds, and the flowers are extra large, very sweet, and of great depth and substance.

REINE MARIE HENRIETTA. An extra fine climbing variety; flowers large, full, and handsome; color, clear cherry red; a grand acquisition to climbing roses.

REINE OLGA DE WURTEMBERG. A lovely bright red; semidouble. A strong rampant grower.

REVE D'OR. (Climbing Safrano-N.) Deep yellow, sometimes coppery yellow or rosy buff; large, full, and sweet.' A beautiful climber.

ROGER LAIMBERIIN. (H. T.) Dark cherry red; each petal prettily típped white; very free bloomer.

RICHIMOND. (H. T.) Very fine rich scarlet; good bloomer.

SHIRLEY HEBBARD. ( $\mathrm{T}$.) Deep saffron yellow; buds very beautiful.

SAFRANO. (T.) Buff apricot; a constant and profuse bloomer; one of the old favorites.

SOLEIL D'OR. "Golden Sun." A grand new jellow rose. The color in bud is a rich chrome yellow tinted with coppery rose, and on expanding becomes a beautiful orange-yellow, shaded with copper and red; a very free bloomer and one of the best and most distinct roses of recent introduction.

SOUVENIR DE PRESIDENT CARNOT. (H. T.) A continuous and free bloomer, with most delightful fragrance; extremely large, both in bud and flower, retaining its full shape even when full blown; long and pointed; color delicate rosy flesh, shaded to pink.

SOUVENIR DE MALMAISON. (B.) Free blooming, of beautiful, clear, flesh color, edges blush.

SOUVENIR DE WOOTTON. (H. T.) One of our best red, everblooming, highly fragrant sorts. Flower is large and full; color beautiful shade of carmine crimson; strong grower.

SUNSET. (T.) Identical in every respect with Perle des Jardins, except that its color is that of rich saffron and orange.

THE QUEEN. (T.) Pure glistening white; buds full and double; very free in bloom.

ULRICH BRUNER. (H. P.) This we consider one of the most satisfactory of all the Hybrids. Flowers large, full and sweet; color, bright, clear red; a profuse bloomer and hardy grower.

WHITE LA FRANCE. (See Augustine Guinoisseau.)

VISCOUNTESS FOLKSTONE. (H. T.) Flesh color, shaded to pink; an extremely beautiful everblooming rose.

WHITE MAMAN COCHET. (T.) This American sport of the grand French variety, Maman Cochet, is one of the best whites of recent introduction; the buds are solid, long and pointed, faintly suffused pink on outside petals, and borne very freely; foliage glossy; plant strong, vigorous and healthy; highly com mended.

WILLIAM ALLEN RICHARDSON. (N.) Fine orange yellow, apricot center; medium size; full, very showy and distinct. A beautiful climber. 


\section{STANDARD ROSES}

We can supply the following roses in standard or tree form, that is, they are budded on single Stems, three to four feet from the ground. $\$ 1.25$ cach.

Augustine Guinosseau.

Bridesmaid.

Bride.

Camoens.

Cheshunt Hybrid.

Conrad F. Meyer.

Caroline Testout.

Dr. Grill.

Frau Karl Druschki.

Gloire de Dijon.

Gloire de Margottin.

Gruss an Teplitz.

General Jacqueminot.

For convenience sake we give below a list of those Roses that climb:

Ard's Gem.

Banksia, White and Yellow.

Bardou Job.

Beauty of Glazenwood.

Cherokee.

Climbing Belle Siebrecht.

Climbing Bridesmaid.

Climbing Cecile Bruner.

Cheshunt Hybrid.

Climbing Cap. Christy.

Climbing C. Testout.

Climbing Devoniensis.

Climbing La France.

Climbing Papa Gontier.

Climbing Niphetos.

Climbing P. des Jarđins.
Kaiserin A. Victoria.

Killarney.

La marque.

L'Ideal.

Marechal Niel.

Mrs. John Laing.

Papa Gontier.

Paul Neyron.

Perle des Jardins.

Pink Maman Cochet.

Rainbow.

Reve d'Or.

Ulich Bruner.

Climbing Kaiserin.

Climbing S. de Wootton.

Cloth of Gold.

Crimson Rambler.

Dorothy Perkins.

Gloire de Margottin.

Gloire de Dijon.

Gruss an Teplitz.

Hugh Dickson (strong grower).

La Marque.

Marechal Niel.

Mad. A Carriere.

Reine Marie Henrietta.

R. O. de Wurtemberg.

Reve d'Or.

W. A. Richardson.

\section{ROSES ARRANGED IN COLOR CLASSES}

WHITE. Augustine Guinosseau, Bride, Cherokee, Cornelia Cook, Gloire Lyonnaise, Kaiserin Augusta Victoria, La Marque, Madame A Carriere Taman Cochet The Queen, White Killarney Alice Grahame, Frau K. Druschki, Elize Sauvage.

YELLOW. Cloth of Gold, Gloire de Dijon, Golden Gate, Isabella Sprunt, Madame Falcot, Marechal Niel, Perle des Jardins, Reve d'Or, Safrano, Sunset, W. A. Richardson, Harry Kirk, Etoile de Lyon, Ketten Freres.

BRONZE YELLOW. Beauty of Glazenwood, Claire Carnot, Dr. Grill, Gold of Ophir, L'Ideal, Soleil d'Or.

PINK AND ROSE SHADES. American Beauty, Belle Siebrecht, Bon Silene, Bridesmaid, Caroline Testout, Killarney, La France, Magna Charta, Mrs. John Laing, Pink Maman Cochet, Paul Neyron, Pink Cherokee, Dorothy Perkins, Conrad F. Meyer, Cath.
Mermet, Hon. I. Bingham, Dr. Campbell Hall, Mrs. G. W. Kershaw, Anna de Diesbach, Mv Maryland, Otto von Bismarck. Countess of Gosford, Mrs. E. Macolly, Madame L. Grolez, Wm. Shean.

SCARLET CRIMSON AND SHADES. Bardou Job, Cheshunt Hybrid Crimson"Rambler, General Jacqueminot, Gloire de Margrid, Criberty, Papa Gontier, Reine Marie Henrietta, Reine gottin, Arthur, Gruss an Teplitz, J. B. Clark, John Hopper, Ben. Cant, Edgeley.

VERY DARK REDS, Baron de Bonstetten, Black Prince, Emperor of Morocco, ir. P. Wilder, Prince C. de Rohan, Maharajah.

BLENDED AND VARIEGATED SORTS. Beaute Inconstant, Countess R. du Parc, L'Ideal, Marie Van Houtte, Rainbow, Countess of Derby, Mildred Grant, The Lyon, Florence Pemberton, Mrs. M. Kennedy, Betty, Albert Durand.

SALMON SHADES. Captain Christy, M'lle C. Bruner, Souvenir de President Carnot, Viscounte

\section{ROSES IN POTS}

We grow the leading varieties of roses in pots, so that if any of our customers are unable to get their planting done during the dormant months, they can purchase potted plants that can be set out at any time. 35c each; $\$ 3.50$ per dozen.

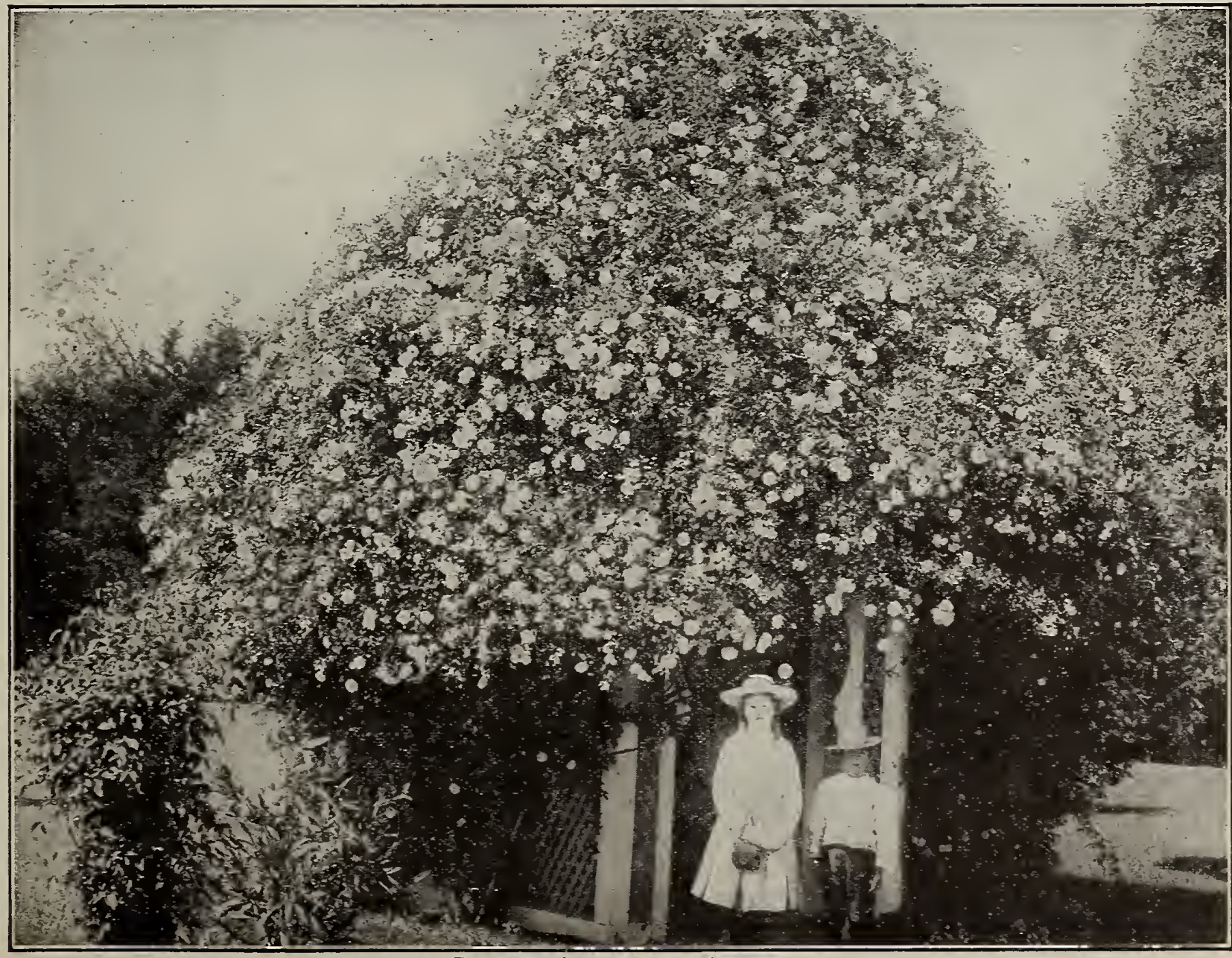




\section{C.C.MORSE \& CO. PLANTS \& TREES}

\section{HARDY EVERGREEN TREES AND SHRUBS}

\section{ABIES-SPRUCE, FTR AND HEMTOCK}

Among these will be found some of the grandest coniferous trees in existence. For reforesting they are unequaled and for home beautifying find no rivals; all of fairly rapid growth.

Concolor. The color of the foliage of this choice sort is a beautiful oduish green; the needles are long and soft and have a fine fir 2 to $21 / 2$ feet, $\$ 1.25$ each.

CIIICIA (Cilician Silver Fir.) A distinet and beautiful species from the mountains of Asia Minor. It is a compact grower, the branches being thickly set on the stems; foliage dark green; quite $75 \mathrm{c}$ each; 2 feet, $\$ 1.00$ each.

CEPFAIOIICA (Cephalonian Silver Fir). From Europe. A remarkable and beautiful species; very broad fồ its height; leaves silvery and dagger-shaped with a spine on the point; quite hardy
and vigorous. Boxed, $11 / 2$ to 2 feet, $\$ 1.25$ each; $21 / 2$ feet, $\$ 2.00$ each.

\section{ABIES DOUGLASIT-Douglas Spruce}

Red Fir. Yellow Fir. Oregon Fino. This variety grows to a height of 300 feet; abounds in the Rocky Mountains. Accommodates itself to many soils, but prefers a deep, moist, cool and dell-drained one, succeeds well on a dry, slaty soll and on sand dunes and exposed situations. Surpasses almost all of the Bailed $11 / 2$ feet, 50c each; $\$ 4.00$ per 10 ; boxed 3 feet, $\$ 1.50$ each; $3 \frac{1}{2}$ feet, $\$ 2.00$.

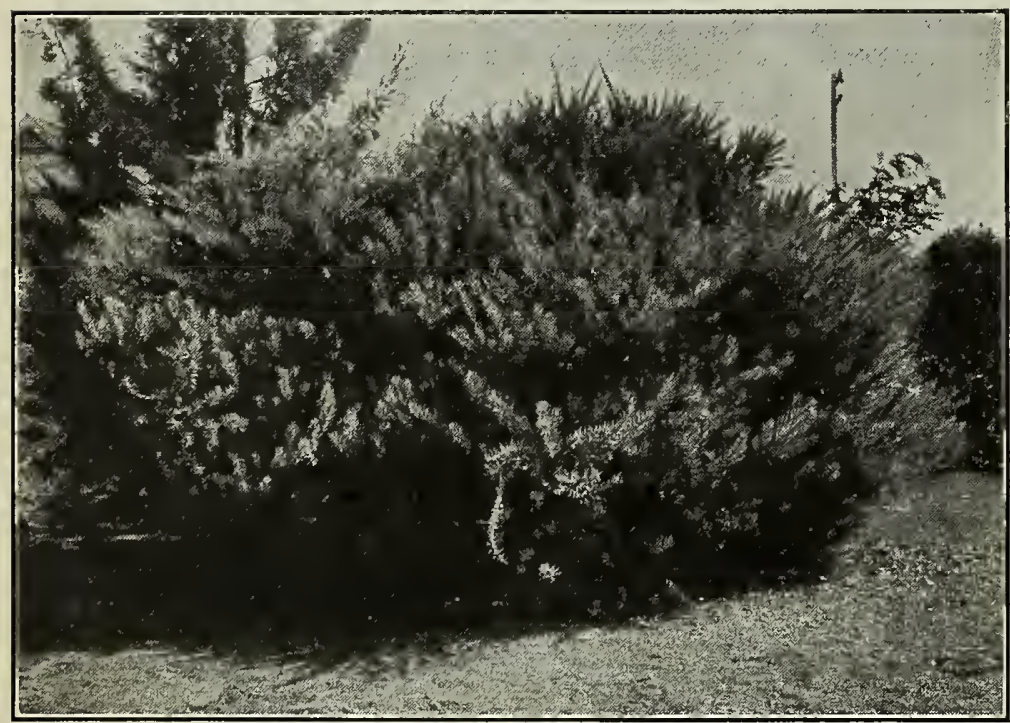

1cacia Cultriformis

ENGELMANNI. This fine new Conifer is found on the higher parts of the Rocky Mountains. In its most favorable localities his species makes a stately tree, 60 to 100 feet high, forming a narrow tapering spire of a rather dark hue. A suitable tree for
reforesting mountain slopes. As a specimen on a lawn it has few equals. G-inch pots, $75 \mathrm{c} \in \mathrm{ach} ; \$ 6.00$ per 10 .

\section{ABIES EXCELSA-Norway spruce}

Perhaps one of the best known spruces. It is of rapid growth, attaining large size; habit of growth most symmetrical. In England and Germany this is the sort that is used for Christmas trees. 5 -inch pots, $50 \mathrm{c}$ each; $\$ 4.00$ per 10 ; balled $1 \frac{1}{2}$ feet, $60 \mathrm{c}$ each; $\$ 5.00$ per 10 .

EXCELSA AUREA. The foliage on the upper side golden yellow in color. Boxed, 1 to $1 \frac{1}{2}$ feet, $\$ 1.25$ each.

FIRMA. A stately tree, attaining in favorable localities a height of 150 feet; branches horizontal, leaves deep glcssy green above. paler beneath. A native of Japan. Boxed, $2 \frac{11 / 2}{6}$ to 3 feet, $\$ 2.00$ each.

LASIACARPA、 Native of Northern California and Southern Oregon; oliage, sea grreen; growth. Boxed, 2 feet, $\$ 1.50$ each.

\section{ABIES MENZEISII}

A native of Alaska and Northwestern coast; thrives in low elevation moist soil and climate, and is found in shady places. Beautiful Pot grown, 2 to $2 \frac{1}{2}$ feet, $\$ 1.00$ each; $\$ 8.00$ per 10 . Boxed 3 feet. $\$ 1.50$.

\section{ABIES NORDMANIANA (Nordmann's Silver Fir)}

This majestic Fir, from the Crimean Mountains, is of symmetrical form, vigorous and quite hardy. Its foliage is quite massive dark green, shining above, and slightly glaucous below, rendering it a very handsome tree throughout the Jear. Considered here and in Europe as one of the finest of the Silver Firs. Balled, $\$ 5.00$ per $10 ;$ boxed $11 / 2$ feet, $\$ 1.50$ each; boxed, $21 / 2$ feet $\$ 3.50$ each.

PARRYANA GLAUCA. A beautiful sort, with lovely sea-green foliage. Bored, 2 feet, $\$ 1.50$ each.

\section{ABIES PINSAPO-(Spanish Silver Fir)}

A beautiful tree: its compact growth and unique appearance render it worthy of a place in the garden. One of the handsomest in ihis class. Balled, 12 to 15 inches, $75 \mathrm{c}$ each; $\$ 6.00$ per 10; boxed, $1 \frac{1}{2}$ feet $\$ 1.50$ each; boxed $21 / 2$ feet, $\$ 3.50$ each. PINSAPO GIAUCA. A form of the preceding; the foliage is distinct and beautiful, being of a lovely sea-green color. Boxed, 15 to 18 inches, $\$ 1.00$ each.

POLITA (Tiger's Tail Spruce). A distinct Japanese species. It is of erect habit and has rigid sharply pointed leaves of a bright green color. Balled, $1 \frac{1 / 2}{2}$ feet, $75 \mathrm{c}$ each.

\section{ACACIA}

The Acacias are all natives of Australia and Tasmania. The wood is valuable and the bark used extensively for tanning purposes. They are all of rapid growth and produce their various shades of yellow flowers in great profusion. For quick growth and shade-affording purposes we know of no better tree. We offer the following varieties, all pot grown:

BAILEYANA. One of the most ornamental; foliage beautiful seagreen, flowers yellow; balled-shaped; very profuse in bloom.

CULTRIFORIIS. Foliage of this variety is triangular in form color beauifiul sea-green; profuse in bloom; of medium-sized $35 \mathrm{c}$ each; $\$ 3.00$ per $10 ; 2$ feet, 500 each.

IMPERIATIS. Leates round, olive-shaped. $2 \frac{1}{2} \mathrm{feet}, 25 \mathrm{c}$ each $\$ 2.00$ per 10.

IATIFOLIA. Resembles the "Melanoxylon" variety, but leaves The longer, and tree more floriferous; flowers long spiked shape. it is excellent for such purposes. 2 to 3 feet, $30 \mathrm{c}$ each, $\$ 2.50$ 源 small plants in $2 \frac{1}{2}-$ inch pots, $\$ 5.00$ per 100 .

ACACIA MELANOXYLON-(BlackWood Tree)

Baron Von Mueller, in his "Select Extra-tropical Plants," writes of this tree: "The well-known Blackwood of our river fiats and moist forest valleys. In irrigated glens of deep soil, the tree will attain a height of 80 feet, with a stem several feet in diameter. The wood is most valuable for furniture, railway and other carriages, boatstern post, ribs, rudder), for tool-handles, crulches, some portions of the work of organ-builders, casizs, numerous other purposes. The fine grained wood is cut into veneers. It takes a polish, and is almost equal to walnut. Our best wood for bending under steam, it does not warp or twist." "

The great billiard-table firm of Alcock \& Co in Sydner and Melbourne, have been making tables from it for the last eight Jears, and at the exhibition of 1888 , there was a piano cased with it which was as handsome a piece of parlor furniture as one could wish to own. The Martin-Henry Rifle Co., have been using it for gun stocks for the last fifteen years because they could get it much cheaper than the French walnut hitherto used by them." Have you any vacant land suitable for the growth of this tree. If so, plant out a grove of them. They will grow into money while
you are asleep.

Not only is the "Melanoxylon" valuable as above, but for sidewalk or avenue trees it has few equals, being of very rapid growth and it can be trimmed so as to make beautiful specimens.

3-inch pots, 2 to 3 feet, 25c each; $\$ 2.00$ per 10. 4-inch pots, 3 feet, $35 \mathrm{c}$ each; $\$ 3.00$ per 10 . 5 -inch pots, 4 to $4 \frac{1}{2}$ feet, $50 \mathrm{c}$ each; $\$ 4.00$ per 10 .

6-inch pots, 6 to 7 feet, 75c each; $\$ 6.00$ per 10 .

MOLIISSIMA. A fine. erect-growing tree, with glaucous green, feathery foliage; flowers yellow, produced in early sprins in great profusion. A rapid-growing tree. 2 feet, $30 \mathrm{c} \mathrm{each}$; $\$ 2.50$ per $10 ; 3$ feet, 40 c each; $\$ 3.50$ per $10 ; 4$ to $41 / 2$ feet, $60 \mathrm{c} \mathrm{each} ; \$ 5.00$ per $10 ; 5$ feet, $75 \mathrm{c}$ each.

PYCNANTHA (Golden Wattle.) Leaves long and narrow, flowers in long solitary auxiliary spikes. 4 to 5 feet, $50 \mathrm{c}$ each. 
RETINOIDES FLORABUNDA. Pendulous habit; sea-green foliage; very floriferous and sweet perfumed. 12 to 18 inches, $15 \mathrm{c}$ each; $\$ 1.00$ per $10 ; \$ 7.00$ per $100 ; 3$ to $3 \frac{1}{1} / 2$ feet, $30 \mathrm{c}$ each; $\$ 2.50$ per $10 ; 4$ to 5 feet, 50 c each; $\$ 4.00$ per $10 ; 6$ feet, $75 \mathrm{c}$ each; $\$ 6.00$ per 10 .

\section{ARAUCARIA}

Named from Auracanos, the native Chilean name for this tree. We list three varieties, one from Chili, one from Australia, and one from Norfolk Island. Which is the handsomest it is hard for us to say. They are all grand, majestic, noble trees, attaining in time immense proportions.

BIDWFLII. Branches in regular whorls; closely set with spiny Walled, $1 \frac{1}{2}$ feet, $\$ 1.00$ each; balled, 2 feet, $\$ 1.50$.

EXCEISA (Norfolk Island Pine). One of the handsomest of all trees; pyramidal in form and very symmetrical; hardy in proand $\$ 4.00$ each, according to size.

IMBRICATA (Chili Pine, or Monkey Tree). A fine tree, of regular pyramidal form; leaves bright green, broad, thick,

pointed.

ARBOR VITAE, See under Thuja,

ARBUTUS UNEDO. "Strawberry Tree." Balled, 8 to 12 inches, $35 \mathrm{c}$ each.

ARDISIA CRISPA. This Japanese shrub is prized chiefly on account of the fine clusters of red berries which it bears at Christmas time in great profusion. 5-1nch pots, $50 \mathrm{c}$ each.

\section{AUCUBA}

JAPONICA. This shrub is sometimes called the "Gold-Dust Tree," on account of its large, glossy toliage being marked with yellow spots. It is an extremely beautiful plant, and is of slow, spreading growth. In the warmer sections it should have partial $50 \mathrm{c}$ each; $\$ 4.00$ per 10 . 7-jnch pots, 2 feet, bushy, $\$ 1.00$ each.

LATIFOLIA VIRIDIS. This variety has dark-green shining foliage; in Winter time it is covered with red berries, which greatly per 10.

DENTATA. Leaves deeply cut, glossy and green. 5-inch pots, $11 / 2$ feet, $50 \mathrm{c}$ each; $\$ 4.00$ per 10 .

LONGIFOLIA PICTA. Large leaves, beautifully spotted. 5inch pots, $1 \frac{1}{2}$ feet, $50 \mathrm{c}$ each; $\$ \AA .00$ per 10.

SPLENDIDA. This variety has beautifully mottled golden foliage. 5 -inch pots, $1 \frac{1}{2}$ feet, $50 \mathrm{c}$ each; $\$ 4.00$ per 10.

\section{AZALEA INDICA}

These beautiful plants are becoming more popular every year for forcing, window, store, and conservatory decorations. They are also adapted for outdoor planting. The - Azaleas which we offer are all grafted and have bushy crowns, and are well set with flower buds.

We can supply the following named sorts at $\$ 1.50$ each:

DEUTSCHE PERLE. Double; pure white.

EIMPRESS OF INDIA. Double; rich rosy salmon.

MIDAM VAN DER CRUYSSEN. Semi-double; crimson. SIMON IMARDNER. Double; clear pink.

VERVAENEANA. Double; rosy salmon, white margin.

AZARA MICROPHYLI, A handsome shrub, having small, glossy leaves; orange-yellow flowers. Where a really beautiful evergreen is desired, we recommend this variety. Pot grown, $11 / 2$ to 2 feet, $50 c$ each.

\section{BAMBOOS}

Of late years the Bamboos have been receiving quite a lot of attention from the Californians who are interested in the horticultural development of their State. There are great possibilities in Bamboo culture; the Bamboo pole is useful for many purposes, and there are many places in this State where it can be grown successfully and profitably.

The San Joaquin Valley, where there is irrigation, would be a good locality for its culture; it needs lots of water, but it must have good drainage.

FALCATA. Small, slender, fine foliage. Clumps, 2 feet, 50c each.

MITIS. One of the largest bamboos; it attains a height of 28 to 38 feet. The canes are used extensively for furniture work, water-pipes, etc. Clumps, 75c each.
BLACK. This variety attains a height of 30 feet. The canes are black, used for makin

QUILIOI. A very large-growing sort, attaining a height of 40 feet. Clumps, 50c each.

BERBERIS DARWINII. This is the finest of all berberis. Foliage thick and leathery: flowers orange-yellow, and deliciously fragrant. 3-inch pots, 30c each; $\$ 2.50$ per 10. Balled, 750 each.

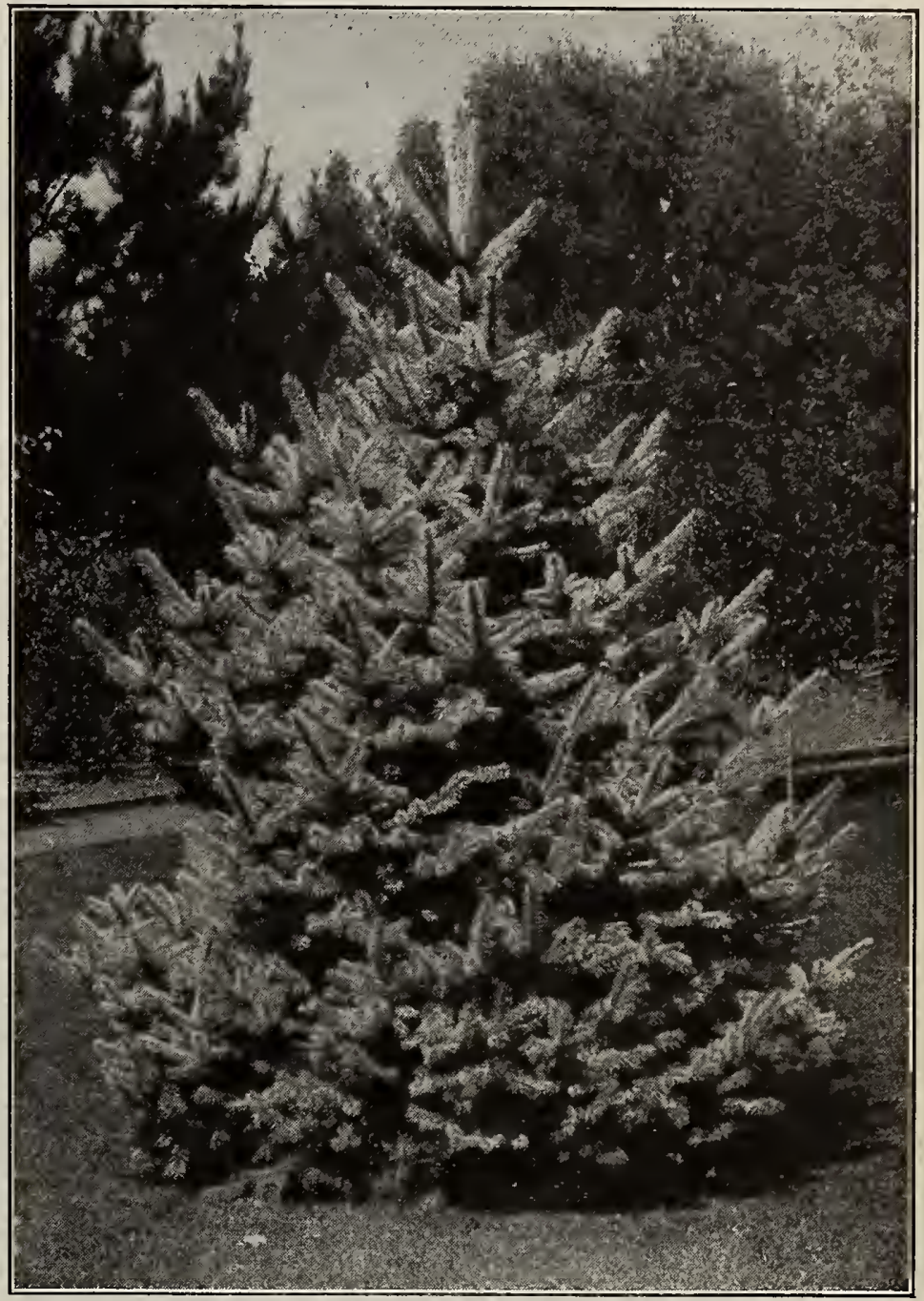

A Beautiful Specimen of Spruce (Abies)

\section{THF BOX}

These are useful-some for bordering, some for hedging, and others as single specimens on the lawn. They are all of slow growth, and never attain very large dimensions. None of them produce flowers, but the foliage is handsome.

ARGENT⿱宀㠯工二

JAPONICA AUREA. Balled, 1 foot, 35c each.

JAPONICA, Plain-leaved. Fine for bordering. $\$ 5.00$ per 100 BOX DWARE. (Suffruticosa). A fine small bush, with glossy: roundish leaves. The variety so extensively used for edging. $\$ 3.00$ per 100 .

\section{BREATH OF HEAVEN. See Diosma.}

\section{THE BROOMS}

ANDREANA. The flowers of this variety are yellow and brown; they are not produced for such a long period as those of the they are much in demand. 12 to 15 inches, $50 \mathrm{c}$ each.

SCOTCE, YELLOW. A very handsome shrub, with drooping branches, covered in the Spring with bright yellow pea-shaped flowers. Very effective for grouping. 3 feet, $50 \mathrm{c}$ each; $\$ 4.00$ per 10. 


\section{C.C.MORSE \& CO. PLANTS \& TREES}

Brooms-Continued.

SPANISH. An upright-growing shrub. Flowers yellow, produced very freely in the Spring and Summer, on long, pendulous $\$ 2.00$ per $10 ; 2$ to 3 feet, $50 \mathrm{c}$ each.

\section{CALIFORNTA NATIVE TREES}

Under this caption will be found trees indigenous to this State. We advocate strongly the systematic planting of these, so that they will not be lost to future generations, as will undoubtedly be the case if some radical change be not effected in forest preservation and forest planting. Why there should be in this country such a lax method of caring for our forests is a wonder to us. In no other country are such methods permitted. As individuals, therefore, it behooves us to do our very utmost toward reforesting. We head the list with the world-famous

\section{CALIFORNIA BIG TREE-(Sequoia Gigantea)}

This is the largest tree known to exist on the American continent. The bark is from one to two feet thick. One of the largest trees (the so-called Grizzly Giant of the Mariposa Grove) is 93 feet $\$ 4.00$ per 10.2 to $21 / 2$ feet, $75 \mathrm{c}$ each, $\$ 6.00$ per 10 .

CAIIFORNIA REDWOOD (Sequoia Sempervirens). From this tree is obtained the most valuable timber in the California forests. It attains a height of 200 to 250 feet, and is from 8 to 12 feet in diameter. The wood is of a rich brownish red strong and durable, and makes excellent timber. Balled, 1 to $11 / 2$ feet, $35 \mathrm{c}$ each; $\$ 3.00$ per $10 ; \$ 20.00$ per 100 . 3 to 4 feet, $\$ 1.00$ each; $\$ 8.00$ per 10 .

CALIFORNIA IIVE OAK (Quercus agrifolia.) A familiar sight in our California landscapes, which adds so much to its beauty. Balled, 2 feet, 50 c each.

MONTEREY CYPRESS. See page 91.

DOUGLAS SPRUCE. See Abies Douglasii, page 88.

LAWSON CYPRESS. See page 91.

MONTEREY PINE. See page 94.

PINE, PONDEROSA. See page 94.

THUJA GIGANTEA. See page 94

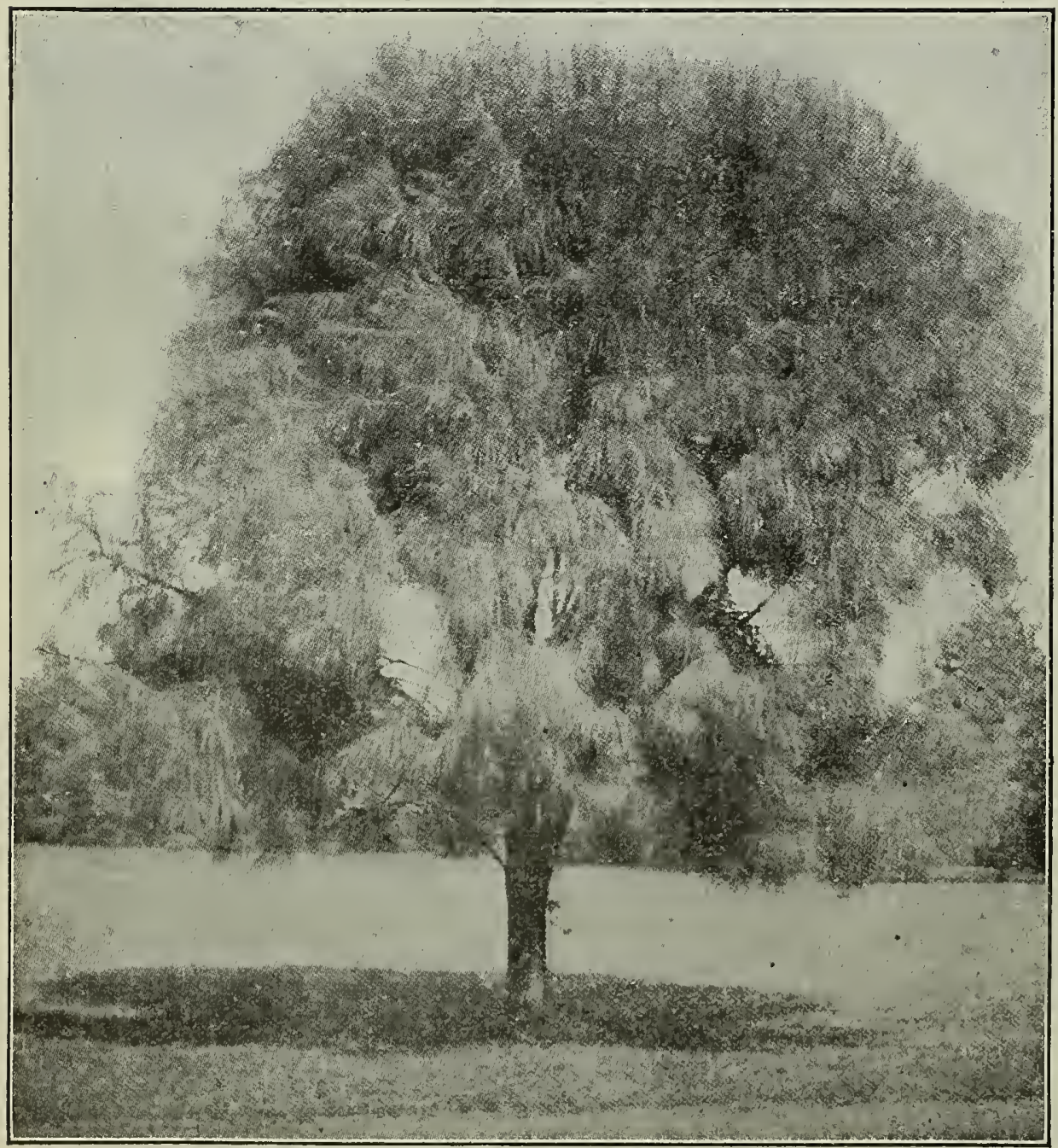

Casuarina stricta, Beef Wood of Australia Read description, it will pay you to do so
CAMELIIAS. These showy Japanese shrubs are familiar to nearly every every one. They bloom early in the Springtime, and are a great acquisition to the garden. The waxy odorless flowers are produced very freely. We offer the Double White, $80 \mathrm{c}$ to $\$ 1.00$ each; Double Pink, 80c to $\$ 1.00$ each; Double Red, $80 \mathrm{c}$ to $\$ 1.00$ each

CAMPHOR TREE (Laurus Camphora). A fast-growing, very symmetrical, ornamental tree, thriving in the very poorest soil. A native of Japan. Bright green foliage; well adapted for lawn purposes. 5 to 6 feet, $\$ 1.50$ each.

COTONEASTER. A small growing evergreen of low-spreading habit: small round foliage; producing red berries along its branches, very showy. 5-inch pots, 50c each.

\section{CASUARINA}

(Beef Wood, She Oak)

The picture of the Casuarina gives us a good idea of the habit of this beautiful tree. The Casuarina is supposed to be named after the Cassowary, a native bird of Australia (akin to the ostrich and emu) on account of its long plumelike foliage, which somewhat resembles the plumage of that bird. The leafless branches are long and pendulous and dark green in color. They are eminently adapted for forest planting in California. The Casuarinas are of very rapid growth and suit themselves alike to the cold bleak winds of the ocean or the hot interior valleys. The wood is very hard and can be advantageously used for many mechanical purposes. As an ornamental tree, we consider the Casuarina one of our best evergreen trees and for sidewalk planting it is very fine. It must, however, be kept pruned for such purposes; and as a tree for making windbreaks or hedges we consider it has no equal, being of such rapid growth and standing pruning so well. The more it is pruned the denser it becomes. They are indigenous to tropical Australia, and some are found in New Caledonia and India. We offer the following varieties:

EQUISETIFOLIA. 5-inch pots, $21 / 2$ to 3 feet, $35 \mathrm{c}$ each; $\$ 3.00$ per 10 .

STRICTA. 3-inch pots, $1 \frac{1}{2}$ to 2 feet, $25 \mathrm{c}$ each; $\$ 1.50$ per $10 ; \$ 8.00$ per 100 .

STRICTA. Balled, $21 / 2$ to 3 feet, $30 \mathrm{c}$ each; $\$ 2.00$ per $10 ; \$ 15.00$ per 100 .

STRICTA. Balled, 4 to 6 feet, $75 \mathrm{c}$ each; $\$ 6.00$ per $10 ; \$ 50.00$ per 100 .

STRICTA. Boxed, trained to Standard shape. 4-foot stems $\$ 1.50$ each.

STRICTA. Transplanted in boxes, $\$ 3.00$ per 100.

SUBEROSA. 5-inch pots, 3 leet, $35 \mathrm{c}$ each; $\$ 3.00$ per 10 .

\section{CEDAR OF IEBANON}

This grand old historic tree, old as it is, has always retained a warm spot in the hearts of tree lovers. It is possessed of much grandeur and for lawn or park adornment it is peculiarly adapted. or park adornment it is peculiarly adapted. Boxed $21 / 2$ feet, $\$ 1.25 ; 31 / 2$ feet, $\$ 2.00$ each.

CEDRUS DEODORA (Indian or Himalayan Cedar). If we were asked to name the handsomest coniferous tree, we would, we think, be compelled to say that the Indian Cedar came as near being perfect as it were possible. The majesty and grandeur of this native of the Himalayan mountains is soul inspiring. To view its graceful proportions, its lovely sea-green drooping branches, is certainly a treat that all must appreciate. It is perfectly at home in this State growing rapidly it it grows at the in thas state in the hot valle is where one sees the finest specimens. As an avenue tree (where it can have plenty of space), it is unsurpassed, and alternating it with a Phoenix Canariensis the two make a grand combination. We have a fine stock of these to offer. The plants are finely shaped and beautifully colored. Balled, 2 to $21 / 2$ feet, $\$ 1.00$ each; $\$ 8.00$ per 10 . Boxed, 3 feet, $\$ 2.00$ each; 4 feet, $\$ 3.00$ each; 5 feet, $\$ 5.00$ each.

THE ATLANTIC CEDAR. Another very fine sort, with very dark green foliage and of upright rapid growth. Boxed, 3 feet, $\$ 2.00$ oach; 1 feet, $\$ 3.00$ each; 9 feet, $\$ 10.00$ each. 
CRATAEGUS CUNEATUM. An evergreen species of the Hawthorn family. It is of dwarfish habit with glossy foliage, and has berries of a bright scarlet color about the

\section{CYPRESS}

ARIZONICA. A variety with beautiful sea-green foliage. Balled, 2 feet, $\$ 1.00$ each.

GLAUCOUS, A species that is very handsome. The foliage is beautiful sea-green and the habit of growih is spreading. of very rapid growth. Balled, 3 feet, $75 \mathrm{c}$ each; $\$ 6.00$ per 10 .

LAWSON, SILVER. This California species has great beauty. It is of rather upright growth; the branches droop gracefully, and the foliage is of a lovely sea-green color. Balled, $2 \frac{1}{2}$ to 3 feet, $75 \mathrm{c}$ each; $\$ 6.00$ per 10 . Boxed, 3 feet, $\$ 1.00 \mathrm{each}$.

MONTEREY. A native of California, and one of the most desirable of evergreens; stands pruning well; very extensively planted
for hedges. Transplanted in boxes. 1 year, \$2.50 per 100; for hedges. Transplanted in boxes. 1 year, $\$ 2.50$ per 100 ; $10 ; \$ 12.50$ per $100 ; 2$ feet, $25 \mathrm{c}$ each; $\$ 2.00$ per $10 ; \$ 15.00$ per 100 ; balled, $21 / 2$ to 3 feet, $30 \mathrm{c}$ each; $\$ 2.50$ per $10 ; \$ 18.00$ per 100; balled, 3 to 4 feet, $40 \mathrm{c}$ each; $\$ 3.50$ per $10 ; \$ 25.00$ per 100.

ITALIAN. Of upright, pyramidal growth. Very much used in landscaping, being peculiarly adapted for such work. Transplanted in boxes, $\$ 5.00$ per $100 ;$ balled, 2 feet, $35 \mathrm{c} \mathrm{each;}$ \$3.00 per 10; $11 /$ feet, $50 \mathrm{c}$ each; $\$ 4.00$ per $10 ; 3$ feet, $75 \mathrm{c}$ each; $\$ 6.00$ per $10 ; 4$ feet, $\$ 1.00$ each.

INTERTEXTA. Foliage dark green of drooping habit; a fine variet for lawn purposes. Boxed, 3ifeet, $\$ 1.00 \mathrm{each}$.

FRASERII. In this variety, perhaps we have one of the hand somest of its class: foliage lovely sea-green, much flattened, rendering it a grand lawn tree. Boxed, 2 feet, $\$ 1.25$ each.

CRYPTOMERIA JAPONICA. A large-growing evergreen from Japan, where it grows to immense size; the wood is much used
in that country for building purposes. Pot grown plants, $31 / 2$ feet, $75 \mathrm{c}$ each; $\$ 6.00$ per 10 .

\section{DAPHNES}

The Daphnes are, we think, very familiar to most of our readers. To those who do not know them we will try and describe them. They are evergreens; the leaves are very pretty; but it is the flowers that attract attention when they are in blossom in early spring; they are small, sweetly scented, and appear in great profusion. They come in two separate colors. White, $11 / 2$ feet, $\$ 1.00$ each; Pink, $11 / 2$ feet, $\$ 1.00$ each.

DIOSMA ALBA (Breath of Heaven). This shrub never attains large proportions. It produces small, white star-shaped flowers in great numbers. The foliage when bruised emits a sweet fragrance. 5 -inch pots, 50c each.

\section{EUCALYPTI}

(Eucalyptus means "Well concealed," referring to the complete manner in which the essential organs of the flowers are concealed.)

There is no doubt in our mind but that the Eucalypti are destined to become the forest tree for this State, just as the Redwood and Big Tree have been in the past. They are all natives of Australia, the climate of which in many respects is similar to our own. The rapidity of growth, the durability of the timber and adaptability to almost any California climate or soil are recommendations which appeal very forcibly to us.

Morse's "Eucalyptus Culture" will be mailed free to any applying for same.

CORYNOCALYX, Sugar Gum. Very ornamental; rapid growing with dark green leaves; timber very durable and used for railroad ties. This gum will grow in a variety of climates; it thrives nea the coast and grows equally well in parts of Southern Arizona. It is of course benefited by moisture, but endures a great amount of drought. Transplanted in boxes, $\$ 2.50$ per $100 ; \$ 20.00$

CIFOLIA, Scarlet-flowering Gum. A beautiful sort, bearing lovely scarlet flowers, thick leathery leaves; hardy only in warmer sections. Pot grown, 35c and 50c each.

GLOBULUS, Tasmanian Blue Gum. One of the most useful of all and of very rapid growth. Adapts itself to a variety of climatic conditions. It thrives in moist, warm regions and hot, dry ones; it succeeds in moist lowlands and dry stony uplands. Excellent for removing stagnant water. Resistant to both quite high and low temperatures. Great extremes always excepted; if freezing weather continues for any length of time, injury to young growth, but not permanent, as it rapidly outgrows to young growth, but not permanent, as it rapidly outper $100 ; \$ 18.00$ per 1000 ; pot grown, 112 to 2 feet, $15 \mathrm{c}$ each; per 100; $\$ 18.00$ per 1000; pot grown, $11 / 2$ to 2 feet, $15 \mathrm{c}$ each; each; $\$ 2.00$ per $10 ; \$ 15.00$ per $100 ;$ balled, 6 to 7 feet, $50 \mathrm{c}$ each; $\$ 2.00$ per 10 .

N. B - Pot grown plants we can recommend for various reasons. For shipping they are knocked out of the pots, without disturbing or injuring the roots, hence no loss ensues in transplanting. They are light and cost of transportation is therefore low.

LEUCOXYLON. "Iron Bark of Australia". Timber possessed of great strength and great durability; exceedingly hard; largely used for underground work. Flowers pink; very ornament

POL YANTHEMA, Red Box. A moderate grower; timber valuable for undergound work, being remarkably hard and durable. Endures extremes from the coast to the hot interior valleys and 15 to 20 degrees. One of the handsomest of the family; very 15 to 20 degrees. One of the handsomest of the family; very $21 / 2$ feet, 20c each; $\$ 1.50$ per 10; 3 feet, 25c each; \$2.00 per 10.

ROBUSTA, Swamp-Mlahogany Gum. Best adapted to a moist warm climate. Very symmetrical while young; quite brittle foliage large, of a deep, glossy white; blooms late in the Fall; very much prized by apiarists. Transplanted in boxes, very strong, $\$ 2.25$ per $100 ; \$ 20.00$ per 1000.

ROSTRATA, Red Gum. Said to attain a height of 200 feet; a rapid grower, adapted to the coast and hot interior valleys. Maximum temperature, 110 to 115 degrees, minimum 15 to 20 degrees. The wood takes on an exceptionally high polish, suitable for interior finish. For this purpose the wood will be of but when the first growth is cut down and the second grows up they appear to grow much straighter; close planting will in a feet, $15 \mathrm{c}$ each; $\$ 1.25$ per $10 ; 21 / 2$ to 3 feet, $25 \mathrm{c}$ each; $\$ 2.00$ per 10; $\$ 15.00$ per 100 . Transplanted in boxes, very strong. per $10 ; \$ 15.00$ per 100 . Transpl.

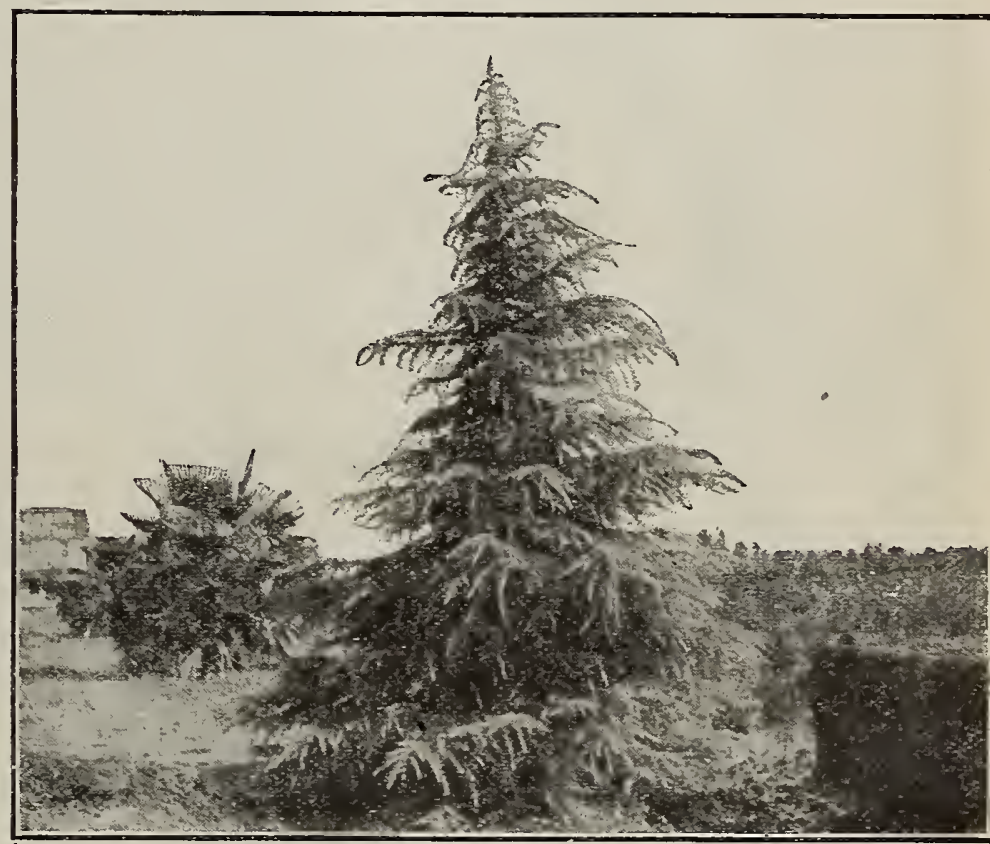

Cedrus Deodora

The Queen of Evergreens

RUDIS. This has been grown very extensively around Fresno, where it has been found to make an excellent avenue tree and also to be of very rapid growth. It withstands both heat and cold and in Arizona its suitability to conditions there has been fully established. It is a very rapid grower, and the wood is quite hard and tenacious. The practical uses of this variety have not been fully demonstrated. Maximum temperature 110 to 118 degrees, minimum 15 to 18 degrees. Transplanted in boxes, very strong, $\$ 2.25$ per $100 ; \$ 18.00$ per 1000 .

SALIGNA. Has not been extensively planted, so no data are forthcoming as to its requirements. In Australia it is said to grow to a height of 100 to 200 feet and is confined to the warmest coast regions, hence it cannot be expected to endure very severe
extremes. Pot grown, $21 / 2$ to 3 feet, $25 \mathrm{c}$ each; $\$ 2.00$ per 10.

STUARTIANA, Apple-scented Gum. Of medium growth, quite erect and stocky; a great resister of frost, enduring temperatures as low as 10 to 18 degrees $F$. Valuable for windbreaks; timber useful for fence posts and for fuel. Transplanted in boxes, $\$ 2.50$ per 100 .

TERETECORNIS, Forest Red Gum. This variety has been receiving much attention of late years. At Mr. Cooper's ranch Santa Barbara, their rate of growth has been about two-thirds that of the Globulus. It grows best near the coast, but endures the dry heat of the interior valleys. Maximum temperature 110 to 115 degrees, minimum 15 to 20 degrees. The wood is red, verv hard, heavy and durable. Transplanted in boxes, 20c each; $\$ 1.50$ per 10 . 
92. C. MORSE \& CO. PLANTS \& TREES 12

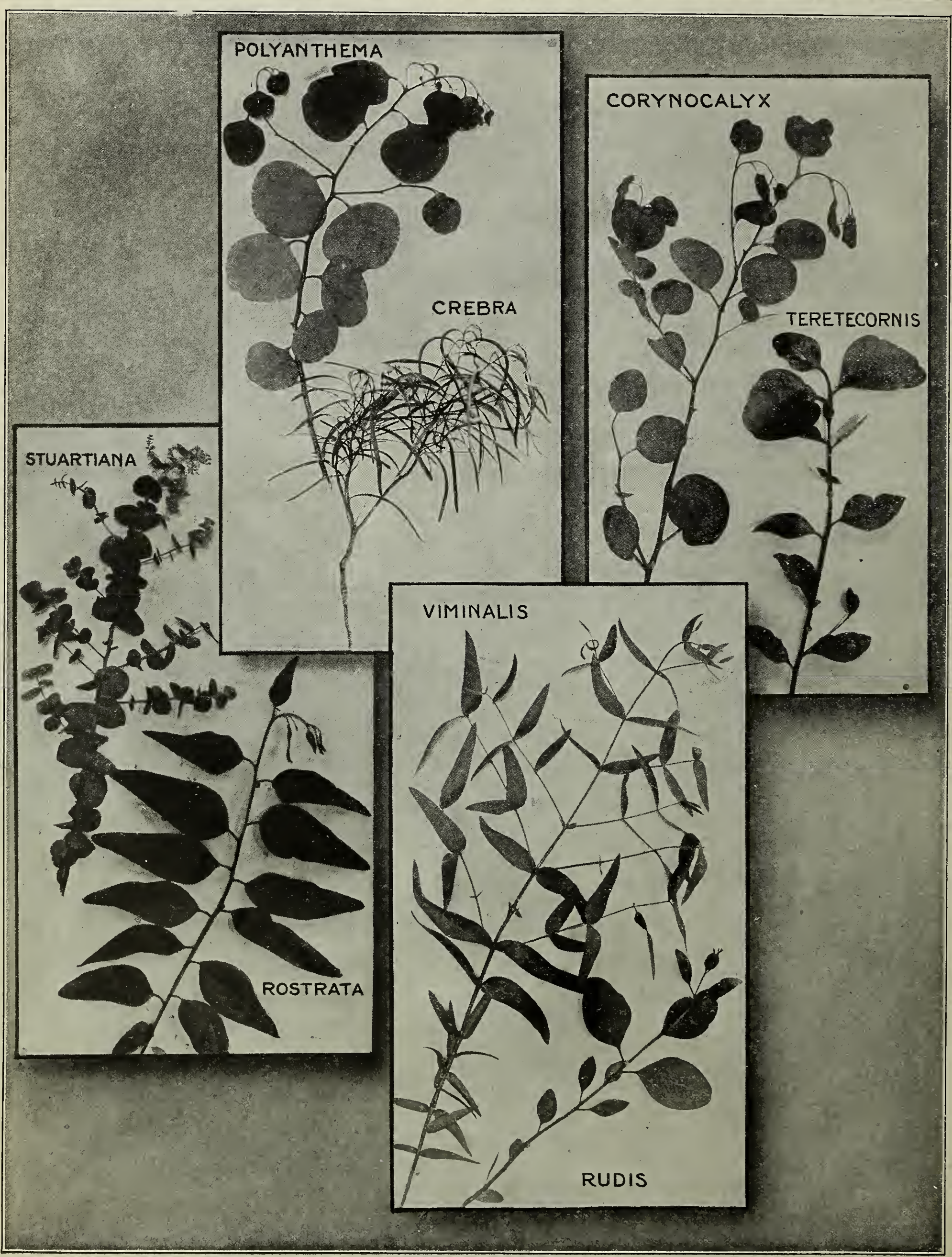


ELAEAGNUS ARGENTEA. A very handsome evergteen shrub, having. dark, glossy foliage, mottled old gold. Pot grown, $11 / 2$ feet, $75 \mathrm{c}$ each.

ESCALONIA ROSEA. A beautiful low growing shrub, producing lovely pink blossoms. 5-inch pots, 35c each; $\$ 3.00$ per 10 .

EUONYMUS, SILVER VARIEGATED, A very pretty ornamental shrub; the foliage is silvery yellow. Balled, $1 \frac{1}{2}$ feet, $35 \mathrm{c}$ each; $\$ 3.00$ per 10 .

EUONYMUS, DUC D'ANJOU. Golden blotch in center of leaf Balled, 1 to $1 \frac{1 / 2}{2}$ feet, $35 \mathrm{c}$ each; $\$ 3.00$ per 10.

EUONYMUS, GOLDEN VARIEGATED. Balled, $1 \frac{1}{2}$ to 2 feet, $35 \mathrm{c}$ each; $\$ 3.00$ per 10 .

FABIANA IMBRICATA. A rery pretty heath-like shrub of erect growth, producing pure white tube-shaped flowers in great pro35 c each.

GREVILLEA ROBUSTA (Australian Silk Oak). A splendid fern-lea ved evergreen tree, which makes a magnificent pot plant for all sorts of decorative purposes; flowers golden yellow; planted out in this State, it soon forms a magnificent lawn or shade tree. 21/2-inch pots, 20c each; $\$ 1.50$ per $10 ; 4$-inch pots, 1 foot $30 \mathrm{c}$ each; $\$ 2.50$ per $10 ; 6$-inch pots, 2 to $2 \frac{1}{2}$ feet, $50 \mathrm{c} \mathrm{each}$.

HABROTHAMNUS ELEGANS. A strong-growing shrub, bearing panicles of small trumpet-shaped, purplish red flowers; makes a grand showing on a lawn or trained against a wall or porch. Pot grown, $1 \frac{1}{2}$ feet, $25 \mathrm{c}$ each.

HEATH, MEDITERRANEAN. This variety is most desirable it produces its small wax-like pink flowers in wonderful profusion.

HOLLY, EUROPEAN. A small tree, with shining dark-green thorny leaves, somewhat resembling the oak in form. In Winter
the tree is covered with bright red berries. Balled, $11 / 2$ feet, $75 \mathrm{c}$ each.

HOLLY, SILVER. Variegated. Balled, 1 to $11 / 2$ feet, $50 \mathrm{ceach}$.

JUNIP ER, IRISH. A distinct and beautiful sort, of erect, dense, conical outline and upright growth; short glaucous-green foliage. Fine for planting in cemeteries. Balled, 2 feet, 50c each.

IAOREL, ENGLISH A fine evergreen, with broad shining green leares, produces large panicles of creamy-white flowers, follower b5 purple berries. Balled, 2 to $21 / 2$ feet, $60 \mathrm{c} \mathrm{each}$.

LAUREL, PORTUGAL. Balled, 1 foot, 35c each; $\$ 3.00$ per 10.

IAUREL, SWEET BAY. A very ornamental, upright growing shrub, with deep, dark-green, fragrant leares, and covered in the Fall with berries. If properly pruned one of the handsomest of decorative plants. The leaves are placed between the layers of Smyrna figs and impart a peculiarly pleasant flaror to the fruit. 5-inch pots, $1 \frac{1 / 2}{2}$ feet, 50c each; boxed, 3 feet, $\$ 1.00$ each.

LAURUSTINUS. A well-known Winter flowering shrub, of great beauty, producing an abundance of white flowers; well adapted for hedges. 3-inch pots, $15 \mathrm{c}$ each; $\$ 1.00$ per $10 ; 4-1 \mathrm{nch}$ pots, 1 fcot, $25 \mathrm{c}$ each; $\$ 2.00$ per 10 .

LAURUSTINUS GRANDIFLORUS. A rariety with much larger flowers than the preceding. Pot grown, 2 feet, 60c each $\$ 5.00$ per 10 .

LEPTOSPERNUM LAEVIGATUM. An erergreen shrub much used in the Golden Gate Park, where it succeeds to perfection. Especially adapted for $\pi$ indy places. Pot grown, 2 to 3 feet, 50c each; $\$ 4.00$ per 10 .

LIB OCEDRUS CHILENSIS. One of our beautiful coniferous trees of low, compact growth; foliage, pleasing green and crimpled in a pearance. Balled, $2 \frac{1}{2}$ feet, $\$ 1.00 \mathrm{each}$.

LIGUSTRUM JAPONICUM. (Japanese Privet). Produces large clusters of white flowers, slightly fragrant, followed by purplish blue berries; leaves glossy, leathery dark green. parge-growing shrub (or small tree). Makes an excellent bedge; stands trimming tiell. It also makes a very handsome sedge; stands trimming mell. It also makes a very handsome $\$ 3.50$ per 10 ; balled, 4 to 5 feet, 60 c each; $\$ 5.00$ per 10 .

LIGUSTRUM OVALIFOLIUM (California Privet). A valuable hedge plant; stands pruning well; and is of rapid growth. 3 feet, $20 \mathrm{c}$ each; $\$ 1.50$ per $10 ; \$ 9.00$ per 100 . Transplanted in boxes, 12 to 15 inches,

IIGUSTRUM ELEGANTISSIMA AUREA. A rariet $y$ with beautiful golden foliage. 2 feet, 35c each; $\$ 3.00$ per 10 .

LOQUAT. This tree produces a rery delicious fruit, which ripen in early Summer; it comes in clusters, and is yellow in color. It is also valuable as an ornamental tree, the leares a re large. crumpled and olive-green in color. Pot grown, $11 / 2$ feet, $35 \mathrm{c}$ each $\$ 3.00$ per 10 .
MAGNOLIA GRANDIFLORA OXONIENSIS. A lovely evergreen species, with large, leathery, bright green leaves that look as if made of wax, a foot or eighteen inches long and four inches wide. In addition to the beauty of the foliage, it bears large
fragrant white flowers. Very choice. B oxed, $2 \frac{1}{2}$ feet, $\mathbf{5 1 . 5 0}$ each; boxed, $2 \frac{1}{2}$ to 3 feet, $\$ 1.75$ each.

METROSIDEROS SEMPERFLORENS. Commonly known as "Bottle Brush." Produces curiously shaped, scarlet flowers in shape of a bottle brush; very handsome and showy. Pot grown, $11 / 2$ feet, $50 \mathrm{c}$ each.

NEW ZEALAND FLAX (Phormium tenax). Has large swordlike leares, or a deep rich green color. From this plant flax is made in New Zealand. Very ornamental. A magnificent plant for lawn decoration. Strong clumps, $\$ 1.50$ each.

NANDINA DOMESTICA. A beautiful, upright-growing plant. of dwarf habit, with a number of reed-like stems, growing from the same root, crowned with deep glossy green foliage and with tall spikes of white flowers. The soung growth is prettily tinged with red. In the Fall it is covered with masses of small red and white berries. $75 \mathrm{c} \mathrm{each}$

\section{THE OLEANDER}

Best suited for the warmer sections, where, if given plenty of water it thrives to perfection. The flowers are produced very freely for a long period. One of the showiest of ever-blooming evergreens.

DOUBLE PINK. $11 / 2$ to 2 feet, $75 \mathrm{c}$ each; 4 -inch pot plants, DOUBLE WHITE. $11 / 2$ to 2 feet, $75 \mathrm{c}$ each; 4 -inch pot plants, $35 \mathrm{c}$ each.

PEPPER TREE. A most popular shade and ornamental tree, with fine feathery foliage, producing clusters of reddish berries in Autumn. Transplanted in boxes of 50. \$2.00 per box

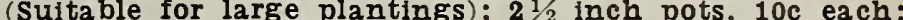
$\$ 1.00$ per $10 ; \$ 6.00$ per $100 ; 4$-inch pots, 2 feet, $35 \mathrm{c} \mathrm{each}$; $\$ 3.00$ per $10 ; 5$ - and 6 -inch pots, $2 \frac{1}{2}$ to 3 feet, 60c each; $\$ 5.00$ per 10 .

\section{PINES}

For reforesting, windbreaks, shelter and shade affording purposes, pines have few equals; all being of rapid growth. Take some of our barren hills and plant them to pines; in a few years what a different appearance the country will have. In the past few years thousands of these have been

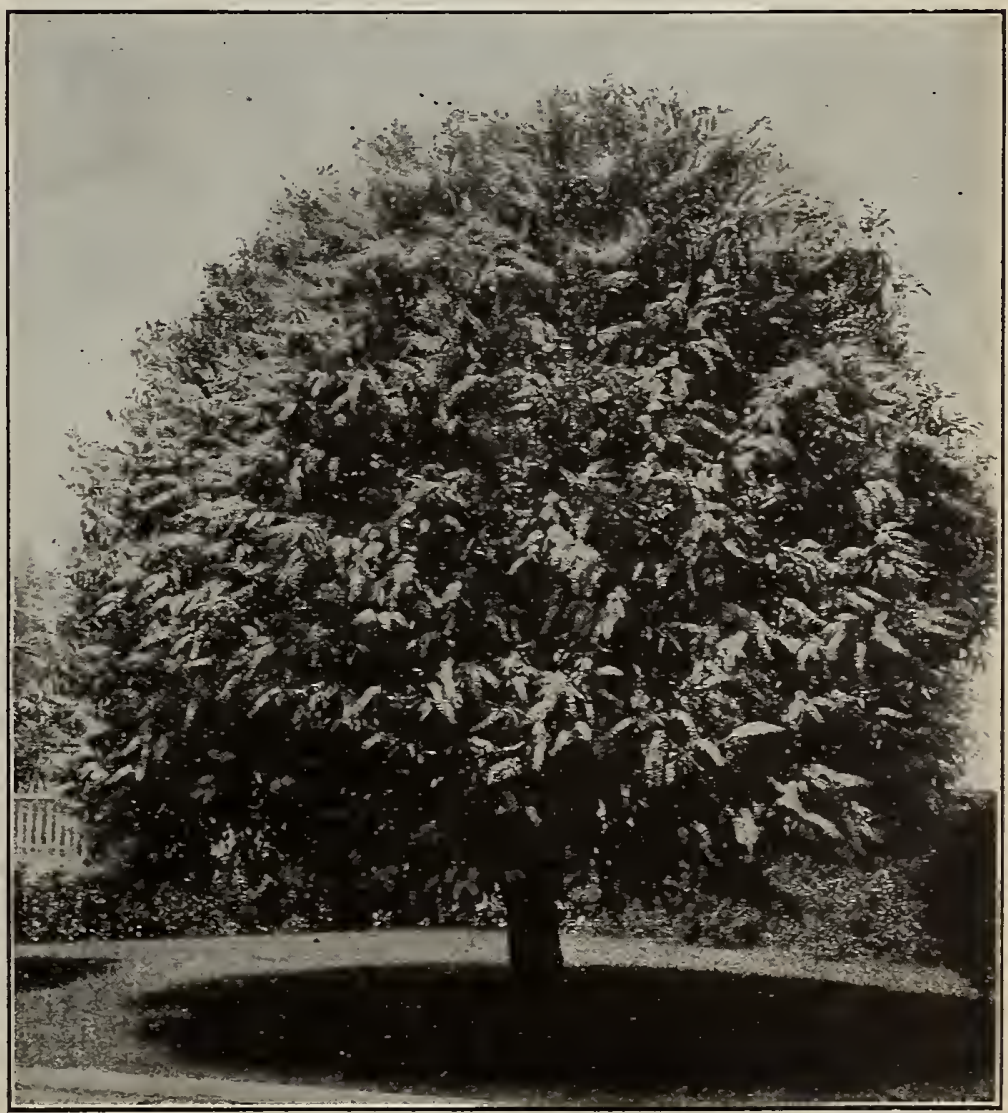

Ligustrum Japonicum "Japanese Privet" 
set out in the Piedmont and Berkeley hills and today that section is assuming a different look. What effect will these have? They will add much beauty to the landscape, attract more rain, and retain the moisture in the ground and preserve the rainfall.

EXCELSA. Bhotan Pine. A native of the mountains of Northern India. A graceful and elegant tree, with drooping silvery pendulous. Hardy and vigorous. Boxed, 3 to 4 feet, $\$ 1.50$ each.

MONTEREY. The most desirable pine for shade, and more extensively planted than any other variety in this State. Transplanted in boxes. $\$ 4.00$ per $100 ; 3$-inch pots, $10 \mathrm{c}$ each; $80 \mathrm{c}$ per $10 ; \$ 5.00$ per $100 ; 4$-inch pors, $20 \mathrm{c}$ each; $\$ 1.50$ per 10 ; balled, 15 to 18 inches, $25 \mathrm{c}$ each; $\$ 2.00$ per 10 ; balled, 4 to 6 feet, $60 \mathrm{c}$ each; $\$ 5.00$ per 10 .

SCOTCH. A fine, robust, rapid-growing tree, with stout, erect shoots and silvery-green foliage. Pot grown, $1 \frac{1 / 2}{2}$ to 2 feet, $25 \mathrm{c}$ each; $\$ 2.00$ per 10 .

PONDEROSA ("Yellow Pine"). Very rapid grower; one of the great timber trees of California. Balled, 2 to $2 \frac{1}{2}$ feet, $35 \mathrm{c}$ each; $\$ 3.00$ per 10 .

LARICIO (Corsician PIne). Stout, spreading branches in regular whorls, forming a beautiful, symmetrical pryamid, Balled, 1 foot, $35 \mathrm{c}$ each; $\$ 3.00$ per 10 .

STROBUS (White Pine). Lovely silvery-green, slender and of most beautíful habit. Balled, 2 feet, 50c each; $\$ 4.00$ per 10 .

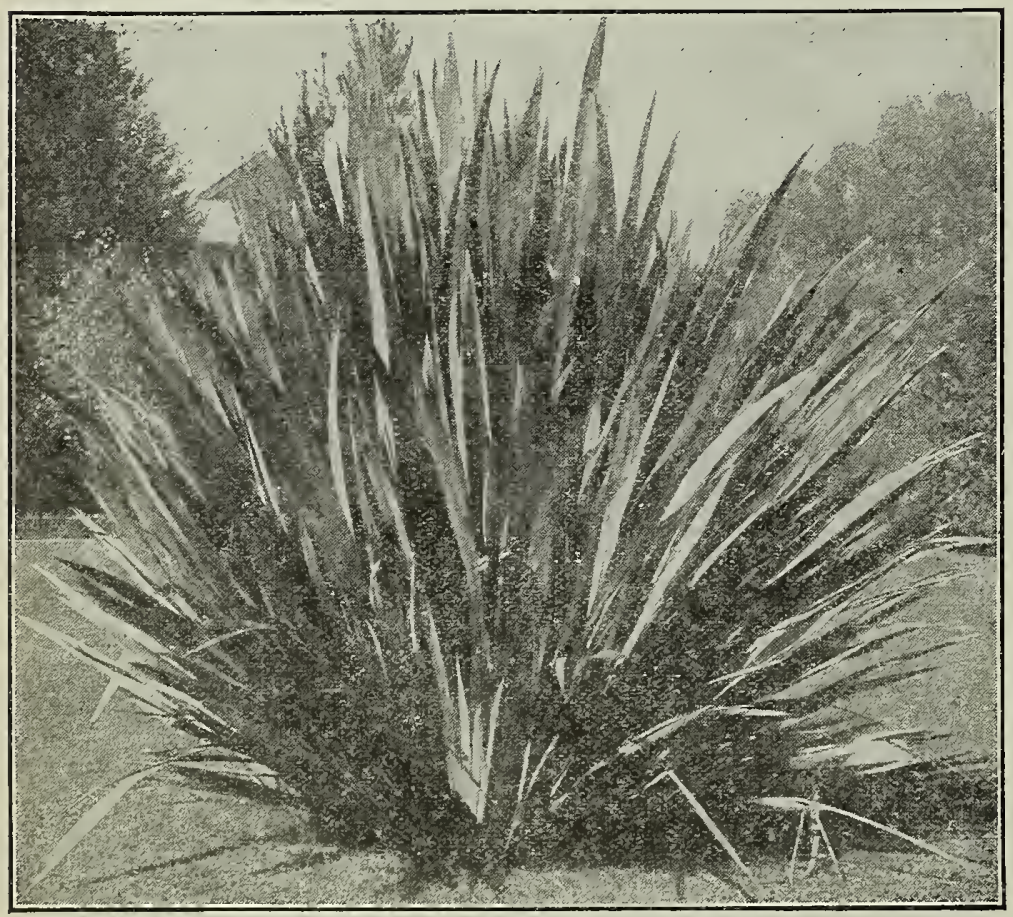

New Zealand Flax (Phormlum)

\section{PITTOSPORUM}

NIGRICANS. A very handsome, upright growing shrub, with silvery light green leaves and black stems. A good hedge plant, and very ornamental as an individual. Pot grown (very bushy) 3 to $31 / 2$ feet, $50 \mathrm{c}$ each; $\$ 4.00$ per $10 ; \$ 35.00$ per 100 .

EUGENOIDES. A large, upright growing shrub, with glossy yellowish green leaves; a very effective shrub, and excellent 10. $\$ 17.50$ per 100 . balled, 1 t $1 / 2$ eet, $25 \mathrm{c} \mathrm{each;} \$ 2.00$ per $\$ 25.00$ per 100 ; balled (very bushy), 3 to $31 \frac{1}{2}$ feet, $50 \mathrm{c}$ each. $\$ 4.00$ per $10 ; \$ 35.00$ per 100 .

TOBIRA. A very desirable sort; the foliage and stems are very stiff; flowers pure white; sweetly scented; of dwarf habit. 4inch pots, 25c each; $\$ 2.00$ per 10 .

UNDULATUM. Flowers sweetly scented; very desirable. 3-inch pots, 20c each; $\$ 1.50$ per 10 .

POLYGALA DALMATIANA. A profuse flowering shrub, with purple pea-blossom-shaped flowers, and pretty light green foliage. pot grown, $11 \frac{1}{2}$ feet, $35 \mathrm{c}$ each.

PRIVET. See Ligustrum, page 93.

REDWOOD. See page 90.
RETINOSPORA OBTUSA. A new and rare sort; leaves very much flattened, coral-like in appearance, and of a lovely dark-green shade, silvery underneath. Balled, grafted plants, $1 \frac{1}{2}$ feet, 50 c each; $\$ 4.00$ per 10 .

RETINOSPORA PLUMOSA. Foliage "plume-like", a lovely species. Pot grown, $1 \frac{1}{2}$ feet, $50 \mathrm{c}$ each.

\section{RHODODENDRONS}

These are among the grandest of our hardy flowering shrubs, and cannot be surpassed for lawn decoration. The flowers range through shades of rose, pink, crimson, white, etc. Should be planted in partial shade We have a magnificent European collection to offer. Price, strong plants with plenty buds, $\$ 2.50$ each.

FASTUOSUM. Light lilac.

J. F. AGNEW. Pale blush, chocolate spots.

JOHN WALTER. Rich crimson.

JOHN WATERER. Dark crimson.

KATE WATERER. Rose; yellow center.

MADAME CARVALHO. White.

VAUBAN. Rosy white; yellow center.

SPRUCE. See Abies.

SKIMMIIA JAPONICA. Flowers white, quite fragrant, leaves rich glossy green. Pot grown, 2 feet, 50c each.

SWAINSONA GREYANA (Darling River Pea). Flowers rose colored produced in sprays of from twelve to twenty flowers each the individual blooms resembling the fowers of a sweet pea. Leaves small; acacia-like. A most desirable ever-blooming plant. Native of New South Wales. 4-inch pots, 35c each; $\$ 3.00$ per $10 ; 5$-inch pots, $50 \mathrm{c}$ each.

SWAINSONA GALEGIFOLIA ALBA. This variety has delicate white flowers. 5-inch pots, 50c each; $\$ 4.00$ per 10.

SWEET BAY. See Laurel.

\section{THUJA-ARBOR VITAE}

A class of evergreen trees and shrubs; among the latter will be found some of our handsomest specimens for lawn adornment. They are of dwarf round neat habit.

GOLDEN. Of slow, compact growth, foliage beautiful bright green, changing at certain periods of the year to golden yellow. Balled, $11 / 2$ feet, $\$ 1.00$ each; $\$ 8.00$ per 10 . Boxed, $2 \frac{1}{2}$ to 3 feet, $\$ 1.50$ each.

GIGANTEA. A California Arbor Vitae, attaining great height in time; the foliage is pleasing green, and the individual branchlest have the appearance of having been pressed between the leaves 50 each; balled, 2 feet, $50 \mathrm{c}$ each; $\$ 4.00$ per 10; boxed, 4 feet, $\$ 2.50$ each.

FILIFORIIS. The foliage of this variety is like "whip cord," a most beautiful and uncommon species, of dense compact growth. We recommend this variety very highly. Boxed, 3 feet, $\$ \mathbf{2 . 5 0}$. each.

IOBBII AUREA. Of upright growth, with beautiful golden foliage. A choice and rare sort. Balled, $1 \frac{1}{2}$ feet, $60 \mathrm{c}$ each; boxed, $2 \frac{1}{2}$ feet, $\$ 1.50$ each.

MINIMA GLAUCA. The beauties of this choice Arbor Vitae are hard to describe; they must be seen to be appreciated; habit of growth unsurpassed. We take pleasure in recommending this variety, as we know they will give the best of satisfaction. Boxed, 2 feet, $\$ 1.00$ each.

THUJOPSIS DOLOBRATA. Leaves shining green above, silvery white beneath; of pendulous and dwarfish habit; branchlets coral-like in appearance; very handsome. Pot grown, $21 / 2$ to 3 feet, $\$ 1.50$ each.

VERONICA ANDERSONII. This variety bears blue flowers. 4-inch pots, 25c each; $\$ 2.00$ per 10 .

VERONICA IMPERIALIS. The finest of the species. Flowers amaranth. 2 feet, 50c each.

VERONICA TRAVERSII. A most desirable sort; of dwarf habit; flowers pure white; excellent for hedge purposes. 4-inch pots, 50 c each; $\$ 4.00$ per 10 ; boxed, 2 feet, $\$ 1.50$ each.

\section{YEW}

ENGLISH. A densel $\bar{y}$ branched, spreading tree; foliage dark and somber; a good sort for clipping into artificial forms. 5-1nch pots, 2 to $2 \frac{1}{2}$ feet, $75 \mathrm{c}$ each.

ENGLISH GOLDEN. A golden, variegated kind of the preceding, This tree "colors up" beautifully during the Summer months. This tree "colors up" beautifully during the

IRISH. An upright growing variety, with deep dark-green foliage; branches erect, closely compressed, forming a pyramidal shaped head: a very distinct and beautiful variety. Balled, 2 feet, $\$ 1.00$ each; $\$ 8.00$ per $10 ; 3$ feet, $\$ 1.50$ each. 


13. SAN FRANCISCO CALIFORNIA U.S.A.WW

SHOWING TWO STREETS PLANTED UNIFORMLY

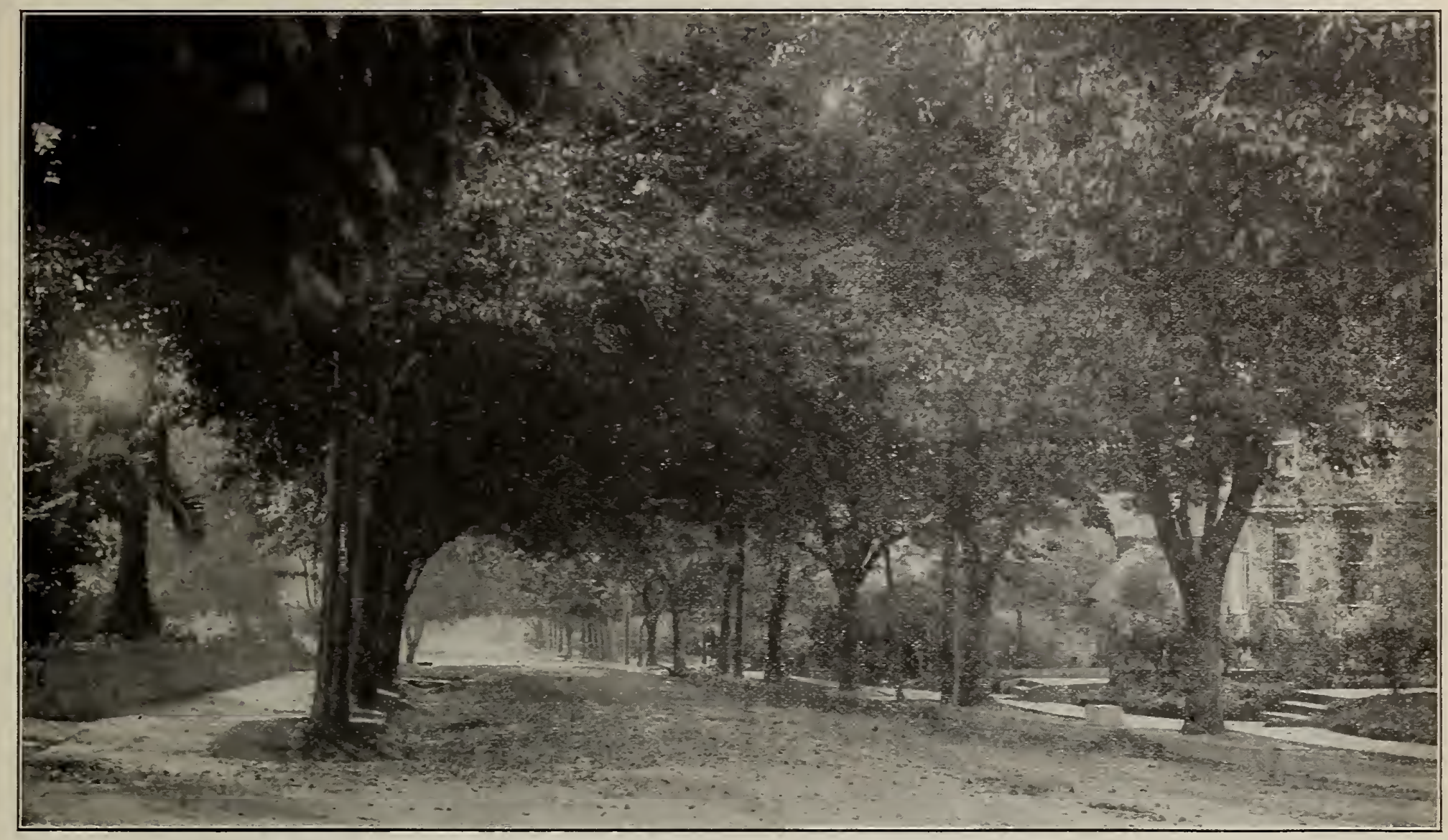

Dwight Way, Berkeley, planted to Elm Trees.

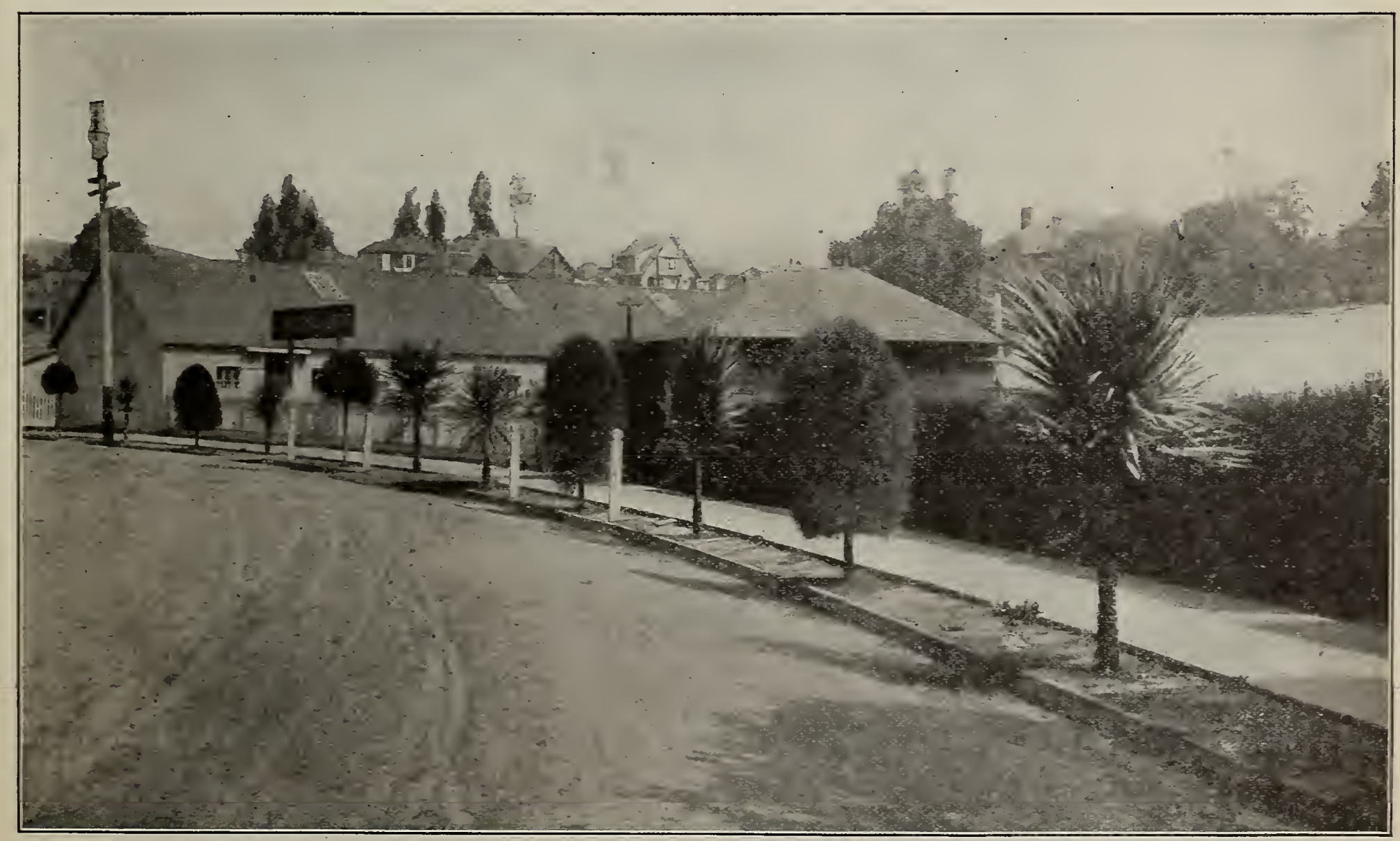

Glen Avenue, Oakland. " View in front of our Nurseries, planted to Casuarinas and Dracaena Palms. Pittosporum Hedge planted in front of fence. 


\section{C.C.MORSE \& CO. PLANTS \& TREES}

\section{THE STREETS BEAUTIFUL}

Have you ever stopped to think how much more beautiful a street planted uniformly to one or two varieties of trees is than one where you will see all kinds of trees planted? Unfortunately, the latter manner of street planting is the custom, and not the exception. Each owner plants to suit his or her fancy or liking. It is not uncommon to see a street planted to a Grevillea, Acacia, Japanese Palm, Linden, Maple, Date Palm or Dracaena.

Owners should get together and decide upon a certain tree to set out on the street. Your property will be greatly increased in value by so doing. We should have our "planting restrictions" as well as our "building restrictions"; the former is as essential as the latter to beautifying our homes and our torns.

Let us assist you in doing street planting systematically. On preceding page we give two beautiful illustrations of certain streets in our towns, laid out as they should be.

Dwight Way, Berkeley, was planted to Elms years ago. Notice what a lovely street it is, it never would have had this appearance if it had been set out to an assortment of trees as is so common nowadays. The other street, Glen Avenue, was planted three years ago to Casuarinas and Dracænas. These have made a beautiful showing for such a short period. The Casuarinas make very handsome specimens when pruned as these trees are, and for sidewalk purposes we consider them a valuable acquisition for such purposes.

The following is a list of trees that malke good sidewalk trees for Oakland, Berkeley and vicinity, descriptions, sizes, and prices will be found in this catalogue:

Acacia Melanoxylon-Evergreen.

Casuarina-Evergreen.

Ligustrum Japonicum (Japanese Privet)-Evergreen.

Birch, European-Deciduous.

The EIm-Deciduous.

The Linden-Deciduous.
Silver Maple-Deciduous.

Norway Maple - Deciduous.

Mountain Ash-Deciduous.

Dracaena Palm.

California Fan Palm.

Japanese Fan Palm.

Make your selection from some of these and get together and agree upon some one variety. We will be pleased to assist you in any way possible and will furnish prices of trees and planting.

\section{DECIDUOUS TREES AND FLOWERING SHRUBS}

In California, where there is such a scarcity of native trees, especially in the middle and southern parts, it is incumbent on all that they plant some shade trees. The first cost of these is not great, and the after attention, until they are old enough to care for themselves, should be a pleasure to those who may have planted them. For roadside planting we particularly recommend the following:

Black Walnut, Catalpa, Elm, Linden, Locust, Maple, Poplar, and Sycamores.

These are all very desirable, fast-growing trees, adapted to California conditions.

A good assortment of flowering trees and shrubs adds greatly to the beauty of all places, and is a source of continuous pleasure. Among the earliest of these to bloom is the Japanese Scarlet Quince, which commences to bloom early in February. It is a very showy shrub and blooms at a time when flowers are at a premium. It is inuch valued. The flowering Peaches next attract attention; when in bloom the tree is one mass of flowers; there are the double pink and the double white; the blooms resemble small roses. Corchorus Japonicus is a very nice flowering shrub. The flowers are of a deep orange shade, double; appearing among the branches for a long period. Crape Myrtles are among our prettiest shrubs; they bloom in summer and autumn; there are various shades, among the best being red and rvhite. IIock Orange, Deutzias, Spiraeas, and Weigileas are also to be commended as being highly ornamental; these all bloom in springtime. The Lilacs are known to all; their sweet fragrance adds greatly to the charm of the garden. Hydrangea Hortensis bears immense white ball-shaped flowers, changing to pink. Hydrangea Paniculata bears pure white flowers, spikeshaped and are very floriferous. A most beautiful flowering tree is the Crabapple-pink and white. The Brooms (Scotch and Spanish) come under this class; they both bear pea-shaped yellow flowers. The Spanish variety we prefer, being the longest bloomer. The Snowballs, which bear immense ball-shaped white flowers, are great favorites. Those who have seen the Japanese Magnolias bloom in early spring will agree with us that once seen they will never be forgotten. The blossoms appear before the leaves, and come in various colors-cup-shaped in appearance; in time they become quite large trees, but are of rather slow growth. Calycanthus Floridus (Sweet Shrub) is much thought of on account of the delightful odor emitted from the foliage. The Hawthorns are old-fashioned favorites.

ALTHEA. One of our showy ever-blooming deciduous shrubs. A great favorite. 3 feet, $35 \mathrm{c}$ each; $\$ 3.00$ per 10.

ASH, EUROPEAN. A lofty tree of rapid growth, with spreading head and gray bark; pinnate leaves and black buds. 4 to 5 feet, $40 \mathrm{c}$ each; $\$ 3.50$ per 10 .

AZALEA MOLIIS. Produces various shades of beautiful flowers, in great luxuriance; mostly brick-red and yellows. $75 \mathrm{c} \mathrm{each}$.

BIRCH, EUROPEAN WHITE. Remarkable for its elegance; very graceful, with silvery bark and slender branches. 6 to 7 feet, $75 \mathrm{c}$ each; $\$ 6.00$ per 10.
BIRCH, CUT-LEAVED WEEPING. A charming tree with deeply lacinated foliage. Its tall, slender, yet vigorous growth, graceful drooping branches, silvery-white bark, and delicately cut foliage, presents a combination of attractive characteristics rarely met with in one tree. 5 to 6 feet, $\$ 1.00$ each.

CALYCANTRUS FLORIDUS (Sweet Shrub). A very desirable shrub, with fragrant wood and foliage; flowers of a rare chocolate color. 2 to 3 feet, $50 \mathrm{c}$ each. 
CATALPA SPECIOSA (Western Catalpa). Leaves, large, heartshaped; of rapid growth; flowers come in long grape-like clusters of white and purple; very fragrant. The timber obtained from
this tree is a valuable. 3 to 4 feet, $35 \mathrm{c}$ each; $\$ 3.00$ per 10. 4 to 6 feet, $50 \mathrm{c}$ each; $\$ 4.00$ per $10 ; 6$ to 8 feet, $75 \mathrm{c} \mathrm{each;} \$ 6.00$ per 10.

CATALPA RAEMPFERII (Japan Catalpa). Flowers creamcolored, speckled purple and yellow, 4 to 6 feet, 50c each; $\$ 4.00$ per 10 .

CERCIS CANADENSIS Judas Tree, or Red Bud). A very ornamental native tree, of medium size, irregular rounded form, with perfect heart-shaped leaves of a pure green color, glossy surface above, and grayish green beneath. The tree derives the name of Red Bud from the profusion of delicate reddish purple flowers with which it is covered before the foliage appears. Fowering a mong them in groups with fine effect. Grown as single specimens they are also beautiful and attractive, and deserve to be classed a mong our finest ornamental trees. $2 \frac{1}{2}$ to 3 feet, $50 \mathrm{c}$ each; $\$ 4.00$ per 10 .

CHERRY, JAPANESE DOUBLE FLOWERING. A very ornamental family of trees; they produce their flowers in great masses, and when in blossom they present a glorious sight. We can feet, 50c each; $\$ 4.00$ per 10.

CRAB APPLE, Betchell's Double Flowering. One of the most beautiful of the many fine varieties of flowering Crabs. Tree of medium size, covered in early spring with large, beautiful double fragrant flowers of a delicate pink color. From a distance the flowers have the appearance of small roses. A great acquisiBlooms when quite young. 4 to 5 feet, $60 \mathrm{c}$ each; $\$ 5.00$ per 10 .

CHESTNUT, AMERICAN. A noble large-growing tree, at first of slow growth, but erentually growing with fair rapidity. 4 to 5 feet, $50 \mathrm{c}$ each; $\$ 4.00$ per 10 .

CORCHORUS JAPONICUS. Produces globular-shaped deep yellow flowers for a long period; foliage slender and graceful. 2 feet, $35 \mathrm{c}$ each.

CRAPE MYRTLE. Words fail to convey an adequate idea of the beauty of this shrub. They succeed best in a warm section and beauty of this shrub. They succeed best in a wariously crimpled petals. We can supply the Red and White varieties. $31 / 2$ feet, $75 \mathrm{c}$ each.

DEUTZIA GRACILIS. A charming species of dwarf habit; flowers pure white; produced in great masses in spring time. Excellent for pot culture. $11 / 2$ feet, $30 \mathrm{c}$ each.

DEUTZIA LEMOINEII. Flowers pure white, borne on stout branches, which are of upright growth; free flowering. 2 to $2 \frac{1}{2}$
feet, $35 \mathrm{c}$ each.

\section{THE ELM}

Is considered our handsomest and quickest growing shade tree, making excellent shade. One of the best trees for country road planting.

AMERICAN BLACK. A magnificent large tree, with drooping, spreading branches; one of the grandest of our native forest trees. 4 to 5 feet, $50 \mathrm{c}$ each; $\$ 4.00$ per 10.

ENGLISH OR FRENCH. An erect, lofty growing tree, of rapid, compact growth, with smaller and more regularly cut leaves than those of the American Elm. 6 to 7 feet, $60 \mathrm{c} ; \mathrm{each} ; \$ 5.00$ per 10 . CORK B ARKED. 6 to 8 feet, $60 \mathrm{c}$ each; $\$ 5.00$ per 10 .
HAWTHORN See Thorn.

HYDRANGEA PANICULATA GRANDIFLORA. This is one of the finest of all hardy shrubs for the lawn or border. The flowers are white, spiked-shaped, and are produced for a long period during summer and fall. 2 feet, $50 \mathrm{c}$ esch; $\$ 4.00$ per 10 .

HYPERICUM MOSERIANUM. It produces long, slender, muchbranched stems. It is marvelously free-flowering; of large size; a rich golden-yellow, which is rendered still more effective by the numerous yellow stamens and crimson anthers, end blooms con tinuously the entire season. Strong plants, 35c each; $\$ 3.00$ per 10.

KOLREUTARIA PANICULATA. A hardy, small, round-headed tree, with fine lobed leaves and large panicles of showy golden yellow flowers, in the latter end of July; leaves change in autumn yellow flowers, in the latter end of July; leaves change in autumn
to a fine yellow. One of the most desirable trees; particularly valuable for its brilliant, colden blossoms, which are produced so late in the season. when few if any trees are in bloom. 4 to 5 feet, $40 \mathrm{c} \mathrm{each} ; \$ 3.50$ per 10 .

LABURNOM, or GOLDEN CHAIN. A beautiful small-growing 4 to 5 feet, $50 \mathrm{c}$ each.

LEMON VERBENA. The fragrance from the foliage of this old favorite is delightfully refreshing. $25 \mathrm{c}$ and $35 \mathrm{c}$ each.

\section{IILAC}

RUBRA DE MARLY. Reddish purple. 2 feet, 50c each; $\$ 4.00$ per 10.

ROTHMAGENSIS. Double. Violet purple. $2 \frac{1}{2}$ to 3 feet, $50 \mathrm{c}$ each; $\$ 4.00$ per 10 .

PERSICA. 2 feet, 35c each; $\$ 3.00$ per 10.

WHITE AND PURPLE. Strong bushy plants. 2 and 3 feet, $35 \mathrm{c}$ and $50 \mathrm{c}$ each.

LINDEN, BROAD-LEAVED AMERICAN. The Linden is a magnificent tree; the leaves are beautiful, thus making a very handsome tree. They produce small, white flowers, very sweetly scented indeed. 4 feet, $50 \mathrm{c}$ each. $\$ 4.00$ per 10 .

LINDEN. EUROPEAN. 7 to 8 feet, 75c each; \$6.00 per 10.

LOCUST, THORNLESS (Bessoniana). A very ornamental variety; it makes a beautiful umbrella-like head, and is free from thorns. Of rapid growth; a m
feet, $60 \mathrm{c}$ each; $\$ 5.00$ per 10 .

LOCUST, COMMON OR BLACK. A rapid-growing tree, with spreading branches. A valuable timber tree, and used for various 9 feet, $75 \mathrm{c}$ each; $\$ 6.00$ per 10 .

LOCUST, PINK FLOWERING (Decnaisneana). This grand flowering deciduous shade tree produces beautiful coral-pink flowers in long grape-like clusters for a long period and is one $\$ 6.00$ per $10 ; 8$ to 10 feet, $\$ 1.00$ each; $\$ 8.00$ per 10 .

MAIDEN HAIR TREE (Salisburia). A remarkable tree from Japan, combining in its habit characteristics of the conifer and deciduous tree. The tree is of medium size and rapid growth; beautiful fern-like foliage, in shape resembles somewhat a Maiden Hair Fern, hence the nam

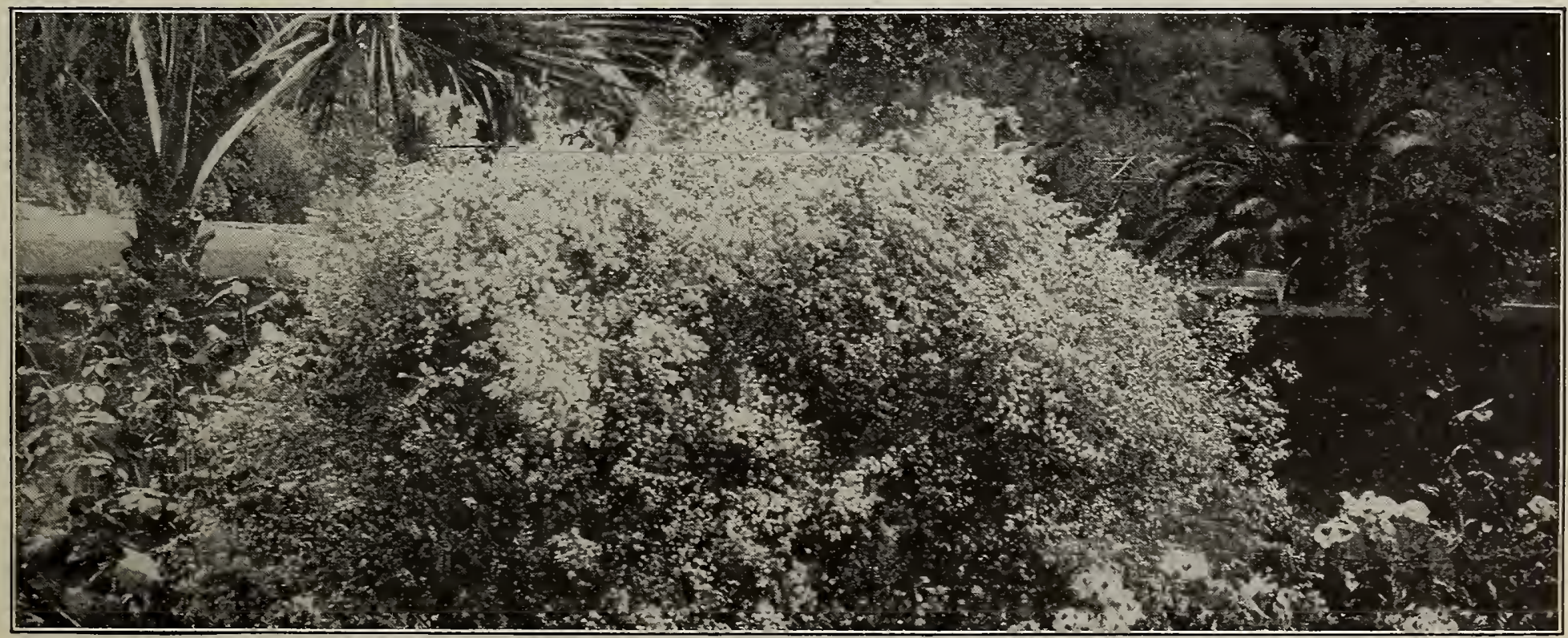

Breath of Heaven. (Diosma Alba)

This "fairy-like" scene was photographed by us on the grounds of the Claremont Hotel, Berkeley 


\section{C. MORSE \& CO. PLANTS \& TREES}

\section{MAPLE}

A valuable and highly ornamental family of trees. The Maples are regular in outline, beautiful in foliage, vigorous growers, free from all diseases, and adapted to all soils, merits, which deservedly render them universally popular.

ENGLISH, or CORK-BARKED. A native of Europe attaining a height of sixty feet; a stocky tree, of compact, roundish habit, with rough corky bark full of deep fissures. An excellent variety in the interior as it does not sunburn. 5 to 6 feet, $50 \mathrm{c} \mathrm{each}$.

NORWAY. A large, handsome tree, with broad, deep green foliage, and of very compact growth, rendering it one of the most desirin the interior valleys. 5 to 6 feet, $50 \mathrm{c}$ each; $\$ 4.00$ per 10 . $\$ 30.00$ per 100.

SILVER, or SOFT. A rapid-growing tree of large size; irregular rounded form; foliage bright green above, silvery beneath; a favorite street and park tree. A very promising and distinct $\$ 5.00$ per $10 ; \$ 35.00$ per 100 .

JAPANESE. None of our autumnal trees can excel these in gor(1) geousness of coloring; they include yellow, blood-red, green and wonderful, some as delicate as the finest lace. Plant in shady place. 2 to 3 feet, $60 \mathrm{c}$ each; $\$ 5.00$ per 10 .

RUBRUM. Produces deep red blossoms, which appear before the leaves. The foliage changes to brilliant scarlet in autumn. A planted in a lawn. 4 feet, $50 \mathrm{c}$ each; $\$ 4.00$ per 10.

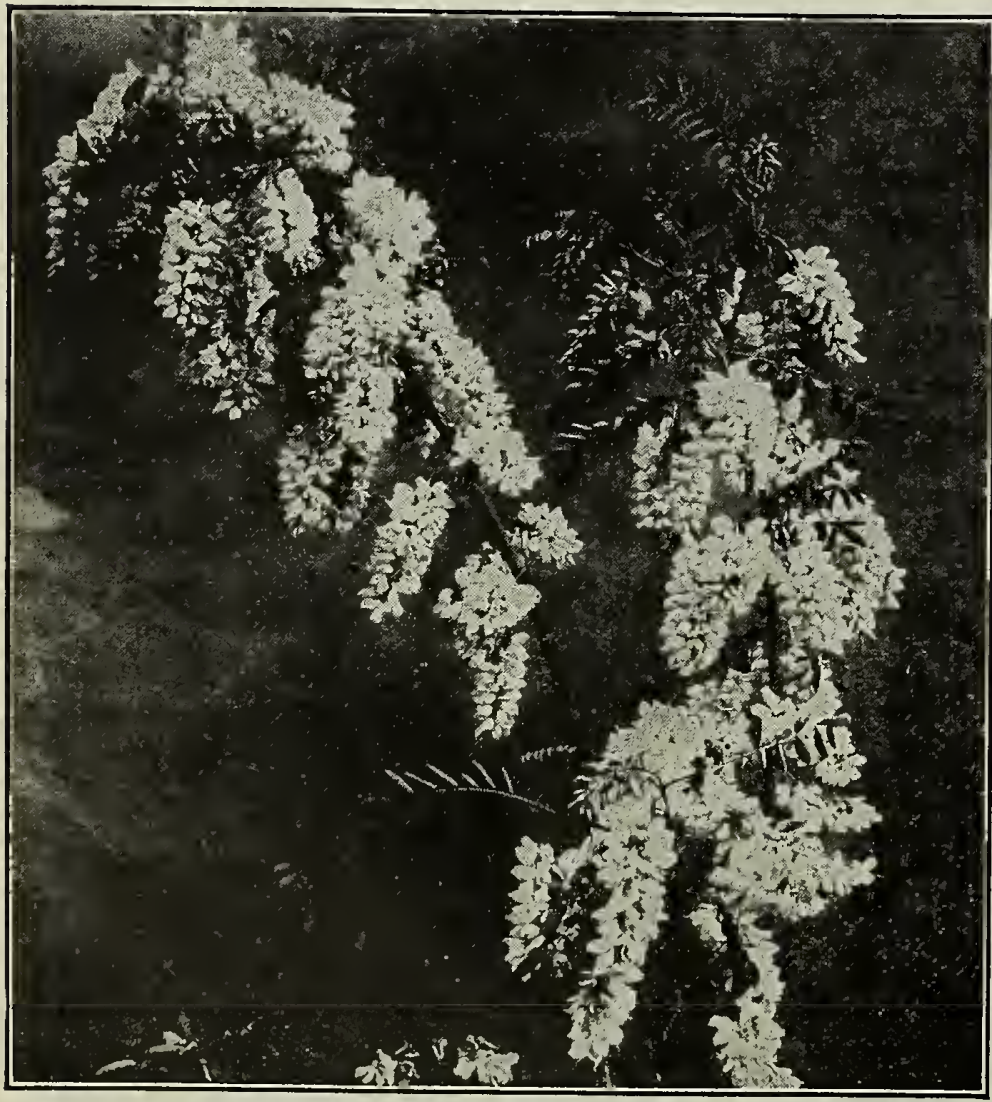

Pink Flowering Locust

\section{MAGNOLIA, JAPANESE}

These highly ornamental medium sized trees with their lavish display of fragrant, many hued flowers, are worthy of a place in every garden of any size. Planted in groups, their effect in the early spring with their brilliant colorings and their rich fragrance is grand beyond description.

CONSPICUA. Flowers large, pure white, cup-shaped, very sweet. $2 \frac{1}{2}$ to 3 feet, $50 \mathrm{c}$ each.

OB OVATA. Purple flowers. 2 to 3 feet, 50c each.

MOCK ORANGE, or SYRINGA. An invaluable shrub, of vigorous habit, very hardy, with large, handsome foliage and beautiful white flowers, produced in the greatest profusion. 3 feet, $35 \mathrm{c}$ each.
MOUNTAIN ASH, EUROPEAN (Rowan Tree). Flowers creamy white; foliage somewhat like the Pepper Tree; covered from August to November with large clusters of orange-colored berries. 5 to 6 feet, $60 \mathrm{c}$ each; $\$ 5.00$ per 10 .

MULBERRY, DOWNING'S EVERBEARING. A very rapid grower. A valuable shade tree; produces a good fruit. 5 to 6 feet, $60 \mathrm{c}$ each; $\$ 5.00$ per 10 .

OAK, ENGLISH. We take pleasure in recommending this historical tree to our customers as one of the most desirable for California. It is of fairly rapid growth; it makes a dense head, and the leaves are a dark glossy green, to which dust does not adhere; it retains its foliage till late in the season, and sheds at a time when we do not want shade. $3 \frac{1}{2}$ feet, $50 \mathrm{c}$ each.

OAK, SCARLET. Perhaps there is no tree that appeals to us more forcibly than those producing scarlet foliage in fall. Just as we rememper "snow at christmas," so do we think of "Autumn at it brings back to us days of long ago. In this variety we have such an ideal tree; the foliage changes to a bright scarlet and remains on the trees until heavy frost cuts them off. 3 to 4 feet. $50 \mathrm{ceach}$.

PEACH, FLOWERING. The double flowering varieties are distinguished for their showy and beautiful bloom. At the blossom ing season in April, every branchlet is covered with a mass of beautifully formed. highly colored flowers, rendering the trees most interesting objects and attracting great attention. We can supply the Double White and Double Pink. 4 to 5 feet, $50 \mathrm{c}$ each.

PEACH, BLOOD IEAVED. A beautiful ornamental variety with lovely blood-red foliage. 4 to 6 feet, $50 \mathrm{c} \mathrm{each;} \$ 4.00$ per 10 .

PAULOWNIA IMPERIALIS. Known as "Empress Tree." A magnificent tropical looking tree from Japan; of extremely rapid growth, and surpassing all others in the size of its leaves, which are twelve to fourteen inches in diameter; blossoms trumpetshaped, for med in large, upright panicles and appearing in May color a beautiful shade of lavender. 8 feet, $\$ 1.00$ each.

PLUM, PURPLE-LEAVED (Pissardi). The young branches are very dark purple; the leaves when young are lustrous crimson changing to a dark purple, and retain this beautiful tint till they drop late in autumn. No other purple-leaved tree or shrub retains its color like this. It also bears a fairly good fruit. 4 to
6 feet, 50c each; $\$ 4.00$ per 10 .

\section{POPLAR}

Poplars are very rapid growing trees and thrive under a great variety of conditions as regards soil, but do best in damp situations and along watercourses. Their leaves are bright among other trees, of heavier foliage and give to a group a sprightly air. They are well adapted for windbreaks and are very effective when planted in groups by themselves.

"BALM OF GILEAD." Of remarkably rapid and luxuriant growth, with large glossy foliage. 5 to 6 feet, $40 \mathrm{c}$ each; $\$ 3.50$ per 10.

CAR OLINA. A very distinct tree, making a large, spreading head Excellent for a venue planting, 5 to 6 feet, $35 \mathrm{c}$ each; $\$ 3.00$ per 10; 8 to 10 feet, 60 c each; $\$ 5.00$ per 10 .

BOLLEANA. Silver-Leaved Poplar. Foliage silvery green above snow white underneath. Adds great beauty to landscape work. 5 to 6 feet, 50 c each; $\$ 4.00$ per 10 .

LOMBARDY. This is one of the characteristic trees of parts of Italy and it is from the Italian province, Lombardy, that its common name is derived. Probably a native of Asia. A very rapid. erect growing tree with a tall spiry form and particularly striking and picturesque when grouped among other trees. 4 to 6 feet, $30 \mathrm{c}$ each; $\$ 2.50$ per $10 ; 7$ to 8 feet, 50c each; $\$ 4.00$ per 10 .

QUINCE (Japanese Scarlet Flowering). This is the first shrub to bloom in spring and the blossoms appear in great profusion, covering every branch and branchlet before th
the leaves. $21 / 2$ feet, 35c each; $\$ 3.00$ per 10.

ROWAN TREE. See under Mountain Ash.

SNOWBALL. This well-known shrub is known to nearly everyone, they produce immense ball-shaped, white flowers in great profusion in May and June. Should be in every collection. 2 feet, 35c each; $\$ 3.00$ per 10.

SYCAMORE. EUROPEAN. 5 to 6 feet, $50 \mathrm{ceach} ; \$ 4.00$ per 10.

\section{SPIRAEA}

A. WATERER ("Crimson Spiraea"). A valuable addition to our shrubs; the flowers are crimson, appearing in great masses. This would make a beautiful hedge; it blooms for a long period. feet, 30c each.

DOUGLASII ROSEA. This variety has spikes of beautiful deep rose-colored flowers. 2 to 3 feet, 30 each; $\$ 2.50$ per 10 .

REVESIANA FLOREPLENA. 2 to $2 \frac{1}{2}$ feet, $35 \mathrm{ceach}$; $\$ 3.00$ per 10. 
TAMARIX GALLICIA. An elegant and handsome flowering small tree, thriving in all soils and locations, whether by the seashore or hot interior valleys. The flowers appear along the branches; per 10.

TEXAS UMBRELLA TREE. This is one of the handsomest of deciduous shade trees, and is adapted particularly to the warm parts of this State, where, when sufficient water is supplied it assumes a grand umbrella-shaped head, affording delightful per $10 ; \$ 45.00$ per 100 .

THORN, DOUBLE WHITE. Has small double white flowers. A highly ornamental variety, on account of both foliage and highly ornamental variety, on
flowers. 6 to 8 feet, $75 \mathrm{c}$ each.

THORN, PAUL'S DOUBLE SCARLET. 4 to 6 feet, $50 \mathrm{ceach}$; $\$ 4.00$ per 10 .

WALNUT, CAIIFORNIA BLACK. One of the best shade trees for California; of rapid growth. 4 to 5 feet, $35 \mathrm{c} \mathrm{each;} \$ 3.00$ per 10.

\section{CLIMBING AND TRAILING PLANTS}

Some nice, rapid-growing, climbing vines planted around our dwelling houses add considerably to the beauty thereof. Some of the following are planted for their foliage alone, and others again for their handsome flowers.

AREBIA QUINATA. A very distinct and pretty climber from Japan. Foliage clover-like in appearance, semi-evergreen; flowers chocolate-
sweet. 50c each.

AMPELOPSIS ENGELMANNI. Shorter jointed than quinquefolia. Strong grower. 2-year-old plants, $50 \mathrm{c}$ each; $\$ 4.00$ per 10 .

AMPEL OPSIS MURALIIS. Resembles the quinquefolia, but is more slender in growth and shorter jointed, with smaller foliage. 2-year-old plants, 50c each; $\$ 4.00$ per 10.

AMPEL OPSIS QUINQUEFOLIA (Virginia Creeper). The leaves are palmate, handsome and luxuriant, assuming in autumn a gorgeous bronzy hue. Strong, 50c each; $\$ 4.00$ per 10 .

AMPEL OPSIS VEITCHII (Boston or Japan IVy). This variety clings closely without any assistance to a stone wall or brick flue
WEIGELIA CANDIDA ("White Flowered Welgelia"). A very each; $\$ 3.00$ per 10

WEIGEIIA ROSEA. An elegant shrub, from Japan. They produce superb, large, trumpet-shaped flowers of a fine rose color. 2 to $2 \frac{1}{2}$ feet, $35 \mathrm{c}$ each; $\$ 3.00$ per 10 .

WILLOW, BABYLONIAN. This is the willow we see so many of in this state and know low. It is best suited to plant in wet land, where it makes rapid growth and affords grateful shade for stock, which browse lazily
of the lower branches, and when so pruned add picturesqueness to our landscapes. 3 to 4 feet, $35 \mathrm{c}$ each; $\$ 3.00$ per 10 .

WILLOW, ASIA MINOR. Foliage narrower than the Babylonian. 4 to 5 feet, $35 \mathrm{c}$ each; $\$ 3.00$ per 10 .

WILLOW GOLDEN. Beautiful yellow branches. 3 to 4 feet, $35 \mathrm{c}$ each; $\$ 3.00$ per 10 or a wooden surface. It is widely planted in California, where it succeeds admirably, and is much admired. $35 \mathrm{c}$ and $50 \mathrm{c} \mathrm{each}$.

AUSTRALIAN PEA VINE. This lovely fast-growing climber we can recommend to those desiring a rapid grower. The flowers are pea-shaped, pink, and produced in great luxuriance. Pot-grown strong plants, 35c each, $\$ 3.00$ per 10.

\section{CLEMATIS}

The Clematis are elegant, slender-branched climbers of rapid growth, with fine foliage and beautiful, large flowers of various colors; they are perfectly hardy, and cannot be excelled as climbing plants in any situation; they are very particular as to soil, that of a loamy texture being the most

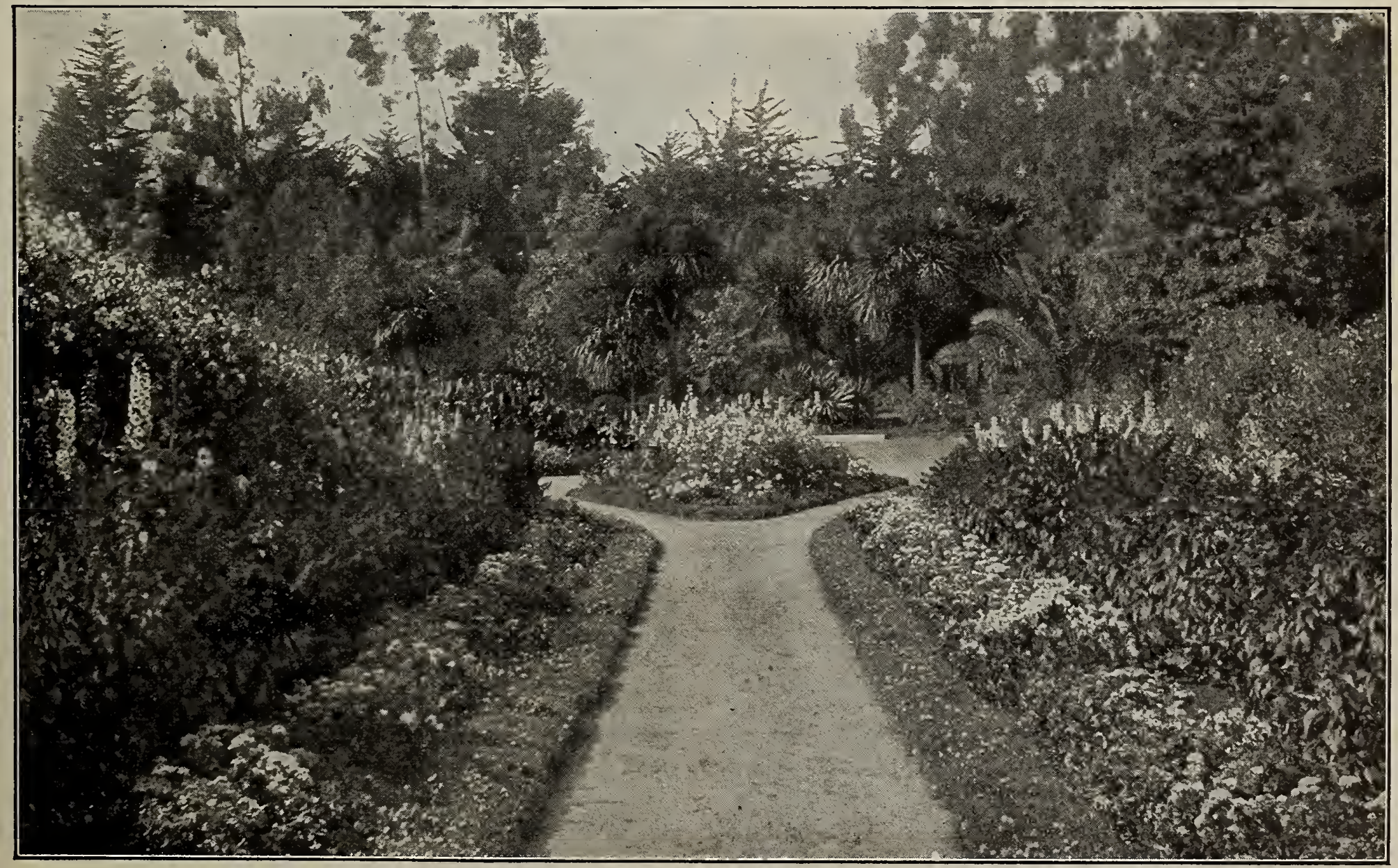

Ageratums planted near walk: Pansles, Salvias, Larkspur, and in the back-ground, Sweet Peas 


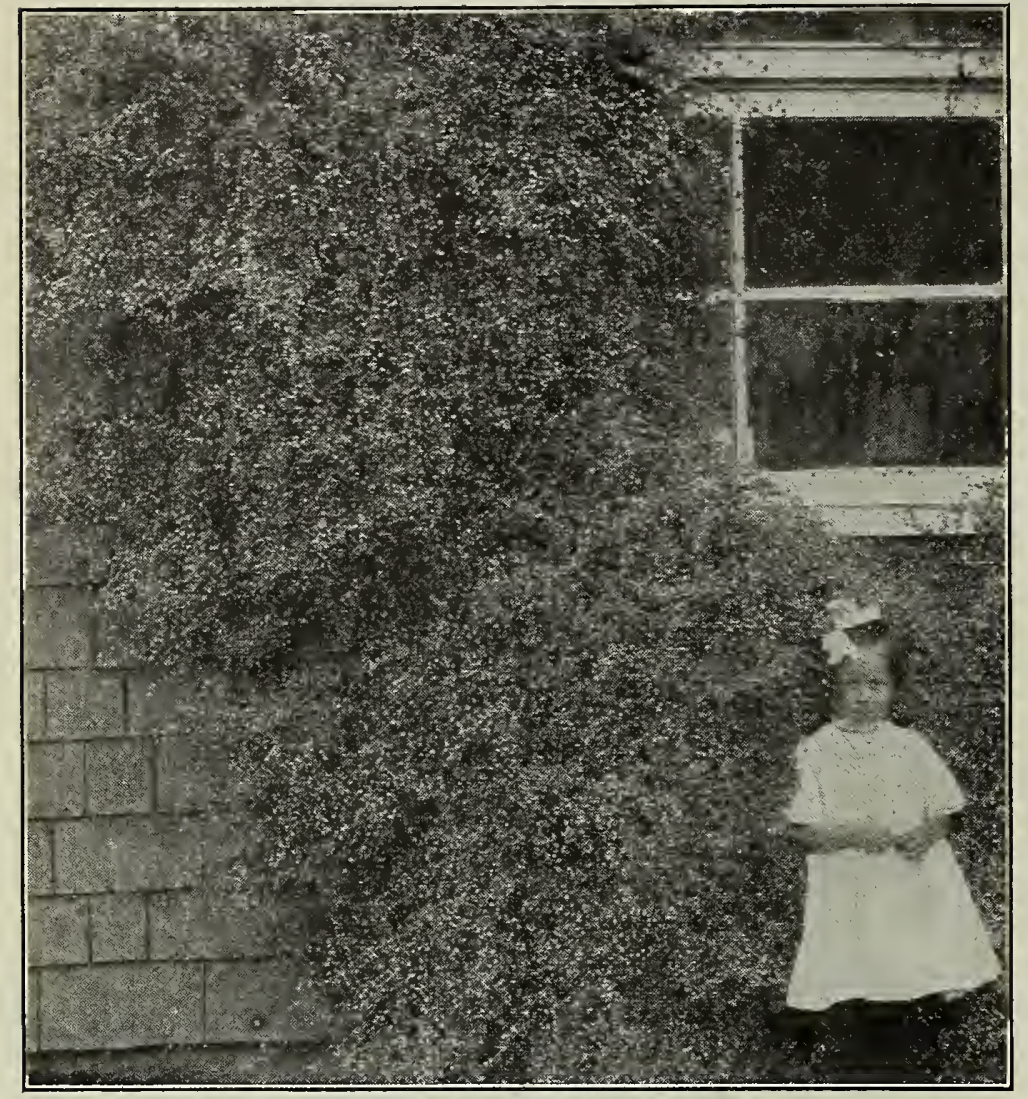

Muehlenbeckia Complexa (New Zealand Mattress Vine)

\section{CLEMATIS-Continued.}

suitable; thorough drainage is indispensable to good, healthy growth; large, deep holes should be dug, and if the soil is heavy it must be replaced; in planting, the roots should all be spread out, and plants pruned down to one-half their height; they should never be allowed to get very dry; an annual manuring should be given, and tops pruned off in December. 75c each, except where noted.

DUCHESS OF EDINB URGH. Fine large double white.

JACKMANII. Deep purple violet.

HENR YII. Large, single white.

MADAII E. ANDREE. Large, single red.

MONTANA. In this variety we have the ideal Clematis for this State. The flowers are produced in spring in wonderful profusion (as will be seen from the picture which we have the pleasure in presenting); they are about the size of a dollar and are pure white. The vine is a rapid, rampant grower. Strong plants, $60 \mathrm{c}$ each.

PANICULATA. A Japanese climber, recently introduced into this country, of unusual and attractive merits; rapid grower; foliage of a glossy, rich green; the flowers are of medium size, pure white,

\section{BOUGAINVILLEA IATPRITIA}

This remarkable variety produces brown flowers, an exceedingly rare color in plants and wondrously beautiful. A very rare plant on account of the difficulty in propagating; after planting in the ground it is of very rapid growth. We have only a limited stock of this variety and can offer strong plants in 6 -inch pots at $\$ 2.50$ each.

B OUGAINVILLEA SANDERIANA. These climbers are becoming greater favorites every year. They have peculiarly shaped flowers, somewhat resembling the leaves in shape, the color being of a rosy lake, and produced at the end of the branches in wonderful profusion. They are indispensable for the greenhouse and do remarkably well in many protected situations out of doors. andong plants, 50c and 75c each.

BIGNONIA GRANDILFORA (Trumpet Vine). Rapid-growing climber, bearing large orange-yellow trumpet-shaped flowers in great profusion. Strong plants, 50c each.

BIGNONIA RADICANS. Scarlet , trumpet flowers; exceedingly showy. 50c each.

FICUS REPENS. A very pretty useful climber; clings to stone, brick or wood; like the Boston Ivy. Evergreen. $25 \mathrm{c}$ and $50 \mathrm{c}$ each. HONEYSUCKLE, CHINESE. Rosy white. 4-inch pots, $40 \mathrm{c}$ eac $h ; \$ 3.50$ per 10 ; from open ground, $50 c$ each.
HONEYSUCKLE, BELGIAN OR ENGLISH. Red and yellow flowers; long bloomer; very fragrant. 4-inch pots, $40 \mathrm{c}$ each; $\$ 3.50$ per 10.

HONEYSUCKLE, HALLEANA, HALL'S JAPAN HONEYSUCKLE. A strong, vigorous, almost evergreen sort, with pure white flowers, changing to yellow; very fragrant; a long and from open ground, 50c each.

HONEYSUCKLE PUNICEA. A most beautiful sort; having scarlet trumpet shaped flowers, 4-inch pots, 50c each; $\$ 4.00$ per 10 .

HOPS (Humulus Lupulus). One of the very best climbers for covering unsightly places. It is a rapid grower, and bears a March delivery, 50c per dozen (60c postpaid).

IVY, ENGLISH, IARGE-LEAVBD. Leaves thick, shining, leathery. 25c, 35c, and $50 \mathrm{c}$ each.

IVY, ENGLISH, SMALL-LEAVED, 5-inch pots, 50c each. IVY, VARIEGATED, SILVER-LEAVED. Large plants, 50c each.

JASMINE GRANDIFLORUM (Catalonian Jasmine). Plant is of shrubby, half-climbing habit, with very delicate foliage and its small, white, star-shaped, fragrant flowers are produced very large plants at $\mathbf{\$ 2 . 5 0}$ each.

JASMINE REVOLUTUM (Yellow-Flowering Jasmine). Produces fragrant yellow flowers. $35 \mathrm{c}$ each.

JASMINE OFFICINALIS. Flowers pure white, sweetly scented produced in early Spring. 35c each.

MANDEVILLEA SUAVEOLENS (Chili Jasmine). Flowers very fragrant; star-shaped; strong climber. 25c each.

MUEHLENBECKIA COMPLEXA (New Zealand Mattress Vine). This pretty, strong-growing climber and trailer is very desirable for covering old stumps of trees, rockwork, etc. The foliage is small, dense, and graceful. 4-inch pots, 35c each; $\$ 3.00$ per 10.

PASSION VINE (Passiflora). These well-known hardy climbers are familiar to and appreciated by all. They are of rapid grow th and very attractive when covered with their large handsome flowers. $35 \mathrm{c}$ each; $\$ 3.00$ per 10 SCARLET. $35 \mathrm{c}$ and $60 \mathrm{c}$ each.

PHYSIANTHUS ALBUS. A beautiful climber, flowering during Summer and Fall. Pure white, fragrant. 5-inch pots, 35c each.

PLUMBAGO CAPENSIS. Can be trained as a bush or climber. Flowers light sky-blue, verbena-shaped, produced throughout the entire Summer; stands drought and water and the brightest sunshine. 35c each.

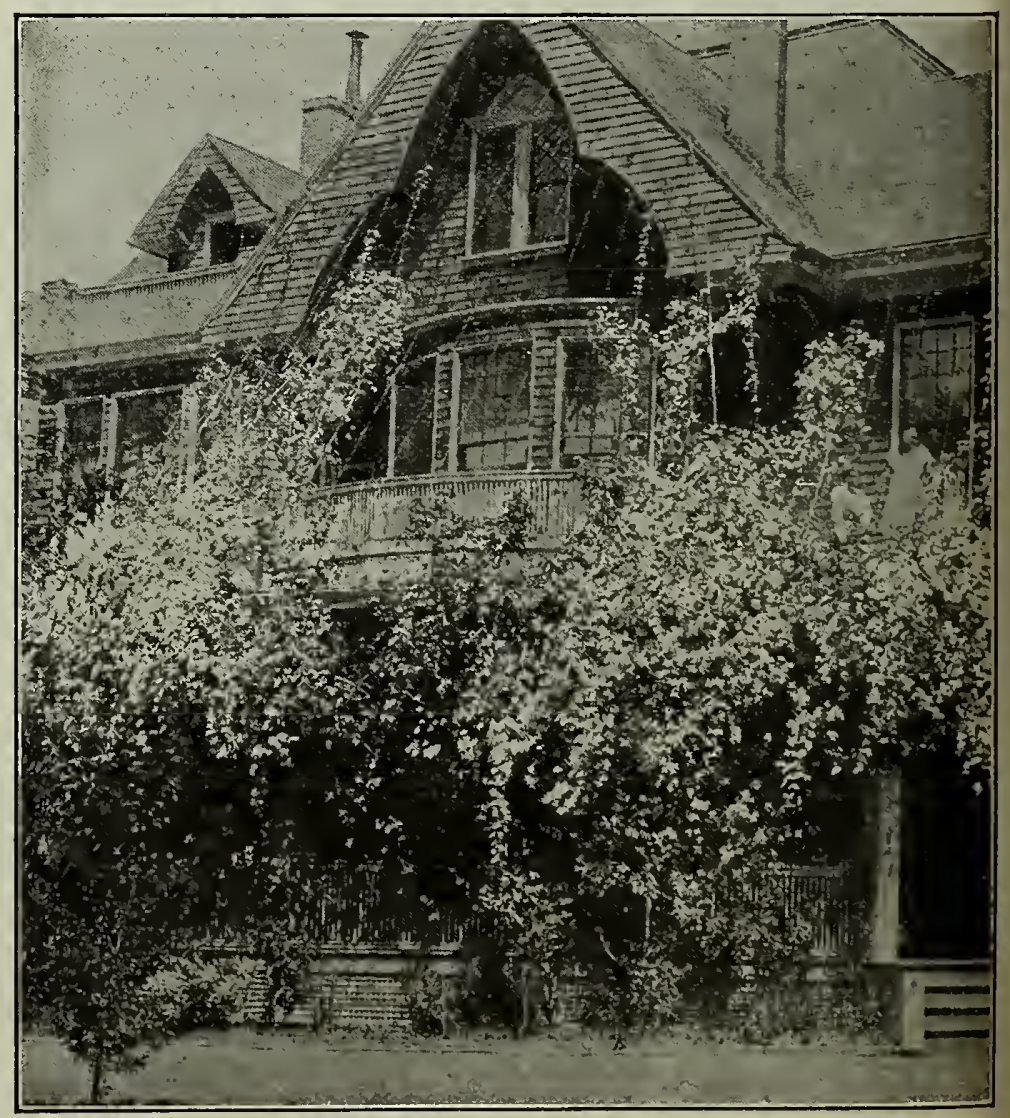

Clematis Montana. Observe how eagerly it is reaching up. 


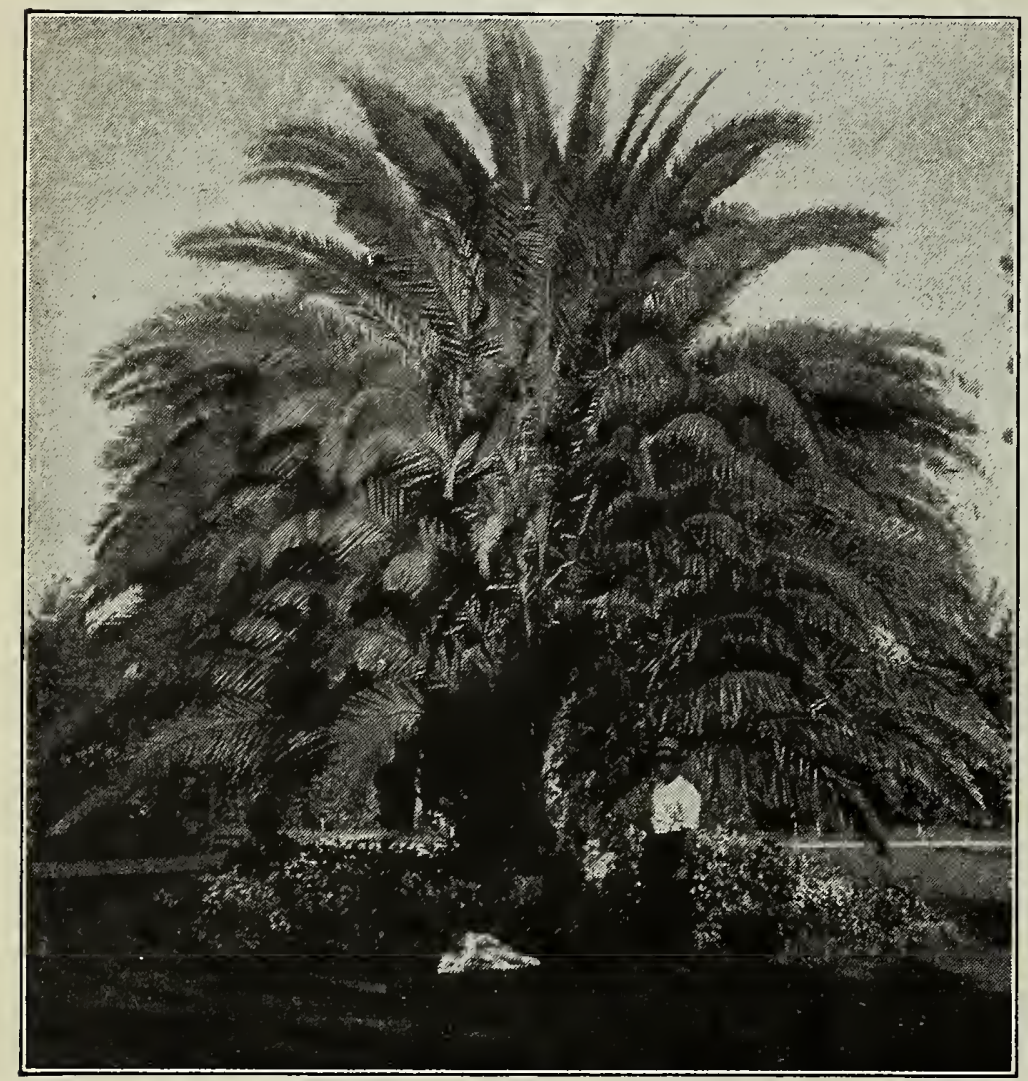

Phoenix Canariensis-Unsurpassed for Grandeur

PALMS-Continued.

* KENTIA FOSTERIANA. One of the finest of the Kentias, with graceful, bright green foliage. Plants, in 4-inch pots, 50c each; in 5-inch pots, $75 \mathrm{c}$ and $\$ 1.00$ each; in 6-inch pots, $\$ 1.50$ each.

*I ATANIA BORBONICA. Leaves, large, fan-shaped, of a very cheerful green color; plant of hardy construction, and adapted to all decorative purposes within doors. Appreciated by all the plant-loving community. 5-inch pots, $75 \mathrm{c}$ each; 6-inch pots, $\$ 1.50$ each.

MUSA ENSETE (Abyssinian Banana). The noblest of all plants is the great Abyssinian Banana. The fruit of this variety is not edible, but the leaves are magnificent, long, broad, and massive. of a beautiful green, with a broad crimson midrib. The plant grows luxuriantly, from 8 to 20 feet high; it grows rapidly and grows luxuriantly, from 8 to 20 feet high; it grows rapidiy and attains gigantic proportions, producing a tropic

PHOENIX CANARIENSIS (The Canary Island Date). The handsomest and hardiest species of the date palm family. Being a rapid grower, it soon develops into beautiful specimens, with pinnate, dark green leaves, from 6 to 21 feet long, the division linear, lance-shaped, very much pointed. It is fully as hardy as the native Fan Palm and differing so widely from that variety in its habit of growth, color, and style of foliage, a finer contract cannot readily be imagined when the two are planted, either opposite or alternately in rows. Balled, $1 \frac{1}{2}$ feet, $\$ 1.50$ each; balled, $21 / 2$ to 3 feet, $\$ 2.50$ each; boxed, $\$ 2.50, \$ 3.50, \$ 5.00$ and $\$ \mathbf{6 . 0 0}$ each, according to size.

PHOENIX DACTYLIFERA. Produces the date of commerce. Boxed, 3 feet, $\$ 4.00$ each.

PAMPAS GRASS. Strong clumps, 60c each.

TRITOMA UVARIA (Red Hot Poker Plant). So called on acThey are borne on long stiff stems during Summer months, and are very effective. Clumps, 50c each.

TRITOMA PFITZERII. Strong roots. 60c each.

*RAPHIS HUMILIS. China and Japan. A hardy little cane palm, which suckers from the roots like the bamboo and forms a dense clump of canes. A delicate and graceful little plant. only 3 to 4 feet in height when full grown. Strong plants in 8 -inch pots, $\$ 4.00$ each.

WASHINGTONIA ROBUSTA. One of the hardiest and most beautiful of palms; in habit of growth resembling our well-known California pan Palm but mow th resembling our well-known leaves fan-shaped, medium size retaining their dark green color leaves fan-shaped, medium size, retaining their dark green color during the Winter months; stems short, thorny; of upright, per 10; boxed, well established, $31 / 2$ feet, $\$ 5.00$ each.

YUCCA, VARIEGATED. 6-inch pots, $\$ 1.50$ each.

\section{CONSERVATORY AND PARLOR DECORATIVE PLANTS}

Under this heading we have included such plants as flourish in the parlor, hall, greenhouse, and some in protected situations out of doors.

ASPARAGUS PLUMOSUS. The leaves are a bright gTeen, are gracefully arched, and are as finely woven as the finest silken mesh, surpassing Maiden-Hair Ferns in grace, fineness of texture and richness of color. $35 \mathrm{c}$ and $50 \mathrm{c}$, according to size.

ASPARAGUS SPRENGERII. A variety of recent introduction It is as a basket plant that this will prove most valuable. In 5 -inch pots, 40c each; in hanging baskets, $\$ 1.50$ each.

ANTHERICUM VARIEGATUM. Foliage beautifully striped yellowish white; succeeds admirably in the window; also much esteemed as a basket plant. 4-inch pots, 35c each.

ASPIDISTRA LURIDA. This is the plant one sees so many of in windows, halls, and stores. The foliage is large, lily-like in appearance, of a dark green color. It is of rugged constitution and will stand in locations that will kill most plants. 75c, $\$ 2.00, \$ 3.00$, and $\$ 5.00$ each, according to size.

ASPIDISTRA LURIDA VARIEGATA. A variegated form of the preceding. Large plants, in 7- and 8-inch pots, $\$ 2.50$ and $\$ 3.50$ each.

BEGONIA. Rex Varieties. Very handsome parlor and greenhouse decorative plants. The leaves are wonderfully formed and marvelously colored. We have a magnificent collection. $50 \mathrm{c}, 75 \mathrm{c}, \$ 1.00, \$ 1.50$, and $\$ 2.00$ each.

COLEUS. 15c and 25c each. Larger plants later in the season, $50 \mathrm{c}$ each.

CYCLAMEN, Charming plants, with beautiful foliage and richlycolored fragrant flowers. Universal favorites for Winter and Spring blooming. Pot grown plants, in leaf and bloom $50 \mathrm{c}$ and $75 \mathrm{c}$ each; smaller plants, $15 \mathrm{c}$ each; $\$ 1.25$ per 10 . FICUS ELASTICA (India Rubber Plant). Very large, smooth leathery leaves, evergreen foliage; generally esteemed one of the finest house plants grown.

FICUS MACROPHYILA. A variety with smaller leaves than the preceding; much valued for parlor or hall decorations. $\$ 1.00$ each.

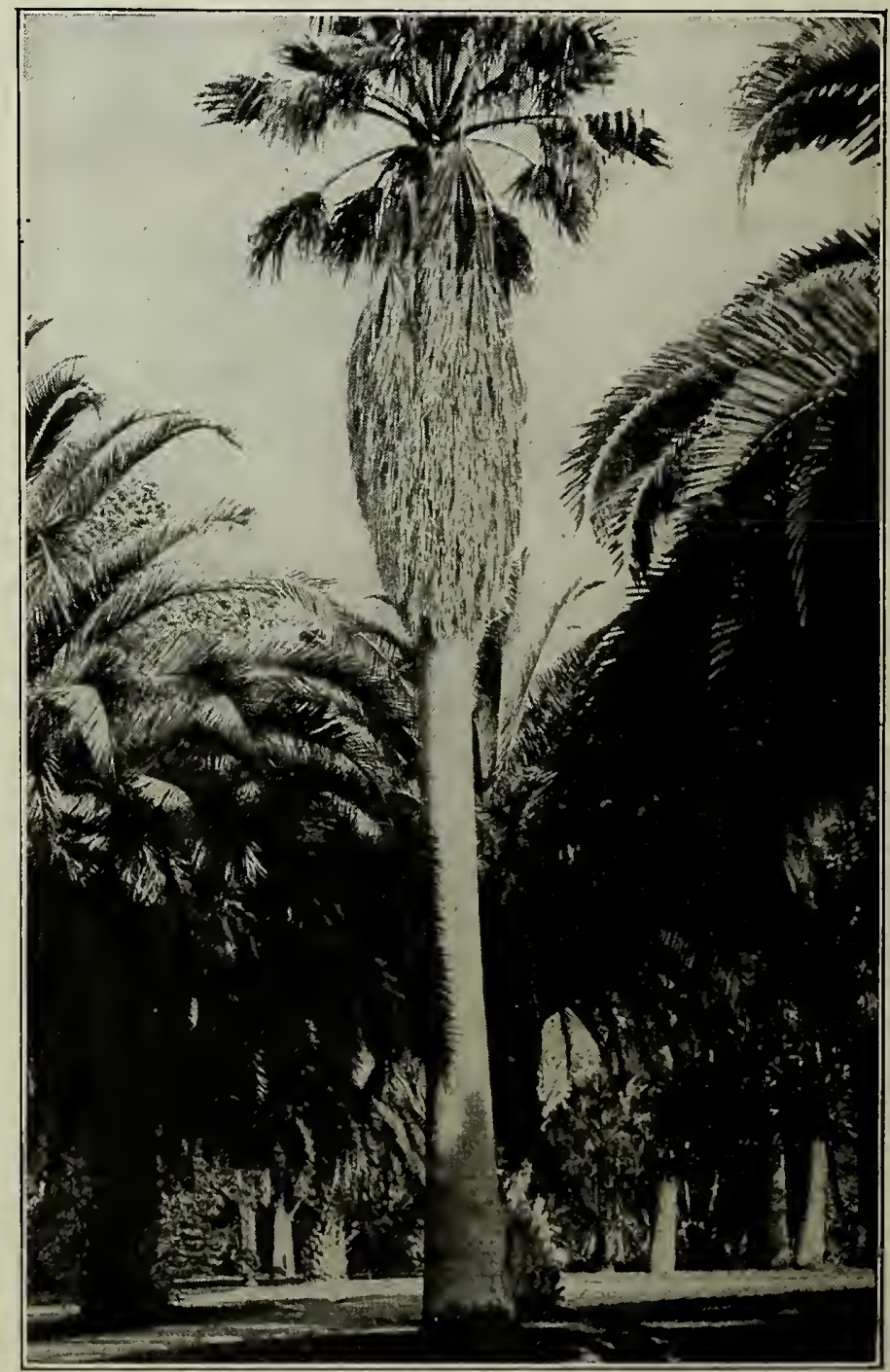

Californis Fan Palm-Growing in Alameda County 
ADIANTUM CUNEATUM (Maiden-Hair Fern). This fine variety is more generally grown than any of the other sorts; for 5-1nch pots, $50 \mathrm{c}$ each; 6- and 7-inch pots, 75c each; in hanging baskets, $\$ 1.50, \$ 2.50$, and $\$ 3.50$ each.

ADIANTUM GRACILIMUM. A variety that has finer and more graceful foliage than the preceding; a most lovely sort. 5-inch pots, 50c each; In hanging baskets, $\$ 2.00$ and $\$ 2.50$ each.

ASPLENIUM FALCATUM (Holly Fern). A favorite variety for house culture; the leaves are dark and very glossy and the fronds beautifully arched. 3-inch pots, 25c each.

JAPANESE FERN HANGING BALLS, 50c each.

NEPHROLEPIS B OSTONIENSIS (Boston Fern). Is one of the very few plants that will thrive under ordinary house care.
It grows well, and improves in size where most all other ferns fail. It grows well, and improves in size where most all other ferns fail.
The fronds droop and arch gracefully over the edge of a pot or basket, and, as it is a very rapid grower, it is not long before they reach the floor from an ordinary parlor table. In pots, $50 \mathrm{c}, 75 \mathrm{c}, \$ 1.00$ each; in pans, $\$ 1.00, \$ 2.00, \$ 3.00$, and $\$ 3.50$ each; in baskets, $\$ 1.50, \$ 2.00, \$ 3.00$, and $\$ 3.50$ each.

NEPHROLEPIS WHITMANII. "This is one of the newest introductions to the "plume foliage" varieties, and it is certainly very fine; must be seen to be appreciated. Does beautifully in hang- ing baskets. In pots, $50 \mathrm{c}, 75 \mathrm{c}, \$ 1.00$ each: in pans, $\$ 1.00$, $\$ 2.00, \$ 3.00$, and $\$ 3.50$ each; in baskets, $\$ 1.50, \$ 2.00, \$ 3.00$ and $\$ 3.50$ each; in hanging baskets, $\$ 1.50$ each.

NEW ZEALAND TREE FERN (Dicksonia antartica). We have always been large importers of this truly grand Tree Fern, and the ever-increasing demand has compelled us to keep up plants to offer from $\$ 5.00$ to $\$ 25.00$, according to size. For greenhouse decoration the New Zealand tree fern cannot be beaten; or for outside work, when planted in sheltered locations. they are also very suitable.

PTERIS ADIANTOIDES. Fronds similar to those of the MaidenHair Fern, only larger; very nice. 3-inch pots, 35c each.

PTERIS DRINKWATERII. Silvery gTeen foliage; very choice. 3-inch pots, 35c each.

PTERIS TREMULA. A favorite house fern; fronds long and arching. 3-inch pots, 35c each.

PTERIS WINSETTI. A beautiful sort, with lovely crested foliage. 3-inch pots, 35c each.

WOODWARDIA. Very useful for planting in shady places; a strong grower. Large roots, $75 \mathrm{c}$ each, $\$ 6.00$ per 10 .

\section{THE DAHLIA}

Of late years these have sprung into wonderfut prominence, and are becoming more and more popular every year. This is not to be wondered at, considering how they have been improved upon. The Cactus Dahlia of today is much superior to the old "show" round, stiff sorts (though still admired by many) of old. The Cactus varieties have long twisted petals, resembling in many cases chrysanthemums.

CULTIVATION.-While the Dahlia is one of the easiest of all flowers to cultivate, it by no means follows that it requires no attention. In fact, no flower that we have ever cultivated will give such a generous response to good cultivation as the Dahlia. Deep and thorough stirring of the soil during the early growth of the plant is indispensable to success. With poor cultivation or neglect, the flower will rapidly degenerate-becoming semi-double and faded in color. The Dahlia, with but few exceptions, should be given an open, sunny situation for at least a portion of each day. It is a rank feeder and should be given rich soil and kept free from weeds. We are in favor of taking up the roots every year, as soon as the tops are cut down by frost, and laid away in sawdust or in a dry place. Plant them out again in MAY OR THEY CAN BE PLANTED AS LATE AS THE END OF JUNE. We strongly advise our customers not to be in a hurry about setting the Dahlia out, as it is essentially a fall flower, and when planted early they bloom in the hot summer months, and the flowers are very inferior, and at that season they are generally infected with an insect called "Diabrotica," resembling a lady bug, which does much damage to the flower of the Dahlia. This insect disappears later on; hence our reason for advising late planting. So many of our customers have been disappointed in this respect just through early planting. Continuing with our remarks about cultivating - as soon as the plants are about two feet high, they should be staked, care being taken that the stake is driven far enough away from the root, so that it may not be injured. Mulch heavily with old, well-rotted manure, and give the plants a thorough soaking once in ten days or two weeks. Frequent syringing adds greatly to the health and vigor of the plant. Disbudding, or picking off some of the flower buds and leaving only a few on one bush adds greatly to the size of the bloom. Dahlias can be set out from two kinds of roots, viz., DRY ROOTS and GREEN POT PLANTS. The former can be obtained as soon as we dig them, in December, and can be kept in sawdust, as above described, till planting time. It is better to order early or when you are getting your other stock.

GREEN POT PLANTS will be ready for delivery during May; they are grown in pots and raised from a cutting. These - green plants-you will please remember, will all bloom the first season after planting, and at the same time they are forming a bulb, which will do for planting out next season. THE DAHLIA KEEPS ON MULTIPLYING YEAR AFTER YEAR.

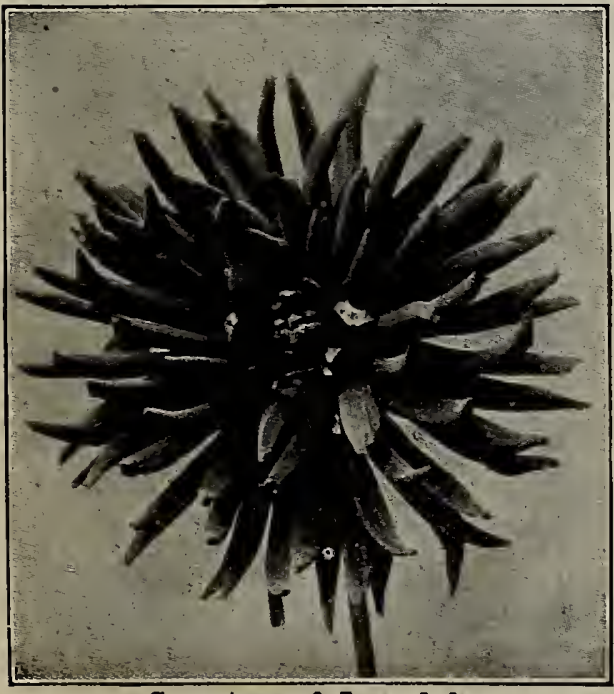

Countess of Lonsdale
NEWEST INTRODUCTIONS25 c each; $\$ 2.50$ per dozen.

MRS. MORSE This variety is one of It is a sport from Mad. H. Chanet. Color. beautiful pure snow-white, showing no yellow shading whatever. It is a decorative Dahlia, flowers large, horne very freely on long stems, throwing the flowers well above the foliage, thus rendering it very valuable for cutting purposes. It is a fine valuable for cutting purposes. It is a fine keeper, lasting for several days after cutting. Thrseres who have seen this Dahlia at our nurseries all say that it is the purest George C. Roeding says: "When on a visit to your nurseries in Oakland a few days ago, I was shown through your nursery of Dahlias. I want to take this opportunity of complimenting you on your magnificent collection. Among the numerous varieties which impressed me was the 'Mrs. Morse.' It is certainly one of the finest white Dahlias I have ever seen. I am of the opinion that it is a very valuable variety and is sure to meet the delighted a pprova of all lovers of these beautiful flowers."

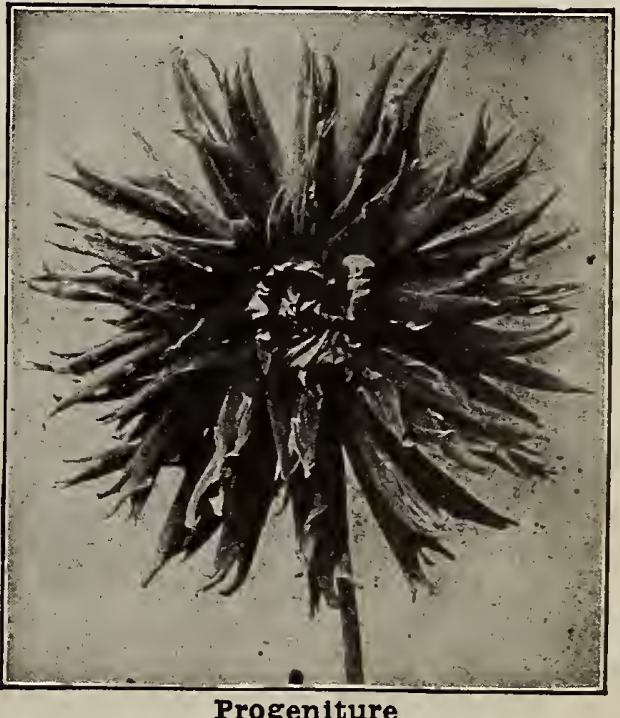

Progeniture 


\section{C.C.MORSE \& CO. PLANTS \& TREES}

BEACON A grand, striking, rich, orange-colored decorative dahlia.

DAYBREAK A very rare shade of burnished copper; true cactus sort; stems bloom.

DOROTHY VERNON A very pleasing cactus Dahlia of exquisite shape.

COLUMBIA A fancy cactus sort; red; petals long and narrow, beautifully tip-

GETTYSBURG An exceedingly large decorative Dahlia; full, round, high cenGL 12 ISBRG ter. Bright rich scarlet. An early and profuse bloomer.

HARBOR LIGHT A grand cactus sort. Flowers bronzy yellow.

LADY COLIN CAMPBELL A fine yellow, shaded orange, cactus Dahlia;

LUCIFER A true cactus, petals long and narrow, twisted; flowers borne very proMRS. ALEXANDER A very large, double rose-colored, show variety.

MRS. WYNDHAM Exceedingly large; white, edge a showy variety.

MADAM VAN DEN DAEL A grand decorative size and beautiful form, pure velvety white. Shading shell pink on outer. end of petals. This variety attracted much attention when on exhibition at our store and nurseries last season.

PRINCESS PONIATOWSKI A very large yelety; very satisfactory in all respects.

SAILOR PRINCE A superb rich crimson cactus, long full to the center; a free early bloomer.

SHAMROCK A true cactus sort; long narrow petals; bright brick red.

THOMPSON Very dark red; a large double show variety.

THE DUKE Most vivid scarlet; very often showing yellow

\section{CHOICE CACTUS DAHLIAS}

Including all of the best of the newer and older sorts.

We will supply dry roots of the following varieties, as long as they last; after they are sold out we will supply green plants; those are ready during May.

Price of Roots and Plants, 25c each; $\$ 2.50$ per dozen.

BEAUTY OF NIGHT. An intense dark, velvety black. The petals are long, pointed and twisted; stems long and stiff, holding the flowers well above the foliage; very free in bloom.

BRITANNIA. Delicate shade of soft salmon pink, blended with apricot. Petals long and twisted. Very full in bloom; stems long and stiff. Superb.

COUNTESS OF LONSDALE. A most beautiful Cactus Dahlia of true type. Color rich salmon tinted with apricot at the base of
the petals, carmine pink toward the tips; stems long and stiff; the petals carmine pink toward the tips
very free in bloom. Hard to beat.

CHARI. The base of the petals yellow, varying to red, with white tips and edges; very full in bloom. Distinct and charming.

COMET. A grand "fancy cactus," which has proved most satisfactory with us. The ground color is silvery rose, speckled with striped crimson. The stems are long and stiff and the flowers are borne well above the foliage; $a$ good bloomer and keeper.

FLAMING0. Very bright scarlet; flowers large, long pointed petals; stems strong, throwing the flowers well above the foliage; extremely profuse in bloom.

F. H. CHAPMAN. Yellow overlaid with deep orange; very bright and effective. A flower of grand form and largest size, with narrow, beautifully incurved petals.

GENERAL BULLER. Rich velvety crimson, nearly black at the base, each floret having a pure white tip, those in the extreme center showing a tinge of plum color. A very remarkable and perfectly distinct flower. Long, erect stems, very free.

GENESTA. The ground color is amber, passing toward the center to golden-yellow; the florets are beautifully arranged. Good free bloomer; stems long and erect.

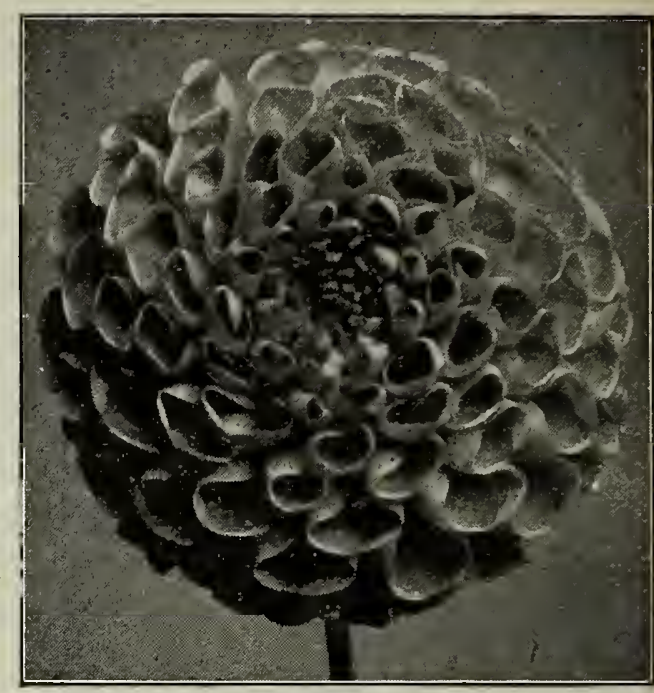

A. D. Livonil

GOLDFINCH. Clear bright cinnamon; the best of this shade: petals gracefully incurved.

INNOVATION. Reddish scarlet, ends of petals distinctly tipped with white. Very fine and much admired.

J. W. BAGGE. Color bright radiant orange. with a tint of shining vermilion, an indescribably beautiful shade; flowers extremely large; stems long; blooming qualities unexcelled.

J. C. JACKSON. The deepest, darkest velvety maroon-black; of true cactus form; fine stems; grand bloomer. Nothing to equal it in its color. Perfection.

KREMHILDE. Delicate shell-pink with white at center; of good cactus form; a free and long bloomer.

MATCHLESS. Dark purple maroon; almost same shade as the "Black Prince" rose. In form, color, size, and growth this variety is perfect. Blooms for a long period.

MONARCH. The color is a rich glowing velvety crimson; stems very long and stout, and hold the flowers well above the foliage. Very floriferous indeed.

MONARCE II. This is a sport of the preceding; the plant is of dwarf habit, and is somewhat on the decorative type; color dazzling magenta; very free in bloom.

MRS. MAWLEY. The finest yellow Cactus Dahlia of largest size. coming on strong stems; fine form and shape; every bloom coming perfect; deep canary-yellow. Superior to all other yellow sorts.

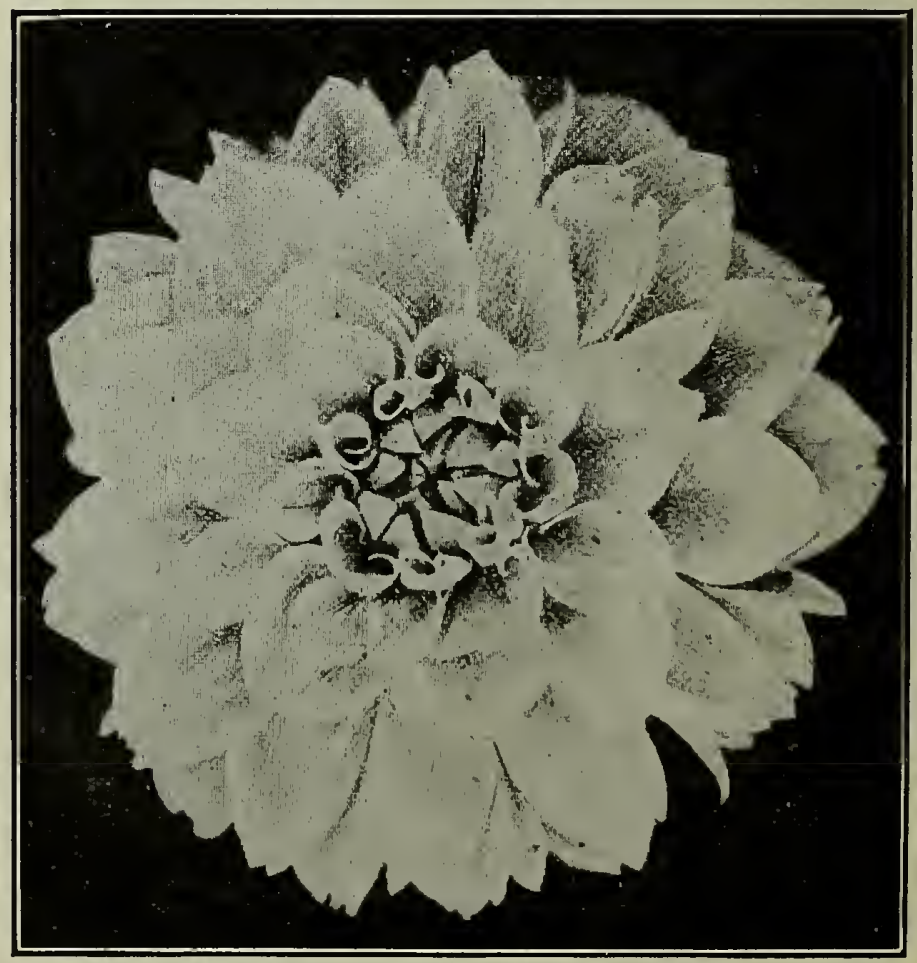

Dahlia-0lympla. Much reduced 
MAJOR TUPPENNY. Center of the petals yellow-tipped and bordered with dark buff, beautifully blended; stems long and strong, carried well above the foliage; a good keeper. A novel color.

MRS. H. J. JONES. Scarlet edged cream and heavily tipped with white, very large and perfect; fine erect habit, blooms well above the foliage; one of the best. most distinct, and valuable of the parti-colored varieties.

OCTOPUS. White, tinted blush, very large; good shape, free bloomer; good.stems and an excellent keeper.

PRINCE OF YELLOWS. Another grand yellow Cactus; not as many-petaled as Mrs. Mawley; stems long and stout; a grand keeper.

PROGENITURE. Intense dark, cardinal-red; large size; heavy flowers, coming perfect, and so free flowering that the whole plant is covered with blooms; petals are heautifully quilled ends cleft, or prettily fimbriated. A unique variety that should be in every garden,.

RICHARD DEAN. One of the most striking novelties of recent years. Vermilion scarlet, with distinct white tips. The habit will please the most exacting. It is upright, and has flower stem of great length. Flowers are of good size and splendid form.

SPOTLESS QUEEN. A grand Cactus Dahlia, pure white; stems long and stiff. are large, of fine form, and, although such a profuse bloomer they are perfectly full to the center until the last.

MRS. ROOSEVELT. One of the finest novelties that has been offered in years. It is of immense size, 6 to 7 inches in diameter something of the form of Grand Duke Alexis, but not so stiff and heavy. The color is a delicate blush pink. The plant is very strong, vigorous, growing about 5 feet high; of branching habit, and for such a large flower an extremely profuse bloomer.

MRS. WINTERS. Color pure waxy white. It blooms very freely. producing flowers from 5 to 7 inches in diameter.

PATRICK HENRY. Pure white; of good decorative shape; stems long and stout; very full in bloom.

SANTA CRUZ. Straw color petals, beautifully tipped rosy-red; elegant shape; good free early bloomer; fine stems; one of the best of its class.

\section{SHOW AND FANCY DAHLIAS}

These are the old style of Double Dahlias much improved. Shape of the flowers in this class is mostly ballshaped. All of them of wonderful formation.

25c each; $\$ 2.50$ per dozen.

ALBERT ELDRED. Orange-pink; petals tipped white. A beautiful combination.

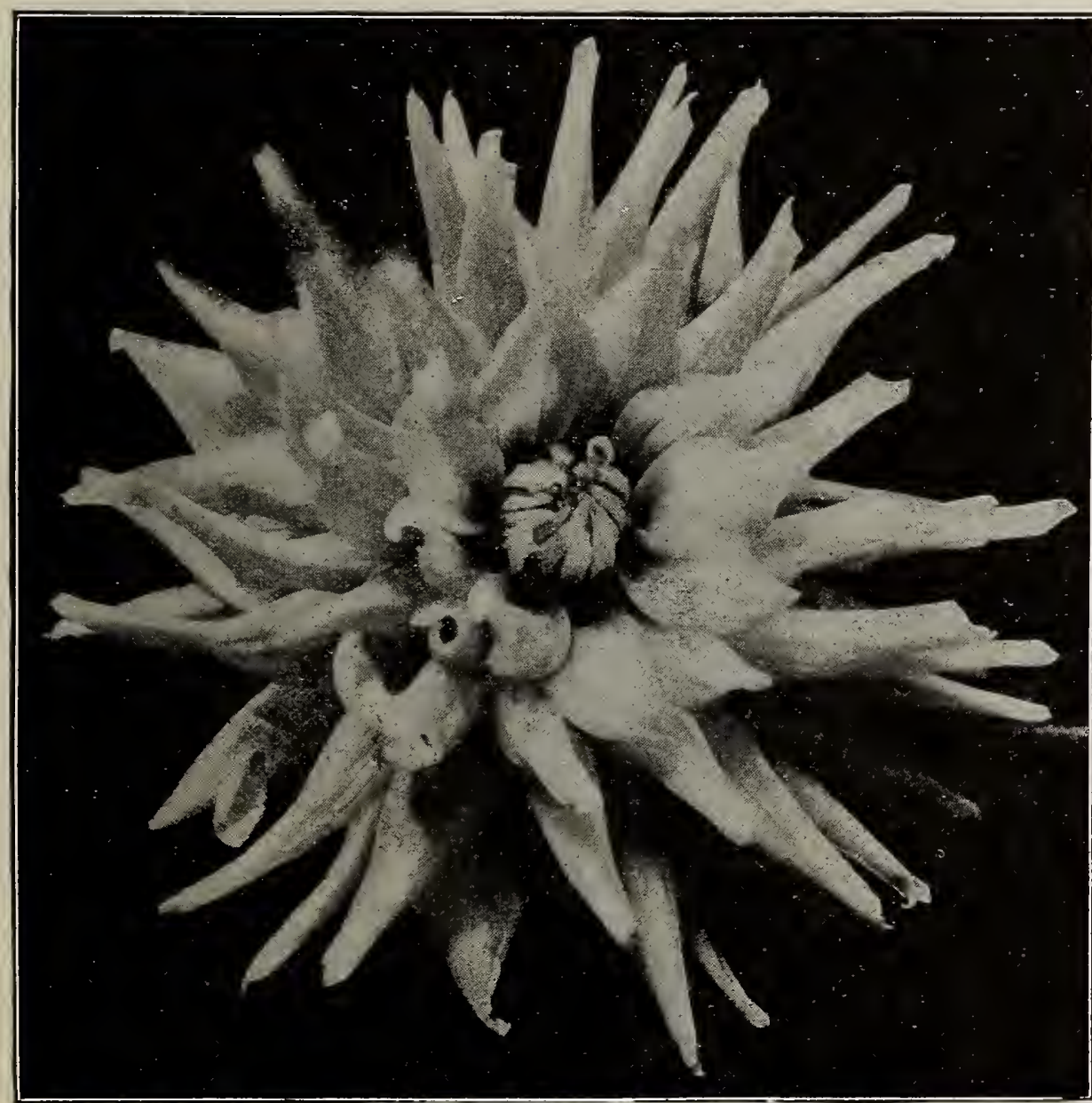

Cactus Dahlia-Winsome

VESUVIUS. A fanc cactus sort, much admired; the ground coloring is cinnamon yellow, and penciled scarlet; petals long and full to center.

WM. JOWETT. Deep cardinal red; perfect cactus form, every petal quilled, very large; stems all that can be desired; very free in bloom.

WINSOME. A very fine white Cactus Dahlia; flowers very large, beautiful cactus form, with twisted, incurved petals, and borne on long, erect stems, holding the flowers well above the foliage.

\section{DECORATIVE DAHLIAS}

25c each; $\$ 2.50$ per dozen

AMERICAN FLAG. Bright orange, sometimes tipped white. Much admired. Free bloomer.

COUNTESS OF PEMBROKE. Perfect form and double to the center. Color rosý lavender. Beautiful shade. A magnificent sort.

FRANK I. BASSETT. Bright roval purple, shading to blue. The nearest approach to a blue Dahlia yet produced; the flowers
A. D. LIVonII. A clear deep rose. The flower is well built up in the center; petals beautifully quilled.

ADMIRAL SCHLEY. A seedling of American Flag and a great improvement on that popular variety. It is of the same color and marking-bright crimson with a broad white stripe through the center of each petal-but much larger and fully as profuse a bloomer.

BIACK DIAMOND. The color is dark, jet-black when the flower flrst expands, and gradually changing to a deep velvety maroon-black. The flowers are large, of regular form, and good substance.

FRANK SMITH. Deep maroon, tipped white large and full to the center; petals beautifully quilled. One of the best "Fancies."

GERIMANIA. A novel variety that has attracted great attention; bright deep pink; petals regreat at tention; brigh
llexed and serrated.

GRAND DUKE ALEXIS. A magnificent flower of large size and distinctly unique; petals are
rolled up so that the edges overlap; color pure rolled

KAISER WILLIAM. A very large yellow; petals tipped red; a grand sort.

JUDAH. The color varies-sometimes solid primrose yellow, sometimes primrose yellow shaded and suffused old gold, sometimes striped and penciled crimson, sometimes the flowers are solid crimson. All these types often appear on the same plant.

LOTTIE ECKFORD. This is a "Fancy Dahlia." The ground is white, spotted and striped The ground is white,
with pink and crimson.

MAID OF KENT. Ánother "Fancy Sort." Scarletcrimson at base of petals, point of each being white. inches across, with full high center, and, owing to the great length of the petals when opening, there is never a green center showing, even when the buds are first expanding. The color is deep rose-pink, striped and penciled with rich crimson.

RED HUSSAR. The flowers are large, of regular form, with a full high center and good texture. The color is purest cardinal-red, without trace of purple or crimson.

STORM KING. Pure white; perfect form. An extremely profuse bloomer. Dwarf habit. Fine for bedding.

\section{SINGLE DAHLIAS}

\section{5c each; $\$ 2.50$ per dozen}

All of these are of dwarf, bushy growth, and need but little staking, unless in very exposed situations. Many people prefer single Dahlias. They are like most single flowers, more esthetic and graceful than the double. The coloring is equally vivid and brilliant, and they bloom even more abundantly. A few plants will give quantities of 
cut flowers from early June to the middle of November, if old blooms are kept picked off.

25c each; $\$ 2.50$ per dozen.

BRILLIANT. Deep, rich, vivid, velvety scarlet; sometimes the flowers come striped with yellow instead of solid color; medium sized; produced on good stems; good keeper; exceedingly free flowering. A mass of bright coloring throughout the entire

LACKBIRD. Black, changing to rich, velvety maroon with a bright red spot at the base of each petal; the flowers are large, regular in form, and of fine texture and finish.

GRACILIS. White. tinted blush; dashed, splashed, streaked, and spotted with crimson and dark red in a beautiful manner. O the hundreds of blooms covering a single bush scarcely two are the hundreds of blooms cove

GAILLARDIA. Golden-yellow, with a broad band or disc of red a round the yellow center; named from its striking resemblance to Gaillardia Grandiflora. A distinct type that will become a popular favorite.

LEONE. A very lovely variety; flowers exceedingly large; white overlaid with a soft pink. A rare combination. It blooms very freely for a lengthened period; the stems are long and stiff, thus making it a very valuable variety for cutting purposes. A vase of these blooms makes a very handsome sight on the dinner table, the electric light showing up the flowers to the greatest possible

LAWRENCE KRAMER. The color is a deep, bright rosy pink of the richest, brightest shade, without tint or blemish, in marked contrast with so many of the so-called pink singles, which are shaded crimson, violet, or lavender.
RAINBOW. Intensely bright crimson, shaded cerise and tipped with pink. The blending and shading of these two colors is indecan do justice to. One of the very best.

\section{COLLARETTE DAHLIAS}

An entirely new type of single Dahlia, which has produced a great sensation the past three years wherever shown, and which has been awarded highest honors. The peculiarity of the type lies in the development of the four stamens into short rays or petals at the base of the petal, which form a frill or collar around the center. As the collar is entirely distinct in color from the rest of the flower, it is most unique and striking. We offer two of the most distinct varieties. We were pleasantly surprised and delighted with the habits of both these varieties, as they are of dwarf, branching habit and extremely profuse bloomers, starting with the earliest and continuing in full bloom until frost. 25c each; $\$ 2.50$ per dozen.

JOSEPH GOUJON. The flowers are quite large, orange-red shading to deep red, with light canary-yellow collar. This variety has ten to twelve petals instead of the regulation eight.

PRESIDENT VIGER. The most beautiful and striking of the two varieties. Rich, deep blood-red, shading darker toward the base of the petals, with pure white collar, occasionally suffused with rosy carmine. The flowers are always perfect, with eight petals; it is an extremely early and profuse bloomer.

\section{CARNATIONS}

In the following list will be found none but the newest and choicest varieties.

NOTE.-Customers selecting their own Carnations are respectfully requested to add to their orders a few supplementary sorts, lest by previous orders the stock of any particular variety should be exhausted; this being especially necessary late in the season. Varieties marked with a star can be supplied now, in 4 and 5 inch pots. 25c each; $\$ 2.50$ per dozen.

Small plants, all sorts, from 3 inch pots, ready about the end of March; $15 \mathrm{c}$ each; $\$ 1.50$ per dozen.

*ARISTOCRAT. Deep pink, brighter than Lawson; flower very full and built high, perfect in form, splendid stem and calyx; good keeper and continuously in bloom.

*EL DORADO. One of the best yellow sorts.

*ENCHANTRESS. Of recent introduction. A very pleasing shade of light pink, deepening toward the center; borne on long stiff stems; habit of plant strong and vigorous.

*ESTELLE. A standard scarlet carnation, in much esteem on ac-

*GLENDALE, Variegated; similar to that old favorite, Mrs. Bradt, but freer in bloom and larger flowers; flowers borne on long stems continuously.

*HARRY FENN. A very large, extremely full flower, deeply fringed and very fragrant. In color, a fine crimson, a little lighter in that variety. Stems long, and stiff enough to carry the flowers very nicely.

*JOHN CARB ONE. A much admired variety; color brilliant rich shade of gold flaked with light carmine; flowers large and produced very freely on strong stems.

MRS. THOMAS. W LAWSON. A grand deep pink carnation of very large size; blooms carried very erect on strong heavy stems; unusually free in growth and bloom. No carnation to ate has created such a sensation as this variety, thirty thousand dollars having been paid for the original stock.

MARIAN. A good pure white carnation; flowers of good size, borne on yood stems; fragrance good.

MRS. PATTON. A beautiful variegated carnation; sent out by the originator of Lawson. Flowers very large and full; carried on long wiry stems; ground color pure glistening white delicately striped with fine pink stripes. Very free in growth and bloom. It is with pleasure that we call the attention of all lovers of carnations to this variegated sort.

*NEL SON FISHER. A very deep pink in color, deeper than Lawson; flowers finely formed, with fringed edges. We can recommend this variety very highly for outdoor planting. To say that this variety originated with the same grower that sent out Mrs. Lawson and Mrs. Patton, should be a guarantee of its sterling qualities.

* PINK ENCHANTRESS. A bright rose colored sport of Enchantress; already as popular as its parent; it has all of the latter's good qualities.

PROSPERITY. One of the most remarkable carnations yet originated, producing probably the largest average size blooms originated, producing probably the largest a verage size blooms The plant is extremely healthy in growth, and a continuous bloomer. It is a first class keeper in every respect and a splendid shipper. The color is distinct from any other variety, the ground color being pure white overlaid with pink mottles, deepening color being pure white overlaid with pink mottles, deepening toward the center, the color scheme reminding one
ful tints often seen in azaleas and rhododendrons.

*VICT ORY. Brilliant scarlet; flowers very large, borne on long stems; vigorous in habit and very free in bloom. Considered the best scarlet ever introduced.

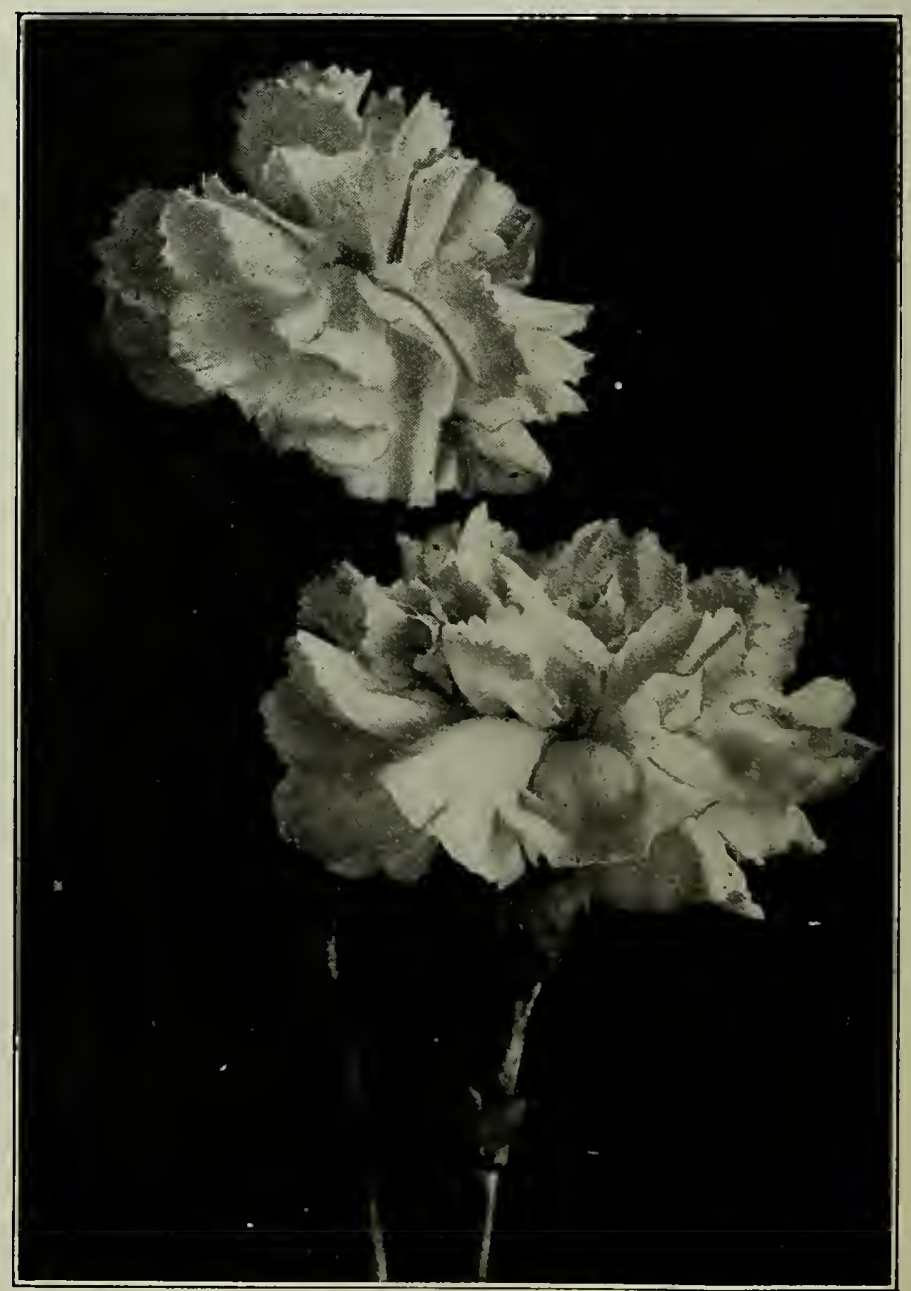

Carnation-White Perfection

WHITE PERFECTION. This is now conceded to be the best white in cultivation; stems good, fine keeper and with a pleasing clove fragrance. 


\section{GERANIUMS}

\section{Price of plants from 3-inch pots, $15 \mathrm{c}$ each; $\$ 1.50$ per dozen}

ALICE OF VINCENNES. Border of intense scarlet, forming a band around the body, color a rosv-pink, heavily veined with scarlet, center white; a very brilliant combination of colors. Single.

BELLE POITEVINE. A lovel s single salmon; very large flowers. CR YSTAL PALACE GEM. Silver foliage; good for bedding. GENERAL GRANT. A fine scarlet; excellent for bedding.

JEAN VIAUD. Soft, pure pink, with two white blotches; dwarfstocky grower, rigid stems, large trusses, perfect florets.

M. P. MORLAN. Large flowers, salmon, center white, surrounded by a halo of bright salmon. Single.

MADAME LANDRY. Double; very free and constantly in bloom throughout the season; trusses large, and florets of the finest size and circular in form; color clear salmon; center shading to

copper with a white eye. This lovely variety has large, round
MADAME L. AB BEMA. This double florets of an exquisite shade of blush pink, mottled, and

MADAME SALEROII. A very fine silver-leaved sort of dwarf habit, and excellent for bedding and bordering.

MRS. GAER. Fine velvety pure white; single.

MRS. GLADSTONE. Very pale pink; single.

NEWSOM. A beautiful single scarlet, shading to red; immense trusses and very free flowering.
S. A. NUTT. The very best of the dark crimson scarlet bedders.

THE CLYDE. An immense single scarlet; trusses very fine. Extra strong grower.

THE SWAN. A grand double white variety, constantly in bloom.

\section{IVY-LEAVED GERANIUMS}

Are indispensable for covering banks, fences, etc. They are almost continuously in bloom, and require very little water.

CHAS. TURNER. The handsomest IVy Geranium ever introduced flowers $21 \frac{1}{2}$ inches, trusses 6 inches across. The color is a bright pink. Quite double. Very useful for window boxes and rockeries.

CHERRY RED. A very fine double variety.

FLOURENS. Large irregular flowers, salmon shaded with rose, large petals.

P. CROZY. A grand hybrid between the zonales and the ivies, having the foliage of the former, while the forms of truss and florets are found only among the ivies. The color is soft bright scarlet, with veinings of maroon. A grand bedder. Profuse in bloom.

\section{PELARGONIUMS}

\section{(Lady Washington Geraniums)-Regal, Fringed and Decorative Varieties}

This magnificent group includes those varieties whose habit is more robust, and the flowers much larger than those of the show Pelargoniums. Their petals are either frilled or fringed and overlap each other in such a manner that they present the appearance of being double. Several of the varieties display a warmth and richness of coloring not found in any other class. Plants in 3 and 4 -inch pots; 25c each; $\$ 2.50$ per dozen.

Please state if we can substitute, if necessary.

BIACK PRINCE. Very dark crimson.

CHAMPION. White, shaded pink towards center.

DOROTHY. Soft shade carmine rose; white center, surrounded with lilac shade; all the petals margined white; upper petals blotched maroon.

DURE OF ALBANY. Deep, rich crimson maroon, margined with rosy lake; light center, surrounded with violet, rose shading. A grand, dark variety, having a very full appearance.

DUCEESS OF TECK. Very large trusses of extra large semidouble white flowers; petals undulated and frilled.
E. G. HILL. Brilliant dark maroon, shaded scarlet, lower petals, lighter shade, with white center; very large.

GLOIRE DE PARIS. Pink; a free and continuous bloomer.

L ORD CLYDE. White, veined and flushed with light purple; petals blotched crimson.

MABEL. Upper petals brilliant dark maroon, under petals soft rosy pink; large white center.

MADAME THIEBAUD. Blotched and marbled rose and white ground; upper petals marked with crimson maroon; large white ground; upper petals marked with crims

MILTON. Upper petals grandly blotched dark maroon, surrounded with bright crimson and edged with rose, lower petals of soft pink, feathered with crimson; light center. Light trusses of fine, elegantly fringed flowers.

MRS. O. W. CHILDS. Rose pink. Very large trusses. A lovely sort.

PRINCE GEORGE. Large trusses of finely fringed white flowers faintly suffused with blush; all petals spotted with purplish lake two upper petals more marked than the others.

VOLANTI NATIONALE ALBA. Large trusses of pure velvety white; a very fine white variety.

\section{CHRYSANTHEMUMS}

To obtain large flowers of this beautiful fall flower it is necessary that especial care and culture be given them. One shoot is left on a plant and all side growth must be kept cut off; up to a certain date about three of the uppermost side shoots should be allowed to grow, but never let these grow above your top or terminal bud.

After each variety catalogued we have inserted the date at which all side growth should be cut away and allow all the strength to go to the one remaining bud. It makes a great difference if you do not "take the bud" at the proper date, for smaller and inferior flower will be the result.

In the small space at our command it is impossible to go into detail, but perhaps the few above hints will help the amateur (to whom we are writing).

Plants from 3-inch pots at 20c each; $\$ 2.00$ per dozen, of the following choice sorts:

A. J. BALFOUR. Bright pink, broad petals of great substance. (10th Sept.)

ALLIANCE. Bronzy-pink; Japanese; mid-season. (20th Aug.) AMATEUR CONSEIL. Red and buff. Japanese. (25th Aug.) BEATRICE MAY. Pure white Japanese; incurved. (10th Aug.) BRIGHTHURST. Pink, slightly shading to cream; large, irregular Japanese sort. (20th Aug.)

CHAS. CRONIN. Immense salmon buff flowers. (25th Aug.)

COLONEL APPLETON. Golden yellow; Japanese incurved; one of the best; late bloomer. (15th Sept.)

CROCDS. Pleasing shade of light yellow; a general favorite. (20th Aug.)

DONALD McLEOD. Yellow and crimson. (20th Aug.)

F. S. VALLIS. A very large jellow; narrow twisted petals; attracts much attention wherever seen. (20th Aug.)

FOUBERT. Yellow with bronze stripe; Japanese; very fine.

HELEN FRICKE. Dark pink; a fine late variety; produces incurved Japanese blooms of good form. (5th Oct.)
J. C. SALTER. Yellow, Japanese. (20th Aug.)

JEANNIE NONIN. A good late white variety; large incurved flowers, (5th Oct.)

KINKORA. Pink, Japanese; midseason. (30th Aug.)

LAVENDER QUEEN. Lavender-pink; good and early. (20th Aug.)

LIL $Y$ MOUNTFORD. A beautiful variety with outer row of petals; pure white, center salmon; very large and good. (25th Aug.)

MADD JEFFREYS. Pure white Japanese; incurved; very dwarf. (30th July.)

MRS. J. A. MILLER. Old gold; very large. (20th Aug.)

MRS. WM. DUCKHAM. Extra large, Japanese reflexed; one of the best exhibition yellows. (20th Aug.)

MRS. J. E. DUNNE. Salmon terra-cotta; Japanese sort; a distinct and novel sort. (20th Aug.)

MRS. W. KNOX. Soft yellow; petals closely reflexing; a Japanese sort of great size. (25th Aug.)

MRS. H. PARTRIDGE. Crimson, reverse of petals old-gold; very large. (20th Aug.)

MRS. H. J. JONES. Glistening white , large incurved. (15th Sept.) 


\section{CRRYSANTHEMUMS-Continued}

MRS. ROBINSON. A good, early incurved pure white. (5th Sept.) MRS. GEO. HEAUME. Unique salmon-bronze; outer petals reflexed; center incurving; a grand acquisition. (25th Aug.)

MAJOR BONNAFON. The most widely grown of yellow sorts for commercial purposes. (10th Sept.)

MONROVIA. An early flowering yellow variety. (20th July).

MOUNIER. Very large deep yellow; form broad, reflexed twisted petals; extra good late sort. (20th Sept.)

NATHAN SMITH. Pure white, Japanese; midseason; excellent. (5th Sept.)

OCTOBER FROST. One of the best early whites. (20th Aug.)

QUEEN. A very fine silvery-white. (20th Aug.)

VIVIAND MOREL. Large reflexed pink; early. (15th Sept.)

WM. DUCKHAM. Pink, Japanese; one of the best of its color for all-round purposes. (20th Aug.)

YANONA. Large white; deep reflexed blooms. (1st Oct.)

\section{ABUTILONS}

20c each; $\$ 2.00$ per dozen.

B OULE DE NEIGE. The best pure white, up to date.

GOLDEN FLEECE, OR GOLDEN BELLS. A bright golden-yellow abutilon, of strong, vigorous habit.

PINK GEM. Lovely rose-colored flowers.

SCARLET GEM. A rich bright scarlet.

THOMPSONII PLENA. Has perfectly double flowers, that resemble in form a double hollyhock. Color a deep orange, shaded

\section{VIOLETS}

CALIFORNIA. Large, single blue. 60c per dozen.

MARIE LOUISE. The well-known double light purple variety. $75 c$ per dozen.

PRINCESS OF WALES. This grand variety is of French origin; produces grand single flowers of a beautiful violet blue color in great abundance, and after years of trial has been found to be the best single blue. 60c per dozen.

\section{HELIOTROPE}

3-inch pots, 15c each, $\$ 1.50$ per dozen. 4-inch pots, $20 \mathrm{ceach}$, QUEEN. Very dark. $\$ 2.50$ per dozen.

SAPPHIRE. Purple, white center.

SUNRAY. Pale lavender.

\section{FUCHSIAS}

In 4-in. pots, $25 \mathrm{c}$ each; $\$ 2.50$ per dozen.

smaller plants $15 \mathrm{c}$ each; $\$ 1.50$ per dozen.

BLACK PRINCE. Sepals bright red, corolla double, dark plume.

BERLINER KINE. A large, double white Fuchsia. One of the GEROLSTEIN. Sepals purple; corolla white; single.

MRS. E. G. HILL. Best and largest; double white.

PHENOMENAL. The largest double Fuchsia of dark color; tube and sepals scarlet carmine, corolla measuring $2 \frac{1}{2}$ inches in OCUMBE, TS, TRAIL-blue color

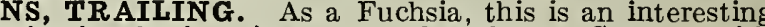
sort, and of value for hanging pots and baskets. Covered with pretty leaves, bright flowers, and red berries. The flowers are small and show several colors, the anthers being blue.

STORM KING. A perfect gem. Dwarf habit: sepals dark carmine, corolla white, shaded rose. A magnificent large, double variety.

\section{HARDY AND HERBACEOUS PERENNIALS}

For many purposes hardy perennial plants are indispensable. To fill vacant spaces among shrubbery, under trees etc., they occupy a place in gardening that annuals cannot supply. Once planted they need very little attention, and can be left from year to year only thinning out now and then. By judicious selection they can be had in bloom throughout the whole year.

ANEMONE JAPONICA. White, Pink, 25c each.

DIGITALIS (Fox Glove). Tall-growing plants, throwing up very long spikes of lovely

CAMPANULA. Very desirable hardy perennials. Should be in every collection. We offer strong pot-grown plants. Single Ready IMarch.

COREOPSIS LANCEOLATA. This handsome perennial is now probably the most popular perennial plant in cultivation. It is of graceful form, are invaluable for cutting for decorative purposes. $15 \mathrm{c}$ each; $\$ 1.25$ per 10.

DELPHINUM-(LARRSPUR). A remarkably showy class of tall growing plants, producing magnificent spikes of blue flowers in summer.

GAILLAKDIA GRANDIFLORA. The brightest of all Gaillardias. Flowers bronze scarlet, bordered with golden yellow, three inches in diameter, produced on long stems. 15c each; $\$ 1.25$ per 10 .

HELIANTHUS MAXIMILLIANA (Single sunflower). A most graceful single-flowered variety, growing from five to seven feet high, continuing in bloom very late in the season. The flowers are produced in long graceful sprays, which make it invaluable for cutting purposes. $15 \mathrm{c}$ each.

IRIS KAEMPFERII (Japanese Iris). The newer va rieties of this King of Iris, introduced from Japan, are marvels of beauty and stateliness. Many of the varieties rival the orchid in point of beauty and fantastic shapes. They commence blooming in June and continue in bloom for 5 or 6 weeks. Many of the flowers measure from 10 to 12 inches in diameter. In separate inches in diameter. In separate each; \$2.00 per dozen.

\section{PHLOX-PERENNIAL}

One of the finest of summer and autumn flowers; of easy culture and they produce in great profusion for a long period,

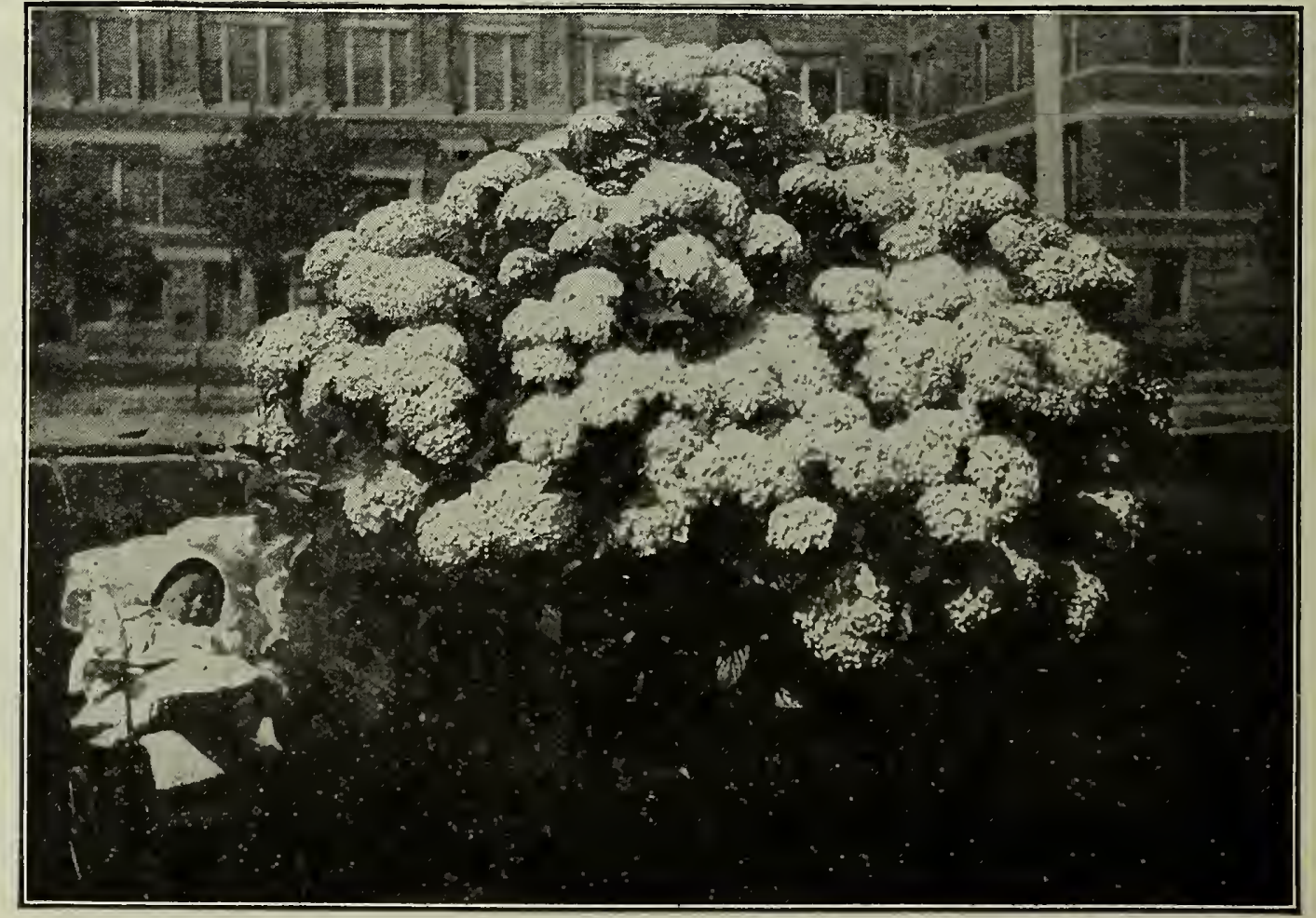

Hydrangea Hortensis 


\section{SAN FRANCISCO CALIFORNLA U.S.A.}

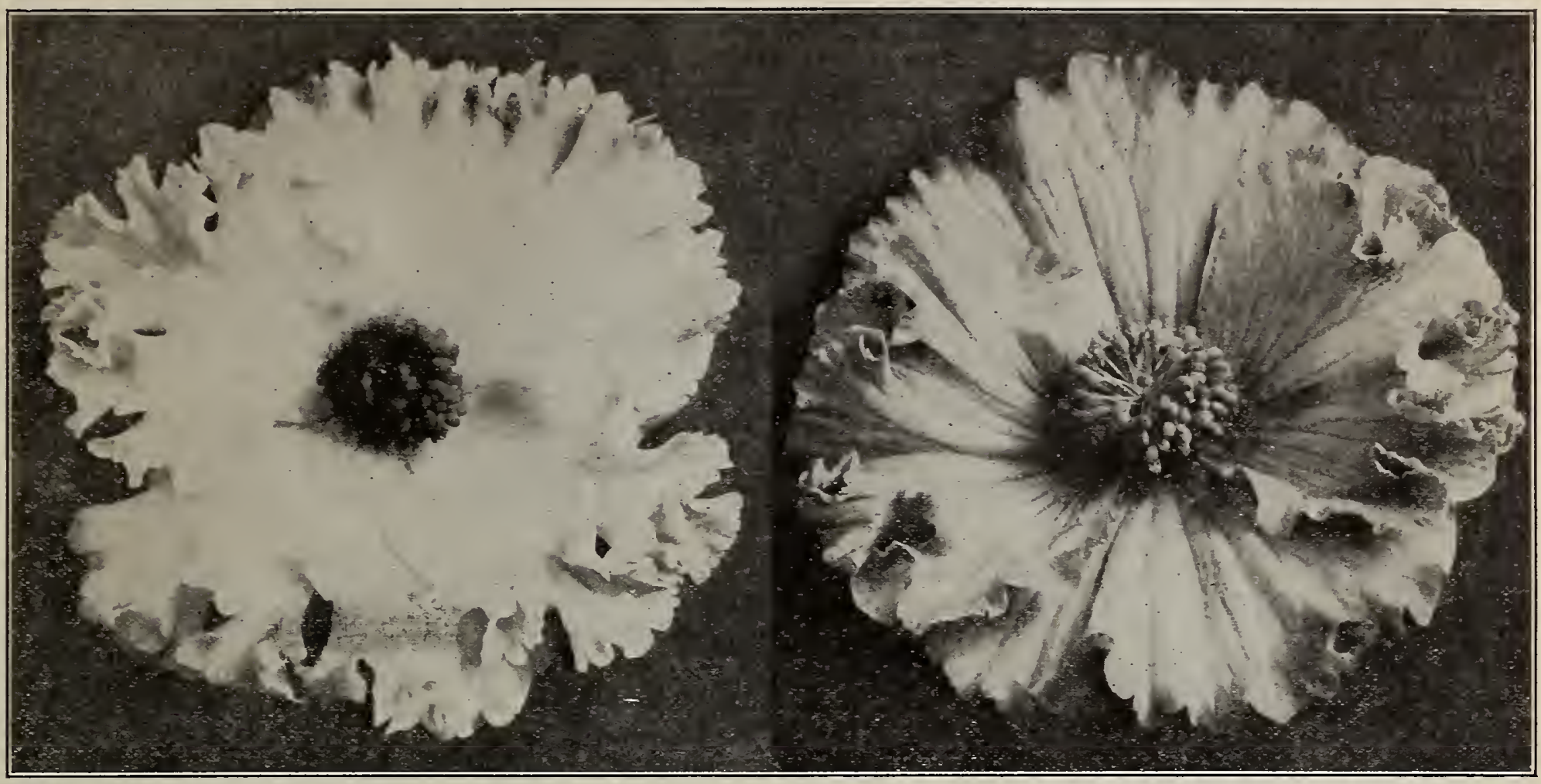

Single Tuberous Rooted Begonias (Much reduced)

\section{MISCELLANEOUS FLOWERING AND BEDDING PLANTS}

Bedding and Border Plants should not be set out much before April 15th, when all danger from frost is over.

ACHYRANTHUS. Leares blood-red; extra good for bedding purposes. $75 \mathrm{c}$ per dozen. $\$ 5.00$ per 100 .

ACHANIA MALVAVISCUS. ("Turiz's Cap"). Flowers vivid scarlet; produced nearly all the year. $25 \mathrm{c}$ each; $\$ 2.00$ per 10 .

ALTERNANTHERA. Much used for bedding purposes; of low growth; stands clipping well. Ready about April 15th. Yellow and Red Varieties, 50c per dozen; $\$ 3.00$ per 100 .

ASTER, SEMPLE'S NEW BRANCHING. Crimson, lavender, pink and white. Ready about April 15th. 35c per dozen $\$ 2.00$ per 100 .
BEGONIA VERNON. This variety grows about eighteen inches high, The foliage, in the sun, turns deep olive green, shaded and magnificently set off by a bundant dark foliage. $15 \mathrm{c} \mathrm{each;} \$ 1.50$ per dozen.

BEGONIA ERFORDII (Beauty of Erford). It is more dwarf and spreading than Vernon and bears three times as many flowers. The color is a lovely soft pink throughout, which does not fade in the hottest sun. It blooms ten months in the year; grows about $t$ welve inches high, and makes a most beautiful border for Cannas. Geraniums, Scarlet Sage, etc. All ready about April 15th. 15c each; $\$ 1.50$ per dozen.

\section{TUBEROUS ROOTED BEGONIAS}

Te have an extra fine strain of these lovely flowers to offer; the seed from which these bulbs were raised was obtained from a noted English specialist. The colors are simpy wonderful and impossible to adequately describe; they come in all shades. The formation of the flowers is also quite distinct, some are large and very double; the singles are beautiful, some have plain edges, some fimbriated, some fluted and others crested. The exhibition we had at our Oakland nurseries this last summer was greatly admired by everyone who saw them, many experts saying they were the finest lot of flowers ever exhibited on the Coast; the size of the flowers was much commented upon, the singles, many of them, measuring 5 inches across.

CULTURE. - The bulbs should be started in damp moss in March and April; when they have made a small growth they should be potted into 4-inch pots, using open soil, plentifully supplied with leaf-mould, sand and rich manure (the Begonia is a great feeder). When the plants have been growing in these pots for 4 or 5 weeks, the roots will begin to fill the pot; they must then be shifted into a 6-inch pot, using the same preparation for potting, and they can be allowed to bloom in these pots, or you can move them into a larger pot if you so desire; 6-inch pot plants will, however, give very good satisfaction. They require a sunny place in the greenhouse and see that they have good drainage. When they commence to bloom, the two small flowers that appear on each side of the center blossom (which is the male flower and the outside flowers are the female) are nipped out and the strength goes to the male flower. They will bloom for a long time; we have had them in bloom for four months at our nurseries. They are a continual source of great pleasure; we know of no flower that will give greater satisfaction than the tuberous rooted Begonia. The above instructions apply to pot culture.

The Tuberous rooted Begonia can also be had and is much used for bedding purposes and gives the very best of satisfaction. A partially shaded place should be selected for this purpose; this can be modified if the sections where planted have cool summers, as for instance, San Francisco, Santa Cruz, Berkeley, and such like climates. The bulbs would do better if started in pots and then when still small planted out; this manner of handling the bulbs would be better than planting them out in the ground we think.

Our collection of one year old bulbs (the best to plant) includes all shades, WHITE, RED, SCARLET, CANARYYELLOW, STRATI COLOR, BRONZE, BUFF, APRICOT, TAN, TERRA COTTA, SALMON, PINK, ROSE, every color excepting BLUE. Those ordering please mention what shades they prefer.

PRICE: 50c EACH; \$5.00 PER DOZEN FOR ONE YEAR OLD BULBS, BY MAII, POSTPAID.

We can also supply a very fine assortment of bulbs producing DOUBLE FLOWERS. $60 \mathrm{c}$ each; $\$ 6.00$ per dozen. 


\section{MISCELLANEOUS BEDDING PLANTS-Continued}

CRASSULA COCCINEA. Flowers beautiful pink coming in umbels: deliciously fragrant. 4-inch pots, 30c each; $\$ 3.00$ per 10.

CINERARIA. As a winter blooming plant for house culture, or for use for bedding under the shade of large trees, these are invaluable. We offer a fine strain. 15c each; $\$ 1.50$ per 12 .

cosmos. Crimson, pink, white and yellow. Ready about April 15th. 25c per dozen; $\$ 1.50$ per 100

DATSIES. Double, all colors 35c per dozen: \$3.00 per 100.

ECHEVERIA (Hen and Chickens). 50c per dozen.

GAZANIA SPLENDENS. Flowers orange-yellow, produced in the greatest abundance in the spring and early summer. For making borders, where there is a lack of water, this plant cannot be beat. 50c per dozen.

GOLDEN FEATHER. 35c per dozen; $\$ 2.50$ per 100.

HYDRANGEA HORTENSIS. This plant is a most satisfactory one blooming as it does for such a long period; they succeed admirably when planted in a shady place in the garden. Large plants, 50c each.

HYDRANGEA. NEW PINK. 50c each.

HYDRANGEA. INDIGO BIUE. $50 \mathrm{c}$ each.

IAVENDER PLANTS. Strong plants. 30c each; $\$ 3.00$ per 10.

LIPPIA REPENS. Used in place of grass for lawns; it does not re quire much water and makes a fairly good substitute. $\mathbf{\$ 3 . 0 0}$ per 100 ; $\$ 25.00$ per 1000 .

LOBELIA. Dwarf blue. Ready April 15th. 35c per dozen; $\$ 3.00$ per 100 。

MESEIMB RYANTHEMUM. These are much used for bedding purposes and planting on banks and hillsides where there is a scarcity of water. They make a gorgeous sight when massed. Perhaps the showiest of them all is the one which produces the lavender-colored one at 50c per dozen; $\$ 3.50$ per 100.

MARGUERITE, WHITE. 15c each; $\$ 1.25$ per dozen.

MAR GUERITE; YELIOW. 15c each; $\$ 1.25$ per dozen.

PANSIES (Morse's Prize Strain). The plants we offer are grown from seed, obtained from a noted grower in Germany, and include from seed, obtained from a noted grower in Germany, and include almost every shade of color, exquisitely spotted

PETUNIA, SINGLE. Ready March 15th. 15c each; $\$ 1.50$ per dozen
PETUNIA, DOUBLE. Large pink. 3-inch pots, 20c each; $\$ 2.00$ per 12.

PRIMULA, CHINESE. Invaluable for winter and early spring flowering. 25c, 35c, and 50c each, according to size.

LA, OB CONICA. Another fine winter and spring blooming variety, 4-inch pots, 25c each; \$2.50 per 12.

ENDENS. Scarlet flowers; continuous bloomers. SEA Ready March. 10c each; $\$ 1.00$ per dozen.

(a) SPER GUIA rose-pink. 50c per dozen; $\$ 3.00$ per 100. STOCK S In foot would make an edging 25 leet long.

STREPTSOL ON JAMESONII (The "Yellow Heliotrope"). A very useful garden plant, producin flowers. $20 \mathrm{c}$ each; $\$ 1.50$ per 10 .

SOLANUM (Jerusalem Cherry). 5-inch pots, 50c each.

VERBENA. MISS WILLMOTT. Color, dark pink; very large truss; stems long, thus making it valuable for cutting; a long and continuous bloomer. An excellent novelty and one which we can recommend. $15 c$ each; $\$ 1.50$ per dozen.

F R R A grand large white; trusses of immense size. 15c each; $\$ 1.50$ per dozen.

colors, and have large, distinct eyes. All colors. Ready March. $10 \mathrm{c}$ each; $\$ 1.00$ per dozen.

\section{GLOXINIAS}

These grand bulbous plants are much used for greenhouse adornment. The flowers are single, trumpet shaped, and come in white, pink and lavender, and are of a rich, velvety texture. Plant in March, April or May; one bulb in a 4-inch pot, afterwards shifting to a 5 or 6-inch pot. Separate Colors. 25c each; $\$ 2.50$ per dozen.

HERB ACEOUS PAEONIES. These grand perennials are among the showiest and most useful plants, and are becoming popular
with the public. They are all hardy and admirably adapted to with the public. They are all hardy and admirably adapted to our climate. growing well in almost any situation or soil, although the flowers will be finer and the color brighter if planted in a
deep rich loam, well manured. We offer a splendid assortment . in six distinct varieties. $30 \mathrm{c}$ each; $\$ 2.50$ per 10 . TREE PAEONIES $\$ 1.00$ each.

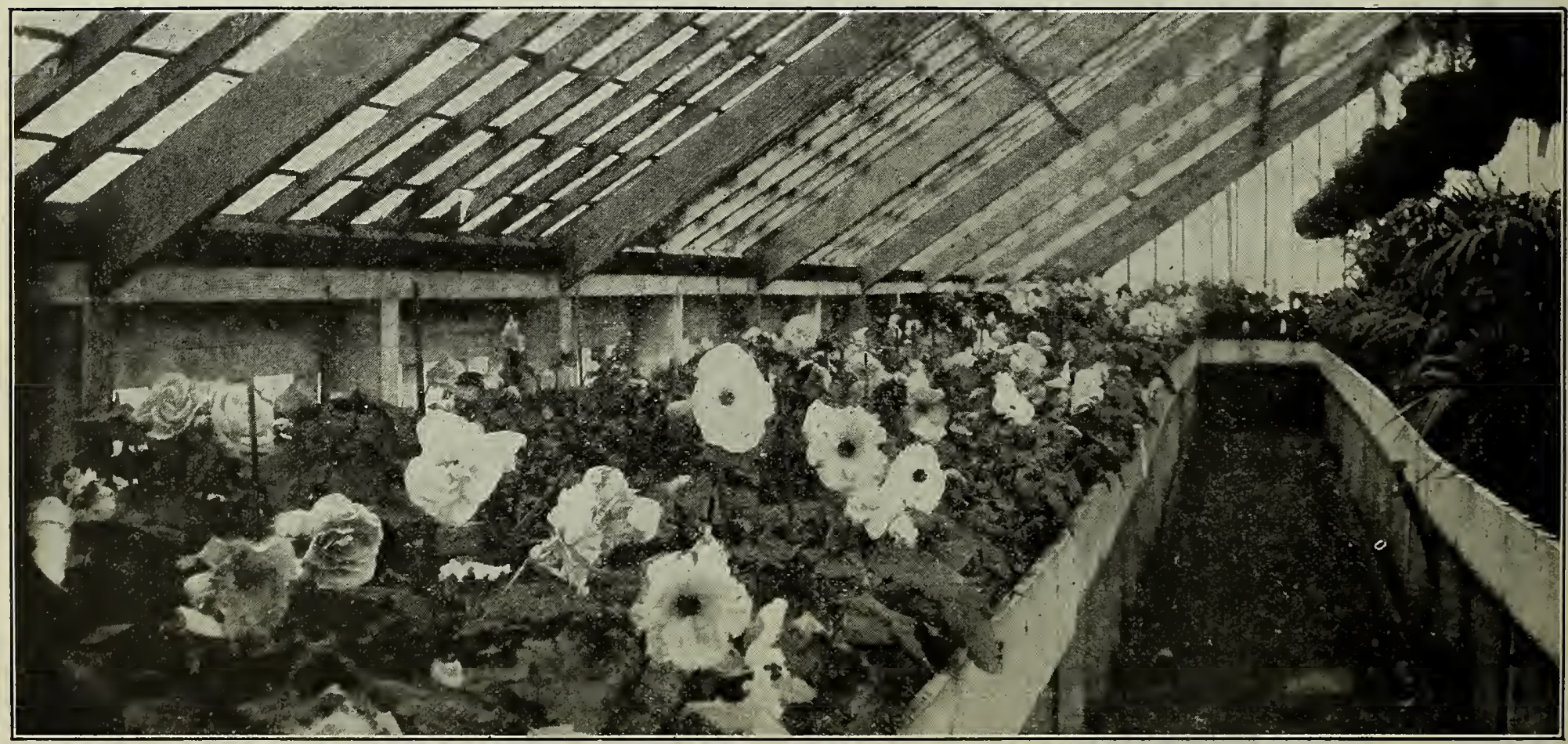

Begonia House at our Oakland Nurseries

\section{GIANT ORCHID FLOWERED CANNAS}

Our collection of those grand summer flowering plants is unexcelled. Price (except otherwise noted), 20c each; $\$ 2.00$ per dozen. Special offer, one of each for $\$ 3.00$.

ALLEMANIA. Orange-red, petals edged yellow; very large. CORONET. A good free-flowering jellow.

DURE OF MARLBOROUGH. Rich crimson-maroon. DUKE OF YORK. Red, yellow border; very large. E. HOSS. Beautiful canary yellow, heavily spotted red. FLORENCE VAUGHAN. Orange-yellow, spotted bright red. INDIANA. Golden-orange; marked and striped with bright red. J. D. EISELL. Bright vermilion scarlet, overlaid with pink.
KING HUMBERT, Velvety orange-scarlet, flecked carmine; heartshaped leaves of a deep purple brown. A grand sort. 35c each. LOUISIANA. Soft glowing scarlet, throat marked orange; very PENNSYL VANIA.

shade of orange and scarlet exquisitely blended. UNCLE SAM. Bright red, yellow throat; extra good. 


\section{FRUIT TREES AND SMALL FRUITS}

The California Cultivator (a paper devoted to horticulture in this State), submitted to us the following questions and asked us to give them an answer thereto; as they bear very greatly on fruit tree planting in California and as we receive daily such questions, from intending planters, we thought we would help planters by giving their questions and our repiy. We know it will be of great assistance to the novice in fruit tree planting.

1. How many months are included in the best planting period, i. e., how early may fruit trees be taken from nursery in fall and how late may they be planted?

1. Late December, January, February and early March.

2. Where is it best to plant them, i. e., can you give a general idea as to planting figs, apples, pears, cherries, walnuts, peaches, and such other fruits? Of course, if you covered all the fruits this would take too much time, but whatever information you can give is greatly needed by tree planters. Orchard after orchard has been set out, only to prove a failure because owners did not understand this question.

2. Figs should be set out in the warmer sections, principally the San Joaquin and Sacramento Valleys, and the other fruits mentioned can be planted from Mendocino to San Diego. The intending planter, however, must use his own judgement about the best locations for each of these fruits.

3. What age and size of tree is best?

3. The best tree to plant out is what nurserymen call "one-year-old" trees; the root is a year older, so this practically makes the tree two years old, but nurserymen style them "one-year-old"; either 3 to 4 feet high or \pm to 6 feet high -1 to 6 feet preferable.

4. How large and how deep should holes be?

4. In sedimentary land, the hole does not require to be so very large, $11 / 2$ feet square will cover it. In heavier soil 2 feet will be necessary.

5. Is it best to plant any deeper in well prepared soil than tree was set in nursery?

5. Plant a little deeper than what they were in the nursery-not more than one inch.

6. Would you recommend close pruning of roots before planting or simply trimming mutilated ends? If you favor close trimming of roots, would you go to the extremes recommended in the Stringfellow method?

6. We recommend medium cutting back of the roots.
We would not go to the extreme as Mr. Stringfellow does, although we practice it a great deal in our nurseries when we are lining out young stock, and have good success with it.

7. Would you top trees, i. e., take off greater portion of top grown in nursery, and if so, before or after setting? Would you do it by exact measurement the orchard over, or according to vigor of trees?

7. Trees should be pruned after planting, not before. They should be cut back about the same height, as near as possible. For instance, if you are planting one-year-old French Prunes, they make in nursery, a straight growth and run 5 to 7 feet high. These trees can all be cut back uniformly to $2 \frac{1}{2}$ to $3 \frac{1}{2}$ feet. This is governed a good deal by the location. In the warmer sections low heading is pursued and in colder sections the trees are not cut back so much.

8. If irrigation water is available, would you settle dirt about the trees with water or by tamping?

8. In the drier sections it is a good idea to use irrigation to settle the soil around the roots after planting, but in the northern parts and in the Santa Clara Valley, where the rain fall is good during the months of January and February, this is not necessary. Work the soil carefully around the roots; in light soil heavier tamping can be done than in heavy, wet land.

9. Would you advise use of fertilizer o: manure, either in hole or on surface, at time of planting?

9. In planting large orchards no fertilizing is done,

10. Is any advantage gained by protecting trunks of newly planted trees from rays of sun? If so what method is best?

10. It is very necessary to protect the trunks of young trees during the first summer months, either by tulle tree protectors, shakes set on the sunny side, or by wrapping newspaper and tying with a cord. This keeps the tree from getting sunburnt and is certainly of great benefit to the young tree.

\section{TO PURCHASER'S ATTENTION}

Frequent cultivating is absolutely necessary; there is no better way of keeping the moisture near the surface. When you water your trees dig away from round them, and afterwards be sure that you hoe back the dry soil. Never allow the soil to bake.

Our fruit trees are grown at our newly acquired nursery at Hayward, without irrigation and have made a remarkably good growth from 4 to 7 feet high, and are strong, sturdy, well-developed stock.

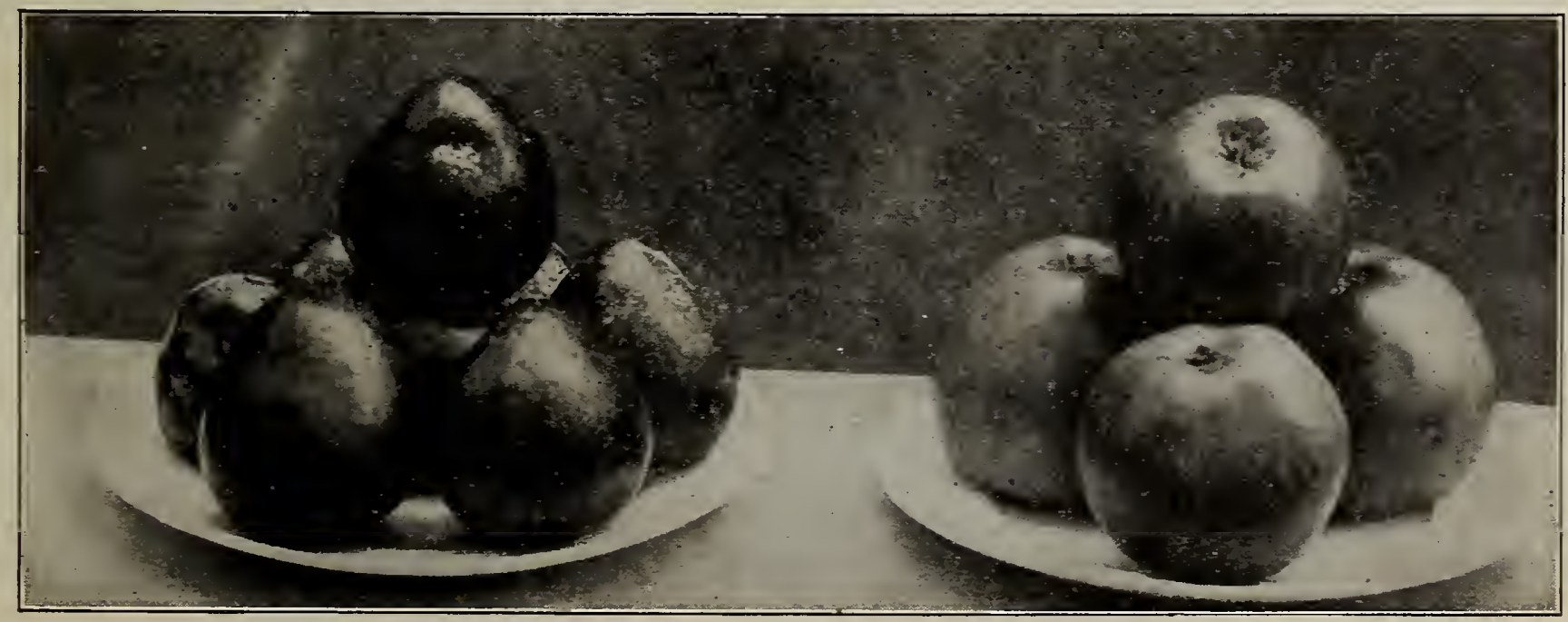




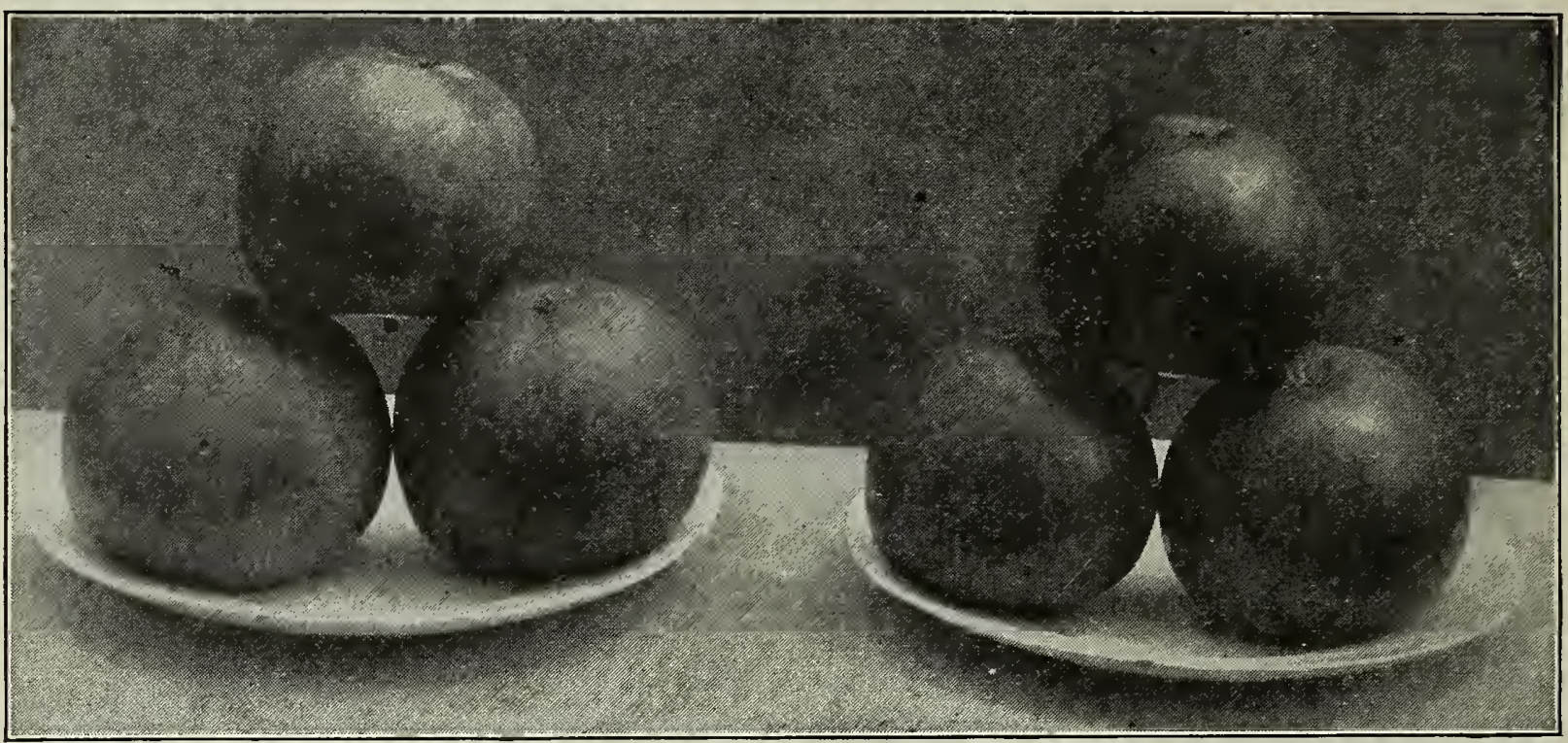

Baldwin Apple

Alexander Apple

While we aim to have all our fruit trees true to name, and hold ourselves ready, on proper proof, to replace, free of charge, all stock that may prove untrue to label, or to refund amount originally paid by the customer, it is mutually understood and agreed between the purchaser and ourselves that our guarantee of genuineness shall not make us liable for any sum greater than that originally paid us for such stock as may prove untrue.

Any further information desired we will be pleased to furnish, and to any who wish we will send experienced men to look over the land and advise what should be planted. Actual expenses only charged for such services.

During the planting season our stock of nursery trees can be seen at our salesyard at Glen Avenue, off Piedmont Avenue, Oakland.

Our list of varieties has been cut down to the very best.

\section{APPLES}

The first fruit in importance is the apple. Its period of ripening, unlike that of other fruits, extends nearly or quite through the year. By making judicious selections of summer, autumn and winter sorts, a constant succession can easily be obtained of this indispensable fruit. Price, 4 to 5 feet high, 35c each; $\$ 2.50$ per $10 ; \$ 18.00$ per 100 .

ALEXANDER. Yellow, streaked with red; brighter red in the sun; flesh yellowish white; crisp, tender and juicy. A very fine market variety. Ripe in September and October.

BISMARCK. Introduced from New Zealand and said to be one of the most promising of recent introductions; a tremendous bearer and one of the very best apples for hot climates. Fruit is of a beautiful golden-yellow color, of the largest size; very highly flavored and as a dessert apple said to have no equal; also suitable for cooking purposes. Ripens early and is a good keeper.
B ALDWIN. Large, roundish, deep bright red over a yellow ground : flesh yellowish white, crisp, juicy, sub-acid. Ripe in November and December. An excelient market sort.

BEN DAVIS. Large and handsome; striped; of good quality; very productive. Ripe in November and December.

EARLY HARVEST. Yellow, excellent for cooking or dessert, July.

ESOPUS-SPITZENBERG. Large, light red, rich. Sprightly, vinous flavor. One of the best. November to January.

GRAVENSTEIN. A large, striped, beautiful, roundish apple; of excellent quality, juicy, high flavored. A good grower and prolific bearer. Ripe in August. 、A good market sort.

JONATHAN. Light yellow, with red stripes; tender and juicy, with a sprightly, vinous flavor; excellent for table or market. Ripens October and November.

KING OF TOMPKINS Co. Very large; yellowish shaded $\mathrm{r}$ ed flesh yellowish, rather coarse; rich vinous flavor. October and November.

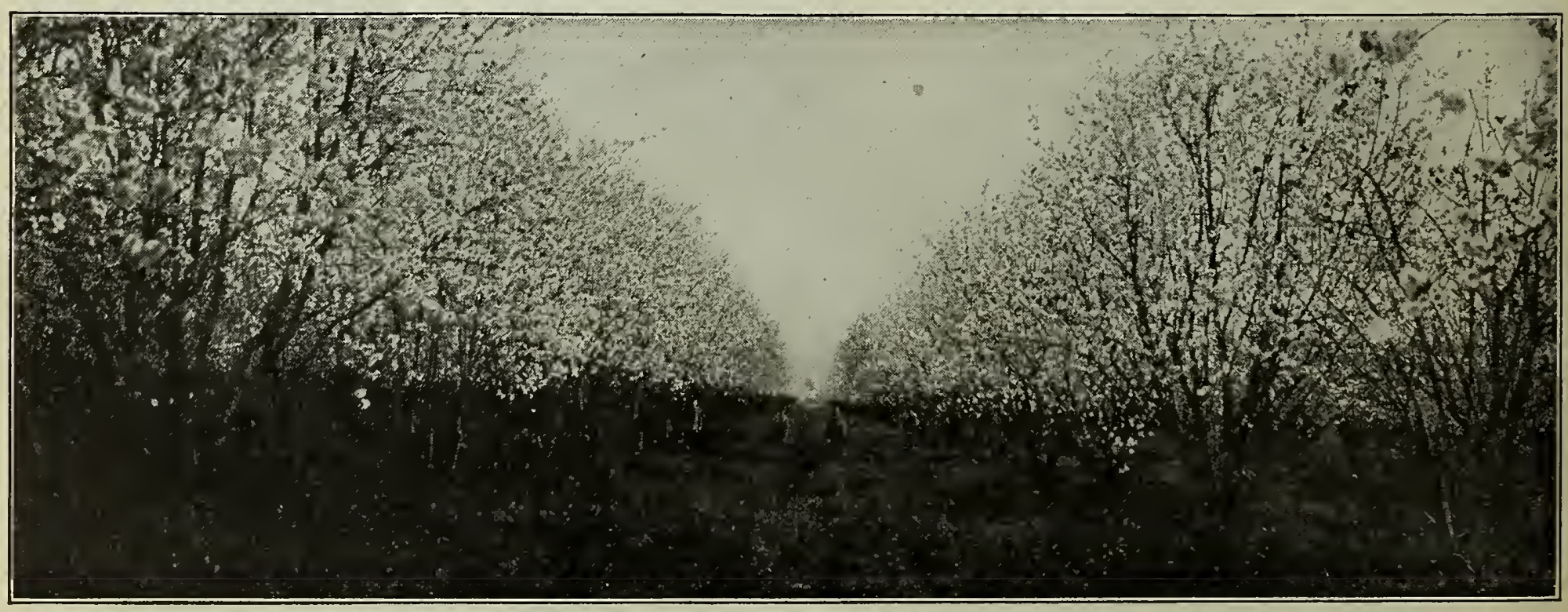




\section{SAN FRANCISCO, CALIFORNIA. U.S.A}

NORTHERN SPY. Greenish-yellow, striped purplish red; flesh NORTHERN SPY. Greenish-yellow;

PARAGON. Large, roundish: flesh firm, rellow; sub-acid and of excellent qualit $r$. Its size, splendid beeping qualities render it a rerr raluable acquisition.

RED ASTRACHAN. Large, roundish, skin deep red; flesh white juicy and crisp. though rather acid. A hardy, rigorous and early bearer. The best early apple. Ripe in June and Juls.

RHODE ISLAND GREENING. Large, greenish rellow. A constant heary bearer. Ripe in October and December.

WHITE WINTER PEARMAIN. Another sort that bears well in this State. Large, roundish, oblong, and pale sellow, dotted with brown; flesh Jellowish, delica te, crisp, juics, sub-a cid; extra fine fla ror. A general farorite. Late keeper.

healthr grower. Ripe December to Februarr.

WINTER B ANANA. A recent introduction, highi 5 commended. WINESAP. Yellow, ground streaked with red; flesh sellow, with YELLOW BELLFL OWER. Very large, oblong, irregular and tapering toward the ere; skin smooth and of pale lemon color flesh firm but tender, juics and sub-acid. One of the standard apples of California. A good grower and rers productive. Ripens Norember to February

YELLOW NEWTOWN PIPPIN: Another rariety rery successfully grown in California. Large; flesh sellow, firm, crisp juicr, of exceedingly rich flaror. The best winter apple. Ripe January to IIarch.

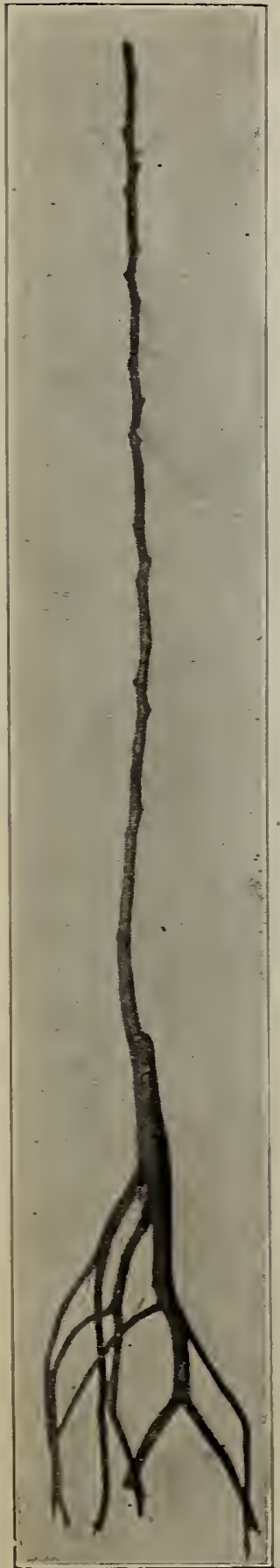

One-year-old Bartlett Pear pruned ready for planting

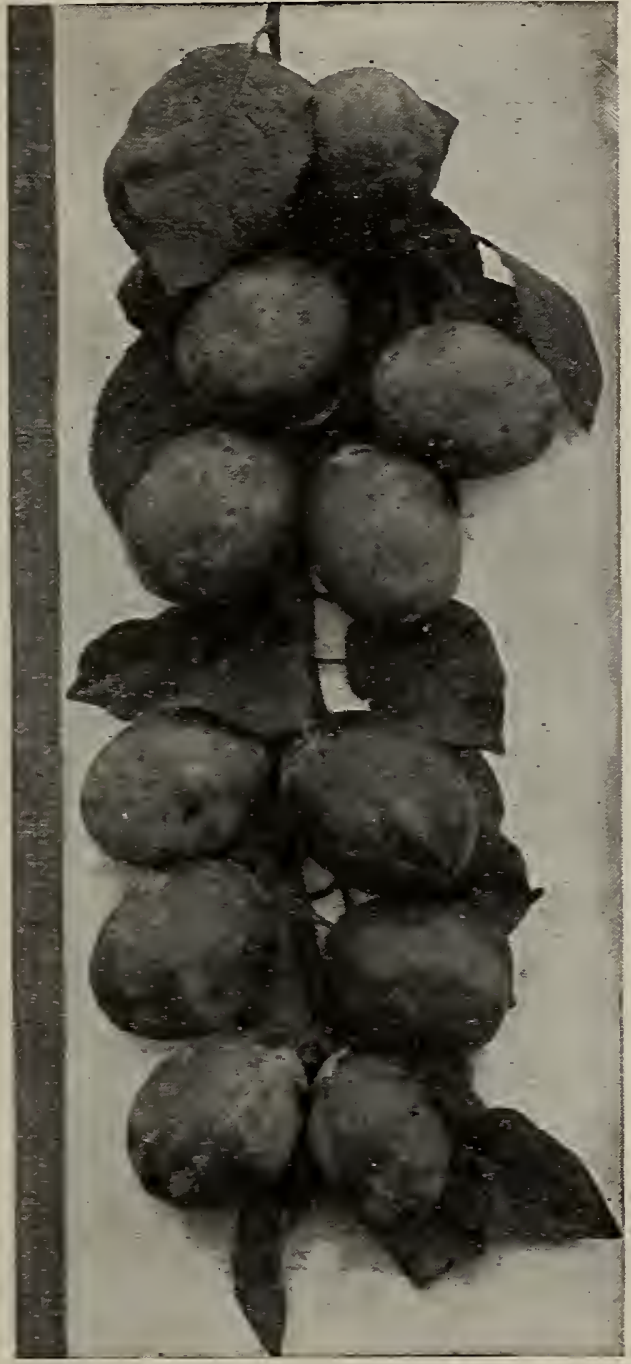

Fungarian Prunes

\section{CRAB APPLES}

Price same as Apples

RED SIBERIAN. Fruit about an inch in diameter. Yellow with a scarlet cheek. An erect. free grower. Bears very roung. YELLOW SIBERIAN, (Golden Beaut
Large, color beautiful golden jellow.

\section{PEARS}

The Pear does well in all soils, but succeeds best on a heavy loam. Summer and Autumn pears should be gathered at least ten days before they are ripe, and the fruit placed in a dark,

\section{PEARS-Continued}

cool place, where it will ripen, acquiring a delicious aroma and fine flavor.

Price, 4 to 5 feet, $35 \mathrm{c}$ each; $\$ 3.00$ per $10 ; \$ 25.00$ per 100 .

BARTLETT. There is no occasion to describe this variet 5 , so well known is it. A vigorous and strong grower. Bears hearily: good for shipping and canning. Ripe in August.

BEURRE CLAIRGEAU. Very large; red cheek with russet ground. Bears vers hearily and when quite joung. Flesh rather coarse BEURRE HARDY. This autumn pear is very desirable on account of its fine flavor and good bearing qualities.

CLAPP'S FAVORITE. A splendid sort; resembles the Bartlett, ripens a few dars earlier; fine, melting, with a sweet vinous flaror. Ripens August.

P. BARRY. This pear was raised br the late B. S. Fox of San Jose. The tree is a good grower, bears immensels and when quite 5oung. The color of fruit is deep sellow, nearly corered with keeper. Best of all late pears. January to March.

WINTER BARTLETT. Fruit large, closely resembling the famous Bartlett, but ripening four months later.

WINTER NELIS. Medium size, roundish, Jellowish green, dotted with russet. Fine flavor. Norember to January.

\section{CHERRIES}

Cherries thrive in almost any well-drained soil. It is one of the most ornamental of all fruit trees, and very desirable for planting, where beauty and shade as well as fruit are desired.

Price, 4 to 6 feet, 35c each; $\$ 3.00$ per $10 ; \$ 20.00$ per 100 .

BING. Fruit large, dark brown or black; rery fine; late. A good hipping ra riety.

BLACK TARTARIAN. VerJ large, bright black. The farorite. CENTENNIAL. Very large white sort; early.

CHAPMAN. TerT large, dark; early; excellent.

EARLY RICHMOND. Dark red; juiç, sprightls acid flaror; a rery fine sour variety.

ENGIISH MORELLO. Large; dark red; of fine quality.

LEWELLING (Black Republican). Large size; a cross between Black Tartarian and Napoleon Bigarreau, haring the size and color of the former and the solid flesh of the latter. Late and good.

MAY DUKE. One of the sour sorts, excellent for tarts; rich, dark red, when fully ripe; quite early.

NAPOLEON BIGARREAU (Royal Ann). Very large; a mber in color. The farorite white cherry.

\section{PLUMS}

The Plum tree attains its greatest perfection on our heavy soils, being entirely free from disease. Plums are very hardy and grow vigorously in all sections.

Price, 4 to 5 feet, $35 \mathrm{c}$ each; $\$ 3.00$ per $10 ; \$ 25.00$ per 100 .

ABUNDANCE. An extremel 5 earls and profuse bearer and strong grower. Fruit large, showy and beautiful, bright cherry red with white bloom; flesh sellow, exceedingly juicy, tender and sTeet. Ripens July and August.

BARTLETT. One of the best of Burbank's recent introductions. Said to be wonderfully productire; a rery ornamental tree with gloss 5 green leares, resembling closel 5 the famous Bartlett Pear in habit of growth, flaror and fragrance. Fruit oral, sellow turning to deep crimson when fully ripe; flesh light salmon

B URB ANK (Japanese). Large, sellowish ground, with red cheeks: flesh jellow; firm.

CALIF ORNIA RED. An earls red plum; excellent for home use

ClIMAX. (A New Early Plum). Cross of Simoni and Botan. Very large, measuring $63 / 4 \mathrm{bs} 11 / 2$ inches in circumference; heart-
shaped. $\mathrm{i}$ superbly rich plum; extremely earls. Ripens in the coast counties early in July, before any other good plum.

COLUMBIA. Purple; rich fla ror; sugary and excellent.

GREEN GAGE. Small, but of the highest excellence; round greenish rellow, with brown dots; rery juics and sweet. August.

SATSUMA. Large; blood-red flesh; of fine flaror.

VICTORIA. Large, round; rellow shaded red in sun; good flaror; a rers fine plum; ripens August.

WASHINGTON. A magnificent large plum, roundish; deep jellow, with pale crimson blush; flesh Jellow, firm, rery sweet and luscious, separating from the stone. Jul 5 and August.

WICKSON. Fruit heart shaped, skin deep cherry red, flesh amber; Ters juics; pit small. A most delicious plum.

YELLOW EGG. Vers large and beautiful; egg-shaped; flesh sellow, rather acid until fully ripe, when it sweetens. Clingstone. 


\section{PRUNES}

The prune crop this past season was light in some sections, consequently prices were good. $5 \mathrm{c}$ per lb. being the basis on which the crop was sold.

Price, 4 to 6 feet, 35c each; $\$ 3.00$ per $10 ; \$ 25.00$ per 100 .

FRENCH (Petite d'Agen). This is the prune now grown so extensively and successfully in California for drying purposes; medium-sized; egg-shaped, violet purple; very rich and sugary. The best prune; prolific bearer. Can supply this variety on

GERMAN. Long, oval, and swollen on one side; skin purple, with a thick blue bloom; flesh firm, green, sweet with a peculiarly pleasant flavor. Separates readily from the stone. September.

HUNGARIAN. Fruit very large, with tendency to come double; reddish violet, covered with a handsome bloom. Very juicy and sweet. Good shipper.

IMPERIAL EPINEUSE. Large and uniform in size. Very sweet, and of high fla vor; the skin is thin and of a reddish purple when green; when dried, coal black.

SUGAR. An extremely early prune. Very large. Ripens August 1st. Skin very tender, at first of a light purple, tinted with green; changing at maturity to dark purple, covered with a thick white bloom. Valuable in localities where the French prune ripens too late for sun-drying.

SIL VER. Very large, oval; skin yellow. Makes a very attractive dried fruit, besides being a good shipper and canner. Bears heavily.

TRAGEDY. This is the earliest of all prunes, and earlier than any plum. Good size, dark purple skin, yellowish-green flesh. Sweet and very rich.

\section{PEACHES}

The Peach tree requires a well-drained moderately rich soil, warm sandy loam is probably the best. In order to preserve the continued healthy growth of the tree and the fine quality of the fruit, the peach should have the shoots and branches cut back to one half the preceding season's growth every year, so as to preserve a round, vigorous head; this should be done the last of February or as early in the spring as practicable.

Price, 1 year, 4 to 5 feet, 35c each; $\$ 3.00$ per $10 ; \$ 18.00$ per 100.

ALEXANDER. Flesh firm and juicy, sweet; early.

ELBERTA. Very large; bright yellow with a beautiful red mottled cheek; juicy and sweet; regular bearer. Ripens about end of July.

EARLY CRAWFORD. This is probably the most extensively grown of all peaches. Very large; color yellow, red cheek; flesh yellow, rich, excellent. Very productive. Ripens about middle of July.

FOSTER. Large yellow; resembles Early Crawford, ripening a little earlier; an excellent sort.

HALE'S EARLY. Medium size, nearly round; skin greenish-white. red cheek; very rich and juicy. Ripens early in July.

LATE CRAWFORD. Very large; yellow with dark red cheek; flesh deep yellow, juicy and melting; of exquisite fla vor; valuable
for canning and drying. Ripens middle to end of August.

LOVELL. Flesh yellow to the pit; solid and of excellent quality; a grand canning and drying peach; ripens about end of August.

MORRIS WHITE. A large white freestone; excellent for table purposes.

MUIR. The best of all peaches for drying, because it loses less than any other in the process. Has a delicious, rich, buttery, sweet fla vor. The fruit is large to very large; skin pure yellow; flesh yellow. Excellent for canning. Ripens end of August.

NICHOLS ORANGE CLING. Very large, yellow with dark crimson cheek; flesh golden-yellow; rich and sugary; a heavy and regular bearer.

PHILLIPS CLING. The best late clingstone; in great demand by the canneries.

SALWAY. A large, yellow English peach, with deep yellow flesh; very juicy, melting and rich. The most valuable late market variety.

SUSQUEHANNA. Large, globular; skin yellow, nearly covered with red; flesh yellow, sweet, juicy and rich. Tree strong grower, bearing heavy and regular crops.

TUSCAN CLING. A very fine early clingstone; a good shipping and canning sort.

\section{NECTARINES}

Price, 3 to 5 feet, 35c each; $\$ 3.00$ per 10.

BOSTON. Large, deep yellow, with a bright blush and deep mottlings of red; flesh yellow, without any red at the stone. Sweet though not rich, with a pleasant and peculiar flavor.

IORD NAPIER. Large, cream color, dark red cheek; flesh white; freestone.

\section{APRICOTS}

Beautiful and delicious fruit. In quality and appearance is between the plum and the peach, combining quality of both. Ripening early, together with its delightful flavor, makes it one of the most valuable fruits. Requires about the same cultivation as the peach or plum. For drying and canning it has no superior. The apricot crop was heavy in the State this past season and the dried fruit sold for phenomenal prices, from $8 \mathrm{c}$ to $12 \mathrm{c}$ being paid to the grower.

Price, 4 to 6 feet, 35c each; $\$ 3.00$ per $10 ; \$ 20.00$ per 100 .

BLENBEIM. An excellent variety and in great demand. The trees are early and regular bearers and have an abundance of foliage thoroughly protecting the fruit. Fruit above medium, oval; orange color, with deep yellow; juicy and rich flesh; July.

HEMSKIRKE. Large, roundish; flesh bright orange, tender and juicy, with a rich plum-like flavor; fruit not quite as large as the Moorpark, but ripening more evenly. August.

MOORPARK. Very large, yellowish-green, brownish-red on the sunny side, marked with numerous dark specks and dots; flesh bright orange, parts freely from the stone.

PEACH. Very large, handsome, and of a delicious flavor; skin deep orange, mottled with dark brown. Flesh of a fine saffron-yellow color, juicy, rich and highly flavored.

ROYAL. A very fine apricot, very extensively planted in this State. Of medium size, yellow with red cheek; immensely productive an early ripening variety.

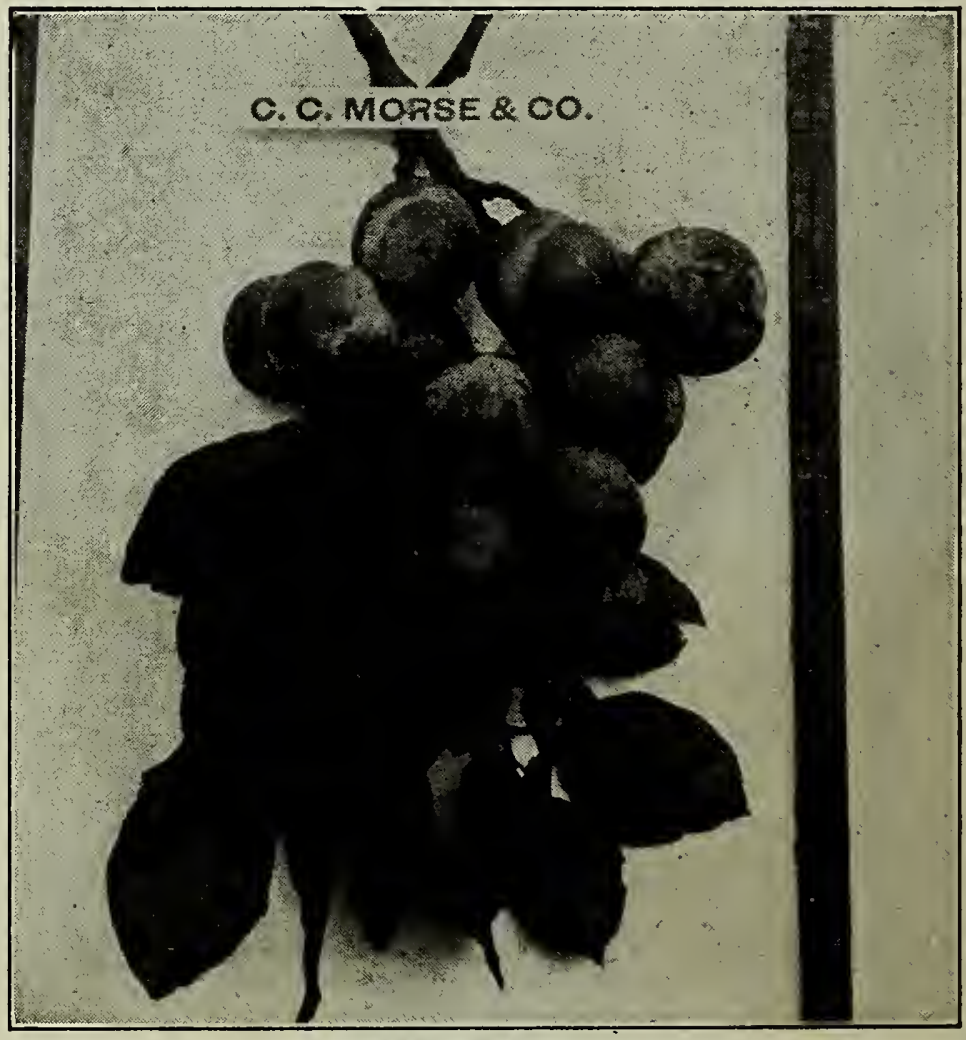

Green Gage Plum

\section{ALMONDS}

The Almond prefers a loose, light, warm soil. It makes quite a large tree, and should have plenty of room. Trees should be headed low and pruned during the first three years. During the past season the almond crop in California was heavy and prices much higher than ever before. From $12 \mathrm{c}$ to $17 \mathrm{c}$ being paid for the paper shells.

Price, 4 to 5 feet, 35c each; $\$ 3.00$ per $10 ; \$ 20.00$ per 100 .

DRAKE'S SEEDLING. Originated with Mr. Drake, of Suisun, California, of the Languedoc class; bears abundantly and regularly where the Languedoc is a total failure.

I. X. I. Tree a sturdy, upright grower, with large leaves; nuts large shells easily, no machine being needed, nor is any bleaching necessary; shell soft but perfect. It bears heavily and regularly. 


\section{ALMONDS-Continued.}

JORDAN. The nuts are long and hard-shell; the kernels are single, narrow, long and plump; the kernel is always removed from the nut proper when exported.

NE PLUS ULTRA. Introduced by Mr. A. T. Hatch. Tree a rapid grower; leaves rather large; a heavy and regular bearer; nuts grower; leaves rather large; a heavy and regular be
large and very long in shape; soft shell; hulls freely.

NONPAREIL. First called Extra. Of a weeping style of growth, smaller foliage than the I. X. L., but still forms a beautiful tree an extraordinarily heavy and regular bearer, with very thin shell, of the Paper Shell type.

\section{QUINCES}

Price, 4 to 5 feet, 35c each; $\$ 3.00$ per 10.

APPLE, or ORANGE. Large, bright jellow. The best. Ripe August and September.

CHAMPION. Very large; flesh cooks as tenderly as an apple, not having hard spots or cores; flavor delicate, imparting an exquisite quince taste and odor to any fruit with which it is cooked. Highly productive, especially so while young.

\section{OLIVE TREES}

Price, 4 to 5 feet, $60 \mathrm{c}$ each.

MANZANILLO. Among the olives of southern Spain, especially around Seville, the Manzanillo is highly prized both for pickling and oil. The fruit is very large. One of the best olives. Very hardy, prolific, and a regular bearer. Makes a fine pickle, and hardy, prolific, and a regula
produces oil of a high grade.

NEVADIILO BIANCO. Medium size, well set on, and its numerous branchlets usually bend with the weight of the fruit. It is for oil only, of which it yields an abundant supply of finest grade. Ripens early.

RUBRA. The tree is a very vigorous, upright grower; succeeds in dry, hilly soils. Fruit of medium size, bears heavy and regular crops. November.

SEVILLANO. The tree is a strong grower; leaves green, greenishwhite on the under side. The largest of olives, and the variety exported from Spain under the name of "Queen Olive." When ripe, of a bluish-black color; flesh adheres to the pit. A regular fine flavor, and the fact that it pickles easily, is sure to cause it to be in demand.

\section{FIGS}

CALIFORNIA BIACK. A well-known local variety. Large, dark purple, almost black when fully ripe. Makes a good dried fig. feet, $40 \mathrm{c}$ each; $\$ 3.50$ per 10 . 4 to 5 feet, $60 \mathrm{c} \mathrm{each} ; \$ 5.00$ per 10 .

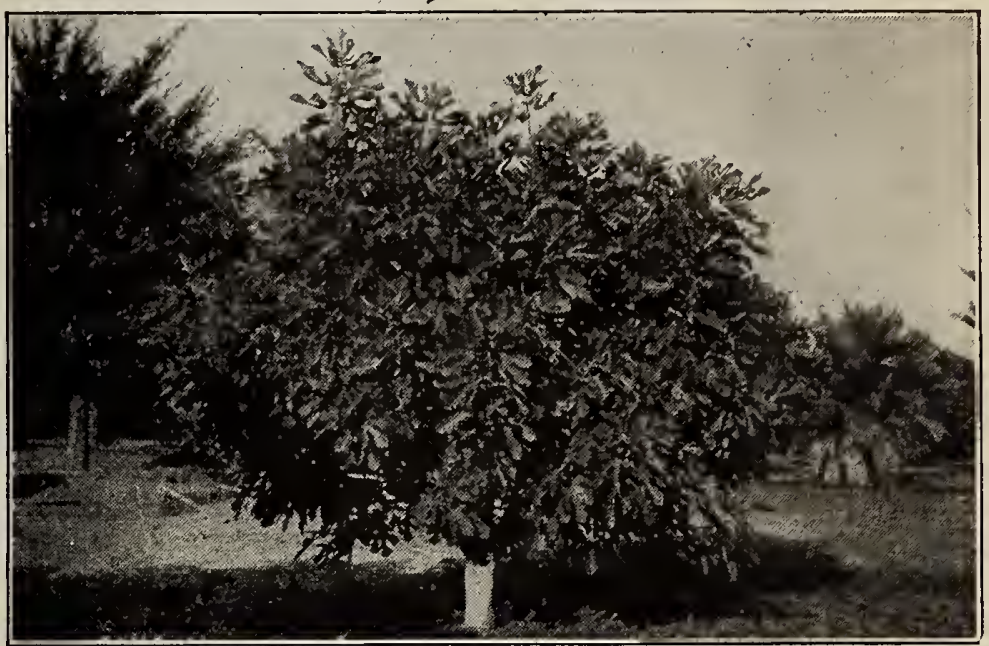

A Calimyrna Fig Tree Showing Habit of Growth

CAIIMYRNA. The geniune Smyrna Fig packed under the name of "Erbeyli" (signifying fine fig) in Asia Minor, and known in "Turkish as "Lop," and in Greek as "Lopia." Large to very large; turbinate; pyriform; very short, stalk short; ribs distinct orifice large, of pale ocher color and widely open when the fig is mature and before shriveling; skin lemon yellow; pulp reddish amber, sometimes pale amber, turning to dark amber just before falling; seeds large, zellow fertile, overspread with a clear, white yrup, giving the fruit a richness and meatiness surpassed by no 作 five-lobed. The dried figs contain $63-92$ per cent sugar, which is $1 \frac{1}{2}$ per cent more sugar than found in the imported Smyrna fig. Dries readily and with less trouble and expense than any other fig, dropping to the ground of its own accord, being practically dry when it falls, requiring when placed on trays only from two to three days' exposure to the sun. This is the Roeding, of Fresno. 3 to 5 feet, 50c each: $\$ 4.00$ per 10 .

WHITE ADRIATIC. Fruit large; skin greenish-yellow color pulp carnation red. Ripens from August to October. 3 to feet, 40c each; $\$ 3.50$ per 10 .

WILD, or CAPRI. Must be grown in connection with every Calimyrna Fig orchard. 3 to 5 feet, $60 \mathrm{cech}$.

\section{ORANGES}

Price, lifted with balls of soil, 4 to 5 feet, $\$ 2.00$ each; $\$ 18.00$ per ten.

MEDITERRANEAN SWEET. Frui medium to large; pulp solid, wit few seeds; ripens late. A very popular sort.

RIVERSIDE WASHINGTON NAVEL. Fruit first-class in ever respect; size medium to large, oval, smooth, symmetrical, seedless; pulp fine grained, flavor excellent. A solid, perfect fruit.

RUBY BLOOD. Fruit below medium nearly round; skin very thin and smooth; pulp ruby-red.

VALENCIA LATE, Or HART'S TARDIFF. An orange of remarkably strong-growing habi and claimed by those fruiting it to be a good bearer; a little late than Mediterranean Sweet, which it resembles very much.

\section{LEMONS}

Price, lifted with balls of soil 4 to 5 feet, $\$ 2.00$ each; $\$ 18.00$ per ten.

EURERA. Tree nearly thornless, of rapid growth, and prolific bearer; fruit of the best quality. A general favorite.

LISB ON. Medium size; sweet rind; very strong in acid; very few seeds; tree a rapid grower and very productive.

VILLA FRANCA. Fruit uniformly medium size, fine grained, swee rind; very few seeds, good keeper; tree strong grower, prolific bearer. 


\section{POMELOS, (Grape Fruit)}

This fruit is becoming one of the most popular of the citrus fruits in the Eastern States, and the demand for it thus far has exceeded the supply. The name of "Grape Fruit," by which it is often called, due to its growing in clusters on the tree, is a misnomer. The growing popularity of this fruit is probably due to its medicinal qualities, particularly for correcting stomach troubles. The tree is fully as hardy as the orange and is a vigorous grower.

Price, lifted with balls of soil, 4 to 5 feet, $\$ 2.00$ each.

MARSH'S SEEDLESS. Medium, practically seedless; skin thin and smooth; pulp juicy; of superior flavor. Keeps late. A valuble acquisition; its delicious favor and having no seeds sho
cause it to take the precedence over many other varieties.

TRIOMPH. Medium size; skin smooth, clear, thin, and fine grained, juicy and well flavored. No bitter in the juice, flesh or memlittle in the white, inner lining of the peel. Tree bears young. little in the white, inner lining of the pees.

\section{LIME-MEXICAN \\ Balled, 3 feet, $\$ 2.00$ each.}

\section{JAPANESE PERSIMMONS}

A magnificent fruit from Japan. Tree highly ornamental. Fruit beautiful in appearance and excellent in quality. 4 to 5 feet, $50 \mathrm{ceach}$

\section{STRAWBERRY GUAVA}

The Guava is an ornamental evergreen shrub with pink, shining foliage, and bears when only 2 feet in height. The fruit is smaller than an English walnut, of a fine claret color, and with a flavor 2 feet, $50 \mathrm{c}$ each.

\section{CHESTNUTS}

AMERICAN SWEET. A valuable native tree, both useful and ornamental; timber is very durable, and possesses a fine grain for oil finish. Nuts sweet, of delicate flavor, and are a valuable article of commerce. No farm should be without its grove of the soil is adapted to its growth. Price, 3 to 4 feet, $35 \mathrm{c}$ each; $\$ 3.00$ per 10 .

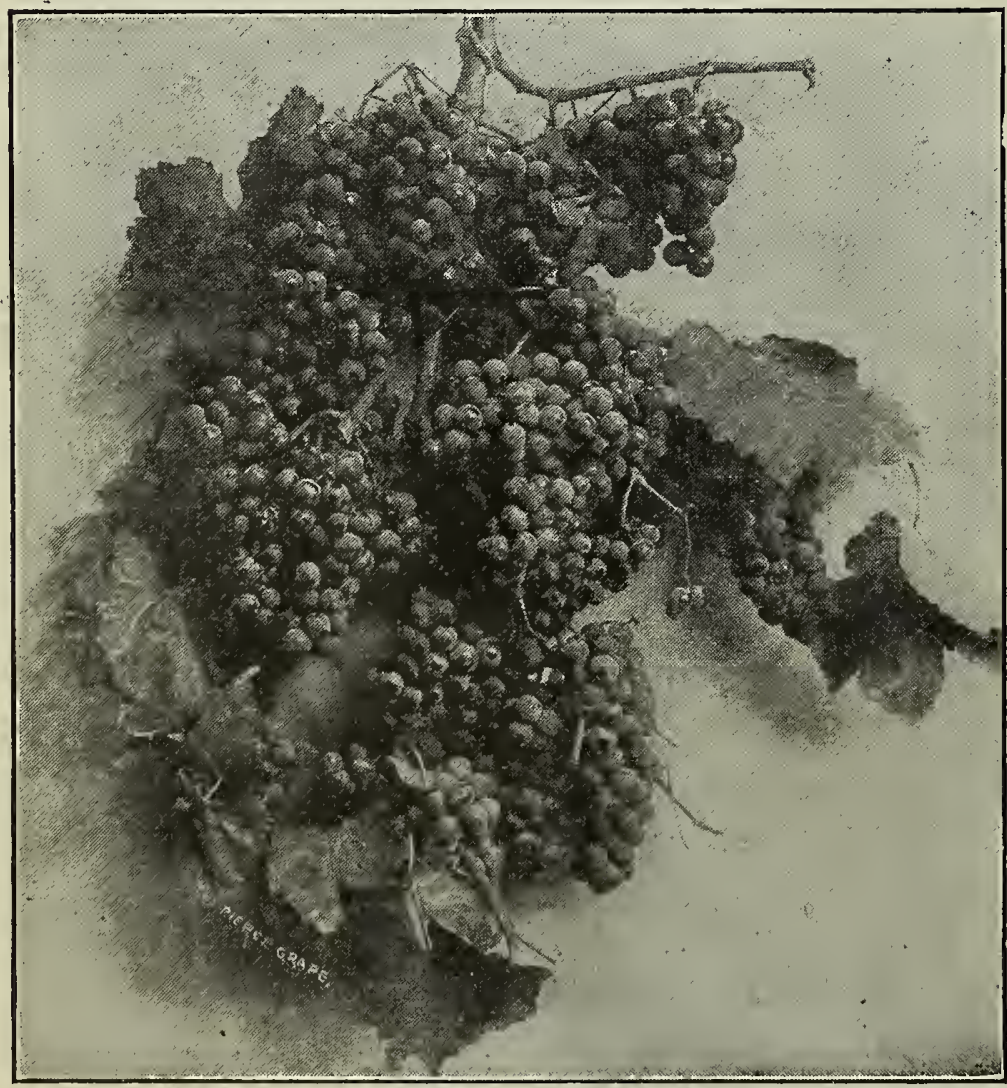

The Pierce Grape

\section{MULBERRY}

DOWNING. Tree of rapid growth; very good as a shade tree, as the leaves are very large; deep green in color; fruit similar in shape to a blackberry; very sweet and aromatic. 5 to 6 feet, $60 \mathrm{c} \mathrm{each}$.
PERSIAN. This variety produces a very large black-red fruit; of exquisite flavor. 2 feet, $50 \mathrm{c}$ each.

\section{LOQUAT}

The fruit of this Japanese tree is very nice. In this State it ripens in April and May, and is about the size of small plums, and comes in clusters; very. sweet and refreshing. The plant itself is very ornamental, having large crimpled foliage of an olive-green color; of spreading, dense growth. $11 / 2$ feet, $35 \mathrm{c} ; \$ 3.00$ per 10 .

\section{WALNUTS}

At the present time there is a great inquiry for grafted walnuts, it having been proven without a question that these come into bearing at a much younger age than do those trees raised from seed; furthermore the California Black Walnut root will thrive in much wetter land than the root of the English variety. By using the Black Walnut for a stock to graft on we have increased the area where this nut can be grown. Grafted trees will bear good crops at from 7 to 9 years. It is no doubt a paying crop; the trees requiring very little pruning and no thinning. The trees should be set 40 feet apart each way. If planted this distance, it will require 27 trees to the acre.

CALIF ORNIA BLACK. A very rapid growing tree, now very extensively used for grafting on. 1 year in seed bed, $\$ 5.00$ per 100 ; transplanted 2 to 3 feet, $20 \mathrm{c}$ each; $\$ 1.50$ per $10 ; \$ 7.50$ per 100; 4 to 5 feet, 35c each; $\$ 3.00$ per 10 .

SANTA BARBARA SOFT SHELL. Tree a vigorous grower, early and abundant bearer. The nut is large; kernel white, sweet and readily extracted; shell thin, easily broken. One of the favorites in Southern California. 5 to 6 feet, $60 \mathrm{c}$ each; $\$ 5.00$ per 10.

FRANQUETTE. Nut is quite large, of an elongated oval shape and very attractive; kernel full sweet and of a rich nutty flavor a late bloomer. Grafted on California Black Wainut root, 3 to 4 feet, $\$ 1.25$ each; $\$ 11.00$ per $10 ; 4$ to 5 feet, $\$ 1.50$ each; $\$ 14.00$ per 10 .

MAYETTE. A very superior nut in every way. Tree an abundant bearer and very late bloomer. Grafted on California Black Walnut root, 3 to 4 feet, $\$ 1.25$ each; $\$ 11.00$ per 10 .

\section{GRAPES FOR TABLE AND RAISINS}

Price, 20c each; $\$ 1.50$ per $10 ; \$ 6.00$ per 100 .

CALIFORNIA BLACK. The well-known Mission Grape.

CORNICHON, BLACK. Berries very large, oblong; covered with beautiful bloom; skin rather thick and dark. A good shipping sort.

FLAME TOKAY. A magnificent, large red grape.

GROS. COLMAN. A large, fancy, black grape, regular heavy bearer a very handsome late keeping variety, unsurpassed for table.

GOLDEN CHASSELAS. A very fine table variety.

MUSCAT OF ALEXANDRIA. Bunches and berries large, pale amber. One of the best for raisins. $\$ 18.00$ per 1,000 .

ROSE OF PERU. Very large bunches; berries rounding, brownish black. One of the best for table.

SULTANA. Bunches long and very compact; berries small, amber colored, seedless; make fine seedless raisins; vine an immense bearer. Grows on sandy soils, producing large crops. $\mathbf{\$ 1 8 . 0 0}$ per 1,000 .

SWEETWATER. Bunches good size; berries medium size, round fruit.

THOMPSON'S SEEDLESS. Vine an enormous bearer and very rapid grower; bunches very large; berries greenish-yellow, firm oval, seedless; skin thin, much larger than the sultana. The raisins are of a very superior quality, and are in good demand. A valuable shipping grape, ripening in July. $\$ 18.00$ per 1,000 .

\section{FORETGN WINE GRAPES}

BEST ASSORTED. $\$ 5.00$ per $100 ; \$ 18.00$ per 1,000 .

\section{RESISTANT GRAPES}

LENOIR, RIPARIA, RUPESTRIS ST. GEORGE. $\$ 4.00$ per 100; $\$ 20.00$ per 1,000 .

Write for prices and varieties of Grapes Grafted on Phylloxera Resistant Roots.

THE PIERCE. Known in San Francisco markets as "Isabella Regia"; a splendid American grape of very large size; excellent flavor; black, with a lovely blue bloom overspreading. Price, 30c each; \$2.50 per 10 .

\section{AMERICAN GRAPES}

Price, 2 years old, 20c each; $\$ 1.50$ per 10.

AGAWAM. One of the best of red varieties; bunches good size; berry tender and juicy.

CONCORD. Bunches large, compact; berries large, round, light, red, sweet. 


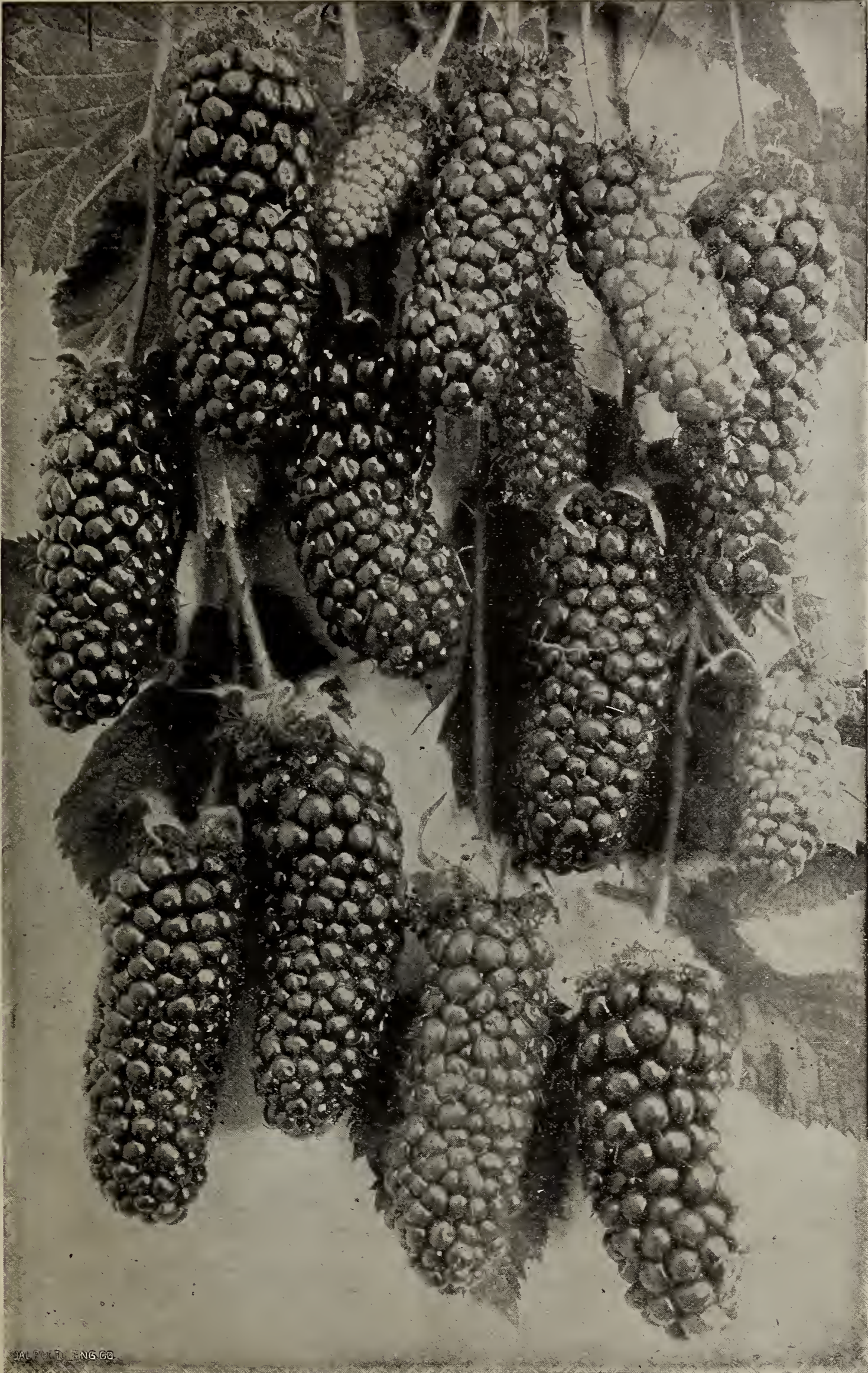

Mammoth Blackberry-Actual size, not exaggerated.

\section{CURRANTS}

Currants and Gooseberries should be planted in good soil, which must be kept rich and well worked. Trim out the old wood as soon as it begins to decline, and shorten all the young shoots, to keep the bushes in good shape. Sprinkle ashes around the roots occasionally, to keep the borers away.

Strong, 2 years old, 20c each; $\$ 1.75$ per 10

B LACK NAPLES. Berries large and black.

CHERRY CURRANT. Ver arge, deep red. One of the best.

FAY'S PROLIFIC. Very productive, with long branches covered with large, rich

WHITE DUTCH. Bunch and berry large, with fine transparent skin.

\section{GOOSEBERRIES}

We can supply the following English sorts. Large fruiting, and of delicious flavor. each; $\$ 2.00$ per 10

CROWN BOB. Large, roundish quality.

LANCASHIRE L A D This splendid sort is of superio quality, almost as large as Industry, having a rich pleasant flavor when ripe color, rich dark red; a vigorous grower.

WHITESMITH. Large, ova shaped; yellowish white slightly
quality.

KEEPSAKE. Very large; fruit of exquisite flavor.

\section{RASPBERRIES}

Plant in rows 5 to 6 feet apart, 2 to 4 feet in the row. Cut the tops off within a few inches of the ground when planted. After the fruit season, cut out all the old wood which bore the last crop of fruit. Pinch the vigorous young shoots several times during the summer. They will then grow stout enough to stand without staking.

CUTHBERT. The largest handsomest and best red Raspberry cultivated. Bears transportation well. Very
productive. $60 \mathrm{c}$ per 10; $\$ 4.00$ per 100 .

SUPERLATIVE. A veryfine new variety said to be of superior quality following is introducer's description: The Superlative is acme of perfection in the Raspberry family. Has hardy and healthy growth. Fruit the largest of any variety. Very prolific. Core is small, flesh very deep. seeds very small. Fruit does not fall from plant iwhen ripe. Leeds very small. Fruit does not fall from plant iwhen ripe. leaves are very large and corrugated making it practically insect proof. Delights in hot weather and matures very early.
Is very heavy cropper. 30c each; $\$ 2.50$ per 10; $\$ 20.00$ per 100. 


\section{C.C.MORSE \& CO. PLANTS \& TREES 2}

\section{BLACKBERRIES}

Plant in good soil, in rows 5 to 6 feet apart, and 3 to 4 feet apart in the row. After the fruiting season, or in early spring, cut out all the dead wood. Blackberries should be planted early, before the buds start. A good top dressing of stable manure, applied annually, will be conducive to large crops. Keep the ground clean.

KITTATINNY. Fruit large, roundish conical, rich glossy black; firm, juicy, sweet and excellent. 60c per 10; $\$ 4.00$ per 100 .

HIMALAYA GIANT. A late Blackberry coming after the other berries a re gone, ripening over a period of several weeks, making berries are gone, ripening over a period of several weeks, making, it especially desirable for family use. In Northern California are over. Like the Loganberry, it must be grown on a trellisthe vines under favorable conditions growing 15 to 20 feet. The berries grow in bunches; are of excellent flavor and the yield $15 \mathrm{c}$ each; $\$ 1.25$ per 10 . Tip rooted plants, $15 \mathrm{c}$ each; $\$ 1.00$ per $10 ; \$ 6.00$ per 100 .

\section{MAMMOTH BLACKBERRY}

\section{Named by some the "The Black Loganberry"}

The fruit is enormously large, some specimens measuring from $2 \frac{1}{4}$ to $21 / 2$ inches long; the very largest blackberry known to the world. The globules are large, seed small, soft and not very abundant; core quite small and very soft. The flavor is a decided improvement on any known variety of blackberry, the acid flavor so pronounced in all other kinds is very mild and pleasant, and when fully ripe is quite sweet. This berry in size and delicious flavor will eclipse any blackberry heretofore produced.

It is advisable in planting the Mammoth Blackberry plants that they be given plenty of room. If grown upon a trellis, which is by far the best way, the rows should be not less than 9 feet apart and the plants 6 to 8 feet in the rows.

One year old plants, $15 \mathrm{c}$ each; $\$ 1.25$ per $10 ; \$ 8.00$ per 100 .

Tip rooted, ready February. 10c each; 75c per 10; $\$ 4.00$ per 100 .

\section{THE MORSE STRAWBERRY}

For many years the aim of the horticulturist in this State has been to produce a Strawberry in all respects similar to that grown in England, where this luscious fruit attains perfection. Success, however, has only been partial. The size was obtained, but at the loss of the flavor, and vice versa, the flavor and aroma were obtained, but lacking the size. English sorts have been introduced and tried, but found wanting, their new environments not being congenial.

In the "Morse Strawberry," introduced by us, we have found the long looked-for ideal berry for California, and it affords us great pleasure to introduce this gem to our customers. We know that everyone who tries this berry will be more than pleased with it. It is a broad assertion when we say that the Morse Strawberry will take the place of all other sorts, especially for home use, when it becomes known-but we really mean what we say.

The berry is of very large size and can be sliced; half a dozen berries constitute a fair-sized dish. It is never hollow or pithy, but always solid and meaty. The color is deep crimson clear to the core. It commences to bear when the plants are quite young, and continues the entire season. We have never before seen such a splendid cropper. The aroma from the fruit is most delicious, having a true Strawberry fragrance. The plant is a strong, thrifty grower, and holds the berries well up on the stem so that a very small proportion of the fruit is spoiled by coming in contact with the soil. The plants we are sending out are strong and thrifty and will give a good crop of fruit the first season. This berry has been tried both in the cool and warm sections of this State, and in both locations it has proven equally satisfactory.

CULTURE: A few suggestions as to how they should be grown may not come amiss. Some of our customers are not as well posted as others, and it is to those that we would offer the following suggestions. First of all, your soil should be enriched with old, well-rotted stable manure dug in the

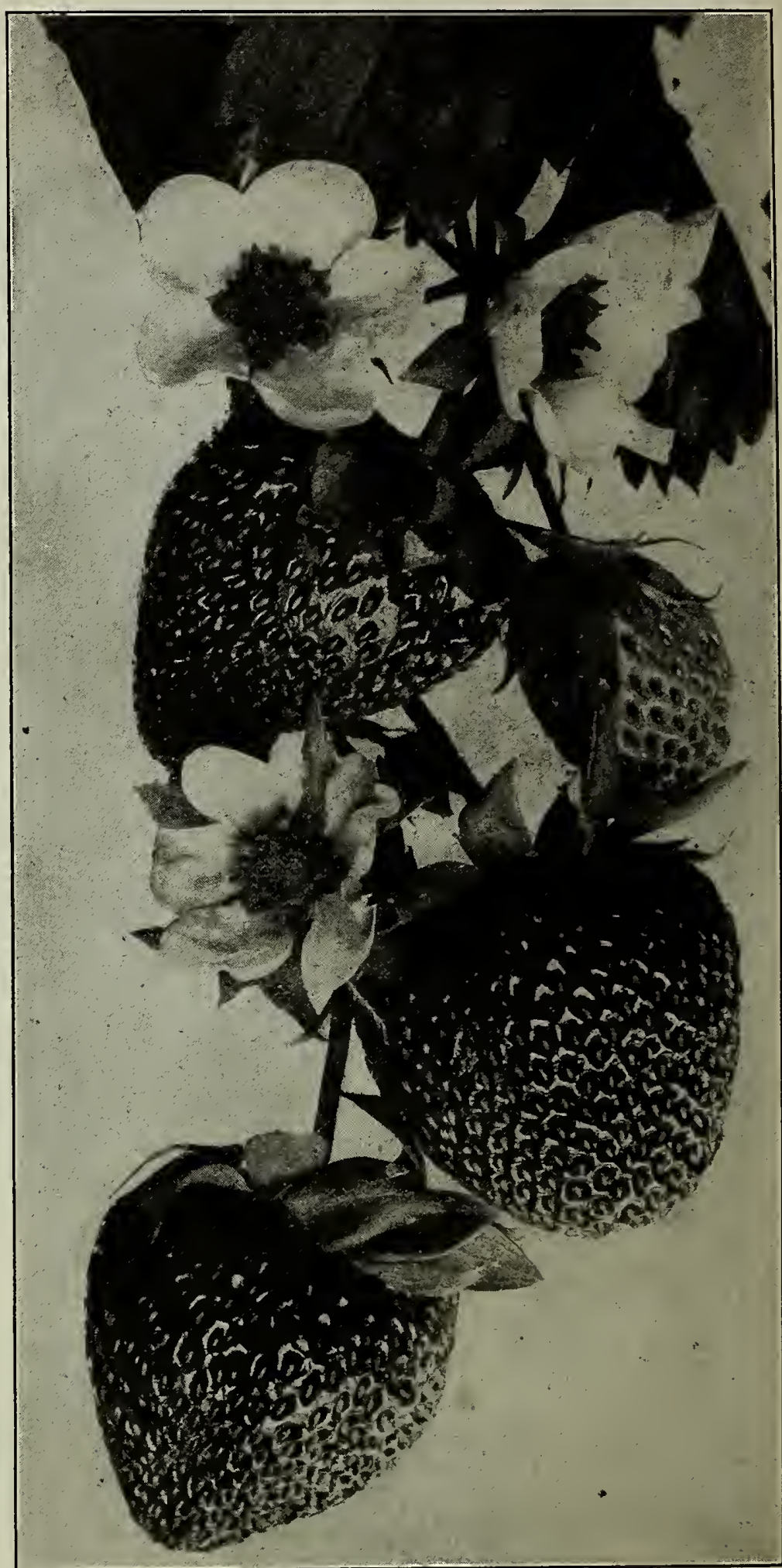

The Morse Strawberry-Best for all purposes.

soil before planting. The plants are set out 9 or 10 inches apart in the row, and 12 inches between the rows. They are generally ridged, and between the ridges a wider space left so that you can irrigate. By this means the ground where the plants are does not get flooded, nor does it become baked. This is especially necessary in large plantings. Of course, in smaller plantings, this manner of planting is not so essential. Keep all runners cut off, and by so doing you will throw the strength into the fruit. The earlier they are planted in the season, the better crop you will have the first season. We have, however, seen the Morse Strawberry planted in March bearing a good crop of fruit in July, another good point not previously mentioned which is found in this berry but in no other sort.

Price, 60c per $12 ; \$ 3.00$ per 100 . 


\section{SAN FRANCISCO, CALIFORNIA. U.S.A}

\section{STRAWBERRIES-OLDER VARIETIES}

Price, 25c per dozen; $\$ 1.50$ per $100 ; \$ 8.00$ per 1000 .

Varieties marked (Imp.) are imperfect in blossom and need at least every third or fourth row to be planted with some perfect or staminate sort. Those marked (Per) are especially good to use as staminates or to be grown alone.

AROMA (Per.) Plant strong grower, produces good crops, of very large dark colored berries, firm and of excellent quality; ripens medium to late.

GANDY. Fruit large, dark dull red and produced in fair quantity; a late variety of fine quality.

LONGWORTE. (Imp.) An old popular variety. Fruit small, very sweet. Requires to have a perfect variety to be planted in proximity.

EXCEISIOR. (Per.). Berries large, long, conical or pointed and a bright scarlet in color. The flesh is bright, juicy, of fair quality, and firm. Plants vigorous and healthy in growth and foliage. Ripens early and is very productive.

BRANDYWINE. (Per.) Plant a luxuriant grower, healthy and hardy, and very productive; blossoms perfect; fruit very large, of good form, bright red all over, and of good quality. Season, medium to very late. It succeeds on any soil.

MAGOON. Large berry, dark red in color, and of very fine aroma.

SENATOR DUNLAP. (Per.) An early variety; berries of good flavor and very popular as a home garden sort.

SHARPLESS. (Per.) An old, well tried variety; fruit very large; bright scarlet; immensely prolific.

KLONDYKE. (Per.) Color of berry rich red, extending to center; of mild flavor, quite juicy; of great productiveness. A fine shipping sort and grown extensively for market as it is an excellent shipper.

LADY THOMPSON. (Per.) Early; very productive; large firm and fine flavor. A valuable market variety. Plant, strong and vigorous grower.

TEXAS. Produces handsome crimson berries with dark red cheeks medium size; firm and solid; fine flavor; good for canning and an excellent shipper.

\section{SPRAYING FORMULAS}

BORDEAUX MTXTURE. Copper sulphate, 6 pounds; quicklime, 4 pounds; water, 40 gallons. Dissolve the copper sulphate by putting it in a bag of coarse cloth and hanging this in a vessel holding at least 4 gallons, so that it is just covered by the water. Use an earthen or wooden vessel. Slake the lime in an equal amount of water. Then mix the two and add enough water to make 40 gallons. It is then ready for immediate use. If the mixture is to be used on peach foliage it is advisable to add an extra pound of lime to the above formula. When applied to such plants as carnations or cabbage it will adhere better if about a pound of hard soap be dissolved in hot water and added to the mixture. For rots, mildews, and all fungous diseases.

AMMONIACAL COPPER CARBONATE. Copper carbonate, ounce; ammonia ( 1 volume 26 per cent Beaume, 7-8 volume of water), enough to dissolve the copper; water, 9 gallons. T-8 volume of water), ate is best dissolved in large bottles where it will keep indefinitely. and should be diluted with water as required. For the same purposes as Bordeaux Mixture.

COPPER SULPEATE SOLUTION. Copper sulphate, 1 pound water, 15 gallons. Dissolve the copper sulphate in the water, when it is ready for use. This should never be applied to foliage but must be used before the buds break. For peaches and nectarines use 25 gallons of water. For fungous diseases.

PARIS GREEN. Paris green, 1 pound; water, 200-300 gallons. If this mixture is to be used upon peach trees, 1 pound of quicklime should be added. Repeated applications will injure most foliage unless lime is added. Paris green and Bordeaux mixture can be applied together with perfect safety. Use at the rate of four ounces of the arsenites to 50 gallons of the mixture. The action of neither is weakened, and the Paris green loses all caustic properties.

LONDON PURPIE. This is used in the same proportion as Prais green, but as it is more caustic it should be applied with two or three times its weight of lime, or with the Bordeaux mixture The composition of London purple is exceedingly variable and unless good reasons exist for supposing that it contains as much arsenic as Paris green, use the latter poison. Do not use London purple on peach or plum trees unless considerable lime is added.

HELLEB ORE. Fresh white hellebore 1 ounce; water, 3 gallons. Apply when thoroughly mixed. This poison is not so energetic as Apply when thoroughly mixed. This poison is not so energetic as
the arsenites and may be used a short time before the sprayed portions

KEROSENE EMULSION. Hard soap, 1/2 pound; boiling water 1 gallon; kerosene, 2 gallons. Dissolve the soap in the water, add the kerosene, and chum with a pump for 5 to 10 minutes. Dilute

\section{THE LOGANBERRY \\ (Raspberry-Blackberry)}

The fruit is as large as the largest-sized blackberry; is of the same shape, with globules similar to that fruit. Color, when fully ripe, a dark, rich red. It partakes of both flavors of the raspberry and the blackberry, being a combination of the two mixed; a very pleasant, mild, vinous flavor, delightful to the taste, not found in any other fruit, but peculiar to this alone. It is excellent for the table, eaten fresh or cooked, and for jellies or jams without an equal. The vines are enormous bearers. One year old plants, $15 \mathrm{c}$ each; $\$ 1.25$ per $10 ; \$ 8.00$ per 100 . Tip rooted, ready February. 10c each; $75 \mathrm{c}$ per $10 ; \$ 4.00$ per 100 .

\section{THE PHENOMENAL BERRY}

Is the result of a cross between the Improved California Dewberry and the Cuthbert Raspberry. Mr. Burbank (the introducer) describes it as larger than the largest berry ever before known; bright crimson raspberry color; productive as could be desired. Tip rooted, ready February. 15 c each; $\$ 1.00$ per 10.

\section{HORSERADISH}

Strong plants, 15c each; $\$ 1.00$ per 10 .

\section{RHUBARB}

LORENZO AND IINNAEUS. Strong roots, 15c each; $\$ 1.50$ per dozen.

\section{AUSTRALIAN CRIMSON WINTER}

The great value of Rhubarb as a vegetable has always been its earliness, and a vast amount of time and labor has been spent in efforts to originate a variety which would produce stalks even a day or two in advance of other early varieties. Australian "Crimson Winter" Rhubarb will produce marketable stalks abundantly, fully six weeks earlier than any other Rhubarb. Price, $25 \mathrm{c}$ each; $\$ 2.00$ per 10. Smaller plants, $15 \mathrm{c}$ each; $\$ 1.00$ per 10 .

10 or 25 times before applying. Use strong emulsion for all scale insects. For insects which suck, as plant lice, mealy bugs, red spider, thrips, bark-lice or scale. Cabbage worms, currant worm and all insects which have soft bodies can also be successfully treated.

\section{DISTANCES FOR PLANTING FRUIT TREES}

Standard Apples

Standard Pears.

Strong Growing Cherries

Duke and Morello Cherries

Standard Plums and Prunes

Apricots, Peaches, Nectarines

Grapes...

Walnuts

Currants, Gooseberries, and Loganberries Raspberries and Blackberries.

Strawberries for Field Culture.

.25 to 30 feet apart each way 20 to 25 feet a part each way 20 to 25 feet a part each way 18 to 20 feet apart each way 18 to 20 feet apart each way 18 to 20 feet a part each way 7 to 10 feet apart each way 40 feet apart each way 3 to 4 by 5 to 7 i to $11 / 2$ by 4 to

\section{NUMBER OF TREES OR PLANTS ON AN ACRE}

Distance

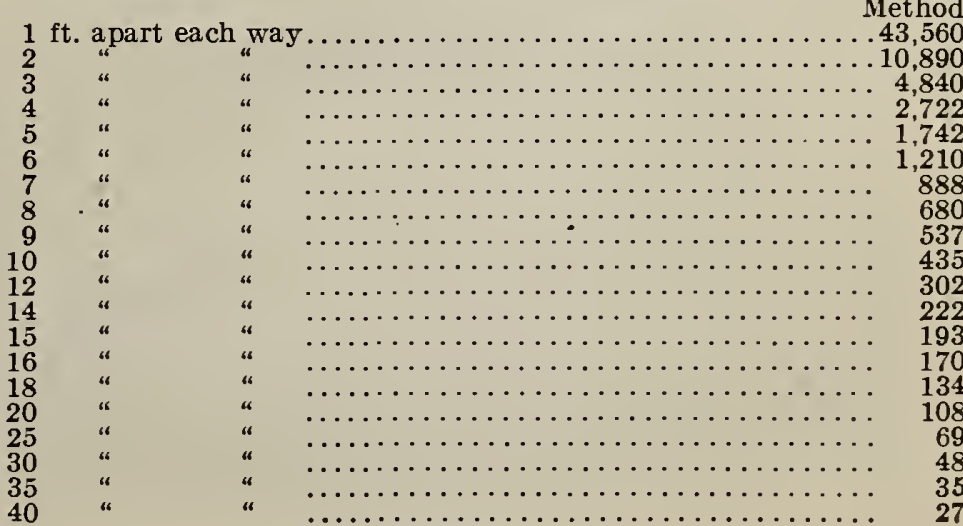




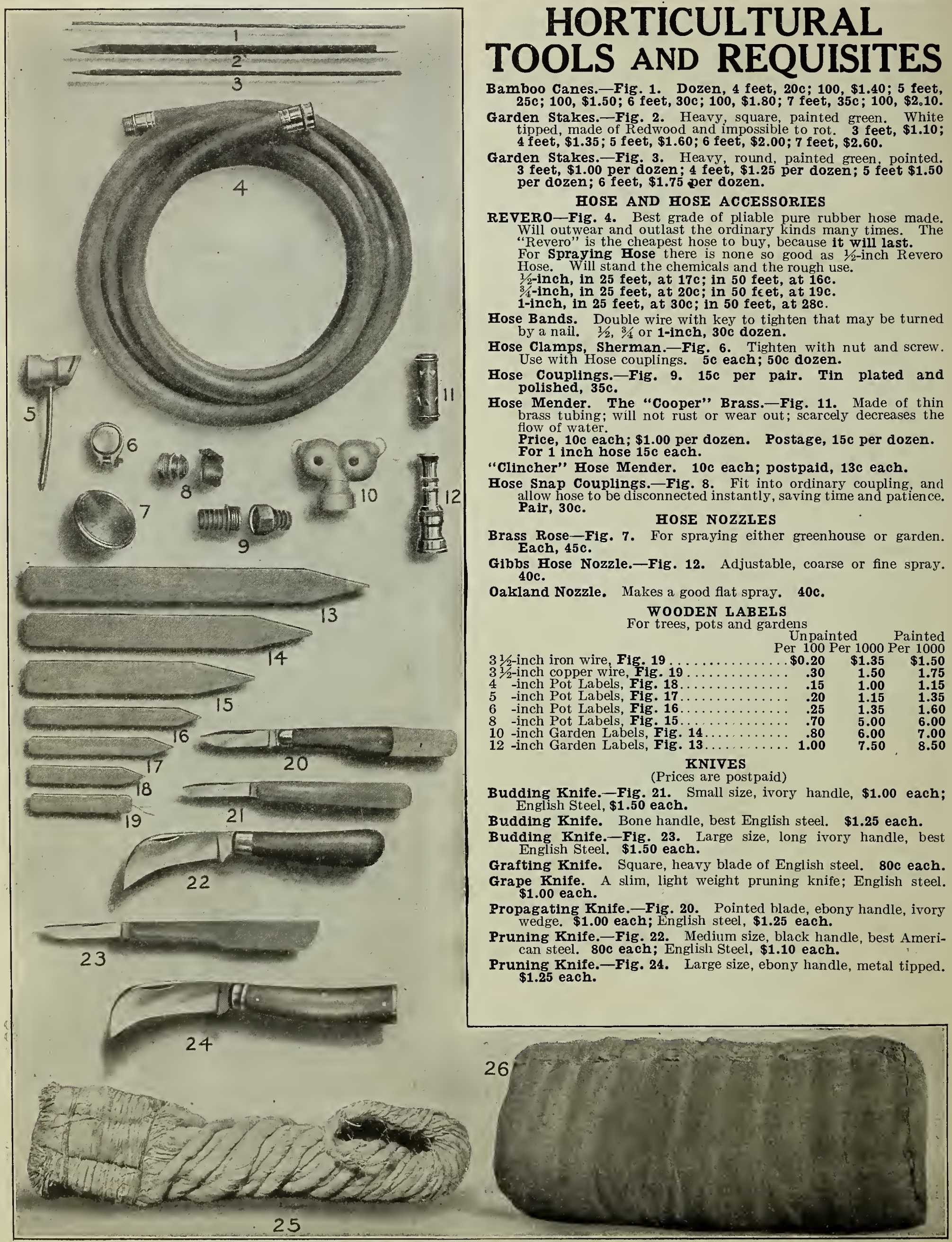




\section{SAN FRANCISCO CALIFORNLA U.S.A.}

\section{HORTICULTURAL TOOLS AND REQUISITES}

Raffia.-Fig. 25. Largely used by nurserymen and others and considered the best and cheapest material for tying known. Lb. 20c; in 10 1b. lots, 15c per 1b.

In bale lots (224 lbs.) write for special eastern prices.

Moss.-Flg. 26. Selected Oregon .......... Ib. 10c; $100 \mathrm{Ibs.} \$ 5.50$ Selected Sphagnum.......... b. 15c;100 lbs. \$6.00

Peat. Best imported peat for growing orchids, bulbs, etc. Use to mix in the soil to start flower seeds. This peat is equivalent and better than "leaf mould," recommended for garden work. Per 1b. 10c; $100 \mathrm{Ibs}$. $\$ 6.00$

Grafting Wax.-Fig. 27. $1 / 4$ lb. 10c; $1 / 21 b .15 c ; 1 b .25 c$.

Trowels.-Fig. 34. Solid shank, cast steel. 50c each. Riveted Shank. 25c each.

Rubber Plant Sprinklers.-Fig. 35. For indoor watering, straightneck. $\$ 1.00$ each.

Rubber Plant Sprinklers, for indoor watering, angleneck. $\$ \mathbf{\$ 1 . 0 0}$ each.

\section{LAWN SPRINKLERS}

"Anaconda"-Tall Revolving Sprinkler. 18 inches high. Throws well. $\$ 1.50$ each.

Meyer's Lawn Sprinkler. Consists of a tin pipe about 4 feet long, mounted and perforated with fine holes which throw a spray in all
directions. Has brass connection and is durable. Each, $\$ 1.25$.

"Twin" Sprinkler.-Fig. 10. Made of zinc metal and cannot rust. Will cover the lawn evenly for 16 feet radius. Very popular. Each 30c.

Fan Sprinkler.-Fig. 5. Made of zinc metal and shaped so that it will water a bed on one side only. Very convenient to use from a cement walk. Each $25 \mathrm{c}$.

\section{GOPHER AND MOLE TRAPS}

Gopher Trap "Novelty".-Fig. 33. Without doubt the best gopher trap made; brass jaws; never fails to catch them. 30c each.

Mole Trap.-Fig. 32. Reddick, is all right. 90c each.

\section{LAWN MOWERS}

We ship these all carefully boxed to any point, delivered free to the railroad.

Philadelphia, Style A.-Fig. 31. Solid steel throughout, ball bearings highly geared; will clip closely and well. Used by the Golden Gate Park extensively for their work. The finest mower made; all päts tested. 15-inch, $\$ 15.00 ; 17-$ inch, $\$ 16.50 ; 19-$ inch, $\$ 18.00$

Philadelphia, Style K.-Fig. 30. Has 5 blades, part steel, single pinion; a good high class mower. 14-inch, $\$ 8.75$; 16-inch, $\$ 9.75 ; 18-1$ inch, $\$ 10.75$.

old Style Philadelphia-Fig. 28. Solid blade and wheel. Impossible to get out of order; will last a lifetime; does good work. 10 -inch, $\$ 5.00 ; 12$-inch, $\$ 6.00 ; 14$-inch, $\$ 7.00 ; 16-1$ - ch, $\$ 8.00$.

The Colonial.-Fig. 29. An extra good mower at a low price. Is substantially built of best iron and steel, and has ball bearers which make it very easy to run. 12-inch, $\$ 4.50 ; 14-1 n c h, \$ 5.00$ 16-inch, $\$ 5.50$.

The Wedgeway.-Fig. 29. Is the same as the Colonial, but without the ball bearings. 12-inch, $\$ 3.75 ; 14-1 \mathrm{nch}, \$ 4.00$.

Grass Collectors. All metal. $\$ 1.50$ to $\$ 1.75$. each. Cloth. $\$ 1.00$ each. Cloth and Metal, \$1.25.
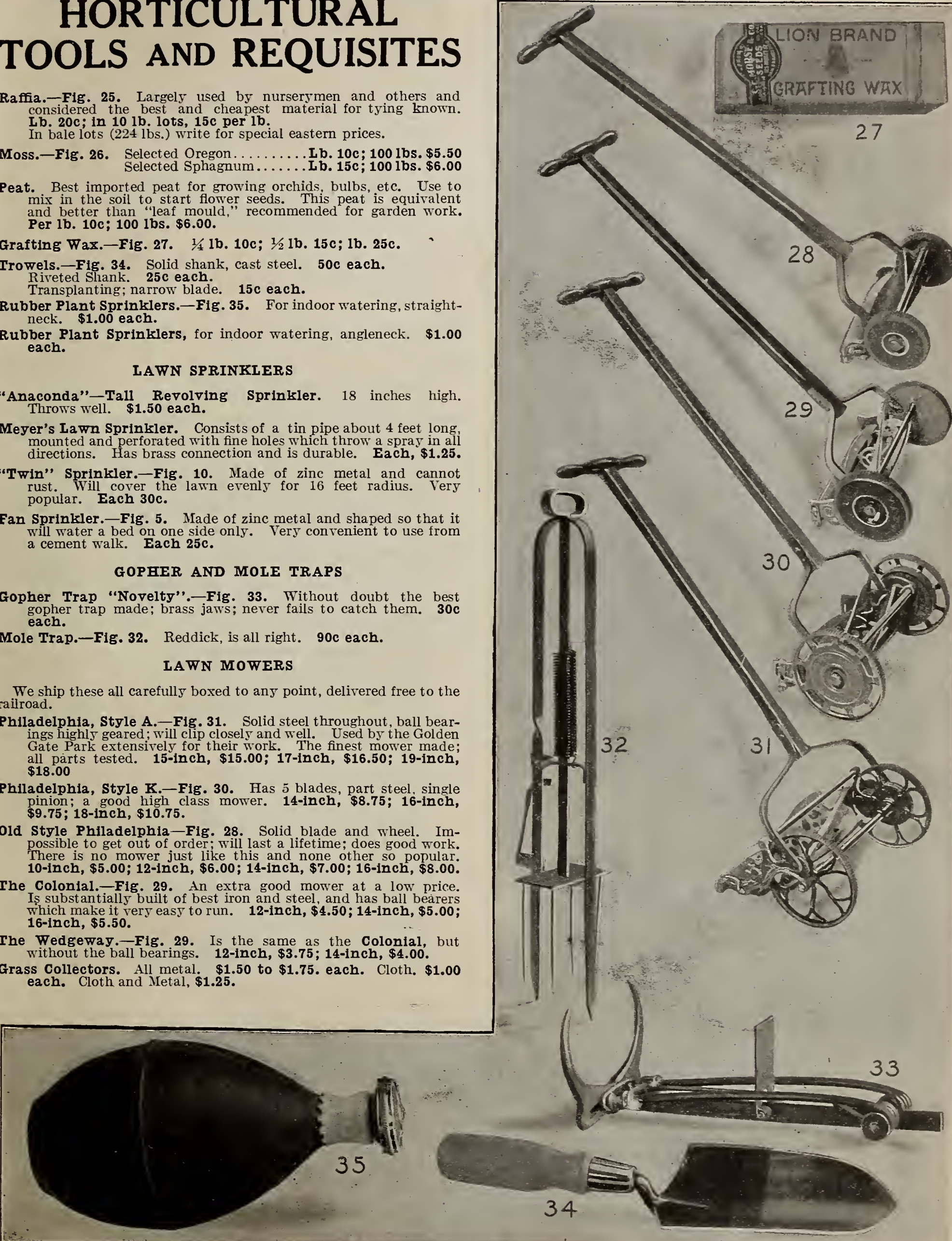

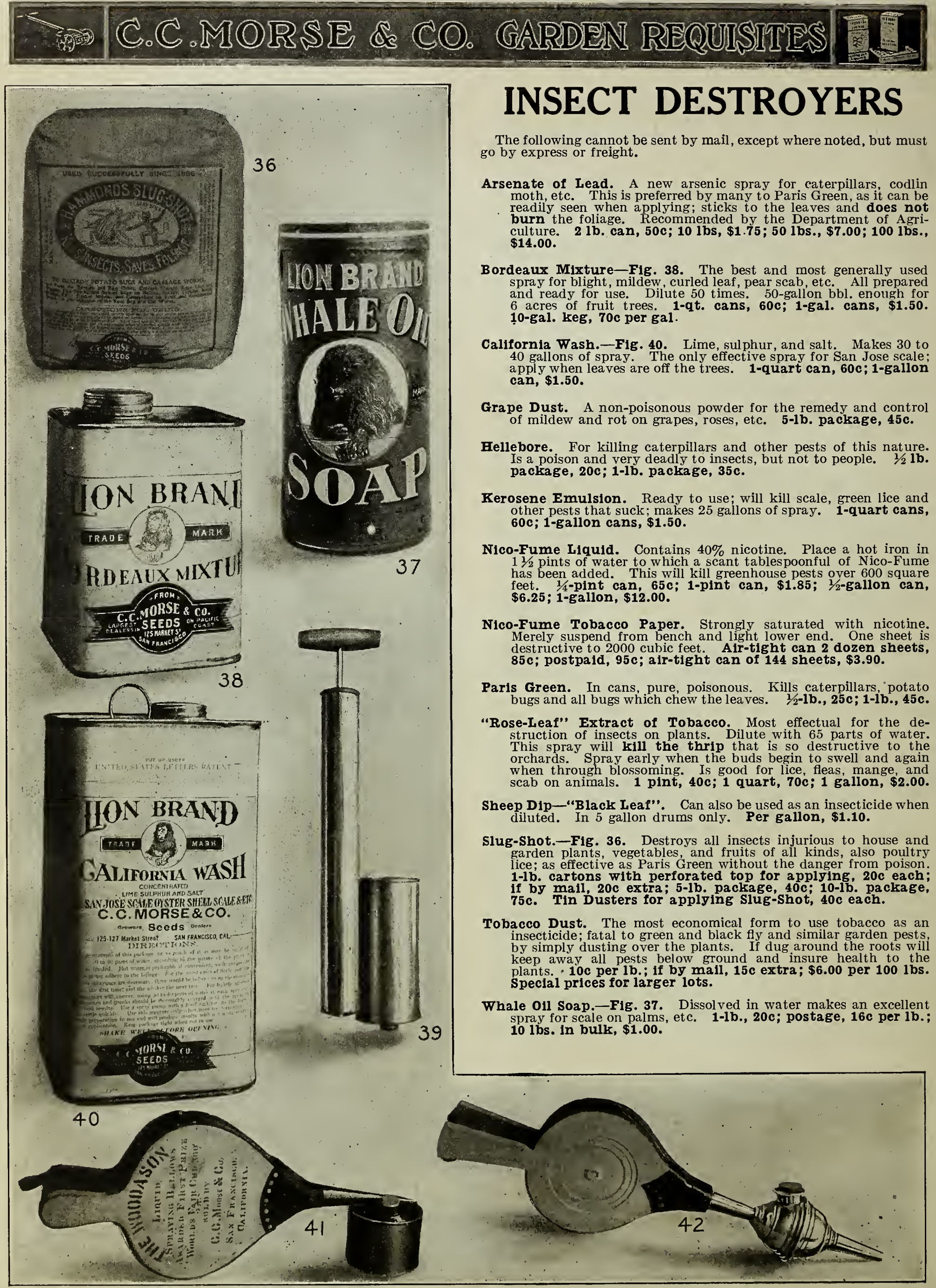


\section{INSECT DESTROYERS}

Sulpho-Tobacco Soap.-Fig. 46. A wonderful insect and bug exterminator 3-oz cake (makes $11 / 2$ gallons prepared solution) 10c: malled, postpaid, $13 \mathrm{c} ; 8-0 z$. cake (makes 4 gallons prepared solution), 20c; mailed, postpaid, $28 \mathrm{c}$.

Tobacco stems. In bales of about 50 lbs. at $3 \frac{1}{2} \mathrm{c}$ per $1 b$.

\section{APPLIANCES FOR INSECTICIDES}

\section{WOODASON BELLOWS AND ATOMIZERS}

These are the best made bellows; will last a long time and are very effective:

Bellows, Double Cone

Bellows, Large Single Cone, with spreader-Fig. 52

Bellows, Small Single Cone.

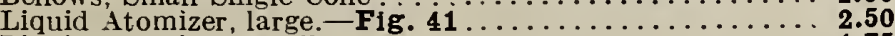

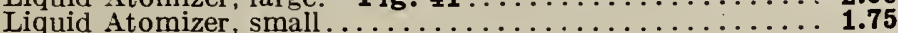

The Morse Garden Syringe.-Fig. 45. Polished brass, 18x1 1/2 inches, fitted with adjustable plunger; one coarse rose, one fine rose, and one jet spray. Best English heavy brass.

HEAVY BRASS SYRINGES-FIg. 45.

18-inch, $\$ 5.00$ each; with water drip, $\$ 5.25$.

20-inch, $\$ 6.00 \mathrm{each}$.

With quick-filling valves. 16-Inch, $\$ 4.50$ each; 18 -Inch, $\$ 5.50$; $20-$ inch, $\$ 6.50$.

Iadies' Garden Syringe.-Fig. 45. Polished blass, $16 \times 11 / 4$ inches, coarse and fine spray and jet. $\$ 4.00$ each.

Orchid Syringe No. 1. Polished brass, $18 \times 1$ 1/2 inches; quick filling valves; drip protector; one rose and five attachments for making mists. $\$ 6.00$ each.

Morse's Tin Sprayer.-Fig. 39. For spraying liquid insecticides of all kinds on plants, kerosene in chicken houses, etc. An all-round useful instrument and at a low price. $60 \mathrm{c} \mathrm{each;} \$ 1.50$ for three; with galvanized can, $75 \mathrm{c}$ each

Houchin Powder Bellows.-Fig. 42. In three sizes. $\$ 1.00, \$ 1.25$ and $\$ 1.40 \mathrm{each}$.

Lawn Force Pump.-Fig. 44. Good for whitewash, bailing boats and general spraying. $\$ 1.00$ each.

White Wash Pump.-Fig. 43. Galvanized iron, fine for chicken houses, fences, etc. $\$ 1.95 \mathrm{each}$.

Lightning Tin sprayer.-Fig. 47. With glass jar for holding the liquid. $90 \mathrm{c}$ each.

Meyers Bucket Pump.-Fig. 48. A standard force pump of heavy brass. \$3.25 each.

Large Floradora Powder Gun.-Fig. 49. Holds 1/2-lb. of powder. $40 \mathrm{c}$ each, postpaid.

Watering Pot.-Fig. 50. Galvanized iron, with brass fittings and two brass roses, one fine and one coarse, with each pot. 6-quart, $\$ 2.50 ; 8$-quart, $\$ 2.75 ; 10$-quart, $\$ 3.25$.

Jumbo Powder Gun.-Fig. 51. 30c each, postpaid.

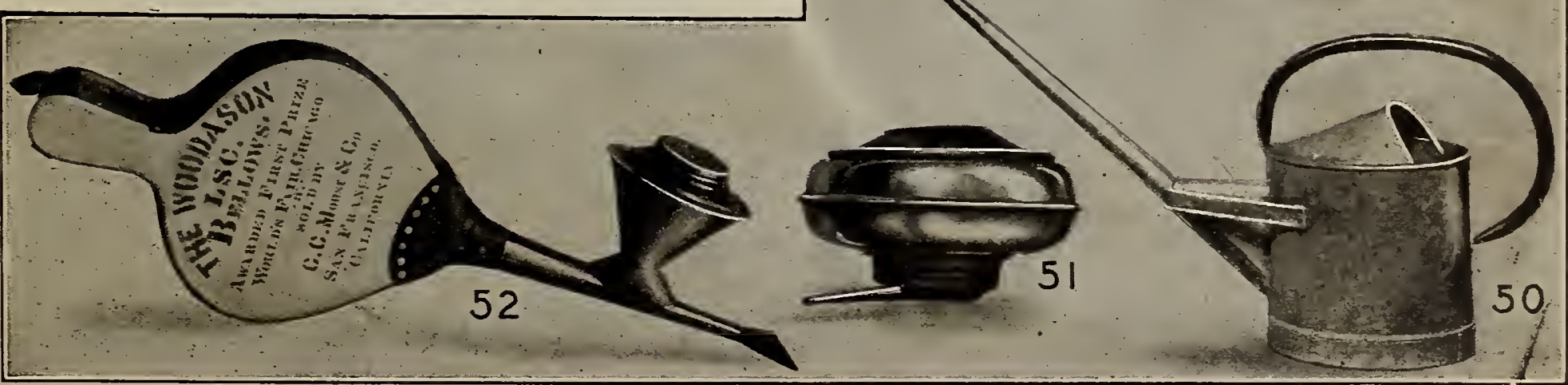




\section{THERMOMETERS}

Japanned greenhouse, 8-inch scale. Fig. E, 20c each; 6 for $90 \mathrm{c}$. Japanned greenhouse, 10-inch scale. Fig. E, 25c each; 6 for $\$ 1.30$. Japanned tin, black oxidized scale, a better thermometer than the above. We recommend this as a good all round thermometer. Fig. D, 50c each.

Spirit Thermometer, accurate, easy to read. $\$ 2.00$ each.

Maximum and minimum thermometer, records each day the extreme heat and cold, has a magnet to set the little steel stops which are left at the highest point each afternoon and at the lowest point each night, thus telling the range of temperature for the day. A high grade thermometer in a copper case. Fig. A, \$4.25 each. Maximum and minimum thermometer, records each day the extreme heat and cold, wood scale. Fig. C, $\$ 1.75$ each.

Mushroom and hot bed, brass point. Fig. B, $\$ 1.25$ each.

Mushroom and hot bed, extra fine, heavy brass. Fig. B, $\$ 2.25$ each.

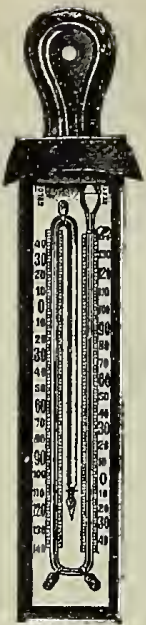

Fig. A

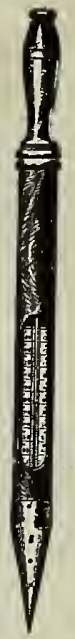

Fig. B

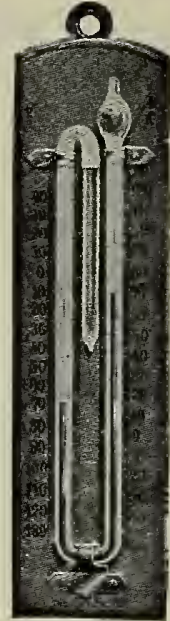

Fig. C

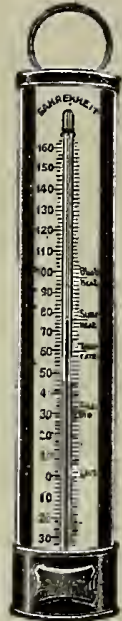

Fig .D

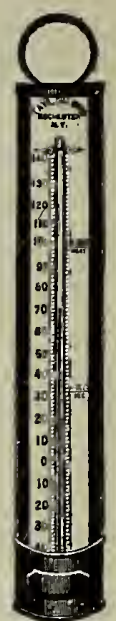

Fig. $E$

\section{LIST OF TOOLS, SPRAYERS,}

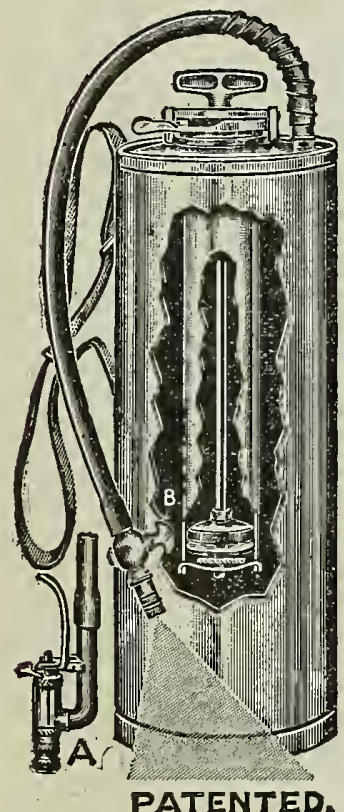

Brass Extension

Elbow.

Two-row attachment.

\section{AUTO SPRAY No. 1}

Fully guaranteed. The only practical compressed air sprayer and useful in every variety of spraying. For trees, shrubs, vines, up to five acres of field crops, disinfectants and small whitewashing jobs. The tank is made of either heavy brass or galvanized iron as ordered, and has a capacity round three gallons of solution. The pump is locked to the tank by a cam and can be removed or replaced by a simple twist of the wrist. The joint is made by direct pressure on a rubber gasket. The pump is of heavy brass, two inches in diameter, and two, or possibly three, pumpings will discharge the contents - under higher constant pressure than any other knapsack sprayer.

We" recommend a brass tank-will not We recommend a brass tank- 1 automatic hut-off operating a self-cleaning wire shut-off operating a self-cleaning wire packed in a wooden box, shipping weight 15 lbs.

Prices:

Auto-Spray No. 1 A-Brass tank with

Stop-cock. ............. $\$ 6.75$ Auto-Spray No. 1 B-Brass tank with 7.65 Auto-Pop.
Auto-Spray No. 1 C-Galvanized tank with Stop-cock............................... Auto-Spray No. $1 \mathrm{D}-$ Galvanized tank
with Auto-Pop................ 5.50 5.75 .45
.45
.90 .90

AUTO-SPRAY No. 3-B

The best all-round equipment in highpressure hand lever pumps.

While primarily built for supplying white-wash and cold water paints, the largest work of this nature being easily undertaken, it is also perfectly adapted to spraying all kinds of trees, plants, to spraying all kinds of trees, plants, shrubs, vines, etc. In fact, it is in every combined convenience of size with exceptional durability and high pressure, with price within reach of all.

The pump is made of heavy brass with adjustable packing. The tank is of eight gallons capacity made of heavy eight gallons capacity made of heavy galvanized iron and the cover is also instantly removed, exposing all working parts.

The machine is furnished complete with eight feet of high grade hose, eight foot extension, stop-cock and latest pattern Vermorel nozzle. Shipping weight 40 pounds.

Auto-Spray No. 3-A, brass tank (not in stock)..\$16.00

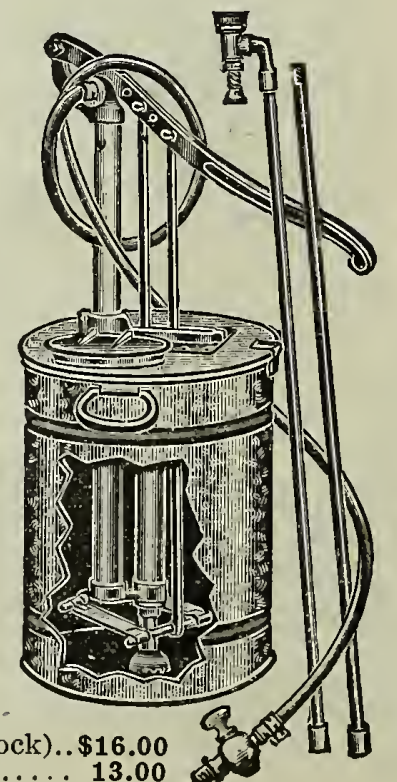

\section{ETC., JUST PUT IN STOCK}

Glazing Points. Sieberts never rust zinc glazing points for greenhouse use; in $5 / 8$ and $7 / 8$ inch size. Per $1 b$. 45c.

ophergo. This is a new poison for these troublesome pests. Gophergo consists of raisins soaked in strychnine and scented. They are very attractive to gophers and are sure death to them. Do not touch with hands the bait, but shove it down an open hole. Poisoned wheat comes in same can. Not allowed in the mails. Half size can, 25c; Can, 50c; Large Can, $\$ 1.00$; Ranch Can, $\$ 2.50$ each.

Squirrel Trap, Lightning. A heavy galvanized iron trap with a trigger quick as lightning. Set over open hole and attach to a stake with a wire. Can be used for other animals also. 35c each; $\$ 3.50$ per doz.

Garden Forks. Small steel hand forks for loosening the soil. Straight prongs, each 35c; Curved prongs, each $35 \mathrm{c}$.

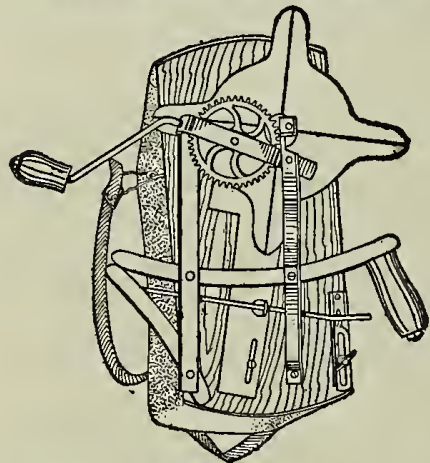

Lawn Rollers, Dunham's Gold Medal. Made with roller bearings so that they run $44 \%$ easier than any other sort Various thizes. Ask for prices.

SEED SOWER, IITTIE GIANT. For broad-casting all kinds of seed. Can be set accurately for any amount of seed per acre and for any variety; for barley, for any variety; for barley, 50 feet to the round. Little Giant 50 feet to the round. Little Giant has steel frame and pressed tin ounce duck and holds threequarters of a bushel. Each, $\$ 2.00$.

Pruning Shears, Hand. 9-inch................ Per pair $\$ 0.50$ 9-inch; nickle plated........Per pair 1.00 $81 / 2$-inch; Rieser pattern with nut to

tighten................ Per pair 2.00

Pruning Shears, Orchard-Rhodes Double Cut. The illustration shows the excepthis pruner; the jaws both have edges so that both

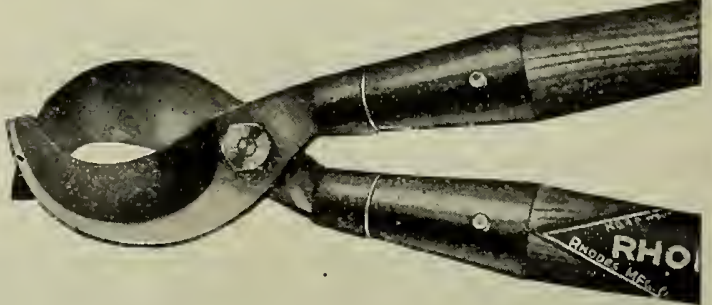
cut and leave the bark unbruised quickly. Most carefully made and a very powerful pruner ful pruner. Made with handles of inch lengths; 20 $30-$ in ch. Any length, each $\$ 2.40$.

Vaporite. A new insecticide for worms and bugs which are underground. With this you can protect your turnips, potatoes, etc., from wire worm and your orchard trees from root aphis and thrip. Dig the powder down into the soil. For large quantities write for quotations. Per can (about $1 \mathrm{lb}$.), 25c.

Yucca Tree Protectors. A perfect protection for young trees against rabbits, grasshoppers, sunburn frost, etc. The usual size is 7 inches wide and of various lengths. 12-inch, per 1000 $\$ 11.00 ; 18$-inch, per $1000, \$ 15.00 ; 24$-inch, per $1000, \$ 18.00$,

Planet Jr. Tools. These are garden hand implements such as wheel Hoes, Seeders and Cultivators. We are prepared to furnish these from warehouse in the city upon application. Ask for prices and descriptions. 
Ask for Diamond Anniver. sary Catalogue of

\section{IRON AGE}

Farm and Garden Imple-

ments. Gives Complete Description.
No. 6. COMBINED DOUBLE AND SINGLE WHEEL HOE, HILL AND DRILL SEEDER
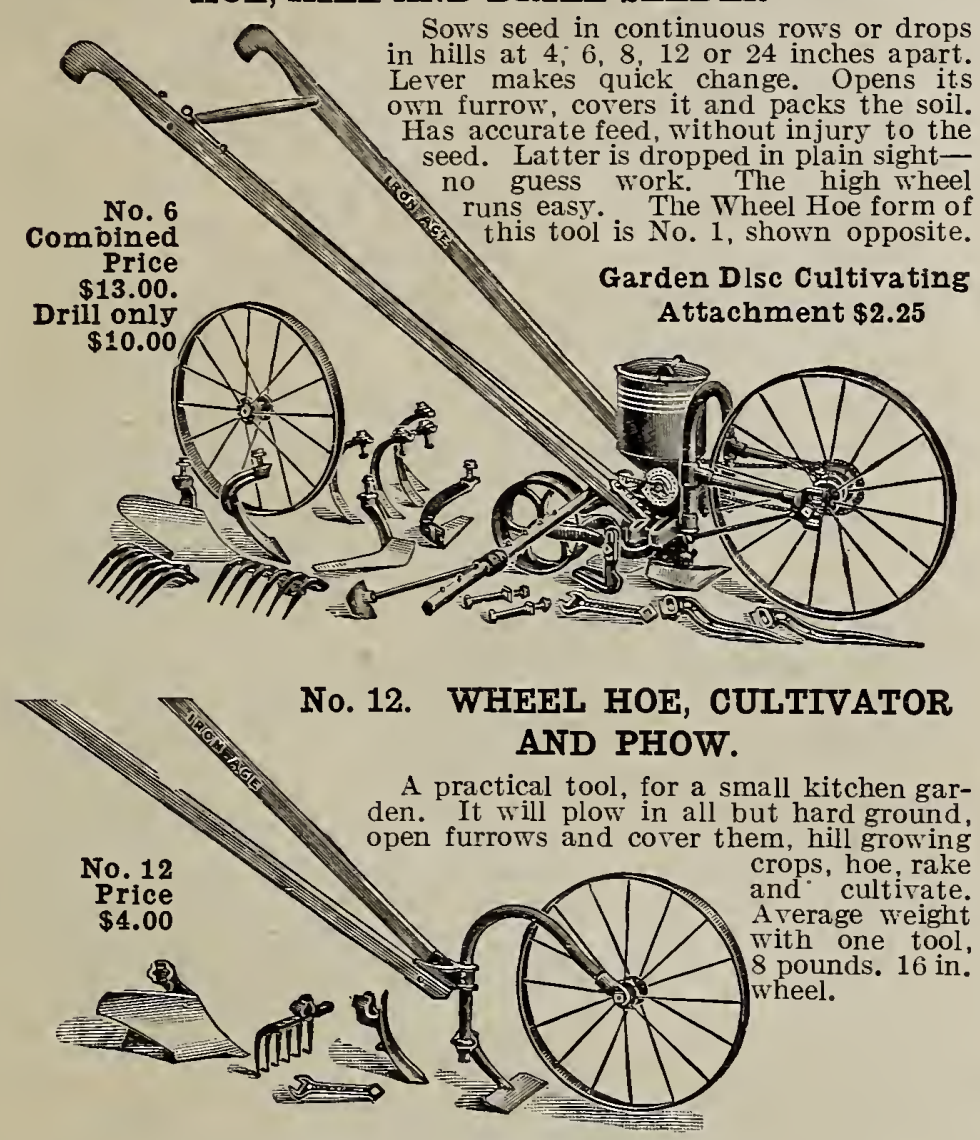

OTHER IRON AGE TOOLS

No. 9. Single Wheel Hoe, complete, $\$ 6.00$.

No. 13. Double Wheel Hoe (Side Hoes and Teeth only). \$6.25.

No. 20. Single Wheel Hoe, complete. \$6.65.

Catalog gives complete description of these and many others including Horse Hoes and Horse Cultivators. Ask for it.

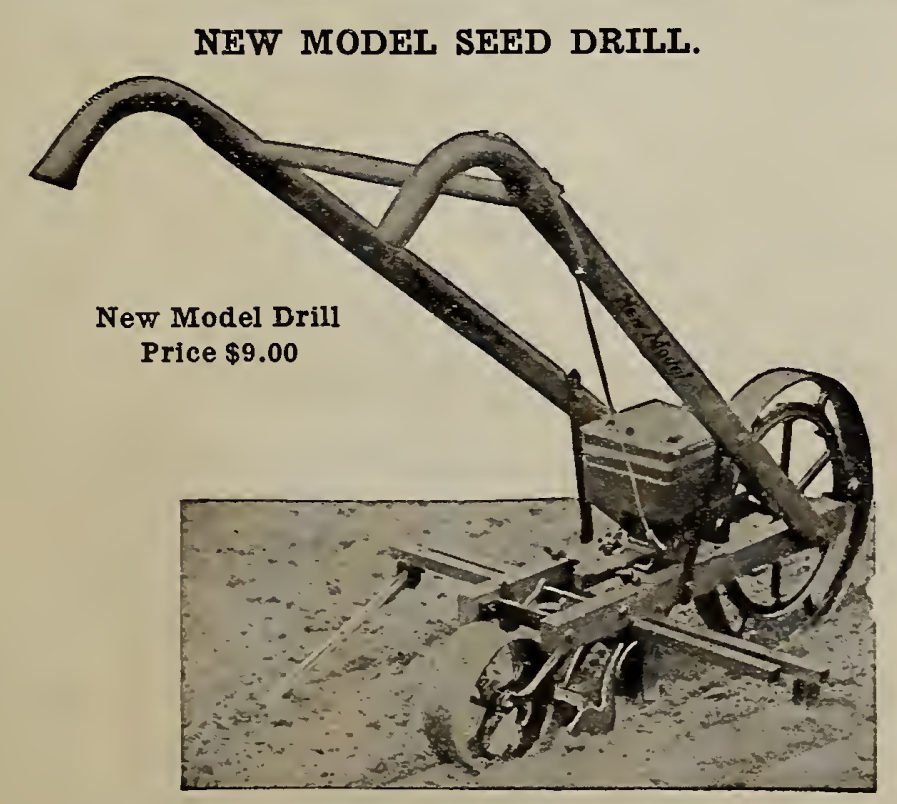

On our own extensive seed farms which are illustrated in the first few pages of this catalogue, we use the New Model Seed Drill exclusively. We have found by trying the different makes that this one is the best. The following are reasons which we ask you to consider:

1st. The New Ilodel will sow in rough, lumpy ground without retting clogged. Many of the light Eastern seeders are inefficient on heavy California soils, but not so with the New Model.

\section{No. 1. DOUBLE AND SINGLE WHEEL HOE.}

Opens and closes furrows, takes care of first working without danger to the young plants, goes astride or between the rows, cultivates, weeds, levels, etc. Does a day's wark in 60 minutes. Sa res oldright with this tool and weeds never get the best of you.

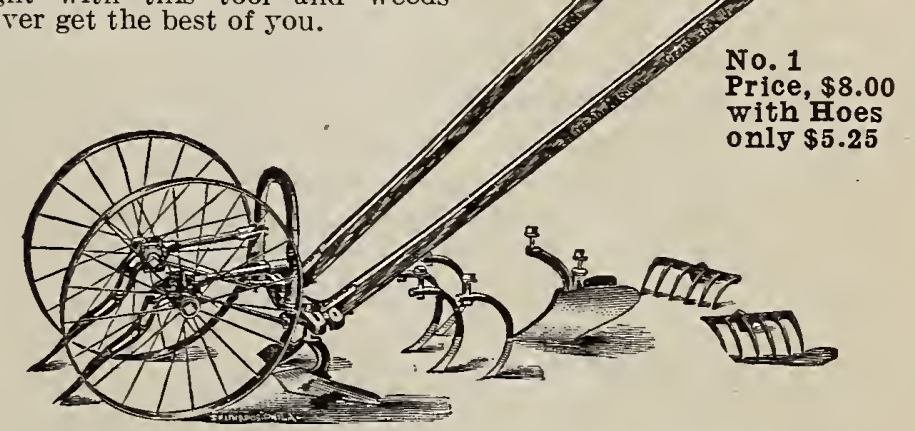

No. 19. WHEEL PLOW AND CULTIVATOR.

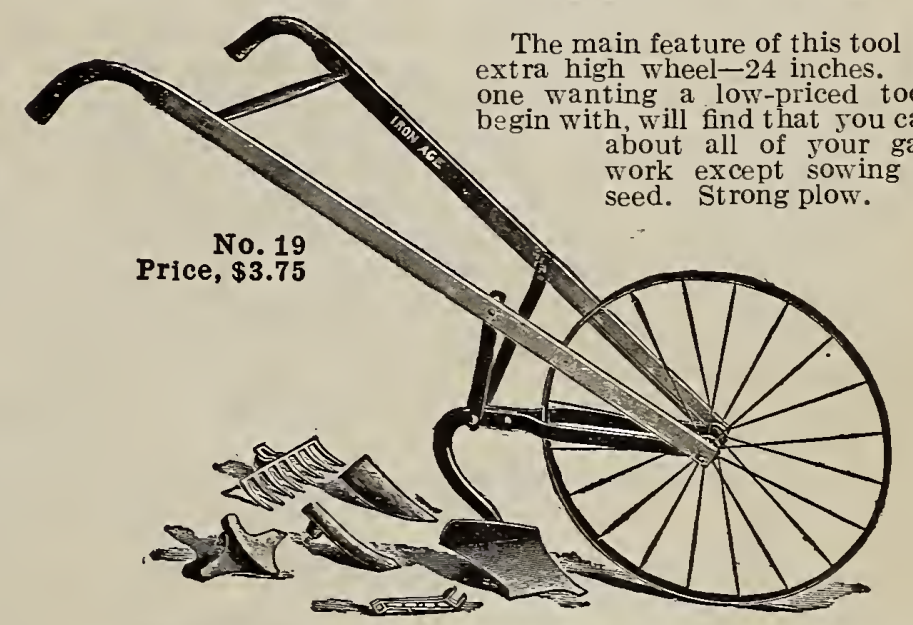

2nd. Can be perfectly adjusted to the finest difference in size between the different seeds.
3rd. New Model seeds evenly and cut-off is quickly and easily 3rd. New Model see

handled; is economical.
4 th. Main wheel is of large size anc width, so will not sink in soft earth. Handles are well bolted and adjustable in height; machine is easy to work.

5th. Opening plow is of steel. adjustable in depth; index shows at a glance how to set for the ordinary seeds. A well made and satisfactory seeder. It will save much labor and give a better stand than other methods of seeding.

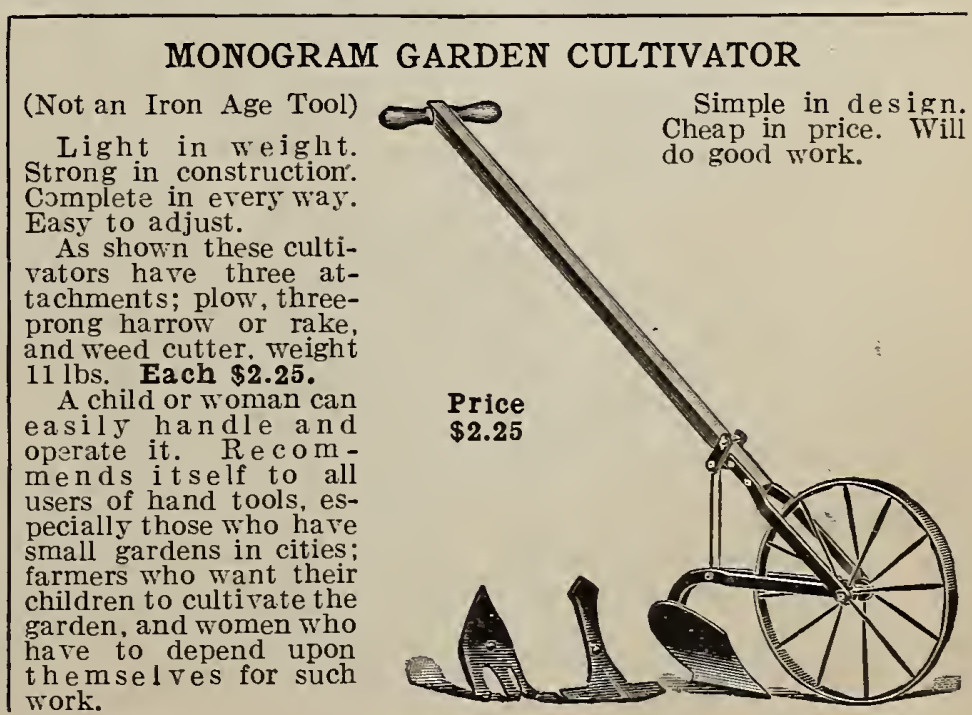




\section{SELECT LIST OF BOOKS By the Best Authors}

Postage must be added as follows: $5 \mathrm{c}$ for books priced at $50 \mathrm{c}$ and under; $10 \mathrm{c}$ for books priced over $50 \mathrm{c}$ to $\$ 1.50$; $20 \mathrm{c}$ for others.

A Woman's Hardy Garden. By Mrs. Ely $\ldots \ldots \ldots \ldots \ldots \mathbf{\$ 1 . 7 5}$

Alfalfa. By F. D. Coburn....................5

Apple Culture. By Prof. L. H. Bailey. Giving much valuable instruction on the subject of this fruit, from planting to picking.

Asparagus. By F. M. Hexamer.

Asparagus Culture. By Wm. Robinson.

Barn Plans and Out Bulldings. By practical writers.

Broom Corn and Brooms. A treatise on raising broom corn and making brooms on a small or large scale.......

Callfornia Fruits and How to Grow Them. An authoritative book on California fruit raising. Complete on fruit trees, nuts, berries. A book needed by every grower. By Prof. E. J. Wickson .....

California Vegetables in Garden and Field. By Prof. E. J. Wickson. Tells all about vegetable raising in this State. Prof. Wickson is Dean of the Agricultural College and is an authority. New edition......

Carrots, Mangelwurzels, Etc. By J. J. H. Gregory. How to raise them, how to keep them and how to feed them.

Cyclopedia of American Horticulture. Comprising suggestions for cultivation of horticultural plants, descriptions of the species of fruits, vegetables, flowers, and ornamental plants sold in the United States and Canada, together with geographical and biographical sketches. An invaluable book of information and reference. Is a modern work of authority and is used by the Agricultural Departments. By Prof. L. H. Bailey, assisted by Wilhelm Miller and many experts. 4 vols...

Encyclopaedia, Nicholson's. With colored plates. The standard English work. 4 vols. and supplement.

Farm Appliances.

Farm Drainage. By Judge French. Describes the principle, process, and effects of draining land, and other valuable information....

Fences, Gates, and Bridges. A much-needed and valuable work, abundantly illustrated.

Fertilizers. By J. J. H. Gregory....

Fertilizers. By Voorhies....

Flowers, and How to Grow Them. By E. E. Rexford....

Forage Plants Other Than Grasses. By Thomas Shaw 287 pages scientific, accurate information on this subject

Forcing Book. By L. H. Bailey $\ldots \ldots \ldots \ldots \ldots \ldots \ldots \ldots$
Forestry, Practical. B. A. S. Fuller. A treatise on the propagation, planting and cultivation, with a descripdigenous trees of the United States.

Fumigation Methods. By Willis J. Johnson. Showing simple and effective means of exterminating insect pest and vermin.........

Gardening in California: Landscape and Flower. By John McLaren, for many years past superintendent of the Golden Gate Park. Mr. McLaren has had a wide experience in California horticulture, the results of which he gives in the pages of this book. Deals exclusively with California plants and flowers..............

Garden Making. By Prof. L. H. Bailey. Instructions for beginners and for the skillful gardener. Covers the whole subject, laying out and planning small city yards and large suburban grounds, plants, trees, bedding, pruning, vegetables, fruits; scientific truths in simple language......

Gardening for Pleasure. By Peter Henderson. Tells how to grow flowers, vegetables and small fruits in the garden and greenhouse; also treats fully on window and

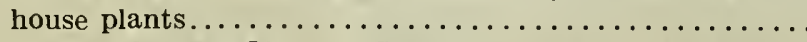

Gardening for Profit. By Peter Henderson. A guide to the successful culture of the market and family garden....
Grape Culturist. By A. S. Fuller. One of the best works on the cultivation and management of hardy grape..... \$1 .50

Grasses and Forage Plants. By Charles L. Flint. Accurately described in a work of 400 pages, containing nearly 200 illustrations of our most common grasses and and a large number of others not so well known......

Handbook of Plants. By Peter Henderson. A concise and comprehensive dictionary on plants, with instructions on propagation and culture................

Horticulturist Rule Book. By Prof. L. H. Bailey. Full of useful information for fruit grower, truck gardeners,

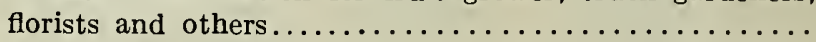

Irrigation Farming. By Lucius Wilcox. The application of water in the production of crops, appliances, prin-

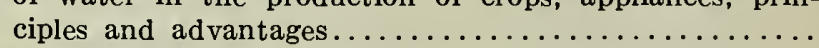

Irrigation for Farm, Garden and Orchard. By Henry Stewart. Methods and management to secure water

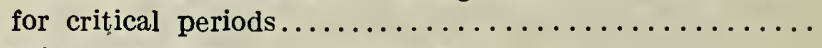

Kings's Irrigation and Drainage............... 1.60

Making Manures. Boomer's methods. A practical and comprehensive guide for making manures on the farm.

Mushroom Culture. By Wm. Robinson. A practical guide to successful production of this crop................

Nursery Book. By Prof. L. H. Bailey. This is a complete handbook of propagation of plants. Tells in plain language what every one who sows a seed, makes a cutting, or sets a graft wants to know...............

Onion Culture. By T. Greiner. For the home garden of the market; new and highly valuable methods are de-

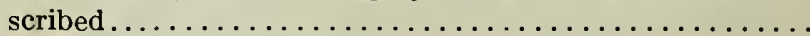

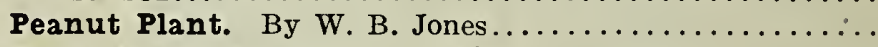

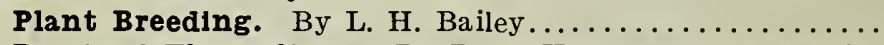

Practical Floriculture. By Peter Henderson. As a guide to the successful propagation and cultivation of florists' plants nothing has been left unsaid..............

Practical Garden Book. By L. H. Bailey. Tells how to grow and propagate all the common garden plants, both vegetables and flowers, in a clear and helpful way. A good book............................. 1.00

Principles of Agriculture. By L. H. Bailey......... 1.25

Principles of Vegetable Gardening. By L. H. Bailey.... 1.50

Pruning Book. By Prof. L. H. Bailey. Where, how and when to prune fruit and ornamental trees and shrubs.... 1.50

Rose, The. By H. B. Ellwanger. Contains full directions for planting, pruning, propagating, and valuable in

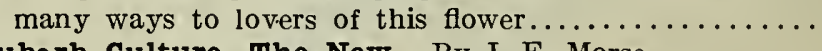

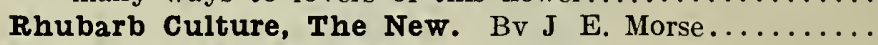

Silos, Silage and Ensilage. By Manley Miles..............

Small Fruit Culturist. By A. S. Fuller. Rewritten, enlarged, and up to date......................... Insects and

Spraying of Plants. By Prof. Lodeman. Insects and fungi; liquids and powders.......................... Full directions for field and garden culture, forcing or pot culture,

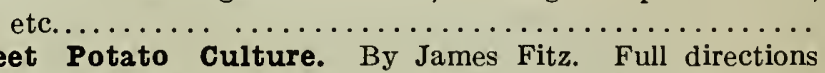
from starting the plants to harvesting and storing......

Swine Husbandry. By F. D. Coburn. Breeding, rearing, and management, treatment, and preservation from disease $\ldots \ldots \ldots \ldots \ldots \ldots \ldots \ldots \ldots \ldots \ldots \ldots \ldots \ldots$

The Garden Book of California. By Belle Sumner Angier. Beautifully illustrated...................... Tobacco Culture. Full practical details by fourteen experienced growers in different sections of the country....
ald Flowers of California. By Mary E. Parsons and Margaret W. Buck. Learn the wildflowers. Nothing will give you more pleasure, and this book is so well written and so well illustrated that anybody can pick

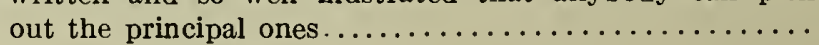




\section{SAN FRANCISCO, CAILIFORNLA. U. S.A}

\section{FOREIGN NAMES OF VEGETABLES}

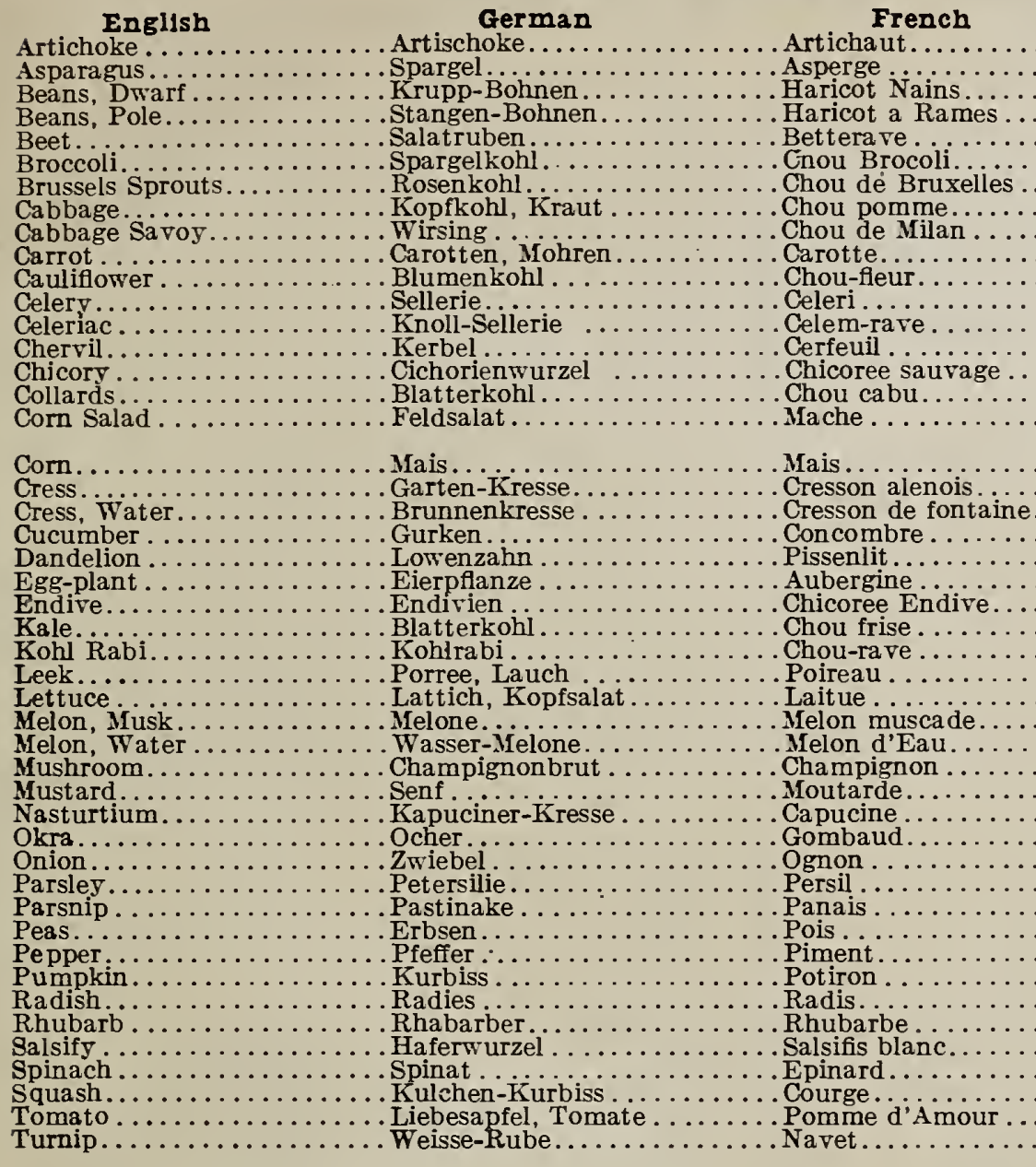

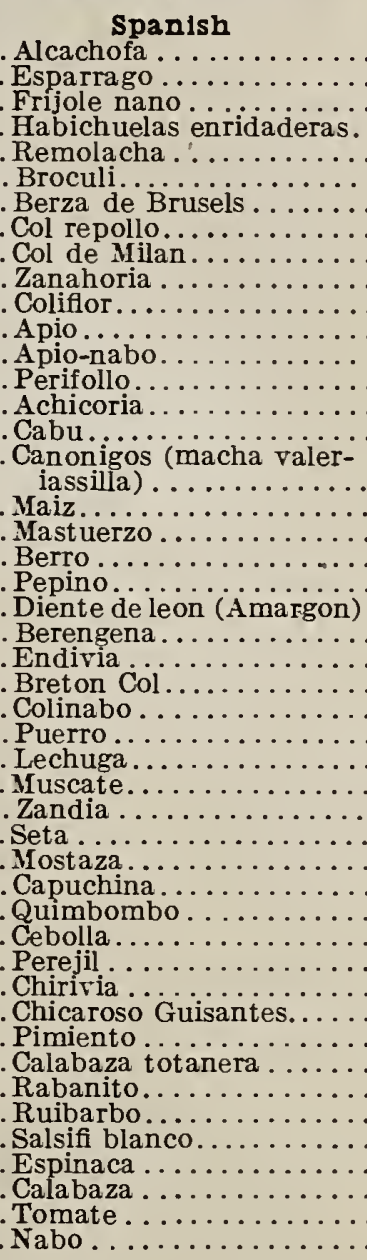

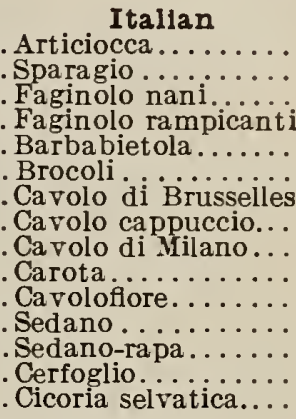

Valeriana

Mais...

Nasturzio aquatico

Cetriolo.

Dente di leone.

Petronciano

Indivia

Cavolo verde

Cavolo rapa

Lat tuga

Popone

Melone d'aqua

Fungo pratajolo.

Nasturzio

Ocra.

Cipollo....

Pastinaca

Pisello.

Peperon

Ravanelio.

Rabarbaro

Sassefrica

Spinace.

Zucca.

Pomo d'ore

\section{INDEX}

\section{GARDEN SEEDS, CLOVERS, GRASSES, TOOLS AND MISCELLANEOUS}

Acacia. See Tree Page Acacia. See Tree Seeds 43 Alfalfa ........... 40 Alfalfa, Arabian...... 40 Artichoke........... 42

Asparagus . Balit Bush. . ${ }_{42}^{7}$

Beans . . . 8, 9, 10, 11, 12

Beans, Soja, Velvet...4 4

Beets ............ 13

Bird Seeds ......... 42

Broccoli.

Brussels Sprouts....... 1

Buckwheat...........4 42

Cabbage.........14, 15

Canary .............. 42

Carrots ........... 16

Celeriac............ 17

Celers.

Chervil .

Chicory

$\begin{array}{lll}\text { Classification ......... } & 46 \\ \text { Planting Directions... } & 49\end{array}$

Abronia.

Abutilon.

Achillea....

Acroclium

Adonis.

Agera tum.

Agrost ema

Alyssum.

Amara nthus.

Anemone.

Arctot is . . . . . . . . .

Aristolochia (or Dutch-

man's Pipe) ....... 51

Labels, Wooden . . . . . . 120

Brach vcome....... 52

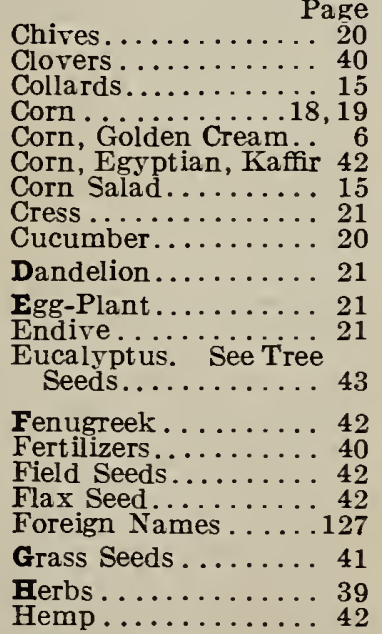

INDEX TO FLOWER SEEDS
Horse Radish Roots . . 39

Hot Beds . . . . . . . . . 50
Hose, etc 120

Implements . . . . . . . 125

Insecticides . . . . . . 12

Kale .

Kent ucky Blue Grass . 40
Kohl Rabi. ........ 22

Lawn Grasses........ 40

Lawn llowers.

Let tuce........... 23,2

Lettuce, Los Angeles..

Mangels. See Beets

Martynia...

Mushroom Spawn.

Muskmelon

Mistard . . . ........ 27

Okra ............ 27

Onion $\ldots \ldots \ldots \ldots 28,29,30$
Onion, Ailsa Craig... Page Onion Sets . ........ 30

Parsley

Parsnip.

Paspalum

Peas..... . 31,32

Peas, Cow, Niles Canadian Field, Whip-

poorw

Pepper

Pepper, Sweet Upright 33

Plants of Vegetables .. 39

Pruning Shears ....... 125

Radish

Raffia ................ 34

Rape, Dwarf Essex ... 42

Rhubarb.

Ruta Baga. . $\ldots \ldots \ldots \ldots . . .3$

Seeds...........4 40

Salsify

\section{AND BULBS}

Armeria . Asparagus Plumosus... 52 Asparagus Sprengeri.. 52

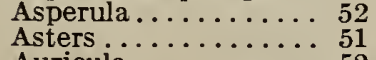

Bignonia (Trumpet Boston $\mathrm{I}$

Browallia ........... 5

Bulbs............48

Australian Pea vine

(Dolichos Lignosus) 52

Bachelor's Button(Cen-

taurea Cyanus) ....5 56

Balloon Vine ....... 52

Balsa m.

Bartonia............ 52

Begonia..........5 5

Begonia Bulbs....... 48
Cacalia (Tassel Flower) 53

Calampellis (Bugle

Calandrinia..........

Calceolaria............ 5

Calendula .............

California Popp

(Eschscholtzia) ....5 58

Calliopsis ......... 53
Campanula (Canter-

bury Bells).....53,54 Canary Bird Flower... 53 Candytuft........ 53 Canna ........... Canterbury Bells...53, 54 Castor Oil Bean....... 55 Celosia Cristata...... 55 Celosia Plumosis ..... 55 Centranthus.

Centrosema

Chrysanthemum ..... 5

Cineraria......... 56

Clarkia........... 55 Centa urea.......... 56
Seasons to Plant .... Page

Sorrel . . . . . . . . . . 3.35

Speltz or Emmer .... 42

Spinach.......... 35

Spra yers, Pumps . 123, 125

Squash .............

$\ldots \ldots . .36$

Sugar Cane

Sunflower.

Swisschard

Teosinte.

Thermomete...... 42

Tobacco

Tobacco Extracts . . . . 122

Tomato......... 3720 to 125

Tools ........120 to 125

Turnip............. 38

Vetch .................. 42

Watermelon......... 26

Wild Rice......... 42

Clematis .......... 56

Cleome Pungens (Spider

Plant).

Clianthus

Cobaea Scandens..... 57

Coleus ............ 57

Collinsia.

Columbine

Coreopsis .

Coxcomb (Celosia).... 55

Cyclamen ......... 57

Dahlia............ 57

Daisy, Double (Bellis) 52

Daisy, Giant Scarlet.. 72 


\section{C.C.MORSE \& CO. PLANTS \& TREES}

\section{INDEX TO FLOWERS AND BULBS-Continued}

Page
ij 57

Daisy, Shasta...... Fi.) 57

Delphinum (Larks spur)........... 62 Dianthus (or Pinks) 57,58 Diantilus (or Pinks) 57, 58
Digitalis, Foxglove ... 58 Dolichos, (Hyacinth Beans) Dusty Miller. S. See Cen- 58 taurea Candidisima 56

Echinocystis, Wild $\mathrm{Cu}$ -

cumber Vine.

Edelweiss .....

Eschscholtzia

Euphorbia ........ 58

Everlasting Pea. See Lathryrus Latifolius 62 Evening Primrose. See
Oenothera........ 65

Feverfew. See Matri$\begin{array}{ccc}\text { caria . . . . . . . . . } 59 & 59 \\ \text { or Pyrethrum..... } & 69\end{array}$ $\begin{array}{ccc}\text { or Pyrethrum...... } & 69 \\ \text { Flax. See Linum.... } & 62\end{array}$ $\begin{array}{ll}\text { Forget-me-not ....... } 59 & 59 \\ \text { Four O'Clock }\end{array}$ $\begin{array}{ll}\text { Four O'Clock } & \\ \text { Foxglove. See Digitalis } & 59\end{array}$ Fuchsia...

Gaillardia.

Geranium .......... 60

Gerbera Jamesoni . . . 72

Gilliflower. See Stocks 71-2 Gladiolus Bulbs.....47, 48 Gladiolus Bulbs... . . . . . 59 Gloxinia

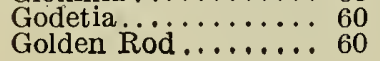

Gomphrena (or Globe

Amaranth)....... 60

Grasses, Ornamental. . 60

Gypsophila (Baby's 60

Breath).
Belenium.

Helichrysum

Heliotrope

Honesty (or Sätin

Hollyhor).

Hollyhock ........... 61

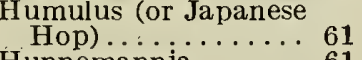

Hunnemannia ........6. 61

Ice Plant

Impatiens Sultani .... 61

Japanese Hop (Humu-

$\begin{array}{ll}\text { lus) } \\ \text { Job's Tears (Coix L.). } & 61\end{array}$

Kennedya .........6 62

Kennilworth İy...... 62

Kudzu vine.......... 62

Lantana

Larkspur ............ 62 Grass............ 65

Lathatera Latifolius .

Lavatera.

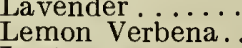

Leptosyne

Lilies. (Bulbs)

Lobelia.
Lophospermum Scan-

Lupins.

Lychnis.......66 63

Mandevillea Suav.

Marigold . . …..... 6

Marigold (Calendula) .

Marguerite. See Chrys-
anthemum, Frutescens : . $\ldots \ldots$ Sé

Matricaria...

Maurandia

Mignonette.

Mina Lobata

Momordica (Bäisam

Apple, Balsam Pear) 64

Moonflower. See Ipo-

moea Alba ........ 61
Morning Glory

Morning Glory..... Se 64

Scabiosa...... . . ..

Musk Plant. See Mim-
ulus Moschatus ... 64

Nasturtium . . . . .64,65

Nemophila, or Love

Nicotiana, or Flower-

ing Tobacco......
Nigella . . . . 65

Oenothera

Oxalis

Pampas Grass ...... 60

Pansy . ............ 66
Passion Flower. . . . 67 Marvel of Peru. See
Four O'Clock ..... 59
Pelargonium. See Page Geranium ........ 60 Pentstemon ......... 67

Perilla.

Petunia..........

Phlox Physalis Francheti. .. 68 Pinks. See Dianthus

and Carnation ..... 5

Platycodon ......... 67

Poppy .....

Primula or Primrose . 69

Pyrethrum...... 69

Rhodanthe........ 69

Ricinus (Castor Beans) 55

Romneya Coulteri or

Matilija Poppy . . . . 69

Rudbeckia........ 69

Salpiglossis . . . . . . . 69

Salvia or Flowering

Sage $\ldots \ldots \ldots \ldots 69,70$
Santolina $\ldots \ldots \ldots \ldots .70$

Sanvitalia ............ 70

Scabiosa ......... 70

Senecio (Tall Jacobea) 70

Silene, or Catchfly.... 70

Smilax $\ldots \ldots \ldots \ldots \ldots 70$

Snapdragon .......... 70

Solanum .......... 70

Statice (Sea Lavender) 70

Stevia .......... 71,71

Stocks.

Sunflower.
Swan River Daisy. See Brachycomb...... 53

Sweet Peas...... 74 to 78

Sweet Pea Novelties.

See page 2 of cover.

See page 7

Sweet Peas. General

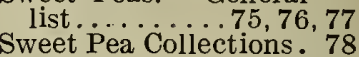

Sweet Rocket, Hes-

peris .i.... se... 72

taurea Moschata ... 56

Sweet William...... 72

Sweet Woodruff, or

Thunbergia, Black

Thunbergia, Black

Eyed Susan ...... 72

Transvaal Daisy . . . . 72

Tritoma $\ldots \ldots \ldots 72$

Torenia.......... 72

Valerian ........ 72

Verbena . . . . . . . 72, 73

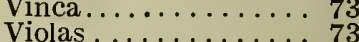

Violet . . . . . . . . . 73

Virginia Creeper . . . . 73

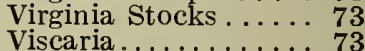

Wallflower ........73 73

Wild Cucumber Vine.

See Echinocystis

Wistaria ......... 73

Xeranthemum ...... 73

Yellow Calla Lily . . . 48

Zinnia.......... 73

\section{INDEX OF PLANTS AND TREES}

Abies............ 88 Abutilion $\ldots \ldots . . . .108$ Achania ............ 109 Achyranthus . . . . . . . . . 109
Adiantum. Akebia . . . . . . . . . . . . 999

Almonds . . . . . . . . . . 114

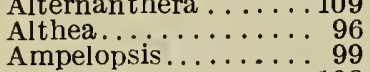

Ampelopsis . . . . . . . . 99

Anthericum . . . . . . . .

Apples............. 112

Apple, Crab, Flowering 97 Araucarias, Assorted. . 89 Arbor Vitae........ 94

Arbutus

Ardisid

Asparagus Fern....... 96

Aspidistra ............ 102

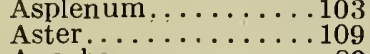

Aucuba............... 89

Australian Pea Vine.. 99

Bamboo....... 89

Banana, Abyssinian . 102

Beautiful Streets..... . 96

Begonias, Bedding .... 109

Begonias, Tub.Rooted 109

Berberry

Bignonia

Birch ..........996

Blackberry...$\cdots \cdots \mathrm{See}^{118}$
Boston Ivy.

Ampelopsis .........

Boston Fern

Nephrolepsis . . . . . . .

Bougain villea ....... 100

Box Tree......... 89

Brahea .. ....... 101
Breath of Heaven ... 91
Broom........... 89

California Big Tree... 90 California Fan Palm ..101 California Live Oak... 90 California Native Trees 91
Calycanthus......... 96 Campanula.

108
Camellias .......... $90 \quad$ Figs ................ 115 Campanula............. Camphor Tree.

Carnation

Casuarina.

Catalpa

Cedar.

Chamoerops

Cherries ............. 113

Cherry, Flowering . . . 97
Chestnut....97 and 116

Chestnut .....97 and 116
Chrysanthemum ..... 107

Cineraria ............ 110

Clematis, Assorted .... 99

Climbing Plants...... 99

Coleus.

Corypha.

Corchorus.

Coreopsis

90

Crab Apples........... 113

Crassula .

Crataegus .............. 91

Cryptomeria........9.917

Cycas................. 101

Cyclamen ............... 102

Dahlias . . . . . . 103 to 106

Dahlias.

....... 110

Daphne.

Delphinum .

Deutzia.

. . . 108

Diosma............ 91

Distances to Plant....119

Echeveria.........110

Elaeagnus......... 93

Erythea .............

Escalonia ............ 93

Eucalyptus, Assorted . 91

Eulalia............101

Eunoymus . . . . . . . 93

Fabiana . . . . . . . . . 93

Ferns ..................

Ficus, Repens ........100

Fuchsia............. 111 to

Gaillardia . . . . . . . 108

Gazania............. 110

Geranium ................ 107

Gooseberries........... 117

Golden Feather.........110

Grapes............ 116

Guava.............. 116

Habrothamnus . . . . . 93

Haw thorn. See Thorn ...

Heath $\ldots . . \ldots \ldots \ldots 93$

Helianthus . . . . . . 108

Holly ............993

Honeysuckle $\ldots \ldots \ldots \ldots 100$

Hop Vine ........100

Hydrangea....97 and 110

Iris, Japanese....... 108

Jasmine . . . . . . . . . 100

Jerusalem Cherry..... 110

Juniper..........993

Kentia............ 101

Laburnum . . . . . . . . . 97

Latinia .............

Laurel ............ 93

Laurustinus . . . . . . . . 93

Lemons ... . . . . . . . 115

Lemon Verbena..... 97

Leptospernum...... 93

Libocedrus

Lilac. . .

Limes.

Iippia .

Lobelia

Maple ........... . 98

Marguerite ......... 110

Metrosideros.......... 93 


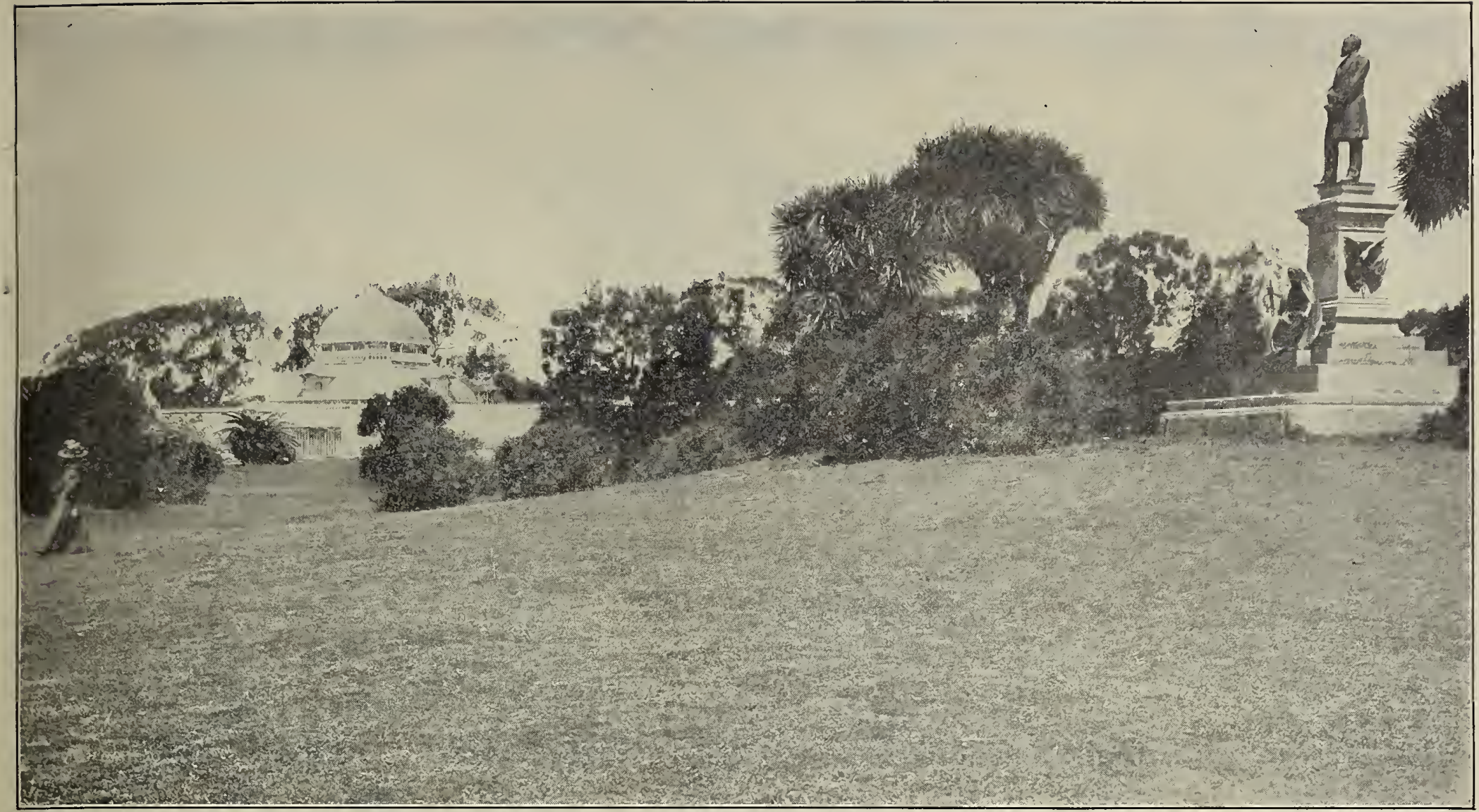

$\theta \otimes \theta$ GRASSES FOR LAWNS. $\theta \otimes \theta$

The finest lawns, which have that dark-green rich look both summer and winter, are made from mixtures of lawn grass seeds properly proportioned for the soil and the climate. The illustration above is one of the fine lawns in Golden Gate Park in San Francisco, which uses each year large quantities of our fine lawn grasses. If you want lawns as good as those in the Park, use our fine seed and as much care as they give, and you can have around your own home just as good a lawn as any in Golden Gate Park.

\section{Morse's California Lawn Mix-}

ture contains only the finest leaved grasses in the correct proportion to make a good fine turf which will wear as no other can and will still look well summer and winter. By express or freight, per lb., 35c; per 100 lbs. $\$ 30.00$. Postpaid per lb.45c.

\section{Pacific Rye Grass (Morse's). The} best grass for a straight lawn in any sandy soil such as is about San Francisco. Pacific Rye Grass is like the hardy Australian Rye Grass, but is longer lived and of a much finer leaf, thus having the advantages of the older sort without its disadvantages. By express or freight, per lb., 25c; per 100 lbs, $\$ 20.00$........... Postpaid per lb. 35c

\section{Morse's “Golden Gate Park" Lawn}

Mixture contains the more hardy grasses which are used to make the sod for the park playgrounds, where the grass has to endure much tramping over. The mixture also contains a very little white clover. By Express or freight, per lb., 35c; per $100 \mathrm{lbs}$, $\$ 30.00 \ldots \ldots \ldots \ldots \ldots$........... Postpaid per lb. 45c. Australian Rye Grass. For many years the only lawn grass for sandy soils like San Francisco, and still very popular. Australian Rye Grass makes a very hardy, bright green lawn and, if treated with care, a very satisfactory one. By express or freight, per 1b., $15 c$; per $100, \$ 10.00$.

Kentucky Blue Grass Postpaid per lb. 25c.
ass makes a lawn of a
llowish during the cold weadark-green color, which gets yellowish during the cold weais a good lawn grass. By express or freight, per lb., $35 \mathrm{c}$; per IOO lbs., $\$ 32.50 \ldots \ldots \ldots \ldots \ldots$. Postpaid, per lb., $45 \mathrm{c}$.

\section{Morse's Special Shade Mixture.} If you are troubled by a shaded spot in your lawn under some tree, where grass ordinarily will not grow, plant our "Special Shade Mixture," and you will soon have a lawn there as good as elsewhere. Our mixture is made from natural wood grasses which grow in shaded places, and for such locations it is unequalled. By express or freight, per lb., 55 c................... Postpaid per lb. 65c.

White Clover. This is the little dwarf growing clover used for lawns in many places, especially around Berkeley, with much success. The color is dark green, the leaves are small and close together, making a desirable lawn. The chief advantage, however, is that white clover roots deeply and so requires less care and water and still looks well. By express or freight, per lb., $35 \mathrm{c}$; per Ioo lbs., $\$ 30.00$

\section{A FEW SUGGESTIONS ON LAWN MAKING}

Prepare the soil well; this means spade it over and dig in some fertilizer or manure. Let the ground stand a month, or else do not apply fertilizer until grass is three months old. Two weeks before planting roll and water the ground well and before sowing the seed hoe the soil, but do not spade it, and roll again.

Sow the seed evenly and roll it in or sprinkle a good cover of sandy loam over it. Where a roller is not available rake the grass in lightly and press down by patting with spade. Water twice a day until the grass comes up. In stiff clayey soils, if planting in summer, use straw or leaves to protect the germinating seeds until the grass is an inch high. Make the lawn any time of year when there is water to irrigate and the ground does not freeze.

Use one pound of seed to 250 square feet of lawn. Keep free from weeds, water well, and keep cut regularly.

Use fertilizer (a good one is our Odorless Lawn Dressing, $50 \mathrm{lbs}$., \$2.00; 100 lbs., \$3.50) when the growth is poor and the grass needs invigorating. 
MARIE CORELLI

$$
\left(\frac{1}{3}\right.
$$

PKT. 15 CTS

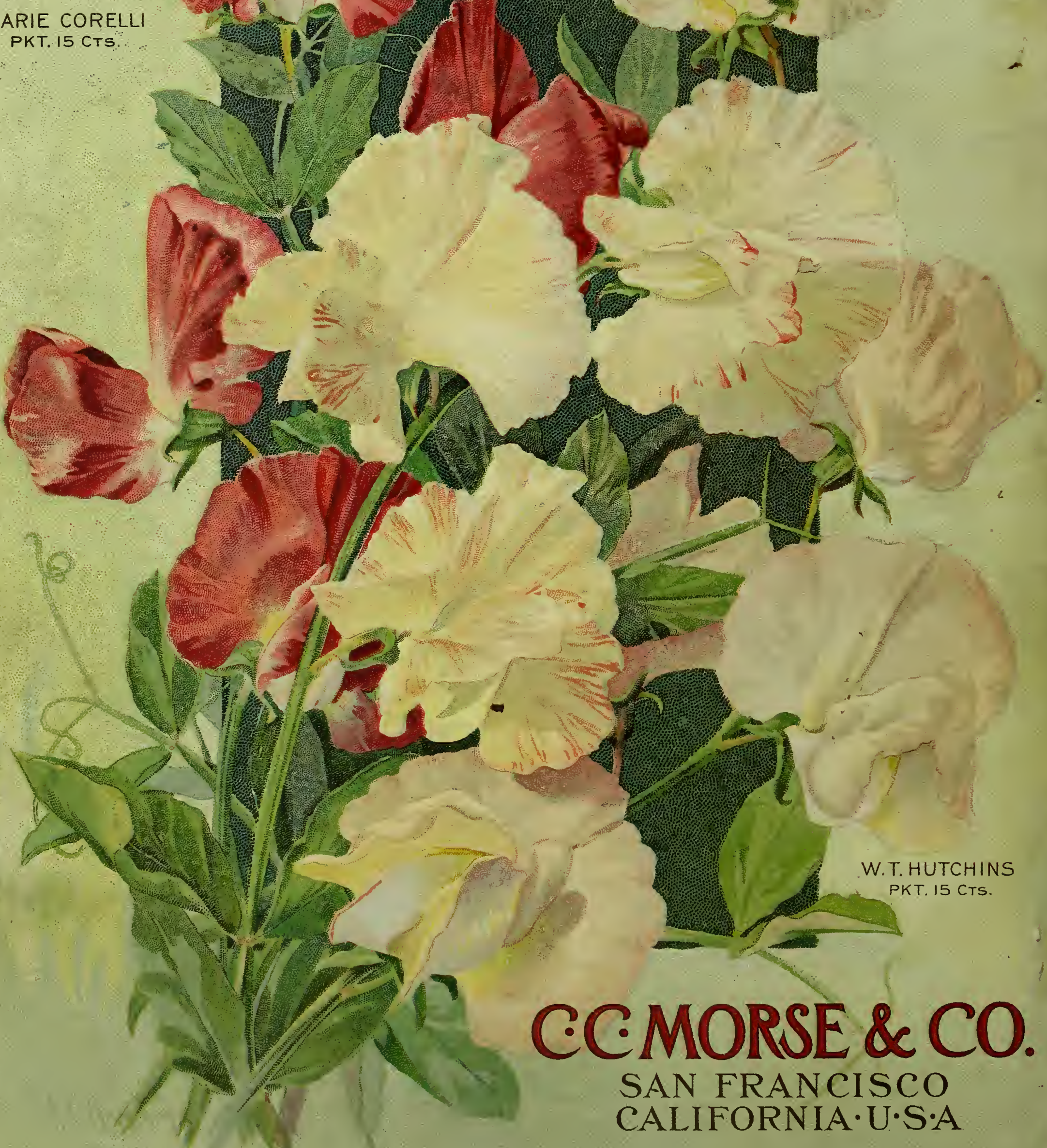

